
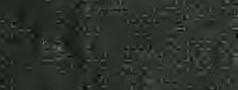
HARVARD UNIVERSITY

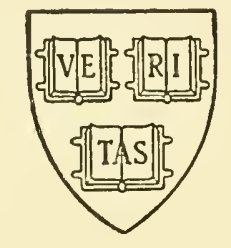

LIBRARY OF THE MUSEUM OF COMPARATIVE ZOÖLOGY

GIFT OF

THOMAS BARBOUR

September 27,1946 
, 




\section{.}




\section{THE REPTHLES}

()1: TIIE

INDO-AUSTRALIAN ARCHIPLAGO. 



\title{
THE REPTILES
}

\author{
UF THE
}

\section{INDO-AUSTRALIAN ARCHIPELAGO}

\author{
II \\ O PHIDIA \\ with 117 illustrations
}

BY

\section{Dr. NELLY DE ROOIJ}

Curator of the Zoological Museum, Amsterdam.

LEIDEN - 1917.

E. J. B R I L L Ltd. 


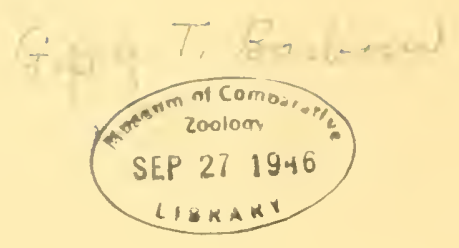

I'RINTED BY E. J. BRILL, LEYDEN (IOLLAND). 


\section{PREFACE.}

In bringing this second volume of the indo-australian Reptiles before the public, I may be allowed gratefully to acknowledge the industry and constant application of Miss DE ROoIJ, which were necessary to complete in so short a space of time the first comprehensive work about the Reptiles, living in the indo-australian region.

In the present volume $S_{4}$ genera and 3 I 8 species of snakes are described. Only very few of them have not yet been found in the Archipelago. They are none the less included because Miss DE ROOIJ rightly supposes that they will be discovered in future also in this part of the world.

With the present volume the work about the indo-australian Reptiles is completed.

It will certainly be of great help to students of this group of animals. Besides, I hope not to be wrong in supposing that it will also be of interest to residents in the Archipelago, many of whom are attracted by the animals living around them, but who lack works to guide them. Such a guide they will find in the work of Miss DE ROOIJ. The numerous figures, so ably and accurately drawn by Mr. J. F. OBbes will greatly facilitate the use of the descriptions.

To promote the study of animals in the Archipelago in both directions, was the aim, when the publication of a series of volumes describing the Vertebrates of the indo-australian Archipelago, was planned. In a previous volume we have explained how their appearance was realised by the interest and help of the late Prof. M. TREUB and by his successor Dr. Koningsberger.

Miss DE RooI has already gratefully acknowledged the assistance she had received from many institutions and indi- 
viduals, while being engaged in working out the Reptiles of the indo-australian region.

In conclusion I have the pleasure to offer my thanks to the publishing firm late E. J. BRILL. In bringing out this volume the publisher had to overcome many and various difficulties, caused by the present sad conditions of life.

Prof. MAX WEBER

Director of the Zoological Museum of the University of Amsterdam. 


\section{INTRODUCTION.}

The second volume of the Indo-Australian Reptiles contains descriptions of all the species of snakes living in the IndoAustralian Archipelago. The material has been treated in the same way as in the first volume, dealing with the Lacertilia, Chelonia and Emydosauria, and I have been able to use the same large collections mentioned in that volume, sent from the western part of the Archipelago: Sumatra and its neighbouring islands, as well as from New Guinea in the east. Moreover, some species have been mentioned living nearest to this region, which may be found there also though they have not yet bcen discovered.

The specimens I could examine myself have a! behind the name of the place where they were collected. Length of head and body means the distance between the tip of the snout and the vent.

Among the localities is enumerated: Pulu Babi. This is one of the three small islands near Simalur bearing the same name; of these three is meant the one lying southwards of Simalur; on $2^{\circ} 7^{\prime} \mathrm{N}$. and $96^{\circ} 40^{\prime} \mathrm{E}$. The same small island is mentioned in the first volume.

For the Snakes too exist excellent lists of synonyms composed by G. A. Boulenger in the Catalogues of the British Museum; therefore I followed this work for the names, except where some doubt arose or when I was of another opinion.

The extraordinary circumstances by which nearly the whole world is oppressed, made it difficult for me to finish my task; objections were made to send out rare species for examination, letters did not reach their destination and last but not least the paper question was an urgent one. Still I beg to return my sincere thanks to all who have rendered me their help in different ways. Dr. VAN LidTh DE JEUde placed the collection of the Leiden Museum at my disposal, which contains 
so many valuable objects; not only that Dr. BUULENGER was so kind as to allow me to examine each snake in the British Museum I wanted to see, but he also gave me his advice on different matters. Specimens for examination were obtained from Prof. Wirén in Upsala, Dr. Annandale in Calcutta and Dr. Roux at Basle, so that descriptions and figures could more easily be made.

Prof. Tornier of the Berlin Museum and Prof. Lohman in Hamburg did not think it safe to send specimens but gave information of the doubtful points; the latter sent a figure made by Dr. DUNCKER to clear up my question, for which I am very grateful. Professor JACOBI of the Dresden Museum informed me about a specimen of Python belonging to that Museum.

For this volume too $\mathrm{Mr}$. OBBes was willing to draw all the figures, in which he succeeded admirably. To the end Prof. MAX WEBER showed his interest in the work by suggesting emendations, which I thankfully applied.

Amsterdam, November I9I7.

Nelly de Rooij. 


\section{SYSTEMATIC INDEX.}

\section{REPTILIA.}

Page

Order Ophidia.

I. Family TyphlopidaE. ... 2

I. Typhlops Schneider ... 2

1. lincatus Boie..... 4

2. krauli Doria ..... 4

3. braminus (Daud.)... 5

4. erycinus Werner.... 6

5. polygrammicus Schlegel 6

6. clbcrti Roux ..... 7

7. multilineatus Schlegel. 7

8. olivaceus (Gray) .... S

9. Lorenzi Werner.... 8

г. Kapaladua Annandale. 9

I I. depressiccts Sternfeld . 9

I 2. conradi Peters ..... IO

13. bipartitus Sauvage. . I

I 4. florensis Blgr. . . ... Iо

I 5. leucoproctus Blgr. . . . I I

I6. flaviz'nter Peters. . . . I I

I 7. nigroalbus D. S B. . . I 2

เ8. mülleri Schlegel .... I 2

19. attr Schlegel ...... J3

20. bisuhocularis Böttger. I 3

21. inomatus Blgr..... 14

2. Family BoInae...... I 4

I. Nurdoa Gray ....... I 5

I. boa Schlegel ..... I 5
Page

2. Liusis Gray........ I6

I. fuscus Peters. . . I 6

2. mackloti D. \& B.... . I 7

3. formieri Werner.... IS

4. albertisi Ptrs. \& Doria is

5. papuamus Ptrs. \& Doria in

3. Python Daudin..... I9

I. reticulatus (Schn.) . . 20

2. molurus (1.). . . . . 22

3. amethystimus (Schn.). . 24

4. timoriensis (Ptrs.) . . 25

5. spilotés (Lacépède). . . 26

6. curtus Schlegel.... 28

4. Chondropython Meyer . . 28

I. viritis (Schlegel). . . 29

5. Einygrus IVagler .... 31

I. carinatus (Schn.). . . 3 I

2. asper (Gthr.) .... 32

3 australis (Montr.) . . 33

3. Family Ilysiddae .... 34

I. Anomalochilus Jidth . . 34

I. reveri Lidth .... 34

2. Cylindrophis Wagler...35

I. rufus (Laur.). . . . . $3^{6}$

2. lincatus Blanford. . . 37

3. opisthorhotus Blgr. . . 38

4. boulengeri Roux . . . $3^{8}$

5. isolepis Blgr..... $3^{8}$ 
4. Family Xenopeltidae . . 39

I. Xcnopeltis Reinw. . . 39

I. unicolor Reinw... . 39

5. Family Colubridae. . . . 4 I

I. Aglypht.........4 4 I Acrochordinat ..... 4 I

I. Acrochordus Hornst . 42

1. jazanicus Hornst. - 43

2. Chersydrus Cuvier. . 43

I. sranulatus (Schn.) . 43

3. Xcwodermus Reinh. . 44

r. jaranicus Reinh. . 44

4. Stoliczkaia Jerdon . . 45

I. borncensis Blgr. . . 45

Colubrinat....... 46

5. Anoplohydrus IVerner. 49

1. acmulans IVerner. . 49

6. Ignanognathus Blgr.. . 50

1. zeerneri Blgr. ... 50

7. Opisthotropis Gthr. . . $5 \mathrm{I}$

I. rugosa (Liclth) . . $5^{\mathrm{I}}$

2. typica (Mocq.) .. 52

S. Tenochrophis Gthr. . 53

I. riporimus Schenkel . 53

9. Polyodontophis Blgr . . 54

1. geminatus (Boie) . 54

Iо. Pscudaxenodon Blgr. . : $5^{6}$

I. inornatus (Boie). . 56

I 1. Dendrophis Boie. . . 57

I. pictus (Gmel.) . . . $5^{8}$

2. calligaster Gthr. . 60

3. Torentsi Lidth. . . 62

4. functulatus (Gray) .63

5. formosus Boie. . 64

6. grastrostictus Blgr. . 64

7. lincolatus Hombr. \&

$$
\text { Jacq. ..... } 65
$$

8. mecki Blgr. .... 66

9. Nouhuysi Lidth . . . 66

12. Dendrelaphis Blgr. . . 67

I. inornatus Blgr. . . 67

2. caudolincatus (Gray) 68

3. terrificus (Ptrs.). . 69
Page

4. papuensis Blgr.. . . . 70

5. modestus Blgr.... . 70

13. Zaocys Cope...... 7 I

r. tornicri Werner... $7 \mathrm{r}$

2. fuscus (Gthr.) ... 72

3. carinatus (Gthr.) . . 73

r4. Tropidonotus Kuhl . . . 73

1. piscator (Schn.). . . 75

2. picturatus Schlegel. . 76

3. truncatus (Ptrs.) . . 77

4. celebicus (Ptrs.e Doria) 78

5. nozat-guineac Lidth . 78

6. sarasinorum Blgr. . 79

7. mairi Gray .... 79

8. montanus Lidth . . . So

9. clongatus Jan .... . So

Iо. punctiocntris Bttgr. . $8 \mathrm{I}$

I r. halmahericus Bttgr. . 82

12. doriae Blgr...... $\mathrm{S} 2_{2}$

I3. lyppomelas Gthr. ... $S_{3}$

I4. conspicillatus Gthr. . $8_{3}$

15. Hrianguligerus Boie. $\mathrm{S}_{4}$

r6. petersi Blgr. .... $\mathrm{S}_{5}$

17. sarazuacensis Gthr. $8_{5}$

IS. chrisargoides Gthr. . S6

9. flarifrons Blgr. . . 87

20. stolatus (L.)..... 87

2 I. vittatus (L.). . . . . S8

22. subminiatus Schlegel. 89

23. chrysargus Schlegel . 89

24. maculatus Edeling . 9 90

I5. Macropisthodon Blgr. . . 9 I

I. flariceps (D. \& B.). . . 9I

2. rhodomclas (Boie) . . 92 plumbicolor (Cant.) . 93

16. Xenelaphis Gthr..... 93

1. hexagonotis (Cant.) . 93

2, cllipsifer Blgr.....995

г 7. Zame'uis Wagler..... 95

1. dipsas (Schlegel). . . 96

2. Furros (Schlegel). . . 96

3. mucosus (L.).... 98

18. Colnuer I......... . . 98

I. porphyracess Cant. . . 99 
3. radiatus Schlegel. . I I I

4. erjthrurus (D. \& B.). 102

5. janseni (Blkr.) . . . $\mathrm{IO}_{2}$

6. tacninms (Cope). . . Iо3 $_{3}$

7. oxyccphalus Boie.. . I04

S. cllganensis Vincig... $1 \mathrm{IO}_{5}$

9. subradiatus Schlegel. 106

19. Gonjophis Blgr..... . I06

I. margaritatus (Ptrs.) . ro6

20. Lycodon Boie. ...... I07

I. subcinctus Boie... . Io8

2. albofuscus (D.\& B.) . ro9

3. stormi Bttgr..... I Io

4. florensis n. sp. .... I ro

5. anticus (L.). . . . . I I I

6. effremis Cant...... I 12

$2 \mathrm{I}$. Lepturoplis Blgr. .... $\mathrm{I}_{1} 3$

I. horneensis Blgr. . . I I 3

22. Stegonotus 1). \& B.... II

I. magnus (Меуег) . . I I 4

2. molestus (Schlegel). . I I 5

3. batjancusis (Gthr.) . . I 6

4. ptumbeus (Macleay). I I 7

5. gïntheri Blgr. . . . I I 7

6. diehli Lindholm... I Is

23. Dryocalamus Gthr. . . I I 8

I. subammulatus (D.\& B.) I I 9

2. Histrigatus Gthr. . I 20

24. Tetralepis Bttgr. ... I 20

I. fiuhstorferi Bttgr. . I 2 I

25. Simotes D. \& B. . . . I 2 I

I. ammulifer Blgr. . . I 122

2. octolineatus (Schn.). . I 23

3. riolucans (Cant.) . . I 24

4. forlesi Blgr. . . . . I 24

5. signatus Gthr. . . . 125

6. subctrinatus Gthr. . I 25

7. purpurascens(Schlegel) I 26

phacnochatimus Cope. I 27

26. Oligodon Boie ..... I 27

I. bitarquatus Boie... I 28

2. trilineatus (D. \& B.) . 129

3. durhcimi Baumann. . I 29

4. everetti Blgr.

5. petroucllae Rotr

6. propinquus Jan ... I 3

7. pulcherrimns Werner. I32

8. pracfrontalis Werner. I32

9. a'ertehalis (Gthr.) . . I33

10. Tialudersi (Blkr.) . . I33

27. Elapoide's Boie. ..... I 34

I. fuscus Boie.... I34

28. Hydrablabes Blgr. . . 135

I. periops (Gthr.) ... I 36

2. pracfrontalis (Mocq.) 137

29. Ablabes D. \& B. . . . I 137

I. tricolor (Schlegel) . I 38

2. libertatis (Barbour) . ${ }_{3} S$

3. baliodims (Boie). . I I39

4. longicanda Ptrs. . . I 40

30. Oreocalamus Blgr. . . I 40

I. hanitschi Blgr. . . . I $4 \mathbf{I}$

3r. Tdiopholis Mocr. .... If 1

I. collaris Mocq. .... $\mathbf{1 4 2}$

2. crevetti Shelf. .... I 42

32. Asroplis F. Müller ... I 43

I. sarasinorum F. Müller I +3

2. saratacensis Shelford I 44

3. albonuchalis (Gthr.) . 144

33. Rhabdoflidium Blgr. . I 45

I. forsteni (D. \& B.). . . I45

34. Psiudorhululium Jan . . I46

I. longiceps (Cant) . . 1 46

35. Brachyorrhus Boie . . I47

I. albus $(\mathrm{I},.) \ldots \ldots$. . I 48

36. Calamorhatulium Bttgr. I48

1. Kinkenthali Pttgr. . . I 49

37. Calamaria Boie. . . I 49

I. Inmlmicoided Boie. . I53

2. rermiformis I). \& B. I 53

3. stihlknechti Stol. . . I 54

4. imllragivica Schenkel I54

5. balnensis Blgr. . . . I I55

6. graborisliyi Fischer. . I55

7. margaritophora Blkr. $5_{56}$

8. prakkei Lidth. . . . I 56

9. Inchalis Blgr. . . . 157 
Page

Io. sumatrana Edeling. . I57

I I. elegans n. sp. . . . . . I 58

12. simalurensis n sp. . . I 59

13. gracilis Blgr. . . . . I 59

I. acutirostris Blgr. . . 160

I 5. curta Blgr. . . . . . 160

16. mïlleri Blgr. ..... . I6

I 7. exeretti Plgr. . . . I I 6 I

IS. accipitalis Jan..... I62

19. Firguleta Boic . . . . 162

20. lantensis n. sp. . . . 163

2 I. leucogaster Blkr. . . . I64

22. quinquetaeniata

Despax...... I 64

23. albopunctata Parbour. I 65

24. bicolor D. \& B . . . I65

25. mookei Blgr. . . . . I 66

26. sondatica Barbour . . 166

27. brachlitra Blgr. . . 167

2S. collaris Blgr. .... 167

29. lateralis Nocq. . . . I 68

30. becarii Peters . . . I6S

3r. rehentischi Blkr. . . . I69

32. cramcnsis rle Rooij . I69

33. mecheli Schenkel ... I69

34. picteti Peracca ... I 70

35. lencocephala D). \& B I I

36. agamensis Blkr.... . 17 I

37. semiammulata Bött-

ger........ I 72

3 S. dïderleini Gough . . . I 72

39. bungaroides Werner. . I73

40. sihlegeli I). \& B. . . . 173

41. limmaci Boie..... I 74

42. hormensis Blkr.... I 175

43. bcnjaminsi Edeling. . I 75

44. jaranica Blgr. . . . 176

45. pavimentata ).\& B. . 176

46. Mclinota Jan.... I 77

47. lorii Blgr. . . . . . I 77

4S. srocillima Gthr. . . . I 78

49. ormata Werner.... I 78

50. hosci Gthr. ..... I 7 S

horeni Enleling. . . I 79
Page

II. Opisthoglypha......... I 79

Homalopsinae. . . . . . I 79

38. Hypsirhima Wagler. . ISo

I. altermans (Reuss) . I80

2. plamber (Boie) . . I $S_{\text {I }}$

3. enhydris (Schn.). . I 8 I

4. matamacnsis Blgr. . I $S_{2}$

5. polylepis Fischer. . $\mathrm{I}_{3}$

6. albomaiulata

(I). \& B.) . . . I $S_{3}$

7. punctata (Gray) . I $S_{4}$

S. doriac (Peters) . . . I $S_{5}$

39. Homalopsis $\mathrm{Kuhl} \ldots \mathrm{IS}_{5}$

I. buccata (L.) . . . IS6

40. Cerborus Cuvier. ... I 87

r. rhluchops (Schn.) . I 87

4. Fordonia Gray .... I $S_{9}$

т. Icucohalia (Schlegel) i 89 papucusis Macleay 190

42. Cantoria Girard . . I90

I. violaced Girard. . . I9I

43. Myron Gray .... I9 I

I. richardsoni Gray. . 192

44. Hipistis Gray..... I 93

I. lydrinus (Cantor). 194

Dipsadomerplinac. . . . 194

45. Dipsadomorpluas Fitz. I9t

I. multimaculatus

(Boie) ..... 195

2. Arapicsii (Boie) . . I96

3. dendrophilus (Boie) 197

4. nigriceps (Gthr.). . I99

5. juspideus (D. \& B.) 199

6. cyntodon (Boie)... 200

7. iregularis (Merr.) $20 \mathrm{I}$

8. flavesccns (I). S li.) 202

46. Psammodynastes Gthr. 202

I. pularrulcutus (Boie) 202

2. pictus Gthr. ... 203

47. Dryophis Dalman. . 204

I. xanthozona Boie. . 205

2. prasinus Boie...206

3. fasciolatus (Fischer) 207

4. mycterizans (Т..). . 208 
48. Dryoplicops Blgr. . . 208 1. ruhescens (Gray). 209 49. Dipsadoide's Annand. 2 Io I. decipiens Annand. 210

50. Chrysopelea Boie.". 2 I r I. rhodoplewron Boie 2 I 2 2. minata (Shaw) . . $2 \mathrm{r} 2$ 3. chrysochlore

(Schleg.) . . . 2 I 4

1II. Proteroglyphar ...... 2 I 5 IIydrophiinat...... 2 I 5

51. Platurus 1)audin . . 216

I. schistorliyuchus

Gthr. .....2 216

2. laticandatus (L.) . 217

3. coluhrimus (Schn.) 217

52. Aifysums Lacépède. 2 I 8

1. 'jtouri (Gray) . 219

2. anstralis Sauvage 2 I9

3. lacais lacépède. . 220

53. Enhydrina Gray. . 220

I. z'alakady'n (Boie). 22 I

54. Thalassophis Schmidt 222

I. anomalus Schmidt 223

2. anmandalei (Isaid-

$$
\text { law).... } 223
$$

55. Hydrus Schneider. . 224

r. platurus (I..) . . 224 56. Hydrophis l Maudin. . 225

I. fromtalis Jan . . 227

2. Migrocinctus Dau-

din .....2227

3. gracilis (Shaw). . 228

4. foncri Blgr. . 229

5. diadema Gthr. . 229

6. fasciatus (Schn.) 230

7. brookei Gthr... 230

8. torquatus Gthr. . 23 I

9. riperinus

$$
\text { (Schmidt) . . 23I }
$$

10. jordoni (Gray) . . 232

I r: mertoni (Roux). . 233

I 2. polyodontus Jan. 233

13. brugmansi Boie. . 233
Page

14. spiralis (Shaw) . . 234

15. granatis (Blgr.) . . 235

16. h.jhridus Schlegel. . 235

I 7. omatus Gray . . . 236

IS. macfarlami (Blgr.) . 237

19. cyanocinctus 1)audin 237

20. savaracensis (Blgr.). 238

21. belcheri (Gray)... . 238

22. pachucratus Fischer. 239

23. stokesi (Gray). . . 239

57. Eulydris Merrem . . . 240

1. hardatikei (Gray) . . 240 Elapinat ....... 24 24

58. Bungarus Daudin. . . 243

1. fasciatus (Schn.). . 243

2. candidus (L.) ... . $24+4$

3. Alaziceps Reinh. . . 245

59. Najir I aurenti. . . . 245

I. trifudians Merr... . 246

2. llumg(t)us Schlegel . 249

6o. Callophis Gthr. .... 250

I. gracilis Gray....2 $25^{\circ}$

6r. Doliophis Girard. . . . $25 \mathrm{I}$

1. birirgatus (Boie). . $25^{\mathrm{I}}$

2. intestinalis (Iaur.). . 253

62. Glyphodom Gthr. . . . 254

I. tristis Gthr. ... 255

63. 7'oricocalamus Blgr. . 255

I. longissimus Blgr.. . 256

2. stanleyamis Blgr. . $25^{6}$

64. Cltrocalamus Sternf. . . 258

r. Proussi Sternf. . . 258

biïrgersi Sternf.. . . 260

65. Apistocalamms Blgr. . . 260

I. pratti Blgr..... 260

2. loriae Blgr...... . $26 \mathbf{r}$

3. syandis Blgr..... . 26I

4. lïunluergi Blgr.... . 262

66. Pseudapistocalamms

Lönnb. ..... 262

I. "1'mani Lönnberg . . 263

67. Pscudclaps D. \& B. . . 264

r. mïlleri (Schlegel) . . 264

68. Dicmenia Gthr. . . . . 266 
I. psammoplits (Schleg.) 266

2. olinucea (Gray) . . 267 69. Pscudeclits Wagler. . 268

1. australis (Gray). . . 268

2. papuanus Ptrs. \& Doria .... 269

3. scutcllatus Peters. . 269 70. Micropechis Blgr. . . 270 r. ikaheka (Lesson). . 270 7 r. Acanthophis Daud. . . $27 \mathrm{I}$ .r. antarcticus (Shaw) . 272

8. Family Amblycephalidae. 273 I. Haplopeltura D. \& B. . 273 I. hoa (Boie) .... 275 2. Amblyecplarlus Kuhl . 275 I. lacais Boie .... 276
2. malaccanus (Ptrs.). . 276

3. nuchalis Blgr. ... 277 4. carinatus Boie... . 277

7. Family Viperidae ... 279 I. Agkistrodon Pal. d. B. . 279 I. rhodostoma (Boie). . . 279

2. Lacluesis Daudin ... . $28 \mathrm{I}$ I. Monticola (Gthr.). . . $2 \mathrm{~S}_{2}$ 2. smmatrams (Raffles). $28_{3}$ 3. fasciatus Blgr. . . . 284 4. purpureomaculatus

(Gray) ..... 284

5. gramineus (Shaw) . 285

6. punicens (Boie)... 286

7. atarleri (Boie)..... 286 


\section{Order OPHIDIA.}

Quadrate bone distally free; temporal region with one temporal arch; the two parts of the mandible connected by ligament; teeth not in alveoli. Anal opening transverse; copulatory organ present, paired.

Snakes have no movable eyelids, the lid forms a transparent disk over the eye; the ear-opening is absent; the tongue is long and slender, forked, and retractile into a basal sheath. Limbs are absent.

They may be divided into nine families, seven of which are represented in the Indo-Australian fauna. Poisonous snakes only belong to two of these, Colubridae and Viperidae.

\section{Synopsis of families.}

$A$. Eyes under the shields; body covered with uniform scales; mandible toothless ............ Typhlopidae p. 2.

B. Eyes exposed; median ventral scales usually enlarged; jaws toothed.

I. Maxillary horizontal.

$a$. Traces of hind limbs, ending in a claw, often visible on each side of the anal opening.

1. Tail prehensile; scales small. ........ Boidae p. 14.

2. Tail not prehensile, very short ....... Ily'siidae p. 34 .

b. No traces of hind limbs.

1. Mental groove present.

$\dagger$ A large azygous occipital present; praemaxillary toothed ........... Yenopeltilae p. 39

†† No azygous occipital; praemaxillary

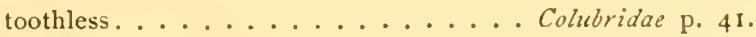

2. No mental groove ............ Amblycephalidae p. 273 .

II. Maxillary short, vertically erectile......... Viperidae p. 279. 


\section{Fam. Typhlopidae.}

Body small, worm-like, covered with uniform, cycloid scales; eyes covered by shields. Head-bones solidly united; no ectopterygoid; pterygoids short, not reaching the mandible; no supratemporal; maxillary small, vertical, loosely fixed and bearing a few teeth; mandible toothless; coronoid present. Pelvis reduced to a single bone.

They lead a subterranean life, usually feeding on worms,

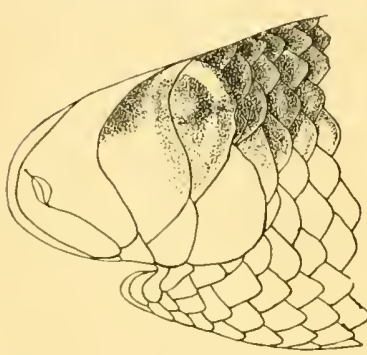

Fig. I. Head of $T_{y}$ phlops and may be found in rotten trees. Oviparous, the few eggs large and long.

A single genus.

\section{Typhlops Schneider.}

(SchNfider, Hist. Amph. II p. 339, ISor).

Head covered with large shields; nasal single or divided. Tail very short.

Distribution. Borders of the Medinigroalbus D. \& $13 . \times 3^{1 / 2} \cdot$ terranean; Africa; S. Asia; Australia;

C. and S. America; West Indies.

Key to the Indo-Australian species.

A. No praeocular; no subocular; ocular in contact

with the second and third labials ...... I. T. lineatus p. 4.

D. Praeocular present, in contact with the third, or second and third labials; no subocular; ocular in contact with the labials.

1. Praeocular in contact with the third labial only

2. T. kraali p. 4 .

II. Praeocular in contact with the second and third labials (fig. I).

a. Nasal cleft proceeding from the praeocular.

b. Nasal cleft proceeding from the first labial.

I. Snout rounded.

+ Nostril inferior.

4a. Rostral about $1 / 3$ the width of the head, not extending to the level of the eyes; nasal completely divided; 20 scales round the body. 4. T. erycinus p. 6.

66. Rostral about $1 / 2$ the width of the head, extending to the level of the eyes; nasal incompletely divided; 22 scales round the body. 5. T. polygrammicus p. 6. 
++ Nostril lateral; 22 scales round the body............ 6. T. elbcrti p. 7 .

2. Snout with sharp edge.

$\dagger$ Rostral extending to between the eyes. 7. T. multilineatus p. 7 .

†† Rostral not extending to between the eyes.

1. Rostral three fifths the width of the head............. S. T. olivaceus p. S.

2. Rostral not quite half the width of the head ........... 9. T. Lorenzi p. S.

c. Nasal cleft proceeding from the second labial.

1. Nasal completely divided.

aa. Snout rounded; nostril lateral; scales

in 26 rows ............ 10. T. kapaladua p. 9 .

b6. Snout with a sharp edge; nostril in-

ferior; scales in 24 rows ...... II. T. depressiceps p. 9.

2. Nasal incompletely divided.

$X$ Nostril inferior.

a. Rostral $2 / 5$ the width of the head, extending nearly to the level of the eyes; is scales round the body. 12. T. conrali p. 10.

b. Rostral large; 22 scales round the body............. I3. T. bipartitus p. Io.

c. Rostral $1 / 4$ the width of the head, not extending to the level of the eyes; 22 scales round the body. I4. T. florensis p. 10.

$\times \times$ Nostril lateral.

I. 20 scales round the body; rostral $1 / 3$ the width of the head, extending to the level of the eyes..... 15. T. leucoproctus p. II.

2.22 scales round the body; rostral narrow, the upper portion $1 / 3$ the width of the head, extending nearly to the level of the eyes...... I6. T. flaviventer p. II.

3. 26 scales round the body; rostral narrow, the upper portion $1 / 3$ the width of the head, extending to between the eyes or nearly so.. I7. $T$. nigraalbus p. J2.

4. 26 or $2 S$ scales round the body; rostral $1 / 2$ the width of the head, not extending to the level of the eyes............. I8. T. mïlleri p. I2. 
$\bar{C}$. Praeocular present; one or two suboculars.

I. Praeocular not in contact with the labials;

I8 scales round the body.

a. A single subocular. .......... I9. T. ater p. I3.

b. Two suboculars............. 20. T. bisulbocularis p. 13.

II. Praeocular in contact with the second, third and fourth labials; a single subocular; 20 scales round the body ..........2I. T. inornatus p. I4.

\section{Typhlops lineatus Boie.}

Typhlops lineatus, Boic, Isis I827, p. $5^{63}$.

Typhlops lineatus, Boulenger, Cat. Snakes I IS93, p. I5.

Snout rounded, strongly projecting; nostrils inferior. Rostral very large; nasal incompletely divided, the cleft proceeding from the first labial; a single large ocular on each side behind the nasal; eyes not distinct; praefrontal, supraoculars and parietals enlarged, transverse; four upper labials. Body with 22 scales round the middle; its diameter 40 to 60 times in the total length; tail about as long as broad, ending in a spine.

Blackish above, each scale spotted with yellow, or yellow or pale brown with dark brown longitudinal lines between the series of scales; head and lower surface yellowish. Total length $485 \mathrm{~mm}$.

Habitat: Nias!; Sumatra (Atjeh, Labuan, Tandjong, Langkat, Deli!, Battak Highlands $800-1000$ M., Indragiri); Borneo (Singkawang, Kuching); Java (Gadok, Buitenzorg!, Salak, Preanger, Sinagar!, Tjibodas I425 M., Wonosobo, Ambarawa, Salatiga!). - Malay Peninsula; Singapore; Penang; Siam.

\section{var. sumatrana Werner.}

Typhlops lineatus var. sumatrana, Werner, Verh. Ges. Wien XLVI IS96, p. I3.

Mouth-opening $U$-shaped, with parallel borders; 24 scales round the body. Pale yellowish with indistinct longitudinal lines. Total length $320 \mathrm{~mm}$; t tail $7 \mathrm{~mm}$. (After Werner; not seen by me).

Ha bitat: Sumatra; Java (Buitenzorg).

\section{Typhlops kraali Doria.}

Typhlops kraalii, Doria, Ann. Mus. Civ. Genova VI I874, p.347, pl. XII, fig. f. Typhlops kraalii, Boulenger, Cat. Sn. I I893, p. 30. 
Snout rounded, projecting; nostrils lateral. Rostral about one third the width of the head, not extending to the level of the eyes; nostril between two nasals, the anterior in contact with the first and second labials; praeocular present, as broad as the ocular, in contact with the third labial only; eyes distinct; head-scales feebly enlarged; four upper labials. Body with 24-26 scales round the middle; its diameter 40 to 42 times in the total length; tail as long as broad, ending in a spine.

Blackish-brown; lower surface of head and middle of belly yellowish. Total length $265 \mathrm{~mm}$.

$\mathrm{Habitat}$ : Kei Islands!.

\section{Typhlops braminus (Daud.).}

Eryx braminus, Daudin, Hist. Rept. VII I803, p. 279.

Typhlops braminus, Boulenger, Cat. Sn. I I 893 , p. I6 (s. syn.).

Snout rounded, projecting; nostrils lateral. Rostral narrow, its upper portion about one third the wiath of the head, not extending to the level of the eyes; nostril between two nasals, the anterior in contact inferiorly with the praeocular and extending to the upper surface of the head; praeocular present, nearly as large as the ocular, in contact with the second and third labials; eyes distinct; head-scales a little larger than the scales of the body; four upper labials. Body with 20 scales round the middle; its diameter 35 to 55 times in the total length; tail as long as broad or a little more long than broad, ending in a spine.

Brown, grey or black above; snout, anal region and end of tail whitish. Lower surface light. Total length $175 \mathrm{~mm}$.

Nom. in dig. Ular hitam (Borneo); duwa or ular duwel (mal.).

Habitat: Nias!; Sumatra (Atjel,, Medan!); Riou; Banka; Java (Gadok, Weltevreden!, Buitenzorg!, Pekalongan!, Kediri!); Madura; Borneo! (Labuan, Kuching, Buntok); Flores!; Lomblem!; Sumba; Timor; Celebes (Manado, Kema, Macassar!, Tamangura); Saleyer!; Buton; Ambon!; Ceram; Ternate; Halmahera; Kei Islands; Aru Islands. - Malay Peninsula; Christmas Island; Andamans; Ceylon; India; Siam; Burma; Formosa; Hongkong; Philippines; Islands of the Indian Ocean; Arabia; S. Africa; Madagascar; Mexico.

A very common form throughout the Archipelago. 


\section{Typhlops erycinus Werner.}

Typhlops erycinus, Werner, Verh. Ges. Wien LI I901, p. 611.

Snout rounded, strongly projecting; nostrils inferior. Rostral hardly one third the width of the head, not extending to the level of the eyes; nasal completely divided, nasal cleft proceeding from the first upper labial and extending on the upper surface of the head; praeocular present, a little larger than the ocular, in contact with the second and third labials; eyes distinct; praefrontal, supraoculars and parietals enlarged, latter shields separated in the middle by a scale; four upper labials, increasing in size posteriorly. Body with 20 scales round the middle; its diameter 44 times in the total length; tail a little more long than broad, ending in a spine.

Greyish-brown above, base of scales dark brown; snout yellow. Lower surface yellow. Total length $350 \mathrm{~mm}$.; tail $10 \mathrm{~mm}$. (After WERNER; not seen by me).

Habitat: German New Guinea.

\section{Typhlops polygrammicus Schlegel.}

Typhlops polygrammicus, Schlegel, Abbild. 1844, p. 40, pl. XXXII, fig. 35-38. Typhlops polygrammicus, Boulenger, Cat. Sn. I I 893 , p. 34 (s. syn.).

Snout rounded, projecting; nostrils inferior. Rostral about half the width of the head, extending to the level of the eyes, the inferior portion more long than broad; nasal incompletely divided, the cleft proceeding from the first labial to the upper surface of the head; praeocular present, narrower than the ocular, in contact with the second and third labials; eyes distinct; praefrontal, supraoculars and parietals much enlarged; four upper labials. Body with 22 scales round the middle; its diameter 3 I to 50 times in the total length; tail one time and one fourth to two times as long as broad, ending in a spine.

Brown or olive above, the scales edged with light. Lower surface whitish, each scale with a brownish spot. Total length $7 \mathrm{I} 7 \mathrm{~mm}$.

Type-specimen examined in the Leiden Museum.

Habitat: Java (Batavia); Timor!; New Guinea ${ }^{1}$ ). - N. and E. Australia.

1) See Bleeker, Nat. Tijdschr. Ned. Ind. XVI I858/59, p. 420. 


\section{Typhlops elberti Roux.}

Typhlops elberti, Roux, Zool. Jahrb. Syst. XXX I9I1, p. 499.

Snout rounded, strongly projecting; nostril lateral. Rostral about one third the width of the head, extending to the level of the eyes; nasal completely divided, the cleft proceeding from the first-labial; praeocular present, narrower than the ocular, in contact with the second and third labials; eyes distinct; praefrontal and supraoculars enlarged; praefrontal forming a broad suture with the rostral. Body with 22 scales round the middle; its diameter 33 times in the total length; tail more long than broad, ending in a spine.

Brownish-black above, the scales edged laterally with yellowish-white, so as to form I I parallel lines, the inferior lateral line of which is a little indistinct. Lower surface also with longitudinal lines, a little lighter than those of the back; between lateral and ventral lines on the flanks three serics of scales, with a dark punctulated median part. Total length $235 \mathrm{~mm}$.; tail $8 \mathrm{~mm}$. (After Roux; not seen by me).

Habitat: Lombok.

\section{Typhlops multilineatus Schlegcl.}

Typhlops multilineatzes, Schlegel, Abbild. 1844, p. 40, pl. XXXII, fig. 39-42. Typhlops multilincatus, Boulenger, Cat. Sn. I I 893, p. 50.

Snout with a sharp edge, strongly projecting; nostril inferior. Rostral very large, finely granulated, extending to between the eyes, the inferior part as broad as long; nasal incompletely divided, the cleft proceeding from the first labial; praeocular present, nearly as broad as the ocular, in contact with the second and third labials; eyes distinct; head-scales much broader than the scales of the body; four upper labials. Body with 20 scales round the middle; its diameter 50 to 60 times in the total length; tail nearly twice as long as broad, ending in a spine.

Grey above, each scale with a dark spot, the spots forming dark brown longitudinal lines on the series of scales. Lower surface lighter. Total length $370 \mathrm{~mm}$.

Habitat: Ceram; Kei Islands; New Guinea (Sermowai river!, Angadi, Fak Fak). 


\section{Typhlops olivaceus (Gray).}

Onychophis olizaceus, Gray, Cat. I845, p. 133.

Typhlops olivaceus, Boulenger, Cat. Sn. I I893, p. 50.

Snout with a narrow, sharp, transverse edge, strongly projecting; nostril inferior. Rostral large, the upper part three fifths the width of the head, not extending to the level of the eyes, the inferior part as broad as long; nasal incompletely divided, the cleft proceeding from the first labial; praeocular present, about as broad as the ocular, in contact with the second and third labials; eyes distinct; praefrontal much enlarged; four upper labials. Body with 20 or 22 scales round the middle; its diameter 50 to 68 times in the total length; tail two times and a half as long as broad, ending in a spine.

Pale brown above, lighter below. Total length $410 \mathrm{~mm}$.

Habitat: Borneo (Baram); Sangir Islands; Misol. Philippines; N. W. Australia.

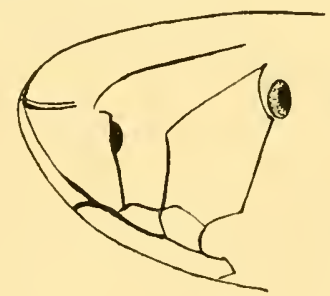

\section{Typhlops lorenzi Werner.}

Typhlops lorenzi, Werner, Mitt. Naturh. Mus. Hamburg XXVI 1909, p. 209.

Snout with a sharp horizontal edge, projecting; nostril inferior. Rostral not quite half the width of the head, not extending to the level of the eyes;

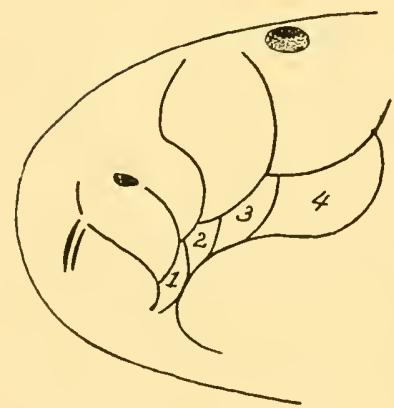
nasal incompletely divided, the cleft proceeding from the first labial; praeocular present, about. as broad as the ocular, in contact with the second and third labials; eyes very distinct; scales between the eyes a little enlarged; four upper labials, increasing in size. Body with 22 scales round the middle; its diameter 56 times in the total length; tail a little more long than

Fig. 2. Typhlops lorenzi

Werner. Head-shields. After a drawing of Dr. Duncker. broad, ending in a spine.

Greyish-green above; rostral brown, bordered with light. Lower surface light olive-green. Total length $337 \mathrm{~mm}$. (After WERnER; not seen by me).

Habitat: Pulu Miang besar, east off Borneo. 
IO. Typhlops kapaladua Annandale.

Typhlops kapaladua, N. Annandale, J. Asiat. Soc. Bengal I I905, p. 208.

Snout rounded, obtuse, projecting; nostril lateral. Rostral one third to half the width of the head, extending to the level of the eyes behind, separating the nasals completely; nasal completely divided, the cleft proceeding from the second labial and not reaching the upper surface of the head; praeocular present, larger than the ocular, in contact with the second and third labials; eyes barely distinguishable; supraoculars large, frontal and parietals feebly developed. Body stout, with 26 scales round the middle, its diameter 27 times in the total length; tail much more broad

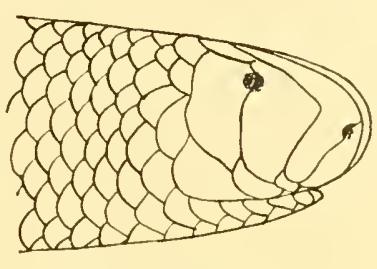

Fig. 3. Typhlops kapaladua Annandale $\times 3$. than long, ending in a spine.

Olive-brown above, each scale with a pale edge; headscales broadly edged with yellow; a yellow $\Pi$ on the snout and a wedge-shaped yellow marking behind each eye; lower part of rostral and labials yellow. Lower surface yellow. Total length $280 \mathrm{~mm}$.; tail $4 \mathrm{~mm}$.

Type-specimen received from the Indian Museum, Calcutta, exanined.

Habitat: "Malay Archipelago"! (Java?).

\section{I. Typhlops depressiceps Sternfeld.}

Typhlops depressiceps, Sternfeld, Sitz. ber. Ges. naturf. Fr. 1913, p. 384 .

Head depressed; snout strongly projecting, with a sharp horizontal edge; nostril inferior. Rostral about three fifths the width of the head, not extending to the level of the eyes; nasal completely divided, the cleft proceeding from the second labial; praeocular present, much larger than the ocular, in contact with the second and third labials; eyes distinct; praefrontals a little enlarged. Body with 24 scales round the middle, its diameter 70 times in the total length; tail about two times and a half as long as broad.

Brownish-yellow above; head and lower surface a little lighter. Total length $328 \mathrm{~mm}$. (After STERNFELd; not seen by me).

Habitat: New Guinea. 


\section{Typhlops conradi Peters.}

Typhlops conradi, Peters, Mon. Berl. Ac. I874, p. I62, pl. without number, fig. I. Typhlops conradi, Boulenger, Cat. Sn. I I893, p. 33; Proc. Zool. Soc. I897, p. 217.

Snout rounded; nostril inferior. Rostral two fifths the width of the head, extending nearly to the level of the eyes; nasal incompletely divided, the cleft proceeding from the second labial; praeocular present, much larger than the ocular, in contact with the second and third labials; eyes distinct; headscales enlarged; four upper labials. Body with is scales round the middle; its diameter $5 \mathrm{~S}$ times in the total length; tail a little more broad than long.

Brown above; head and end of tail white. Lower surface light. Total length $175 \mathrm{~mm}$. (After PETERs; not seen by me).

$\mathrm{Hab}$ it a $\mathrm{t}: \mathrm{N}$. Celebes.

Note. Boulenger supposes, that $T$. conradi Peters may be the same as $T$. ater Schleg. and that the presence of a subocular has not been observed (see Proc. Zool. Soc. I S97, p. 2 I7).

\section{Typhlops bipartitus Sauvage.}

Typhlops bipartitus, Sauvage, Bull. Soc. Philom. (7) III 1879, p. 59.

Typhlops bipartitus, Boulenger, Cat. Sn. I 1893, p. 37.

Snout rounded; nostrils inferior. Rostral large; nasal incompletely divided; praeocular present, as broad as the ocular; eyes distinct in one specimen, not visible in another; four upper labials. Body with 22 scales round the middle; tail more long than broad, ending in a small spine.

Yellowish-green above; light brown below. Total length $250 \mathrm{~mm}$. (After Sauvage; not seen by me).

Habitat: N. New Guinea (Tidore Island?) ${ }^{1}$ ).

\section{I4. Typhlops florensis Boulenger.}

Typhlops florensis, Boulenger, Ann. Nat. Hist. (6) XIX I 897, p. 505.

Snout rounded, projecting; nostril inferior. Rostral about one fourth the width of the head, not extending to the level of the eyes, the lower portion half as broad as long; nasal incompletely divided, the cleft proceeding from the second labial and extending to the upper surface of the snout; praeocular

I) Tidore Island is a small island near Teruate; but T. bipartitus has been enumerated in a list of reptiles from the northern part of New Guinea. 
present, narrower than the ocular, in contact with the second and third labials; eyes distinguishable; praefrontal, supraoculars and parietals enlarged; four upper labials. Body with 22 scales round the middle; its diameter 42 times in the total length; tail twice as long as broad, ending in a spine.

Olive-grey above; whitish below. Total length $255 \mathrm{~mm}$.

Type-specimen examined in the British Museum.

Habitat: Flores!.

\section{I5. Typhlops leucoproctus Boulenger.}

Typhlops leucoproctus, Boulenger. Ann. Nat. Hist. (6) IV I 889 , p. 361 ; Cat. Sn. I I 893, p. 20.

Snout rounded, projecting; nostril lateral. Rostral about onc third the width of the head, extending to the level of the eyes; nasal incompletely divided, the cleft proceeding from the second labial; praeocular present, a little narrower than the ocular, in contact with the second and third labials; eyes distinguishable; head-scales a little cnlarged; four upper labials. Body with 20 scales round the middle; its diameter 40 to 65 times in the total length; tail one time and a half to two times as long as broad, ending in a spine.

Dark brown above, the scales with a light anterior margin in the anterior part of the body; lighter below; labials and anal region yellowish. Total length $220 \mathrm{~mm}$.

Habitat: New Guinea (Fly River!). - Queensland; Murray Island.

\section{I6. Typhlops flaviventer Peters.}

Typhlops flavizenter, Peters, Mon. Berl. Ac. IS64, p. 271.

Typhlops flaziventer, Peters \& Doria, Ann. Mus. Civ. Genova XIII 1878, p. $38_{4}$. Typhlops flaviventer, Boulenger, Cat. Sn. I I \$93, p. 25.

Snout rounded, strongly projecting; nostril lateral. Rostral narrow, its upper part one third the width of the head, extending nearly to the level of the eyes; nasal incompletely divided, the cleft proceeding from the second labial; praeocular present, nearly as large as the ocular; eyes distinct; headscales a little enlarged; four upper labials. Body with 22 scales round the middle; its diameter 50 to 60 times in the total length; tail two times as long as broad, ending in a spine.

Blackish-brown above; yellowish below. Total length $300 \mathrm{~mm}$. 
Habitat: Batjan; Ternate; Halmahera; New Guinea (Fak Fak!, Mansinam Adorĕh, Sattelberg).

\section{I7. Typhlops nigroalbus D. \& B.}

Typhlops nigroalbus, Dum. \& Bibr., Erp. Gén. VI 1844, p. 295. Typhlops nigroalbus, Boulenger, Cat. Sn. I I893, p. 24.

Snout rounded, strongly projecting; nostril lateral. Rostral narrow, its upper part about one third the width of the head, extending to between the eyes or not quite so far; nasal incompletely divided, the cleft proceeding from the second labial; praeocular present, broader than the ocular, in contact

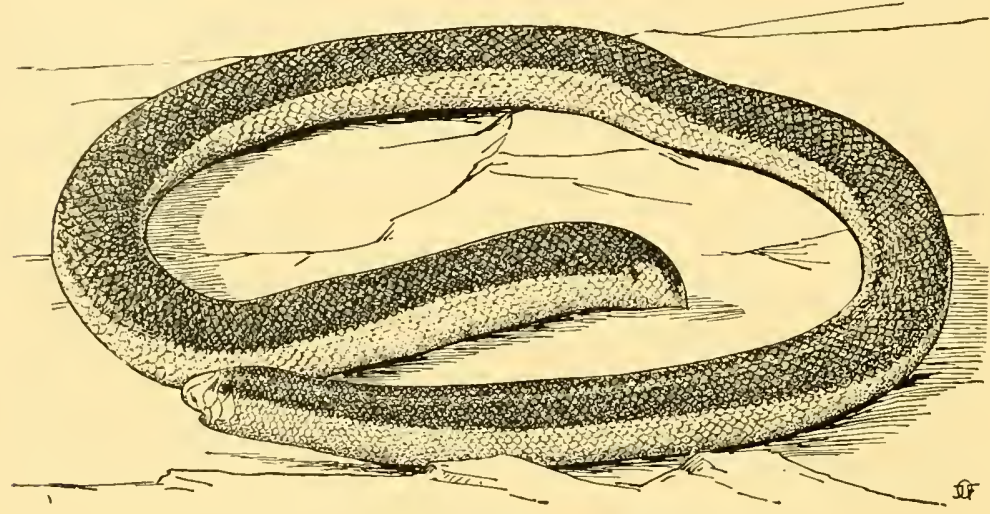

Fig. 4. Typhlops nigroalbus D. \& B. $X^{4} / 5$.

with the second and third labials; eyes distinct; head-scales much enlarged; four upper labials. Body with 26 scales round the middle; its diameter 30 to 33 times in the total length; tail more broad than long, ending in a spine.

Black above; yellowish below. Total length $360 \mathrm{~mm}$.

Nom. ind ig. Ular balang.

Habitat: Nias!; Sumatra (Pakanten!, Surian!, Padang!); Borneo (Samarinda!). - Malay Peninsula; Penang; Singapore; Siam.

\section{IS. Typhlops mülleri Schlegel.}

Typhlops mülleri, Schlegel, Abbild. I $\$ 44$, p. 32, pl. XXXII, fig. 25-28. Typhlops muelleri, Boulenger, Cat. Sn. I I 893, p. 25.

Differs from $T$. nigroalbus on the following points: Rostral broader and shorter, half the width of the head, not extending 
to the level of the eyes. Scales in 26 or 28 series. Total length $285 \mathrm{~mm}$.

Type-specimen examined in the Leiden Museum.

Habitat: Sumatra (Bila Penang, Labuan, Deli, Indragiri, Padang!).

\section{Typhlops ater Schlegel.}

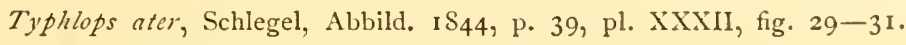

Typhlops ater, Boulenger, Cat. Sn. I I 993 , p. 53.

Snout rounded, nostril lateral. Rostral oval, long, extending to the level of the eyes; nasal completely divided, the cleft proceeding from the second labial; praeocular present, separated from the labials by a subocular; ocular in contact with the third and fourth labials; eyes distinct, under the suture between the praeocular and the ocular; four upper labials. Body with 18 scales round the middle; its diameter 68 times in the total length; tail nearly two times as long as broad, ending in a very small spine.

Black or dark brown above; reddish-brown below, inferior part of head and anal region white. Total length $164 \mathrm{~mm}$.; tail $6 \mathrm{~mm}$.

Type-specimen examined in the Leiden Museum.

Habit a t: Java!; Celebes (Tomolon!); Ternate; Halmahera.

\section{Typhlops bisubocularis Böttger.}

Typhlops bisubocularis, Büttger, Zool. Anz. XVI I S93, p. 336.

Typhlops bisubocularis, Boulenger, Cat. Sn. III I 896, p. 590.

Snout rounded, projecting; nostril lateral. Rostral about a third the width of the head; nostril between two nasals, the anterior small and in contact with the first and second labials; praeocular present, longer and narrower than the ocular, separated from the labials by two large suboculars, the anterior smaller than the posterior; borders of eyes not distinct; headscales in three transverse series, broader and nearly two times as long as the scales of the body, especially the praefrontal; four upper labials. Body with is scales round the middle; its diameter 44 times in the total length; tail one time and a half as long as broad, with a very small and short spine at the end.

Dark grey above, each scale with narrow light edges. Lower surface light grey with broad light edges; edges of the headscales, snout, chin, end of tail and some spots of the anal 
region white. Total length I3I $\mathrm{mm}$; tail $4.5 \mathrm{~mm}$. (After BÖTTGER; not seen by me).

Habitat: West-Java.

\section{I. Typhlops inornatus Boulenger.}

Typhlops inornatus, Boulenger, Ann. Nat. Hist. (6) I r888, p. 344; Cat. Sn. I I893, p. 54.

Snout rounded, depressed, projecting; nostril lateral. Rostral nearly half the width of the head, not extending to the level of the eyes; nostril between two nasals, the anterior in contact with the first and second labials; praeocular present, larger than the ocular, in contact with the second and third labials; a single subocular; eyes distinct; head-scales a little enlarged; four upper labials, third largest. Body with 20 scales round the middle; its diameter 43 times in the total length; tail a little more long than broad, ending in a spine.

Black above; a little lighter below; mouth bordered with yellow; anal region or end of tail yellow. Total length $170 \mathrm{~mm}$.

Type-specimen examined in the British Museum.

Habitat: New Guinea (Sogere I750 feet!, Albert Edward Ranges 6000 feet!).

2. Fam. BOIDAE.

Body strong, covered with uniform scales above; ventral

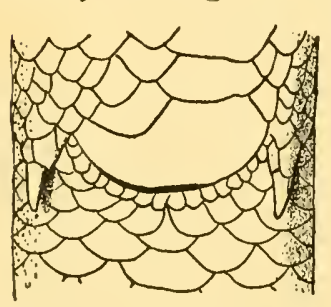

Fig. 5. Python molurus (L.)

Hind limbs. Nat. size. scales transversely enlarged; eyes exposed. Ectopterygoid present; pterygoids, palatines and maxillaries movable, the former extending to the quadrate or mandible; supratemporal present, suspending quadrate; praefrontal in contact with nasal. Jaws toothed; mandible with coronoid; a mental groove. Small parts of pelvis and hind limbs, latter usually ending in a claw, visible on each side of the anal opening (fig. 5).

Key to the Indo-Australian subfamilics and genera. A. Supraorbital bone present ............. Pythoninae.

I. Praemaxillary toothed.

a. Rostral and anterior upper labials without or with shallow pits; tail not or slightly prehensile. 
1. Nostril lateral, between two nasals..... I. Nardoa p. I5.

2. Nostril supero-lateral in a partly divided

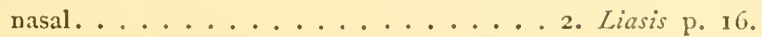

b. Rostral and anterior upper labials deeply pitted;

tail prehensile ............... Python p. 19.

II. Praemaxillary toothless.......... 4. Chondropython p. 28 .

F. No supraorbital bone; praemaxillary toothless ... Boinae.

Head distinct from neck; anterior teeth enlarged . 5. Enygrus p. $3 \mathbf{I}$.

Subfamily Pythoninae.

I. Nardoa Gray.

(GraY, Zool. Miscell. p. 45, I842).

Head slightly distinct from neck, covered with symmetrical shields; nostril lateral, between two nasals, which are separated from their fellows by the internasals; some of the lower labials pitted; eye small, pupil vertical; praemaxillary toothed; anterior teeth very long. Body a little compressed, covered with smooth scales. Tail short, not or slightly prehensile; most of the subcaudals in two rows:

Distribution. New Guinea; Bismarck Archipelago.

A single species.

\section{Nardoa boa (Schlegel).}

Tortrix ioa, Schlegel, Phys. Serp. I $\$_{37}$, p. 22. Lardoa boa, Boulenger, Cat. Sn. I I $\$ 93$, p. 76.

Rostral about twice as broad as deep, not visible from above; internasals more broad than long, two fifths to one third the length of the praefrontals; one pair of praefrontals; frontal as long as broad or a little more long; two pair of parietals; loreal small; one large praeocular; two (three) postoculars; nine to twelve upper labials, two or three entering the eye; three or four of the posterior lower labials pitted. Scales in 35-39 rows;

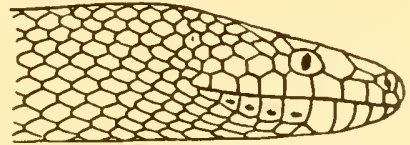

Fig. 6. Nardoa boa (Schlegel). After SCHLEgeL. ventrals 245-267; anal entire; subcaudals $47-52$.

Brown with black rings or uniform blackish-brown; a light spot behind the eye. Young specimens with black and orange rings. Length of head and body $\delta_{30} \mathrm{~mm}$; t tail $\mathrm{I} 20 \mathrm{~mm}$.; largest specimen known I $540 \mathrm{~mm}$. 
Habitat: New Guinea (Simpsonhafen). - Bismarck Archipelago.

Feeds on mice; nocturnal.

\section{Liasis Gray.}

(Gray, Zool. Miscell. p. 44, 1842).

Head distinct from neck, covered with symmetrical shields; nostril in a semi-divided nasal; a pair of internasals, separating the nasals; rostral and upper labials pitted or without pits; some lower labials pitted; eye rather small; pupil vertical; praemaxillary toothed; anterior teeth very long. Body cylindrical or a little compressed, covered with small smooth scales. Tail moderate or short, not or very slightly prehensile; subcaudals in two rows or the greater part only.

Distribution. Timor; New Guinea; N. Australia.

$$
\text { Key to the Indo-Australian species. }
$$

A. Rostral without pits ............... I. L. fuscus p. I6.

$B$. Rostral with a pit or groove on each side.

1. Two pair of praefrontals.

a. Rostral scarcely visible from above; two postoculars; first and second upper and five lower labials pitted ................ 2. L. mackloti p. I7.

b. Rostral clearly visible from above; three postoculars; first, second and third upper and three lower parietals pitted. . . . . . . . . 3. L. tornieri p. Is.

II. A single pair of praefrontals.

I. Upper labials 12 or 13 , two or three anterior pitted; 6 lower labials pitted; parietals followed by small shields; subcaudals $62-79 \ldots . .44$. L. albertisi p. I8.

2. Upper labials Io or II, two or three anterior pitted; 4 lower labials pitted; parietals as long as frontal; subcaudals $82-88 \ldots \ldots . . .5$. . . papuanus p. I9.

\section{Liasis fuscus Peters.}

Liasis fuscus, Peters, Mon. Berl. Ac. I873, p. 607.

Liasis fuscus, Boulenger, Cat. Sn. I I 993, p. 78 (s. syn.).

Rostral more broad than deep, just visible from above, not pitted; internasals more long than broad, half the length of the praefrontals, which extend to the frontal or are separated 
from it by a small shield; a second pair of much smaller praefrontals, separated from one another by the first pair of praefrontals; frontal about one time and a half as long as broad, slightly shorter than its distance from the tip of the snout; one or two pair of parietals; a single large loreal; one prae- and two postoculars; ten to twelve upper labials, first with a shallow pit, fifth and sixth or sixth and seventh entering the eye; three or four posterior lower labials pitted. Scales in 47 or 49 rows; ventrals $275-29 \mathrm{I}$; anal entire; subcaudals $65-72$.

Brown above; yellowish below. Length of head and body I $140 \mathrm{~mm}$; t tail $190 \mathrm{~mm}$.

Habitat: Timor ${ }^{1}$ ); New Guinea (Fly river!). - Islands of Torres Straits; N. Australia.

\section{Liasis mackloti D. \& B.}

Liasis mackloti, Dum. \& Bibr., Erp. Gén. VI I $\$_{44}$, p. 440.

Liasis mackloti, Boulenger, Cat. Sn. I IS93, p. 79.

Rostral more broad than deep, scarcely visible from above, with a feeble pit on each side; internasals a little more long than broad, hardly half the length of the praefrontals, which

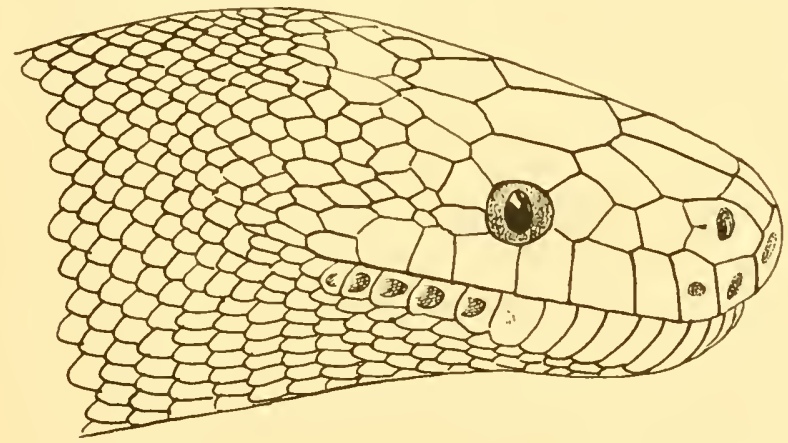

Fig. 7. Tiasis mackloti D. \& B. $X \mathrm{I}^{3} / 4$.

separate the posterior, smaller pair of praefrontals; frontal about one time and a half as long as broad, as long as its distance from the tip of the snout; a pair of parietals, followed by smaller shields; a large loreal; one prae- and two postoculars; eleven upper labials, first and second pitted, fifth and sixth entering the eye; five posterior lower labials pitted.

I) See Bethencourt Ferreira, J. Sc. Lisboa (2) V I 898 , p. I 54.

INDO-AUSTRALIAN REPTILES II. 
Scales in 49-55 rows; ventrals 267-302; anal entire; subcaudals $64-49$.

Brown above, with scattered, small, yellowish and dark brown spots. Lower surface yellowish or brownish. Length of head and body $1420 \mathrm{~mm}$.; tail $260 \mathrm{~mm}$.

Nom. indig. Ular menke (Timor).

Habitat: Savu!; Samao!; Timor!.

\section{Liasis tornieri Werner.}

Liusis Tornieri, Werner, Zool. Anz. XX r\$97, p. $26 \mathrm{r}$; Verh. Ges. Wien I.I I901, p. 611 .

Rostral two times as broad as deep, clearly visible from above, with a shallow groove on each side; internasals one time and a half as long as broad, two thirds the length of the praefrontals, which separate the posterior pair of small praefrontals; frontal about one time and one fourth as long as broad, as long as its distance from the rostral; a pair of parietals; a single large loreal; a large praeocular, with a very small subocular below it (on one side); three elongate postoculars; eleven upper labials, first to third with a groove, fifth and sixth entering the eye; three posterior lower labials grooved. Scales in 65 rows; ventrals 375 ; anal entire; subcaudals 86 , of which the first four are paired, the next four single, $6_{5}$ paired and I $_{3}$ single.

Brown above; head with dark dots. Lower surface yellowishwhite. Length of head and body $1330 \mathrm{~mm}$; tail $220 \mathrm{~mm}$.; attains a length of 2 M. (After WERNER; not seen by me). Habitat: New Guinea (Stephansort).

\section{Liasis albertisi Ptrs. \& Doria.}

Liasis albertisii, I'eters \& Doria, Ann. Mus. Civ. Genova Nlll I $\$ 7 \$, P \cdot 401$, pl. III, fig. 2 .

leiopython gracilis, Hubrecht, Notes I.eyden Mus. I IS79, p. I5. liasis albertisii, Boulenger, Cat. Sn. I 1893, p. So.

Rostral more broad than deep, just visible from above, with a groove or pit on each side; internasals a little more long than broad, not half as long as the praefrontals; praefrontals large, in a single pair; frontal a little more long than broad, shorter than its distance from the tip of the snout; a pair of parietals, followed by small shields; a single, large loreal; a 
large praeocular and three or four postoculars; twelve or thirteen upper labials, first two or three pitted, fifth and sixth or fifth to seventh entering the eye; six posterior lower labials pitted. Scales in $49-55$ rows; ventrals $262-284$; anal entire; subcaudals $62-79$.

Reddish-brown above; head blackish; labials yellow with black bars. Lower surface yellow. Length of head and body I $250 \mathrm{~mm}$.; tail $200 \mathrm{~mm}$.; attains a length of more than $2 \mathrm{M}$.

Habitat: Salawatti! (type of Leiopython gracilis Hubr.); New Guinea (Kapaor, Aroma, Rigo, Bara Bara, Inawi, Madew on St. Joseph river $2-3000$ feet).

\section{Liasis papuanus Ptrs. \& Doria.}

Liasis papuanus, Peters \& Doria, Ann. Mus. Civ. Genova XIII I 878 , p. 400, pl. III, fig. I.

Liasis papuanus, Boulenger, Cat. Sn. I rS93, p. So.

Rostral more broad than deep, visible from above, with a shallow groove or pit on each side; internasals about one time and a half as long as broad, two thirds to three fourths the length of the praefrontals; praefrontals large, in a single pair; frontal one time and a half as long as broad, as long as its distance from the rostral; parietals large, equalling the frontal; a single large loreal; praeocular large; two or three postoculars; ten or eleven upper labials, first two or three pitted, fifth and sixth or sixth and seventh entering the eye; four posterior lower labials pitted. Scales in $65-7 \mathrm{I}$ rows; ventrals $358-390$; anal entire; subcaudals $82-88$.

Olive-brown above; base of scales black. Lower surface yellowish. Length of head and body $1980 \mathrm{~mm}$.; tail $320 \mathrm{~mm}$.; attains a length of $3 \%, \mathrm{M}$.

Habitat: New Guinea (Ramoi, Fak lak!). - Ferguson Island.

\section{Python Daudin.}

(Daudis, Hist. Rept. Y p. 226, ISo3).

Head distinct from neck, covered with symmetrical shields or small scales on the crown and with large shields on the snout; nostril in a semi-divided nasal; a pair of internasals, separating the nasals; rostral and anterior upper labials deeply pitted; some lower labials pitted; eye with vertical pupil; praemaxillary toothed; anterior teeth very long. Body a little 
compressed, covered with small, smooth scales. Tail moderate or short, prehensile; subcaudals in two rows or the greater part only.

Distribution. Tropical and South Africa; S. E. Asia; New Guinea; Australia.

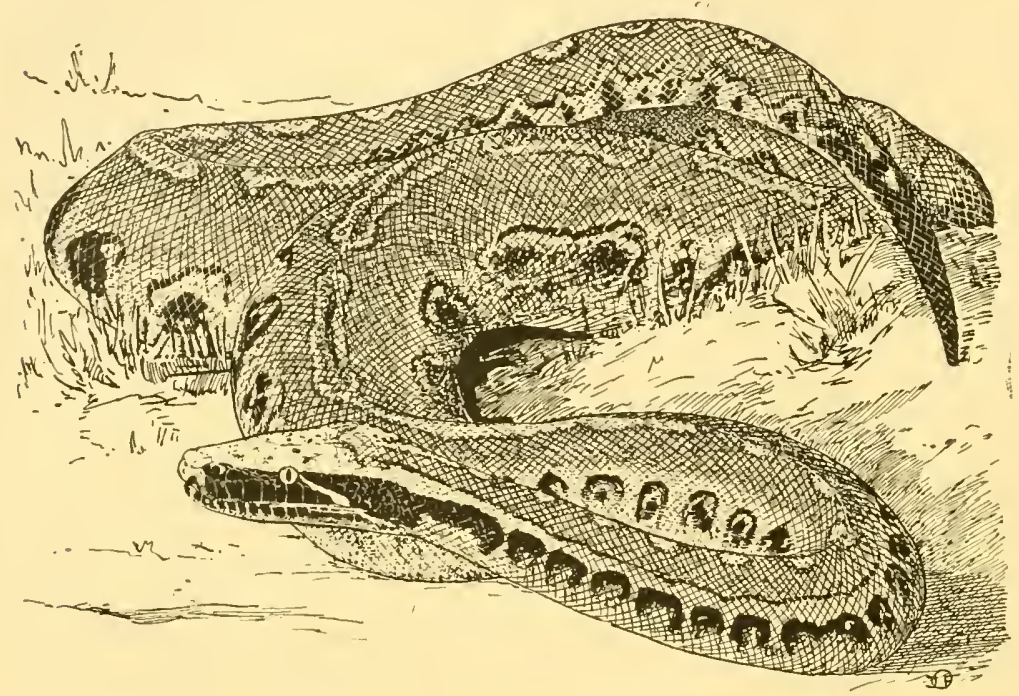

Fig. S. Python curtus Schlegel. $\times \%$.

Key to the Indo-Australian species.

A. Subcaudals more than 50 .

I. More than 60 scales across the body.

a. Four upper labials pitted; $7 \mathrm{~S}-102$ subcaudals. x. P. reticulatus $\mathrm{p} .20$.

b. Two upper labials pitted; $60-72$ subcaudals. 2. I'. molurus p. 22.

11. Scales in 60 rows or less across the body.

a. Crown with large shields; four upper labials pitted.

I. Four or five postoculars; six or seven lower labials pitted.......... 3. P. amethystinus P. 24.

2. Three postoculars; five lower labials pitted. 4. P. timorensis p. 25.

b. Crown with scales or small irregular shields;

$2-3$ upper labials pitted ......... 5. P. spilotes p. 26.

B. Subcaudals $28-32$; two upper labials pitted ... 6. P. curtus p. 28 .

\section{Python reticulatus (Schn.).}

Boa reticulata, Schneider, Hist. Amph. II ISor, p. 264.

Python reticulatus, lioulenger, Cat. Sn. I I 893 , p. $\$_{5}$ (s. syn.). 
Rostral as broad as deep, visible from above, with a deep pit on each side; internasals about one time and a half as long as broad; a pair of large praefrontals; supraocular large, sometimes divided; frontal large, usually single; two prae- and threc or four postoculars; twelve to fourteen upper labials, four anterior deeply pitted, seventh or eighth entering the eye; two or three anterior and five or six posterior lower labials

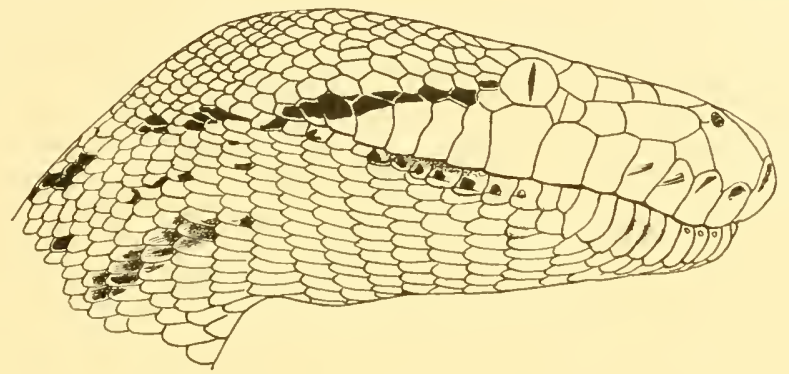

Fig. 9. Python reticulatus (Schn.) $\times 3 / 4$.

pitted (fig. 9). Scales in 69-79. rows; ventrals 297-330; anal entire; subcaudals $78-102$.

Yellowish or brown above, with large dark markings, crossshaped or rhomboidal; a black median line on the head from the tip of the snout to the nape; an oblique dark line from the eye to the corner of the mouth. Lower surface yellowish with small brown spots or brown. Young specimens with three series of whitish, black-edged spots on the back and sides. Total length $7.25 \mathrm{M}$; attains a length of $9 \mathrm{MI}$.

Nom. indig. Ular sawah, ular santja (mal.); sawah-n-ètěm (Simalur); ular petola (Ambon).

Habitat: Simalur!; Nias; Mentawei Islands (Sipora); Sumatra (Atjeh!, Pangkalan Brandan!, Labuan, Medan!, Bralrang!, Langkat, Serdang!, Djambi!, Kertadjaja, Tandjung Laut, Palembang!, Battak Highlands, Padang Bedagei, Ringgat!, Indragiri, Padang Highlands!); Banka!; Riou!; Natuna Islands; Borneo (Singkawang, Sebruang Valley, Kuching, Baram, Lundu, Oya, Rejang river, Sandakan Bay, Bulangan river, Samarinda!, Balikpapan, Muara Djawa!, Bandjermassin); Java! (Batavia, Buitenzorg, Depok, Tengger Mts. I200 M.); Sumbawa; Flores; Timor!; Celebes (Gorontalo, Minahassa, Manado!, Kema, Konaweha river, Kandari, Macassar); Buton; Obi major!; Batjan; Ternate!; Halmahera!; Ambon!; Ceram!; Banda; Timor Laut. - 
Singapore; Penang; Malay Peninsula; Nicobars; Burma; Siam; Indo-China; Philippines.

A very common snake, living in the neighbourhood of water and feeding on mammals and birds; nocturnal. The eggs are large, oval, soft-shelled and are incubated by the female.

\section{Python molurus (L.).}

Coluber molurus, Linné, Syst. Nat. I I 766, p. 387 .

Python bivittatus, part., Schlegel, Phys. Serp. III I 837 , p. 403 , pl. XV, fig. I-4. Python molurus, Boulenger, Cat. Sn. I I 893, p. 87.

Python bivittatus, Werner, Zool. Jahrb. Syst. XXVIII 1909, p. 271.

Rostral more broad than deep, visible from above, with a deep pit on each side; internasals about one time and a half as long as broad; a pair of large praefrontals; supraocular large; frontal divided; two prae- and three or four postoculars; sometimes a series of suboculars (fig. $10 b$ ); eleven to thirteen upper labials, two anterior deeply pitted, usually sixth or seventh entering the eye (fig. IO $a$ ); some anterior and posterior lower labials pitted. Scales in $6 \mathrm{I}-75$ rows; ventrals $242-265$; anal entire; subcaudals 60--72.

Dark brown above, with blackish markings bordering long, subquadrangular spots; flanks with large black-edged spots, with lighter or whitish centres; head with a triangular dark marking, sometimes distinct from the tip of the snout to the nape; a dark lateral streak, passing through the eye and a dark vertical bar below the eye. Lower surface yellowish, brown-spotted on the sides. Length of head and body $2400 \mathrm{~mm}$.; tail $300 \mathrm{~mm}$; reaches a length of $10 \mathrm{M}$.

Habitat: Java; Celebes (Bonthain). - Malay Peninsula; Indo-China; S. China; Siam; India; Ceylon.

N ot e. P. bivittatus Schleg. has been regarded by BOULEnGER as a synonym of P. molumus L. WERNER (op. cit.) distinguishes $P$. bivittatus as a distinct species, after having seen in the Vivarium in Vienna two kinds: light Pythons (molums) and dark Pythons (bivittatus). The difference between these two forms is in the colour, in the scaling of the head and in length. WERNER describes them as follows: In I'. molurus there is one labial entering the eye; the animal does not grow longer than about 4 M. and is of a greyish- or yellowish-brown colour, with reddish-brown, dark-edged spots, those of the flanks 
usually with light centres; on the head the triangular dark marking is only distinct in its posterior part, on the nape (fig. I I $a$ ). This form is found in India and Ceylon.

$P$. bivittatus is distinguished by WERNER by a row of suboculars, by its greater length (IO M.) and by its darker colour, the lanceolate marking on the head is dark and distinct to the tip of the snout (fig. I $b$ ) and the dark spots of the flanks have no light centres. The places, where this form lives are: Indo-China, S. China, the Malay Peninsula, Java and Sumatra?.

After examination of the specimens in the collections of the British Museum, the Leiden and Amsterdam Museums, and the living specimens in the Amsterdam, Rotterdam and

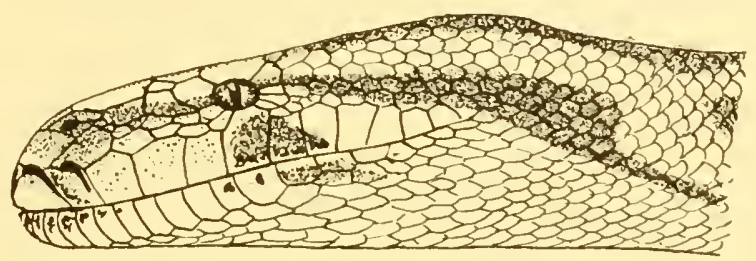

a

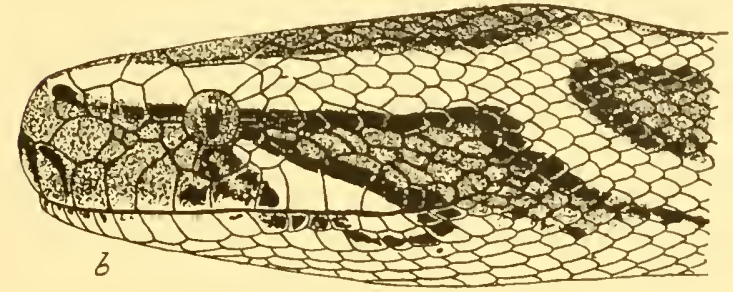

ligr. Io. representing the extremes. $a$. Light Python [P. molurus (L.)] b. Dark Python [P. bivittatus Schleg.]. Nat. size.

London Zoological Gardens, I came to the conclusion, that $P$. bivittatus cannot be held up as a distinct species, but that the specimens of $P$. molurus, living in S. China and Java belong to a darker race than those from the Indian Continent. Proofs for my supposition are the following remarks. A young, light-coloured specimen from Assam in the British Museum, with the dark marking on the head distinct as far as the praefrontals has a series of suboculars; the skin from Hyderabad. Sind in Russell's Indian Serpents is light-coloured but the triangular marking on the head is distinct as far as the nasals; a young specimen from India, also light-coloured has the dark marking on the head sharply defined as far as the internasals, 
its seventh labial shows a curious shape, it is entering the eye, but a subocular is nearly formed (figured by BUULENGER, Reptiles Malay Peninsula igr2, fig. 30, p. 106). The dark form found in Java may be named $P$. molurus sondaica Werner (see: Der Zoologische Garten XL, 1899, p. 24).
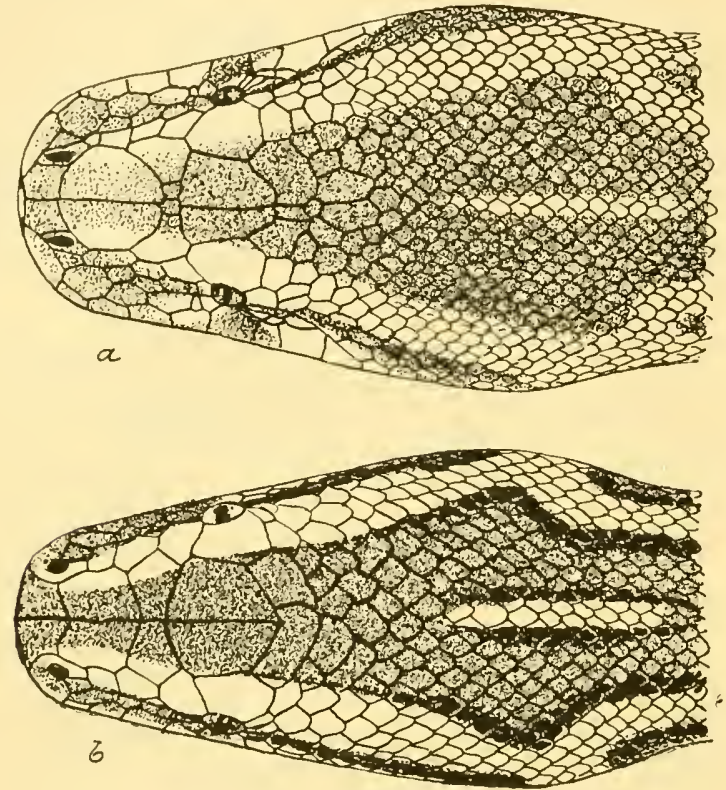

Fig. II. representing same specimens of fig. Io. $a$. Light Python [P. molurus (1..)] b. Dark Python [P. bivittatus Schleg.] Nat, size.

The specimen of $P$. molurus from Macassar, mentioned by A. B. Meyer (Abh. Mus. Dresden 1886/87, p. 13) is not found in the Dresden Museum. But the collections of this Museum contain another specimen of the same species, collected by RibBE \& KüHN near Bonthain, S. Celebes.

\section{Python amethystinus (Schn.).}

Boa amethystina, Schneider, Hist. Amph. II ISoI, p. 254. Python amethystinus, Boulenger, Cat. Sn. I I 893, p. $S_{3}$ (s. syn.).

Rostral as broad as deep or a little more broad than deep, visible from above, with a deep pit on each side; internasals as long as broad or a little more long than broad; praefrontals large, a second pair of smaller praefrontals, separated from one another; frontal large, in contact with the anterior pair of praefrontals or separated from them by one or two shields; 
supraocular large; two or three pair of parietals; loreal region covered with smaller shields (fig. I2); two or three prae- and four of five postoculars; twelve to fourteen upper labials, four anterior deeply pitted, sixth and seventh or seventh and eighth entering the eye; six or seven posterior lower labials pitted. Scales in 39-53 rows; ventrals 289-349; anal entire; subcaudals $85-120$.

Yellowish- or reddish-brown above, uniform or with dark

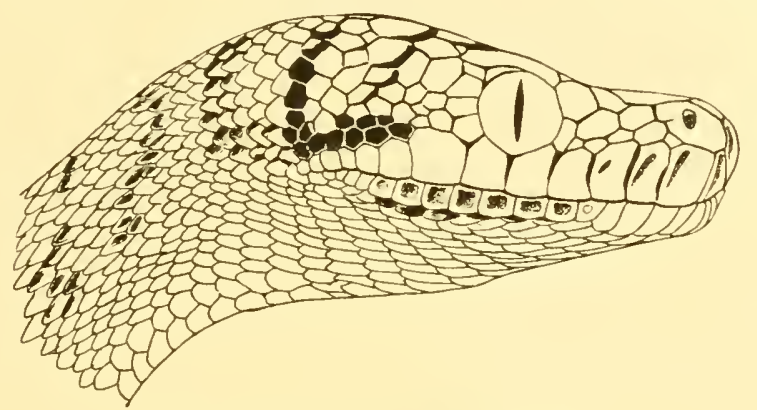

Fig. 12. J'ython amethystinus (Schn.) X2.

markings. Lower surface yellowish. Length of head and body $2710 \mathrm{~mm}$; tail $400 \mathrm{~mm}$; ; attains a length of $31 \% \mathrm{M}$.

Habitat: Timor; Banda; Saparua!; Ambon!; Ceram!; Haruku!; Halmahera; Batjan!; Salawatti; Misol; New Guinea (Jobi, Yule and Nicura Islands, Sorong, Fak Fak, Jakati, Mansinam, Humboldt Bay!, Jamur river, Tobadi, Setekwa river, Lorentz river!, Erima, Astrolabe Bay, Stephansort, Eitapé, Garup, Simpsonhafen, Fly river, St. Joseph river, Moroka in Bartholomew Range 2300 feet, Bara Bara); Kei Islands; Aru Islands; Timor Laut. - Trobriand Island; Bismarck Archipelago; Islands of Torres Straits; N. Queensland.

Note. BOULENGER distinguishes three groups of colour varieties:

I. Uniform brown, or with indistinct dark and light markings;

2. Pale brown with dark cross-shaped markings and two stripes on each side;

3. Dark reddish-brown, with whitish spots or irregular transverse bars.

4. Python timoriensis (Ptrs.).

Liusis amethystinus var. timoricnsis, Peters, Mon. Berl. Ac. IS76, p. 533, pl. without number, fig. 3 . 
Liasis Petersii, Hubrecht, Notes Leyden Mus. 1 I879, p. 16.

Python timorcnsis, Boulenger, Cat. Sn. I IS93, p. 85.

Rostral as broad as deep, just visible from above, with a deep pit on each side; internasals much more long than broad, as long as the anterior praefrontals; a second pair of praefrontals; supraocular and frontal large; two pair of parietals; loreal region covered with small shields (fig. I 3 ); a large and a

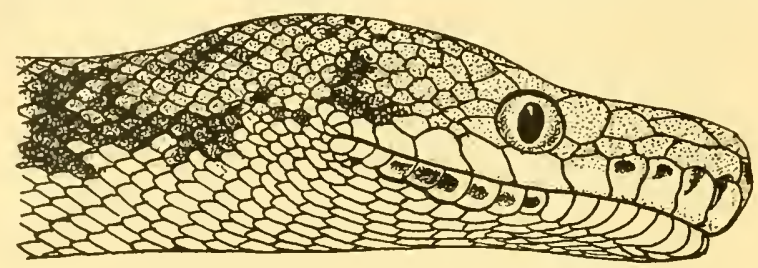

Fig. 13. Python timoriensis (Ptrs.)

Type of Liasis Petersii Hubr.

small praeocular; three postoculars; twelve upper labials, four anterior deeply pitted, sixth entering the eye; five of the lower labials pitted. Scales in 60 rows; ventrals 288; anal entire; subcaudals $22+$ ?, last 9 single.

Reddish-brown above, with blotches of dark scales; head with a median dark line. Lower surface yellow. Length of head and body $793 \mathrm{~mm}$; tail (broken) $45 \mathrm{~mm}$.

Habitat: Flores! (type of Liasis Petersii Hubr.); Timor.

\section{Python spilotes (Lacépède).}

Coluber spilotes, Iacépède, Ann. Mus. IV I804, p. I 94, 209.

Python spilotes, Boulenger, Cat. Sn. I I $\$ 93$, p. S2 (s. syn.).

Rostral as broad as deep, or a little more deep than broad,

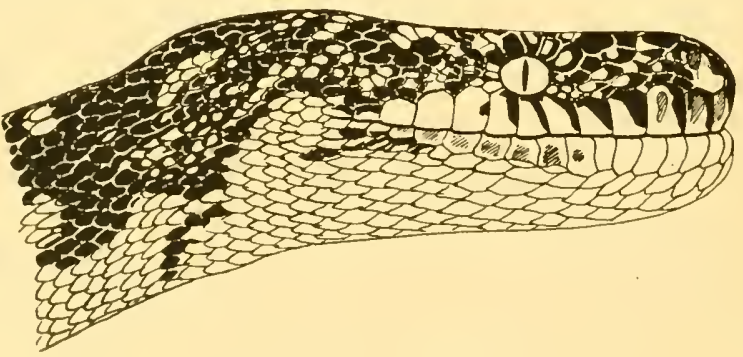

Fig. 14. I'ython spilotes (Lac.) Nat. sizc.

visible from above, with a deep pit on each side; internasals ats long as broad; a pair of praefrontals, sometimes broken up into 
small shields, like the other scales of the crown; sometimes a frontal and two or three supraoculars distinguishable; loreal region covered with small scales (fig. I4); eleven to thirteen upper labials, two or three anterior deeply pitted, sixth and seventh or seventh and eighth entering the eye; six or seven lower labials pitted. Scales in 45-53 rows; ventrals 25 I-304; anal entire or divided; subcaudals $63-92$.

Black, olive-brown or pale brown above, variegated with yellow and black. Length of head and body $1750 \mathrm{~mm}$; tail $250 \mathrm{~mm}$.

Habitat: New Guinea (Yule Island, St. Joseph river). Australia.

This tree-Python is very variable in coloration. Three forms may be distinguished:

I. Black above, each scale with a yellow dot, and sometimes with scattered yellow, black-edged spots; upper labials blackedged. Lower surface yellow, posterior ventrals and subcaudals spotted or edged with black.

2. Olive-brown above, each scale edged with black, with yellow, black-edged spots and transverse bars, or with three yellow stripes, the middle one partly interrupted; upper labials black-edged. Lower surface yellow, posterior ventrals and subcaudals spotted or edged with black.

3. Pale brown with dark brown, black-edged spots or transverse bands, or dark brown with lighter markings; upper labials yellow or anterior labials black-edged; sometimes a light, darkedged streak on each side of the body anteriorly. Lower surface yellow, spotted with black.

\section{var. macrospila IVerner.}

Python spilotes var. macrospila, Werner, Zool. Jahrb. Syst. XXVIII I 909, p. 274.

Differs on the following points:

Rostral followed by 3 pair of shields; five or six lower labials pitted. Scales in 41 rows. Three series of dark spots, alternating.

Length of head and body $1500 \mathrm{~mm}$.; tail $250 \mathrm{~mm}$. (After WERNER; not seen by me).

Habitat: ? A single male specimen in the Brussels Museum. 


\section{Python curtus Schlegel.}

Sython curtus, Schlegel, Dierentuin, Rept. 1872, p. 54, with fig. F'ython curtus, Boulenger, Cat. Sn. I I 893 , p. So (s. syn.).

Rostral more broad than deep, visible from above, with a decp pit on each side; internasals as long as broad; two pair of large pracfrontals; frontal longitudinally divided; supraocular large; several pair of transverse parietals; loreal large; a praeocular with small scales below it (fig. I 5); one or two postoculars; sometimes a series of suboculars; ten or eleven upper labials, two anterior deeply pitted; anterior and posterior lower labials feebly pitted. Scales in 53-57 rows; ventrals I60-I75, anal entire; subcaudals $26-32$.

Brown or red above, with round pale spots, sometimes confluent, on the vertebral line; flanks with grey, black-edged

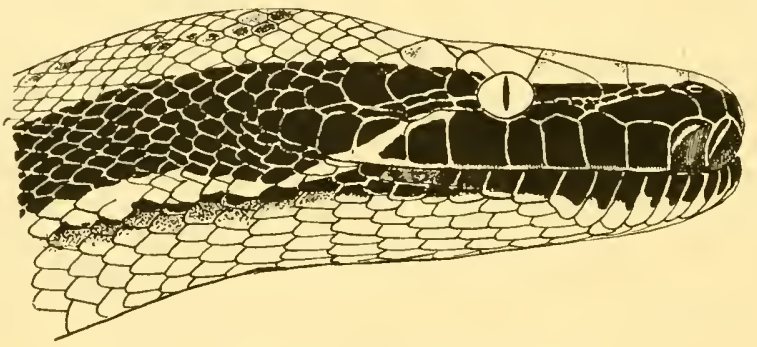

Fig. 15. P'ython curtus Schleg. Nat. size.

spots or wavy bands; head with a black median line, followed by white, black-edged spots; a broad dark band on each side of the head, with an oblique white streak from the eye to the corner of the mouth. Lower surface whitish, sometimes spotted with brown. Length of head and body $1250 \mathrm{~mm}$.; tail $120 \mathrm{~mm}$; attains a length of $3 \mathrm{M}$.

Habitat: Sumatra (Medan in Deli!, Surbo Dolok in Raja Mts.); Borneo (Kuching, Lawas in Bruni, Sibu, Telang). Singapore; Malay Peninsula.

Likes swampy country; feeds chiefly on rats.

\section{Chondropython Meyer.}

(A. B. Meyer, Mon. Berl. Ac. p. I34, IS74).

Head distinct from neck, covered with small scales; nostril in a single or divided nasal; a pair of internasals, separating the nasals, and separated from each other by small scales; 
rostral, anterior upper labials and a few lower labials deeply pitted; eye with vertical pupil; praemaxillary without teeth; anterior teeth large, posterior small. Body a little compressed, covered with small, smooth scales. Tail moderate, prehensile; subcaudals in two rows.

Distribution. New Guinea; Aru Islands.

A single species.

\section{Chondropython viridis (Schlegel).}

Python viridis, Schlegel, Dierentuin, Rept. I\$72, p. 54.

Chondropython viridtis, Boulenger, Cat. Sn. I I\$93, p. 90 (s. syn.).

Rostral as broad as deep, or a little more narrow than deep; a pair of nasals and a pair of internasals; head covered with small scales, I 7-20 from eye to eye on the forehead; scales round the eye not larger than the others; twelve to fifteen upper labials, two or three anterior pitted; sixth to eighth or eighth and ninth entering the eye; seventh to twelfth, eighth to thirteenth, or ninth to fourteenth lower labials pitted. Scales in $57-65$ rows; ventrals 227-254; anal entire; subcaudals 68-I29.

Green above, uniform or with small yellow spots along the back; or red with bluish, black-edged spots. Lower surface whitish or yellowish. Young specimens pinkish or yellow, with red or red-brown markings or rust-brown with sulphurous spots. A young specimen from the Lorentz river, S. New Guinea showed the following colours: reddish-brown above; a narrow dark line from the nape to the tail not broader than one scale; on each side of this line a series of triangular yellow spots, bordered with brown, most of them alternating; along each side of the body a series of small yellow spots, covering about three or four scales; on each side of the head a line from the nostril to the temporal region, passing through the eye; two yellow spots between the eyes; on the occiput a -shaped band; just behind the head an elongate yellow spot, bordered with brown; tail with dark brown transverse lines. Length of head and body $1250 \mathrm{~mm}$.; tail $200 \mathrm{~mm}$.

Nom. indig.: Yamomong (German New Guinea).

Type-specimen examined in the Leiden Museum.

Ha bitat: Aru Islands! (Manumbai on Kobroor); New Guinea (Jobi, Mafoor, Mt. Arfak, Mansinam, Andai!, Humboldt Bay!, lake Sentani, Mimika-, Setekwa- and Lorentz! rivers, Eitapé, 


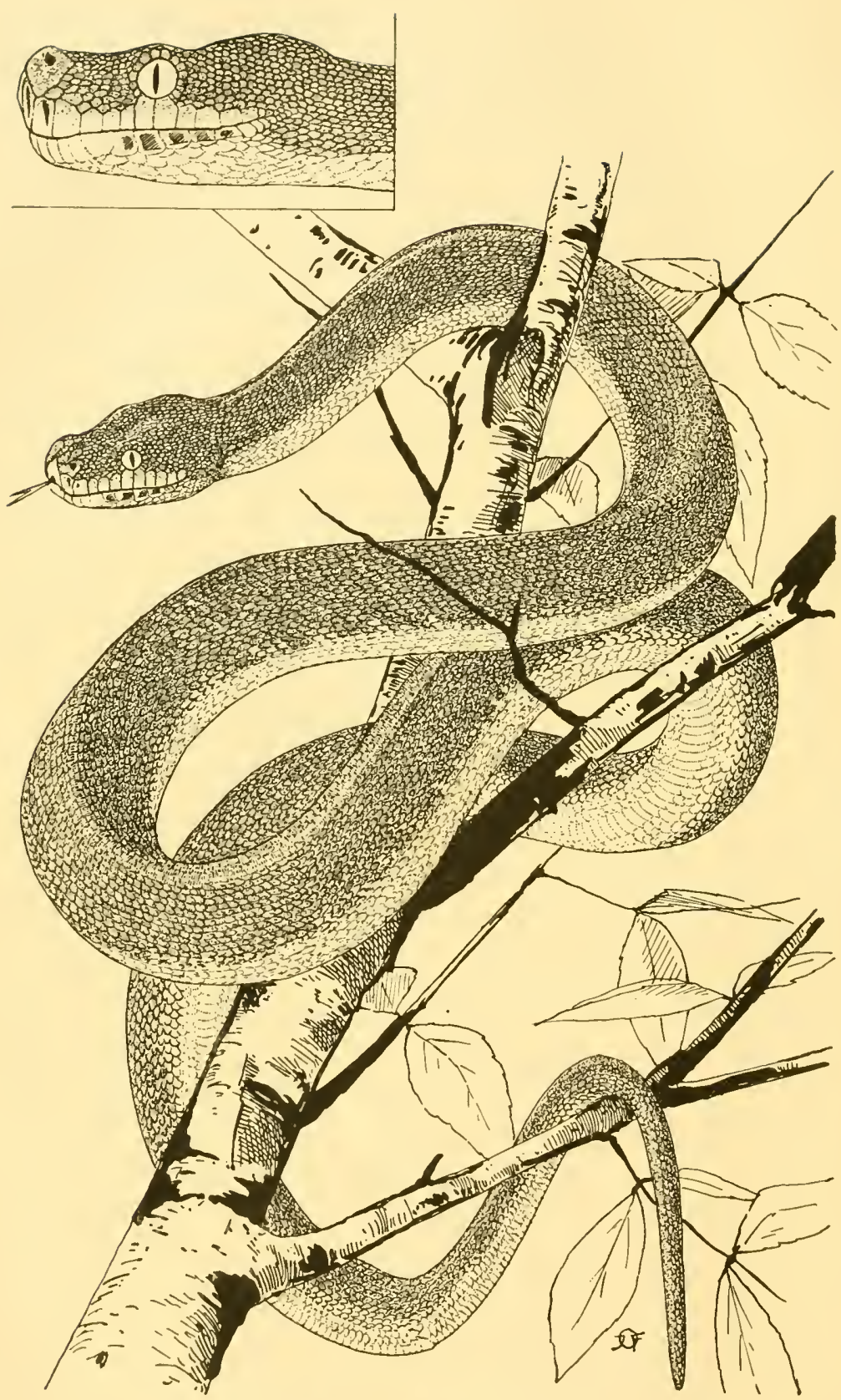

Fig. 16. Chondropython viridis (Schleg.) $\times 1 / 2$. Head $\times i / 8$. 
Bogadjim, Bongu, Astrolabe Bay, Sattelberg Soo M., Bara Bara, Albert Edward Range 6000 feet, Dinawa in Owen Stanley Range, Milne Bay, St. Joseph river); Schouten Islands (Mysore).

\section{Subfamily Boinae.}

5. Enygrus Wagler.

(WAgLer, Syst. Amph. p. I66, I8 30 ).

Head distinct from neck, covered with small scales; eye with vertical pupil; praemaxillary without teeth; anterior teeth large, posterior small. Body compressed, covered with kceled scales. Tail short, prehensile; subcaudals single.

Distribution. Moluccas; New Guinea; Polynesia.

Key to the Indo-Australian species.

A. Two or three labials entering the eye ....... I. E. carinatns p. 3 I. l. A series of suboculars.

I. Subcaudals $14-22 \ldots \ldots \ldots$. . . . . . . . . . . . . 32.

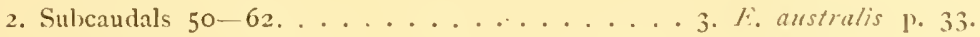

\section{Enygrus carinatus (Schn.).}

liou carinata, Schneider, Hist. Amph. II I8or, p. 26 I.

Enygrus carinatus, Boulenger, Cat, Sn. I I\$93, p. 107 (s. syn.).

Snout very promincnt, obliquely truncate; canthus rostralis angular; rostral more broad than deep, not visible from above; sometimes some supraocular scales enlarged; head with small, irregular scales, with small tubercles or short keels, five to ten scales between the eycs on the forehead; eyc bordered by IO-I 4 scales; ten to thirteen upper labials, two or three entering the eye. Scales in 33-43 rows, all strongly keeled, the kecls forming straight lines; ventrals $160-200$; anal entire; subcaudals $38-56$.

Yellowish or pale reddish-brown above with dark brown markings. Length of head and body $790 \mathrm{~mm}$; tail I IO $\mathrm{mm}$.

Habitat: Celebes (Minahassa); Sangir Islands; Salibabu Islands!; Halmahera!; Ternate!; Batjan!; Ceranı!; Ambon!; Haruku!; Saparua!; Banda; Goram; Timor Laut; Misol; Batanta; Salawatti; New Guinea (Jobi, Rubi, Dorei, Sorong, Andai, Mansinam, Djamna Island, Wendèsi, Mawes, Humboldt Bay, Tanah Merah Bay!, Kaiserin-Augusta or Sepik river!, Mimika river, Lorentz river, Tami, Bongu, Bogadjim, Simpsonhafen, 
Friedrich-Wilhelmshafen, Erima, Astrolabe Bay, Huon Bay, Bukaua, Sattelberg, Bara Bara, Haveri); Valise Island; Schouten Islands (Mysore). - Ferguson Island; Trobriand Island; Woodlark Island; Louisiade Archipelago; Solomon Islands; Bismarck Archipelago; Pelew Islands.

Three groups of colour varieties may be distinguished:

I. Yellow or pale brown above, with dark markings and stripes; lores and temples dark brown with yellow spots. Lower surface yellow, with dark brown blotches or a stripe on each side and speckled with brown in the middle.

2. Yellow or brown above, with a dark zigzag dorsal band or rhomboidal blackish spots; head with a dark streak on each side. Lower parts spotted with black.

3. Y ellow or pale red-brown above, uniform or with dark spots. Lives on trees.

\section{Enygrus asper (Gthr.).}

Erebophis asper, Günther, Proc. Zool. Soc. I877, p. I32, pl. XXI. Enygrus asper, Boulenger, Cat. Sn. I I 893 , p. Iog.

Snout prominent, oblique, truncate; canthus rostralis angular; rostral more broad than deep, not visible from above; head

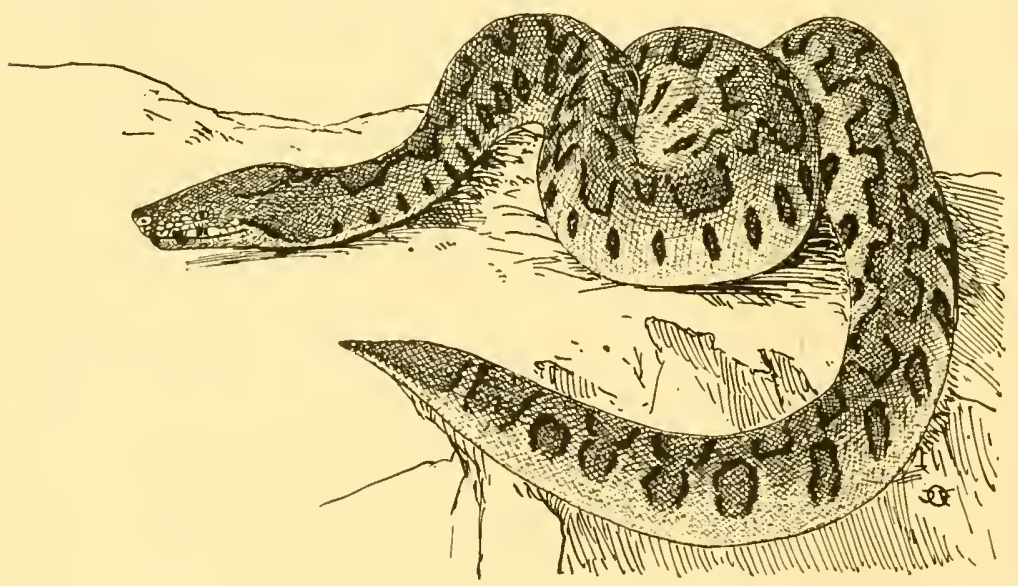

Fig. 17. Enygrus asper (Gthr.) $\times 1 / 3$.

covered with small irregular scales with small tubercles or short keels; 8 -II scales between the eyes on the forehead; eye bordered by Io to I5 (IS) scales; nine to thirteen upper labials separated from the eye. Scales in 33-39 rows, 
all strongly keeled, the keels forning oblique lines; ventrals I30-I53; anal entire; subcaudals I4-22.

Red-brown above, with a series of large, dark, black-edged spots on the back, sometimes confluent into a zigzag stripe. Lower surface yellow, uniform or brown-spotted. Length of head and body $930 \mathrm{~mm}$; t tail $55 \mathrm{~mm}$.

Habitat: Goram; Misol!; Batanta; Salawatti; Waigeu!; New Guinea (Jobi, Sorong, Fak Fak, Andai, Mawes, Moaif, Matterer Bay, Humboldt Bay!, Mosso river, Tami river, lake Sentani!, Koimé river!, Pokembo, Cyclop Mts., Parau, KaiserinAugusta or Sepik river!, Mimika river, Lorentz river!, Eitapé, Bongu, Simpsonhafen, Berlinhafen, Friedrich-Wilhelmshafen, Erima, Stephansort, Astrolabe Bay, Bukaua, Sattelberg, Dinawa in Owen Stanley Range, Madew on St. Joseph river 2-3000 feet); Seleo Island; Valise Island; Schouten Islands (Mysore). Duke of York Island; Bismarck Archipelago.

Note. A specimen from Matterer Bay, N. New Guinea was caught at sea.

\section{Enygrus australis (Montrouzier).}

Boa austrális, Montrouzier, Rev. et Mag. Zool. XII IS60, p. 95.

Enygrus australis, Boulenger, Cat. Sn. I I 893, p. 105.

Snout proninent, truncate; canthus rostralis rounded; rostral more broad than deep, not visible from above; head covered with small, irregular scales with tubercles or short keels; I I-I4 scales between the eyes on the forehead; eye bordered by I4-1S scales; ten to fourteen upper labials, separated from the eye. Scales in 37-4I rows, all strongly keeled, the keels forming straight lines; ventrals 232-295; anal entire; subcaudals $50-62$.

Brown, olive or reddish above, with or without a series of large dark spots, sometimes forming a zigzag band or a dark vertebral stripe, edged with yellow; sometimes a series of light spots along each side; a dark streak on each side of the head, passing through the eye and a dark bar between the eyes. Lower surface uniform yellowish or spotted with black. Length of head and body $990 \mathrm{~mm}$; tail $140 \mathrm{~mm}$.

Habitat: Woodlark Island. - Solomon Islands; Bismarck Archipelago; New Hebrides; Loyalty Islands; Samoa. 


\section{Fam. Ilysildae.}

Body round, covered with uniform scales above; ventrals not or feebly enlarged. Bones of the head more or less solidly united; ectopterygoid present; pterygoid extending to the quadrate; supratemporal small, between the other bones; quadrate short; praefrontal in contact with nasal. Mandible with coronoid; jaws and palate toothed. Parts of pelvis the same as in preceding family, ending in a claw, usually visible on each side of the anal opening.

This family is intermediate between the Boidae and the Uropeltidae, an Indian and Ceylonese group of burrowing snakes.

Key to the Indo-Australian genera.

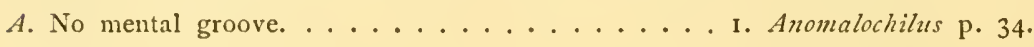
B. Mental groove present .............. 2. Cylindrophis p. 35 .

\section{A nomalochilus Lidth.}

(VAn Lidti de Jeude, in M. Weber, Zool. Ergebn. I p. ISo, 1\$9o/9I).

Head small, not distinct from neck, covered with large, symmetrical shields; nostril in a single nasal, touching the second upper labial and forming a suture with its fellow behind the nostril; no loreal or praeocular; a postocular; eye small, distinct from the surrounding shields; praemaxillary toothless; no mental groove (fig. I 8 ). Body round, covered with smooth scales, in 2 I rows; ventrals scarcely enlarged. Tail short and blunt; subcaudals single, paired at the end.

Distribution. Sumatra.

A single species.

\section{Anomalochilus weberi Lidth.}

Anomalochilus weberi, v. Lidth de Jeude, in M. Weber, Zoolog. Ergeb. I890/91. p. $18 \mathrm{r}, \mathrm{pl} . \mathrm{XV}$, fig. $1-3$.

Anomalochilus weberi, Boulenger, Cat. Sn. I I893, p. I34.

Head very small, depressed; the distance between the corners of the mouth equals that between an angle of the mouth and the tip of the snout; rostral large, more deep than broad; frontal nearly two times as large as the supraocular, quadrangular, the anterior angle obtuse, the posterior almost right; parietals not enlarged; postocular small, triangular; four upper labials, third largest, touching the praefrontal and the eye. 
Scales in 2 I rows; ventrals scarcely differing from the others, 244; anal divided; subcaudals 8, 6 undivided.

Brown above, the scales edged with light; a series of about 28 round, light spots on each side of the back, paired or alternating; an interrupted whitish line on the flanks; praefrontals and frontal each with a light spot; two small, round

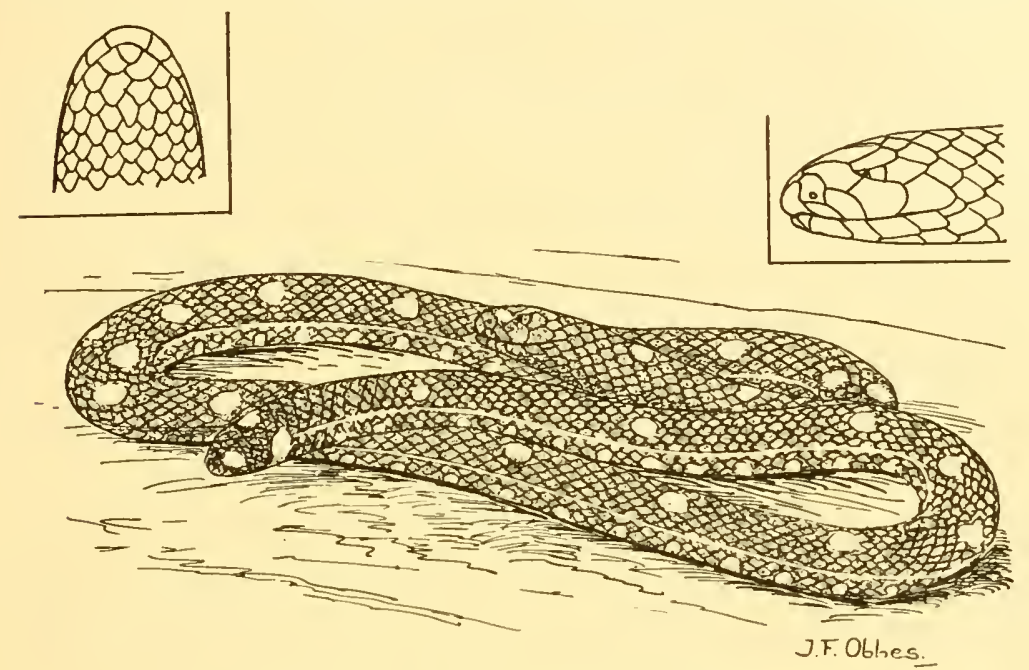

Fig. 18. Anomalochilus weberi Lidth.

Nat. size. Side view and lower view of head.

spots on the tip of the tail. Lower surface with irregular light spots, placed in pairs or confluent; anal whitish; lower part of tail with a white cross band.

Type-specimen examined in the Leiden Museum.

Habitat: Sumatra (Kaju tanam!).

\section{Cylindrophis Wagler.}

\section{(IVAgler, Icon. Amph., I828).}

Head small, not distinct from neck, covered with large, symmetrical shields; nostril in a single nasal; no loreal or praeocular; a postocular; eye small, distinct from the surrounding shields, with round or vertically elliptic pupil; praemaxillary toothless; IO-I2 subequal teeth in each maxillary; mental groove present (fig. 19). Body round, covered with smooth scales in I9-23 rows; ventrals not or feebly enlarged. Tail short and blunt.

Distribution. S. E. Asia; Ceylon. 
Key to the Indo-Australian species.

$A$. Ventrals broader than the surrounding shields.

I. Diameter of the eye about half its distance from

the nostril; scales in 19 or 21 rows ...... I. C. rufus p. 36 .

II. Diameter of the eye one third to one fourth its

distance from the nostril.

a. Interocular width equal to the length of the

snout; scales in $2 \mathrm{I}$ rows ........ 2. C. lineatus p. 37.

b. Interocular width more than the length of

the snont; scales in 23 rows....... 3. C. opisthorhodus p. 38 .

$B$. No enlarged ventrals.

I. Nasals forming a suture behind the rostral;

scales in 20 rows ............ 4. C. boulengeri p. 38 .

2. Nasals separated from one another; scales in

22 rows. ................. . . . isolepis p. 38 .

\section{Cylindrophis rufus (Laur.).}

Anguis rufa, Laurenti, Syn. Rept. 1768, p. 7 I.

Cylindrophis rufus, Boulenger, Cat. Sn. I I $\$ 93$, p. 135 (s. syn.).

Diameter of the eye about half its distance from the nostril; the distance between the eyes more than the length of the snout; nasals forming a suture; frontal at least as large as the

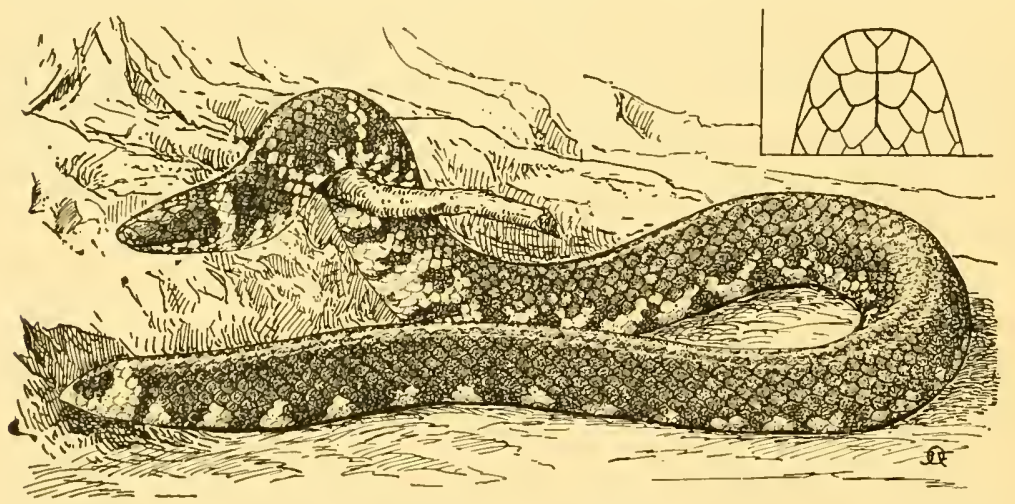

Fig. 19. Cylindrophis rufus (Laur.) $\times 1 / 2$. Lower view of head. $\times 4 / 3$.

supraocular, larger than the parietals, as long as its distance from the rostral or longer; six upper labials, third and fourth entering the eye. Scales in 19 or 2 I rows; ventrals not twice as large as the neighbouring scales, 185-245; anal divided; subcaudals 5 - 10 . 
Brown or black above, iridescent, uniform or with alternating light transverse bands, sometimes an orange collar. Lower surface white, with transverse black spots or bands or black with white transverse bands; lower part of tail bright vermilion. Total length $\$ 25 \mathrm{~mm}$.

Nom. in dig. Ular kapala dua (mal.); ular gelenggang; oraj teropong (sund.); majara (Toradja-name).

Habitat: Sumatra (Labuan, Medan!, Langkat, Stabat, Assahan, Bedagei, Indragiri, Padang, Kertadjaja, Benakat, Lematang ilir in Palembang); Banka!; Riou; Java (Batavia, Buitenzorg, Sukabumi!, Kagok in Tegal!, Pekalongan!, Semarang!, Ambarawa, Kediri!, Ngawi, Tengger Mts. 1200 M., Surabaia!); Borneo (Baram river, Rejang river, Sadong, Kuching, Buntok, Barito river, Mt. Dulit, Singkawang, Sintang, Landak!, Balikpapan, Bandjermassin, Pontianak); Celebes! (Manado, Posso!, Matinang Mts. 3300 feet, Tomohon, Tempe!, Macassar!); Sangir Islands; Batjan. - Singapore; Penang; Malay Peninsula; Burma; Siam; Cambodja.

This burrowing snake is viviparous; when worried it remains flat on the ground and raises its tail so that it resembles the head, hence the malay name, which signifies: two-headed snake; in Central Celebes it is also designed as the snake with two heads.

\section{Cylindrophis lineatus Blanford.}

Cylindrophis lineatus, Blanford, Proc. Zool. Soc. IS8I, p. 217, pl, XX. Cylindrophis lineatus, Boulenger, Cat. Sn. I IS93, p. 137.

Diameter of the cye about one third to one fourth its distance from the nostril; the distance between the eyes equals the length of the snout; nasals forming a suture; frontal about as large as the supraocular, a little larger than the parietals; six upper labials, third and fourth entering the eye. Scales in 2 I rows; ventrals almost twice as large as the neighbouring scales, 210-2I5; anal divided; subcaudals 9-10.

Dark brown or black above, iridescent, with two longitudinal whitish or red bands on the back; head and tail yellowish or red. Lower surface white, with alternating black transverse bands; lower part of tail white. Total length $730 \mathrm{~mm}$.

Habitat: Borneo (Matang!, Pangkalan ampat). - Malay Peninsula? ').

I) See Boulenger, Reptiles Malay Peninsula I912, p. II2. 


\section{Cylindrophis opisthorhodus Boulenger.}

Cylindrophis opisthorhodus, Boulenger, Ann. Nat. Hist. (6) XIX I897, p. 506.

Diameter of the eye about one third its distance from the nostril; the distance between the eyes greater than the length of the snout; nasals forming a suture; frontal as large as the supraocular, slightly larger than the parietals, as long as its distance from the rostral; six upper labials, third and fourth entering the eye. Scales in 23 rows; ventrals only a little larger than the neighbouring scales, I $84-\mathrm{I} 87$; anal divided, subcaudals $6-7$.

Pale brown or buff above, with small, irregularly disposed black spots; head yellowish, black-spotted. Lower surface white, with continuous or alternating black transverse bars, which are connected on the sides by a black stripe from behind the head to the base of the tail; an interrupted black stripe along the middle of the belly; anal region black; lower part of tail of a bright pink colour. Total length $230 \mathrm{~mm}$.

Type-specimens examined in the British Museum.

Habitat: Lombok 1500 feet?.

\section{Cylindrophis boulengeri Roux.}

Cylindrophis boulengeri, Roux, Zool. Jahrb. Syst. XXX I9I I, p. 500.

Diameter of the eye about one third its distance from the nostril; the distance between the eyes equals the length of the snout; nasals forming a suture; frontal larger than the supraocular, much larger than the parietals, triangular, the anterior border as long as its distance from the snout and a little longer than its length; six upper labials, third and fourth entering the eye. Scales in 20 rows; no enlarged ventrals; subcaudals 6 .

Black above; a white wavy line on the upper labials; on each side of the nape a triangular spot, the point directed posteriorly. Lower surface greyish-black with yellowish-white transverse bands of $2-3$ rows of scales; subcaudals white. Total length $550 \mathrm{~mm}$. (After Roux; not seen by me).

$\mathrm{Hab}$ it a t: Wetar.

\section{Cylindrophis isolepis Boulenger.}

Cylindrophis isolepis, Boulenger, Ann. Nat. Hist. (6) XVIII I896, p. 62.

Diameter of the eye two fifths its distance from the nostril; 
the distance between the eyes equals the length of the snout; nasals separated by the rostral, which is in contact with the praefrontals; frontal a little larger than the supraocular, much larger than the parietals, as long as its distance from the tip of the snout; six upper labials, third and fourth entering the eye. Scales in 22 rows; no enlarged ventrals; subcaudals 5. Black above, each scale white-edged. Lower surface black with two alternating series of large, white blotches; lower part of tail orange. Total length $430 \mathrm{~mm}$.

Type-specimen examined in the British Museum.

Habitat: Djampea Island!.

\section{Fam. Xenopeltidae.}

Body round, covered with uniform scales above, enlarged ventrals beneath. Bones of the head more or less solidly united; ectopterygoid present; pterygoid extending to the quadrate; supra-temporal present, suspending quadrate; praefrontal in contact with nasal. Jaws, palate and praemaxillary toothed; mandible without coronoid; a mental groove.

A single genus.

I. Xenopeltis Reinw.

(REINwardt, in Boie, Isis p. 564, I827).

Head not distinct from the neck; eye small, with vertically elliptic pupil; nostril between two nasals; frontal in contact with a large azygous interparietal, which is bordered by four parietals; mental groove present; dentary bone movable on the apex of the articular; numerous small, equal teeth, 4 on each side of the praemaxillary, $33-38$ in the maxillary and 35 or 36 on each side of the mandible. Body cylindrical, covered with smooth scales in 15 rows; ventrals large. Tail short; subcaudals in two rows.

Distribution. India; Indo-China; Malay Peninsula and Archipelago.

A single species.

\section{Xenopeltis unicolor Reinw.}

Jenopeltis unicolor, Reinwardt in Boie, Isis 1827 , p. 564.

Xenopeltis unicolor, Boulenger, Cat. Sn. I $1 \$ 93$, p. I68 (s. syn.). 
Head depressed, snout rounded; nostril between two nasals; frontal as long às its distance from the rostral; praeocular large; two postoculars, upper one largest; a small supraocular, smaller

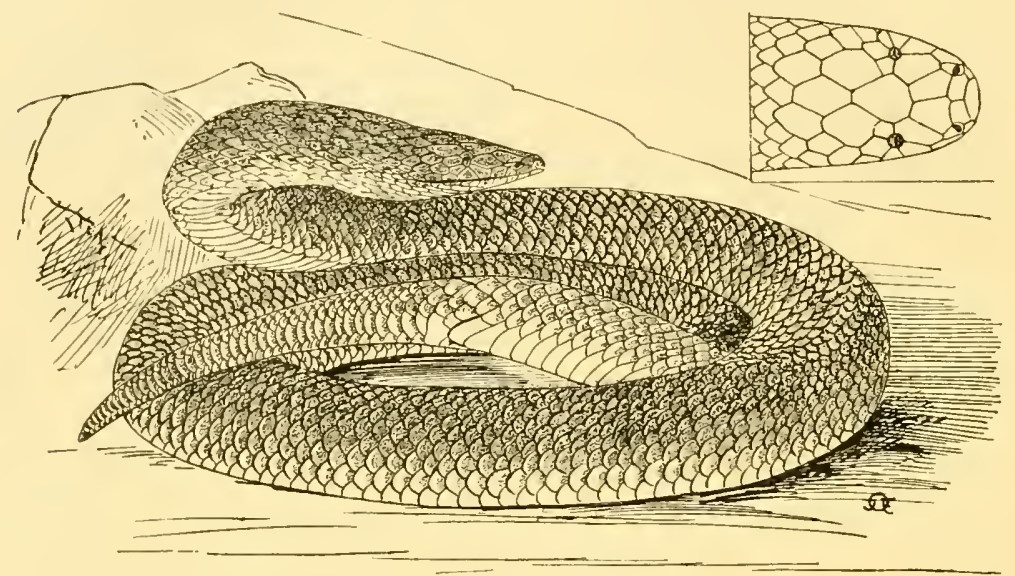

Fig. 20. Yenopeltis unicolor Reinw. $X 1 / 2$. Upper view of head.

than the upper postocular; a large, azygous interparietal, in the middle of four parietals; eight upper labials, first in contact with the internasal, fourth and fifth entering the eye; a pair

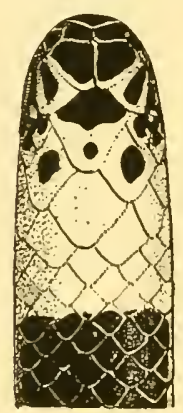

Fig. 2I. Xeno-lur); Ulen tana (C. Celebes).

peltis unicolor

Reinw. Head of young specimen. $\times 2^{1 / 2}$. of small chin-shields, in contact with the three anterior lower labials. Scales in 15 rows, smooth; ventrals I64-I93; anal divided; subcaudals $26-3 \mathrm{I}$.

Brown or blackish above, iridescent, the scales light-edged; upper lip pale yellow. Lower surface white. In young specimens the head is whitish and a yellow collar is present. Length of head and body $900 \mathrm{~mm}$.; tail $100 \mathrm{~mm}$.

Nom. in dig. Ular ekor merak; Soratu (Sima-

Habitat: Simalur!; Nias!; Sumatra (Pulu Weh!, Atjeh, Medan!, Labuan, Langkat, Indragiri, Singkarah!, Rau, Gunung Sahilan!, Agam, Ringgat!, Padang!, Palembang!); Siak!; Riou!; Banka!; Java (Gadok, Buitenzorg!, Preanger, Salatiga!, Tengger MIts. I 200 M.); Borneo! (Kuching, Singkawang, Kapuas river, Kutei, Bulangan river, Balikpapan, Bandjermassin); Celebes 
(Manado!, Posso!, Kema, Kandari). - Singapore; Penang; Malay Peninsula; Siam; Indo-China; Burma; S. India.

Generally lives underground, burrowing; feeds on small mammals and other snakes.

\section{Fam. Colubridae.}

Body round or compressed, covered with imbricate or juxtaposed scales, with or without apical pits, smooth or keeled; ventrals usually transversely enlarged. Bones of head movable; ectopterygoid present; pterygoid extending to the mandible or the quadrate; supratemporal suspending quadrate; praefrontal not in contact with the nasal. Maxillary horizontal; jaws toothed, praemaxillary without teeth; mandible without coronoid; a mental groove.

With regard to the teeth, the Colubridae may be divided into three groups:

A. Teeth not grooved, solid ................... Aglypha p. 4I.

$B$. One or more posterior maxillary teeth grooved;

more or less poisonous ............ . Opisthoglypha p. 179.

C. Anterior maxillary teeth grooved or perforated; poisonous .................... Proteroglypha p. 215.

Each group is composed of a number of subfamilies:

$$
\text { Aglypha. }
$$

1. Postfrontal bone produced over the supraorbital region; scales not imbricate. Aquatic...... Acrochordinae p. $4 \mathrm{r}$.

2. Postfrontal bone not produced over the supraorbital region; scales imbricate. Aquatic, terrestrial or arboreal .................... Colubrinae p. 46 .

\section{Opisthoglypha.}

1. Nostrils superior, valvular. Viviparous. Aquatic. Homalopsinue p. I 79.

2. Nostrils lateral. Terrestrial or arboreal. . . . . Dipsadomorphinae p. 194.

$$
\text { Proteroglypha. }
$$

1. Tail strongly compressed. Marine........ Hydrophiinac p. 215.

2. Tail round. Mostly viviparous. Terrestrial ... Elapinae p. 241.

Subfamily Acrochordinae.

Key to the Indo-Australian genera.

$A$. No distinct ventral shields.

I. Body slightly compressed............ I. Acrochordus p. 42 . 
II. Body and tail compressed, a fold below ..... 2. Chersy.trus p. 43 . $B$. Ventral shields well developed.

a. Head covered with uniform scales........ 3. Xenodermus p. 44 .

b. Head covered with symmetrical shields.......4. Stoliczkain p. 45 .

Aquatic snakes. Scales not imbricate.

\section{Acrochordus Hornstedt.}

(HornstedT, Abh. Acad. Stockholm VIII p. 307, 1787).

Head not distinct from neck, small, covered with small juxtaposed scales; nostrils on the top of the snout, close together; eye very'small; pupil vertically elliptic; teeth almost equal, about $\mathrm{I}_{5}$ in each maxillary. Body stout, a little compressed, covered with small, tubercular, spinose scales; no ventral shields. Tail short, round, prehensile.

Distribution. Malay Peninsula and Archipelago to New Guinea. A single species.

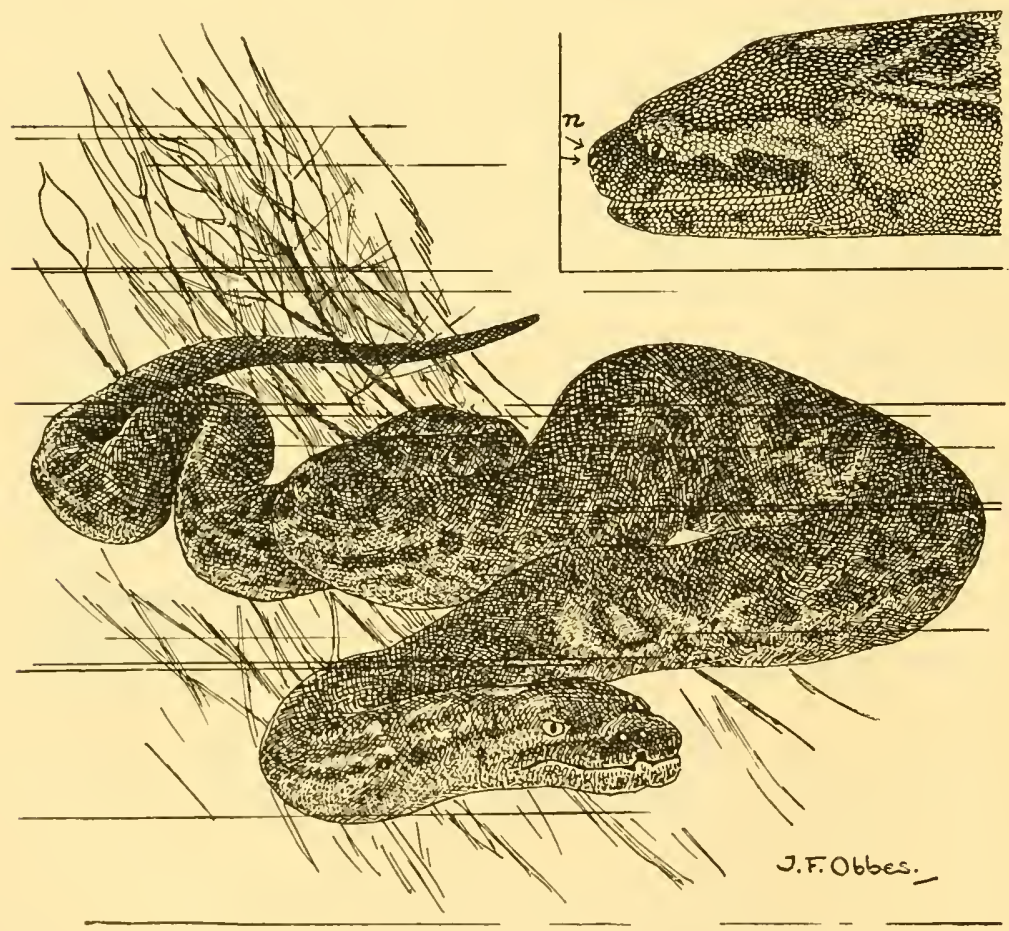

Fig. 22. Acrochordus javanicus Hornst. $X 1 / 2$. Side view of head; $n$ nostril. 


\section{Acrochordus javanicus Hornst.}

Acrochordus jazanicus, Hornstedt, Abh. Ac. Stockholm VIHI I7 7, p. 307, pl. XII. Acrochordus javanicus, Boulenger, Cat. Sn. I I893, p. 173.

No shields on the head, but very small, rough scales, larger near the mouth; I 20--I 50 scales round the body, dorsals largest.

Brown or olive above, spotted or marbled with black. Lower surface lighter. Length of head and body $1855 \mathrm{~mm}$.; tail $245 \mathrm{~mm}$.; attains a length of nearly $3 \mathrm{M}$.

Nom. indig. Ular belalei gajah (mal.).

H a bit at : Sumatra (Upper Langkat, Indragiri); Siak! ; Java! (Buitenzorg); Borneo! (Baram district, Sadong river, Sarawak); New Guinea (Mimika river, Lorentz river, Fly river). - Malay Peninsula; Siam; N. Queensland (rivers of the Gulf of Carpentaria).

Aquatic, living in ditches and canals. A female in captivity brought forth 27 young ones, which were very active. Feeds on water beetles and fruit.

\section{Chersydrus Cuvier.}

(Cuvier, Règne Anim. II p. 75, ISI 7 ).

Head not distinct from neck, small, covered with small juxtaposed scales; nostrils on the top of the snout, close together; eye very small; pupil vertically elliptic; teeth almost equal, I2-I5 in each maxillary. Body stout, compressed, covered with small, rhomboidal, juxtaposed scales with a tubercle-like keel, spinose beneath; no ventral shields; a fold of the skin along the middle of the belly. Tail short, compressed, prehensile.

Distribution. S. E. Asia; Papuasia.

A single species.

\section{Chersydrus granulatus (Schn.).}

Hydrus granulatus, Schneider, Hist. Amph. I I 799, p. 243.

Chersydrus granulatus, Boulenger, Cat. Sn. I I $\$ 93$, p. 174 (s. syn.).

No rostral; a series of larger shields on the lips, separated from the mouth by a row of very small scales; no chin-shields. About IOo scales round the body, dorsals largest.

Olive or blackish with lighter transverse bands or annuli, sometimes disappearing in the adult. Length of head and body $900 \mathrm{~mm}$.; tail $100 \mathrm{~mm}$.

Nom indig. Ular kadut (mal.). 
Ha bit a t: Sumatra (Atjeh!, Deli, Djambi!, Gunung Sahilan!, Ringgat!, Taluk!); Java (Batavia, Pekalongan river!, Pasuruan!); Flores!; Timor!; Borneo (Buntal); Celebes (Nortl Celebes!, Kema, Macassar!); Ambon!; Ternate!; New Guinea (Fak Fak,

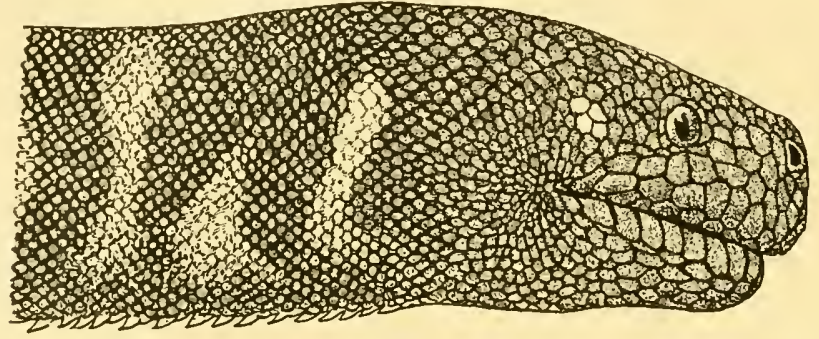

Fig. 23. Chersydrus granulatus (Schn.) $>2$.

Lorentz river, Merauke, Fly river, Jobi); Schouten Islands (Mysore). - Penang; Singapore; Malay Peninsula; Andamans; Siam; Cochin China; Burma; Madras; Ceylon; Philippines; N. Queensland.

Lives in rivers; often found at sea. Viviparous. Feeds on fish.

\section{Xenodermus Reinh.}

(Reinhakut, Overs. Vid. Selsk. Forh. p. 6, I 836 ).

Head distinct from neck, covered with small juxtaposed scales; nostrils in a single nasal, directed forwards; eye moderate; pupil round; teeth almost equal, about 15 in each maxillary. Body slender, compressed, covered with small, keeled, juxtaposed scales and longitudinal rows of large tubercles; ventrals well developed. Tail long; subcaudals single.

Distribution. Malay Peninsula; Sumatra; Borneo; Java.

A single species.

\section{Xenodermus javanicus Reinl.}

Xenodermus javanicus, Reinhardt, op. cit. and Vidensk. Selsk. Skrift X I $8_{43}$, p. 257 , pl. II. fig. I-S.

Xenodermus javanicus, Boulenger, Cat. Sn. I I 893, p. 175.

Rostral small, triangular, not visible from above; nasals in contact behind the point of the rostral; two pair of small shields behind them; labials enlarged, about 20 on each side. $40-48$ scales round the body, the tubercles in pairs along each 
side of the back, alternating with single ones on the vertebral line; ventrals I73-I 85 ; anal entire; subcaudals $128-147$.

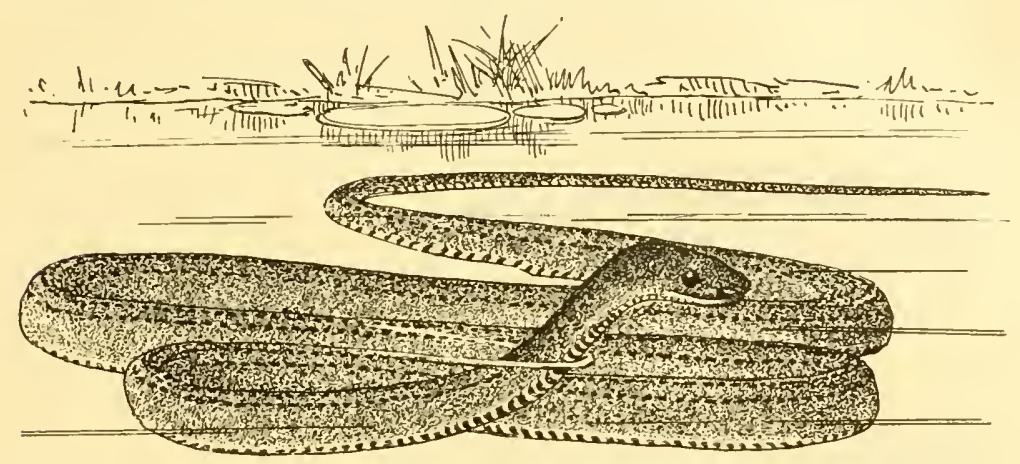

J.F.Obbes.

Fig. 24. Yenodermus jazonicus Reinh. $\times 4 / 5$.

Dark brown above; lower parts lighter. Length of head and body $225 \mathrm{~mm}$.; tail $228 \mathrm{~mm}$.

Habitat: Sumatra! (Perlak in S. Atjeh); Java!; Borneo (Kuching). - Penang; Malay Peninsula.

A rare species.

\section{Stoliczkaia Jerdon.}

(Jerdon; Proc. As. Soc. Bengal p. 8 I, I870).

Head distinct from neck, covered with large shields; nostrils clirected forwards, in a single nasal; eye small or prominent; pupil round or vertically elliptic; teeth almost equal, small, about I $_{4}$ in each maxillary. Body slender, compressed, covercd with strongly keeled, elliptical, juxtaposed scales, larger towards the ventrals; latter well developed. Tail long; subcaudals single.

Distribution. N. E. India; Borneo.

A single species.

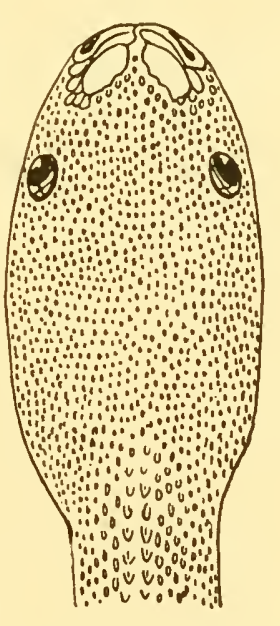

Fig. 25. Yenodermus javanicus Reinh. Upper view of head. $\times 4$.

\section{Stoliczkaia borneensis Boulenger.}

Stoliczkaia borneensis, Boulenger. Ann. Nat. Hist. (7) IV IS99, p. 452, figured in Journ. Straits Branch. Asiat. Soc. 34 1900, pl. I, fig. 2.

Rostral moderate, triangular, not visible from above; inter- 
nasals very narrow; praefrontals large, separated from the frontal and supraoculars by a series of scales; frontal more broad than long, shorter than the parietals; supraocular very small; eye prominent, with vertically elliptic pupil, bordered by the supraocular, two or three praeoculars, the fifth labial ${ }^{1}$ )

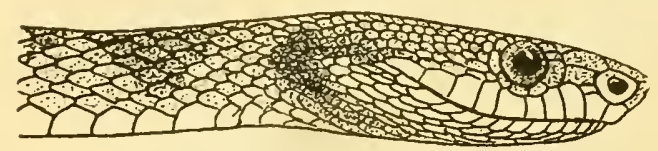
and 7 or 8 small scales; nostrils large; loreal more long than deep; ten upper labials, last two longest;

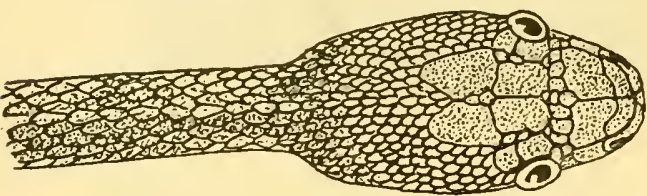
temporals small; a pair of small chinshields in contact with three lower labials. Scales in 30 rows, lar-

Fig. 26. Stoliczkaia borneensis Blgr. After a figure from Boulenger published by Hanitsch. gest on the vertebral region and near the ventrals; those between them small and separated by naked skin; ventrals 210 ; anal entire; subcaudals 124.

Rufous, with large blackish spots, as large as the space between them or larger, disposed in three longitudinal series. Lower surface brown, the shields edged with a yellowish colour. Length of head and body $510 \mathrm{~mm}$; tail $240 \mathrm{~mm}$. (After BOULENGER; not seen by me).

Habitat: Borneo (Mt. Kina Balu 4200 feet).

Subfamily Col u b r in a e.

Key to the Indo-Australian genera.

$A$. Nostrils directed upwards.

I. Internasals absent; loreal present; maxillary and mandible with 5 or 6 solid teeth; scales in 19 rows. 5. Anoplohydrus p. 49.

2. Internasals small, trapezoid; loreal absent; maxillary, palatal and mandibular teeth with spatulate crowns, ribbed along the outer side, 23 in each maxillary; scales in 19 rows ....... 6. Iguanognathus p. 50.

3. Internasals small, triangular or crescentic; loreal present; maxillary teeth small, equal, 20-25; scales in 17 or 19 rows ........ 7. Opisthotropis p. 51 .

4. Internasals and loreal present; maxillary teeth equal, 19 or 20 ; scales in 19 rows...... S. Tenochrophis p. 53.

I) The species is figured with a series of suboculars, see fig. 26 . 
B. Nostrils lateral.

I. Teeth very small, equal, closely set, $37-50$ in each maxillary, head not or slightly distinct from neck; pupil round; scales smooth, in 17 rows. 9. Polyodontophis p. 54.

II. Maxillary with less than 40 teeth.

$\dagger$ Head distinct from neck; internasals distinct

from praefrontals.

I. Pupil round.

a. Scales oblique, at least anteriorly.

$X$ Scales in 19 rows .......... 10. Psendoxenodon p. 56.

$X \times$ Scales in $13-15$ rows.

aa. Naxillary teeth $20-33$, posterior enlarged............. Dendrophis p. 57.

b6. Maxillary teeth $\mathbf{1} 8-23$, anterior longest............. I2. Dindrelaphis p. 67 .

b. Scales in longitudinal series.

1. Scales in even numbers, 12, 16 or 18. 13. Zuocys p. 71 .

2. Scales in odd numbers.

+ Posterior maxillary teeth longest.

aa. Naxillary teeth i $8-40$, conti-

nuous; scales keeled, in 15-2 I

rows............ 14. Tropidonotus p. 73 .

66. Naxillary teeth $14-22$, last two

very large, separated from the

others; scales keeled, in I9 rows. 15. Macropisthodon p. 9 I.

cc. Vaxillary teeth 25-30; scales

smooth, in 17 rows ...... 16. Yenelaphis p. 93.

dd. Maxillary teeth $12-20$; scales smooth or keeled, in $\mathbf{1}_{3}, \mathbf{I}_{5}$ or

17 rows........... 17. Zamenis p. 95.

++ Maxillary teeth equal.

a. Ventrals rounded or angulate laterally; scales in $19-27$ rows. . I I . Coluber p. $9 \$$.

b. Ventrals and subcaudals with a lateral keel and a notch on each side; scales in 19 rows...... 19. Gonyophis p. 106.

2. Pupil vertically elliptic.

a. Anterior maxillary teeth enlarged, separated from the rest.

I. Body long; scales smootlı or keeled, in $17-21$ rows........... 20. Lycodon p. 107.

2. Body extremely slender; scales keeled, in 17 rows...........21. Lepturophis p. II3. 
6. Posterior maxillary teeth largest; scales smooth.

aa. Eye moderate or small; ventrals with an obtuse lateral angle; maxillary teeth I5-20; scales in 15 or 17 rows. . 22. Stegonotus p. I14.

66. Eye large; ventrals strongly keeled on each side; maxillary teeth 8-io; scales in 13 or 15 rows.......... 23. Dryocalamus p. II 8 .

†† Head not distinct from neck; internasals distinct ${ }^{1}$ ).

$\odot$ Pupil round.

I. Posterior maxillary teeth smallest; scales in

I5 rows.............. 24. Tetralepis p. I20.

2. Posterior maxillary teeth largest.

a. Maxillary teeth 8-12; pterygoid toothed;

scales in 15-21 rows. ....... Simotes p. I 21.

b. Maxillary teeth 6-8; pterygoid toothless;

scales in 15 or 17 rows ......26. Oligodon ' 1 ) p. 127. 3. Maxillary teeth subequal.

a. Anterior temporal present.

a. Praeocular absent, scales in 15 rows. 27. Elapoides p. I34.

B. Praeocular present.

aa. Maxillary teeth about is; scales in

15 or 17 rows. ......... 28. Hydrablabes p. 135 .

66. Maxillary teeth $15-30$; scales in

13 or 15 rows. .......... 29. Ablabes p. I37.

cc. Naxillary teeth about Io; scales in

I7 rows ............ 30. Oreocalamus p. I40.

b. No anterior temporal; scales in 15 rows.

I. Nostril between two shields.

X Supraocular absent; no praeocular;

loreal absent......... 31. Idiopholis p. I4I.

$X \times$ Supraocular small; no praeocular;

loreal present.......... 32. Agrophis p. 143.

2. Nostril in a single nasal.

a. Praeocular large, reaching or nearly

reaching the nasal ......33. Rhabulophidium p. 145

6. Praeocular small or absent. . . . 34. Pseudorhabdium p. 146.

$\odot \odot$ Pupil vertically elliptic; scales in 17 or

19 rows ................ B. Brachyorrhus p. I47.

I) Oligodon durheimi, pulcherimus and praefrontalis have the internasals. fused with the praefrontals. 
†† Head not distinct from neck; internasals fused

with praefrontals.

I. Nostril between two shields; scales in 15 rows. 36. Calamorhabdium p. 14 S.

II. Nostril in a single nasal: scales in 13 rows. 37 . Calamaria p. 149.

Aquatic, terrestrial or arboreal snakes. Scales imbricate.

\section{Anoplohydrus Werner.}

(Werner, Mitt. Naturhist. Museum Hamburg XXVI p. 214, 1909).

Head short, not distinct from neck; eye small; pupil round; nostril directed upwards; nasals divided, in contact behind the rostral; internasals absent; loreal present. Maxillary and mandibular teeth 5-6, solid, anterior a little shorter than posterior; palate and pterygoid toothed. Body round, moderate, covered with smooth scales, without pits, in 19 rows. Tail short; subcaudals partly in two rows.

Distribution. Sumatra.

A single species.

\section{Anoplohydrus aemulans Werner.}

Amoplohydrus aemulans, Werner; op. cit. fig. 3 .

Rostral low, scarcely visible from above, more broad than deep; suture between the nasals as long as the praefrontal; frontal hexagonal, pointed behind, longer than its distance from the tip of the snout, shorter than the parietals; loreal more long than

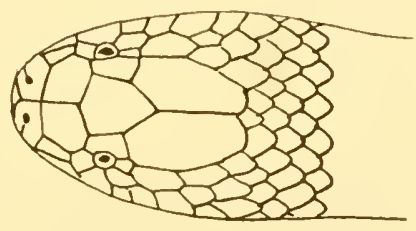
deep; one prae- and two postoculars; temporals $\mathrm{I}+2$; seven upper labials, third and fourth entering the eye ${ }^{1}$ ); four lower labials in contact with the anterior chin-shields; posterior chinshields small, separated by scales; mental small, separated from the chin-shields by the first lower

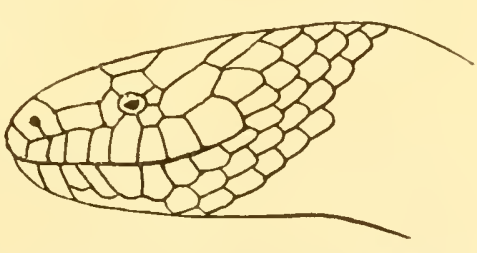

Fig. 27. Anoplohy'drus aemulans

Werner. After Werner. labials. Scales in 19 rows, ventrals I59; anal divided; subcaudals $1 / 1+3+{ }^{30} / 30+I$.

I) The species is figured with $S$ labials, the fifth entering the eye, see fig. 27. INDO-AUSTRALIAN REPTILES II. 
Blackish-brown above, iridescent, with narrow yellowish transverse bands, alternating on the back; flanks with broader yellow vertical spots from the third row of scales to the ventrals, partly alternating with the dorsal bands; anterior chinshields with yellow centre. Chin and throat dark with yellowish spots in the middle of the scales. Length of head and body $374 \mathrm{~mm}$.; tail $56 \mathrm{~mm}$. (After Werner; not seen by me).

Habitat: Sumatra (Pudang in district Babongan).

\section{Iguanognathus Boulenger.}

(Boulenger, Ann. Nat. Hist. (7) II p. 73, I898).

Head small, slightly distinct from neck; eye small; pupil round; nostril directed upwards, between two nasals; internasals small, trapezoid; no loreal. Maxillary, palatal and mandibular teeth with spatulate crowns, ribbed along the outer side, about equal, 23 in each maxillary (fig. 28). Body round, covered with smooth scales without pits, in 19 rows; ventrals rounded. Tail moderatc; subcaudals in two rows.

Distribution. Sumatra.

A single species.

1. Iguanognathus werneri Boulenger.

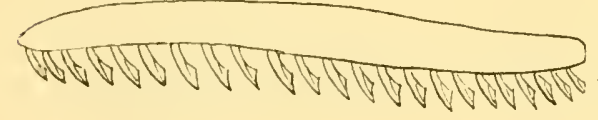

Iguanognathus zerneri, Boulenger,

Ann. Nat. Hist. (7) II $1 \$ 98$, p. 73 , tekst-fig.
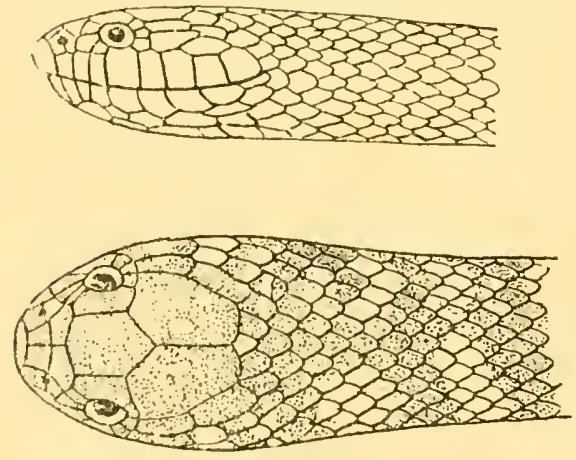

Fig. 28. Iguanggnathus werneri Blgr. After Houlenger.

Snout sliort and broad, rounded; rostral two times as broad as deep, just visible from above; internasals small, trapezoid, as long as broad; praefrontals as long asinternasals, twice as broad; frontal twice as broad as the supraocular, longer than its distance from the tip of the snout, shorter than the parietals; three praeoculars, the middle one in contact with the posterior nasal; three postoculars; temporals $2+2$; eight upper labials, fourth entering the eye; 
four lower labials in contact with the anterior chin-shields; latter shorter than the posterior which are separated by scales. Scales in 19 rows, smooth, those on sacral region and tail striated and feebly keeled; ventrals I36; anal divided; subcaudals 53 .

Dark brown above, sides lighter, with black vertical bars, spotted with white; a white line across the snout, a white, oblique streak behind the eye, widening towards the mouth; a pair of light spots on the parietals near their suture; five anterior labials with a small spot each. Lower surface whitish with black transverse bars, most of them interrupted and alternating, continued from the bars of the flanks; subcaudals black, each with a whitish spot. Length of head and body $263 \mathrm{~mm}$; tail $87 \mathrm{~mm}$.

Type-specimen examined in the British Museum.

Habit at: Sumatra!.

Only one specimen known.

\section{Opisthotropis Günther.}

$$
\text { (Günther, Ann. Nat. Hist. (4) IX p. I6, IS27). }
$$

Head small, not distinct from neck; eye small; pupil round; nostril directed upwards; nasals divided or partly divided; internasals small, crescentic or triangular; loreal present. Maxillary and mandibular teeth small and equal, 20-25 in each maxillary. Body round, covered with keeled and striated scales, without pits, in I7 or 19 rows; ventrals rounded. Tail moderate; subcaudals in two rows.

Distribution. IV. Africa; S. China; Sumatra; Borneo.

Key to the Indo-Australian species.

A. Scales in I7 rows: nasals separated.......... I. O. rugost p. $5 \mathrm{I}$. B. Scales in 19 rows; nasals in contact .......... O. typica p. 52.

\section{Opisthotropis rugosa (Lidth).}

Lepidognathus rugosus, v. Lidth de Jeude in M. Weber, Zoolog. Ergebn. Reise N. O. Ind. I I $\$ 90 / 91$, p. 187 , pl. XVI, fig. $1-5$.

Opisthotropis rugosa, Boulenger, Cat. Sn. I I $\$ 93$, p. $2 \$_{4}$.

Head depressed; rostral as deep as broad; nasal divided, separated from its fellow; internasals crescent-shaped, together forming a triangle with a rouncled top; loreal large; a pair 
of praefrontals; frontal as broad as long, pentagonal; one praeand one postocular; temporals $I+2$; twelve upper labials, last two smallest, third to tenth separated from the edge of the mouth by small trigonal scales and from the orbit by three suboculars; the ten anterior labials separated from the shields above them by a longitudinal groove; posterior chin-

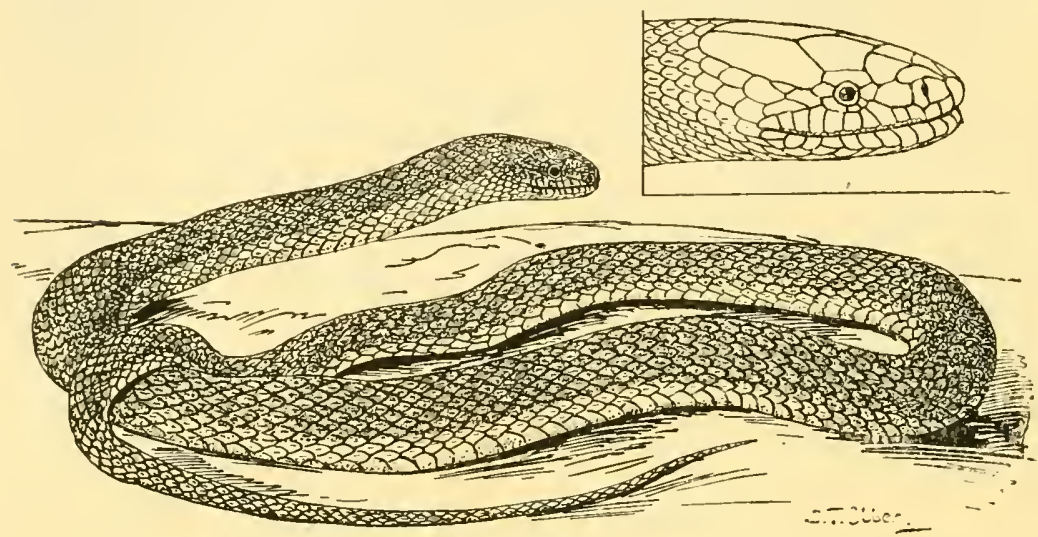

Fig. 29. Opisthotropis rugosa (Lidth). Nat. size. Side view of head.

shields separated by two scales. Scales in I7 rows, strongly keeled and striated; ventrals 170; anal divided; subcaudals 95.

Olive above, the scales white-edged; anterior upper labials and outer row of scales ycllow. Lower surface yellow. Length of head and body $343 \mathrm{~mm}$.; tail $\mathrm{I} 30 \mathrm{~mm}$.

Type-specimen examined in the Leiden Muscum.

Habitat: Sumatra (Kaju tanam!).

\section{Opisthotropis typica (Mocq.).}

IIelicopsoides typicus, Mocquard, Le Natural. IS9o, p. 154; Nouv. Arch. Mus.

(3) II I89o, p. I41, pl. IX, fig. 3.

Opisthotropis typica, Boulenger, Cat. Sn. I IS93, p. 285.

Snout short and broad, depressed; rostral twice as broad as deep; nasals partly divided, in contact behind the rostral; internasals small, triangular; praefrontal single or double; frontal large, as long as broad, pentagonal; supraocular very small; loreal long, divided or partly divided; two prae- and two postoculars; temporals $I+I+2$; eleven upper labials, separated from the orbit by three suboculars, six anterior, twice as deep as long, four last divided. Scales in I9 rows, keeled and striated; ventrals I74-IS4; anal divided; subcaudals $76-85$. 
Olive-brown above; yellowish below. Length of head and body $295 \mathrm{~mm}$.; tail $95 \mathrm{~mm}$.

Type-specimen examined in the Paris Museum.

Habitat: N. Borneo (Mt. Kina Balu!).

\section{S. Xenochrophis Günther.}

(GüN7her, Rept. Brit. Ind. p. 273, IS64).

Head slightly distinct from neck; eye small; pupil round; nostril directed upwards and slightly outwards; nasal undivided; a pair of internasals; loreal present. Naxillary teeth 19 or 20 ,

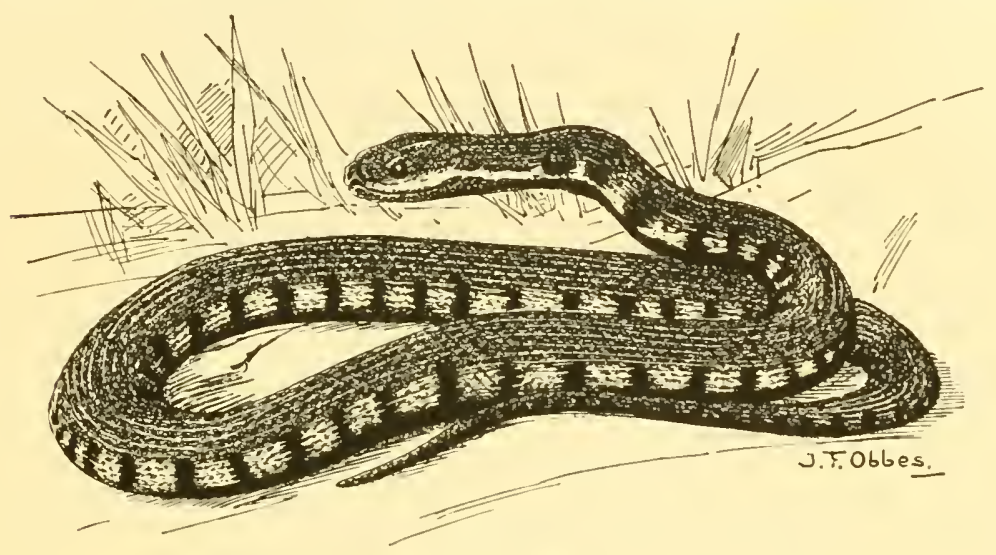

Fig. 30. Ienochrophis aiperinus Schenkel $\times 9 / 10$.

subcqual; anterior mandibular teeth largest. Body round or a little compressed, covered with keeled scales, without pits, in 19 rows; ventrals rounded. Tail moderate; subcaudals in two rows.

Distribution. India; Malay Peninsula; Sumatra.

A single species in the Indo-Australian region.

\section{Xenochrophis viperinus Schenkel.}

Menochrophis vipirinus, Schenkel, Verh. Ges. Basel XIII 1901, p. 155.

Head triangular, snout slightly turned up; canthus rostralis distinct, loreal region concave; rostral twice as broad as deep, visible from above; nasal undivided, but traces of a dividing groove present; internasals about as long as broad, their outer border parallel, not convergent; praefrontals larger than the internasals; frontal longer than its distance from the tip of 
the snout, shorter than the parietals; loreal small, about twice as deep as long; two prae- and three or four postoculars (lower of the latter perhaps a subocular); temporals $2+3+3$, the anterior very small; seven upper labials, third and fourth entering the eye; five lower labials in contact with the anterior chin-shields; latter shorter than the posterior, which are separated by a scale. Scales in I9 rows; ventrals IO I anal divided; subcaudals 59 .

Greyish above; head reddish-brown with small; yellow dots;

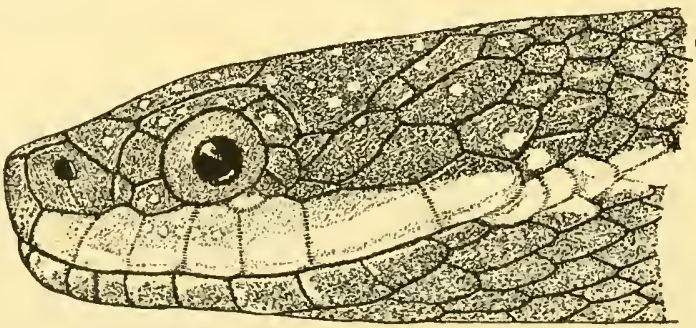

Fig. 31. Tonochrophis viperinus Schenkel. Side view of head $\times 5$.

upper lip pale brown, with black spots on the lower part of the posterior labials and a yellow longitudinal line, continued on the sides of the neck and body as a yellow streak, interrupted by about 30 black transverse spots. Lower surface black; throat dotted with light. Length of head and body I76 mm.; tail $74 \mathrm{~mm}$.

Type-specimen received from the Basle Museum, examined. Habitat: Sumatra (Indragiri!).

\section{Poly od on t o ph is Boulenger.}

(Boulenger, Faun. Ind. Rept. p. 301, 1890).

Head short, not or slightly distinct from neck; eye rather small; pupil round. Teeth very numerous, equal, $30-50$ in each maxillary; dentary bone free from the articular posteriorly. Body round, long, covered with smooth scales, without pits, in 17 or 19 rows. Tail long; subcaudals in two rows.

Distribution. Madagascar; Comoro Islands; S. E. Asia; C. America.

A single species in the Indo-Australian region.

I. Polyodontophis geminatus (Boie).

Coluber geminatus, Boie, Isis I826, p. 211.

Polyodontophis geminatus, Boulenger, Cat. Sn. I IS93, p. I85 (s. syn.). 
Sitynophis geminatus, Barbour, Mem. Mus. Comp. Zool. Harv. Coll. XllV I 912 , P. 107.

Rostral twice as broad as deep, visible from above; suture between the internasals shorter than that between the praefrontals; frontal longer than its distance from the tip of the snout, shorter than the parietals; loreal as long as deep or slightly more deep; a praeocular; two postoculars, in contact with the parietal; temporals $2+2$; nine upper labials, fourth to sixth entering the eye; four lower labials in contact with the anterior chin-shields; latter as large as the posterior. Scales in 17 rows; ventrals $144-I_{3}$; anal divided; subcaudals (51) $89-145$.

Brown or black above, usually with two light longitudinal

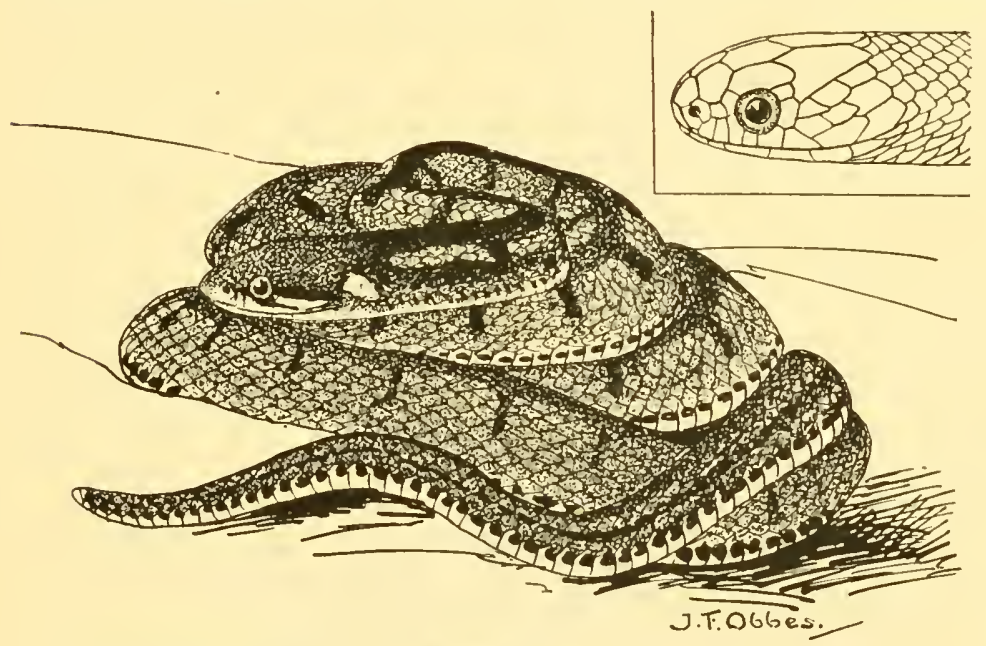

Fig. 32. Polyodontophis geminatus (Boie) $\times 3 / 4$. Side view of head.

streaks, which may be black-spotted; upper lip with a white, black-edged streak; a yellow or black collar sometimes present, head yellowish, reddish-brown or clark brown above, with yellow black-edged spots. Lower surface yellowish, each ventral and subcaudal with a black spot at the outer end. Length of head and body $485 \mathrm{~mm}$.; tail $335 \mathrm{~mm}$. (tip broken).

I abitat: Nias; Sumatra (Serdang!); Borneo (Kina Balu, Baram, Muching, Kuching, Sarawak, Mukah, Singkawang, Pontianak river); Java (Buitenzorg, Tjipanas!, Salatiga!, Nongkodjadjar in Tengger Mts. I 300 M.!); Lombok. - Malay Peninsula; Singapore; Siam. 
10. P s e ud oxe nod on Boulenger.

(Boulenger, Faun. Ind. Rept, p. 340, 1890).

Head distinct from neck, which is dilatable (fig. 33); eye large; pupil round. Maxillary teeth $20-28$, increasing in size posteriorly; the last two separated from the others by an interspace and much enlarged; mandibular teeth subequal. Body round, covered with imbricate scales in 17 or 19 rows, without pits, dorsals keeled, those on the anterior part of the body narrow and in oblique series; ventrals rounded. Tail moderate; subcaudals in two rows.

Distribution. India; S. China; Java.

A single species in the Indo-Australian region.

I. Pseudoxenodon inornatus (Boic).

Ycnodon inornatus, Boie, Isis, 1827, p. 541.

Pscuioxcnodon inornatus, Boulenger, Cat. Sn. I 1893, p. 272.

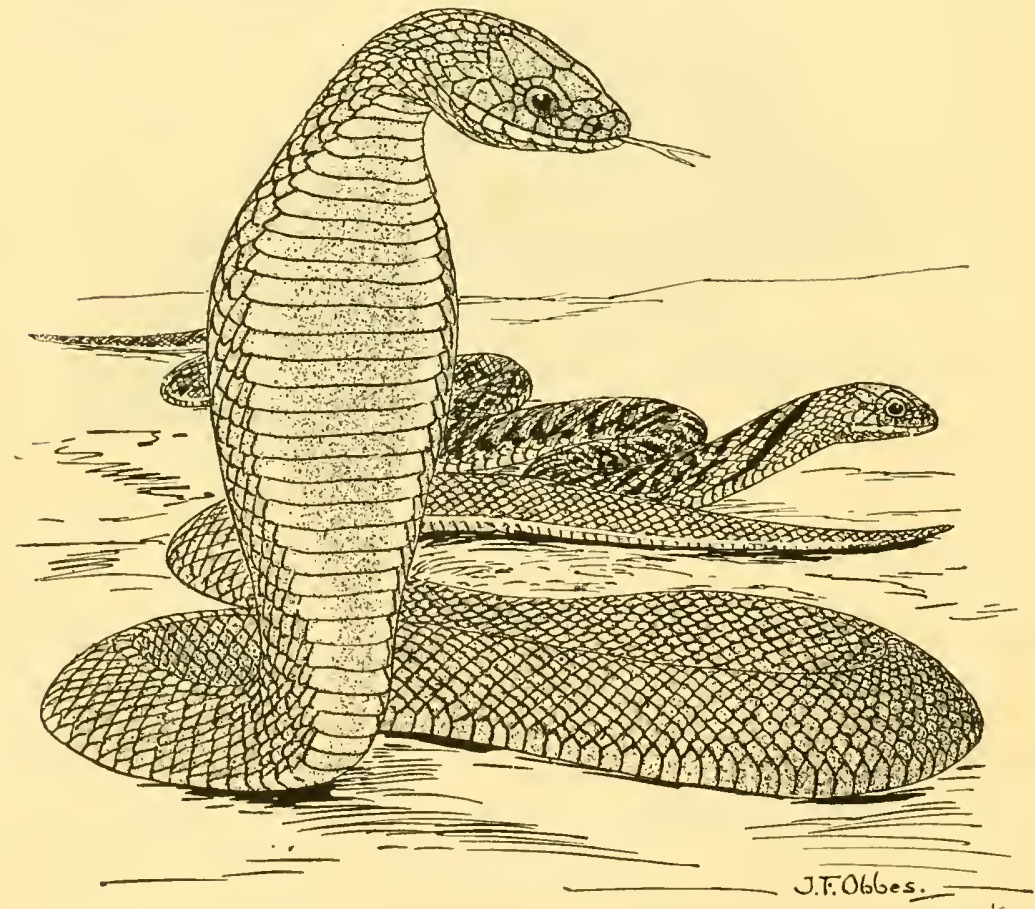

Fig. 33. Pseudorenodon inornatus (Boie) $\times 4 / 5$.

loung specimen with black oblique bands on the background.

Rostral more broad than deep, visible from above; inter- 
nasals shorter than the praefrontals; frontal as long as or longer than its distance from the tip of the snout, shorter than the parietals; loreal more deep than long; two or three prae- and three postoculars; temporals $2+2$ or $2+3$; eight upper labials, fourth and fifth entering the eye; four or five lower labials in contact with the anterior chin-shields; latter and the posterior pair about equal and broad. Scales in 19 rows, dorsals keeled, laterals smooth; ventrals I I 8 - I 2 I ; anal divided; subcaudals $36-4 \mathrm{I}$.

Olive-brown above; lower surface yellowish or brownish, speckled with dark brown; a light streak on each side. Young ones with a $\wedge$-shaped black band on the nape. Length of head and body $400 \mathrm{~mm}$; tail $70 \mathrm{~mm}$.

Type-specimen examined in the Leiden Museum.

Habit at: Java !.

\section{Dendrophis Boie.}

(Bore, Isis, p. 520, I 827 ).

Head distinct from neck, rather long; eye large; pupil round. Maxillary teeth $20-33$, posterior enlarged; anterior mandibular teeth longest. Body long, compressed, covered with smooth scales with pits, in 13 or 15 rows, disposed obliquely, the vertebral row enlarged; ventrals with a lateral keel and notch. Tail long; subcaudals in two rows, keeled and notched like the ventrals.

Distribution. S. E. Asia; Australia.

Key to the Indo-Australian species.

.4. Eye not longer than its distance from the nostril;

maxillary teeth $20-26$.

I. Scales in 15 rows ............. . . D. pictus p. 58 .

11. Scales in 13 rows.

a. Ventrals 174-2II; a dark streak on each side of the head ............. 2. D. calligaster p. 60.

b. Ventrals $159-163$; a dark streak on each

. side of the head ............. 3. D. Lorintzi p. 62 .

c. Ventrals 191--220; no dark streak on the sides of the head ............ . D. punctulatus p. 63 .

B. Eye usually longer than its distance from the nostril; maxillary teeth $27-33$. 
I. Scales in 15 rows............ 5. D. formosus p. 64 .

II. Scales in $I_{3}$ rows.

a. Three postoculars. ............. 6. D. gastrostictus 4.64 .

b. Two postoculars.

I. Frontal as long as its distance from the tip of the snout, as long as or a little shorter than the parietals; upper lip yellow; subcaudals 13I-159........ 7. D. lincolatus p. 65 .

2. Frontal as long as its distance from the tip of the snout, much shorter than the parietals; upper lip white, sharply limited above by a black line; subcaudals I37-147. 8. D. neeki p. 66.

3. Frontal much longer than its distance from the tip of the snout, slightly shorter than the parietals; upper labials yellowish-white, with a dark band behind the eye; sub-

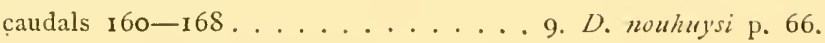

I. Dendrophis pictus (Gmel.).

Coluber pictus, Gmelin, Syst. Nat. I 178s, p. I1 16.

Dendrophis pictus, Boulenger, Cat. Sn. II I 894, p. 78 (s. syn.).

Maxillary teeth 23-26; eye as long as its distance from the nostril. Rostral more broad than deep, visible from above; internasals as long as or slightly shorter than the praefrontals; frontal as long as its distance from the rostral or the tip of the snout, shorter than the parietals; loreal long; onc praeand two postoculars; temporals $2+2, \mathrm{I}+\mathrm{I}$ or $\mathrm{I}+2$; nine (seven or eight) upper labials, fifth and sixth or fourth to sixth entering the eye; five (four) lower labials in contact with the anterior chin-shields; latter shorter than the posterior, which are separated by one anterior and two posterior scales. Scales in 15 rows, vertebrals about as large as the outer; ventrals I5I-204; anal divided; subcaudals IO3-I74.

Olive or brown above; a yellow lateral stripe, bordered below by a dark line between the outer scales and the ventrals; a black stripe on each side of the head passing through the eye and widening or broken up into spots, separated by bluishgreen bands on the nape; upper lip yellow. Lower surface yellowish or greenish. Length of head and body $740 \mathrm{~mm}$; tail $440 \mathrm{~mm}$.

N om. in dig. Ular tambang (mal.); tĕlampar (jav.); duwata and ule lewora (Toradja-names). 
Ha bi t a t: Nias; Mentawei Islands (Siberut!); Sumatra (Atjch, Labuan, Medan!, Bindjey, Pangkalan Brandan!, Gambir!, Brastagei!, Langkat, Laut Tador, Assahan, Bedagei, Indragiri,

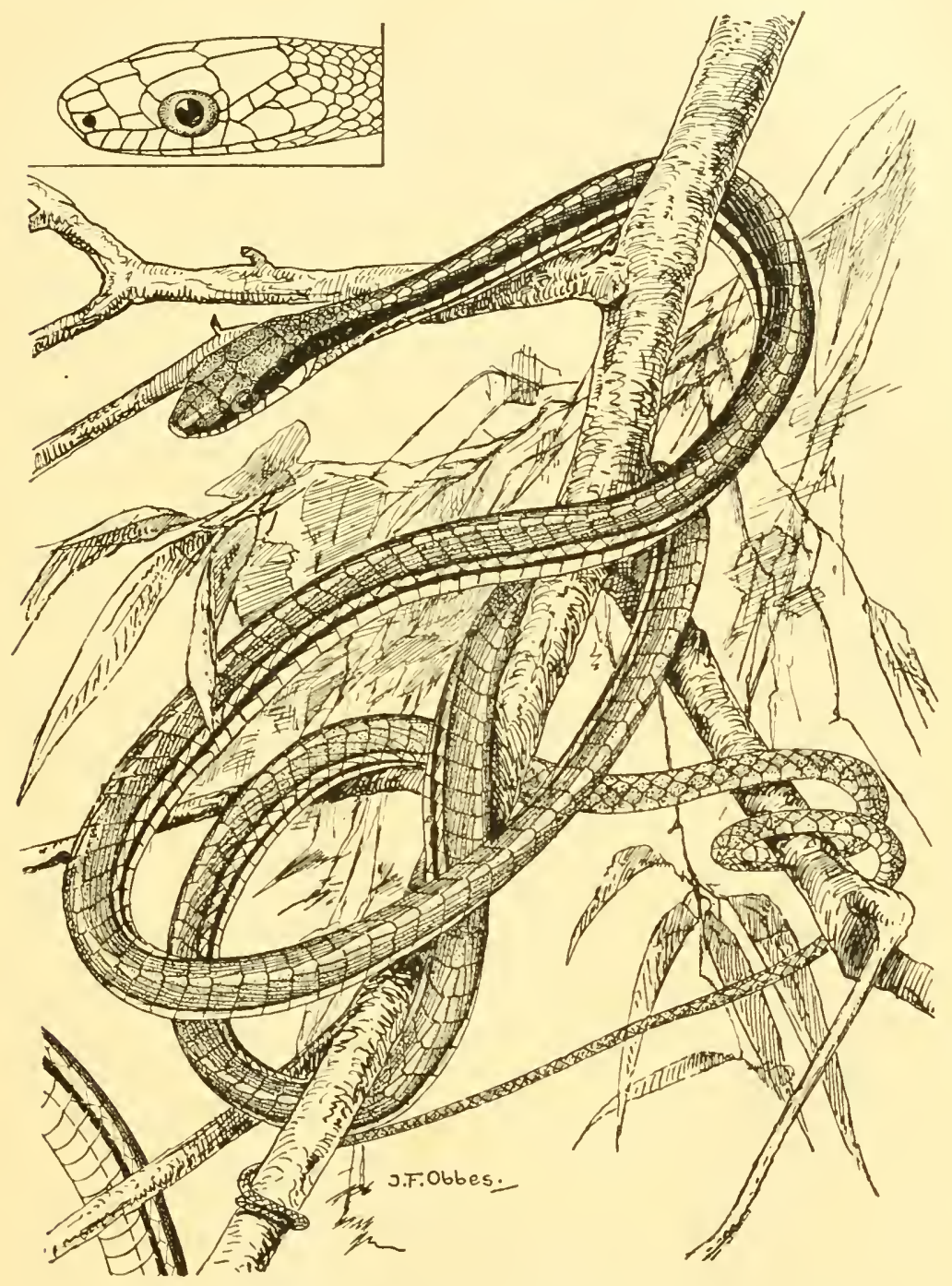

Fig. 34. Dendrophis pictus (Gmel.). Nat. size. Side view of head.

Djambi!, Sidju, Tandjung Laut and Kertadjaja in Palembang, Gunung Sugei in Lampong district, Sidjundjung!, Solok!, Fort de Kock, Singkarah!, Silago, Indrapura, Kalung!, Padang 
I500-3000 feet, Agam); Banka!; Riou!; Natuna Islands; Borneo (Bulangan river, Sandakan Bay, Baram river, Mt. Dulit, Sebruang Valley, Kuching, Sungei duri, Montrado, Singkawang, Sintang, Kapuas river, Kutei, Buntok, Balikpapan, Bandjermassin, Tandjong); Java (Batavia, Anjer, Depok, Darok, Bantam, Gadok, Buitenzorg!, Sukabumi!, Cheribon!, Pekalongan!, Salatiga!, Garum!, Ambarawa, Idju!, Kediri!, Ngawi, Surabaja!); Bali; Lombok; Sumbawa; Flores!; Alor; Timor; Rotti ; Buton ; Celebes (Manado, Gorontalo, Kema, Kandari); Sangir Islands (Siao); Ternate; Misol; Ceram; Ambon!. - Sulu Islands; Philippines; Penang; Malay Peninsula; Andamans; Nicobars; Sian; Burma; India.

A widely distributed and common snake, living on trees, among bushes, often near rice-fields; it feeds on lizards and frogs and is ovoviviparous.

\section{var. striata Cohn.}

Dendorophis pictus var. striata, Cohn, Zool. Anz. XX1X 1906, p. 543.

Dendrophis pictus var. striatu, de Rooy, in Kleiweg de Zwaan, Cianiolog.

Untersuch. Niasischer Schädel 1915, p. 299, with fig.

Snout shorter and broader than in the preceding one; chinshields short and broad, posterior pair separated by irregular scales in the posterior part. Keel of the ventral shields beginning immediately on the throat; ventrals 152-163; subcaudals $103-142$.

Light brown above, with black oblique bars from the vertebral shields to the ventrals; no yellow lateral stripe; head darker, a black stripe on each side, passing through the eye; lips yellow. Lower surface grey with lighter ventral keels or sand-colour with brown keels; throat yellow. Length of head and body $525 \mathrm{~mm}$.; tail $250 \mathrm{~mm}$.

Habitat: Nias!; Sumatra; (Deli!, Sungei Putih near Serdang!, Assahan, Djambi!).

\section{Dendrophis calligaster Günther.}

Dendrophis calligaster, Giinther, Ann. Nat. Ilist. (3) XX I867, p. 53. Dendrophis calligaster, Boulenger, Cat. Sn. II IS94, P. So (s. syn.).

Dendrelaphis schlenckeri, D. Ogilby, Proc. Linn. Soc. N. S. Wales XXIII I 898, p. $36 \mathbf{I}$.

Maxillary teeth 20--26; eyc not longer than its distance from the posterior border of the 1uostril. Rostral more broad 


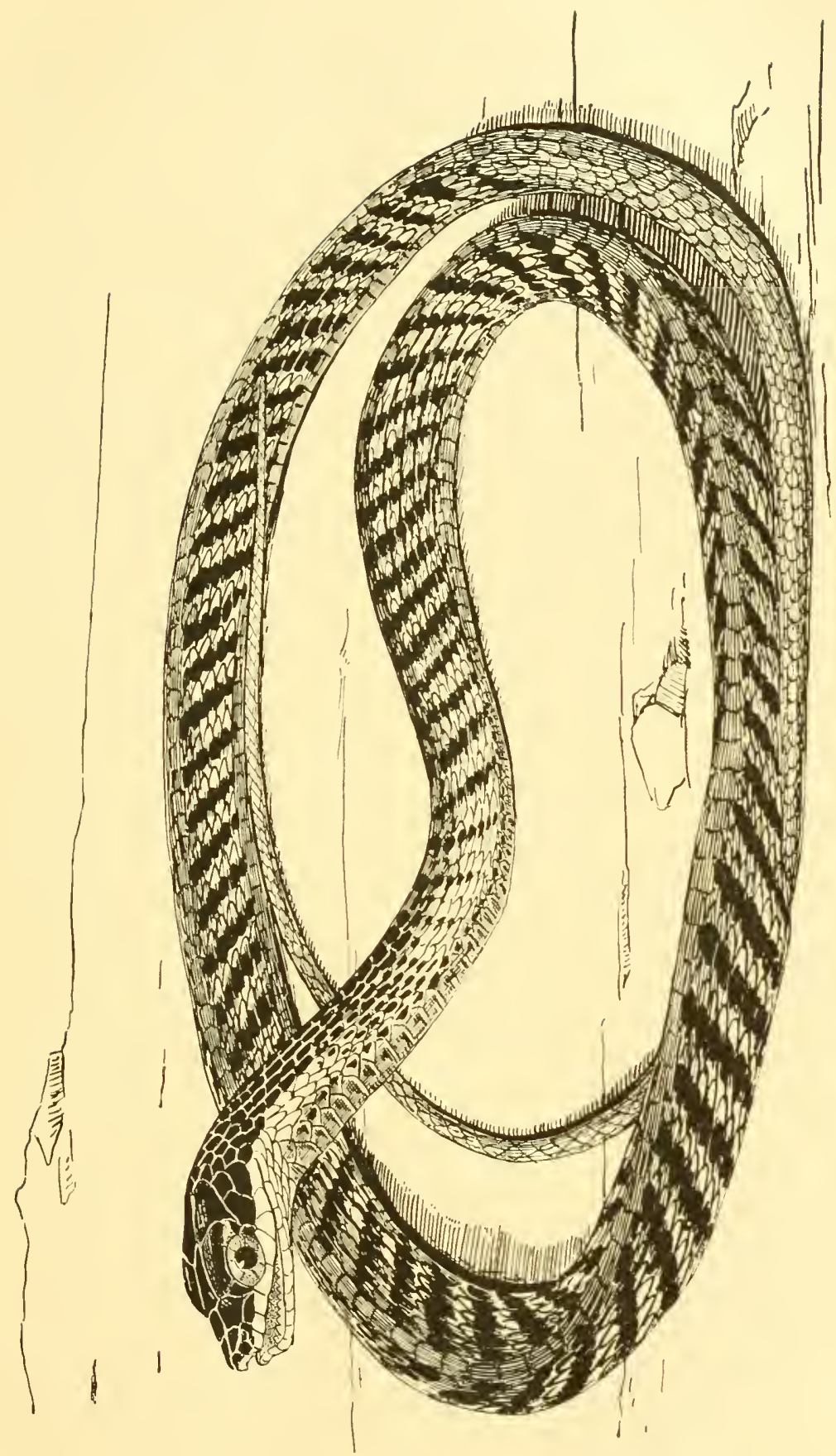

Fig. 35. Dendrophis fictus striata Cohn. 
than deep, visible from above; internasals as long as or longer than the praefrontals; frontal as long as its distance from the rostral or the tip of the snout, usually shorter than the parietals; loreal much more long than deep; one prae- and two (three) postoculars; temporals $2+2$ or $\mathrm{I}+2$; eight or nine upper labials, fourth and fifth or fifth and sixth entering the eye; five (four) lower labials in contact with the anterior chin-shields; latter much shorter than the posterior. Scales in 13 rows, the vertebrals as large as the outer; ventrals I74-2II; anal divided; subcaudals I I 8 - I 55 .

Bronze, olive, green or black above, the scales often blackor yellow-edged; anterior dorsal region sometimes tinged with vermilion and the scales of the vertebral row yellow; a black streak on each side of the head, passing through the eye and often meeting its fellow on the rostral, extending to the neck, were it may break up into spots; upper lip yellow. Lower surface pale olive, sometimes speckled with dark, or yellow, greenish or blackish; throat yellow. Length of head and body $840 \mathrm{~mm}$; tail $430 \mathrm{~mm}$.

Habitat: Ternate; Halmahera; Waigeu!; Batanta; Salawatti; Timor Laut; Kei Islands; Aru Islands; New Guinea (Jobi, Mafoor, Sorong, Fak Fak, Mt. Arfak, Kapaor, Andai, Mansinam!, Amberbaki, Mt. Epa, Supiori, Tjintan Bay, Mawes, Matterer Bay, Sermowai river!, Humboldt Bay!, Mimika and Utakwa rivers 3000 feet, Lorentz river!, Fly river, Inawi, Hula, Bara Bara, Aleya, Fife Bay! (types of Dendrelaphis schlenckeri Ogilby), Dinawa, Stephansort, Bogadjim, Bongu, Erima, Berlinhafen, Simbang, Germaniabucht); Valise Island; Schouten Islands (Mysore). - d'Entrecasteaux and Louisiade Archipelago; Solomon Islands; Bismarck Archipelago; Islands of Torres Straits; Qucensland.

\section{Dendrophis lorentzi Lidth.}

Dendroplis lorentsi, v. Jidth de Jeude, Nova Guinea, Vol. IX Zoolog. I9II, p. 274, Taf. VIII, fig. 2 .

Maxillary teeth 22; eye as long as its distance from the posterior border of the nostril. Rostral more broad than deep, visible from above; internasals about as long as the praefrontals; frontal longer than its distance from the tip of the snout, shorter than the parictals; loreal about twice as long 
as deep; one prae- and two or three postoculars; temporals I $+2+2$ or $2+2+2$, the upper anterior small; eight upper labials, fourth and fifth entering the eye; four or five lower labials in contact with the anterior chin-shields; latter much shorter than the posterior. Scales in 13 rows, the vertebrals about as long as the outer; ventrals $159-\mathrm{I}_{3}$; anal divided; subcaudals I 2 I-I 40 .

Olive-brown above, with black oblique bands anteriorly; neck bluish; dark spots on the parietals, frontal and supraoculars; a dark stripe along the upper border of the posterior labials to the eye; loreal, nasal and anterior labials with dark posterior sutures; an indistinct dark longitudinal band behind the head and a short stripe behind each parietal. Lower surface olive-brown; bluish below the neck, yellowish on the throat. Length of head and body $580 \mathrm{~mm}$; t tail $240 \mathrm{~mm}$.

Type-specimen examined in the Leiden Museum.

Habitat: New Guinea (Mimika river, Lorentz, river!).

\section{Dendrophis punctulatus (Gray).}

Leptophis punctulatus, Gray, King's Voy. Austral. II IS27, p. 432.

Dendrophis punctulatus, Boulenger, Cat. Sn. II I $S_{94}$. p. S2.

Maxillary teeth 23-26; eye not longer than its distance from the posterior border of the nostril. Rostral one time and a half to one time and two thirds as broad as deep, visible from above; internasals as long as or a little longer than the praefrontals; frontal as long as or longer than its distance from the tip of the snout, shorter than the parietals; loreal more long than deep; one prae- and two postoculars; temporals $I+2,2+2$ or $I+I$, anterior long; seven or eight (nine) upper labials, fourth and fifth (fifth and sixth) entering the eye; five lower labials in contact with the anterior chinshields; latter much shorter than the posterior. Scales in 13 rows, vertebrals about as large as outer; ventrals I9I-220; anal divided; subcaudals I I 5 - I 44 .

Olive or brown above, uniform or with black-edged scales; some scales with yellowish outer border; upper lip yellow. Lower surface olive or brown with yellowish keels; throat and anterior ventrals yellow; the posterior ventrals sometimes marbled with black or black in the middle and the subcaudals black with yellow keels. Length of head and body $1200 \mathrm{~mm}$.; tail $440 \mathrm{~mm}$. 
Habitat: New Guinea (near Astrolabe Bay). - N. and E. Australia.

\section{Dendrophis formosus Boie.}

Dentrophis formosa, Boie, Isis I827, p. 542.

Dendrophis formosus, Boulenger, Cat. Sn. II I $\$ 94$, p. 84 .

Maxillary teeth 28-3I; eye large, as long as its distance from the rostral or the anterior border of the nostril. Rostral more broad than deep, visible from above; internasals longer than the praefrontals; frontal as long as its distance from the tip of the snout, as long as the parietals; loreal long; one prae- and two to four postoculars; temporals $2+2$; nine upper labials, fifth and sixth, fourth to sixth or third to fifth entering the eye; five lower labials in contact with the anterior chinshields; latter much shorter than the posterior. Scales in 15 rows, vertebrals larger than the outer, ventrals 174-205; anal divided; subcaudals 132-158.

Olive, bronze or yellowish-brown above, with black-edged scales and red and green tints; a black stripe on each side of the head, passing through the eye, widest on the nape; neck red-brown; sometimes two black lines along each side of the body posteriorly; upper lip greenish-yellow. Lower surface pale green. Length of head and body $940 \mathrm{~mm}$.; tail $480 \mathrm{~mm}$.

Habitat: Sumatra (Labuan, Deli!, Singkarah!, Padang, Indrapura, Tandjong); Borneo (Sandakan Bay, Baram, Kapuas river, Kuching, Tandjong); Java (Batavia, Buitenzorg!, Willis Mts. 5000 feet). - Singapore; Penang; Malay Peninsula; Siam.

\section{Dendrophis gastrostictus Boulenger.}

Dendrophis gastrostictus, Boulenger, Cat. Sn. II IS94, p. 86, pl. IV, fig. 3.

Maxillary teeth 33 ; eye very large, as long as its distance from the anterior border of the nostril. Rostral more broad than deep, just visible from above; internasals as long as the praefrontals; frontal as long as its distance from the tip of the snout, much shorter than the parietals; loreal more long than deep; one prae- and three postoculars; temporals $2+2$; eight upper labials, fourth and fifth entering the eye; four or five lower labials in contact with the anterior chin-shields; latter much shorter than the posterior. Scales in 13 rows, vertebrals nearly as large as outer; ventrals 162 ; anal divided; subcaudals 148 . 
Bronze above; head, nape and tail almost black; upper lip yellow; a black line passing through the eye. Lower surface yellowish, with numerous black dots and spots; throat yellow. Length of head and body $; 00 \mathrm{~mm}$.; tail $420 \mathrm{~mm}$.

Type-specimen examined in the British Museum.

Habitat: N. W. New Guinea!.

\section{Dendrophis lineolatus Hombr. \& Jacq.}

Dendrophis lineolata, Hombr. \& Jacq., Voy. Pôle Sud. Zool. III Rept. I $S_{42}$, p. 20, pl. II, fig. I.

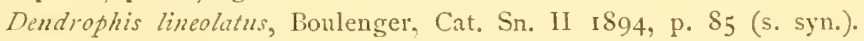

Maxillary teeth 27-32; eye very large, as large as its distance from the centre or the anterior border of the nostril. Rostral more broad than deep, just visible from above; internasals as long as or longer than the praefrontals; frontal as long as its distance from the tip of the snout, as long as or shorter than the parietals; loreal more long than deep; one prae- and two postoculars; temporals $2+2, \quad I+2$ or $I+I$; eight or nine upper labials, fourth and fifth or fifth and sixth entering the eye; five lower labials in contact with the anterior chin-shields; latter much shorter than the posterior. Scales in I 3 rows, vertebrals as large as outer; ventrals I72-203; anal divided; subcaudals I 3 I - I 59 .

Olive above, with black-edged scales; some of the lateral scales with yellowish or white outer border; body often with black, oblique bars anteriorly; head dark; upper lip yellow. Lower surface greenish or greyish-olive with yellow keels; throat and neck below yellow; a black streak along the middle of the tail. Length of head and body I250 mm.; tail $570 \mathrm{~mm}$.

Habitat: Aru Islands; Misol; Waigeu!; New Guinea (Jobi, Mafoor, Passim, Haas, Amberbaki, MIt. Karon, lakc Sentani!, Koimé river!, Humboldt Bay!, Tana, Kaiscrin-Augusta river, Mimika and Setekwa rivers, Lorentz river, Merauke, Fly river, Haveri, Bara Bara, Aleya, Astrolabe Bay); Schouten Islands (Mysore). - Pelew Islands; Bismarck Archipelago; Ferguson \& Voodlark Islands.

\section{var. elegans D. Ogilby.}

Dendrophis elegans, Douglas Ogilby, Record Austr. Mus. I I S9o, p. I 94. Dendrophis elegans, v. Lidth de Jeude, Nova Guinea Vol. IX Zool. I9II, p. 275, Taf. VIII, fig. I. 
Dendrophis lineolatus var. elegans, Boulenger, Transac. Zool. Soc. XX I9I4, p. 264 .

Differs from the preceding one in having squarely cut off parietals; head black above; body olive-brown with black spots, and black oblique bars anteriorly.

Misol; New Guinea (Mt. Arfak, Koimé river!, Humboldt Bay!, Lorentz river).

\section{Dendrophis meeki Boulenger.}

Dendrophis Mecki, Boulenger, Ann. Nat. Hist. (6) XVI I895, p. 32.

Maxillary teeth 32 or 33 ; eye very large, as long as its distance from the centre or the anterior border of the nostril. Rostral almost twice as long as the praefrontals; frontal as long as its distance from the tip of the snout, much shorter than the parietals; loreal more long than deep; one prae- and two postoculars; temporals $2+2$ or 3 ; eight or nine upper labials, fourth and fifth or fourth to sixth entering the eye; five lower labials in contact with the anterior chin-shields; latter shorter than the posterior. Scales in 13 rows, vertebrals about as large as outer; ventrals I68-I79; anal divided; subcaudals 137-I 47 .

Dark olive above; upper lip white, bordered above by a black line passing through the eye. Lower surface pale olive, freckled with dark. Length of head and body $740 \mathrm{~mm}$; tail $420 \mathrm{~mm}$.

Type-specimens examined in the British Museum.

Habitat: New Guinea (Haveri!, Moroka in Bartholomew Range 2300 feet). - Ferguson Island.

\section{Dendrophis nouhuysi Lidth.}

Dendrophis nouhuysi, v. Lidth de Jeude, Nova Guinea Vol. IX Zoologie I9II, p. 277, Taf. Vill, fig. 3 .

Maxillary tecth 28; eye large, as long as its distance from the anterior border of the nostril. Rostral more broad than deep, visible from above; internasals as long as the praefrontals; frontal much longer than its distance from the tip of the snout, about one time and a half as long as internasals and praefrontals together, shorter than the parietals; loreal more long than deep; one prae- and two postoculars; temporals $2+2+2$ or $\mathrm{I}+2+2$; cight upper labials, fourth and fifth entering the eye; five lower labials in contact with the anterior chin- 
shields; latter shorter than the posterior. Scales in 13 rows, vertebrals smaller than the outer; ventrals I76-IS2; anal divided; subcaudals I60-I 68 .

Olive-green above; head and neck darker; labials yellowishwhite; a dark band behind the eye on the upper labials. Lower surface light olive-green with irregular smaller and larger spots; throat yellowish. Length of head and body $460 \mathrm{~mm}$.; tail $240 \mathrm{~mm}$.

Type-specimens examined in the Leiden Museum.

Habitat: New Guinea (Lorentz river!).

\section{I2. De ndrelaph is Boulenger,}

(Boulenger, Fauna Ind. Rept. p. 339, 1S9o).

Head long, distinct from neck; eye large; pupil round. Maxillary teeth I 8-23, anterior maxillary and mandibular teeth longest. Body long, compressed, covered with smooth scales with pits, in 13 or 15 rows, disposed obliquely, the vertebral row not or a little enlarged; ventrals with a lateral keel and notch. Tail long; subcaudals in two rows, keeled and notched like the ventrals.

Distribution. India; Ceylon; Burma; Malay Peninsula to New Guinea.

Key to the indo-Australian species.

A. Scales in 15 rows.............. I. D. inornatus p. 67 .

li. Seales in 13 rows.

1. Eye longer than its distance from the nostril. 2. D. candolineatus p. $6 \mathrm{~S}$.

II. Eye as long as its distance from the nostril.

I. Ventrals 167-I82; black lines along the body and tail; nine upper labials .... 3. D. Cerrificus 1. 69.

2. Ventrals i $85-190$; no black lines along the body and tail; eight upper labials.... 4. D. papuensis p. 70.

3. Ventrals IS5-I93; no black lines along the body and tail; nine upper labials .... 5. 1). modestus P. 70.

\section{Dendrelaphis inornatus Boulenger.}

Dendrelaphis inornatus, Boulenger, Ann. Nat. Hist. (6) XIX I\$97, p. 507.

Eye as long as or shorter than its distance from the nostril. Rostral more broad than deep, visible from above; internasals as long as the praefrontals; frontal as long as its distance from the tip of the snout, shorter than the parietals; loreal 
long; onc prae- and two postoculars; temporals $2+2$; nina or ten upper labials, fifth and sixth or fourth to sixth entering the cye; five lower labials in contact with the anterior chinshields; latter much shorter than the posterior. Scales in I5 rows, vertebrals cnlarged; ventrals I9I-I99; anal divided; subcaudals I $32-$ I 38 .

Pale olive-brown above, some of the scales edged with white on the outer side; outer row of scales pale olive or greyish; a black streak on each side of the head, passing through the eye; upper lip and praeocular yellow. Lower surface greenishgrey or yellow, the outer ends of the shields pale olive or greyish. Length of head and body $\$ 20 \mathrm{~mm}$; tail $380 \mathrm{~mm}$.

Type-specimens examined in the British Museum.

Habitat: Sumba; Savu!, Samao!.

\section{Dendrelaphis caudolineatus (Gray).}

Ahaetulla saudolineato, Gray, 11l. Ind. Zool. II I 834, pl. LXXXI. Dendrelaphis caudolineatus, Boulenger, Cat. Sn. II I 894, p. 89 (s. syn.).

Eye longer than its distance from the nostril. Rostral more broad than deep, visible from above; internasals as long as or shorter than the praefrontals; frontal longer than its distance from the tip of the snout, shorter than the parietals; loreal long; one prae- and two postoculars; temporals $2+2$; nine upper labials, fifth and sixth (fourth to sixth) entering the eye; five lower labials in contact with the anterior chin-shields; latter shorter than the posterior. Scales in I 3 rows; ventrals I 7 I-I 89 ; anal divided; subcaudals 97-I 8 .

Brownish or greenish-yellow above, with black longitudinal lines, formed by the edges of the scales; a yellow lateral streak between two black bands, the lower band on the outer ends of the ventrals; lips yellow. Lower surface yellow; a black median line along the tail. Length of head and body I I $40 \mathrm{~mm}$.; tail $380 \mathrm{~mm}$.

Nom. indig. Ular bandèra (Borneo).

Habitat: Pulu Babi!; Nias!; Mentawei Islands (Sipora); Sumatra (Medan!, Serdang!, Stabat, Bindjey, Djambi!, Singkarah!, Silago, Padang! I 500-300o feet); Riou!; Natuna Islands; Borneo (Sandakan Bay, Baram, Kucling, Matang, Simanggang, Limbang, Oya, Kapuas river, Buntok, Pontianak, Muara Djawa!, 
Balikpapan); Java. - Malay Peninsula; Siam; Penang; Singapore; S. India; Philippines.

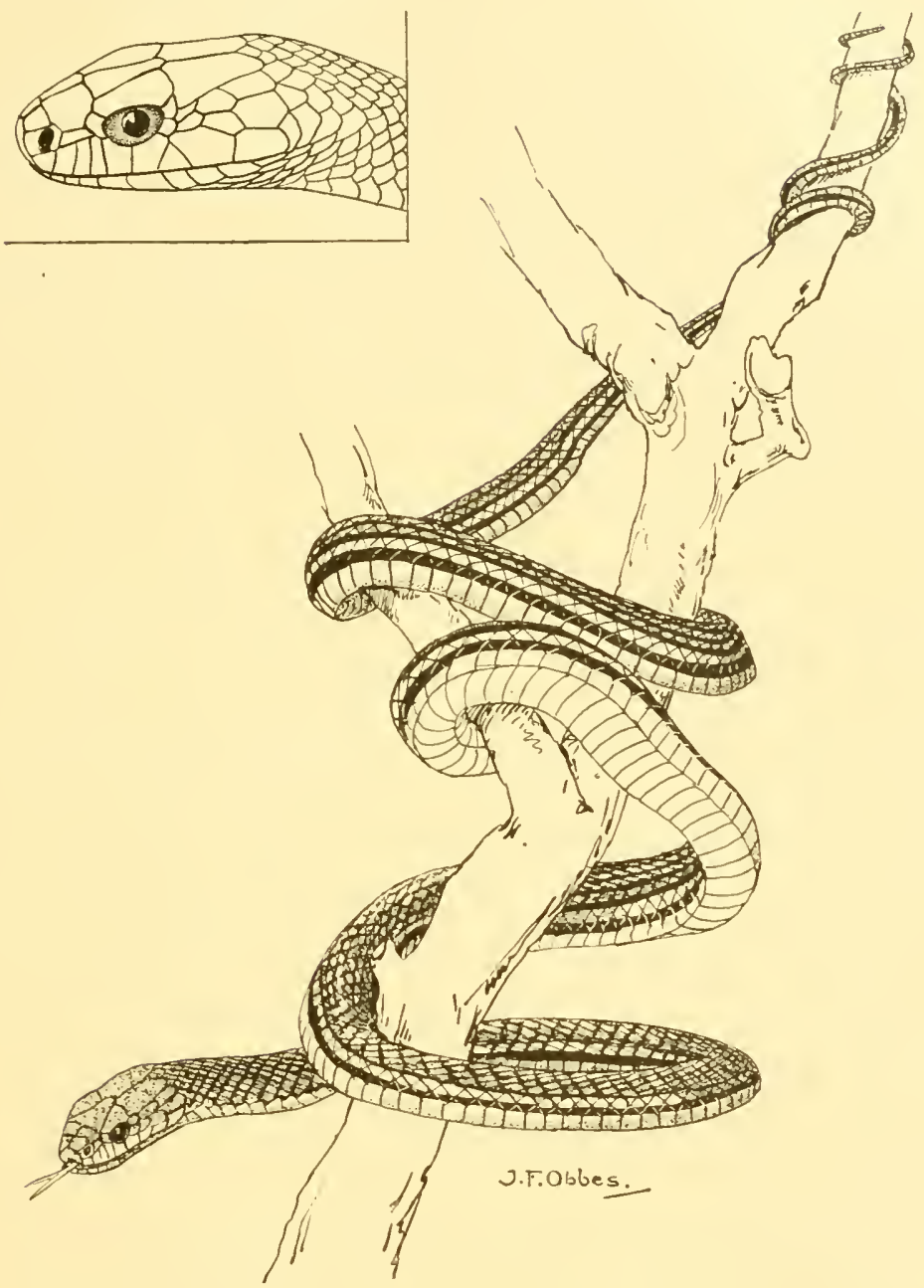

Fig. 36. Dindrelaphis candolineatus (Gray). $\times 1 / 2$. Side view of head.

\section{Dendrelaphis terrificus (Peters).}

Dendrophis terrificus, Peters, Mon. Berl. Ac. I872, p. $5^{8} 3$.

Dendrelaphis terrificus, Boulenger, Cat. Sn. II I $\$ 94$, p. 90 (s. syn.).

Eye as long as its distance from the nostril. Rostral more broad than deep, visible from above; internasals as long as or shorter than the praefrontals; frontal as long as its distance 
from the rostral, shorter than the parietals; loreal long; one prae- and two postoculars; temporals $2+2$; nine upper labials, fifth and sixth or fourth to sixth entering the eye; five lower labials in contact with the anterior chin-shields; latter shorter than the posterior. Scales in I 3 rows; ventrals $167-182$; anal divided; subcaudals 92 -I I3.

Olive above, some of the scales black-edged or with white outer border; a black stripe on each side of the head and neck, passing through the eye, sometimes continued along the body and tail. Lower surface pale yellowish-green; a black line along the outer edge of the shields; a black median line along the tail. Length of head and body $750 \mathrm{~mm}$.; tail $300 \mathrm{~mm}$.

Habitat: Celebes (Gorontalo, Manado!, Minahassa). Philippines.

\section{Dendrelaphis papuensis Boulenger.}

Dendrelaphis papuensis, Boulenger, Ann. Nat. Hist. (6) XVI 1895, p. 405; Cat. Sn. III I 896, p. 630.

Eye as long as its distance from the nostril. Rostral more broad than deep, visible from above; internasals as long as the praefrontals; frontal as long as its distance from the tip of the snout, shorter than the parietals; loreal long; one praeand two postoculars; temporals $2+2$; eight upper labials, fourth and fifth entering the eye; five or six lower labials in contact with the anterior chin-shields; latter shorter than the posterior. Scales in 13 rows; ventrals $185-190$; anal divided; subcaudals I 19-I 26.

Olive-brown above, head and neck blackish; a black streak on each side of the head and neck, passing through the eye; upper lip white; vertebral scales on anterior part of body lighter, edged with whitish in front. Lower surface pale olive. Length of head and body $740 \mathrm{~mm}$; tail $310 \mathrm{~mm}$.

Type-specimens examined in the British Museum. Habitat: Trobriand Islands!.

\section{Dendrelaphis modestus Boulenger.}

Dendrelaphis modestus, Boulenger, Cat. Sn. II 1894, p. $9 \mathbf{r}$.

Eye as long as its distance from the nostril. Rostral more broad than deep, visible from above; internasals as long as the praefrontals; frontal as long as its distance from the rostral 
or the tip of the snout, shorter than the parietals; loreal long; one prae- and two postoculars; temporals $2+2$ or $\mathrm{I}+2$; nine upper labials, fifth and sixth entering the eye; five lower labials in contact with the anterior chin-shields; latter shorter than the posterior. Scales in I 3 rows; ventrals I85-I93; anal divided; subcaudals 1I4-I 2 I.

Olive above, with black-edged scales; an indistinct dark streak on each side of the head, passing through the eye; upper lip yellow. Lower surface pale green, the posterior ventrals and the subcaudals margined with black; liead yellow below. Length of head and body $805 \mathrm{~mm}$.; tail 3 I $5 \mathrm{~mm}$.

Type-specimens examined in the British Museum.

Habitat: Ternate!; Halmahera!; Batjan.

\section{3. Zaocys Cope.}

(Cope, Proc. Ac. Philad. p. 563, 1860).

Head long, distinct from neck; eye large; pupil round. Naxillary teeth 20-33, increasing in size posteriorly; mandibular teeth about equal. Body long, slightly compressed, covered with smooth or keeled scales with pits, in 12 , 14,16 or Is rows; ventrals rounded. Tail long; subcaudals in two rows.

Distribution. S. E. Asia.

Key to the Indo-Australian species. A. A single loreal; scales in 12 rows......... I. Z. tornicri p. 71 . b. Two or three loreals; scales in 16 or IS rows.

I. Scales smooth; subcaudals 160-179........ 2. Z. fuscus p. 72.

II. Scales of two or four median rows keeled: subcaudals

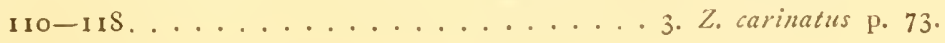

\section{Zaocys tornieri Werner.}

Zaocy's tornicri, IVerner, Verh. Ges. Wien XLVI IS96, p. I5, Taf. I, fig. I.

Rostral twice as broad as deep; internasals as long as the praefrontals; frontal as long as its distance from the tip of the snout, a little shorter than the parietals; loreal more long than deep; no subocular; two postoculars; temporals I + I; nine upper labials, fifth and sixth entering the eye. Scales in I 2 rows, two middle rows strongly keeled as far as the base of the tail; ventrals I46; anal divided; subcaudals I 3 I.

Brown above; sides of head yellowish. Lower surface greenish; 
a blackish median line along the lower side of the tail. Length of head and body $720 \mathrm{~mm}$.; tail $410 \mathrm{~mm}$. (Not seen by me).

Habitat: Sumatra.

\section{Zaocys fuscus (Günther).}

Coryphodon fuscus, Gïnther, Cat. I 858 , p. II 2.

Zaocy's fuscus, Boulenger, Cat. Sn. I x 993, p. 37 , pl. XXVII, fig. 2.

Rostral more broad than deep, visible from above; internasals shorter than the praefrontals; frontal as long as its distance from the rostral or the tip of the snout, shorter than the parietals; three loreals; one praeocular; one or two small suboculars; two postoculars; temporals $2+2$; nine upper labials, fifth and sixth (fourth and fifth) entering the eye; five lower

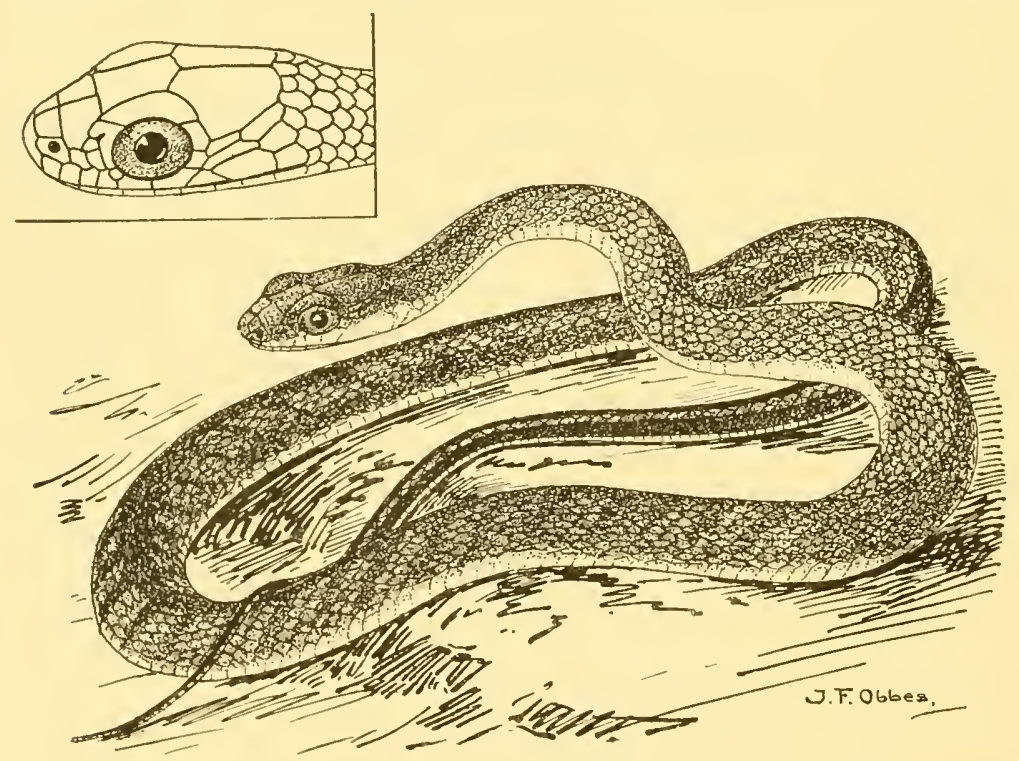

Fig. 37. Zaocys fuscus (Gthr.) $\times 4 / 5$. Side view of head.

labials in contact with the anterior chin-shiclds; latter much shorter than the posterior. Scales in $I 6$ rows, smooth; ventrals I 83 - I98; anal divided; subcaudals I60-I79.

Olive or olive-brown above, sometimes with a red, blackedged vertebral line and dark oblique bars on the posterior part of the body; a black lateral band posteriorly, covering the outer ends of the ventrals and subcaudals. Lower surface pale yellow. Length of head and body $1900 \mathrm{~mm}$; tail $1000 \mathrm{~mm}$. 
Ha bitat: Nias!; Sumatra (Labuan, Deli!, Langkat, Lebong. donok!); Banka!; Natuna Islands; Borneo (Mt. Mulu 2000 feet, Kuching, Sibu, Buntok, Balikpapan). - Penang; Malay Peninsula.

\section{Zaocys carinatus (Günther).}

Coryphodon carinatus, part., Günther, Cat. I858, p. II2.

Zaocy's carinatus, Boulenger, Cat. Sn. I I\$93, p. 377, pl. XXVII, fig. I.

Rostral more broad than deep, visible from above; internasals shorter than the praefrontals; frontal as long as its distance from the rostral, shorter than the parietals; two or three loreals; one praeocular; a subocular; two postoculars; temporals $2+2$; nine upper labials, fifth and sixth entering the eye; five lower labials in contact with the anterior chin-shields; latter much shorter than the posterior. Scales in 16 or 18 rows, the two or four median rows keeled; ventrals 208-2I5; anal divided; subcaudals I IO-IIS.

Olive-brown or blackish in the anterior part, with yellow spots or irregular transverse bands, pale brown or yellowish with a black network posteriorly. Lower surface yellowish, black and yellow posteriorly. Length of head and body $2250 \mathrm{~mm}$.; tail $750 \mathrm{~mm}$.

Type-specimen examined in the British Museum.

Ha b it at: Sumatra (Labuan in Deli, Gunung Sugei in Lampong district); Borneo! (Kuching, Sebruang Valley); Java (Depok). - Singapore; Malay Peninsula.

\section{I4. Tropidonotus Kuhl.}

(Kunl, in Férussac, Bull. Sc. Nat. II p. SI, I $\$ 24$ ).

Head generally distinct from neck; eye moderate or large; pupil round. Maxillary teeth $\mathrm{I} 8-40$, continuous, posterior longest; mandibular teeth about equal. Body long, round, covered with smooth or keeled scales, usually with pits, in I5-33 rows; ventrals rounded. Tail long; subcaudals in two rows.

Distribution. Europe; Asia; Africa; N. Australia; N. and C. America.

The snakes of this genus live in the neighbourhood of water, feeding on frogs and fish. Oviparous, laying 10-40 eggs. 
Key to the Indo-Australian species.

A. Maxillary teeth gradually enlarged posteriorly.

I. Internasals much narrowed in front; nostrils directed upwards and outwards; scales in I9 rows .................. T. Thiscator 1) 75 .

II. Internasals broadly truncate in front; nostrils lateral.

a. Scales in 15 rows.

† Upper lalials 8 usually.

X Subcaudals less than 60.

I. Scales strongly keeled; three or four postoculars. ...........

2. Scales feebly keeled; two postoculars.

2. T. picturatus p. 76 .

3. Scales feebly keeled; three postoculars.

$a a$. Internasals shorter than praefrontals; frontal longer than its distance from the tip of the snout. b6. Internasals as long as praefrontals; frontal as long as its distance from the tip of the snout ...... 4. T. celcbicus p. 78 .

5. T. novae-guineae p. 78 . $X X$ Subcaudals usually more than 60 .

I. Ventrals 137-141; subcaudals $65-75$; I prae- and 3 postoculars.

2. Ventrals I37-I70; subcaudals 5I-110; 2 prae- and 3 postoculars.

3. Ventrals 164 ; subcaudals 76 ; 2 praeand 3 postoculars; tail with longitudinal dark bands..........

4. Ventrals 162-I65; subcaudals $72 ; 2$ prae- and 3 postoculars; posterior part of body with dark longitudinal lines.

6. T. sarasinorum p. 79 .

7. T. mairi p. 79.

8. T. montanus p. So.

9. T. clongatus p. So.

† Upper labials 9.

$a a$. Ventrals $\mathbf{1} 62$; belly white, with 6 longi-

tudinal rows of black dots ...... Io, $T$. punctiventris p. $\$ \mathbf{I}$.

$6 \dot{0}$. Ventrals I $72-\mathbf{I} S 0$; belly white anteriorly, spcckled and powdered with blackish in the middle, black postcriorly. ............ I I. T. hulmahcricus p. 82 .

b. Scales in $\mathbf{I} 7$ ruws.

I. Three labials entering the eye; ventrals $14 \mathrm{I}-\mathrm{I} 5 \delta$; subcaudals $50-\delta_{5} \ldots \ldots$ I2. $T$. doriac $\mathrm{p} . \mathrm{S} 2$. 
2. Two labials entering the eye; ventrals

I82-196; subcaudals 99-III..... I3. T. hypomelas p. $8_{3}$.

c. Scales in 19 rows.

I. A single anterior temporal....... I4. $T$. conspicillatus p. $\$_{3}$.

2. Two anterior temporals.

+ Scales of outer row smooth or feebly

keeled; frontal one time and a half

to one time and three fourths as long

as broad.............. I 5. T. trianguligerus p. $\mathrm{S}_{4}$.

++ Scales all strongly keeled; frontal one

time and one third as long as broad. I6. T. petersi p. $\mathrm{S}_{5}$.

$B$. Two or three last maxillary teeth abruptly

enlarged.

I. Scales in 17 rows; three labials entering the eye. $17 . T$. saravacensis 1 . $\$ 5$.

II. Scales in $2 \mathrm{I}$ rows. . . . . . . . . . IS. T. chry'sargoides p. 86.

III. Scales in 19 rows.

a. Two labials entering the eye; anal entire. 19. T. favifrons p. S7.

b. Three labials entering the eye; anal divided.

I. A single anterior temporal.

aa. Third to fifth labials entering the eye. 20, T. stolatus p. 87 .

b6. Fourth to sixth labials entering the eye 21 . T. villatus p. SS.

2. Two anterior temporals.

†Internasals shorter than praefrontals;

scales of outer row smooth. ..... 22. T. subminiatus p. 89 .

†† Internasals as long as praefrontals; all

the scales strongly keeled.

I. Subcaudals 56-94; eye large... 23. T. chrysurgus p. S9.

2. Subcaudals 95-I17; eye very large. 24. T. maculatus p. 90.

\section{Tropidonotus piscator (Schn.).}

Hydrus piscator, Schneider, Hist. Amph. I 1799, p. 247.

Tropidonotus piscator, Boulenger, Cat. Sn. I I893, p. 230 (s. syn.).

Natrix piscator, Barbour, Mem. Mus. Comp. Zool. Harv. Coll. ILIV 19I2, p. 109.

Eye shorter than its distance from the nostril; latter turned upwards; rostral visible from above; internasals narrowed in front, as long as the praefrontals; frontal longer than its distance from the end of the snout, as long as the parietals or shorter; loreal about as long as deep; one prae- and three sometimes four postoculars; temporals $2+2$ or $2+3(I+2)$; ninc upper labials, fourth or fourth and fifth entering the eye; five lower labials in contact with the anterior chin-shields; latter shorter than the posterior. Scales keeled, of two or three outer rows 
smooth, in 19 rows (rarely 17); ventrals 125 - I 50; anal divided; subcaudals $65-90$.

Yellowish or olive-brown above, usually with black spots in 5 series, the spots sometimes very large or with four black stripes on the nape, five on the body; sometimes scarlet markings on the sides; a black streak below the eye and another behind the eye; sometimes two small black-edged yellow spots on the parietals. Lower surface yellow or whitish, the shields often

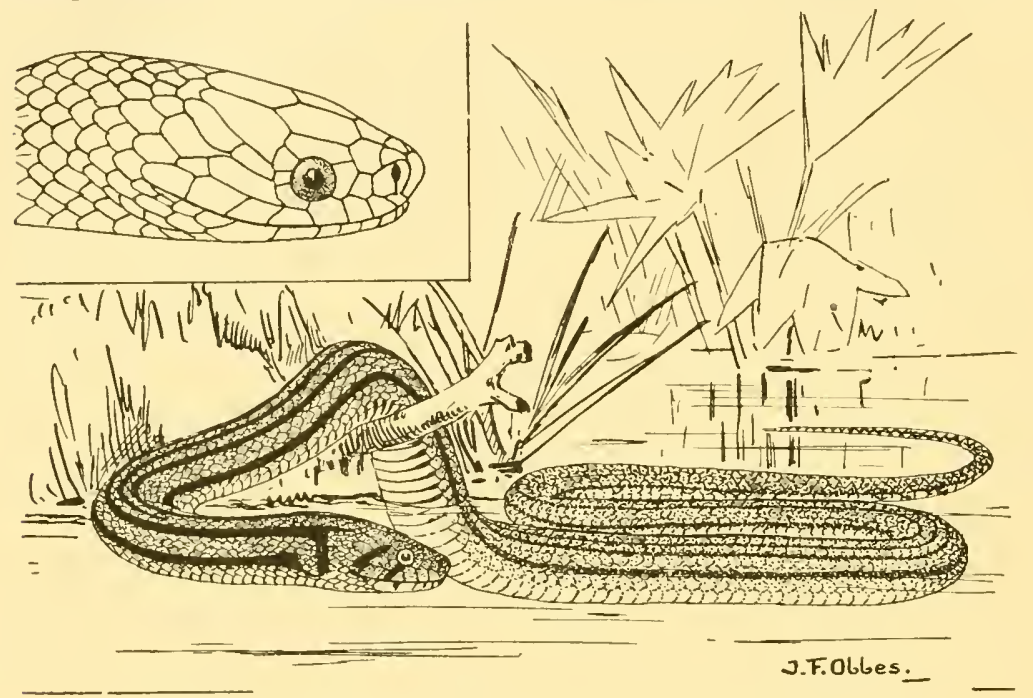

Fig. 3 S. Tropidonotus piscator (Schn.) $\times 1 / 2$. Side view of head.

edged with black. Length of head and body $900 \mathrm{~mm}$; tail $300 \mathrm{~mm}$.

Habitat: Sumatra (in Palembang district!); Java (Batavia, Buitenzorg!, Bantam, Depok, Gadok, Cheribon!, Pekalongan!, Garum!, Kediri!); Borneo (Landak!); Celebes (Manado, Macassar!). - Malay Peninsula; Penang; Singapore; Andamans; Burma; India; S. China; Siam.

\section{Tropidonotus picturatus Schlegel.}

Tropidonotus picturatus, Schlegel, Phys. Serp. $1 S_{37}$, p. 314, pl. XII, fig. $\$$ \& 9 . Tropidonotus picturatus, Boulenger, Cat. Sn. I IS93, p. 215; Ann. Mus. Civ. Genova (2) XVIJI IS97, p. 703.

Eye as long as its distance from the centre of the nostril; rostral visible from above; internasals about as long as the praefrontals; frontal longer than its distance from the tip of the 
snout, shorter than the parietals; loreal as deep as long; two or three prae- and three or four postoculars; temporals $I+1$, I +2 or $2+3$; eight (nine) upper labials, fourth and fifth (fifth and sixth) entering the eye, sixth largest; four lower labials in contact with the anterior chin-shields; latter shorter than the posterior. Scales strongly keeled, in I5 rows; ventrals I23-I37; anal divided; subcaudals 40-6I.

Uniform brown above, each scale with two small yellow spots; head-shields with longitudinal black spots; sides of head yellow, with a black bar below the eye, continued on the throat, meeting its fellow in the middle and forming a short longitudinal stripe or broken up into spots; another black stripe from the eye to the angle of the mouth and continued along each side of the neck, forming a broad transverse band across the nape. Lower surface yellow, uniform or brown-spotted or with dark spots on the outer ends of the ventrals. Length of head and body $500 \mathrm{~mm}$.; tail $\mathrm{r} 20 \mathrm{~mm}$.

Habitat: ') Waigeu; New Guinea (Sorong, Mt. Epa, Lobo Bay!, Triton Bay, Andai, Mansinam, Amberbaki, Mt. Arfak, Rubi, Passim, Dorei, Tana, Jobi, Sepik river, Bongu, Erima, Berlinhafen, Mimika, Setekwa and Lorentz! rivers, Fly river, Moroka 2300 feet, Haveri, Fife Bay, Huon Gulf); Schouten Islands (Mysore); Aru Islands. - Ferguson Island; N. Australia.

\section{Tropidonotus truncatus (Peters).}

Styporhynchus truncatus, Peters, Mon. Berl. Ac. IS63, p. 399.

Tropidonotus truncatus, Boulenger, Cat. Sn. I I893, p. 2 I6.

Snout prominent; eye moderate; rostral broad; internasals almost quadrangular, as long as the praefrontals; frontal longer than its distance from the tip of the snout, shorter than the parictals; two prae- and two postoculars; temporals $\mathrm{I}+2$; eight upper labials, third to fifth entering the eye; four lower labials in contact with the anterior chin-shields; latter much shorter than the posterior. Scales keeled, in 15 rows; ventrals I42-I49; anal divided; subcaudals 43.

Brown or black above; head reddish-brown with a light, black-edged streak, powdered with brown, on the upper lip

1) Part of the Tropidonotus, recorded from New Guinea as T. picturatus possibly belong to $T$. mairi Gray and $T$. doriae Blgr., which are separated from $T$. picturatus Schleg. by Boulenger in $\mathbf{I} \$ 97$. 
and the side of the neck. Lower surface black with whitish dots or pale brown, dotted with black. Length of head and body $425 \mathrm{~mm}$.; tail $75 \mathrm{~mm}$.

Habitat: Ternate; Halmahera!; Batjan.

\section{Tropidonotus celebicus (Ptrs. \& Doria).}

Styporhynchus celebicus, Peters \& Doria, Ann. Mus. Civ. Genova XIII i S7S, p. 3 S6. Tropidonotus celebicus, Boulenger, Cat. Sn. I I $\$ 93$, p. 216.

Snout truncate; eye moderate; rustral more vertical than in the preceding one; internasals quadrangular, shorter than the praefrontals; frontal longer than its distance from the tip of the snout, shorter than the parietals; one prae- and three postoculars; temporals I +2 ; eight upper labials, third to fiftl entering the eye; four lower labials in contact with the anterior chin-shields; latter shorter than the posterior. Scales keeled, smooth anteriorly, in 15 rows; ventrals $125-142$; anal divided; subcaudals $45-53$.

Brown above, with or without three longitudinal blackishbrown bands, separated by yellow streaks; a black collar, edged posteriorly with a yellow band, anteriorly with two yellow spots; neck sometimes with light transverse bands; lips white, powdered with black. Lower surface yellow, uniform or dotted with black. Length of head and body $360 \mathrm{~mm}$; t tail $90 \mathrm{~mm}$.

Habitat: Celebes! (Kandari, Buol 2000 feet).

\section{Tropidonotus novae-guineae Lidth.}

Tropidonotus novae-guineae, v. Lidth de Jeude, Nova Guinea, Vol. IX Znol. $19 \mathrm{Ir}, \mathrm{p} .27 \mathrm{I}$.

Eye as large as its distance from the centre of the nostril. Rostral about twice as broad as deep, visible from above; internasals as long as the praefrontals, broadly truncate anteriorly; frontal broad, as long as its distance from the tip of the snout, shorter than the parietals; loreal more deep than long; two prae- and three or four postoculars; temporals $2+2$, the lower anterior not in contact with the postocular; eight upper labials, fourth and fifth entering the eye; four or five lower labials in contact with the anterior chin-shields. Scales in I 5 rows, kecled; ventrals 137 ; anal divided; subcaudals 52 . Grey above, with black spots arranged in transverse rows; behind the head and near the tail these spots form trans- 
verse bands; tail without spots; upper labials grey with dark sutures. Lower surface light; tail with a series of dark spots in the middle.

Type-specinen examined in the Leiden Museum.

Habitat: S. New Guinea (Lorentz river!).

\section{Tropidonotus sarasinorum Boulenger.}

Tropidonotus Sarasinorum, Boulenger, Ann. Nat. Hist. (6) XVII I 896, p. 393 : Proc. Zool. Soc. I $\$ 97$, p. 218.

Snout prominent, truncate; eye moderate, rostral more broad than deep, not visible from above; internasals as long as the pracfrontals; frontal longer than its distance from the tip of the snout, shorter than the parietals; loreal as long as deep; one prae- and three postoculars; temporals $\mathbf{I}+2$ or $\mathrm{I}+3$; eight upper labials, third to fifth entering the eye; four lower labials in contact with the anterior chin-shields; latter shorter than the posterior. Scales in 15 rows, strongly keeled; ventrals I37-I4I; anal divided, subcaudals 65-75.

Reddish-brown anteriorly, olive or dark grey behind, with blackish transverse bands; a dark nuchal blotch in connection with a dark streak on each side of the head along the upper border of the labials, which are whitish and speckled with brown. Lower surface yellow, sides reddish, dotted with black; posterior ventrals and subcaudals in the male grey. Length of head and body $380 \mathrm{~mm}$.; tail $150 \mathrm{~mm}$.

One of the type-specimens examined in the British Museum. Habitat: Celebes (Loka on Bonthain Peak 3500 feet!).

\section{Tropidonotus mairi Gray.}

Tropidonolus mairii, Gray, Grey Trav. Austr. II I $S_{41}$, p. 442.

Tropidonotus mairii, Boulenger, Ann. Mus. Civ. Genova (2) XVIII I897, p. 703. Natrix mairii, Barbour, Mem. Mus. Comp. Zool. Harv. Coll. XIIV 1912, p. I07.

Eye larger than in $T r$. picturatus, longer than its distance from the anterior border of the nostril; rostral visible from above; internasals slightly shorter than the praefrontals; frontal longer than its distance from the tip of the snout, shorter than the parietals; two (rarely one) prae- and three (rarely two or four) postoculars; temporals $\mathrm{I}+\mathrm{I}$ or $\mathrm{I}+2(2+2)$; eight (nine) upper labials, fourth and fifth or third to fifth (fourth to sixth) entering the eye; five (four) lower labials in 
contact with the anterior chin-shields; latter shorter than the posterior. Scales strongly keeled, in I 5 rows; ventrals I $37-170$; anal divided; subcaudals 5 I-I IO.

Olive, brown or black above, with small black spots or with transverse bars anteriorly; a black band behind the head; a black line between temporals and labials; upper lip white with black sutures. Lower surface yellowish or coral-red; ventrals and subcaudals sometimes edged with black. Length of head and body $68_{4} \mathrm{~mm}$.; tail $250 \mathrm{~mm}$.

Habitat: New Guinea (Haas, Mts. Karon, Fak Fak, Pokembo, Jamur river!, lake Sentani!, Begowre and Betèwi rivers!, Humboldt Bay!, Kaiserin-Augusta river!, Mimika river, Utakwa river 2100-2500 feet, Lorentz river!, Etna Bay, Merauke!, Moroka 2300 feet, Haveri, Borepata, Dinawa, Madew); Valise Island. - Ferguson and Trobriand Islands; Queensland.

\section{Tropidonotus montanus Lidth.}

Tropidonotus montanus, v. Lidth de Jeude, Nova Guinea Vol. IX Iọ I , Zool., p. 27 I.

Eye as large as its distance from the centre of the nostril; rostral more broad than deep, visible from above; internasals shorter than the praefrontals; frontal longer than its distance from the tip of the snout, shorter than the parietals; loreal more deep than long; two prae- and three postoculars; temporals $I+2$, the anterior large; eight upper labials, fourth and fifth entering the eye; four lower labials in contact with the anterior chin-shields. Scales in 15 rows, keeled; ventrals I64; anal divided; subcaudals 76 .

Reddish-brown above, with dark markings on the middle; on the tail and just before the tail the spots fuse into longitudinal bands; head grey; upper labials light, with dark sutures. Lower surface light with dark transverse streaks on each side of the ventrals; subcaudals with dark sutures. Length of liead and body $610 \mathrm{~mm}$; tail $190 \mathrm{~mm}$.

Type-specimen examined in the Leiden Museum.

Habitat: S. New Guinea (near Lorentz river I 360 M.!).

\section{Tropidonotus elongatus Jan.}

Tropidonotus picturatus var. elongatus Jan, Elenco d. Ofidi 1 $863, \mathrm{p} .72$; Iconogr. gén. 27 1868, pl. IV, fig. 2.

Tropidonotus clongatus, Boulenger, Ann. Mus. Civ. Genova (2) XVIIl IS97, p. 703.

Eye large, as long as its distance from the anterior border 
of the nostril; rostral just visible from above; internasals broadly truncate anteriorly, as long as the praefrontals; frontal longer than its distance from the tip of the snout, shorter than the parietals; loreal more deep than long; two prae- and three postoculars; temporals $\mathrm{I}+2$; eight upper labials, fourth and fifth or third to fifth entering the eye; five lower labials in contact with the anterior chin-shields; latter shorter than the posterior. Scales strongly keeled, in 15 rows; ventrals $162-165$; anal divided; subcaudals 72 .

Blackish-brown above, with yellow transverse bands on the anterior part of the body; posterior part of body with dark longitudinal lines, the vertebral line broadest; head and neck blackish; upper lip yellow, bordered above by a dark brown line; fourth, fifth and sixth labials with a dark brown spot near the border of the mouth; outer row of scales along the neck yellowish. Lower surface yellowish anteriorly, ventrals with blackish outer ends and black spots, posteriorly blackish with yellowish outer borders. Length of head and body $62 \mathrm{I} \mathrm{mm}$.; tail $219 \mathrm{~mm}$.

Habitat: Ceram!.

\section{IO. Tropidonotus punctiventris Böttger.}

Tropidonotus punctiventris, Böttger, Zool. Anz. XVIII I 895, p. 129; Abh. Senckenb. Ges. XXV 1900, p. 353, Taf. XV, fig. 6.

Tropidonotus punctiventris, Boulenger, Cat. Sn. III I 896, p. 602.

Eye large, as large as its distance from the anterior border of the nostril; rostral just visible from above; internasals broadly truncate anteriorly, their suture as long as the suture between the praefrontals; frontal slightly longer than its distance from the tip of the snout, much shorter than the parietals; loreal more deep than long; two prae- and three postoculars; temporals $2+3$; nine upper labials, fourth to sixth entering the eye, seventh largest; five lower labials in contact with the anterior chin-shields; latter about half as large as the posterior. Scales in 15 rows, all strongly keeled; ventrals 162 ; anal divided; subcaudals 74 .

Dark olive-grey above, with indistinct black spots or light network, the keels, especially on the sides of the tail lighter; two white, black-edged spots on the parietal region; lips white, the sutures between the four anterior labials black. Lower surface IIDO-AUSTRALIAN REPTILES II. 
white, posteriorly grey, with about 6 longitudinal rows of black dots, forming three black lines on the lower part of the tail. Length of head and body $345 \mathrm{~mm}$; tail $116 \mathrm{~mm}$. (After BÖTTGER; not seen by me).

Habit at: Halmahera.

\section{I. Tropidonotus halmahericus Böttger.}

Tropidonotus halmahericus, Böttger, Zool. Anz. XVIII I\$95, p. I30; Abh.

Senckenb. Ges. XXV I900, p. 354, Taf. XV, fig. 5.

Tropidonotus halmahericus, Boulenger, Cat. Sn. III I\$96, p. 609.

Eye as large as its distance from the anterior border of the nostril; rostral just visible from above; nostril large; internasals broadly truncate anteriorly, as long as or longer than the praefrontals; frontal as long as its distance from the tip of the snout, shorter than the parietals; loreal more deep than long; one or two prae- and three postoculars; temporals $2+3$; nine upper labials, fourth to sixth entering the eye; five lower labials in contact with the anterior chin-shields; latter much shorter than the posterior. Scales in 15 rows, all strongly keeled; ventrals I 72-ISo; anal divided; subcaudals 57-IO $7+$ ?.

Reddish-white anteriorly, with black spots, or black with reddish-white spots near the sides or with white half-rings, narrower than the black interspaces; middle part of the body usually black, with a row of round, reddish-white spots on each side, covering about three scales; head black above; upper labials black above, white below; tail black above. Lower parts white anteriorly, black-spotted and powdered in the middle and brownish-black to deep black posteriorly. Length of head and body $890 \mathrm{~mm}$; t tail $404 \mathrm{~mm}$.

One of the type-specimens examined in the British Museum.

Nom. indig. Ular darabang = flying snake.

Habitat: Halmahera!; Batjan.

\section{I2. Tropidonotus doriae Boulenger.}

Tropidonotus doriae, Boulenger, Ann. Mus. Civ. Genova (2) XVIII i 897, p. 704.

Eye large; rostral just visible from above; internasals broadly truncate anteriorly, as long as the praefrontals; frontal longer than its distance from the tip of the snout, shorter than the parietals; loreal more deep than long; two prae- and three postoculars; temporals $2+2$ or $\mathrm{I}+2$ or I $+\mathrm{I}$; eight (some- 
times nine) upper labials, third to fifth or fourth to sixth entering the eye; four or five lower labials in contact with the anterior chin-shields; latter shorter than the posterior. Scales in 17 rows, strongly keeled, those of the outer row feebly keeled; ventrals I4I-I 58 ; anal divided; subcaudals $50-85$.

Yellow, reddish or grey above, with dark or black transverse bars or alternating spots; upper labials yellow with black sutures. Lower surface yellowish, uniform or with dark dots. Length of head and body $820 \mathrm{~mm}$.; tail $260 \mathrm{~mm}$.

Habitat: Aru Islands; New Guinea (Mimika and Lorentz! rivers, Sekanto river!, lake Sentani!, Begowré and Sangké rivers!, Humboldt Bay!, Mosso, Haveri, Moroka 2300 feet, Dinawa).

\section{I3. Tropidonotus hypomelas Günther.}

Tropidonotus hypomelas, Günther, Proc. źool. Soc. $1 S 77,1$. I3o, fig. I. Tropidonotus hypomelus, Boulenger, Cat. Sn. I IS93, p. 264.

Eye very large; rostral broad, visible from above; internasals truncate anteriorly, as long as the praefrontals; frontal as long as its distance from the tip of the snout, shorter than the parietals; loreal as long as deep; two prae- and three postoculars; temporals $2+3$; nine upper labials, fifth and sixth entering the eye; five lower labials in contact with the anterior chin-shields; latter shorter than the posterior. Body slender; scales in 17 rows, all keeled; ventrals 182-196; anal divided; subcaudals 99-I I I.

Olive-brown above, with small black spots; a row of lighter spots along each side on the posterior part of the body; upper lip white with black sutures. Lower surface white in front, black posteriorly, with a median series of black spots. Length of head and body $690 \mathrm{~mm}$.; tail $270 \mathrm{~mm}$.

Type-specimen examined in the British Museum.

Habitat: New Guinea (Kaiserin-Augusta river). - Duke of York Island!; Bismarck Archipelago.

\section{Tropidonotus conspicillatus Günther.}

Tropidonotus conspicillatus, Günther, Proc. Zool. Soc, 1S72, p. 596, fig. 4 . Tropidonotus conspicillutus, Boulenger, Cat. Sn. I IS93, p. 222.

Eye moderate; nasal entire or partly divided; rostral scarcely visible from above; internasals broadly truncate anteriorly, 
about as long as the praefrontals; frontal a little longer than its distance from the tip of the snout, shorter than the parietals; loreal more deep than long; one prae- and three postoculars; temporals $1+2$ or $\mathrm{I}+3$; eight upper labials, third to fifth entering the eye; five lower labials in contact with the anterior chin-shields; latter shorter than the posterior. Scales in I9 rows, all keeled or those of the outer row smooth; ventrals I 38 - I52; anal divided; subcaudals 40-54.

Brown or reddish-brown above, with a dark network and two longitudinal series of yellow spots or transverse lines; head with small yellow, dark-edged spots; a yellow, black-edged streak on the upper lip, another from the eye to the corner of the mouth; nape dark, with two interrupted yellow transverse streaks. Lower surface yellow, uniform or dotted with brown. Length of head and body $325 \mathrm{~mm}$; tail $75 \mathrm{~mm}$.

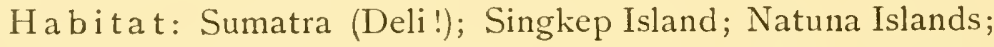
Borneo (Sandakan Bay!, Baram river, Mt. Dulit, Kuching, Sarawak, Simanggang, Matang!, Tampassuk river, Tandjong). Malay Peninsula.

\section{I5. Tropidonotus trianguligerus Boie.}

Tropidonotus trianguligerus, Boie, Isis I 827, p. 535 .

Tropidonotus trianguligerus, Boulenger, Cat. Sn. I 1893, p. 224 (s. syn.).

Natrix trianguligera, Barbour, Mem. Mus. Comp. Zool. Harv. Coll. XLIV I 912 , p. 108.

Eye moderate; rostral scarcely visible from above; internasals trapezoid, as long as or longer than the praefrontals; frontal as long as its distance from the tip of the snout, shorter than the parietals; loreal as long as deep or more deep; one (2) prae- and three or four postoculars; temporals $2+2$ or $2+3$; nine upper labials, fourth to sixth entering the eye; five lower labials in contact with the anterior chin-shields; latter shorter than the posterior. Scales in I9 rows, strongly keeled, those of the outer row feebly keeled or smooth; ventrals I 34-I5O; anal divided; subcaudals 67-105.

Dark olive above, with small black spots; a lateral series of large, triangular black spots, the points reaching the ventrals and sometimes forming bands across the belly, separated by red interspaces; on the posterior part of the body the spots are indistinct; upper labials yellow, with black sutures. Lower 
surface yellow, uniform or the ventrals edged with black. Length of head and body $860 \mathrm{~mm}$.; tail $340 \mathrm{~mm}$.

Nom. indig. Ular tjahe (mal.).

Habitat: Nias!; Mentawei Islands (Sipora); Sumatra (Labuan, Deli!, Brastagei!, Assahan, Rája Mts. Indragiri, Kertadjaja in Palembang, Gunung Sugei in Lampong district, Gunung Sahilan!, Taluk!, Ringgat!, Silago, Singkarah!, Kaju tanam!, Indrapura, Rau, Kalung!, Matur!, Baso!, Sungei Pati Bubur near Ajerbangis!, Padang I500-3000 feet, Agam, Tandjong); Banka; Borneo (Sandakan Bay, Baram river, Kina Balu, Bongon, Sarawak, Kuching, Oya, Rejang river, Singkawang, Pontianak, Telang, Lihong Bahaja, Samarinda!); Java (Buitenzorg!, Depok, Preanger!, Gunung Ungaran!, Salatiga!, Ambarawa, Tengger Mts. I 200 M.); Celebes (Macassar 2000 feet); Sangir Islands (Siao); Ternate. - Malay Peninsula; Penang; Singapore; Burma.

\section{I6. Tropidonotus petersi Boulenger.}

Tropidonotus maculatus, Peters, Mon. Berl. Ac. IS7I, p. 575.

Tropidonolus pelersi, Boulenger, Cat. Sn. I I 893 , p. 225.

Eye moderate; rostral scarcely visible from above; internasals as long as the praefrontals; frontal as long as its distance from the tip of the snout, shorter than the parietals; loreal more deep than long; one prae- and three or four postoculars; temporals $2+3$; nine upper labials, fourth to sixth entering the eye; five lower labials in contact with the anterior chinshields; latter shorter than the posterior. Scales in I9 rows, all strongly keeled; ventrals I4O-I50; anal divided; subcaudals $65-78$.

Brown above, with small black spots, on each side a series of black spots; head dark olive, vermiculated with black; labials yellow, with black sutures. Lower surface yellow, the shields edged with black. Length of head and body $270 \mathrm{~mm}$; tail IOO mm.

Habitat: Sumatra (Deli!); Borneo (Kuching, Saribas).

\section{Tropidonotus sarawacensis Günther.}

Tropidonotus sarawacensis, Günther, Proc. Zool. Soc. I872, p. 596. Tropidonotus saravacensis, Boulenger, Cat. Sn. 11893 , p. 261.

Head short; eye large; rostral not or just visible from above; internasals as long as or slightly shorter than the praefrontals; 
frontal longer than its distance from the tip of the snout, shorter than the parietals; loreal more deep than long; one prae- and three postoculars; temporals $2+3$; eight upper labials, third to fifth entering the eye; five or six lower labials in contact with the anterior chin-shields; latter shorter than the posterior. Scales in I7 rows, all strongly keeled; ventrals I 36-I54; anal divided; subcaudals 52-89.

Olive-brown above, with a series of dark transverse bars, two series of yellow spots or yellow stripes; or blackish above, with orange spots anteriorly; a series of black spots on each side; head vermiculated with black; labials yellow, with black sutures. Lower surface black and yellow, sometimes black predominating. Length of head and body $400 \mathrm{~mm}$; tail I $60 \mathrm{~mm}$.

H a bit at: Borneo (Kina Balu!, Mt. Dulit, Matang!, Kuching, Penrissen Road).

\section{S. Tropidonotus chrysargoides Günther.}

Tropidonotus chrysargoides, Günther, Cat. Col. Snakes I858, p. 71.

Tropidonotus chry'sargoides, Boulenger, Cat. Sn. I 1893, p. 260; Proc. Zool.

Soc. 1897, p. 219.

Tropidonotus callistus, Günther, Proc. Zool. Soc. I873, p. I70.

Tropidonotus callistus, Boulenger, Cat. Sn. I I S93, p. 263.

Eye large; rostral more broad than deep, scarcely visible from above; internasals broadly truncate anteriorly, as long as the praefrontals; frontal as long as or longer than its distance from the tip of the snout, shorter than the parietals; loreal as long as deep or slightly more deep; one prae- and two to four postoculars; temporals $2+2$ or $2+3$; eight or nine upper labials, fourth to sixth, fourth and fifth or fifth and sixth entering the eye; five or six lower labials in contact with the anterior chin-shields; latter shorter than the posterior. Scales in 21 rows, strongly keeled; ventrals $148-16 \mathrm{I}$; anal divided; subcaudals $64-85$.

Dark olive above; upper lip yellow. Lower surface yellow, the shields edged with olive. Young specimens (Tr. callistus) with a white vertebral stripe with a scolloped edge anteriorly; a round white spot on each side behind the head, another on the occiput and a white band across the frontal, supraoculars and praeoculars; upper labials white with black sutures. Lower surface and outer row of scales white, with a black band 
along the outer ends of the ventrals. Length of head and body $545 \mathrm{~mm}$; t tail $\mathrm{I} 65 \mathrm{~mm}$.

Habitat: Java; Celebes! (N. Celebes (type of Tr. callistus)!, Minahassa, Manado, Tomohon!, Bone Valley, Kema, Rurukan); Sangir Islands (Siao).

\section{I9. Tropidonotus flavifrons Boulenger.}

Tropidonotus flavifrons, Boulenger, Ann. Nat. Hist. (5) XX I887, p. 96; Cat. Sn. I I 893, p. 263.

Head short, eye moderate; rostral more broad than deep, scarcely visible from above; internasals broadly truncate anteriorly, half as large as the praefrontals; frontal longer than its distance from the tip of the snout, shorter than the parietals; loreal as long as deep; one prae- and two or three postoculars; temporals $2+3$; eight or nine upper labials, fourth and fifth or fifth and sixth entering the eye; five lower labials in contact with the anterior chin-shields; latter shorter than the posterior. Scales in 19 rows, feebly keeled, those of the outer row smooth; ventrals I46-I55; anal entire; subcaudals 87-IO2.

Olive above, with a dark network; two series of white spots along each side, parallel or alternating, the upper series on the sixth row of scales, the lower larger and on the border of the ventrals; on the snout and forehead a large yellow spot; labials with black sutures. Lower surface whitish with large black spots; lower side of the tail black, each subcaudal with a greyish spot. Length of head and body $36 \mathrm{I} \mathrm{mm}$.; tail $\mathrm{I} 79 \mathrm{~mm}$.

Habitat: Borneo (Kina Balu!, Sebruang Valley, Penrissen Hills in Sarawak).

\section{Tropidonotus stolatus (L.).}

Coluber stolutus, Linné, Syst. Nat. I I766, p. 379.

Tropidonotus stolatus, Boulenger, Cat. Sn. I IS93, p. 253 (s. syn.).

Eye moderate; rostral just visible from above; internasals narrowed anteriorly, about as long as the praefrontals; frontal longer than its distance from the tip of the snout, as long as the parietals; loreal as long as deep or more deep; one praeand three postoculars; temporals $I+I$ or $I+2$; eight upper labials, third to fifth entering the eye; five or six lower labials in contact with the anterior chin-shields; latter shorter than 
the posterior. Scales in I9 rows, strongly keeled, those of the outer row smooth; ventrals 120-I6I; anal divided; subcaudals $50-89$.

Greenish or brownish-olive above, spotted with black or with black transverse bars, interrupted by two yellow longitudinal bands; prae- and postoculars yellow. Lower surface white, usually with a black spot on each side of each ventral. Length of head and body $500 \mathrm{~mm}$.; tail I $80 \mathrm{~mm}$.

Habitat: Borneo:!. - Singapore; Penang; Malay Peninsula; Nicobars; Siam; Burma; India; Ceylon; China; Philippines.

Note. This species seems to be an Indian form; a specimen, apparently captured in Borneo, is in the British Museum; another with the indication Arch. Ind. Dr. BLEEKER in the Leiden Museum.

It feeds on frogs and lays a few eggs, about 10.

\section{I. Tropidonotus vittatus (L.).}

Coluber vittatus, Linné, Mus. Ad. Frid. 1754, p. 26, pl. XVIII, fig. 2.

Tropidonotus vittatus, Boulenger, Cat. Sn. I I893, p. 255.

Natrix vittata, Barbour, Mem. Mus. Comp. Zool. I Harv. Coll. XLIV I9I2, p. I Io.

Eye moderate; rostral just visible from above; internasals narrowed in front, about as long as the praefrontals; frontal as long as its distance from the tip of the snout, shorter than the parietals; loreal as long as deep or more deep; one praeand three postoculars; temporals $\mathrm{I}+\mathrm{I}$ or $\mathrm{I}+2$; nine upper labials, fourth to sixth entering the eye; five lower labials in contact with the anterior chin-shields; latter shorter than the posterior. Scales in 19 rows, strongly keeled, those of the outer row smooth; ventrals 140-I49; anal divided; subcaudals 53-84.

Light brown above, with three black longitudinal bands, lateral broadest, bordered below by a white line; head and nape spotted or marked with black; lips white, with black sutures. Lower surface white, the shields edged with black, the dark part broadest on the sides. Length of head and body $410 \mathrm{~mm}$.; tail $150 \mathrm{~mm}$.

Nom. indig. Ular kisik (mal.).

Habitat: Sumatra (Pulu Weh!, Kertadjaja, Palembang); Banka!; Java (Gadok, Anjer, Batavia, Buitenzorg!, Preanger!, Depok, Darok, Bantam, Pekalongan!, Salatiga!, Ambarawa, Ngawi, Tengger Mts. I 200 M.); Celebes (Manado). 


\section{Tropidonotus subminiatus Schlegel.}

Tropidonotus sulminiatus, Schlegel, Phys. Serp. I 837, p. 313 .

Tropidonotus subminiatus, Boulenger, Cat. Sn. I 1893, p. 256.

P'seudoxenodon intermatius, Lönnberg; Zool. Anz. XX11 1899, p. 109.

Natrix subminiata, Barbour, Mem. Mus. Comp. Zool. Ilarv, Coll. XIIV I9I2, P. III.

Eye large; rostral just visible from above; internasals broadly truncate in front, shorter than the praefrontals; frontal as long as or longer than its distance from the tip of the snout, shorter than the parietals; loreal as long as deep or more deep; one prae- and three or four postoculars; temporals $2+2$ or $2+3$; eight upper labials, third to fifth entering the eye; five lower labials in contact with the anterior chin-shields; latter slightly shorter than the posterior. Scales in 19 rows, strongly keeled, those of the outer row smooth; ventrals $132-175$; anal divided; subcaudals $65-87$.

Brown, grey or olive-green, uniform or with a black and ycllow network; neck often reddish; sometimes a dorso-lateral series of light spots and a black oblique spot below the eye. Young specimens with a black transverse band, bordered with yellow behind on the nape. Lower surface yellow, usually with a black dot on each side of each ventral. Length of head and body $805 \mathrm{~mm}$; tail $255 \mathrm{~mm}$.

Nom. indig. Ular pitjung or ular lempeh (mal.).

Habitat: Java (Gadok, Anjer, Batavia!, WVeltevreden!, Buitenzorg!, Sukabumi!, Semarang!, Salatiga!, Garum!, Kediri!, Surabaja, Pasuruan); S. E. Borneo!; Celebes (Manado); Ternate!. - Penang; Malay Peninsula; S. China; Burma; Assam; Siam; E. Himalayas.

Feeds on frogs and toads.

\section{Tropidonotus chrysargus Schlegel.}

Tropidonotus chrysargus, Schlegel, Phys. Serp. I837, p. 312, pl. XII, fig. 6 \& 7 . Tropidonotus chrysargus, Boulenger, Cat. Sn. I IS93, p. 258 (s. syn.).

Natrix chrysarga, Barbour, Mem. Mus. Comp. Zool. Harv. Coll. XLIV I9I 2, p. I 12.

Eye large; rostral just visible from above; internasals broadly truncate in front, as long as the praefrontals; frontal as long as its distance from the tip of the snout, shorter than the parietals; loreal about as deep as long; one or two prae- and three postoculars; temporals $2+2$ or $2+3$; eight or nine upper labials, fourth to sixth or third to fifth entering the 
eye; five or six lower labials in contact with the anterior chinshields; latter shorter than the posterior. Scales in I9 rows, all strongly keeled; ventrals $140-176$; anal divided; subcaudals 56-94.

Brown or olive-green above, usually with yellow spots or transverse bars on each side of the back; the skin between the scales sometimes red; upper labials yellow with black sutures, the yellow colour continued as an angular or crescentic band on the nape. Young specimens with black transverse bars or black-spotted. Lower surface yellow, sometimes black-dotted and with black spots along each side. Length of head and body $575 \mathrm{~mm}$.; tail I9I $\mathrm{mm}$.

Habitat: Simalur!; Nias!; Mentawei Islands (Sipora); Sumatra (Atjeh, Bindjey, Bringin!, Labuan, Battak Highlands Soo-1000 M., Pagarkaja in Palembang, Kaju tanam!, Mt. Singalang, Kalung!, Fort de Kock!, Padang I 500-3000 feet, Agam); Java (Batavia, Mt. Salak, Sukabumi!, Tjibodas I 425 M.!, Mt. Wilis 5000 feet, Wonosobo, Salatiga!, Tengger Mts. I 200 M., Prigan I Soo-2300 feet); Flores!; Borneo! (Sandakan Bay, Kina Balu, Mt. Dulit, Sarawak, Kuching, Rejang river, Bandjermassin); Celebes!; Ternate ${ }^{1}$ ). - Penang; Malay Peninsula; Siam; Burma; S. China; E. Himalayas; Palawan; Balabac.

\section{Tropidonotus maculatus Edeling.}

Tropidonotus maculatus, Edeling, Nederl. Tijdschr. Dierk. II I864, p. 203.

Tropidonotus maculatus, Boulenger, Cat. Sn. I I $\$ 93$, p. 260 (s. syn.).

Natrix maculata, Barbour, Mem. Mus. Comp. Zool. Harv. Coll. XLIV I 912 , p. I 12.

Eye very large; rostral scarcely visible from above; internasals trapezoid, as long as the praefrontals; frontal as long as its distance from the tip of the snout, shorter than the parietals; loreal as long as deep or more deep; one prae- and three postoculars; temporals $2+3$; nine upper labials, fourth to sixth entering the eye; five lower labials in contact with the anterior chin-shields; latter shorter than the posterior. Scales in 19 rows, all strongly keeled; ventrals $140-156$; anal divided; subcaudals 95 - I I 7 .

Olive above, with four longitudinal series of small, square, black spots and two of yellowish spots; upper labials yellow with black sutures. Lower surface yellow, the shields edged

I) See A. B. Meyer, Abh. Dresden $1886 / 87$ p. 10. 
with black. Length of head and body $540 \mathrm{~mm}$; tail $270 \mathrm{~mm}$.

Habitat: Sumatra (Deli!, Lower Langkat, Siboga, Benakat in Palembang); Natuna Islands; Borneo! (Baram river, Kina Balu, Mt. Dulit, Kuching, Limbang, Sadong river, Mt. Mulu Iooo feet, Spitang river, Labuan). - Malay Peninsula.

\section{Macropisthodon Boulenger.}

(Boulenger, Cat. Snakes I p. 265, I893).

Head distinct from neck; eye moderate or large; pupil round. Maxillary teeth I2-2O, separated by an interspace from a pair of very large fangs; mandibular teeth about equal. Body stout, covered with strongly keeled scales, with pits, in 19-27 rows; ventrals rounded. Tail moderate; subcaudals in two rows.

Distribution. S. E. Asia.

Key to the Indo-Australian species.

A. Maxillary teeth 18 to $20+2$; usually 8 upper labials:

black, or with black transverse bands........ 1. M. flaviceps 1. 91.

f. Maxillary teeth 12 to $15+2$; usually 7 upper labials;

a dark vertebral stripe............. 2. M. rhodomelas p. 92.

I. Macropisthodon flaviceps (Dum. \& Bibr.).

Amphiesma flavieeps, Duméril \& Bibron, Erp. Gén. VIl 1854, p. 738. Macropisthodon flaviceps, Bonlenger, Cat. Sn. I I $\$ 93$, p. 266 (s. syn.).

Rostral just visible from above, twice as broad as deep; internasals shorter than the praefrontals; frontal as long as or slightly shorter than its distance from the tip of the snout, shorter than the parietals; loreal as long as deep or more deep; one prae- and three or four (rarely two or five) postoculars; temporals $2+2$ or $2+3$; eight (sometimes 7 ) upper labials, fourth and fifth (or third and fourth) entering the eye; five or six lower labials in contact with the anterior chin-shields; latter shorter than the posterior. Scales in is rows, strongly keeled; ventrals 120-I3S; anal divided, subcaudals 49-6o.

Black above; head ycllowish-brown or olive; olive beneath with black transverse bands or entirely black. Y oung specimens with greyish or pale olive transverse bars, wider towards the sides and beconing indistinct in the adult; a broad orange band across the nape, separated from the head by a broad black band. Length of head and body $650 \mathrm{~mm}$; tail $190 \mathrm{~mm}$. 
I a b itat: Nias; Sumatra (Labuan, Medan!, Bedagei, Laut Tador in Upper Langkat, Indragiri, Gunung Sahilan!, Gunung Sugei in Lampong district); Borneo (Kuching, Sebruang Valley, Bandjermassin, Kutei, Samarinda!). - Malay Peninsula.

\section{Macropisthodon rhodomelas (Boie).}

Tropitonotus rhodomclas, Boie, Isis I 827, p. 535 .

Macropisthodon rhodomeles, Boulenger, Cat. Sn. I 1893, p. 266.

Rostral scarcely visible from above, at least twice as broad as deep; internasals shorter than the praefrontals; frontal slightly longer than its distance from the tip of the snout, shorter than the parietals; loreal as long as deep or more deep;

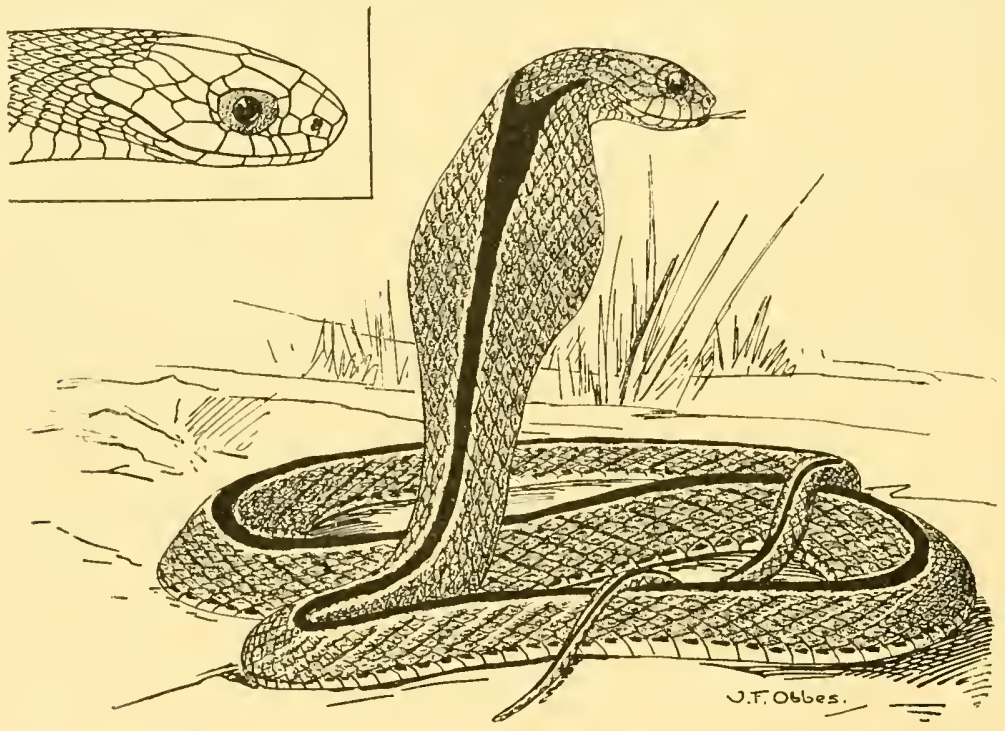

Fig. 39. Macropisthodon rhodomclas (Boie) $\times 3 / 4$. Side view of head.

one, sometimes two praeoculars; usually a small subocular and three or four postoculars; temporals $2+2,2+3$ or $3+3$; seven (rarely 8) upper labials, third and fourth (or fourth and fifth) entering the eye; four or five lower labials in contact with the anterior chin-shields; latter about as long as or shorter than the posterior. Scales in 19 rows, strongly keeled; ventrals I 24-I 38 ; anal divided; subcaudals $42-58$.

Grey or reddish-brown above, with a dark vertebral stripe ending in a V-shaped bluish spot on the nape; lips, throat 
and flanks pink; sometimes dark oblique lines on the anterior part of the body from the vertebral stripe running downwards and anteriorly. Lower surface yellow with small black spots along each side. Length of head and body $435 \mathrm{~mm}$.; tail $85 \mathrm{~mm}$.

Habit at: Sumatra (S. Atjeh, Deli!, Labuan, Langkat, Raja Mts., Indragiri, Kertadjaja, Muara Rupit, Palembang, Gunung Sugei in Lampong district, Gunung Sahilan!, Taluk!, Tandjong); Banka!; Borneo! (Mt. Dulit, Kuching, Sarawak, Matang, Limbang); Java! (Tjikao). - Singapore; Malay Peninsula; Siam.

The Raffles Museum, Singapore, possesses a specimen which is said to be from Macassar, Celebes.

This species sits up like a cobra when angry, flattening its neck.

Macropisthodon plumbicolor (Cant.) is doubtfully mentioned from Java in Boulenger's Catalogue p. 268. No other indication of its occurrence in the Sunda Islands could be found, the species being an Indian and a Ceylonese form, so that the locality Java most probably is a mistake.

\section{I6. Xenelaphis Günther.}

(Günther, Rept. Brit. Ind. p. 250, I864).

Head distinct from neck; eye rather large; pupil round. Maxillary teeth 25-30, gradually increasing in sizc; anterior mandibular teeth largest. Body long, round, covered with smooth scales with pits, in 17 rows, the vertebral row more or less enlarged and six-sided; ventrals rounded. Tail long; subcaudals in two rows.

Distribution. S. E. Asia.

Key to the Indo-Australian species.

1. Subcaudals I40-I79; brown above, with more or less distinct black transverse bands anteriorly... I. I, hexagonotus P. 93. f. Subcaudals 134; body with is black-edged brown streaks, separated by cream-coloured interspaces. . 2. X. cllipsifer P. 95.

\section{Xenelaphis hexagonotus (Cantor).}

Coluber hexagonotus, Cantor, Cat. Mal. Kept. I 847, p. 74. Tinclathis hexagonotus Boulenger, Cat. Sn. II IS94, p. 8.

Rostral more broad than deep, visible from above; internasals as long as or slightly longer than the praefrontals; frontal 
as long as its distance from the tip of the snout, shorter than the parietals; loreal about as long as deep; one praeocular, a large subocular below it, wedged in between the third and fourth upper labials; two postoculars, with a large subocular below, between the eye and the fifth and sixth labials; sometimes a third subocular, separating the eye from the labials; temporals $2+2$; eight upper labials, fourth entering the eye or separated from it; four or five lower labials in contact with the anterior chin-shields; latter as long as the posterior. Scales

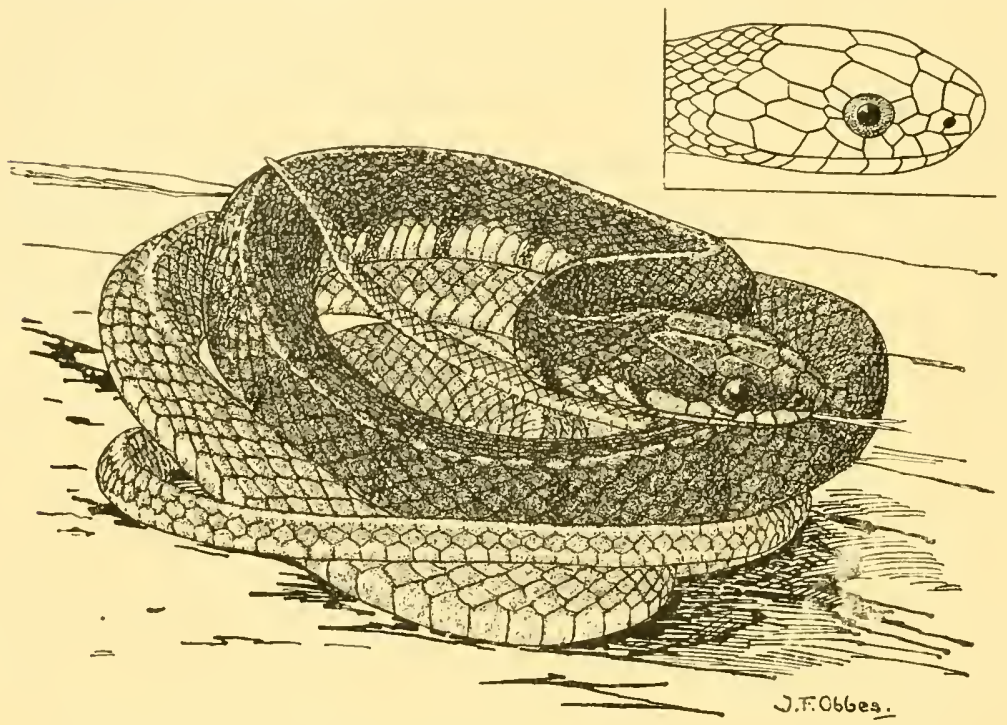

Fig. 40. Tenelaphis hexagonotus (Cant.) $\times \%$. Side view of head.

in I 7 rows, the vertebral row a little enlarged; ventrals I 85 - I98; anal divided; subcaudals I40-I79.

Brown above, with black transverse bands on the anterior part of the body, becoming indistinct with age, so that the outer ends of the bands alone are visible; scales of the posterior part of the body with a black spot and black basal part. Lower surface yellowish; each ventral and subcaudal with a black spot on the outer end; subcaudals black-cdged. I.ength of head and body $1050 \mathrm{~mm}$.; tail $600 \mathrm{~mm}$.

II ab it at: Sumatra (Stabat near Bindjey, Medan!, Serdang!, Indragiri, Taluk!, Bunga Maas); Banka!; Borneo (Baram, Sebruang Valley, Rejang river, Lundu, Kuching); Java (Buitenzorg). - Penang; Singapore; Malay Peninsula; Burma. 


\section{Xenelaphis ellipsifer Boulenger.}

Tenelaphis ellipsifer, Boulenger, Proc. Zool. Soc. I900, p. IS 4 , pl. XVI.

Rostral more broad than deep, visible from above; internasals about as long as the praefrontals; frontal as long as its distance from the tip of the snout, shorter than the parietals; loreal more long than deep; one praeocular, a large subocular below it, wedged in between the third and fourth upper labials; two postoculars, a long subocular below, between the eye and the fifth and sixth labials; temporals $2+2$; eight upper labials, fourth entering the eye or separated from it; five lower labials in contact with the anterior chin-shields; latter shorter than the posterior. Scales in I7 rows, vertebral row not distinctly enlarged; ventrals 186; anal divided; subcaudals I 34 .

Cream-coloured above, with is large, elliptic, black-edged, brown streaks; sides cream-coloured, spotted or marbled with black; head and neck pale brown, sides of neck with interrupted, black, longitudinal markings; upper lip yellow; base of tail like the body, posterior part brown with a black lateral streak. Lower surface uniformly yellow. Length of head and body $1400 \mathrm{~mm}$; tail $600 \mathrm{~mm}$.

Type-specimen examined in the British Museum.

Habitat: Borneo (Sarawak river, Pangkalan ampat!, Kina Balu).

I7. Zamen is Wagler.

(WVagler, Syst. Amph. p. I 88, i 830 ).

Head long, distinct from neck; eye large; pupil round. Maxillary teeth $\mathrm{I} 2-20$, largest posteriorly; mandibular teeth equal, or anterior enlarged. Body long, round, covered with smooth or feebly keeled scales with pits, in I $5-43$ rows; ventrals rounded or with an obtuse keel laterally. Tail long; subcaudals in two rows.

Distribution. Europe; Asia; N. Africa; N. \& C. America.

Key to the Indo-Australian species.

A. Scales in 13 rows; ventrals $1 S_{7-1} 97 \ldots \ldots$...... Z. dipsas p. 96 .

$B$. Scales in 15 rows; ventrals $160-177 \ldots \ldots . .2 .2$. korros $\mathrm{P} .96$.

C. Scales in 17 rows; ventrals $1 \mathrm{~S}_{7}-213 \ldots . . .3$. . . mucosus p. $9 \mathrm{~S}$. 


\section{Zamenis dipsas (Schlegel).}

Herpetodryais dipsas, Schlegel, Phys. Serp. I\$37, p. 197.

Zamenis dipsas, Boulenger, Cat. Sn. I I 893, p. $3 S_{3}$.

Snout obtuse, projecting; eye very large. Rostral just visible from above; internasals shorter than the praefrontals; frontal as long as or longer than its distance from the tip of the snout, shorter than the parietals; loreal more long than deep; praeocular single or divided; not touching the frontal; a small subocular below; two postoculars; temporals $\mathrm{I}+2$ or $2+2$; eight upper labials, fourth and fifth entering the eye; four or five lower labials in contact with the anterior chin-shields; latter shorter than the posterior. Scales smooth, in I 3 rows; ventrals 187-197; anal entire; subcaudals I02-139.

Blackish-brown above; sides yellow anteriorly with vertical black bars; upper lip yellow. Lower surface yellow anteriorly, brown in the middle, blackish-brown posteriorly. Young specimens pale yellowish-brown with dark spots or cross-bands or with two dark dorsal stripes, uniformly olive posteriorly; a yellow collar, sometimes interrupted in the middle. Length of head and body $1450 \mathrm{~mm}$.; tail $550 \mathrm{~mm}$.

Habitat: Celebes (Manado!, Tomohon, Rurukan!, Kolaka on Mingkoka Bay); Halmahera.

\section{Zamenis korros (Schlegel).}

Coluber korros, Schlegel, Phys. Serp. I837, p. 139.

Zamenis korros, Boulenger, Cat. Sn. I I $S_{93}$, p. $3 S_{4}$.

Ptyas korros, Barbour, Mem. Mus. Comp. Zool. Ilarv. Coll. NLIV igiz, p. II 5.

Snout obtuse, projecting; eye very large. Rostral visible from above; internasals shorter than the praefrontals; frontal as long as its distance from the tip of the snout or a little longer, as long as the parietals; two or three loreals; a large praeocular, sometimes touching the frontal; a small subocular below; two postoculars; temporals $2+2$; eight upper labials, fourth and fifth entering the eye; five lower labials in contact with the anterior chin-shields; latter shorter than the posterior. Scales smooth or feebly keeled on the posterior part of the body, in 15 rows; ventrals $160-177$; anal divided; subcaudals $122-\mathrm{I} 45$.

Brown or olive above; the scales on the posterior part of the body and on the tail often yellow and edged with black. 
Lower surface yellow. Young specimens with transverse series of round whitish spots or with narrow yellow transverse bars. Length of head and body $10 S 0 \mathrm{~mm}$; t tail $700 \mathrm{mn}$.

Nom. indig. Ular korros (mal.) or ular liar.

Habitat: Sumatra (Labuan, Djambi!, Gunung Sahilan!,
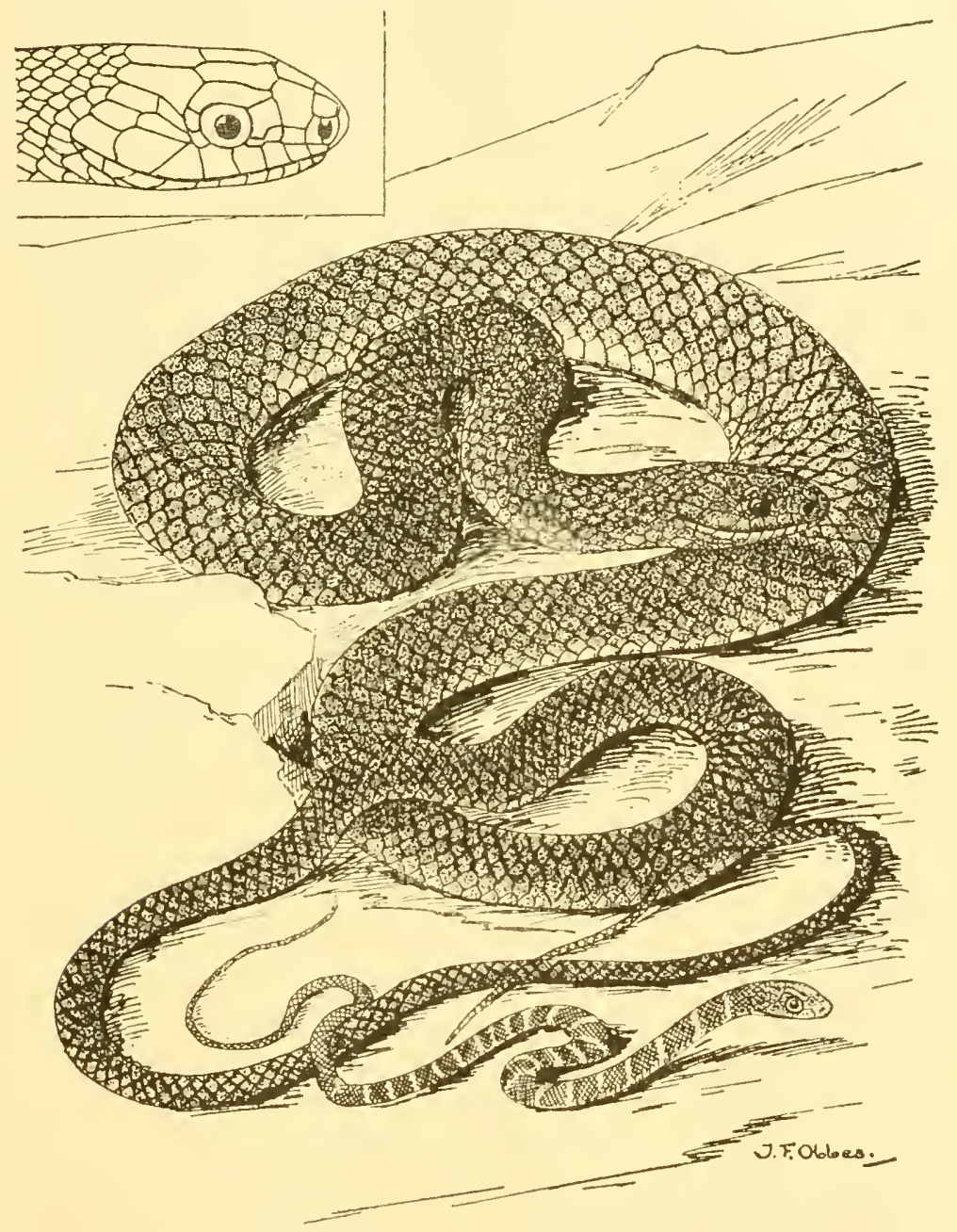

Fig. 41. Zamenis korros (Schleg.) i $1 / 2$.

loung specimen with light bars on the foreground. Side view of head.

Fort de Kock!, Padang!, Palembang, Gunung Sugei in Lampong district); Java (Gadok, Bantam, Depok, Anjer, Buitenzorg!, Pekalongan!, Semarang, Salatiga!, Garum!, Kediri!, Prigan INDO-AUSTRALIAN REPTILES II. 
I $800-2300$ feet); Bornco (Bandjermassin, Samarinda!). Singapore; Penang; Malay Peninsula; Siam; S. China; Y unnan; Burma; Assam; E. Himalayas.

The Rat-snake feeds on birds and frogs as well as on rats.

\section{Zamenis mucosus (L.).}

Coluber mucosus, Linné, Syst. Nat. 1 1766, p. 388.

Zamenis mucosus, Boulenger, Cat. Sn. I I 893, p. 385 (s. syn.).

Snout obtuse, projecting; eye very large. Rostral visible from above; internasals shorter than the praefrontals; frontal as long as its distance from the tip of the snout, as long as the parietals or shorter; usually three loreals; praeocular large, not in contact with the frontal; a small subocular below; two postoculars; temporals $2+2$; eight upper labials, fourth and fifth entering the eye; five lower labials in contact with the anterior chin-shields; latter shorter than the posterior. Scales keeled on the posterior part of the back, in 17 rows; ventrals I 87-2I3; anal divided; subcaudals 95-143.

Yellowish-brown or olive-brown above, usually with black transverse bands on the posterior part of the body and on the tail; lips yellow, with black edges of the labials. Lower surface yellow, the posterior ventrals and subcaudals often edged with black. Young specimens usually with light transverse bands on the anterior part of the body. Length of head and body $1730 \mathrm{~mm}$.; tail $550 \mathrm{~mm}$.; attains a length of nearly $4 \mathrm{M}$.

Habitat: Sumatra (Deli); Java (Batavia, Semarang!, Salatiga!, Ambarawa!, Garum!). — Singapore; Malay Peninsula; Andamans; S. China; Siam; Burma; India; Ceylon; Transcaspia.

Not as common as the preceding one. When angry this Ratsnake dilates its neck and raises its head like a cobra and produces a strong growling sound. The female lays $\$-16$ eggs.

\section{I8. Coluber L.}

(Linné, Syst. Nat. I p. 375, I766).

Head long, distinct from neck; eye large; pupil round. Maxillary teeth I 2-22, equal; anterior mandibular teeth longest. Body long, round or a little compressed, covered with smooth or keeled scales with pits, in $15-35$ rows; ventrals rounded or angulatc. Tail long; subcaudals in two rows.

Distribution. Europe; Asia; N. \& Tropical America. 
Key to the Indo-Australian species.

A. Scales in 19 rows.

. I. Scales smooth; anal divided. . . . . . . . 1. C. porphyracens p. 99.

II. Scales keeled; anal entire.

a. All caudal scales keeled ...... ... 2. C. melanurus p. 99.

b. Outer caudal scales smooth. . ...... 3. C. radiatus p. Ior.

$B$. Scales in 21 rows............ 4. C. erythrurus p. 102.

C. Scales in $23-27$ rows.

I. Anal divided.

a. Three labials entering the eye...... 5. C. jansini p. 102.

b. Two labials entering the eye.

I. Subcaudals $89-114 \ldots . . .6 .6$. . . tacnimms p. 103.

2. Subcaudals 122-157 ....... 7. C. oxycephalus p. 104.

II. Anal entire.

I. Three labials entering the eye....... S. C. engunensis p. 105.

2. Two labials entering the eye ....... 9. C. subratiatus p. 106.

\section{Coluber porphyraceus Cantor.}

Coluber porplyyraceus, Cantor, Proc. Zool. Soc. I 839, p. 51.

Coluber porphyraceus, Boulenger, Cat. Sn. II 1 S94, p. 34 (s. syn.).

Rostral more broad than deep, visible from above; internasals shorter than the praefrontals; frontal broad, as long as or longer than its distance from the tip of the snout, shorter than the parietals; loreal small, more long than deep; praeocular large; two postoculars; temporals I +2 ; eight upper labials, fourth and fifth entering the eye; four or five lower labials in contact with the anterior chin-shields; latter longer than the posterior. Scales in I9 rows, smooth; ventrals 190-2 IS, rounded; anal divided; subcaudals $52-76$.

Red or reddish-brown above, with dark brown, black-edged transverse bands; two longitudinal black lines along the body and tail, sometimes indistinct anteriorly; head with a black streak along the middle, another from the eye to the first transverse band. Lower surface yellow. Length of head and body $620 \mathrm{~mm}$; t tail $140 \mathrm{~mm}$.

Habitat: Sumatra (Medan!, Brastagei on Battak Highlands!, Alahan Pandjang, near Danau di Talang). - Singapore; Malay Peninsula; Andamans; Yunnan; Burma; Assam; E. Himalayas.

\section{Coluber melanurus Schlegel.}

Coluber milanurus, Schlegel, Phys. Serp. I\$37, p. I4I, pl. V, fig. II \& 12. 
Coluber melanurus, Boulenger; Cat. Sn. II I 894, p. 60.

Elaphe melanura, Barbour, Mem. Mus. Comp. Zool. Harv. Coll. XLIV 1912, p. II 7.

Rostral more broad than deep, visible from above; internasals shorter than the praefrontals; frontal as long as or longer than its distance from the tip of the snout, shorter than the parietals; loreal as long as deep or a little more long; a large praeocular; two postoculars; temporals $2+2$ or $2+3$; nine upper labials, fourth to sixth entering the eye; five or six lower labials in contact with the anterior chin-shields; latter as long as the posterior. Scales in 19 rows, 21 on the neck, strongly

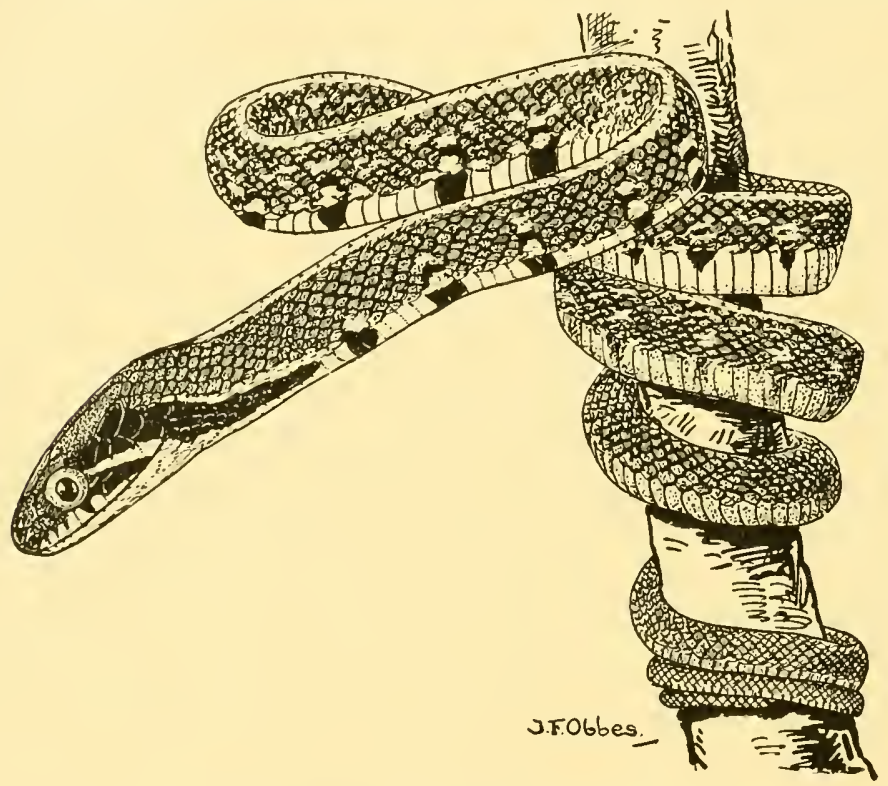

Fig. 42. Coluber melanurus Schleg. Young specimen. Nat. size.

keeled; ventrals 193-234, with an obtuse lateral keel; anal entire; subcaudals 89 - I 15.

Brown or greyish anteriorly, with a reddish, black-edged vertebral band; dark brown or black posteriorly; on each side a series of black spots anteriorly, the markings disappearing in the adult; head with a dark streak below the cye; an oblique streak from the eye to the mouth and another on the temporal region and the neck. Lower surface yellow anteriorly, brown or blackish behind. Young specimens with a series of black ocelli with yellow centres on each side of the body anteriorly. Length of head and body $1400 \mathrm{~mm}$.; tail $400 \mathrm{~mm}$. 
Nom. indig. Ular babi (mal.).

Habitat: Simalur!; Nias!; Mentawei Islands (Siberut!); Sumatra (Sabang on Pulu Weh!, Atjeh, Bindjey, Labuan, Asahan, Medan!, Serdang!, Pangkalan Brandan!, Langkat, Bedagei, Indragiri, Djambi:, Tandjung Laut in Palembang, Indrapura, Kaju tanam!, Gunung sahilan!, Muara Labu, Batang Singlajang!, Fort de Kock, Agam, Kalung!, Padang!); Banka!; Riou!; Borneo (Kutei, Bulangan river, Sandakan Bay, Bongon, Baram river, Rejang river, Kuching, Sungei duri, Singkawang, Sintang, Buntok, Balikpapan); Java (Anjer, Buitenzorg!, Mt. Salak 2200 feet, Tjibodas, Wonosobo, Semarang, Salatiga!, Ambarawa, Surabaja); Celebes (Manado!, Macassar!). - Penang; Singapore; Malay Peninsula; Nicobars; Andamans; Burma; S. China.

Note. BETHENCOURT FERREIRA mentions a snake from Timor (Journ. Sc. Lisboa (2) V I S97, p. I I 3) much resembling C. melanurus and young specimens of $C$. crythrurus. He gives this form the name of $C$. melammus var. timoriensis. It has one or two suboculars; 237 ventrals; 96 subcaudals.

\section{Coluber radiatus Schlegel.}

Colutir radiatus, Schlegel, Phys. Serp. 1837 , p. 135, pl. V, fig. 5 \& 6. Coluber radialus, Boulenger, Cat. Sn. II I894, p. 6I (s. syn.).

Rostral more broad than deep, visible from above; internasals shorter than the praefrontals; frontal as long as or shorter than its distance from the tip of the snout, shorter than the parietals; loreal more long than deep; praeocular large; two postoculars; temporals generally $2+2$; eight or nine upper labials, third to fifth, fourth and fifth or fourth to sixth entering the eye; four or five lower labials in contact with the anterior chin-shields; latter as long as the posterior. Scales in I9 rows, 2 I on the neck, keeled on the posterior part of the body, outer rows smooth; ventrals $224-245$, with an obtuse lateral keel; anal entire; subcaudals $85-100$.

Yellowish-brown above, with one or two black stripes on each side of the back anteriorly, the lower often broken up; head with a black line across the occiput; three black lines radiating from the eye. Lower surface yellow, uniform or speckled with olive. Length of head and body $1280 \mathrm{~mm}$; tail $330 \mathrm{~mm}$. 
Nom. indig. Ular tikus (mal.).

Habitat: Sumatra (Siboga, Agam, Padang); Java (Gadok, Batavia, Krawang!, Buitenzorg, Semarang, Tjandi!, Salatiga!, Kediri!); W. \& S. E. Borneo!. - Singapore; Penang; Malay Peninsula; Siam; Cochin China; Burma; Assam; Bengal; E. Himalayas.

\section{Coluber erythrurus (Dum. \& Bibr.).}

Plagiodon erythruns, Duméril \& Bibron, Erp. Gén. VII 1854, p. 175. Colubir crythrurus, Boulenger, Cat. Sn. II I 894 . P. 62 (s. syn.).

Rostral more broad than deep, visible from above; internasals shorter than the praefrontals; frontal as long as its distance from the tip of the snout, shorter than the parietals; loreal about as deep as long; a large praeocular; two postoculars; temporals $2+2$; nine upper labials, fourth to sixth entering the eye; six lower labials in contact with the anterior chinshields; latter as long as the posterior. Scales in $2 \mathrm{I}$ rows, keeled, 23 on the neck; outer row of caudal scales smooth or feebly keeled; ventrals 2I I - 235; anal entire; subcaudals 86-I I 2.

Dark brown above, anteriorly reddish-brown with a $\mathrm{V}$-or $\lambda$-shaped black marking on the neck; lips yellowish. Lower surface yellowish anteriorly, dark brown behind; subcaudals lighter. Young specimens with black vertical bands on each side, alternating with one another. Length of head and body $1300 \mathrm{~mm}$.; tail $370 \mathrm{~mm}$.

Nom. in dig. Ule alo (Toradja-name).

Ha bitat: Celebes (Gorontalo, Manado, Posso!, Kema, Kandari, Macassar, Tjamba); Buton. - Philippines; Sulu Islands.

This snake can inflate its neck, resembling a cobra.

\section{Coluber janseni (Bleeker).}

Gonyosoma jansenii, Bleeker, Nat. Tijdschr. Nederl. Ind. XVI I 858, p. 242. Coluber janseni, Boulenger, Cat. Sn. II I894, p. 57, pl. I, fig. 2.

Snout obtuse, projecting; rostral more broad than deep, visible from above; internasals slightly shorter than the praefrontals; frontal as long as or shorter than its distance from the tip of the snout, shorter than the parietals; loreal at least twice as long as deep; praeocular large, in contact with the frontal; two postoculars; temporals $1+2$ or $2+3$; nine or ten upper labials, fifth to seventh entering the eye; five or six 
lower labials in contact with the anterior chin-shiclds; latter much longer than the posterior. Scales in 23 or 25 rows, smooth or feebly keeled; ventrals $247-256$ with a lateral angle; anal divided; subcaudals I 22-I 40 .

Olive or yellowish above, all the scales black-edged or only a few; posteriorly black; a broad blackish lateral band sometimes present. Lower surface yellowish anteriorly, blackish with yellow lateral keels posteriorly; subcaudals black, towards the end of the tail yellowish with dark edges. Young specimens pale olive anteriorly, with or without small black markings, greyish posteriorly. Length of head and body $1540 \mathrm{~mm}$.; tail $450 \mathrm{~mm}$.

Nom. indig. Tomesumpu (Toradja-name).

Habitat: Celebes (Kema, Tomohon, Kottabangu, Manado, Posso!, Mapane, Luhu, Macassar).

\section{Coluber taeniurus (Cope).}

Elaphis tuiniurus, Cope, Proc. Ac. Philad. I860, p. 565.

Coluber taeniurus, Boulenger, Cat. Sn. II I 894 , p. 47 (s. syn.).

Rostral more broad than deep, visible from above; internasals much shorter than the praefrontals; frontal as long as or shorter than its distance from the tip of the snout, as long as or slightly shorter than the parietals; loreal more long than cleep; praeocular large, sometimes in contact with the frontal; often a small subocular; two postoculars; temporals $2+2$ or $2+3$; nine (eight) upper labials, fifth and sixth (fourth and fifth) entering the eye; five or six lower labials in contact with the anterior chin-shields; latter as long as or longer than the posterior. Scales in 23 or 25 rows, dorsals feebly keeled, outer rows smooth; ventrals $230-305$, with a lateral angle; anal divided (rarely entire); subcaudals 89-ir4.

Grey-brown or olive above, with a black network or transverse lines anteriorly, a light vertebral stripe between two black bands posteriorly; head and nape uniform; a black band on each side of the head passing through the eye. Lower surface yellowish in front, greyish behind with a black stripe along each side, bordered above by a whitish streak. Length of head and body $1600 \mathrm{~mm}$.; tail $400 \mathrm{~mm}$.

Habitat: Sumatra (Pajo); Borneo (Braang, Sarawak river, Sadong river, caves of Batu Hapu Pengaron and Barabei!). - 
Malay Peninsula; Siam; Cochin China; Sikkim; China; E. Himalayas.

Note. In the limestone caves of the Malay Peninsula this snake lives in the dark feeding on bats. There it is of a much paler colour, without the dark network, the lower parts whitish; head bluish-grey; sides with a purplish band, getting black towards the tail.

\section{Coluber oxycephalus Boie.}

Colulier oxyecphalus, Boie, Isis, I 827, p. 537.

Coluber oxycephalus, Boulenger, Cat. Sn. II I 894, p. 56 (s. syn.).

Gonyosoma oxycephala, Barbour, Mem. Mus. Comp. Zool. Harv. Coll. XIIV I 9 I 2 , p. I I 6 .

Snout long, projecting; rostral about as broad as deep, visible from above; internasals shorter than the praefrontals,

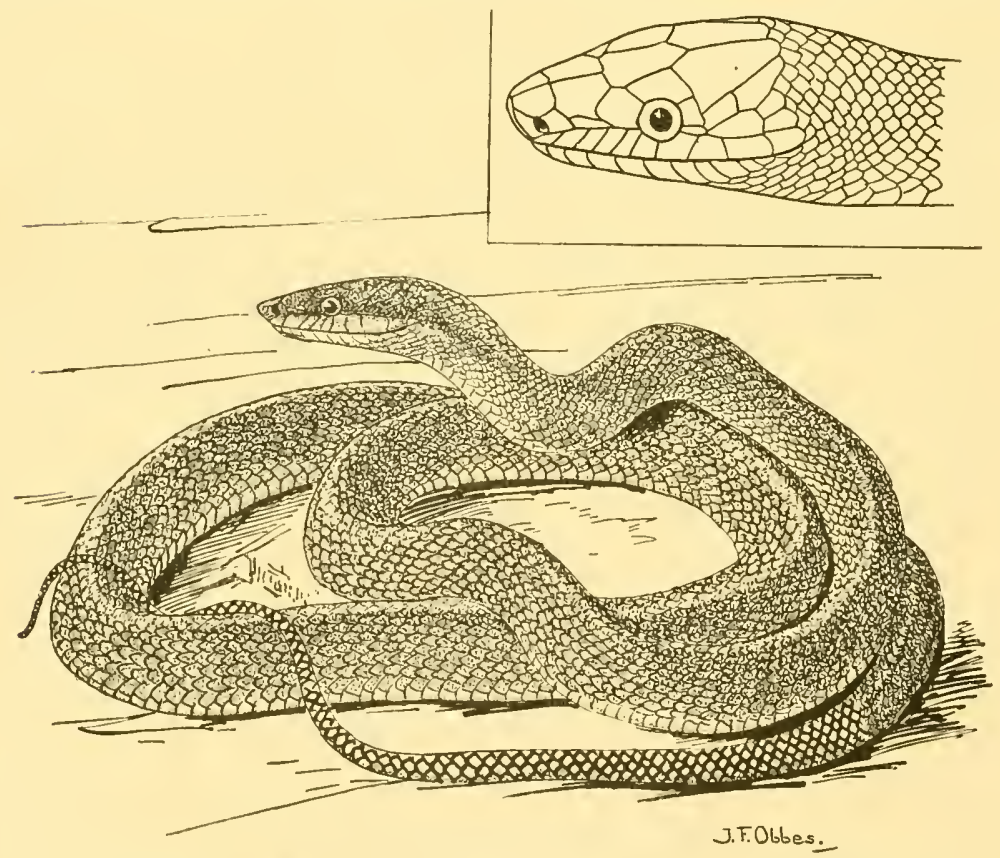

Fig. 43. Coluber oxycephalus Boie $X \%$. Side view of head.

which are large; frontal as long as its distance from the rostral or the tip of the snout, shorter than the parietals; loreal long; praeocular large, in contact with the frontal; two postoculars; 
temporals $2+3$; nine to eleven upper labials, fifth and sixth or sixth and seventh entering the eye; six lower labials in contact with the anterior chin-shields; latter much longer than the posterior. Body compressed; scales in 23-27 rows, smooth or feebly keeled; ventrals $233-263$, with a lateral angle; anal divided; subcaudals $122-157$.

Green above, usually with black edges on the scales; head olive-brown; a black streak on each side passing through the eye; tail yellowish-brown, sometimes with vermilion bands. Lower surface yellow or greenish. Young specimens olivebrown with narrow oblique light bars on the posterior part of the back; lower parts lighter, throat yellowish, each ventral bordered behind with yellow, ventral keels yellowish. Length of head and body $1820 \mathrm{~mm}$; t tail $480 \mathrm{~mm}$.

Nom. indig. Ular bangka laut or ular bamban (mal.).

Ha bit at: Nias!; Sumatra (Labuan, Medan!, Stabat, Assahan, Raja Mts., Indrapura, Singkel, Kertadjaja, Palembang); Banka!; Riou!; Natuna Islands; Borneo (Sandakan Bay, Baram, Braang, Kuching, Santubong, Trusau river, Rejang river, Kapuas river, Labuan, Singkawang, Pontianak, Bandjermassin, Balikpapan, Samarinda!); Java (Gadok, Depok, Buitenzorg!, Pekalongan!, Salatiga!, Ambarawa, Prigan 1SOO-2300 feet); Lombok; Celebes (Manaco!, Manado!). - Penang; Singapore; Malay l'eninsula; Siam; Nicobars; Andamans; Burma; E. Himalayas; Philippines.

\section{S. Coluber enganensis Vincig.}

Coluber inganchsis, Vinciguerra, Ann. Mus. Civ. Genova (2) XII IS9z, p. 524. Coluber engancnsis. Boulenger, Cat. Sn. II I $S_{94}$, p. 63 .

Rostral slightly more broad than deep; fourth, fifth and sixth upper labials entering the eye; posterior chin-shields not or slightly longer than anterior. Scales in 23 rows $(25$ on the neck); ventrals 239-243; anal entire; subcaudals 107-ioS.

Brown above, uniform or with black spots in longitudinal series on the anterior part of the body; a dark streak belind the eye. Lower surface yellowish, spotted with brown posteriorly. Length of head and body $1110 \mathrm{~mm}$.; tail $310 \mathrm{~mm}$. (Not seen by me).

Habitat: Engano Island. 


\section{Coluber subradiatus Schlegel.}

Coluber subradiatus, Schlegel, Phys. Serp. 1837, p. 136.

Coluber subradiatus, Boulenger, Cat. Sn. II I 894, p. 64 .

Rostral much more broad than decp; internasals shorter than the praefrontals; frontal as long as its distance from the tip of the snout, shorter than the parietals; loreal more deep than long; praeocular large; a subocular; two postoculars; temporals $2+2$ or $2+3$; nine upper labials, fifth and sixth entering the eye, fourth very small; five lower labials in contact with the anterior chin-shields; latter much shorter than the posterior. Scales in 23 or 25 rows ( 25 or 27 on the neck); ventrals 226-248; anal entire; subcaudals 80--IO2.

Reddish-brown above, with two black stripes along each side of the anterior part of the body; the stripes sometimes broken up into spots; a black streak behind the eye. Lower surface yellowish. Length of head and body $990 \mathrm{~mm}$.; tail $260 \mathrm{~mm}$.

Habitat: Lombok; Flores!; Alor; Sumba; Rotti!; Timor!; Samao!.

\section{I9. Gony ophis Boulenger.}

(Boulenger, Ann. Nat. Hist. (6) VIll p. 290, 1891).

Head long, distinct from neck; eye moderate; pupil round. Maxillary teeth 23, equal; mandibular teeth about equal. Body long, compressed, covered with feebly keeled scales with pits, in 19 rows, disposed obliquely anteriorly; ventrals with a lateral keel and a notch on each side. Tail long; subcaudals in two rows, keeled and notched like the ventrals.

Distribution. Malay Peninsula; Borneo.

A single species.

\section{Gonyophis margaritatus (Peters).}

Gonyosoma margaritatum, Peters, Mon. Berl. Ac. I871, p. 578; Ann. Mus. Civ. Genova III I 872, p. 39 pl. V, fig. 3 . Gonyophis margaritatus, Boulenger, Cat. Sn. II I $\$ 94$, p. 71.

Rostral more broad than deep, visible from above; internasals shorter than the praefrontals; frontal as long as its distance from the tip of the snout, shorter than the parietals; loreal more long than deep; praeocular just touching the frontal or separated from it; two postoculars; temporals $2+2$ or 3 ; nine 
upper labials, fourth to sixth or fifth and sixth entering the eye; four or five lower labials in contact with the anterior chinshields; latter as long as the posterior. Scales in 19 rows, feebly keeled; ventrals 230-249; anal divided; subcaudals 108 - I 30.

Black above, each scale with a yellowish-green spot, or green with black-bordered scales; posterior part of body and tail
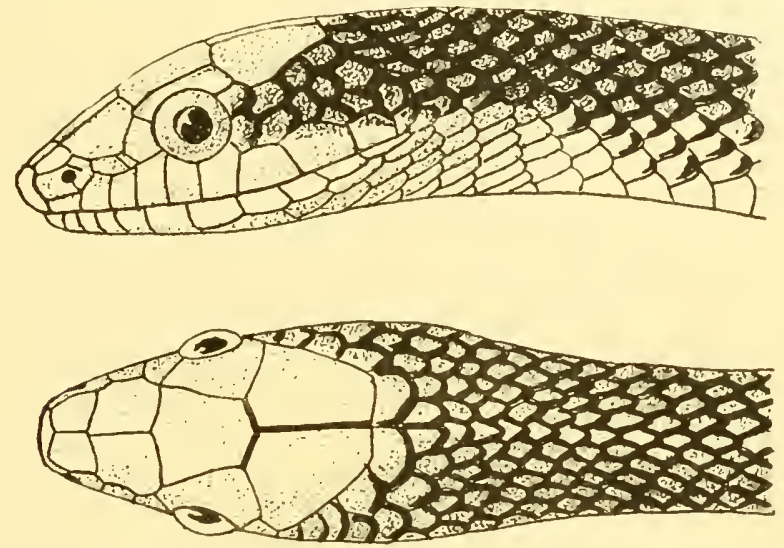

Fig. 44. Gonyophis margaritatus (Ptrs.). After Peters.

with orange rings; a black streak on each side of the head behind the eye, and another on the suture between the parietals. Lower surface yellowish, sometimes with black edges to the shields. Length of head and body $1160 \mathrm{~mm}$; tail $370 \mathrm{~mm}$.

Habitat: Borneo (Mt. Dulit, Sarawak, Kuching, Mt. Merinjak 2200 feet on Sadong river, Balikpapan!). - Singapore; Malay Peninsula.

20. Ly codon Boie.

(Bole, Isis p. 52I, 1827).

Head slightly distinct from neck, depressed; eye rather small; pupil vertically elliptic; nostril large. Naxillary curved anteriorly, 3-6 anterior teeth fang-like, separated by an interspace from the rest, $7-15$, of which the posterior are largest; anterior mandibular teeth long. Body long, round or compressed, covered with smooth or keeled scales with pits, in 17, I9 or 21 rows; ventrals rounded or with a lateral keel. Tail moderate; subcaudals single or in two rows.

Distribution. S. E. Asia.

Nocturnal and oviparous snakes. 
Key to the Indo-Australian species.

A. No praeocular: praefrontal entering the eye; scales

in 17 rows ................................ subcinctus p. 10 .

B. Praeocutar present, separating the eye from the praefrontal.

I. Scales keeled, in 17 rows ........... 2. L. albofuscus p. 109.

II. Scales smooth.

a. Subcaudals single.

X Scales in 19 rows ........... 3. L. stormi p. IIo.

$X X$ Scales in $2 \mathrm{I}$ rows ........... . . f. florensis p. I Io.

b. Subcaudals in two rows: scales in 17 rows.

I. Loreal present; anal divided ...... 5. L. aulicus p. I I I.

2. No loreal; anal entire........... 6. L. cffrenis p. 112.

\section{Lycodon subcinctus Boie.}

Lycodon subcinctus, Boie, Isis i 827 , p. $55 \mathrm{I}$.

Lycodon subcinctus, Botilenger, Cat. Sn. I 1893 , p. 359.

Snout broad, much depressed; eye small; rostral just visible from above; internasals much shorter than the praefrontals; frontal shorter than its distance from the tip of the snout, much shorter than the parietals; loreal long, widely separated from the internasal, usually entering the eye; no praeocular; two or three postoculars; temporals $I+2$; eight upper labials, third to fifth or sixth entering the eye; four lower labials in contact with the anterior chin-shields; latter longer than the posterior. Scales in I7 rows, dorsals feebly keeled; ventrals 128-230, with a lateral angle; anal divided (rarely entire); subcaudals 6I-90 pair.

Dark brown or black above, with a white occipital region and widely separated rings on the body and tail, disappearing in the adult. Lower surface brown or yellowish-brown. Length of head and body $820 \mathrm{~mm}$.; tail $\mathrm{I} S 0 \mathrm{~mm}$.

Habitat: Simalur!; Nias; Mentawei Islands (Siberut!); Sumatra (Labuan, Deli!, Bedagei, Langkat, Fort de Kock, Pajo, Rau, Padang); Borneo! (Sandakan, Bulangan river, Kuching, Muching); Java (Batavia, Depok, Buitenzorg!, Salak, Sukabumi!, Semarang, Tjandi!, Gunung Ungaran!, Wonosobo, Madiun!, Kediri!, Nongkodjadjar in Tengger Mts. I 300 M.!, Prigan I $800-2300$ feet); Lombok; Sumbawa. - Penang; Singapore; Malay Peninsula; Siam; Philippines.

Feeds on lizards. 


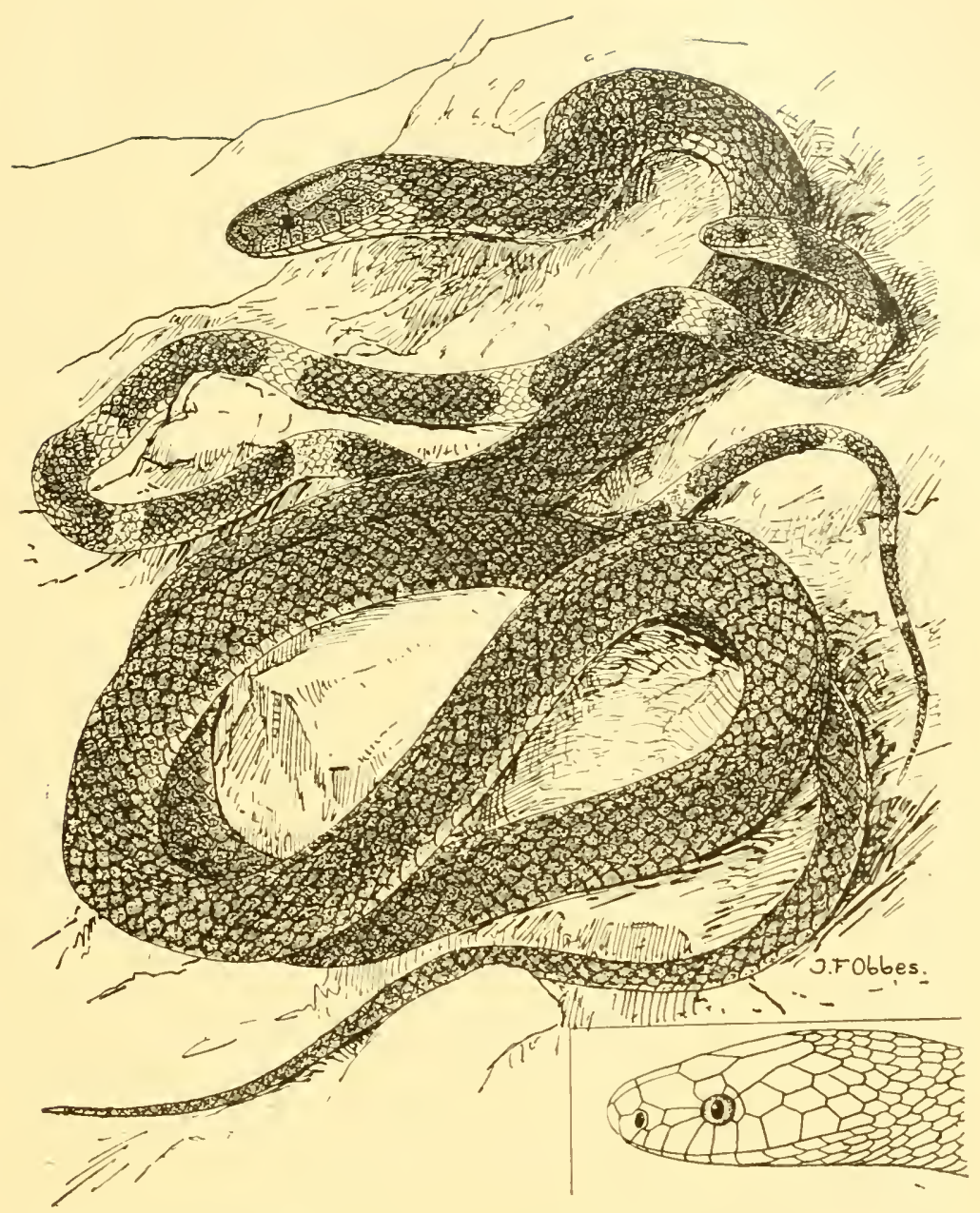

Fig. 45. Lycodon subcinctus Boie $X 4 / 5$. Young specimen with light bands. Side view of head.

\section{Lycodon albofuscus (Dum. \& Bibr.).}

Sphecodés albofuscus, Duméril \& Bibron, Erp. Gén. V'II 1854, p. 394.

Lyiodon albofuscus, lioulenger, Cat. Sn. I IS93, p. 357.

Snout depressed; eye moderate; rostral just visible from above; internasals half as long as the praefrontals; frontal as long as the praefrontals or slightly longer, much shorter than the parietals; loreal more long than deep, not entering the eye; one prae- and two postoculars; temporals $2+2$; eight 
upper labials, third to fifth entering the eye; five lower labials in contact with the anterior chin-shields; latter shorter than the posterior. Body slender; scales in 17 rows, all strongly keeled; ventrals $238-256$, with strong lateral angle; anal divided; subcaudals I 55-208 pair.

Dark brown above; yellowish below. Young specimens with yellow transverse bands. Length of head and body I I So mm.; tail $590 \mathrm{~mm}$.

Habitat: Nias; Sumatra (Deli!, Indragiri); Borneo (Kina Balu, Rejang river, Kuching).

\section{Lycodon stormi Böttger.}

Lycodon stormi, Böttger, Zool. Anz. XV I892, p. 4is.

Ljcodon stormi, Boulenger, Cat. Sn. I i 893 , p. 357; Proc. Zool. Soc. IS97, p. 219 , pl. XII, fig. 3 .

Head much depressed; eye small; rostral just visible from above; internasals much shorter than the praefrontals; frontal as long as praefrontals and internasals together, as long as its distance from the tip of the snout, much shorter than the parietals; loreal a little more long than deep, large, not entering the eye; one praeocular not in contact with the frontal; two postoculars; temporals $\mathrm{I}+3+4$ or $3+4+4$; eight or nine upper labials, third and fourth or third to fifth entering the eye; five lower labials in contact with the anterior chin-shields; latter longer than the posterior. Scales in 19 rows, smooth; ventrals $2 \mathrm{I} 7-23 \mathrm{I}$, with a lateral angle; anal entire; subcaudals $73-7$, single.

Brown above, with 23 white, black-spotted annuli. Lower surface brown with whitish annuli. Length of head and body $585 \mathrm{~mm}$; tail I $35 \mathrm{~mm}$.

Habit at: Celebes (Buol!).

\section{Lycodon florensis n. sp.}

Head much depressed; eye small; rostral just visible from above; internasals small, suture between them half the suture between the praefrontals; frontal as long as its distance from the tip of the snout, shorter than the parietals; loreal more long than deep, not entering the eye; two praeoculars, not in contact with the frontal; two (three) postoculars; temporals $2+3+4$; nine (eight) upper labials, third to fifth (third and fourth) entering the eye; five lower labials in contact with the anterior 
chin-shields; latter about as long as the posterior. Scales in 2 I rows, smooth; ventrals 2 I 8 , with a lateral angle; anal entire; subcaudals 66 , single.

Brown above, paler towards the sides; an indistinct light

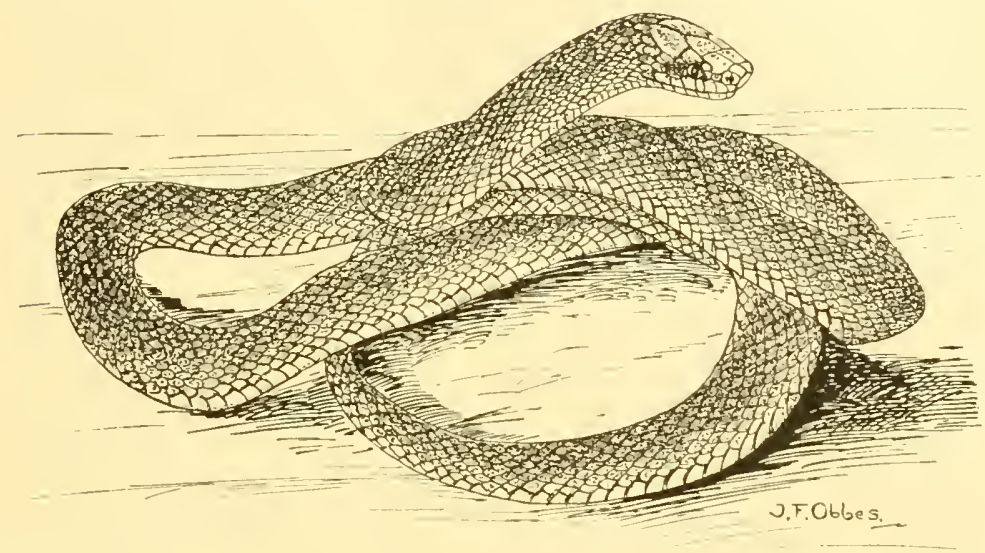

Fig. 46. Lycodon florewsis n. sp. $\times{ }^{4 / 5}$.

lateral streak; head yellowish, powdered with brown, a brown streak from the nostril through the eye to the angle of the mouth. Lower surface yellow, each ventral with a pale brown

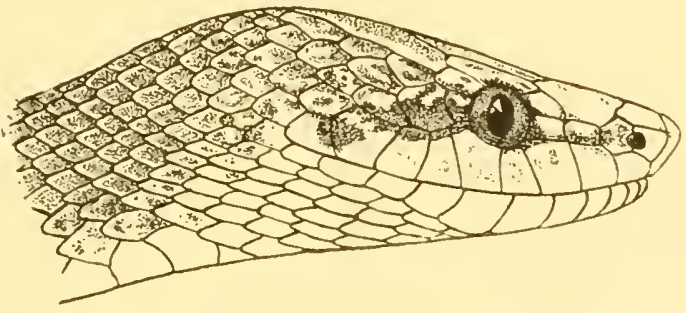

Fig. 47. Lycodon florensis n. sp. Side view of head $\times 3$.

spot at the outer ends; tail pale brownish below. Length of head and body $456 \mathrm{~mm}$.; tail II $2 \mathrm{~mm}$.

Type-specimen in the Amsterdam Museum.

Habitat: Flores (near Kotting!).

\section{Lycodon aulicus (L.).}

Coluber aulicus, Linné, Mus. Ad. Frid. I 1754, p. 29, pl. XII, fig. 2. Lycodon aulicus, Boulenger, Cat. Sn. I I \$93, p. 352 (s. syn.).

Snout much depressed, lips swollen; eye small; rostral just 
visible from above; internasals much shorter than the praefrontals; frontal usually shorter than its distance from the tip of the snout, shorter than the parietals; loreal long, not entering the eye, in contact with the internasal; one praeocular, usually in contact with the frontal; two (sometimes three) postoculars; temporals $2+3$ or $3+3$; nine upper labials, third to fifth entering the eye; four or five lower labials in contact with the anterior chin-shields; latter longer than the posterior. Scales in I7 rows, smooth; ventrals I $76-224$, with an obtuse lateral angle; anal divided (rarely entire); subcaudals 53-8o pair.

Brown above, with a fine yellow network; a yellow collar or a triangular yellow spot on each side of the occiput; sometimes yellow transverse, bifurcating bands on the back or a series of quadrangular yellow spots; labials yellow, some or all with a brown spot. Lower surface white or pale yellow. Length of head and body $400 \mathrm{~mm}$.; tail IIO $\mathrm{mm}$.

Nom. indig. Ular tana (mal.).

Habitat: Sumatra (Labuan in Deli, Singkel, Palembangdistrict!); Java (Tangerang!, Batavia!, Buitenzorg!, Anjer, Depok, Pekalongan!); Bali; Sumbawa; Suniba; Savu; Rotti!; Timor!; Flores!; Lomblem; Alor; Wetar; Saleyer!; Celebes (Raha, Macassar!, Tempe!, Bonthain); Kalao Island. - Philippines; Malay Peninsula; Singapore; Yenang; Andamans; Nicobars; Cochin China; Siam; Burma; Himalayas; India; Ceylon.

The female lays a few eggs, 3-9.

\section{Lycodon effrenis Cantor.}

Lycodon effraenis, Cantor, Cat. Mal. Rept. 1847, p. 70, pl. XI, fig. 2. Lycodon effrenis, Boulenger, Cat. Sn. I I $\$ 93$, p. 356 (s. syn.).

Snout much depressed; eye moderate; rostral just visible from above; internasals half as long as the praefrontals; frontal as long as or slightly longer than its distance from the tip of the snout, shorter than the parietals; no loreal; praefrontal in contact with the second and third labials; a praeocular, not in contact with the frontal; two or three postoculars; temporals $2+3$ or $3+3$; nine upper labials, third to fifth entering the eye; five lower labials in contact with the anterior chin-shields; latter longer than the posterior. Body slender; scales in 17 rows, smooth; ventrals $215-228$, with a lateral angle; anal cutirc; subcaudals $75-9^{8}$ pair. 
Brown above, with a few yellowish rings, indistinct in the adult. Lower surface brown. Young specimens with a yellowish streak on each side of the head. Length of head and body $530 \mathrm{~mm}$; tail $\mathrm{I} 70 \mathrm{~mm}$.

Habitat: Sumatra (Deli); Borneo (Singkawang, Baram!). Penang; Malay Peninsula.

Lycodon fasciatus Anders. is recorded from the "Indes Néerlandaises" by Despax (Bull. Mus. d' hist. natur. N0.4 I9I 2, p. 3). This species normally lives in Burma, Assam and Yunnan, so that the locality above mentioned does not seem probable.

\section{I. Lepturophis Boulenger.}

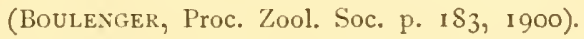

Head distinct from neck, much depressed; eye moderate; pupil vertically elliptic; nostril very large, between two nasals and the first upper labial. Maxillary teeth $6+6$. Body very long and slender, round, covered with strongly keeled scales with pits, the keels finely serrated, in 17 rows; ventrals keeled and notched laterally. Tail very long and slender; subcaudals in two rows.

Distribution. Borneo.

A single species.

\section{Lepturophis borneensis Boulcnger.}

Lephurophis borneensis, Boulenger, Proc. Zool. Soc. I900, p. 183 , pl. XV.

Snout much depressed, broadly truncate; rostral just visible
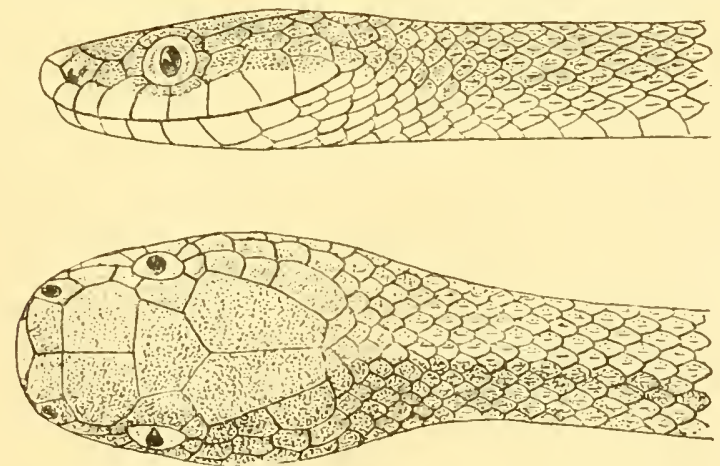

Fig. 48 . Lepturophis borneensis Blgr. After Boulenger.

from above; internasals scarcely half as long as the praefrontals; frontal as long as the praefrontals, half as long as the parietals; INDO-AUSTRALIAN REPTILES II. 
loreal more long than deep; one prae- and two postoculars; temporals $2+2$; eight upper labials, third to fifth entering the eye; five lower labials in contact with the anterior chinshields; latter as 'long as the posterior. Scales in 17 rows; ventrals 241; anal divided; subcaudals 193.

- Brown above; white below. Length of head and body 9 IO mm.; tail $570 \mathrm{~mm}$. (After BOUlenGer; not seen by me). Habitat: Borneo (Kuching, Sarawak).

\section{Stegonotus Dum. \& Bibr.}

(Dumérit, \& Bibron, Mem. Ac. Sc. XXili p. 477, I 853 ).

Head distinct from neck; eye moderate or small; pupil vertically elliptic. Maxillary teeth $15-20$, increasing in size to the median ones; two or three last large; anterior mandibular tecth enlarged. Body long, round or a little compressed, covered with smooth scales with pits, in 15,17 or 19 rows; ventrals with an obtuse lateral angle. Tail rather long; subcaudals single or in two rows.

Distribution. Philippines; Moluccas; New Guinca; Queensland.

Key to the Indo-Australian species.

A. Scales in I9 rows ................ S. magnus p. II4.

$B$. Scales in 17 rows.

I. Two labials entering the eye ......... 2. S. modestus p. II5.

II. Three labials entering the eye.

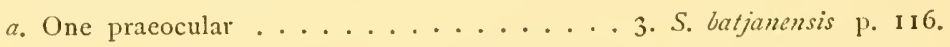

b. Two praeoculars.............. 4. S. plumbeus p. 117.

C. Scales in 15 rows.

I. One anterior temporal; eight upper labials, fourth and fifth entering the eye; loreal twice as long as deep; ventrals $180-197 \ldots . . .5$. . . S. gintheri p. II7.

2. Two anterior temporals; seven upper labials, third and fourth entering the eye; loreal not quite one time and a half as long as deep; ventrals $167-18_{3} .6 . S$. dichli p. IIS.

\section{Stegonotus magnus (Meyer).}

Iycodon magnus, Meyer, Mon. Berl. Akad. IS74, p. 136.

Stegonotus magnus, v. Lidth de Jeude, Nova Guinea IX, Zool. 2 I9II, P. 273.

Rostral more broad than deep, wedged in between the internasals; latter half as long as the praefrontals; frontal slightly 
more long than broad, shorter than the parietals; loreal more long than deep; two prae- and two postoculars; temporals $2+2$; eight or nine upper labials, fourth and fifth entering the eye; four lower labials in contact with the anterior chinshields. Scales in 19 rows; ventrals 207-222; anal entire; subcaudals 74 pair.

Whitish above with a reddish tinge, scales of the back brown or with brown base or bordered with brown, sometimes partly dark-banded; head brown, the scales light-edged. Lower surface white. Length of head and body I $220 \mathrm{~mm}$.; tail (broken) I SO mm.

Habitat: New Guinea (Lorentz river!); Schouten Islands (Mysore).

\section{Stegonotus modestus (Schlegel).}

Lycodon modestus, Schlegel, Phys. Serp. I $\$ 37$, p. I19, pl. IV, fig. 16 \& 17 .

Stegonotus modestus, Boulenger, Cat. Sn. I IS93, p. 366 (s, syn.); Ann. Mus.

Civ. Genova (2) XVIII I 897, p. 704.

Ly'codon cucullatum, Duméril \& Bibron, Erp. Gén. V'II IS54, p. 376.

Stegronotus cucullatus, Boulenger, Cat. Sn. I IS93, p. 365 (s. syn.).

Strgonotus reticulatus, Boulenger, Ann. Nat. Hist. (6) XVI IS95, P. 3 I.

Rostral more broad than deep, visible from above; inter-

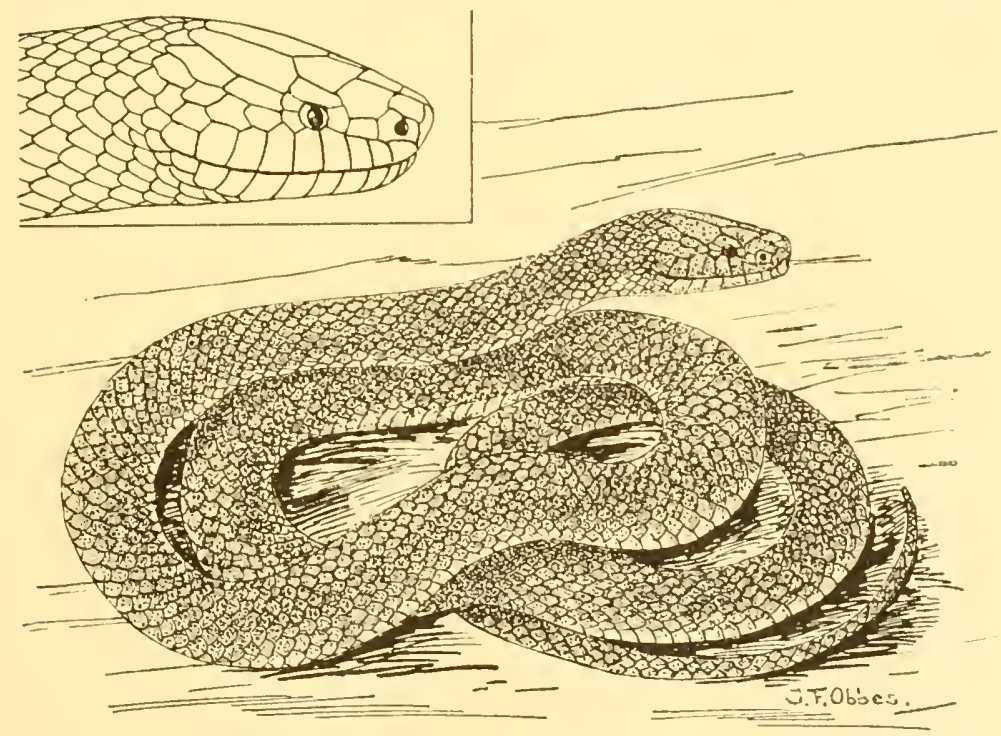

Fig. 49. Stegonotus motestus (Schleg.) $\times 1 / 2$. Side view of head.

nasals about two thirds the length of the praefrontals; frontal 
as long as or shorter than its distance from the tip of the snout, much shorter than the parietals; loreal more long than deep; two (one) prae- and two postoculars; temporals $\mathrm{I}+2$, $2+2$ or $2+3$; seven or eight (9) upper labials, third and fourth (fourth and fifth) entering the eye; four or five lower labials in contact with the anterior chin-shields; latter as long as or longer than the posterior. Scales in 17 rows; ventrals I70-230; anal entire; subcaudals 68-I05 pair.

Brown above; sides sometimes whitish, with black edges on the scales (S. reticulatus); upper lip yellowish. Lower parts yellow, often a brown spot at the outer end of each ventral. Length of head and body $\$ 90 \mathrm{~mm}$; tail $250 \mathrm{~mm}$.

Type-specimen examined in the Leiden Museum.

Habitat: Samao!; Ternate; Halmahera; Salawatti; Misol; Ceram; Buru; Ambon!; Kei Islands!; Aru Islands; New Guinea (Fak Fak, Sorong, Rubi, Amberbaki, Mansinam, Dorei, Passim, Jobi, Mafoor, Manokwari, lake Sentani, Setekwa!- and Mimika rivers, Utakwa river 2500 feet, Lorentz river!, Fly river!, Hula, Haveri, Bara Bara, Mt. Victoria in Owen Stanley Range, Madew on St. Joseph river 2-30oo feet, Samarai Island, Sepik river, Tami, Bogadjim, Stephansort, Bongu, Sattelberg, Valise Island); Schouten Islands (Mysore). -- Ferguson and Trobiand Islands; Woodlark Island; Islands of Torres Straits; Cape York; Bismarck Archipelago.

\section{Stegonotus batjanensis (Gthr.).}

Coluber (Liclaphis) batjanensis, Günther, Ann. Nat. Hist. (3) XV 1\$65, p. 93, pl. II, fig. A.

Stegonotus batjanensis, Boulenger, Cat. Sn. I I $\$ 93$, p. 368.

Rostral much more broad than deep, visible from above; internasals about half as long as the pracfrontals; frontal as long as its distance from the tip of the snout, much shorter than the parietals; loreal more long than deep; one prae- and two postoculars; temporals $\mathrm{I}+2$ or $2+2$; eight upper labials, third to fifth entering the eye; five lower labials in contact with the anterior chin-shields; latter as long as or longer than the posterior. Scales in 17 rows; ventrals $200-236$; anal entire; subcaudals $7 \mathrm{~S}-S_{7}$ pair.

Dark brown or grey above; head and sides of head yellowish or orange with black-edged shields. Lower surface yellowish, 
ventrals laterally edged with black; subcaudals edged with black or entirely black. Young specimens with yellowish or orange narrow transverse bars, widening towards the belly, the anterior interrupted on the vertebral line and alternating. Length of head and body I $200 \mathrm{~mm}$; tail $320 \mathrm{~mm}$.

Habitat: Batjan; Halmahera; Morotai!; Ambon!.

\section{Stegonotus plumbeus (Macleay).}

Hlerbertophis phumbeus, Macleay, Proc. Linn. Soc. N. S. W. VIII ISS4, p. 434. Stegronotus: plumbeus, Boulenger, Cat. Sn. I $1 \$ 93$, p. 368 .

Stigonotus flumbeus, Longman, Míem. (Queensl. Mus. II I913, p. 41. Stegonotus plumbeus, Boulenger, Trans. Zool. Soc. London XX 1914, p. 264.

Rostral almost twice as broad as deep, visible from above; internasals two thirds as long as the praefrontals; frontal short and broad, as long as its distance from the rostral, shorter than the parietals; loreal oblong; two prae- and two postoculars; temporals $2+3$; nine upper labials, third to fifth entering the eye; five lower labials in contact with the anterior chinshields; latter longer than the posterior. Scales in 17 rows; ventrals 2II-2I9; anal entire; subcaudals $67-74$ pair.

Leaden-black above, uniform; scales on the sides whiteedged. Lower surface yellowish-white; lateral ventral keel yellow, each ventral with a dark brown spot on each side of the keel; subcaudals with a black patch on their base. Length of head and body II $S_{3} \mathrm{~mm}$; t tail $257 \mathrm{~mm}$.

Habitat: S. New Guinea (Setekwa river!). - Queensland (Herbert river).

\section{Stegonotus güntheri Boulenger.}

Stegonotus Guentheri, Boulenger, Ann. Nat. Hist. (6) XVI iS95, p. 3 I.

Rostral much more broad than deep, visible from above; internasals shorter than the praefrontals; frontal as long as its distance from the rostral, much shorter than the parietals; loreal about twice as long as deep; one prae- and two postoculars; temporals $1+2$; eight upper labials, fourth and fifth entering the eye; four or five lower labials in contact witl? the anterior chin-shields; latter longer than the posterior. Scales in 15 rows; ventrals ( 176$)$ ISo-197; anal entire; subcaudals (73) 75 pair.

Black or dark brown above, paler on the sides; upper lip 
white. Lower surface white. Length of head and body $920 \mathrm{~mm}$.; tail $230 \mathrm{~mm}$.

Type-specimens examined in the British Museum.

Habitat: New Guinea (Bongu). — Ferguson Island!.

\section{Stegonotus diehli Lindholm.}

Stegonotus dichli, Lindholm, Jahrb. Nassau Ver. LVIII I905, p. 236.

Rostral much more broad than deep, just visible from above; internasals shorter than the praefrontals; frontal longer than its distance from the tip of the snout, shorter than the parietals; loreal not quite one time and a half as long as deep; one or two praeoculars, the upper separated from the frontal; two postoculars; temporals $2+2$; seven upper labials, third and fourth entering the eye; four lower labials in contact with the anterior chin-shields; latter as long as the posterior. Scales in 15 rows; ventrals $167-\mathrm{I}_{3}$; anal entire; subcaudals 75-II 2 pair.

Dark brownish-grey above, lighter on the sides; a whitish spot on the praefrontals near the outer border; hindborder of the internasals, suture between the parietals and suture between parietals and frontal and supraocular whitish; a short oblique whitish streak on the posterior part of the parietals; upper lip whitish, with round grey spots on the sutures; a narrow whitish collar, interrupted in the middle and continued anteriorly on the temporal region, which is grey-spotted. Lower surface whitish, sutures between the subcaudals greyish. Length of head and body 4I5 mm.; tail $125 \mathrm{~mm}$.

Ha bit at: New Guinea (Bogadjim on Astrolabe Bay, KaiserinAugusta river!, Bégowre river!, Lorentz river!).

23. Dryocalamus Günther.

(Güntuer, Cat. Col. Snakes P. I2I, IS58).

Head distinct from neck, depressed; eye rather large; pupil vertically elliptic. Maxillary teeth $S-\mathrm{r}$, short, increasing in size posteriorly; anterior mandibular teeth longer than posterior; one or two tooth-like knobs on the basisphenoid. Body a little compressed, slender, covered with smooth scales, with pits, in $I_{3}$ or 15 rows; ventrals strongly keeled on each side. Tail moderate; subcaudals in two rows.

Distribution. Malay Peninsula; Sumatra; Natuna Islands; Borneo. 
Key to the Indo-Australian species.

A. One praeocular ............... . D. subannulatus p. IIg. b. No praeocular............... 2. D. tristrigatus p. 120.

I. Dryocalamus subannulatus (Dum. \& Bibr.).

Odontomus subannulatus, Duméril \& Bibron, Erp. Gén. V'II 1854, p. 454. Dryocalamus subannulutus, Boulenger, Cat. Sn. I I 893, p. 37 I (s. syn.).

Rostral visible from above; nasal divided or partly divided; suture between the internasals as long as or longer than that between the praefrontals; frontal longer than its distance from the tip of the snout, shorter than the parietals; loreal more long than deep, entering the eye; one prae- and two post-

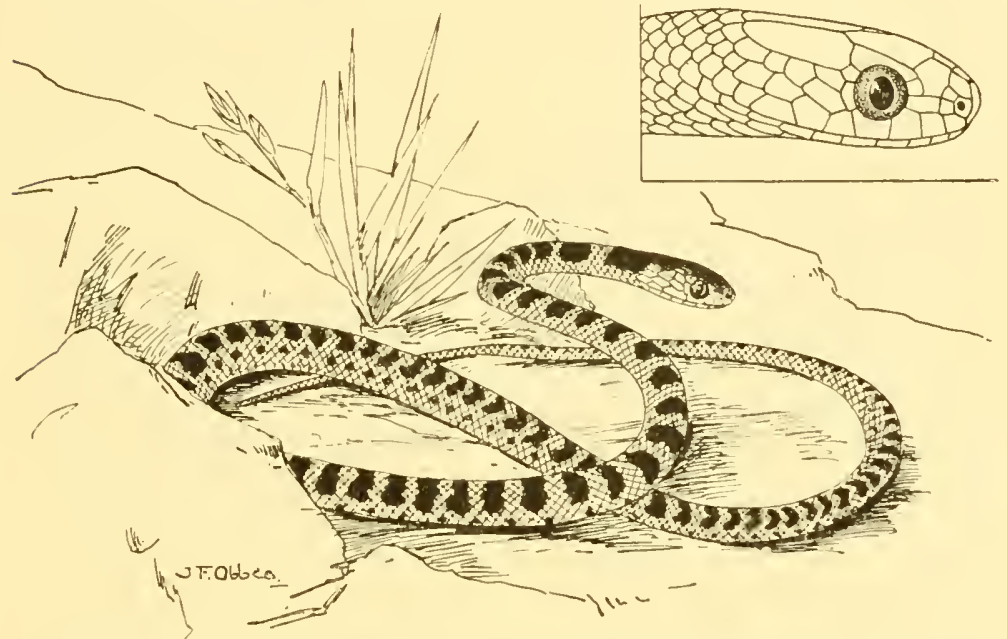

Fig. 50. Dryocalamus subannulatus (D. \& B.). Nat. size. Side view of head.

oculars; temporals $2+2$; seven upper labials, third and fourth entering the eye; three or four lower labials in contact with the anterior chin-shields; latter longer than the posterior. Scales in 15 rows; ventrals 225-244; anal entire; subcaudals 88- 107.

Light brown above, with large, brown, transverse spots across the back; on each side a series of small spots, alternating with the dorsals; two transverse brown streaks on the head, the anterior on the praefrontals, the other between the eyes; a brown spot on the parietals. Lower surface yellowish. Length of head and body $225 \mathrm{~mm}$; t tail $70 \mathrm{~mm}$.

Type-specimen examined in the Leiden Museum. 
Habitat: Sumatra (Labuan in Deli, Indragiri, Gunung Sahilan!, Padang!); Riou!. - Singapore; Malay Peninsula.

\section{Dryocalamus tristrigatus Günther.}

Dryocalamus tristrigatus, Günther, Cat. Col. Snakes. I858, p. I21.

Dryocalamus tristrigatus, Boulenger, Cat. Sn. I I893, p. 372, pl. XXV, fig. 3 . Dryocalamus trilincatus, Brown, Proc. Acad. Philad. LIV I902, p. I79 1).

Rostral more broad than deep, visible from above; nasal undivided; suture between the internasals shorter than that between the praefrontals; frontal longer than its distance from the tip of the snout, shorter than the parietals; loreal about twice as long as deep, entering the eye; no praeocular; two postoculars; temporals $2+2$ or $2+3$; seven (six) upper labials, third and fourth entering the eye; four lower labials in contact with the anterior chin-shields; posterior chin-shields very short. Scales in I 5 rows; ventrals $2 \mathrm{I} S-23 \mathrm{I}$; anal entire; subcaudals s6-96.

Dark brown above, with three white stripes; outer row of scales white; shields of the head edged with white; upper lip white. Lower surface white. Length of head and body $280 \mathrm{~mm}$.; tail so mm.

Type-specimen examined in the British Museum.

Habitat: Natuna Islands!; Borneo (Claudetown on Baram river, Baran!, Labuan, Mt. Mulu 2000 feet, Kuching, Penrissen Road).

\section{Tetralepis Böttger.}

(Böttger, Ber. Offenb. Ver. Naturk, p. 124, 1892).

Head small, not distinct from neck; eye small; pupil round. Maxillary teeth I4, third to eighth longest, last six decreasing in size; mandibular teeth increasing in size to the fifth, last very small. Body round, covered with smooth scales, without pits, in I 5 rows; ventrals rounded. Tail short; subcaudals in two rows.

Distribution. Java.

A single species.

I) In the description of $D$. trilincatus, Brown states that his specimen from the Baram district has only one postocular. In the British Museum I examined a specimen of D. tristrigatus from the Natuna Islands with two postoculars on the right side and one on the left. 


\section{Tetralepis fruhstorferi Böttger.}

Tetralepis fruhstorferi, Böttger, Ber. Offenb. Ver. Naturk. I 892, p. I 24. Titralepis frulistorferi, Boulenger, Cat. Sn. I I893, p. 320.

Rostral just visible from above; nasal large, twice as long as deep; suture between the internasals longer than that between the praefrontals; frontal a little longer than its distance from the tip of the snout, much shorter than the parietals; loreal as long as deep; one prae- and two postoculars; temporals $\mathbf{I}+2$ or $\mathbf{I}+\mathbf{I}+2$, the anterior long; four upper labials, third entering the eye, fourth very long; four lower labials in contact

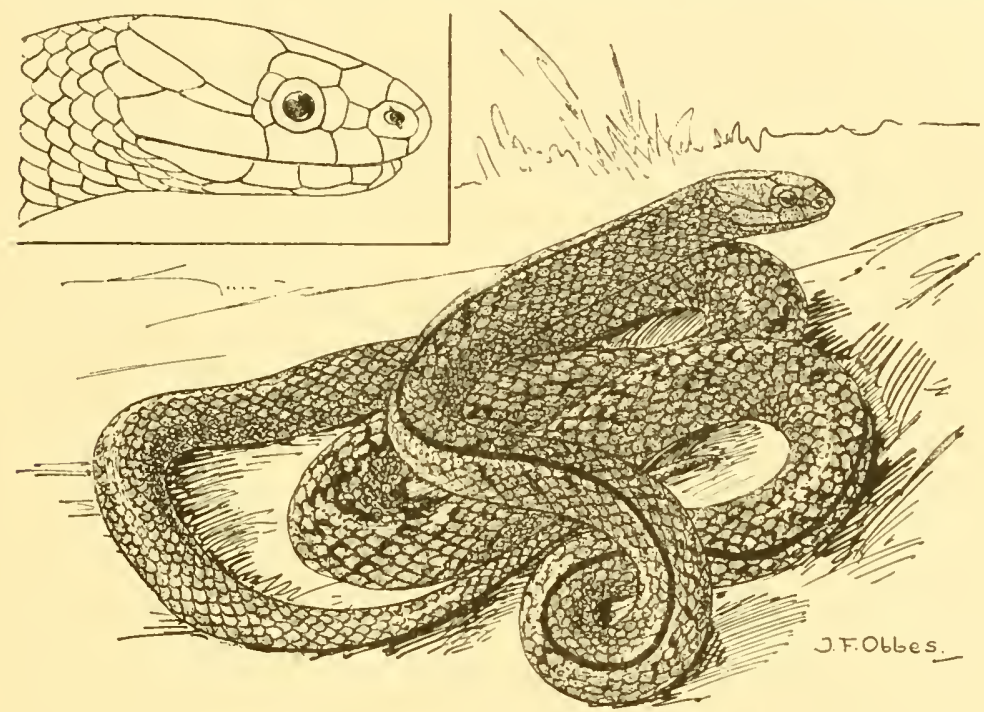

Fig. 51. Tetralepis fruhstorferi Bttgr. Nat. size. Side view of head.

with the anterior chin-shields; latter shorter than the posterior. Scales in 15 rows; ventrals $187-20 \mathrm{I}$; anal divided; subcaudals $43-56$.

Dark reddish-brown above, with a dark vertebral line. Lower surface bluish- or reddish-grey, each ventral witl two brownish spots, the spots forming two longitudinal series along the belly. Length of head and body $432 \mathrm{~mm}$.; tail $70 \mathrm{~mm}$.

Habitat: Java! (Tengger Mts. I 200 M.).

\section{Simotes Dum. \& Bibr.}

(Duméril \& Bibron, Mém. Ac. Sc. Xxili p. 472 , 1853).

Head short, not distinct from neck; eye small; pupil round. 
Maxillary teeth 8-12, posterior strongly enlarged, compressed; mandibular teeth about equal. Body round, covered with smooth or feebly keeled scales with or without pits, in $13-21$ rows; ventrals rounded or with an obtuse lateral keel. Tail short; subcaudals in two rows.

Distribution. S. E. Asia.

$$
\text { Key to the Indo-Australian species. }
$$

A. Scales in 15 rows.............. I. S. annulifer P. 122.

b. Scales in 17 rows.

1. Two anterior temporals ........... 2. S. octolincatus p. I 23 .

II. One anterior temporal.

a. Fourth and fifth labials entering the eye. . 3. S. violaceus p. I 24.

b. Third and fouth labials entering the eye.

X Two postoculars........... 4. S. forbesi p. 124.

$X X$ One postocular.

I. Scales smoath .......... 5. S. signatus p. 125 .

2. Scales feebly keeled........6. S. subcarinatus p. 125.

C. Scales in 19 or 21 rows ........... . . S. purpurascens p. 126.

\section{Simotes annulifer Boulenger.}

Simotes annulifor, Boulenger, Proc. Zool. Soc. IS93, p. 524; Cat. Sn. II IS94, p. 226, pl. V11l, fig. 3 .

Nasal divided; rostral large, visible from above; suture between the internasals shorter than that between the praefrontals; frontal longer than its distance from the tip of the snout, shorter than the parietals; loreal small; one prae- and two postoculars; temporals $I+2$; seven upper labials, third and fourth entering the eye; four lower labials in contact with the anterior chin-shields; latter longer than the posterior. Scales in 15 rows; ventrals 153 ; anal entire; subcaudals 49.

Brown above, with 26 black annuli on the back, enclosing oval, yellowish spots; sides spotted with black and with vertical and oblique yellow lines; head yellowish-brown, a dark bar across the forehead, passing through the eye; a large $\lambda$-shaped spot from the frontal to the nape; an oblique bar on the temporal region; lips black-spotted. Lower surface white, with a serics of black spots on each side; chin and throat blackspotted. Length of head and body I $30 \mathrm{~mm}$; tail $30 \mathrm{~mm}$.

Habit at: N. Borneo!. 
Note. In Bull. Mus. d'hist. nat. $\mathrm{N}^{\circ} .4$ 1912, p. 4, R. Despax describes a specimen caught in the Dutch East Indies and preserved in the Paris Museum, which is exactly like the only specimen known, but for the number of scales, which is I 7 , the anal shield which is divided and the number of subcaudal shields which is 53 . Length of head and body $239 \mathrm{~mm}$; tail $66 \mathrm{~mm}$. As it is the only specimen found, it is difficult to say if it should rank as a variety (Simotes annulifer var. bipartita Despax) or should be regarded as a distinct species.

\section{Simotes octolineatus (Schn.).}

Elaps octolinealus, Schneider, Hist. Amph. II I Sor, p. 299.

Simotes octolineatus, Boulenger, Cat. Sn. II is94, p. 224.

Holarchus octolineatus, Barbour, Mem. Mus. Comp. Zool. Harv. Cull. XLIV I 912 , p. I I 8 .

Nasal divided; rostral visible from above; suture between the internasals almost as long as that between the praefrontals; frontal longer than its distance from the tip of the snout, as long as the parietals; loreal as long as deep; one prae- and two postoculars; temporals $2+2$; six upper labials, third and fourth entering the eye; four lower labials in contact with the anterior chin-shields; latter longer than the posterior. Scales in 17 rows; ventrals $155-197$, with an obtuse angle; anal entire; subcaudals $43-61$.

Yellow or pale brown above, with six or eight black longitudinal stripes, or black with yellow lines (the vertebral line sometimes scarlet), narrower than the interspaces; head yellow, the two median black dorsal stripes confluent on the frontal; a black curved transverse band passing through the eyes; an oblique band on each side from the parietals to below the angle of the mouth. Lower surface yellow, sometimes with a series of black spots on each side, which may confluent into a line. Length of head and body $580 \mathrm{~mm}$.; tail $100 \mathrm{~mm}$.

Nom. in dig. Ular birang (Borneo); ular pitar (mal.).

Habitat: Nias!; Sumatra (Labuan, Medan!, Langkat, Bedagei, Singkel, Gunung Sahilan!, Padang); Siak!; Banka; Riou!; Borneo (Sandakan, Baram river, Mt. Kina Balu, Rejang river, Santubong, Kuching, Sungei duri, Singkawang!, Sintang, Montrado, Mt. Dulit, Bandjermassin, Samarinda!); Java (Depok, 
Buitenzorg); Celebes (Macassar!). — Singapore; Malay Peninsula; S. India, Sulu Islands.

\section{Simotes violaceus (Cantor).}

Coronella violacéa, Cantor, Proc. Zool. Soc. I839, p. 50.

Simotes violaceus, Boulenger, Cat. Sn. II I 894, p. 222 (s. syn.).

Nasal divided; rostral visible from above; suture between the internasals usually shorter than that between the praefrontals; frontal as long as its distance from the tip of the snout, as long as the parietals; loreal more long than deep; a praeocular; usually a small subocular between the third and fourth labials; one or two postoculars; temporals $\mathrm{I}+2$; eight upper labials, fourth and fifth entering the eye; three or four lower labials in contact with the anterior chin-shields; latter two times as large as the posterior or larger. Scales in 17 rows; ventrals I60-I96; anal entire; subcaudals 33-4I.

Pale brown or reddish above, with or without dark transverse bands; markings on the head indistinct. Lower surface uniform or with quadrangular brown spots. Length of head and body $685 \mathrm{~mm}$; tail $75 \mathrm{~mm}$.

Habitat: N. Borneo (Bongon!). - Siam; Camboja; Burma; Assam; Bengal; S. China.

\section{Simotes forbesi Boulenger.}

Simrotes forbesii, Boulenger, Proc. Zool. Soc. $188_{3}$, p. 387 , pl. XLII; Cat. Sn. II I $\$ 94$, p. 225.

Nasal divided; rostral visible from above; suture between the internasals shorter than that between the praefrontals; frontal longer than its distance from the tip of the snout, as long as the parietals; loreal more deep than long; one praeand two postoculars; temporals $\mathrm{I}+2$ or $2+2$; seven upper labials, third and fourth entering the eye; four lower labials in contact with the anterior chin-shields; latter almost twice as long as the posterior. Scales in 17 rows; ventrals $150-169$ with a slight lateral angle; anal entire; subcaudals $43-48$.

Greyish-brown above, dark borders on the scales; two fine dark brown lines along the back, on the inner border of the seventh row of scales, separated by three series of scales; head with symmetrical dark markings; a dark band across the fore-head. Lower surface yellowish, a lateral series of brown 
spots or a stripe, the posterior ventrals sometimes brown in the middle, yellow on the sides. Length of head and body $247 \mathrm{~mm}$; tail $58 \mathrm{~mm}$.

Type-specimens examined in the British Museum.

Habitat: Timor Laut!; Dammar Island.

\section{Simotes signatus Gthr.}

Simotes signatus, Günther, Rept. Brit. Ind. I 864, p. 215 , pl. XX, fig. F. Simotes signatus, Boulenger, Cat. Sn. II I 894, p. 226.

Nasal divided; rostral visible from above; suture between the internasals as long as or shorter than that between the praefrontals; frontal longer than its distance from the tip of the snout, as long as the parietals; loreal small, square; one prae- and one postocular; temporals $\mathrm{I}+2$; seven upper labials, third and fourth entering the eye; three or four lower labials in contact with the anterior chin-shields; latter a little longer than the posterior. Scales in I7 rows; ventrals $14 \mathrm{I}-\mathrm{I} 57$; anal entire; subcaudals $47-59$.

Dark brown above, with rhomboidal transverse yellow spots or bands; head with symmetrical dark brown markings and yellow interspaces. Lower surface yellow; a lateral series of brown spots. Length of head and body $390 \mathrm{~mm}$.; tail I $30 \mathrm{~mm}$.

Habit a t: Sumatra (Labuan, Medan!, Serbadjadi!, Langkat, Indragiri); Java. - Singapore.

\section{Simotes subcarinatus Gthr.}

Simotes subcarinatus, Günther, Proc. Zool. Soc. IS72, p. 595, pl. XXXIV, fig. B. Simotes subcarinatus, Boulenger, Cat. Sn. II I\$q4, p. 226.

Nasal divided; rostral visible from above; suture between the internasals shorter than that between the praefrontals; frontal longer than its distance from the tip of the snout, as long as the parietals; loreal small, square; one prae- and one postocular; temporals $\mathrm{I}+\mathrm{I}+2$; seven upper labials, third and fourth entering the eye; four lower labials in contact with the anterior chin-shields; latter almost twice as large as the posterior. Scales in I7 rows, feebly keeled: ventrals 155-I66; anal entire; subcaudals 50- 54 .

Dark brown or olive above, with yellowish or pinkish, blackedged, transverse bands, the anterior chevron-chaped; head yellowish, with symmetrical brown or crimson markings. Lower 
surface yellowish or crimson; sides with brown spots. Length of head and body $315 \mathrm{~mm}$.; tail $80 \mathrm{~mm}$.

Type-specimen examined in the British Museum.

Habitat: Sumatra '); Borneo! (Kuching, Matang, Sarawak (Kidi-district!).

\section{Simotes purpurascens (Schlegel).}

Yenodon purpurascens, Schlegel, Phys. Serp. 1837, p. 90, pl. III, fig. 13, 14. Simotes purpurascens, Boulenger, Cat. Sn. II I894, p. 218 (s. syn.).

Nasal divided; rostral visible from above; suture between the internasals as long as or longer than that between the praefrontals; frontal much longer than its distance from the tip of the snout, as long as or longer than the parietals; loreal

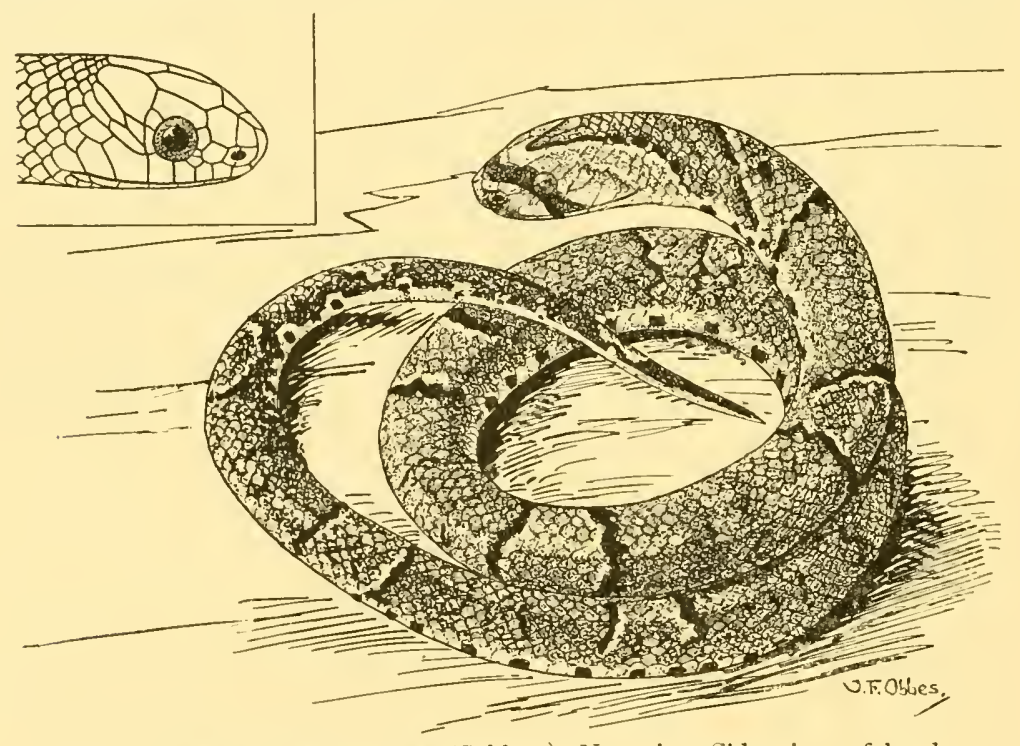

Fig. 52. Simotes purpurascens (Schleg.). Nat. size. Side view of head.

square; one or two praeoculars; one or two suboculars and two or three postoculars; temporals $2+2$ or $2+3$; eight upper labials, fourth and fifth or fifth only entering the eye; four or five lower labials in contact with the anterior chin-shields; latter almost twice as long as the posterior. Scales in 19 or $2 \mathrm{I}$ rows; ventrals $\mathrm{I} 60-2 \mathrm{IO}$, with lateral angle; anal entire; subcaudals $40-60$.

1) Sec: Wernek, Verh. Gesells. Wien XiliI i $S_{94}$, p. 355. 
Purple or brown above, with dark, black-edged, wavy bands or with yellowish transverse bands; a large, pointed, dark brown marking on the occiput and nape, the point on the frontal, often confluent with a dark band, passing through the eyes; a dark oblique streak on the temporal region. Lower surface yellowish, pinkish or coral-red with square dark spots. Young specimens greyish with about 14 black transverse bands, broadest on the middle of the back and edged with light, the broad interspaces with 5 narrow black wavy bands. Ilead with usual black markings. Total length $950 \mathrm{~mm}$.

$\mathrm{H}$ a b i t a t: Nias!; Mentawei Islands (Sipora); Sumatra (Sabang on Pulu Weh!, Atjeh, Labuan, Deli!, Indragiri, Djambi!, Bunga Maas, Gunung Sahilan!, Palembang); Borneo (Labuan, Saiap on Mt. Kina Balu, Saribas, Kuching, Pangkalan ampat, Matang, Kidi district, Paku, Penrissen Road, Buntok, Samarinda!); Java! (Tengger Mts. I 200 M.). - Singapore; Penang; Malay Peninsula; Siam; Cochin China; S. China.

Note. Simotes phacnochalinus Cope is mentioned from Java (:) in Boulenger's Catalogue II p. 225. This locality does not seem probable, as the species occurs in the Philippines only. No recent publication about the Reptiles of the Sunda Islands enumerates $S$. phaenochalinus among the snakes of Java.

\section{Oligodon Boie.}

(BoIE, Isis, p. $519, I_{2} S_{7}$ ).

Head short, not distinct from neck; eye small; pupil round; internasals present or absent. Naxillary teeth $6-8$, posterior strongly enlarged; pterygoid toothless; palatines toothless or with two or three teeth. Body round, covered with smooth scales in 15 or 17 rows; ventrals rounded or with an obtuse lateral keel. Tail short; subcaudals in two rows.

Distribution. S. E. Asia; Syria; Lower Egypt.

Key to the Indo-Australian species.

$A$. Scales in 17 rows.

I. Internasals present; anal entire.

a. Two postoculars; subcaudals $30-46 \ldots$ I. O. bitorquatus p. I28.

6. One postocular; subcaudals $52-62 \ldots$. . O. trilineatus p. I 29.

II. Internasals absent; anal divided........ 3. O. durheimi p. 129. 
B. Scales in 15 rows.

I. Anal entire.

a. Nasal divided.

I. Internasals in contact ........ 4. O. everetti p. I 30 .

2. Internasals separated......... 5. O. petronellae p. I3 I.

b. Nasal undivided............. 6. O. propinquus p. I31.

II. Anal divided.

a. No internasals.

I. Nasal divided; two postoculars; subcaudals $30 . \ldots \ldots \ldots \ldots . . . .7$. . . pulcherrimus p. I 32.

2. Nasal undivided; one postocular; subcaudals $37 \ldots \ldots$......... 8. O. praefrontalis p. 132 .

b. A pair of internasals.

I. Nasal divided; subcaudals $54 \ldots . .9$ 9. O. verteliralis p. 133 .

2. Nasal undivided or partly divided; subcautals $2 \mathrm{I}-2 \mathrm{~S} \ldots \ldots \ldots$. . . . . . . O. waandersi p. 133 .

\section{Oligodon bitorquatus Boie.}

Oligodon bitorquatus, Boie, Isis IS27, p. 5I9.

Oligodon bitorquatus, Boulenger, Cat. Sn. Il I 894, p. 237 (s. syn.).

Rostral visible from above; nasal divided; suture between the internasals shorter than that between the praefrontals;

\section{WTW}
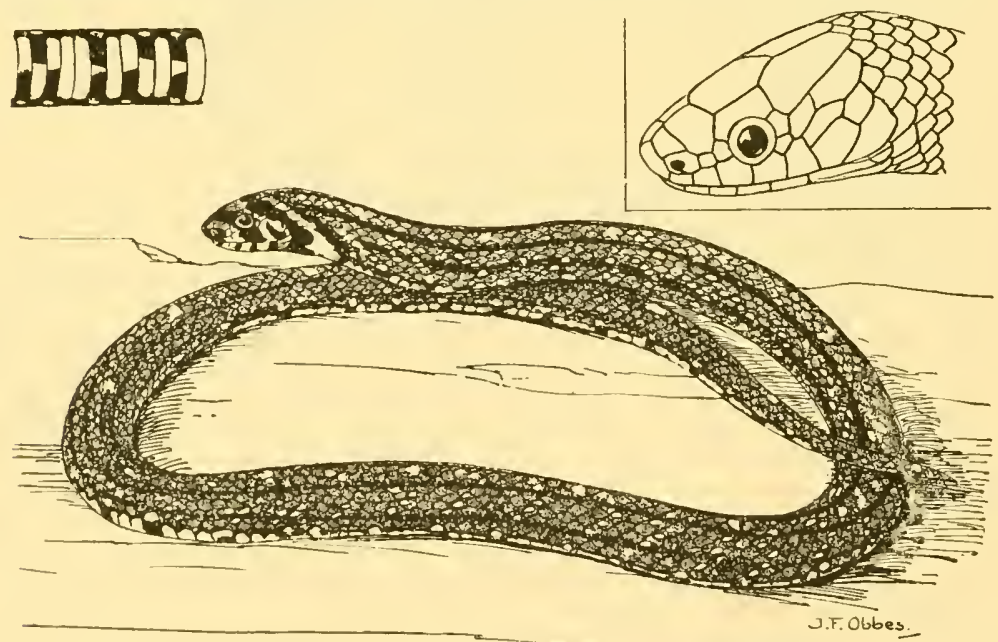

Fig. 53. Oligalon bitorquatus Boie. Nat. size. Side view of head; ventral shields.

frontal longer than its distance from the tip of the snout, as long as or shorter than the parietals; loreal more long than 
deep or absent; one prae- and two postoculars; temporals I +2 or $2+2$; seven upper labials, third and fourth entering the eye; three or four lower labials in contact with the anterior chin-shields; latter almost twice as long as the posterior. Scales in $\mathrm{I} 7$ rows; ventrals $140-\mathrm{I} 65$; anal entire; subcaudals $30-46$.

Purple or dark brown above, with small yellow or red spots; often a median series of larger spots; head with symmetrical dark markings and one or two yellowish bands, the posterior on the occiput. Lower surface red, with quadrangular or transverse black spots. Length of head and body $303 \mathrm{~mm}$; tail $67 \mathrm{~mm}$.

Habitat: Java (Gadok, Gunung Pengalengan 4000 feet and Tjisurupan, Batavia, Krawang!, Buitenzorg!, Mt. Salak, Mt. Gedeh 4500 feet, Tjibodas I425 M., Gunung Ungaran!, Salatiga!, Ambarawa, Mt. Wilis 5000 feet, Kediri!, Tengger Mts. 1200 M.); Ambon? ').

\section{Oligodon trilineatus (Dum. \& Bibr.).}

Simotes trilineatus, Duméril \& Bibron. Erp. Gén. VII $1 \$_{54}$, p. 636 . Oligodon trilineatus, Boulenger, Cat. Sn. II I 894, p. 238.

Rostral visible from above; nasal divided; suture between the internasals about as long as that between the praefrontals; frontal longer than its distance from the tip of the snout, as long as the parietals; loreal more long than deep; one praeand one postocular; temporals $I+2$ or $2+2$; seven upper labials, third and fourth entering the eye; four lower labials in contact with the anterior chin-shields; latter almost twice as long as the posterior. Scales in 17 rows; ventrals $145-157$; anal entire; subcaudals 52-62.

Dark brown or black above; a yellow (red) vertebral stripe and a fine light line along each side; head yellowish-brown with dark oblique bands, not continuous on the crown. Lower surface blackish; a white line along each side. Length of head and body $250 \mathrm{~mm}$.; tail $80 \mathrm{~mm}$.

Habitat: Nias!; Sumatra (Manindjau!).

\section{Oligodon durheimi Baumann.}

Oligodon durheimi, Baumann, Zool. Jahıb. Syst. XXXIV 1913, p. 269, fig. C.

Rostral visible from above; nasal divided; internasals absent;

I) A young specimen preserved in the British Museum.

INDO-AUSTRALIAN REPTILES II. 
praefrontals large; frontal longer than its distance from the tip of the snout, as long as the parietals; loreal more deep than long; one prae- and two postoculars; temporals $\mathrm{I}+2$; seven upper labials, third and fourth entering the eye; four lower labials in contact with the anterior chin-shields; latter more than twice as long as the posterior. Scales in 17 rows; ventrals I74; anal divided; subcaudals $4 \mathrm{I}$.

Olive or brown above, with a median dark, black-edged band, widening on the nape and enclosing light, black-edged spots; neck with an oblique black spot on each side, beginning on the parietals; head with a dark crescent-shaped band, passing through the eyes and confluent on the frontal with the median band of the back. Lower surface yellow with black transverse spots; a median reddish longitudinal line, most distinct posteriorly, covering the greater part of the subcaudals. Length of head and body $314 \mathrm{~mm}$.; tail $54 \mathrm{~mm}$.

Type-specimen received from the Bern Museum, cxamined. Habitat: Sumatra (Battak Highlands Soo--1000 M.!).

\section{Oligodon everetti Boulenger.}

Oligodon everetti, Boulenger, Proc. Zool. Soc. IS93, p. 524; Cat. Sn. II I 894 p. I39, pl. XI, fig. I.

Rostral visible from above; nasal divided; suture between the internasals shorter than that between the praefrontals; frontal longer than its distance from the tip of the snout, shorter than the parietals; loreal small, more long than deep; one prae- and two postoculars; temporals I +2 ; seven upper labials, third and fourth entering the eye; four lower labials in contact with the anterior chin-shields; latter longer than the posterior. Scales in 15 rows; ventrals $138-154$; anal entire; subcaudals $46-65$.

Grey above, with three blackish-brown stripes, the median one three scales wide and enclosing small yellowish spots; head brown with two black bands, the anterior passing through the eyes, the posterior across the frontal. Lower surface coralred, the ventrals with black outer ends. Length of head and body $300 \mathrm{~mm}$; tail $70 \mathrm{~mm}$.

Typc-specimen examined in the British Museum.

Habitat: Borneo (Kina Balu!, Tandjong, Bandjermassin). 


\section{Oligodon petronellae Roux.}

Oligolon ornatus, Roux, Revue Suisse Zool. Vol. 22 I914, p. 29.

Rostral large; nasal large, divided; internasals well developed, separated by the rostral, which is in contact with the praefrontals; frontal longer than its distance from the tip of the snout, shorter than the parietals; loreal more long than deep; one prae- and two postoculars; temporals $\mathrm{I}+2$; seven upper labials, third and fourth entering the eye; three or four lower labials in contact with the anterior chin-shields; latter longer than the posterior. Scales in 15 rows; ventrals I 52 ; anal entire; subcaudals $19+$ ?

Greyish-brown above, with dark brown markings, some of them bordered with light spots; a brown spot on the hind part of the parietals, divided into two parallel bands on the nape and along the back, which form posteriorly lozenge-shaped markings; about $2 \mathrm{I}$ of those markings, some bordered with white spots; head with a dark brown transverse band across the snout, a large spot on the frontal, another on the parietals and continued obliquely along each side of the neck; upper labials spotted with black. Lower surface brick-red, every second ventral with dark brown spots near the outer ends; tail almost entirely red below. Length of head and body $408 \mathrm{~mm}$.; tail (broken) $42 \mathrm{~mm}$.

Type-specimen received from the Genève Museum, examined. Habitat: Sumatra!.

Note. Dr. JEan Roux of Basle had described this new species under the name of O.ornatus, when he became aware that this name was used already for a snake of Formosa (Van Denbukgit, Proc. Cal. Acad Sc. III igio, p. 53). So at his request it has been changed into the one put above this description.

\section{Oligodon propinquus Jan.}

Oligodon propinquus, Jan, Arch. Zool. Anat. Phys. 11 1862, p. 38. Oligodon propinquus, Boulenger, Cat. Sn. II I894. p. 240.

Rostral visible from above; nasal entire; suture between the internasals longer than that between the praefrontals; frontal longer than its distance from the tip of the snout, as long as the parietals; loreal small, more long than deep; one prae- 
and two postoculars; temporals $\mathrm{I}+2$; seven upper labials, third and fourth entering the eye; four lower labials in contact with the anterior chin-shields; latter longer than the posterior. Scales in 15 rows; ventrals 140 ; anal entire; subcaudals 27.

Black above, with yellow dots; a series of yellow spots along the back. Lower surface whitish. Length of head and body $245 \mathrm{~mm}$; ; tail $40 \mathrm{~mm}$. (Not seen by me).

Habitat: Java.

\section{Oligodon pulcherrimus Werner.}

Oligodon pulcherrimus, Werner, Mitt. Naturhist. Mus. Hamb. XXVI 1909, p. 227 fig. 4 .

Rostral visible from above; nasal divided; no internasals; frontal as long as its distance from the tip of the snout, shorter than the parietals; loreal small, a little more long than deep; one prae- and two postoculars; a long anterior temporal with a second one under its posterior part; seven upper labials, third and fourth entering the eye; four lower labials in contact with the anterior chin-shields; latter as long as the posterior. Scales in I5 rows; ventrals I79; anal divided; subcaudals 30.

Brown above, with a dark longitudinal band beginning on the frontal, widening on the nape and enclosing 36 light brown, black-edged, hexagonal spots; sides bluish-grey, spotted with black and white near the ventrals; head brown with a dark brown crescent-shaped band between the eyes on the praefrontals, supraoculars and frontal; an oblique band from the anterior part of the parietals to the corner of the mouth, continued and widened on the neck; a dark spot on the rostral, below the nostril, below the eye and on the suture between the fifth and sixth upper labials. Lower surface yellow, the outer ends of the ventrals alternatively spotted with black and white; mental with a black spot and black posterior border; first lower labials edged with dark posteriorly; chin-shields and anterior ventrals spotted with black. Length of head and body $325 \mathrm{~mm}$.; tail $42 \mathrm{~mm}$. (After Werner; not seen by me).

Habitat: Sumatra (Pudang in district Bobangan).

\section{Oligodon praefrontalis Werner.}

Oligodon praefrontalis, Werner, Mitt. Naturhist. Mus. Hamb. XXX I9r3, p. 25.

Rostral visible from above; nasal entire; no internasals; prac- 
frontal fused with loreal and touching the second upper labial; one prae- and one postocular; temporals $1+2$; seven upper labials, third and fourth entering the eye. Scales in 15 rows; ventrals I93; anal divided; subcaudals 37.

Greyish-brown above, with a yellowish-brown median band, covering the vertebral row of scales and the next half. Lower surface yellowish-white; outer end of the ventrals alternatively light and dark. Length of head and body $210 \mathrm{~mm}$.; tail $31 \mathrm{~mm}$. (After WERnER; not seen by me).

Habitat: Pulu Weh (Sabang).

\section{Oligodon vertebralis (Günther).}

Simotes vertebralis. Günther, Ann. Nat. Hist. (3) XV 1865, F. 91. Oligodon virtebralis, Boulenger, Cat. Sn. II I $\$ 94$, p. 245, pl. XI, fig. 2.

Rostral visible from above; nasal divided; suture between the internasals longer than that between the praefrontals; frontal longer than its distance from the tip of the snout, shorter than the parietals; loreal small, square; one prae- and two postoculars; temporals $\mathrm{I}+2$; seven upper labials, third and fourth entering the eye; four lower labials in contact with the anterior chin-shields; latter about twice as large as the posterior. Scales in 15 rows; ventrals 154; anal divided; subcaudals 54.

Brown above, with small yellow, black-edged spots, largest on the vertebral line; head yellowish, with two brown, blackedged bands, the anterior passing through the eyes; the posterior across the frontal. Lower surface yellowish; throat brown-spotted. Length of head and body $270 \mathrm{~mm}$.; tail $75 \mathrm{~mm}$.

Type-specimen examined in the British Museum.

Habitat: Borneo (Kina Balu!, Bandjermassin!).

\section{IO. Oligodon waandersi (Bleeker).}

Rhabdion aidandirsi, Bleeker, Nat. Tijdschr. Nederl. Ind. XXII I860, p. 8 . Oligrodon wandersii, Bonlenger, Cat. Sn. Il IS94, p. 245, pl. XI, fig. 3 ; Proc.

Zool. Soc. 1897, p. 221.

Oligodon taeniurus, F. Müller, Verh. Ges. Basel I I 894, p. S26.

Rostral visible from above; nasal entire or partly divided; suture between the internasals as long as or longer than that between the praefrontals; frontal longer than its distance from the tip of the snout, as long as or shorter than the parietals; loreal small or absent; one prae- and two postoculars; tem- 
porals $I+2$; seven upper labials, third and fourth entering the eye; three or four lower labials in contact with the anterior chin-shields; latter as long as or longer than the posterior. Scales in 15 rows; ventrals I $34-\mathrm{I}_{3}$; anal divided (very rarely entire); subcaudals $2 \mathrm{I}-28$.

Orange, red, brown or black above, with or without small yellow or orange, dark-edged spots, sometimes in pairs or forming transverse series; often a yellow collar; a yellow or reddish vertebral stripe posteriorly; head with a dark brown transverse band on the occiput; a dark oblique streak below the eye. Lower surface yellowish-white or pinkish, with or without grey dots or black spots; often a black stripe along the outer ends of the ventrals. Length of head and body 3 IO $\mathrm{mm}$; tail $45 \mathrm{~mm}$.

Nom. in dig. Baluntete (Toradja-name).

Habitat: Celebes (Pinogo in Bone Valley! (types of Oligodon taeniurus), Masarang, Tomohon, Rurukan, Minahassa, Posso!, Boni).

\section{E1 apoides Boie.}

(BoIE, Isis, p. 519, I 827 ).

Head not distinct from neck; eye small; pupil round; nostril large, between two nasals, posterior nasal concave; praeocular absent, loreal and praefrontal entering the eye. Maxillary teeth about 20, small, equal; mandibular teeth about equal. Body round, slender, covered with lanceolate keeled scales, without pits, in 15 rows; ventrals rounded. Tail long; subcaudals in two rows.

Distribution. Sumatra; Java.

A single species.

\section{Elapoides fuscus Boic.}

Elapoidtes fuscus, Boie, Isis I\$27, p. 519.

Lilapoides fuscus, Buulenger, Cat. Sn. 1 I 893, p. 307.

Snout short and broad, rounded; rostral more broad than deep, visible from above; suture between the internasals as long as or shorter than that between the praefrontals; frontal as broad as long or more broad, shorter than the parietals; supraocular very small; no praeocular, loreal and praefrontal entering the eye; a small postocular; temporal narrow, long; six upper 
labials, third and fourth entering the eye, fifth large; three or four lower labials in contact with the anterior chin-shields; latter as long as posterior. Scales in 15 rows, strongly keeled; ventrals 146-I5s; anal entire; subcaudals 74-9I.

Dark brown above, or brown with yellow spots, or yellow anteriorly with a dark brown vertebral stripe and dark spots

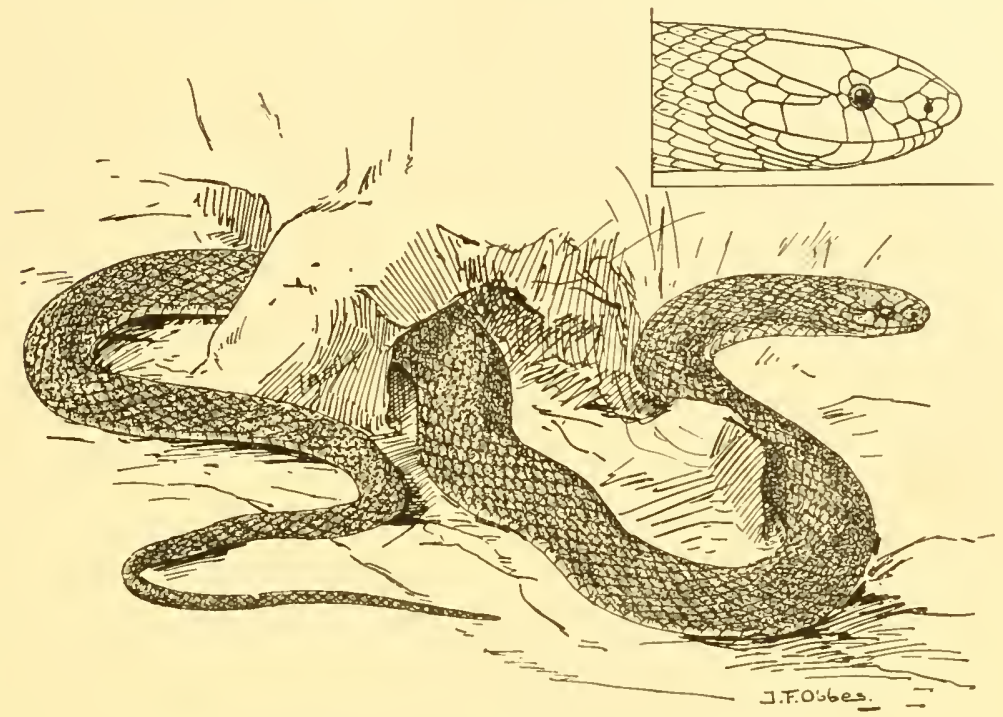

Fig. 54. Elapoides fuscus Boie $\times 3 / 4$. Side view of head.

on each side, dark brown posteriorly. Lower surface yellow, brownish on the tail. Length of head and body $350 \mathrm{~mm}$; tail $\mathrm{I} 20 \mathrm{~mm}$.

Ha bit at: Sumatra; Java (Buitenzorg!, Sindanglaia 5000 feet, Sukabumi!, Tjibodas, Mt. IVilis 5000 feet, Nongkodjadjar in Tengger Mts. I 300 M.!).

A mountain form, not uncommon at an elevation of above 3000 feet.

\section{Hydrablabes Boulenger.}

(Boulesger. Ann. Nat. Hist. (6) V'll p. 343, ISgI).

Head small, not distinct from neck; eye small; pupil round; nostril valvular, an oblique slit between two nasals; three pair of chin-shields. Maxillary teeth small, equal, about 18 ; mandibular teeth small, equal. Body long, round, covered with 
smooth scales, without pits, in I 5 or I 7 rows; ventrals rounded. Tail moderate; subcaudals in two rows.

Distribution. Borneo.

Key to the Indo-Australian species.

A. Scales in 17 rows; two praefrontals........ I. H. periops p. 136 .

fi. Scales in 15 rows; a single praefrontal. .... 2. H. pratefrontalis p. 137.

\section{Hydrablabes periops (Günther).}

Ablabes periops, Günther, Proc. Zool. Soc. I872, p. 595, fig. 3. Hydrablabes periops, Boulenger, Cat. Sn. I I893, p. 296.

Snout short and broad; rostral just visible from above; internasals not half as large as the praefrontals, usually in contact with the loreal; frontal more than twice as broad as

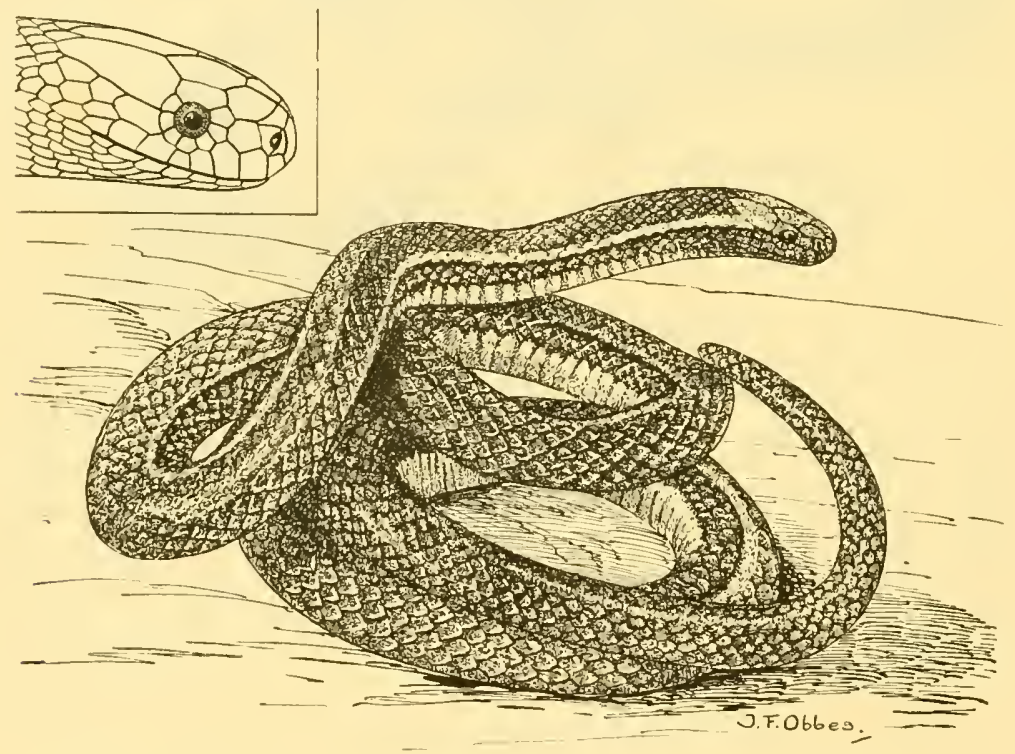

Fig. 55. Ifydrablabes periops (Gthr.). Nat, size. Side view of head.

the supraocular, as long as its distance from the tip of the snout, much shorter than the parietals; loreal more long than deep; two prae-, two post- and two or three suboculars; temporals I +2 ; eight or nine upper labials, all separated from the eye; three pair of chin-shields, second largest and separating the third. Scales in I7 rows; ventrals 190-209, the last divided; anal divided; subcaudals $62-74$. 
Olive-brown above, with a yellow streak along each side of the body anteriorly, sometimes indistinct; sides darker. Lower surface whitish, ventrals edged with black, subcaudals black, edged with white. Length of head and body $436 \mathrm{~mm}$.; tail $95 \mathrm{~mm}$.

Habit at: Borneo (Matang, Landak!).

\section{Hydrablabes praefrontalis (Mocq.).}

Ablubes periops var. pracfrontalis, Mocquard, Le Natural. 1890, p. 154; Nouv.

Arch. Mus. (3) II I89o, p. I37, pl. IX, fig. I.

Hydrablabis pracfrontalis, Boulenger, Cat. Sn. I 1893, p. 297.

Differing from the preceding species on the following points: Praefrontals fused into a single shield; scales in 15 rows; ventrals $178-202$; subcaudals 72 .

Olive-brown above, with a dark vertebral stripe, sometimes indistinct and two black dorso-lateral lines, broken up into spots posteriorly. Lower surface yellow, the outer edge of each ventral dark brown; subcaudals edged with brown; a dark median line along the tail. Length of head and body $346 \mathrm{~mm}$.; tail $90 \mathrm{~mm}$.

Type-specimen examined in the Paris Museum.

Habitat: Borneo (Kina Balu!).

\section{A blabes Dum. \& Bibr.}

(Dumíril \& Bibron, Erp. Gén. VII p. 304, I854).

Head not or scarcely distinct from neck; cye small or moderate; pupil round; nasal cntire or divided; loreal present or absent. Maxillary teeth small, equal, 15-30; mandibular teeth about equal. Body round, slender, covered with smooth or feebly keeled scales without pits, in I 3 to 17 rows; ventrals rounded. Tail long; subcaudals in two rows.

Distribution. S. E. Asia; Japan.

Key to the Indo-Australian species.

A. Scales in 15 rows.

1. No loreal; nasal single.............. 1. A. tricolor p. 138 .

2. Two loreals; nasal divided. ........... 2. A. libertatis p. 138 .

$B$. Scales in $\mathbf{1} 3$ rows.

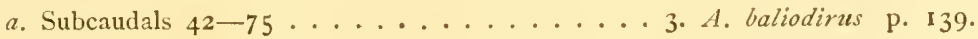

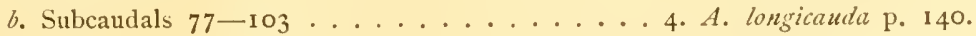




\section{Ablabes tricolor (Schlegel).}

Herpetodryas tricolor, Schlegel, Phys. Serp. I837, p. I87, pl. VI, fig. I6-I8. Ablabes tricolor, Boulenger, Cat. Sn. 11 I $\$ 94$, p. 281 (s. syn.).

Snout long, depressed, two times as long as the diameter of the eye. Rostral more broad than deep, visible from above; nasal entire; internasals as long as or shorter than the praefrontals, which are in contact with the second and third labials; no loreal; frontal as long as its distance from the tip of the snout, shorter than the parietals, not broader than the supraocular; one prae- and two postoculars; temporals $I+2$; eight upper labials, fourth and fifth entering the eye; four or five lower labials in contact with the anterior chin-shields; latter shorter than the posterior. Scales in 15 rows, smooth; ventrals 140-I87; anal divided; subcaudals $103-137$.

Olive or greenish above; a black streak on each side of the head and anterior part of the body, passing through the eye; upper lip yellowish-white. Lower surface yellowish-white; a pale olive streak along each side of the belly. Length of head and body $340 \mathrm{~mm}$.; tail $220 \mathrm{~mm}$.

Habitat: Nias!; Sumatra (Labuan, Deli, Asahan, Bunga Maas); Banka!; Java (Buitenzorg!, Tengger Mts. I 200 M.); Borneo (Matang, Montrado, Singkawang!, Pontianak). - Singapore; Penang; Malay Peninsula.

\section{Ablabes libertatis (Barbour).}

Liopeltis libertatis, Barbour, Proc. Biol. Soc. Wash. XXIII I910, p. 169.

Rostral as broad as deep, visible from above; nasal divided; internasals shorter than the praefrontals, which are in contact with the supraoculars; frontal a little longer than its distance from the tip of the snout, longer than the suture between the parietals, broader than the supraocular; two loreals, the anterior square, the posterior lower and narrower; one praeand two postoculars, upper twice as large as lower; temporals $2+2$; eight upper labials, fourth and fifth entering the eye, seventh largest; five lower labials in contact with the anterior chin-shields; latter shorter than the posterior. Scales in 15 rows, smooth; ventrals 173; anal divided; subcaudals 109 (tip of tail broken).

Uniform slate colour above, lighter below. Length of head and body? (After BARBour; not seen by me).

Habitat: Java (Buitenzorg). 


\section{Ablabes baliodirus (Boie).}

Coronella baliodeira, Boie, Isis, I827, p. 539.

Ablabes baliodirus, Boulenger, Cat. Sn. II I 894, p. $28_{3}$.

Liopellis baliodirus, Barbour, Mem. Mus. Comp. Zool. Harv. Cull. XI.IV 1912 , p. I I 8 .

Rostral more broad than deep, visible from above; nasal divided; internasals shorter than the praefrontals; frontal longer than its distance from the tip of the snout, shorter than the parictals; loreal small; one or two prae- and two postoculars; temporals $\mathrm{I}+2$; seven upper labials, third and fourth entering the eye; four or five lower labials in contact with the anterior chin-shields; latter as long as or shorter than the posterior.

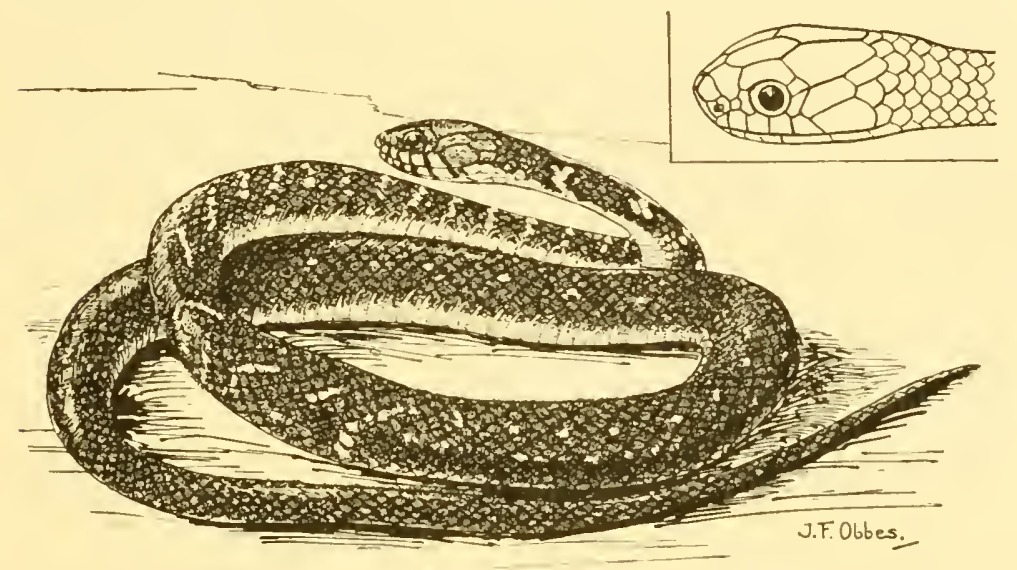

Fig. 56. Ablabes baliodirus (Boie). Nat. size. Side view of head.

Scales in 13 rows, smooth; ventrals I 5 - I 37 ; anal divided; subcaudals $42-75$.

Brown above, with or without small, black-edged, yellow spots; sometimes with blackish transverse bands or two series of large, alternate black spots anteriorly, or with two light, dark-edged streaks along the body and another on the nape; head sometimes yellowish; lips yellowish with black sutures. Lower surface yellowish or coral-red, the outer ends of the shields usually brown and sometimes with a black dot; lower part of tail sometimes with a black median line. Length of head and body $275 \mathrm{~mm}$; tail $125 \mathrm{~mm}$.

Habitat: Nias; Sumatra (Labuan, Deli!, Djambi!, Kertadjaja in Palembang, Manindjau!, Indrapura, Padang); Natuna 
Islands; Borneo (Kina Balu, Pangkalan ampat, Kuching, Saribas, Kidi district, Baram, Kutei); Java (Anjer, Pandeglang, Batavia, Buitenzorg, Salak, Sukabumi!, Ambarawa, Willis Mts. 5000 feet, Ngawi, Tengger Mts. I200 M.). - Penang; Malay Peninsula.

\section{Ablabes longicauda Peters.}

Ablabes longicaudus, Peters, Mon. Berl. Ac. IS71, p. 574.

Diadophis bipunctatus, v. Lidth de Jeude, M. Weber's Zoolog. Ergebn. I 1S9o, p. I 84 , pl. XVI, fig. 9.

Ablabes longicuuda, Boulenger, Cat. Sn. II I 894, p. 284.

Rostral more broad than deep, visible from above; nasal divided; internasals as long as or shorter than the praefrontals; frontal longer than its distance from the tip of the snout, shorter than the parietals; loreal small, sometimes confluent with the posterior nasal; one or two prae- and two postoculars; temporals I +2 ; eight (seven) upper labials, third to fifth (third and fourth) entering the eye; four lower labials in contact with the anterior chin-shields; latter a little longer than the posterior. Scales in I3 rows; ventrals I IO-I22; anal divided; subcaudals 77 - 103 .

Dark brown or black above, with five orange longitudinal lines, disappearing on the posterior part of the body; the vertebral line beginning behind the nape, the dorso-laterals widening in front, descending obliquely with black borders towards the throat; a yellow chevron-shaped collar, pointing backwards, the point confluent with the vertebral line; the black of the head continued on the temple as a triangular spot; eye bordered with black; upper lip yellowish with a few black spots. Lower surface red, a brown spot at the outer end of each ventral. Length of head and body $260 \mathrm{~mm}$.; tail $\mathrm{I} 70 \mathrm{~mm}$.

Habitat: Sumatra (Deli, Kaju tanam (type of Diadophis bipunctatus Lidth)!); Borneo (Rejang river, Mt. Batu song, Busau, Baram, Matang, Bidi, Kidi district in Sarawak!); Java (Sukabumi!). - Penang; Malay Peninsula.

\section{Oreocalamus Boulenger.}

(Boulenger, Ann. Nat. Hist. (7) IV p. 452, I899).

Head not distinct from neck; eye small; pupil round; nostril between a nasal and the first upper labial; internasals present; 
loreal present. Maxillary teeth about IO, nearly equal; mandibular teeth subequal. Body round, covered with smooth scales without pits, in I7 rows; ventrals rounded. Tail short; subcaudals in two rows.

Distribution. Borneo.

A single species.

\section{Oreocalamus hanitschi Boulenger.}

Oreocalamus Hanitschi, Boulenger, Ann. Nat. Hist. (7) IV IS99, p. 452, figured in Journ. Straits Branch Asiat. Soc. 34, 1900 pl. I, fig. 3.

Snout pointed; rostral as deep as broad, visible from above; internasals longer than its distance from the tip of the snout, shorter than the parietals; nostril close to the rostral, between the nasal and the first labial; loreal more long than deep, wedged in below between the second and third labials;

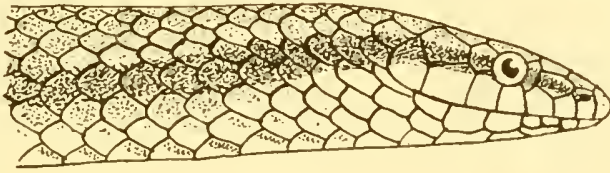
one prae- and one postocular; temporals I +2 ; eight upper labials, fourth and fifth entering the eye, seventh largest; four lower labials in contact with the anterior chin-shields; latter longer than the poste-

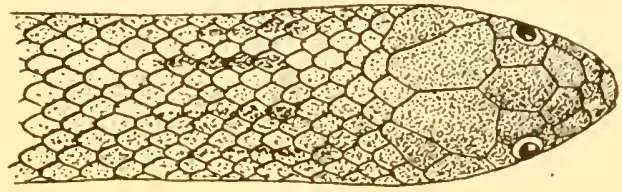

Fig. 57. Orcocalamus hanitschi Blgr. After a figure by Boulenger published by Hanitsch. rior. Scales in I7 rows; ventrals I27; anal entire; subcaudals 26.

Blackish-brown above. Lower surface yellowish-white with a few scattered brown dots; outer ends of ventrals blackish; tail brown beneath with a dark median streak. Length of head and body $325 \mathrm{~mm}$.; tail $50 \mathrm{~mm}$. (After BOUlENGER; not seen by me).

Habitat: Borneo (Mt. Kina Balu 4200 fect).

Only one specimen known.

\section{I. Id iopholis Mocquard.}

(MoçUard, Le Naturaliste p. 35, I $\$ 92$ ).

Head not distinct from neck; eye very small; pupil round; nostril betwcen two scales; internasals small; an azygous shield 
separating the internasals, present or absent; no supraocular; loreal, praeocular and anterior temporal absent. Maxillary teeth numerous, small and equal. Body round, covered with smooth scales without pits, in 15 rows; ventrals rounded. Tail short; subcaudals in two rows.

Distribution. Borneo.

Key to the Indo-Australian species.

A. A small shield separating the internasals: a broad

yellowish collar................... I. I. collaris p. 142 .

B. No shield between the internasals; no yellow coliar. 2. I. cocretti p. 142.

\section{Idiopholis collaris Mocquard.}

Idiopholis collaris, Mocquard, Le Natural. IS92, p. 35 ; Mem. Soc. Zool. Fr. V I892, p. 191, pl. VII, fig. I.

Idiopholis collaris, Boulenger, Cat. Sn. II IS94, p. 327.

Snout obtuse, short; rostral narrow, more deep than broad; frontal more broad than long, as long as the praefrontals,
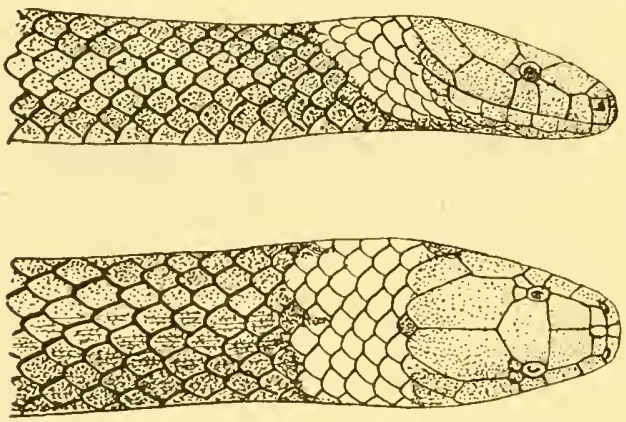

Fig. 58. Idiophalis collaris Mocq. After Mocounard. half as long as the parietals; internasals small, separated by a small shield; supraoculars, Ioreals, praeoculars and temporals absent; six upper labials, third and fourth entering the eye, fifth largest and in contact with the parietal; anterior chin-shields longer than the posterior.

Scales in 15 rows; ventrals 127 ; anal entire; subcaudals 28 . Dark brown above; a broad yellowish-white collar behind the parietals. Lower surface lighter brown. Total length $190 \mathrm{~mm}$. (After MoçUaRD; not seen by me).

Habitat: N. E. Borneo (Sebruang Valley).

\section{Idiopholis everetti Shelford.}

Idiopholis Everetti, Shelford, Ann. Nat. Ilist. (7) VIII I90I, p. 517.

Snout obtuse, short; rostral narrow, more deep than broad; 
frontal more broad than long, as long as the praefrontals, less than half as long as the parietals; internasals small; no azygous shicld separating the latter; supraoculars, loreals, praeoculars and temporals absent; two postoculars; six upper labials, third and fourth entering the eye, fifth largest, in contact with the parietal; three lower labials in contact with the anterior chin-shields; latter slightly longer than the posterior. Scales in I 5 rows; ventrals I 33 ; anal entire; subcaudals 25. Uniformly dark bluish grey; head and neck slightly paler below. Length of head and body $137 \mathrm{~mm}$.; tail $\mathrm{IS} \mathrm{mm}$.

Type-specimen examined in the British Museum.

Habitat: N. Borneo (Sawa!).

\section{Agrophis F. Müller.}

(F. MÜt.ter, Verh. Natur. Ges. Basel X p. \$27, I\$94).

Head small, not distinct from neck; eye very small; pupil round; nostril between two nasals, the anterior nasal very small; praeocular and temporals absent; loreal ancl praefrontal cntering the eye; internasals and supraoculars very small. Maxillary teeth I4, about equal; mandibular teeth decreasing in size posteriorly. Body round, covered with smooth scales without pits, in 15 rows; ventrals rounded. Tail short; subcaudals in two rows.

Distribution. Borneo; Celebes.

Key to the Indo-Australian species.

A. Five upper labials.

I. Ventrals 139-164; subcaudals $36-40 \ldots$ I. A. sarasinorum P. 143 .

II. Ventrals II 3 ; subcaudals $26 \ldots . . .2$. . A. saraa'acensis p. 144. 1. Six upper labials; ventrals 141 ; subcaudals 43 . 3. A. albonuchalis p. I44.

\section{Agrophis sarasinorum F. Müller.}

Agrophis sarasinorum, F. Niuller, op. cit., with text-fig.

Asrophis sarasinorum, Boulenger, Proc. Zool. Soc. IS97, p. 222, pl. XIlI, fig. I.

Snout long, obtusely pointed; rostral large, visible from above; internasals small; praefrontals twice as long as the nasals; frontal large, rhomboidal, as long as its distance from the tip of the snout, shorter than the parietals; supraocular very small; no praeocular; loreal and praefrontal entering the eye; postocular minute; five upper labials, third and fourth 
entering the eye, fifth largest; three lower labials in contact

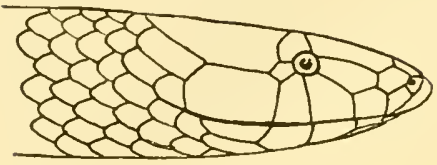

with the anterior chin-shields; mental not quite touching the anterior chin-shields; latter slightly shorter than the posterior. Scales in I 5 rows; ventrals $139-164$; anal entire; subcaudals $36-40$.

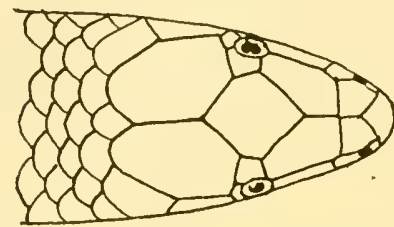

Fig. 59. Agrophis sarasinorum F. Müller. After Boulenger. Tail pointed.

Blackish-brown above, iridescent. Lower surface whitish, the shields darker at the base. Length of head and body $190 \mathrm{~mm}$. ; tail $45 \mathrm{~mm}$.

$\mathrm{H}$ a bit at: Celebes (Sudara Volcano 4450 feet, Lokon Volcano 5150 feet, Masarang Volcano 4000 feet!).

\section{Agrophis saravacensis Shelford.}

Agrophis saravacensis, Shelford, Ann. Nat. Hist. (7) VIII I90I, p. 5 I6.

Snout obtusely pointed; rostral large; praefrontals large, nearly as long as the frontal; latter large, rhomboidal, shorter than the parietals; supraocular and postocular very small; five upper labials, third and fourth entering the eye, fifth largest; mental in contact with the anterior chin-shields; three lower labials in contact with the latter, which are longer than the posterior. Scales in 15 rows; ventrals II 3 ; anal entire; subcaudals 26. Tail pointed.

Dark brown, iridescent; a red blotch on each side of the head just above the angle of the jaw, and an irregular red band on the neck. Length of head and body $120 \mathrm{~mm}$; t tail $22 \mathrm{~mm}$.

Type-specimen examined in the British Museum.

Habitat: Borneo (Kuching in Sarawak!).

Only one specimen known.

\section{Agrophis albonuchalis (Günther).}

Geophis albonuchalis, Günther, Ann. Nat. Hist. (6) XVII IS96, p. 229. Agrophis albonuchalis, Boulenger, Proc. Zool. Soc. I897, p. 222.

Snout pointed; internasals triangular, one fourth as large as the pracfrontals, which enter the orbit; frontal large, more broad than long, pressing back the supraocular to the postero- 
superior angle of the orbit; parietals as large as the anterior shields together; postocular minute; six upper labials, third and fourth entering the eye; mental in contact with the anterior chin-shields; latter much longer than the posterior; fifth lower labial long and narrow. Scales in 15 rows; ventrals I4I; anal entire; subcaudals 43. Tail pointed.

Deep black, with a broad, white collar, covering half of the occipitals and the neck. Length of head and body $196 \mathrm{~mm}$.; tail 4I mm. (After GüNTHER; not seen by me).

Habitat: Borneo (Baram in Sarawak).

\section{Rhabdophidium Boulenger.}

(Boulenger, Cat. Sn. II p. 328, I894).

Head not distinct from neck; eye small; pupil round; nostril in a small nasal, which is in contact with or separated from the praeocular; internasals present; temporals absent. Maxillary teeth 10-I2, about equal; mandibular teeth subequal. Body round, covered with smooth scales without pits, in I 5 rows; ventrals rounded. Tail short; subcaudals in two rows.

Distribution. Celebes.

A single species.

\section{Rhabdophidium forsteni (Dum. \& Bibr.).}

Rhabdion forsteni, Duméril \& Bibron, Erp. Gén. VII I 854, p. II6. Khabdophidium forsteni, Boulenger, Cat. Sn. II I894, p. 328.

Snout pointed; rostral more broad than deep, visible from above; internasals shorter than the praefrontals; frontal longer than its distance from the tip of the snout, shorter than the parietals, about twice as broad as the supraocular; pracocular large, reaching the nasal or separated from it; one postocular; five or six upper labials, third and fourth entering the eye, fifth largest and in contact with the parietal; first lower labial in contact with its fellow behind the mental; three lower labials in contact with the anterior chin-shields; latter longer than the posterior. Scales in 15 rows; ventrals $137-160$; anal entire; subcaudals $2 \mathrm{I}-34$.

Uniformly blackish above; upper lip pale brown or yellowish. Lower surface yellowish-white or brown, with or without a black median streak along the tail. Young specimens with INDO-AUSTRALIAN REPTILES II. 
yellow variegations. Length of head and body $390 \mathrm{~mm}$.; tail so $\mathrm{mm}$.

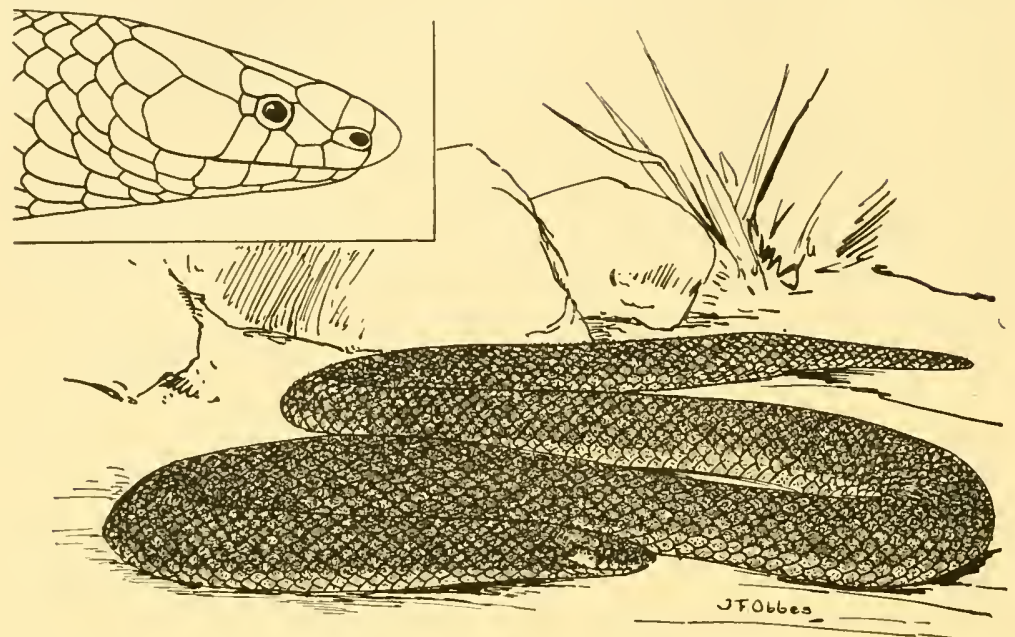

Fig. 60. Rhabdophidium forsteni (D. \& B.) $\times 3 / 4$. Side view of head.

H a b it a t: Celebes! (Tomohon!, Rurukan).

\section{Pseudorhabdium Jan.}

(Jan. Arch. Zool. Anat. Phys. II p. Io, I862).

Head not distinct from neck; eye small; pupil round; nasal very small; internasals small; loreal absent; praeocular small or absent; temporals absent; the parietals in contact with the labials. Maxillary teeth IO-I2, equal; anterior mandibular teeth longer than posterior. Body round, covered with smooth scales without pits, in I 5 rows; ventrals rounded. Tail short; subcaudals in two rows.

Distribution. Malay Peninsula and Archipelago; Philippines. A single species in the Indo-Australian region.

\section{Pseudorhabdium longiceps (Cant.).}

Calamaria longiceps, Cantor, Journ. Asiat. Soc. Bengal XVI I847, p. 9Io, pl. 40 , fig. I.

Pscudorhabdium longiceps, Boulenger, Cat. Sn. II I 894, p. 329.

Snout pointed; rostral small, as deep as broad, visible from above; internasals small; frontal as long as or shorter than its distance from the tip of the snout, shorter than the parietals, more than twice as broad as the supraocular; praeocular small 
or absent; one postocular; no temporals; five upper labials, third and fourth entering the eye; mental in contact with the anterior chin-shields; latter in contact with three lower labials and about twice as large as the posterior. Tail pointed. Scales in 15 rows; ventrals $129-146$; anal entire; subcaudals IO-2S.

Brown or black above, iridescent; a yellow collar sometimes present and a yellow vertical spot above the angle of the

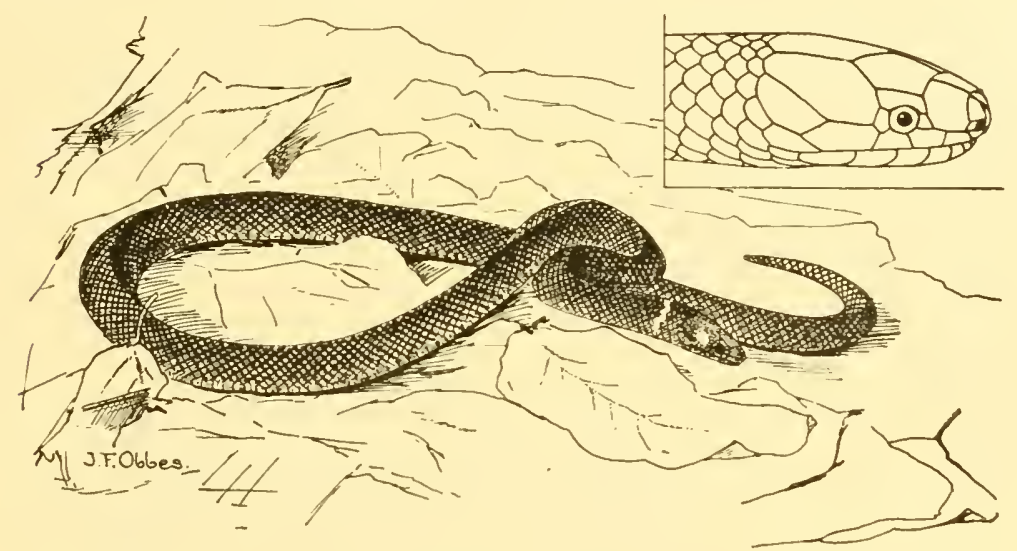

Fig. 61. Psendorhabdium longiceps (Cant.). Nat. size. Side view of head.

mouth. Lower surface dark brown, ventrals and outer scales with pale brown posterior border. Length of head and body I95 mm.; tail $35 \mathrm{~mm}$.

Habitat: Nias!; Sumatra (Deli!, Langkat, Indragiri, Singkarah!, Gunung Sahilan!, Ajerbangis!); Borneo (Sarawak, Kuching, Penrissen Road, Simanggang, Sebruang Valley, Pontianak); Celebes (Macassar!). - Philippines; Malay Peninsula; Penang; Singapore.

35. Brachyorrhus Boie.

(BoIE, Isis, p. 519, I827).

Head not distinct from neck; eye small; pupil vertically elliptic; nasal small, single or divided; internasals sometimes fused; loreal absent; praeocular present or absent. Maxillary teeth 20-22, equal; posterior mandibular teeth shortest. Body round, covered with smooth scales without pits, in I7 or 19 rows; ventrals rounded. Tail short; subcaudals in two rows.

Distribution. Java; Timor; Moluccas; New Guinea.

A single species. 
I. Brachyorrhus albus (L.).

Coluber allins, Linné, Mus. Ad. Frid. I754, p. 24, pl. XIV, fig. 2.

Brachyorrhus albus, Boulenger, Cat. Sn. I 1893, p. 305 (s. syn.).

Snout obtusely pointed; rostral as deep as broad, visible from above; internasals as long as or shorter than the praefrontals, sometimes fused; frontal longer than its distance from the tip of the snout, shorter than the parietals, much broader than the supraocular; praeocular distinct or fused with the praefrontal; two postoculars; temporals $\mathrm{I}+2$ or $2+3$; six or seven upper labials, third or fourth or third and fourth entering the eye; four lower labials in contact with the single pair of

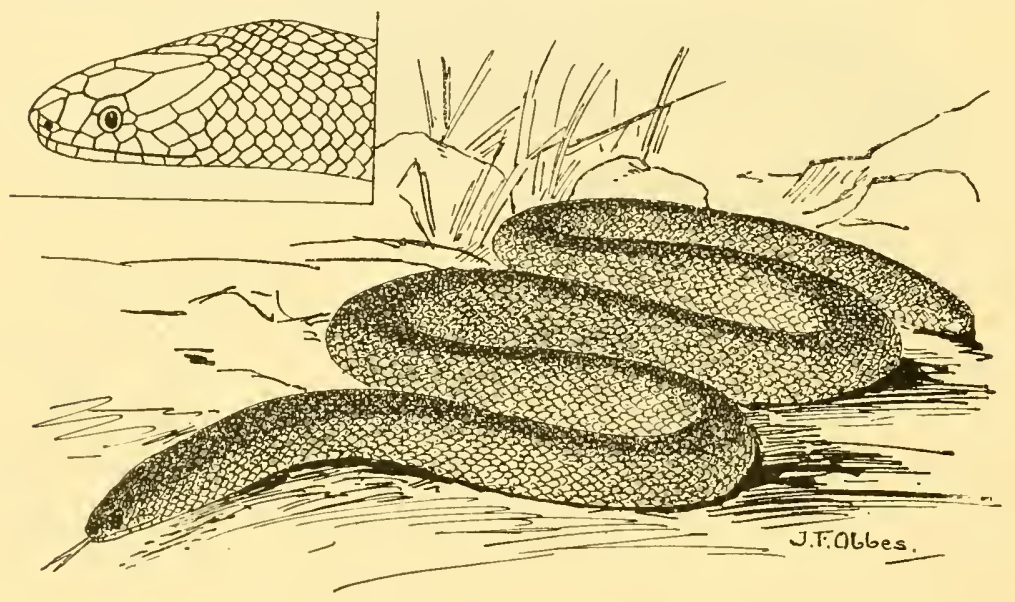

Fig. 62. Brachyorrhus albus (L.) $\times 1 / 2$. Side view of head.

chin-shields. Scales in 17 or 19 rows; ventrals 146-182; anal divided (rarely entire); subcaudals 20-46.

Uniformly brown above; lower parts yellowish. Young specimens with an interrupted yellow band across the occiput; a brown median streak or series of spots along the belly and tail. Length of head and body $672 \mathrm{~mm}$.; tail $\mathrm{S}_{7} \mathrm{~mm}$.

Habitat: Java!; Borneo!; Timor!; Ternate; Halmahera!; Batjan!; Ceram!; Ambon!; Buru!; Haruku!; Banda; Aru Islands; New Guinca (Jobi, Amberbaki, Andai, Mt. Arfak).

\section{Calamorhabdium Böttger.}

(BötTger, Katalog. Rept.-Samml. Mus. Senckenb. II p. $\&_{2}$, I $\$ 9 \$$ ).

Head not distinct from neck; cye small; pupil round; nostril between the nasal and the first upper labial; internasals, loreal, 
praeocular and temporals absent. Maxillary teeth $\mathbf{I}_{3}$, about equal; mandibular teeth subequal. Body round, covered with smooth scales without pits, in 15 rows; ventrals rounded. Tail short, with an obtuse point; subcaudals in two rows.

Distribution. Batjan.

A single species.

\section{Calamorhabdium kükenthali Böttger.}

Calamorhabdium kuekenthali, Böttger, Katalog. Rept. Samml. Mus. Senckenb. II I 898, p. 82; Abh. Senckenb. Ges. XXV I900, p. 360, Taf. XV, fig. 7.

Snout pointed; rostral much more deep than broad, visible from above, separating the nasals; frontal as long as its distance from the tip of the snout, shorter than the parietals; internasals and praeocular absent; postocular small; temporais absent; five upper labials, third and fourth entering the eye; mental in contact with the anterior chin-shields; latter in contact with three lower labials, longer than the posterior, which are in contact antcriorly. Scales in 15 rows; ventrals I25-I40; anal entire; subcaudals IO- 17 .

Blackish-grey above, iridescent; the scales of the flanks with whitish centre; lips whitish; a broad, indistinctly bordered, whitish collar, interrupted in
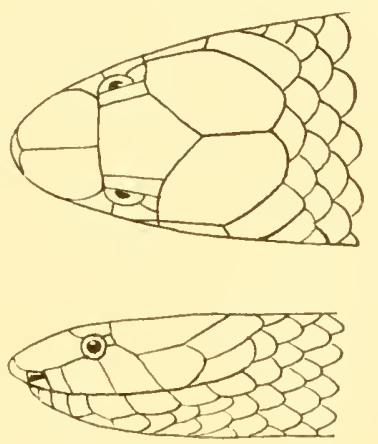

Fig. 63. Calamorhabdium kiikenthali Bttgr. After Böttger. the middle. Lower surface whitish with blackish square spots and black posterior borders of the scales; a median black line along the tail. Length of head and body $195 \mathrm{~mm}$.; tail $10 \mathrm{~mm}$. (After BöTTGER; not seen by me).

Habit at: Batjan.

\section{Calamaria Boie.}

(BoIE, in Férussac, Bull. Sc. Nat. IX p. 236, 1826).

Head not distinct from neck; eye small; pupil round; nasal very small; internasals and loreal absent; praeocular present or absent; temporals absent, parietals in contact with the labials. Maxillary teeth 8 -I I, about equal; anterior mandibular teeth longer than posterior. Body round, covered with smooth 
scales without pits, in 13 rows; ventrals rounded. Tail short; subcaudals in two rows.

Distribution. From Assam and Burma to the Moluccas.

Small, gentle snakes, living on the ground under stones and fallen trees; feeding on insects and worms.

Nom. In dig. Oraj surapari (Sund.).

Key to the Indo-Australian species.

$A$. Less than 300 ventrals.

I. Five or six upper labials.

AA. Frontal more long than broad.

1. Mental in contact with the chin-shields.

$\approx$ Frontal not twice so broad as the supraocular.

† Rostral more broad than deep.

$a a$. Diameter of the eye less than its distance from the mouth; ventrals $177-217 ;$ subcaudals 16-23............ 1. C. lumbricoidea p. 153 .

$6 b$. Diameter of the eye equal to its distance from the mouth; ventrals 147-210; subcaudals 15-26........... 2. C. vermiformis p. 153 .

cc. Diameter of the eye more than its distance from the mouth.

$X$ Frontal shorter than the parietals; uniformly brown or olive above; subcaudals 22-23 3. C. slahlincihti p. 154.

$X X$ Frontal shorter than the parietals; 6 whitish streaks on the body; subcandals 19-2I. 4. C. indragirica p. I54.

$X \times X$ Frontal as long as the parietals; subcaudals $28 \ldots$... 5. C. baluchsis p. 155 .

†† Rostral as broad as deep.

$a a$. Frontal as long as the parietals.

I. Frontal one time and two thirds as long as broad; ventrals 187 ; subcaudals $20-22 \ldots . .6$ 6. C. grabowskyi p. I55.

2. Frontal one time and one third as long as broad; ventrals I49-165; subcaudals I2-19. 7. C. margaritophora p. I56.

b6. Frontal shorter than the parietals; ventrals 126-1 44; subcaudals $25-30 \ldots$....... S. C. prakkci p. 156 . 
3. Frontal at least twice as broad as the supraocular.

† Frontal as long as the parietals...... 9. C. muchalis p. 157.

†† Frontal shorter than the parietals.

$a a$. Rostral more broad than deep. 2

1. Ventrals 1 29-176; subcaudals 12-31.

$X$ Diameter of the eye equals its distance from the mouth.

$\odot$ Frontal more than twice as broad

as supraocular......... IO. C. sumatrana p. 157 .

$\odot \odot$ Frontal twice as broad as supraocular; six white vertical spots on each side of the body anteriorly. II. C. elegans p. I58.

Diameter of the eye one time and one third its distance from the mouth ............ I2. C. simalurcnsis p. 159 .

2. Ventrals $21 \mathbf{1}-235$; subcaudals 10-13. $\mathbf{1}_{3}$. C. gracilis p. $\mathbf{1} 59$.

66. Rostral as broad as deep.

1. Frontal four times as broad as the supraocular; ventrals 156-179: subcaudals $14-24 \ldots \ldots . . . . .14$. C. acutirostris p. 160.

2. Frontal twice as broad as the supraocular.

$X$ Subcaudals white, 14; ventrals 154. 15. C. curta p. 160.

$X X$ Subcaudals $I I-2 I$, with two white

bands, enclosing a dark one; ventrals

$130-18_{7} \ldots \ldots \ldots \ldots$. . . . m 6. milleri p. I6r.

2. First lower labial in contact with its fellow.

a. A praeocular; a postocular.

$X$ Frontal not more than twice as broad as

the supraocular.

† Diameter of the eye much more than its

distance from the mouth ........ I7. C. cueretti p. I6r.

t† Diameter of the eye not more than its

distance from the mouth.

aa. Anal divided ........... 18. C. occipitalis 1). 162 .

66. Anal entire.

$\odot$ First and second labials subequal.

I. Ventrals 15I-200; subcaudals

15-30............ 19. C. virgulata p. 162.

2. Ventrals 123-146; subcaudals $24-27 \ldots \ldots$. . . . . . . lautensis p. 163 .

$\odot \odot$ Second labial larger than first. 
1. Rostral almost as broad as deep; ventrals $133-151 ;$ subcaudals $12-23 \ldots \ldots \ldots . \ldots 21$. . C. lencogaster p. 164 .

2. Rostral as broad as deep; ventrals

178 ; subcaudals $26 \ldots . . .22$. C. quinquctaeniata p. 164. 3. Rostral slightly more broad than

deep: ventrals 247 ; subcaudals 14. 23. C. allopunctata p. 165.

$X X$ Frontal more than twice as broad as the supraocular.

I. Ventrals 143-152; subcaudals 24-29. 24. C. bicolor p. 165 .

2. Ventrals 147-155; subcaudals 23... 25. C. brookci p. 166.

3. Ventrals I 54; subcaudals 10......26. C. sondaica p. 166.

4. Ventrals 182-210; subcaudals 9-19. . 27. C. brachyura p. 167.

5. Ventrals $232-265$; subcaudals $10-30.28$. C. collaris p. I67.

6. A praeocular; no postocular ........ 29. C. latcralis p. I68.

c. A praeocular; two postoculars ........ 30. C. beccarii p. 168.

d. No praeocular.

1. Ventrals 142; subcaudals 29; uniform yel-

lowish inferiorly............ 31. C. rebentischi p. 169.

2. Ventrals 150-I52; subcaudals 22-23; tail

with a dark median streak below..... 32, C. coramcnsis p. 169.

3. Ventrals 187 - I94; subcaudals 14-16; ven-

trals with blackish spots on their outer ends. 33. C. mecheli p. I 69.

BB. Frontal as broad as long.

$\dagger$ First lower labial in contact with its fellow.

aa. Rostral as broad as deep; ventrals 157 ;

subcaudals $22 \ldots \ldots \ldots \ldots . \ldots . . . . .34$. pictcti p. 170.

b6. Rostral more broad than deep.

I. Praeocular present; ventrals 136-171;

subcaudals 19-45......... 35. C. lcucoccphala p. 171.

2. No praeocular; ventrals 135-174; sub-

caudals $2 \mathrm{I}-38 \ldots \ldots . \ldots \ldots$. . . a . a amensis p. I7 I.

cc. Rostral more deep than broad.

I. Ventrals 140; subcaudals 27..... 37. C. semianmulata p. 172.

2. Ventrals $164 ;$ subcaudals $22 \ldots . . .38$. C. döderleini p. I72.

†† Mental in contact with the chin-shields.

1. Praeocular present; ventrals 170; sub-

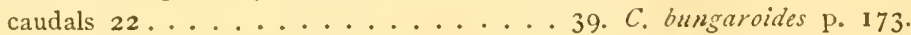

2. No praeocular; ventrals I38; subcaudals 33. 40. C. schlegeli p. 173.

11. Four upper labials, second and third entering

the eye.

a. Frontal more long than broad.

† Mental in contact with the chin-shields. 
$\times$ Praeocular present.

I. Tail obtuse; ventrals $135-163$; subcaudals $9-23 \ldots . . . .4$ 4. C. linnaei p. I74.

2. Tail obtuse; ventrals $152-192$; subcaudals 17-22 ...... 42. C. borneensis P. 175. 3. Tail with a sharp point; ventrals

145-154; subcaudals 17--20...43. C. benjaminsi p. 175 .

$X \times$ No praeocular; ventrals $158-\mathbf{I} 8 \mathbf{I}$;

subcaudals $15-17 \ldots \ldots . . .44$. C. javanica p. 176.

i† First lower labial in contact with its fel-

low; ventrals I 33 - 82 ; subcaudals $9-27.45$. C. pavimentata p. I76.

6. Frontal as broad as long: mental in contact with the chin-shields; ventrals $133-182$; subcaudals $16-24 \ldots . . . . . .46$. . . melanota p. 177.

111. Four upper labials, third entering the eye. 47. C. lowi p. 177. b. More than 300 ventrals; no postocular.....48. C. gracillima p. I7S.

\section{Calamaria lumbricoidea Boie.}

Calamaria humbricoitca, Boie, Isis, I827, p. 540.

Calamaria variabilis, v. Lidth de Jeude, in M. Weber, Zool. Ergebn. I890, p. $\mathbf{s}_{3}$, pl. XVI. fig. $\mathrm{S}$.

Calamaria lumbricuidea, Bonlenger, Cat. Sn. II I894, p. 333.

Diameter of the eye shorter than its distance from the mouth; rostral more broad than deep, visible from above; frontal more long than broad, shorter than the parietals, not twice so broad as the supraocular; one prae- and one postocular; five upper labials, the four anterior about equal, third and fourth entering the eye; mental in contact with the anterior chin-shields; both pairs of chin-shields in contact with each other. Scales in I 3 rows; ventrals $177-217$; anal entire; subcaudals $16-23$. Tail ending in a point.

Dark brown above, with or without a yellowish band across the parietals. Lower surface whitish; tail usually with a median dark brown streak. Length of head and body $3 \$ 5 \mathrm{~mm}$.; tail $35 \mathrm{~mm}$.

Habitat: Nias; Sumatra!; Java! (Batavia, Buitenzorg, Tjibodas I425 M., Volcano Tjisurupan); Celebes (Manado!).

\section{Calamaria vermiformis Dum. \& Bibr.}

Calamaria z'ermiformis, Duméril \& Bibron, Erp. Gén. V'II I $8_{54}$, p. 85 . Calamaria z'ermiformis, Boulenger, Cat. Sn. II I894, p. 333 (s. syn.).

Diameter of eye equal to its distance from the mouth; rostral 
a little more broad than deep, visible from above; frontal more long than broad, not twice so broad as the supraocular, shorter than the parietals; one prae- and one postocular; five or six upper labials, third and fourth entering the eye; mental in contact with the anterior chin-shields; posterior chin-shields in contact or separated. Scales in 13 rows; ventrals $147-210$; anal entire; subcaudals $15-26$. Tail ending in a point. Dark brown or black above, head often entirely or partially yellow; body sometimes with yellow transverse bars or series of spots; a lateral streak along the two outer rows of scales sometimes yellowish. Lower surface yellowish, with or without large transverse black spots or bands. Length of head and body $377 \mathrm{~mm}$; tail $33 \mathrm{~mm}$.

Habitat: Sumatra (Labuan, Medan!, Langkat, Raja Mts., Battak Highlands Soo-rooo M., Fort de Kock!, Kaju tanam!, Padang); Natuna Islands; Borneo (Kina Balu!, Bongon, Mt. Batu song, Baram, Kuching, Matang, Tandjong); Java!(Volcano Tjisurupan, Sukabumi!); Ternate. - Malay Peninsula.

\section{Calamaria stahlknechti Stol.}

Calamaria stahlknechti, Stoliczka, Journ. As. Soc. Beng. XLII 1873, p. 119, pl. XI, fig. 2 .

Calamaria stahlknechtii, Boulenger, Cat. Sn. II I $\$ 94$, p. 335.

Diameter of eye greater than its distance from the mouth; rostral more broad than deep, visible from above; frontal more long than broad, not twice so broad as the supraocular, shorter than the parietals; one prae- and one postocular; five upper labials, third and fourth entering the eye; mental in contact with the anterior chin-shields; posterior chin-shields separated. Scales in 13 rows; ventrals $14 \tau-1 \sigma_{3}$; anal entire; subcaudals 22-23. Tail ending in a point.

Brown or olive above; a yellowish collar, interrupted in the middle; yellow or red below, with or without black transverse spots or bands. Length of head and body $24 \mathrm{I} \mathrm{mm}$.; tail $24 \mathrm{~mm}$.

Habitat: Nias!; Sumatra.

4. Calamaria indragirica Schenkel.

Calamaria indragirica, Schenkel, Verh. Ges. Basel xill 1901, p. 164.

Diameter of eye about one time and a half as large as its distance from the mouth; rostral more broad than deep, visible 
from above; frontal one time and a half as long as broad, not quite twice so broad as a supraocular, shorter than the parietals; one prae- and one postocular; five upper labials, third and fourth entering the eye, fifth much larger than the others; mental in contact with the anterior chin-shields. Scales in I 3 rows; ventrals I49; anal entire; subcaudals I9-2I.

Blackish above, with 6 white streaks, two superior beginning behind the head to the base of the tail, running between the fifth and sixth rows of scales; the middle one only distinct on the neck; the lower along the outer row of scales, bordered below by a black band. Lower surface yellowish; tail with a black median line. Length of head and body I $37 \mathrm{~mm}$.; tail I I $\mathrm{mm}$.

One of the type-specimens received from the Basle Museum, examined.

Habitat: Sumatra (Indragiri!).

\section{Calamaria baluensis Boulenger.}

Calamaria baluensis, Boulenger, Proc. Zool. Soc. I893: p. 524; Cat. Sn. II I S94, p. 335, pl. XVII, fig. I.

Diameter of the eyc much greater than its distance from the mouth; rostral slightly more broad than deep, visible from above; frontal nearly twice as long as broad, not twice so broad as a supraocular, as long as the parietals; one praeand one postocular; five upper labials, third and fourth entering the eye; mental in contact with the anterior chin-shields; three lower labials in contact with the anterior chin-shields; both pairs of chin-shields in contact with each other. Scales in I 3 rows; ventrals 175-206; anal entire; subcaudals 24-29. Tail ending in a point.

Brown above, with small black spots; an interrupted black streak along each side of the head and neck, passing through the eye; upper lip white. Lower surface white, with three longitudinal series of small black spots, or ventrals black at the base; a dark median line along the tail. Length of head and body $307 \mathrm{~mm}$; tail $33 \mathrm{~mm}$.

Habitat: N. Borneo (Kina Balu!, Saiap on Kina Balu).

\section{Calamaria grabowskyi Fischer.}

Calamaria grabowskyi, Fischer, Arch. f. Nat. I885, p. 50, pl. IV, fig. I. Calamaria grabowskii, Boulenger, Cat. Sn. II I $\$ 94$, p. 336 .

Diameter of the eye greater than its distance from the mouth; 
rostral almost as deep as broad; frontal one time and two thirds as long as broad, not twice so broad as a supraocular, as long as the parietals; one prae- and one postocular; five upper labials, third and fourth entering the eye; mental and three lower labials in contact with the anterior chin-shields; both pairs of chin-shields in contact with each other. Scales in 13 rows; ventrals 187 ; anal entire; subcaudals 20-22. Tail ending in a point.

Brown above, with small black spots; an interrupted dark lateral line anteriorly; outer row of scales black, white-edged, or with a white terminal spot. Lower surface black, the ventrals edged with white; tail with a black median line. Length of head and body $398 \mathrm{~mm}$.; tail $32 \mathrm{~mm}$.

Type-specimens examined in the British Museum.

Habitat: Borneo (Kina Balu!, Telang Tameanglayang in S. E. Borneo!).

\section{Calamaria margaritophora Bleeker.}

Calamaria margaritophora, Bleeker, Nat. Tijdschr. Ned. Ind. XXI I860, p. 294. Calamaria margaritifera, Boulenger, Cat. Sn. II I894, p. 336, pl. XVII, fig. 2.

Diameter of the eye equal to its distance from the mouth; rostral as deep as broad; frontal more long than broad, not twice so broad as a supraocular, nearly as long as the parietals; one prae- and one postocular; five upper labials, third and fourth entering the eye; mental and three lower labials in contact with the anterior chin-shields; posterior ones in contact or separated. Scales in 13 rows; ventrals $149-165$; anal entire; subcaudals I2-I9. Tail ending in a point.

Brown above, with longitudinal black lines or series of spots; outer row of scales with yellowish spots; head black above; a yellow vertical bar at the base of the tail. Lower surface yellowish. Length of head and body $267 \mathrm{~mm}$.; tail $13 \mathrm{~mm}$.

One of the type-specimens examined in the British Museum. Habitat: Sumatra; Java.

\section{S. Calamaria prakkei Lidth.}

Calamaria Prakkei, v. Lidth de Jeude, Notes Leiden Mus. XV IS93, p. 252. Calamaria prakkii, Boulenger, Cat. Sn. II IS94, p. 337.

Diameter of the eye equal to its distance from the mouth; rostral as deep as broad; frontal one time and a half as long 
as broad, not twice so broad as a supraocular, shorter than the parietals; one prae- and one postocular; five upper labials, third and fourth entering the eye, fifth largest; mental in contact with the anterior chin-shields; both pairs of chin-shields in contact. Scales in I3 rows; ventrals I 26-I44; anal entire; subcaudals $25-30$. Tail obtuse, with a conical scale at the end.

Dark brown above, with bluish gloss; scales of outer row with a light spot; sometimes indistinct black longitudinal lines on the back; an indication of a light collar present or absent; four anterior upper labials white, with dark sutures. Lower surface yellow, with or without small dark spots; tail with a median black line. Length of head and body $220 \mathrm{~mm}$.; tail $40 \mathrm{~mm}$.

Type-specimens examined in the Leiden Museum.

Habitat: Borneo (Sandakan Bay!).

\section{Calamaria nuchalis Boulenger.}

Calamaria mechalis, Boulenger, Ann. Nat. Ilist. (6) XVIII I896, p. 62; Proc. Zool. Soc. I $\$ 97$, pl. Xill, fig. 3 .

Diameter of the eye greater than its distance from the mouth; rostral more broad than deep; frontal one time and two thirds as long as broad, three times as broad as a supraocular, as long as the parietals; one prae- and one postocular; five upper labials, third and fourth entering the eye; mental and three lower labials in contact with the anterior chinshields; both pairs of chin-shields in contact. Scales in I 3 rows; ventrals I35; anal entirc; subcaudals 16 . Tail ending in an obtuse point.

Dark brown above, with small round black spots; a black lateral streak along the second row of scales, outer row white; head dark brown, speckled with black; nape yellowish, with two large black blotches; tail with three or four yellow blotches on each side. Lower surface white, each ventral with a black dot at the outer end; subcaudals white, a black median line posteriorly. Length of head and body $165 \mathrm{~mm}$.; tail $15 \mathrm{~mm}$.

Type-specimen examined in the British Museum.

Habitat: S. Celebes 2000 feet!.

IO. Calamaria sumatrana Edeling.

Calimaria sumatrana, Edeling, Nat. Tijdschr. Nederl. Ind. XXXI 1870, p. 379. Calamaria sumatrana, Boulenger, Cat. Sn. II IS94, p. 339.

Diameter of the eye equals its distance from the mouth; 
rostral slightly more broad than deep; frontal more long than broad, more than twice as broad as a supraocular, slightly shorter thain the parietals; one prae- and one postocular; five upper labials, third and fourth entering the eye; mental in contact with the anterior chin-shields; both pairs of chin-shields in contact. Scales in 13 rows; ventrals I29-I76; anal entire; subcaudals $\mathrm{I} 2-3 \mathrm{I}$. Tail ending in a point.

Dark brown or reddish above, with five black longitudinal lines or series of spots; scales of the outer row with a white spot; nape with a yellow collar, sometimes interrupted in the middle; sometimes a yellow marking at the base of the tail. Lower surface yellowish; a black median line along the tail. Length of head and body $253 \mathrm{~mm}$; tail $12 \mathrm{~mm}$.

Habitat: Sumatra (Medan!, Langkat, Gunung Sahilan!); Borneo (Kutei); Java (Sindanglaia in Preanger). - Singapore.

\section{Calamaria elegans n. sp.}

Diameter of the eye equals its distance from the mouth; rostral more broad than deep; frontal more long than broad, twice as broad as a supraocular, shorter than the parietals; one prae- and one postocular; five upper labials, third and

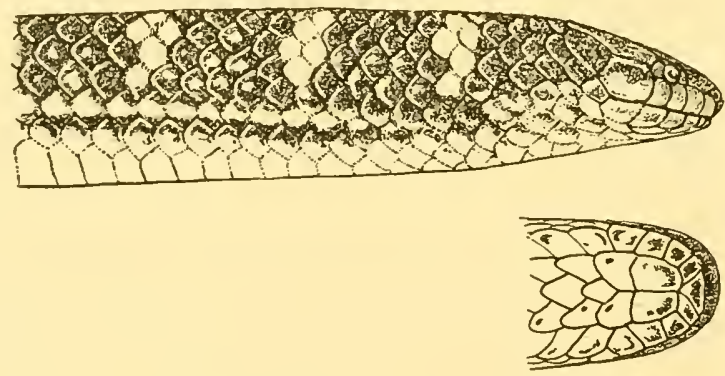

Fig. 64. Calamaria elegans n. sp. Chin-shields. $\times 21 / 2$.

fourth entering the eye; mental in contact with the anterior chin-shields; both pairs of chin-shields in contact. Scales in I 3 rows; ventrals I33; anal entire; subcaudals 27 . Tail ending in a point.

Brown above, with black spots in longitudinal series; outer row of scales with white spots, on the neck and anterior part of body six vertical white spots on each side. Lower surface yellow, each shield with a small brown spot on the outer 
ends; a dark median line along the tail. Length of head and body $167 \mathrm{~mm}$.; tail $26 \mathrm{~mm}$.

Type-specimen examined in the Amsterdam Museum.

Habitat: Simalur-W. off Sumatra!

\section{I2. Calamaria simalurensis n. sp.}

Diameter of the eye one time and one third its distance from the mouth; rostral more broad than deep; frontal more long than broad, twice as broad as a supraocular, shorter than the parietals; one prae- and one postocular; five upper labials, third and fourth entering the eye; mental in contact with the anterior chin-shields; both pairs of chin-shields in contact. Scales in I 3 rows; ventrals I 36 ; anal entire; subcaudals 27. Tail ending in a point.

Dark brown above, with black spots in longitudinal series; outer row of scales
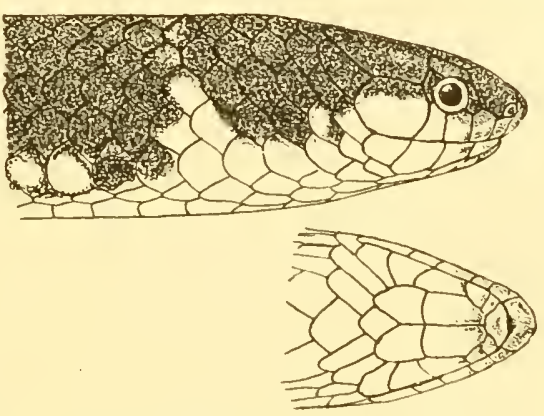

Fig. 65. Calamaria simalurensis n. sp. Chin-shields. $\times 3 \frac{1}{2}$. with white spots, an indistinct narrow yellow collar on the nape, broadening on the sides. Lower surface yellow, each ventral (except the 9 anterior) and subcaudal with a dark brown triangular spot on the outer end. Length of head and body $229 \mathrm{~mm}$; t tail $34 \mathrm{~mm}$.

Type-specimen examined in the Amsterdam Museum.

Ha bitat: Simalur-W. off Sumatra!

\section{I3. Calamaria gracilis Boulenger.}

Calamaria gracilis, Boulenger, Ann. Nat. Hist. (6) XVIII i\$96, p. 63; Proc. Zool. Soc. 1897 , pl. XIV, fig. 3.

Diameter of the eye equals its distance from the mouth; rostral slightly more broad than deep; frontal one time and a half as long as broad, twice as broad as a supraocular, much shorter than the parietals; one prae- and one postocular; five upper labials, third and fourth entering the eye; mental and three lower labials in contact with the anterior chin-shields; both pairs of chin-shields in contact. Scales in 13 rows; ventrals 
2II-235; anal entire; subcaudals 10-I3. Tail rounded at the end.

Grey-brown above, with small black spots; outer row of scales white, black at the base. Lower surface white, the outer edge of the ventrals black, and a continuous or interrupted median series of small black spots. Young specimens with interrupted yellowish collars. Length of head and body 3 I $2 \mathrm{~mm}$.; tail $8 \mathrm{~mm}$.

Type-specimens examined in the British Museum.

Habitat: S. Celebes (Bonthain Peak 6000 feet!, Bua Praeng).

\section{I4. Calamaria acutirostris Boulenger.}

Calamaria acutirostris, Boulenger, Ann. Nat. Hist. (6) XVII 1866, p. 394 ; Proc. Zool. Soc. I897, pl. XIII, fig. 2.

Snout pointed; diameter of the eye hardly equals its distance from the mouth; rostral as deep as broad; frontal as long as broad or a little more long, four times as broad as a supraocular, much shorter than the parietals; one prae- and one postocular; five upper labials, third and fourth entering the eye; mental and three lower labials in contact with the anterior chin-shields; posterior chin-shields smaller and separated by a scale. Scales in I 3 rows; ventrals I 56-I79; anal entire; subcaudals I4-24. Tail ending in a point.

Blackish-brown above; white below. Length of head and body $207 \mathrm{~mm}$.; tail $43 \mathrm{~mm}$.

Type-specimens examined in the British Museum.

Habitat: S. Celebes (Loka-Bonthain Peak 3500 feet!, Bua Praeng).

\section{I5. Calamaria curta Boulenger.}

Calamaria curta, Boulenger, Ann. Nat. Hist. (6) XVIII 1S96, p. 62; Proc. Zool. Soc. I 897 , pl. Xiv, fig. 2.

Diameter of the eye greater than its distance from the mouth; rostral almost as deep as broad; frontal one time and two thirds as long as broad, twice as broad as a supraocular, much shorter than the parietals; one prae- and one postocular; five upper labials, third and fourth entering the eye; mental and three lower labials in contact with the anterior chin-shields; both pairs of chin-shields in contact. Scales in 13 rows; ventrals I54; anal cntire; subcaudals 14. Tail ending in a point. 
Olive-brown above, each scale with a black spot at the base; two outer rows of scales white, also black at the base; head dark brown with indistinct black variegations. Lower surface black, with white borders to the ventrals; subcaudals white. Length of head and body $300 \mathrm{~mm}$.; tail I $5 \mathrm{~mm}$.

Type-specimen examined in the British Museum.

Habitat: S. Celebes 2000 feet!.

\section{Calamaria mülleri Boulenger.}

Calamaria Muelleri, Boulenger, Ann. Nat. Hist. (6) XVII IS96, p. 394; Proc. Zool. Soc. I 897 , pl. XIV, fig. I.

Diameter of the eye greater than its distance from the mouth; rostral as deep as broad; frontal much more long than broad, twice as broad as a supraocular, as long as or slightly shorter than the parietals; one prae- and one postocular; five upper labials, third and fourth entering the eye; mental and three lower labials in contact with the anterior chin-shiclds; posterior chin-shields shorter, both pairs in contact. Scales in I 3 rows; ventrals I30-I 87 ; anal entire; subcaudals II-2I. Tail ending in a point.

Dark brown above, uniform or spotted with black, reddishbrown or brick-recl, the scales speckled and edged with black; a black streak on each side of the head, passing through the eye; upper lip white. Lower surface white, the ventrals spotted with black or edged with black or with vermilion or with a lateral series of black spots; a black or red band between two white ones along the tail below. Length of head and body 2 I $5 \mathrm{~mm}$.; tail $20 \mathrm{~mm}$.

Type-specimens examined in the British Museum.

Habitat: Celebes (Loka-Bonthain Peak 3500 feet!, Indrulaman 2000 feet, Bua Praeng, Luhu I 700 feet, between Lake Posso and Tomini gulf, Macassar?).

The specimens from Macassar referred by A. B. MEIER to Calamaria gervaisii will probably be found to belong to C. miilleri (Boulenger, Proc. Zool. Soc. IS97).

\section{Calamaria everetti Boulenger.}

Calamaria eqeretti, Boulenger, Proc. Zool. Soc. IS93, p. 525 ; Cat. Sn. II I 894 , p. $34^{\circ}$, pl. XVIII, fig. $1,2$.

Diameter of the eye much longer than its distance from the mouth; rostral more broad than deep; frontal one time and INDO-AUSTRALIAN REPTILES II. 
a half as long as broad, not twice so broad as a supraocular, shorter than the parietals; one prae- and one postocular; five upper labials, third and fourth entering the eye; first lower labial in contact with its fellow behind the mental; three lower labials in contact with the anterior chin-shields; both pairs of chin-shields in contact. Scales in 13 rows; ventrals I44-I 84 ; anal entire; subcaudals I6-24. Tail ending in a point.

Brown above, with longitudinal series of darker spots, forming two lines along each side; scales of outer row white with dark brown borders; head brown, with dark spots; sometimes a yellow collar. Lower surface yellowish, uniform or with a median series of black dots; a dark line along the tail usually present. Length of head and body $3 \mathrm{I} 2 \mathrm{~mm}$; t tail IS $\mathrm{mm}$.

Habitat: Mentawei Islands (Siberut!); Borneo (Pangkalan ampat, Baram!, Sarawak). - Palawan!.

\section{I8. Calamaria occipitalis Jan.}

Calamaria occipitalis, Jan, Arch. Zool. Anat. Phys. II 1862, p. 9. Calamaria occipitalis, Boulenger, Cat. Sn. II I894, p. 342.

Diameter of the eye shorter than its distance from the mouth; rostral much more broad than deep; frontal more long than broad, one time and a half as broad as a supraocular, as long as the parietals; one prae- and one postocular; five upper labials, third and fourth entering the eye; first lower labial in contact with its fellow behind the mental; both pairs of chin-shields in contact. Scales in I 3 rows; ventrals $177-179$; anal divided; subcaudals 20-2I. Tail ending in a point.

Blackish above; two outer series of scales whitish; upper lip and a band across the occiput whitish. Lower surface whitish; a black median line along the tail. Length of head and body $460 \mathrm{~mm}$; tail $40 \mathrm{~mm}$. (Not seen by me).

Habitat: Java.

\section{I9. Calamaria virgulata Boie.}

Calamaria virgulata, Boie, Isis, I827, p. 540.

Calamaria bogorensis, v. Lidth de Jeude, M. Weber, Zool. Ergebn. I ISgo, p. IS2. Calamaria virgulata, Boulenger, Cat. Sn. II IS94; p. 340 (s. syn.).

Diameter of the eye equal to its distance from the mouth; rostral almost as deep as broad; frontal more long than broad, twice as broad as a supraocular, shorter than the parietals; 
one prae- and one postocular; five upper labials, third and fourth entering the eye; first lower labial in contact with its fellow behind the mental; both pairs of chin-shields in contact. Scales in 13 rows; ventrals $15 \mathrm{I}-200$; anal entire; subcaudals I5-30. Tail obtuse.

Dark brown or black above, with or without yellowish or small black spots, or yellow with brown spots. Lower surface black, uniform or with yellow markings, or yellow with black outer ends to the ventrals. Length of head and body $410 \mathrm{~mm}$.; tail $30 \mathrm{~mm}$.

Habitat: Sumatra (Mt. Singalang, Fort de Kock); Java (Buitenzorg! (types of C. bogorensis), Sindanglaia 3500-4500 feet, Pengalengan 4000 feet, Volcano Tjisurupan, Tjibodas I425 M., Rarahan); Celebes (Manado, Lake Posso).

\section{Calamaria lautensis n. sp.}

Diameter of the eye equals its distance from the mouth; rostral about as broad as deep; frontal more long than broad, twice as broad as a supraocular, shorter than the parietals; one prae- and one postocular; five upper labials, third and fourth entering the eye; first lower labial in contact with its

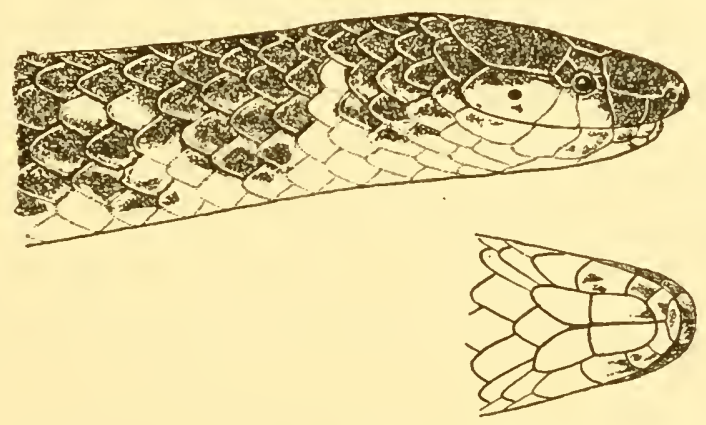

Fig. 66. Calamaria lautensis n. sp. Chin-shields. $\times 3^{1 / 2}$.

fellow behind the mental; both pairs of chin-shields in contact. Scales in 13 rows; ventrals 123-I46; anal entire; subcaudals $24-27$. Tail ending in a point.

Brown or greyish above, with small darker spots; on the nape two or three white vertical spots, sometimes indistinct; a white streak on the posterior labials; outer row of scales with white spots. Lower surface yellow, each shield with a 
small dark spot on the outer ends; a broad dark median line along the tail. Length of head and body $245 \mathrm{~mm}$.; tail $33 \mathrm{~mm}$.

Type-specimens examined in the Amsterdam Museum.

Habitat: Simalur!; Cocos Islands (Pulu si Laut N.W. off Simalur!).

\section{Calamaria leucogaster Bleeker.}

Calamaria lencogaster, Bleeker, Nat. Tijdschr. Nederl. Ind. XXI, I860, p. 293. Calamaria leucogaster, Boulenger, Cat. Sn. II I894, p. 34 I.

Snout pointed; diameter of the eye equal to its distance from the mouth; rostral almost as deep as broad; frontal more long than broad, about twice as broad as a supraocular, shorter than the parietals; one prae- and one postocular; five or six upper labials, second larger than the first or third, third and fourth or fourth and fifth entering the eye; first lower labial in contact with its fellow behind the mental; three lower labials in contact with the anterior chin-shields; both pairs of chin-shields in contact. Scales in 13 rows; ventrals 133-151; anal entire; subcaudals $12-23$. Tail ending in a point.

Brown or purplish above, with eight dark longitudinal lines or traces of lines; nape blackish, followed by a yellow collar; upper lip yellow; a dark streak behind the eye; tail with two dark transverse spots. Lower surface uniformly yellow. Length of head and body $187 \mathrm{~mm}$; tail $\mathrm{I} 3 \mathrm{~mm}$.

One of the type-specimens examined in the British Museum.

Habitat: Sumatra (Ampatlawang!, Battak Highlands Soo--Iooo M.); Borneo (Kina Balu, Kuching, Matang, Sarawak!, Labuan).

\section{Calamaria quinquetaeniata Despax.}

Calamaria quinquetaeniata, Despax, Bull. Mus. d'Hist. Nat. I912, p. 6.

Diameter of the eye two thirds its distance from the mouth; rostral as deep as broad; frontal more long than broad, twice as broad as a supraocular, shorter than the parietals; one prae- and one postocular; five upper labials, second larger than first, third and fourth entering the eye, fifth very large; first lower labial in contact with its fellow behind the mental; posterior chin-shields separated posteriorly by a scale. Scales in 13 rows; ventrals 178 ; subcaudals 26 . Tail obtuse.

Palc brown above, with five bluish-black iridescent longi- 
tudinal bands; on each side behind the head a yellowish spot, interrupting the lateral bands; two yellowish spots on the tail, the anterior on the base and a median dark line. Lower surface yellowish-white, each ventral and subcaudal with a black spot on the outer ends; a dark median line along the tail. Length of head and body $228 \mathrm{~mm}$; tail $27 \mathrm{~mm}$. (After DEsPAX; not seen by me).

Habitat: Dutch East Indies.

\section{Calamaria albopunctata Barbour.}

Calamaria albopunctata, Barbour, Bull. Mus. Zool. Cambr. LI 1907/o8, p. 319.

Diameter of the eye shorter than its distance from the mouth; rostral a little more broad than deep; frontal more long than broad, less than twice as broad as a supraocular, much shorter than the parietals; one prae- and one postocular; five upper labials, second and fifth largest, third and fourth entering the eye; first lower labial in contact with its fellow behind the mental; both pairs of chin-shields in contact. Scales in I 3 rows; ventrals 247; anal entire; subcaudals 14 . Tail ending bluntly.

Dark brown above; two outer rows of scales with light centres; a light band on the occiput. Lower surface yellow with a few dusky markings; a blackish median line along the tail. Length of head and body? (After BARBOUR; not seen by me).

Habitat: Dutch East Indies.

\section{Calamaria bicolor Dum. \& Bibr.}

Calumaria bicolor, Duméril \& Bibron, Erp. Gén. VII I 854, P. 78.

Calamaria bicolor, Boulenger, Cat. Sn. II 1 $\$ 94$, p. 342.

Diameter of the eye a little shorter than its distance from the mouth; rostral as deep as broad; frontal more long than broad, about three times as broad as a supraocular, almost as long as the parietals; one prae- and one postocular; five upper labials, third and fourth entering the eye; first lower labial in contact with its fellow behind the mental; both pairs of chinshields in contact. Scales in 13 rows; ventrals 143-152; anal entire; subcaudals 24-29. Tail ending in a point.

Black above; two outer rows of scales whitish; upper lip whitish. Lower surface whitish; tail with or without a black median line. Length of head and body $318 \mathrm{~mm}$.; tail $57 \mathrm{~mm}$. 
Habitat: Borneo (Kina Balu!, Paku in Upper Sarawak, Singkawang).

\section{Calamaria brookei Boulenger.}

Calamaria brookii, Boulenger, Ann. Nat. Hist. (6) XV I895, p. 329; Cat. Sn. III I896, p. 647 .

Diameter of the eye equals its distance from the mouth; rostral as deep as broad; frontal one time and one fourth as long as broad, three times as broad as a supraocular, much shorter than the parietals; one prae- and one postocular; five upper labials, third and fourth entering the eye; first lower labial in contact with its fellow behind the mental; three lower labials in contact with the anterior chin-shields; both pairs of chin-shields in contact. Scales in 13 rows; ventrals I47-I55; anal entire; subcaudals 23. Tail obtusely pointed.

Yellowish-brown above, with five black stripes, the middle one broadest, covering one scale and two halves; outer row of scales yellowish-white, the upper part of the scales black; head marbled with black; a black collar and two black bands across the tail, the anterior at the base. Lower surface yellowish. Length of head and body $197 \mathrm{~mm}$; tail $23 \mathrm{~mm}$.

Type-specimen examined in the British Museum.

Ha bitat: Borneo (Matang!, Kidi district).

\section{Calamaria sondaica Barbour.}

Calamaria sondaica, Barbour, Bull. Mus. Zool. Cambr. LI I907/08, p. 3 I9.

Diameter of the eye a little shorter than its distance from the mouth; rostral almost as deep as broad; frontal slightly more long than broad, more than twice as broad as a supraocular, much shorter than the parietals; one prae- and one postocular; five upper labials, first nearly three times as large as the second, third and fourth entering the eye; the first lower labial in contact with its fellow behind the mental. Scales in I 3 rows; ventrals I54; anal entire; subcaudals IO. Tail obtuse.

Dark reddish-brown above, iridescent, with six dark longitudinal lines, distinct on the neck, indistinct on the body; the rows of scales separated by white lines; last row of scales with a lateral white line. Lower surface yellowish, blotched with angular dark markings; one median and two lateral black 
lines along the tail. Length of head and body? (After BARBOUR; not seen by me).

Habitat: Java (Buitenzorg).

\section{Calamaria brachyura Boulenger.}

Calamaria brachyura, Boulenger, Ann. Nat. Hist. (6) XVI I895, p. 48 I Cat. Sn. III 1896, p. 647.

Calamaria anceps, Werner, Verh. Ges. Wien XLVI IS96, p. IS.

Diameter of the eye equals its distance from the mouth; rostral slightly more broad than deep; frontal more long than broad, more than twice as broad as a supraocular, shorter than the parietals; one prae- and one postocular; five upper labials, third and fourth entering the eye, fourth smallest; first lower labial in contact with its fellow behind the mental; three lower labials in contact with the anterior chin-shields; both pairs of chin-shields in contact. Scales in I 3 rows; ventrals I 32-2IO; anal entire; subcaudals 9-I 9.

Dark grey-brown above, with six black longitudinal lines, disappearing anteriorly; two outer rows of scales black and white; nape with a narrow yellow transverse band; a similar band at the base of the tail; head black with a yellow spot on each praefrontal and parietal; upper lip white. Lower surface white, each ventral with a black spot at the outer end; a black median line along the tail. Length of head and body $2 \mathrm{~S}_{4} \mathrm{~mm}$.; tail $7 \mathrm{~mm}$.

Type-specimen examined in the British Muscum.

Habitat: Borneo (Kina Balu!, Saiap on Kina Balu).

\section{S. Calamaria collaris Boulenger.}

Calamaria collaris, Boulenger, Proc. Zool. Soc. IS97, p. 225, pl. XIV, fig. 4.

Diameter of the eye equals its distance from the mouth; rostral small, more broad than deep; frontal one time and one third to one time and a half as long as broad, twice as broad as a supraocular or more so, much shorter than the parietals; one prae- and one postocular; five upper labials, third and fourth entering the eye; first lower labial in contact with its fellow behind the mental; three lower labials in contact with the anterior chin-shields; both pairs of chin-shields in contact. Scales in 13 rows; ventrals $232-265$; a nal entire; subcaudals Io-30. Tail very obtuse. 
Dark grey-brown above, with black dots or spots; scales of the outer row with a white centre; a yellowish collar, most distinct in the young. Lower surface yellowish-white, the ventrals spotted or edged with dark brown or with a median series of dark brown spots. Length of head and body $3 \% 0 \mathrm{~mm}$.; tail Io $\mathrm{mm}$.

Type-specimens examined in the British Museum.

Ha bit a t: Celebes (Bone Mts., Tomohon, Rurukan 4000 feet!).

\section{Calamaria lateralis Mocquard.}

Calamaria lateralis, Mocquard, Le Natural. IS90, p. 154; Nouv. Arch. Mus. (3) II I 890, p. 136, pl. VIII, fig. 4.

Calamaria lateralis, Boulenger, Cat. Sn. II I 894, p. 342.

Diameter of the eye shorter than its distance from the mouth; rostral visible from above; frontal more long than broad, as long as the parietals; one praeocular; postocular fused with the supraocular; five upper labials, third and fourth entering the eye, fifth largest; first lower labial in contact with its fellow behind the mental; both pairs of chin-shields in contact. Scales in I 3 rows; ventrals I46; anal entire; subcaudals 2 I. Tail ending in a point.

Blackish-brown above; a white lateral line along the second and third rows of scales. Lower surface lighter brown. Length of head and body $233 \mathrm{~mm}$.; tail $12 \mathrm{~mm}$.

Type-specimen examined in the Paris Museum.

Habitat: Borneo (Kina Balu!).

\section{Calamaria beccarii Peters.}

Calamaria beccarii, Peters, Ann. Mus. Civ. (ienova III IS72, p. 34.

Calamaria beccarii, Boulenger, Cat. Sn. II IS94, p. 343.

Rostral visible from above; frontal more long than broad; one prae- and two postoculars; five upper labials; first lower labial in contact with its fellow behind the mental; both pairs of chin-shields in contact. Scales in I 3 rows; ventrals I5O; anal entire; subcaudals 16.

Brown above, with six dark longitudinal lines. Lower surface dirty white; tail with a black median line on its posterior part. Length of head and body I69 $\mathrm{mm}$.; tail $\mathrm{I} 4 \mathrm{~mm}$. (Not seen by me).

Habitat: Borneo (Sarawak). 


\section{I. Calamaria rebentischi Bleeker.}

Calamaria rebcntischi, Bleeker, Nat. Tijdschr. Ned. Ind. XXI I860, p. 293. Calimaria rebentischii, Boulenger, Cat. Sn. II I894, p. 343, pl. XVIII, fig. 3 .

Diameter of the eye much shorter than its distance from the mouth; rostral more broad than deep; frontal slightly more long than broad, about twice and a half as broad as a supraocular, shorter than the parietals; no praeocular; one postocular; five upper labials, third and fourth entering the eye; first lower labial in contact with its fellow behind the mental; three lower labials in contact with the anterior chin-shields; both pairs of chin-shields in contact. Scales in 13 rows; ventrals I42; anal entire; subcaudals 29. Tail ending in an obtuse point.

Purplish-brown above; scales of the outer row with a white spot. Lower surface uniformly yellowish. Length of head and body $243 \mathrm{~mm}$; t tail $37 \mathrm{~mm}$.

Type-specimen examined in the British Museum.

Habitat: Borneo (Singkawang!).

\section{Calamaria ceramensis de Rooy.}

Calamaria ceramensis, de Rooy, Bijdr. Dierk. I9 I9I3, p. 26.

Diameter of the eye shorter than its distance from the mouth; rostral more broad than deep; frontal more long than broad, two times and a half as broad as a supraocular; no praeocular; one postocular; five upper labials, third and fourth entering the eye; first lower labial in contact with its fellow behind the mental; both pairs of chin-shiclds in contact. Scales in 13 rows; ventrals $150-152$; anal entire; subcaudals $22-23$.

Purplish-brown above, with dark spots; scales of the outer row with a white spot; head grey; a yellowish collar running across the posterior points of the parietals. Lower surface yellowish; tail with a median black linc. Length of head and body $222 \mathrm{~mm}$; tail $23 \mathrm{~mm}$.

Type-specimens examined in the Amsterdam Museum.

Habitat: W. Ceram!.

\section{Calamaria mecheli Schenkel.}

Calamaria mecheli, Schenkel, Verh. Ges. Basel XIII 1901, p. I65.

Diameter of the eye about three fourths its distance from the mouth; rostral as broad as deep; frontal slightly more 
long than broad, nearly three times as broad as a supraocular, much shorter than the parietals; no pracocular; one postocular; five upper labials, third and fourth entering the eye, fifth longest; first lower labial in contact with its fellow behind the mental; posterior chin-shields posteriorly separated by a scale. Scales in 13 rows; ventrals $187-194$; anal entire; subcaudals $14-16$.

Light brown above; scales with dark borders; a vertebral row of elongate black spots and on each side two dark brown longitudinal stripes, the lower covering the two outer rows of scales; ventral part of the outer row whitish; head brown, white-speckled behind the eyes; lips light, this colour continued on the temporal region; base of tail with a light, sometimes interrupted transverse band. Lower surface light, with or without irregular dark dots along the median line; outer ends of the ventrals dark brown; anal brown. Length of head and body $200 \mathrm{~mm}$; tail $10 \mathrm{~mm}$.

Type-specimen received from the Basle Museum, examined. H a bitat: Sumatra (Indragiri!).

\section{Calamaria picteti Peracca.}

Calamaria Picteti, Peracca, Revue Suisse Zool. VIl 1900, p. 325, pl. 14, fig. $\mathbf{I}-3$.

Diameter of the eye shorter than its distance from the mouth; rostral as broad as deep; frontal as broad as long, four times as broad as a supraocular, shorter than the parietals; one prae- and one postocular; six upper labials, third and fourth entering the eye, fifth largest; first lower labial in contact with its fellow behind the mental; both pairs of chin-shields in contact, the anterior nearly twice as long as the posterior. Scales in 13 rows; ventrals I57; anal entire; subcaudals 22. Tail obtuse.

Light brown above, darker on the head, with 3 I black transverse spots on the back, largest anteriorly and some white scales; tail with 3-6 black spots, more or less confluent; upper lip with small black spots, a larger one on the fourth and fifth labials; irregular spots on the temporal region; flanks with a black line, formed by small black spots, anteriorly between the ventrals and the outer row of scales, posteriorly between the two outer rows. Lower surface dirty white. Length 
of head and body I $39 \mathrm{~mm}$.; tail I $5 \mathrm{~mm}$. (After PERACCA; not seen by me).

Habit a t: Borneo (Sarawak).

(See note sub $\mathrm{N}^{\circ}$. 37).

\section{Calamaria leucocephala Dum. \& Bibr.}

Calamaria leacoceplata, Duméril \& Bibron, Erp. Gén. VII 1854, p. $8_{3}$. Calumaria leucocephala, Boulenger, Cat. Sn. II 1\$94, p. 344 (s. syn.).

Diameter of the eye much shorter than its distance from the mouth; rostral much more broad than deep; frontal as broad as long, four times as broad as a supraocular, shorter than the parietals; one prae- and one postocular; five upper labials, third and fourth entering the eye; first lower labial in contact with its fellow behind the mental; both pairs of chin-shields usually in contact. Scales in I 3 rows; ventrals $136-171$; anal entire; subcaudals 19-45. Tail ending in a point.

Dark brown or black above; head lighter or yellowish. Lower surface yellowish or red; tail sometimes with a faint brown median line. Length of head and body $402 \mathrm{~mm}$; tail $48 \mathrm{~mm}$.

Habitat: Sumatra (Gambir!, Deli, Battak Highlands Soo-IOOO M., Supat and Dawas in Palembang, Padang I $500-3000$ feet); Borneo (Kuching, Matang, Samarinda!); Java (Salak, Sukabumi!). - Singapore; Penang; Malay Peninsula.

\section{Calamaria agamensis Blecker.}

Calamaria agamensis, Bleeker, Nat. Tijdschr. Nederl. Ind. XXI 1860, p. 292. Calamaria agamensis, Boulenger, Cat. Sn. II 1894. p. 343.

Diameter of the eye much shorter than its distance from the mouth; rostral more broad than deep; frontal at least as broad as long, at least four times as broad as a supraocular, shorter than the parietals; no praeocular; one postocular; five upper labials, third and fourth entering the eye; first lower labial in contact with its fellow behind the mental; posterior chinshields usually separated. Scales in 13 rows; ventrals $135-174$; anal entire; subcaudals $21-38$. Tail ending in a point.

Black above; yellow below, often with a brown median line along the tail. Length of head and body $247 \mathrm{~mm}$; tail $43 \mathrm{~mm}$.

Habitat: Sumatra; Borneo (Singkawang); Java (Batavia, Salak, Sukabumi!, Nongkodjadjar in Tengger Mts. I 300 M.!). 


\section{Calamaria semiannulata Böttger.}

Calamaria scmiannulata, Böttger, Katalog Rept. Senckenb. Mus. II I89\$, p. $S_{4}$.

Diameter of the eye much shorter than its distance from the mouth; rostral more deep than broad; frontal as long as broad, about three times as broad as a supraocular, much shorter than the parietals; one prae- and one postocular; five upper labials, third and fourth entering the eye; first lower labial in contact with its fellow behind the mental; posterior chinshields in contact anteriorly. Scales in I 3 rows; ventrals I 40 ; anal entire; subcaudals 27. Tail ending obtusely.

Reddish-yellow above, with 26 dark brown transverse bands or broad spots, about as broad as the interspaces; the spot on the nape broadest; each scale of the outer row with a brown spot; head brown above, with an oblique dark brown streak behind the eye and another behind the angle of the mouth. Lower surface uniformly light reddish-yellow. Length of head and body $175 \mathrm{~mm}$; tail $25 \mathrm{~mm}$. (After BöTTGER; not seen by me).

Habitat: Borneo.

Note. In Zoological Record I S99, Reptiles p. 22 C. picteti, described by PERACCA (see $\mathrm{N}^{\circ} .34$ on p. I70) is regarded as a C. semiannulata. As I did not see either of them I cannot makc out this question; so I hold both of them up as distinct species because of their differences, mentioned in the descriptions:

C.picteti: rostral as broad as deep; six upper labials; ventrals I 57 ; subcaudals 22 .

C. semiannulata: rostral more deep than broad; five upper labials; ventrals I40; subcaudals 27.

\section{Calamaria döderleini Gough.}

Calamaria Döderlcini, Gough, Zool. Anz. XXV 1902, p. 645.

Diameter of the eye half its distance from the mouth; rostral more deep than broad; frontal as long as broad, nearly three times as broad as a supraocular, shorter than the parietals; one prae- and one postocular; five upper labials, third and fourth entering the eye, fifth largest; first lower labial in contact with its fellow behind the mental; both pairs of chin-shields in contact. Scales in 13 rows; ventrals I 64 ; anal entire; subcaudals 22. Tail ending bluntly. 
Dark brown above, with a purplish gloss; black transverse bands on the back, two scales wide, narrower than the interspaces; each scale of the outer and some of the second row with a white centre. Lower surface yellowish, with black transverse bars, the outer ends of the ventrals black; a black median line along the tail. Length of head and body $260 \mathrm{~mm}$.; tail $25 \mathrm{~mm}$. (After Gough; not seen by me).

Habitat: Sumatra (Langkat).

\section{Calamaria bungaroides IVeruer.}

Calamaria bungaroides, Werner, Zool. Anz. XXIV I90I, p. 300.

Frontal as long as broad, three times as broad as a supraocular in the middle, much shorter than the parietals; one prae- and one postocular; six upper labials, third and fourth entering the eye; mental in contact with the anterior chinshields; both pairs of chin-shields in contact. Scales in 13 rows; ventrals I70; anal entire; subcaudals 22.

Dark grey above, with $25+4$ narrow, white transverse bands; two outer rows of scales white; head and point of tail yellowish-white. Lower surface white, with $23+3$ narrow blackish cross bands, covering $\mathrm{I}-2$ ventrals, some of them interrupted in the middle and alternating. Length of head and body $79 \mathrm{~mm}$.; tail $26 \mathrm{~mm}$. (After WERNER; not seen by me).

Habit at: Java?.

\section{Calamaria schlegeli Dum. \& Bibr.}

Calamaria schlegelii, Duméril \& Bibron, Erp. Gén. V'Il I $S_{54}$, p. SI. Calamaria schlegelii, Boulenger, Cat. Sn. II 1894 : p. 345.

Diameter of the eye shorter than its distance from the mouth; rostral more broad than deep; frontal about as broad as long, three times as broad as a supraocular, shorter than the parietals; no praeocular; one postocular; five upper labials, third and fourth entering the eye; mental in contact with the anterior chin-shields; posterior chin-shields separated. Scales in 13 rows; ventrals 138 ; anal entire; subcaudals 33 . Tail ending in a point.

Blackish above; temporal region whitish. Lower surface whitish; a brown median line along the tail. Length of head and body $222 \mathrm{~mm}$.; tail $37 \mathrm{~mm}$.

Habitat: Sumatra (Padang Highlands!); Borneo. 


\section{I. Calamaria linnaei Boie.}

Calamaria linnaei, Boie, Isis, I827, p. 539.

Calamaria linnaci, Boulenger, Cat. Sn. II I 894 , p. 345 (s. syn.).

Diameter of the eye equals its distance from the mouth; rostral as deep as broad; frontal more long than broad, not quite twice so broad as a supraocular, as long as the parietals; one prae- and one postocular; four upper labials, second and third entering the eye, second and fourth largest; mental in contact with the anterior chin-shields; both pairs of chinshields in contact usually. Scales in I 3 rows; ventrals I 35-I63; anal entire; subcaudals $9-23$. Tail obtuse.

Reddish or brown above, with black transverse bars, or

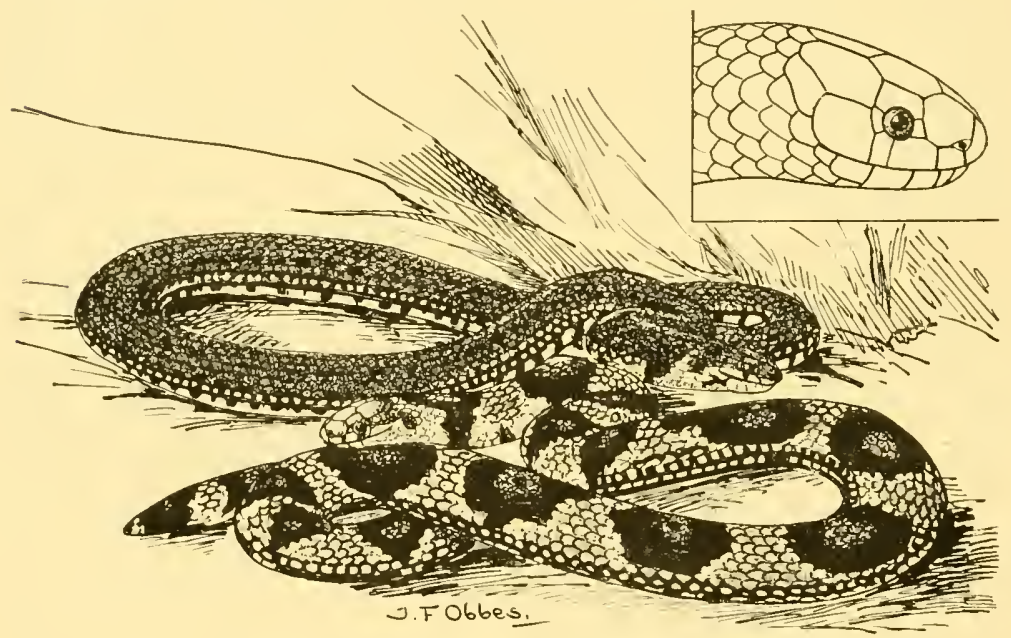

Fig. 67. Calamaria linnaci Boie. Nat size.

A specimen with small dark spots and another with dark rhomboidal markings. Side view of head.

with small black spots, with or without a black vertebral line; sometimes this line interrupted by dark, light-edged rhomboidal markings; the small black spots on the back sometimes regularly disposed in the median line of each scale, forming longitudinal lines; head sometimes with small dark spots and a dark stripe along the upper border of the fourth upper labial. Lower surface red, with or without quadrangular black spots, which may alternate on the median line, or uniformly black. Length of head and body $305 \mathrm{~mm}$; tail $15 \mathrm{~mm}$.

IIabitat: Sumatra (Pondok Gedek, Palembang-district!); 
Java (Gadok, Buitenzorg!, Salak, Sindanglaia, Gunung Bunder, Gunung Pengalengan 4000 feet, Volcano Tjisurupan, Preanger, Sukabumi!, Mt. Wilis 5000 feet, Kediri!, Salatiga!, Ambarawa, Wonosobo, Nongkodjadjar in Tengger Mts. I 300 M.!, Prigan ISoo-2300 feet); Borneo!; Celebes (Manado).

\section{Calamaria borneensis Bleeker.}

Calamaria borneensis, Bleeker, Nat. Tijdschr. Nederl. Ind. XXI rS6o, p. 296. Calamaria borneensis, Boulenger, Cat. Sn. II I $\$ 94$, p. 347 , pl. XIX, fig. 1.

Snout prominent; diameter of the eye shorter than its distance from the mouth; rostral more deep than broad; frontal more long than broad, about two times and a half as broad as a supraocular, shorter than the parietals; one prae- and one postocular; four upper labials, second and third entering the eye, second much larger than first and third; mental and two lower labials in contact with the anterior chin-shields; both pairs of chin-shields in contact. Scales in I 3 rows; ventrals I 52-192; anal entire; subcaudals 17-22. Tail obtusely pointed.

Dark brown above, uniform or with six black longitudinal lines; sometimes a white lateral streak between two black ones of which the lower runs on the outer ends of the ventrals; on the sides of neck and tail some yellow spots; end of tail black or with black spots. Lower surface yellowish, or with small black dots or checkered black and white. Length of head and body $306 \mathrm{~mm}$; t tail $24 \mathrm{~mm}$.

Type-specimen examined in the British Museum.

Habitat: Borneo (Claudetown on Baram river!, Sintang!, Matang, Kuching, Sarawak, Paku, Simanggang).

\section{Calamaria benjaminsi Edeling.}

Calamaria benjaminsii, Edeling, Nederl. Tijdschr. Dierk. II I864, p. 202. Calamaria benjaminsii, Boulenger, Cat. Sn. II I\$94, p. 347.

Rostral almost as broad as deep; frontal more long than broad; supraocular small; one prae- and one postocular; four upper labials, second and third entering the eye, second and fourth largest; mental in contact with the anterior chin-shields; both pairs of chin-shields in contact. Scales in 13 rows; ventrals I45-I54; anal entire; subcaudals $17-20$. Tail pointed.

Uniformly blackish-purple above; outer row of scales with white spots; upper lip reddish. Lower surface red, with a black 
streak along the side of the ventrals; tail with a median black line. Length of head and body $237 \mathrm{~mm}$.; tail $23 \mathrm{~mm}$. (Not seen by me).

$\mathrm{Ha}$ bitat: Borneo (Bulangan river, Bandjermassin).

\section{Calamaria javanica Boulenger.}

Calamaria javanica, Boulenger, Ann. Nat. Hist. (6) VII IS9r, p. 279; Cat. Su. II IS94, p. 347, pl. XIX fig. 2.

Diameter of the eye about equal to its distance from the mouth; rostral almost as deep as broad; frontal slightly more long than broad, three times as broad as a supraocular, shorter than the parictals; no praeocular; one postocular; four upper labials, second and third entering the eye, second and fourth largest; mental and three lower labials in contact with the anterior chin-shields; posterior chin-shields separated. Scales in 13 rows; ventrals $158-$ I 81 ; anal entire; subcaudals $15-17$. Tail ending obtusely.

Dark brown above, each scale with a light dot; a yellow, interrupted collar; upper lip yellow. Lower surface uniformly yellowish; a dark median line along the tail. Length of head and body $195 \mathrm{~mm}$; t tail $12 \mathrm{~mm}$.

Type-specimen examined in the British Museum.

Habitat: Sumatra (Perlak in S. Atjeh); Java!.

\section{Calamaria pavimentata Dum. \& Bibr.}

Calamaria pavimentata, Duméril \& Bibron, Erp. Gén. VII 1854, p. 7 1. Calamaria pavimentata, Bonlenger, Cat. Sn. II I 894 , p. 348 (s. syn.).

Diameter of the eye nearly cqual to its distance from the mouth; rostral as deep as broad; frontal more long than broad, twice and a half as broad as a supraocular, shorter than the parietals; one prae- and one postocular; four upper labials, second and third entering the eye; first lower labial in contact with its fellow behind the mental; three lower labials in contact with the anterior chin-shields; both pairs of chin-shields in contact. Scales in 13 rows; ventrals $133-182$; anal entire; subcaudals 9-27. Tail ending in a point.

Reddish-brown above, with five dark, longitudinal lines or series of spots; nape dark brown; a yellow collar; a pair of yellow spots on the base of the tail and at the end. Lower surface yellowish, uniform or mottled with brown or brown 
with light borders to the shields; usually a dark line along the tail. Length of head and body $305 \mathrm{~mm}$.; tail $15 \mathrm{~mm}$.

Habit at: Sumatra (Labuan); Java (Buitenzorg). — Penang; Malay Peninsula; S. China; Siam; Burma.

\section{Calamaria melanota Jan.}

Calamaria linnaei vars. melanota and gastrogramma, Jan, Arch. Zool. Anat. Phys. II r862, p. 5, pI. V.

Calamaria melanota, Boulenger, Cat. Sn. II $18 \mathrm{a} 4$, p. 349.

Diameter of the eye shorter than its distance from the mouth; rostral as deep as broad; frontal as broad as long, three or four times as broad as a supraocular, shorter than the parietals; one prae- and one postocular; four upper labials, second and third entering the eye, second and fourth largest; mental and three lower labials in contact with the anterior chin-shields; both pairs of chin-shields in contact. Scales in 13 rows; ventrals I33-182; anal entire; subcaudals I6-24. Tail ending in a point.

Black above, the scales lighter in the centre; lateral scales white, black-edged. Lower surface white, the shields with black edges. Length of head and body $210 \mathrm{~mm}$.; tail $30 \mathrm{~mm}$.

Habit at: Java; S. E. Borneo! (Tandjong).

\section{Calamaria lowi Boulenger.}

Calamaria lovii, Boulenger, Ann. Nat. Hist. (5) XIX 1887 , p. 196; Cat. So.

II 1894, p. 350, pl XIX, fig. 4 .

Diameter of the eye about half its distance from the mouth; rostral almost as deep as broad; frontal as broad as long, three times as broad as a supraocular, shorter than the parietals; no praeocular; one postocular; four upper labials, third entering the eye; mental and three lower labials in contact with the anterior chin-shields; both pairs of chin-shields in contact. Scales in I 3 rows; ventrals 203-236; anal entire; subcaudals 14-22. Tail obtuse.

Dark brown or plumbeous above, with light dots in longitudinal series; upper lip yellowish; anterior part of body with a lateral series of large, yellow spots and a few spots on the tail. Lower surface uniformly blackish with a yellow transverse bar above the vent or blotched with dark brown and yellow. Length of head and body $243 \mathrm{~mm}$.; tail $22 \mathrm{~mm}$.

Type-specimen examined in the British Museum.

Habitat: Borneo (Baram, Rejang and Niah rivers!). 


\section{Calamaria gracillima Günther.}

Calamaria gracillima, Günther, Proc. Zool. Soc. I872, p. 594, pl. XXXIX, fig. A. Calamaria gracillima, Boulenger, Cat. Sn. II I 894 , p. 350.

Eye very small; rostral as deep as broad; frontal slightly more broad than long, shorter than the parietals; supraocular very small, confluent with the postocular; no praeocular; four upper labials, second and third entering the eye, second and fourth largest; first lower labial in contact with its fellow behind the mental; three lower labials in contact with the anterior chin-shields; both pairs of chin-shields in contact. Scales in I 3 rows; ventrals $300-320$; anal entire; subcaudals I3-I4. Tail obtuse, rounded at the end.

Blackish, with a few yellowish or red spots along each side of the body and a pair at the base of the tail. Lower surface blackish. Length of head and body $275 \mathrm{~mm}$.; tail ro $\mathrm{mm}$.

Type-specimen examined in the British Museum.

Habitat: Borneo! (Matang!, Tegora).

The next two species could not be placed in the dichotomical list, as the descriptions are rather incomplete; the specimens could not be examined by me.

\section{Calamaria ornata Werner.}

Calamaria ornata, Werner, Mitt. Naturh. Mus. Hamburg XXVI 1909, p. 229, fig. 6.

Snout projecting, rounded; rostral more broad than deep; frontal about twice as long as broad, about three times as broad as a supraocular, shorter than the parietals; one praeand one postocular; five upper labials, third and fourth entering the eye, fifth largest; mental in contact with the anterior chin-shields, which are twice as long as broad; posterior chinshields small, separated in the middle. Scales in I 3 rows; ventrals I48; anal?; subcaudals 17 .

Coloration? Measurements? (After Werner; not seen by me). Habitat: Sumatra (Sungei Lalak in Indragiri).

\section{Calamaria hosei Günther.}

Calamaria Hosei, Günther, Ann. Nat. Hist. (6) XVII r896, p. 229.

Eye very small; frontal at least four times as broad as a supraocular; a minute praeocular and a very small postocular; five upper labials; mental in contact with the anterior chin- 
shields. Scales in 13 rows; ventrals I 38 ; anal?; subcaudals I 9.

Pinkish above, the scales bordered and speckled with black and with 18 black transverse bars, narrower than the interspaces and contracted on the sides; three black bars on the tail; head brown above, the brown colour forming two oblique bands on the sides; tail with a black stripe along each longitudinal series of scales. Lower surface white, with a few dark spots; subcaudals blackish. Length of head and body $312 \mathrm{~mm}$.; tail $37 \mathrm{~mm}$. (After GÜNTHER; not seen by me).

Habitat: Borneo (Entoyut river in Baram district).

\section{Doubtful species.}

Calamaria hoeveni Edeling, Nat. Tijdschr. Nederl. Ind. XXXI I 870 , p. 380 ; Cat. Sn. II 1894, p. 337 is perhaps a colourvariety of $C$. margaritophora Blkr.

Rostral well visible from above; frontal one time and a half as long as broad; five upper labials, third and fourth entering the eye; mental in contact with the anterior chinshields; both pairs of chin-shields separated by a small scale. Scales in I 3 rows; ventrals I69; anal entire; subcaudals 9.

Brown above, with transverse pale, black-edged bands; a series of whitish spots along the outer row of scales; head marbled with black. Lower parts yellowish with black spots. Length of head and body $292 \mathrm{~mm}$.; tail I $3 \mathrm{~mm}$. (Not seen by me).

$\mathrm{Hab}$ it at: Sumatra.

\section{Subfamily Homalopsinae.}

Key to the Indo-Australian genera.

A. Nasals in contact above the rostral.

1. Scales smooth; parietals well developed..... 38. Hypsirhina p. 18o.

2. Scales keeled; parietals well developed ..... 39. Homalopsis p. 185 .

3. Scales keeled; parietals broken up into scales .. 40. Cerberus p. 187.

b. Internasal separating the nasals.

I. Ventrals without keels.

a. Loreal absent; scales smooth; body stont. . . 4x. Fordonia p. IS9.

b. Loreal present; scales smooth; body very long. 42. Cantoria p. I9o.

c. Loreal present; scales keeled. ........ 43. Myron p. I9I.

11. Ventrals narrow, with two keels ...... 44. Hipistes p. 193.

Aquatic snakes; viviparous. Nostrils valvular, on the upper surface of the snout. 
38. Hy psir hin a Wagler.

(WaGler, Syst. Amph. I69, I830).

Head small, not or slightly distinct from neck; eye small; pupil round or vertically elliptic; shields of head large; nasals in contact, partly divided, the cleft beginning at the first labial or the loreal; internasal single or double; loreal present. Maxillary teeth $10-16$, separated by an interspace from two enlarged, grooved teeth; anterior mandibular teeth longest. Body round, covered with smooth scales without pits, in I9-33 rows; ventrals rounded. Tail rather short; subcaudals in two rows.

Distribution. S. E. Asia; Papuasia; N. Australia.

Key to the Indo-Australian species.

A. One or more labials entering the eye.

1. Scales in 19 rows.

a. Two internasals ............ I. H. alternans p. I So.

b. A single internasal ........... 2. H. plumbea p. I8I.

II. Scales in 21 (23) rows.

a. Four or five lower labials in contact with

the anterior chin-shields.

1. Loreal in contact with the internasal. 3. H. enhydris p. I8I.

2. Loreal not in contact with the internasal. 4. H. matamensis p. 182 .

b. Three lower labials in contact with the anterior chin-shields........... 5. H. polylepis p. $1 \delta_{3}$.

III. Scales in $27(25)$ rows ..........6. H. albomaculata p. I83. $B$. Eye separated from the labials.

I. Internasal single ........... 7. H. punctata p. I $\$_{4}$.

2. Two internasals............ 8. H. doriae p. 185 .

\section{Hypsirhina alternans (Reuss).}

Brachyorrhos alternans, Reuss, Mus. Senckenb. I I 834, P. I55, pl. IX, fig. 3. IIypsirhina alternans, Boulenger, Cat. Sn. III I 896, p. 4 (s. syn.).

Rostral more broad than deep; two internasals; frontal broader than the supraocular, as long as or longer than its distance from the tip of the snout, shorter than the parictals; loreal as long as deep, in contact with the internasal; one prae- and one or two postoculars; temporals I +2 ; eight upper labials, fourth entering the eye; four or five lower labials in contact with the anterior chin-shields, which are larger than 
the posterior; these are separated by scales. Scales in I9 rows; ventrals I25-I52; anal divided; subcaudals $24-36$.

Purplish-brown above, with indistinct light transverse bars, the first on the occiput. Lower surface yellowish, with black transverse bands or large, alternating black spots. Total length $465 \mathrm{~mm}$.

Ha bit at: Sumatra (Deli!); Banka!; Borneo (Kuching); Java!.

\section{Hypsirhina plumbea (Boie).}

Homalopsis plumbea, Boie, Isis 1827, p. 560 .

Hypsirhina plumbca, Boulenger, Cat. Sn. III I 896, p. 5 (s. syn.).

Rostral more broad than deep; a single internasal (sometimes two), more broad than long; frontal as long as its distance from the tip of the snout, shorter than the parietals; loreal in contact with the internasal; one prae- and two postoculars; temporals I +2 ; eight upper labials, fourth or fourth and fifth entering the eye; four or five lower labials in contact with the anterior chin-shields; posterior chin-shields shorter, separated from one another. Scales in I 9 rows; ventrals I I 7- I 39; anal divided; subcaudals 29-47.

Brownish or greyish above, uniform or with a median series of black spots; upper lip white. Lower surface white, generally with a dark line along the middle of the tail and sometimes with dark spots or black dots on the median line of the belly. Length of head and body $420 \mathrm{~mm}$.; tail $65 \mathrm{~mm}$.

Habitat: Sumatra (Atjeh, Labuan, Medan!, Langkat!, Serdang!, Raja Mts., Bedagei, Palembang); Java (Batavia, Semarang, Salatiga!, Malang!, Kediri!); Bornco (Labuan, Samarinda!, Bandjermassin); Celebes! (Manado!, Kema, Kandari, Tempe!, Macassar!, Lamontjong). - Penang; Malay Peninsula; Siam; Indo China; S. China; Burma.

\section{Hypsirhina enhydris (Schn.).}

Hydrus enhydris, Schneider, Hist. Amph. I I799, p. 245. Ifypsirhina enhydris, Boulenger, Cat. Sn. III IS96, p. 6 (s. syn.).

Rostral twice as broad as deep; a single internasal, about twice as broad as long; frontal broader than the supraocular, as long as or shorter than its distance from the tip of the snout, as long as the parietals; loreal in contact with the internasal; one prae- and two (one) postoculars; temporals $\mathrm{I}+2$; 
eight upper labials, fourth entering the eye; four lower labials in contact with the anterior chin-shields; posterior chin-shields longer and separated from one another. Scales in $2 \mathrm{I}$ rows (I9 or 23); ventrals I50-I77; anal divided, subcaudals $47-78$.

Brown, olive or dark grey above, with two light longitudinal bands, sometimes indistinct. Lower surface white, with a dark line on each side of the ventrals and a median dark line or series of dots, which is sometimes absent. Length of head and body $545 \mathrm{~mm}$.; tail $\mathrm{I} 35 \mathrm{~mm}$.

Nom. indig. Ular ajer (mal.).

Habitat: Sumatra (Djambi!, Kertadjaja, Palembangdistrict!, Padang); Java (Batavia, Buitenzorg, Pekalongan!, Ambarawa, Salatiga!); Banka!; Borneo! (Singkawang, Montrado, Simanggang, Saribas, Kapuas river, Bandjermassin); Celebes (Macassar); New Guinea (Lorentz river). - Singapore, Penang; Malay Peninsula; Siam; Cochin China; S. China; Burma; India; Ceylon.

\section{Hypsirhina matannensis Boulenger.}

Hypsirhina Matannensis, Boulenger, Proc. Zool. Soc. 1897, p. 225, pl. XV, fig. I.

Rostral more broad than deep; two internasals; frontal broader than the supraocular, longer than its distance from the tip of the snout, shorter than the parietals; loreal more long than deep, not in contact with the internasal; one prae- and one postocular; temporals I +2 ; eight upper labials, fourth and fifth entering the eye; five lower labials in contact with the anterior chin-shields; posterior chin-shields shorter and separated from one another. Upper head-shields, labials, chin-shields and scales of the throat rough with granules. Scales in 2 I rows; ventrals I 37 ; anal divided; subcaudals 43.

Dark olive-brown above, with an indistinct dark line on the vertebral scales. Throat yellowish-white; anterior ventrals yellowish-white with large transverse olive-brown spots; middle ventrals almost olive-brown; posterior ventrals and subcaudals olive-brown with yellowish borders; an olive-brown line on the middle of the tail below. Length of head and body $175 \mathrm{~mm}$; t tail $65 \mathrm{~mm}$.

Type-specimen received from the Basle Museum, examined. Habitat: Celebes (Lake Matanna!). 


\section{Hypsirhina polylepis Fischer.}

Hy'psirhina polylepis, Fischer, Abh. Nat. Ges. Hamb. IX ISS6, p. I4. Hypsirhina polylepis, Boulenger, Cat. Sn. III IS96, p. 9.

Rostral more broad than deep; internasal single or double, twice as broad as long; frontal broader than the supraocular, slightly longer than its distance from the tip of the snout, as long as or a little shorter than the parietals; loreal more long than deep, not in contact with the internasal; one or two prae- and two postoculars; temporals $\mathrm{I}+2$ or $\mathrm{I}+3$; eight upper labials, fifth or fifth and sixth entering the eye; three lower labials in contact with the anterior chin-shields, which separate the posterior. Scales in 2 I or 23 (25) rows; ventrals I37-I56; anal divided; subcaudals $37-48$.

Dark olive or blackish above, the scales sometimes lightedged; a yellow lateral streak along the second row of scales. Lower surface brown, spotted with yellow or with a light spot on each ventral near the outer end; tail dark, each subcaudal with a yellow spot. Length of head and body $775 \mathrm{~mm}$.; tail $125 \mathrm{~mm}$.

Habitat: New Guinea (Fly river!, Lorentz river!).

Note. The specimens from the Lorentz river have two outer rows of scales yellow, this yellow band continued to the corner of the mouth, with dark spots. Lower surface yellow, throat and anterior ventrals powdered with brown; sometimes a dark median subcaudal line.

\section{Hypsirhina albomaculata (Dum. \& Bibr.).}

Homalopsis albomaculatus, Duméril \& Bibron, Erp. Gén. VII 1854, p. 974. Hypsirhina albomaculata, Bonlenger, Cat. Sn. III 1896, p. II.

Rostral more broad than deep; two internasals; praefrontals sometimes longitudinally divided ${ }^{\mathrm{I}}$ ); frontal broader than the supraocular, as long as its distance from the tip of the snout and as the parietals or latter a little longer; loreal slightly more long than deep, in contact with the internasal; one prae- and one or two postoculars; temporals $\mathrm{I}+2$ or 3 ; eight or nine upper labials, fifth (fourth) entering the eye; five or six lower labials in contact with the anterior chin-shields, which

I) None of Io specimens from Simalur have divided praefrontals; three specimens have 25 rows of scales round the body. 
are larger than the posterior; latter separated by scales. Scales in 27 (25) rows; ventrals 140-I5O; anal divided; subcaudals $37-48$.

Olive-brown above, with small yellow or orange spots; one

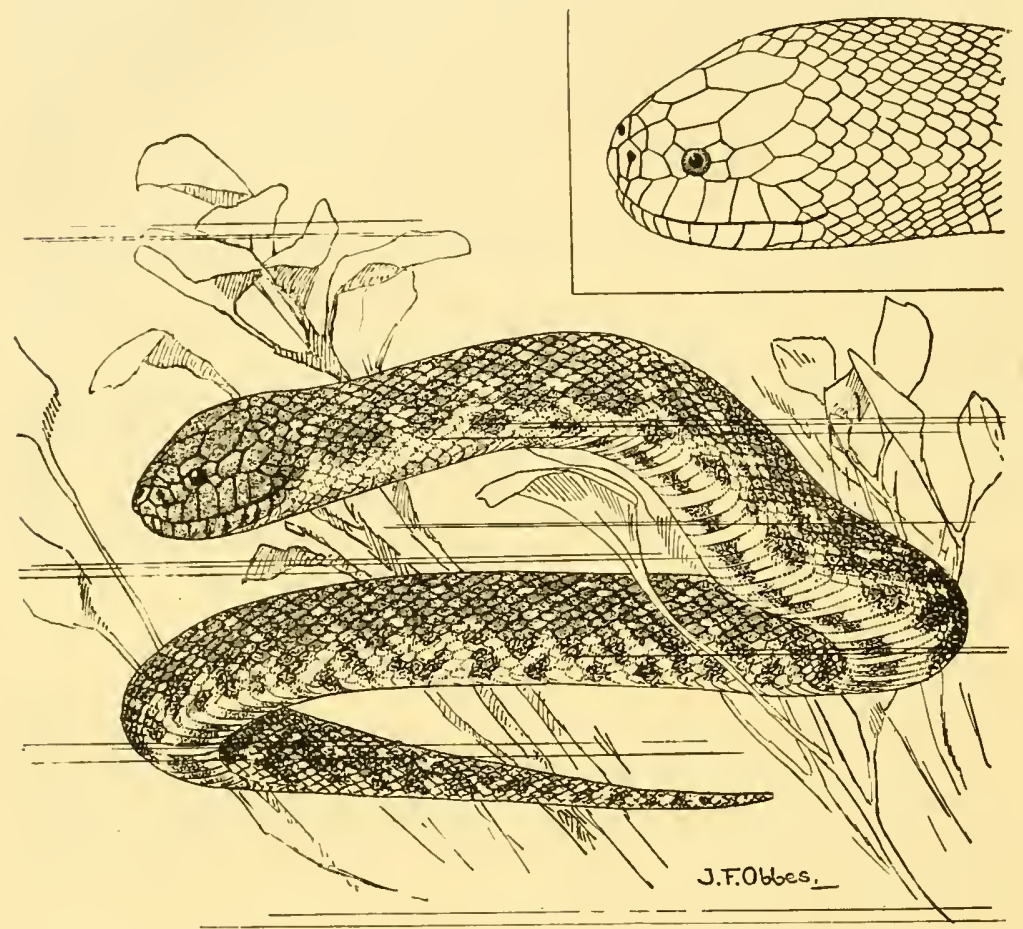

Fig. 68. Hypsirhina albomaculata (D. \& B.) $\times 2 / 3$. Side view of head.

or two yellow bars across the nape, sometimes indistinct. Lower surface yellow or orange, black-spotted. Length of head and body $528 \mathrm{~mm}$.; tail $94 \mathrm{~mm}$.

Habitat: Simalur!; Nias; Sumatra (Padani).

\section{Hypsirhina punctata (Gray).}

Phytolopsis punctala, Gray, Cat. Sn. I 849, p. 68.

Hypsirhina punctata, Boulenger, Cat. Sn. III I896, p. I2 (s. syn.).

Rostral a little more broad than deep; internasal small, single; frontal not broader than the supraocular, as long as its distance from the tip of the snout, as long as or a little shorter than the parietals; one or two loreals, not in contact 
with the internasal; one prae- and two postoculars; temporals small; twelve to fourteen upper labials, the anterior four or five deep, the posterior much lower and separated from the eye by small scales; five or six lower labials in contact with the anterior chin-shields, which are much larger than the posterior; the latter separated from one another. Scales in 25 or 27 rows; ventrals I33-I 56; anal divided; subcaudals $28-4 \mathrm{I}$.

Dark brown above, uniform or with small yellow spots, sometimes forming transverse bars; one or two yellow transverse bands on the nape, another between the eyes. Lower surface yellow. Length of head and body $330 \mathrm{~mm}$.; tail $40 \mathrm{~mm}$.

Habitat: Sumatra (Labuan, Deli!, Lalak and Djapura in Indragiri, Taluk!); Banka!; Borneo (Singkawang, Kuching). Malay Peninsula.

\section{Hypsirhina doriae (Peters).}

Homalophis doriae, Peters, Mon. Berl. Ac. I $87 \mathrm{I}$, p. 577 .

Hypsirhina doriae, Boulenger, Cat. Sn. III IS96, p. I3.

Rostral as deep as broad; two internasals; frontal broader than the supraoculars, shorter than its distance from the tip of the snout, as long as the parietals or a little shorter; supraoculars divided into two or three small shields; two loreals, more deep than long, in contact with the internasal; one prae-, two or three post- and two or three suboculars; temporals small; fifteen upper labials, the posterior transversely divided; chin-shields large, separated from the mental by the two anterior pair of lower labials. Scales in $3 \mathrm{I}$ or 33 rows; ventrals I4I-I46; anal divided; subcaudals 45- 55 .

Olive-brown above, yellow below, uniform or spotted with blackish. Length of head and body $680 \mathrm{~mm}$; tail $120 \mathrm{~mm}$.

Ha bit a t: Borneo (Sandakan Bay!, Sarawak, Kuching, Baram district!, Kapuas river ')).

\section{Homalops is Kuhl.}

(Kunt, Isis p. 474,1822 ).

Head distinct from neck; eye small; pupil vertically elliptic; shields of head large; nasals in contact, partly divided, the

I) A specimen from this locality had 27 rows of scales; ventrals 160 ; subcaudals 44; length of head and body $715 \mathrm{~mm}$.; tail $95 \mathrm{~mm}$. (Bkown, Proc. Acad. Philad. LIV 1902, p. Iso). 
cleft beginning at the first labial; internasal single or double; loreal present. Maxillary teeth I I-I 3 , decreasing in size posteriorly and separated by an interspace from two slightly enlarged, grooved teeth; anterior mandibular teeth longest. Body round, covered with keeled and striated scales without pits, in 37-47 rows; ventrals rounded. Tail moderate; subcaudals in two rows.

Distribution. S. E. Asia.

A single species.

I. Homalopsis buccata (L.).

Coluber buccatus, Linné, Syst. Nat. I I 766, p. 377.

Homalopsis buccata, Boulenger, Cat. Sn. III I896, p. I4 (s. syn.).

Internasals smaller than praefrontals; frontal often broken up into small shields, a little broader or sometimes narrower than the supraocular; parietals short; loreal present, sometimes

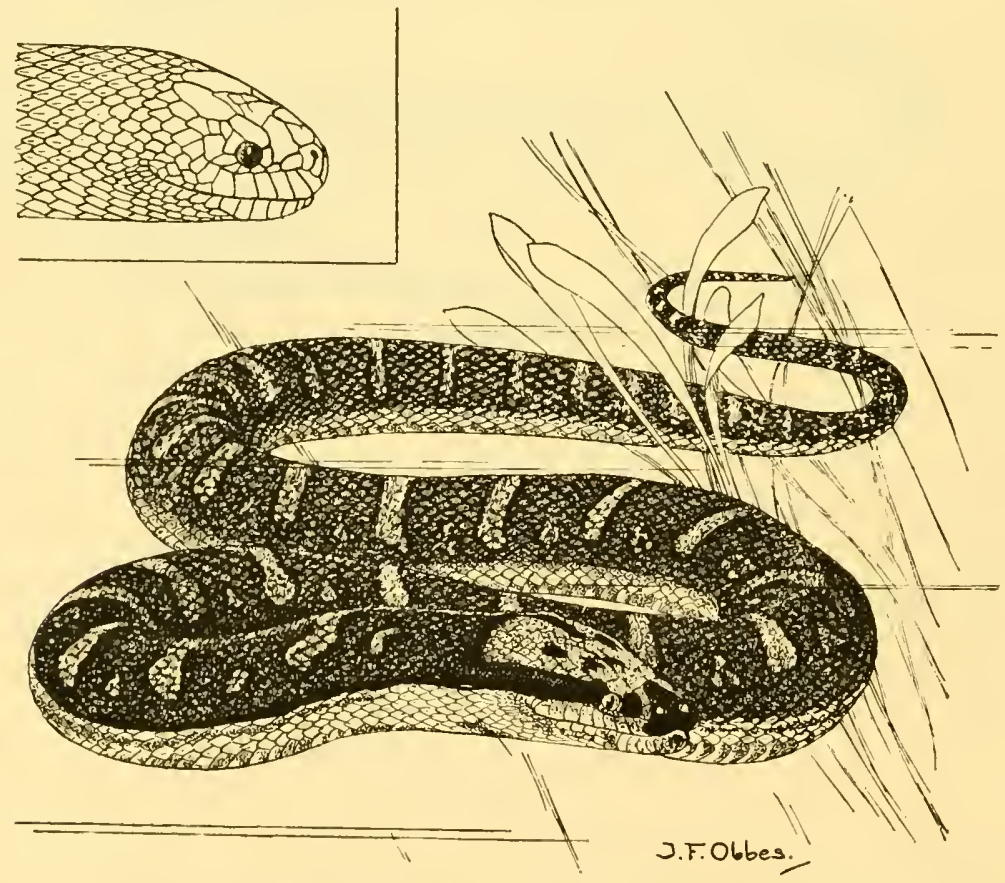

Fig. 69. Homalopsis buccata (L.) $\times 1 / 2$. Side view of head.

divided; one or two prae- and two postoculars; one to three suboculars may be present; temporals small; ten to twelve upper labials, fifth or sixth entering the eye or narrowly 
separated from it; two or three pair of chin-shields, inner in contact with the three anterior lower labials. Scales in $37-47$ rows; ventrals I58-176; anal divided; subcaudals 70-106.

Dark brown above, with narrow, pale brown, black-edged transverse bands, in young specimens yellow; head pale with a triangular or $\mathrm{V}$-shaped dark marking on the snout, a $\Lambda$-shaped spot on the occiput, and a dark band on each side passing through the eye and extending to before the eye. Lower surface white or yellowish, with dark brown spots along each side; tail with brown spots. Length of head and body $820 \mathrm{~mm}$.; tail $230 \mathrm{~mm}$.

Nom. indig. Ular kadut (mal.).

Habitat: Sumatra (Atjeh!, Labuan, Serdang!, Stabat, Langkat, Deli!, Laut Tador, Indragiri, Djambi!, Ringgat); Banka!; Riou!; Borneo (Bulangan river, Labuan, Kuching, Buntal, Rejang river, Sebruang Valley, Pontianak, Landak!; Singkawang; Montrado; Bandjermassin); Java (Batavia, Buitenzorg!, Depok, Preanger, Pekalongan!, Salatiga!, Surabaia!); Celebes (Macassar!). — Malay Peninsula; Siam; Indo China; Burma.

Feeds on fish and frogs.

\section{Cerberus Cuvier.}

(Cuvier, Règne Anim. 2nd ed. II p. 81, 1829).

Head small, slightly distinct from neck; eye small; pupil vertically elliptic; snout covered with shields; parietals broken up into scales; nasals in contact, partly divided, the cleft beginning at the first or second labial; two (one) internasals; loreal present. Maxillary tecth $12-17$, separated by a short interspace from two slightly enlarged, grooved teeth; anterior mandibular teeth longest. Body round, covered with keeled and striated scales without pits, in 23-29 rows; ventrals rounded. Tail a little compressed; subcaudals in two rows.

Distribution. S. E. Asia; N. Australia.

A single species.

\section{Cerberus rhynchops (Schn.).}

Hydrus rhynchops, Schneider, Hist. Amph. I I 799, p. 246.

Ceroerus rhynchops, Boulenger, Cat. Sn. III I 896, p. I6, (s. syn.).

Hurria rhynchops, Barbour, Mem. Mus. Comp. Zool. Harv. Coll. XLIV I9I2, p. 123. 
Frontal distinct or broken up into small shields; nasal cleft extending to the first upper labial, sometimes to the second; loreal usually in contact with the three or four anterior labials and with the internasal; eye bordered by four or six shields, a supraocular, a praeocular, one or two post- and one, two or three suboculars; nine or ten upper labials; four lower labials in contact with the anterior chin-shields; posterior chinshields smaller, between the anterior and the labials. Scales strongly keeled, in 23 or 25 (27) rows; ventrals 122-I60; anal divided; subcaudals 49-72.

Grey, olive or dark brown above, with black spots or transverse bands, sometimes indistinct; a light lateral band; a black

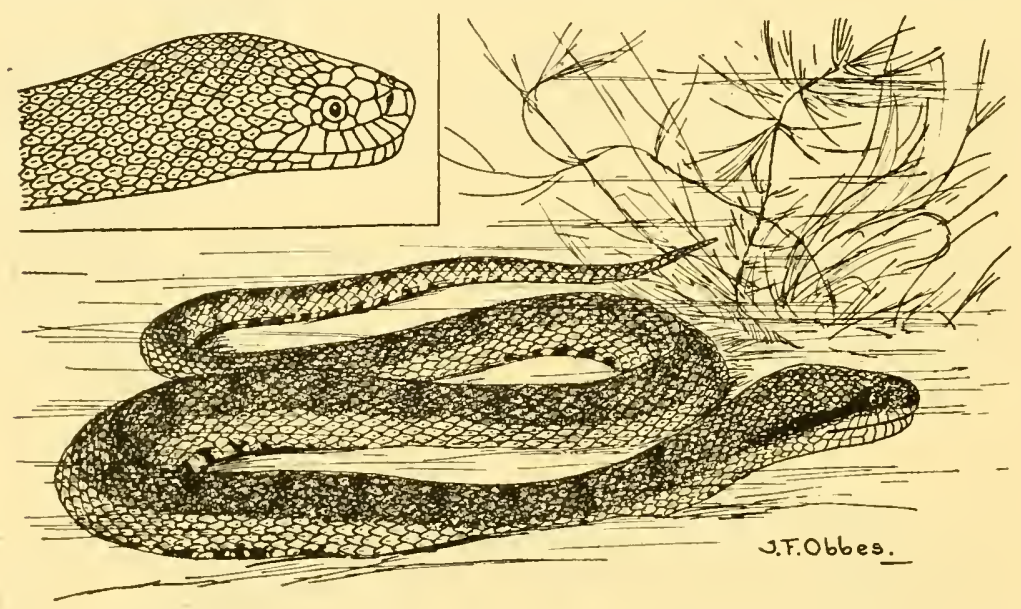

Fig. 70. Cerlerus rhynchops (Schn.) $\times 1 / 2$. Side view of head.

streak on each side of the head, passing through the eye. Lower surface whitish, spo'ted with black, or with black transverse bands or almost entirely black. Length of head and body $800 \mathrm{~mm}$; tail $180 \mathrm{~mm}$.

Nom. indig. Sawa butah-hè (Simalur).

Habitat: Simalur!; Nias!; Pulu Nako!; Mentawei Islands (Sipora, Siberut!); Engano; Sumatra (Sabang on Pulu Weh!, Peudawa, Atjeh!, Labuan, Medan!, Tandjung Laut in Palembang, Ringgat!. Padang); Siak!; Riou!; Banka!; Borneo (Bulangan river, Sandakan Bay, Labuan, Sibu, Kuching, Buntal, Singkawang!, Pontianak river, Bandjermassin, Samarinda!); Java (Batavia, Cheribon sea!, Semarang!); Bali ; Lombok; Flores!; 
Sumba; Rotti!; Timor!; Wetar; Celebes (Manado!, Kema, Kandari, Pare Pare!, Raha); Sangir Islands; Ternate!; Halmahera; Batjan; Buru; Ceram; Ambon!; Saparua; Goram; New Guinea!. - Pelew Islands; Malay Peninsula; Penang; Andamans; Nicobars; Siam; Indo China; Burma; Ceylon; India; Philippines; N. Australia.

Not rare at the sea-coast; feeds on fish.

\section{I. Fordonia Gray:}

(Gray, Zool. Misc. p. 67, $1 \$_{42}$ ).

Head small, not distinct from neck; eye very small; pupil vertically elliptic; shields of head large; nasals undivided or partly divided, separated by a single internasal; no loreal. Maxillary teeth small, 7 or 8 , followed by two enlarged, grooved teeth; mandibular teeth about equal. Body round, covered with smooth scales, without pits, in 25-29 row; ventrals rounded. Tail short, subcaudals all or partly in two rows.

Distribution. Burma; Cochin China; Indian Archipelago; N. Australia.

A single species.

I. Fordonia leucobalia (Schleg.).

Homalopsis leucobalia, Schlegel, Phys. Serp. II $1 \$_{37} ;$ p. 345, pl.XIIt, fig. S, 9. Fordonia leucobalia, Boulenger, Cat. Sn. III I\$96, p. 2 I (s. syn.).

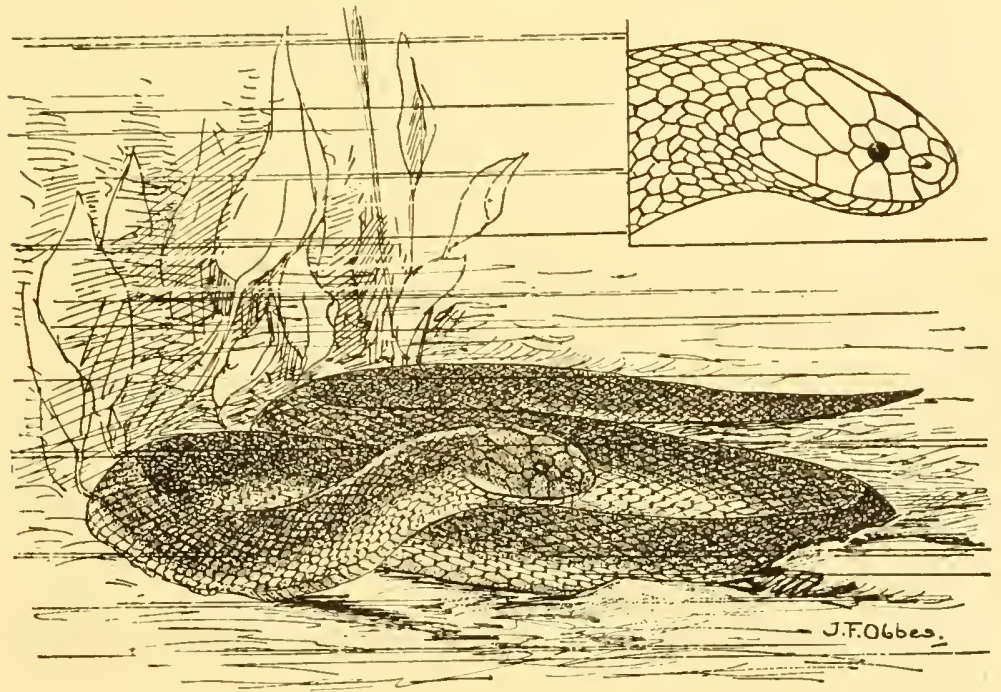

Fig. 71. Fordonia leucobalia (Schleg.) $\times 3 / 4$. Side view of head. 
Frontal more long than broad, longer than its distance from the tip of the snout, shorter than the parietals; one prae- and two postoculars; temporals $I+3$ or $2+3$; five upper labials, third entering the eye; three lower labials in contact with the anterior chin-shields, which are a little larger than the posterior. Scales in $25-29$ rows; ventrals $130-156$, last often divided; anal divided; subcaudals $26-43$.

Yellow, red, brown or black above, spotted or variegated with black, yellowish-white or greenish. Lower surface yellowish-white. Length of head and body $820 \mathrm{~mm}$.; tail I Io $\mathrm{mm}$.

Type-specimen examined in the Leiden Museum.

Habitat: Sumatra (Deli!); Borneo (Kuching, Santubong, Niah, Pontianak, Bandjermassin); Java (Cheribon sea!, Ambarawa); Timor!; Ceram!; Ambon; New Guinea (Yule Island, Mimika river, Lorentz river, Merauke, Fly river). - Singapore; Penang; Malay Peninsula; Nicobars; Cochin China; Burma; Bengal; N. Australia.

Lives in rivers, estuaries and along the sea-shore; feeds on crustaceans and fish.

Doubtful species.

Fordonia papuensis Macleay, Proc. Linn. Soc. N. S. W. II I 877 , p. 35; Cat. Sn. III I896, p. 23, is perhaps a synonym of $F$. leucobalia (Schleg.).

Third labial not entering the eye. Scales in 22 rows. (Not seen by me).

Habitat: New Guinea (Katow).

\section{Cantoria Girard.}

(Girard, Proc. Ac. Philad. p. I82, I857).

Head small, not distinct from neck; eye very small; pupil round; shields of head large; nasal partly divided, the cleft beginning at the praefrontal; internasal single, separating the nasals; loreal present. Maxillary teeth 10 or II, posterior longest and grooved; anterior mandibular teeth longest. Body slightly compressed, very long, covered with smooth scales without pits, in 19 rows; ventrals rounded. Tail moderate; subcaudals in two rows.

Distribution. Burma; Malay Peninsula; Sumatra; Borneo; Timor.

A single species. 


\section{Cantoria violacea Gir.}

Cantoria violacea, Girard, Proc. Ac. Philad. I $\$ 57$, p. I $\$ 2$.

Cantoria violacea, Boulenger, Cat. Sn. IIl I $\$ 96$, p. 23 (s. syn.); Rept. Malay

Penin. 1912, p. 165, fig. 5 I.

Frontal more long than broad, shorter than its distance from the tip of the snout and shorter than the parietals; one prae- and one postocular; one subocular; loreal more long than deep; one long anterior temporal, in contact with the postocular and the subocular; five upper labials, separated from the eye; three lower labials in contact

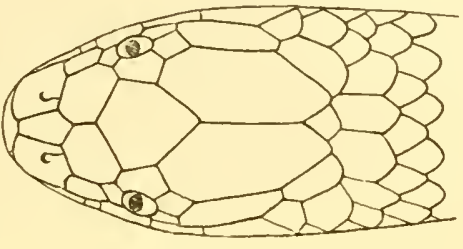
with the anterior chin-shields. Scales in 19 rows; ventrals $260-284$; anal divided, subcaudals $52-64$.

Black above, with white transverse bands, widest towards the belly, narrower than the interspaces; head with white spots. Lower surface white, with grey spots, which are a continuation

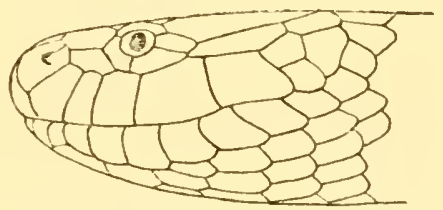

Fig. 72. Cantoria violacaz Gir. After BOUlenger. of the transverse bands; tail sometimes with complete rings. Total length $1220 \mathrm{~mm}$.

Habitat: Sumatra (Tandjong Laut in Palembang); Borneo; Timor. - Singapore; Malay Peninsula!; Burma.

Rare.

\section{My ron Gray.}

(Gray, Cat. Sn. p. 70, I 849$)$.

Head small, not or slightly distinct from neck; eye very small; pupil vertically elliptic; shields of head large; nasal partly divided, the cleft beginning at the first or second labial; internasal single or double, separating the nasals; loreal present. Maxillary teeth about IO, separated by a short interspace from two enlarged, grooved teeth; anterior mandibular teeth longest. Body round, covered with keeled and striated scales without pits, in 2 I rows; ventrals rounded. Tail feebly compressed, short; subcaudals in two rows. 
Distribution. Aru Islands; New Guinea; N. Australia. A single species.

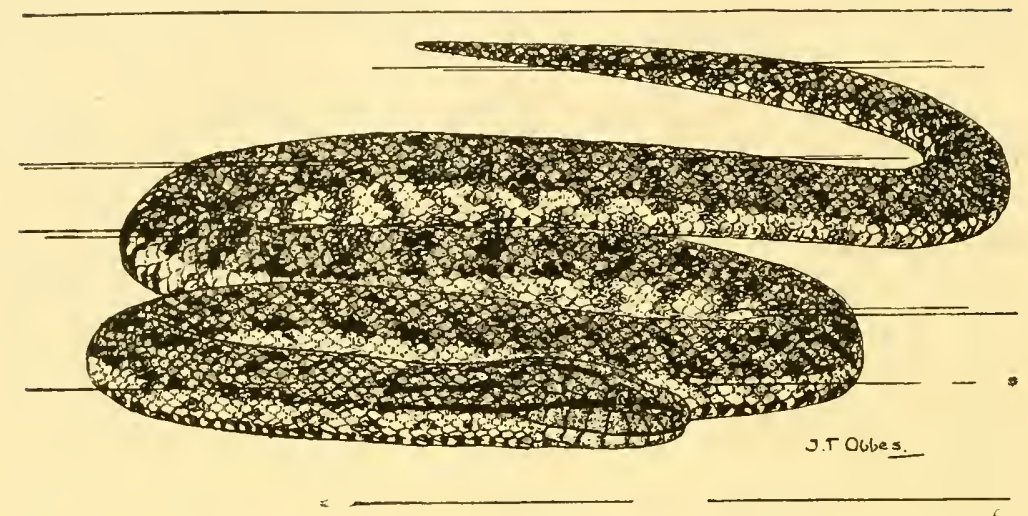

Fig. 73. Myron richardsoni Gray. $\times 4 / 5$.

I. Myron richardsoni Gray.

Myron richardsonii, Gray, Cat. Sn. 1849 , p. 70.

Myron richardsonii, Boulenger, Cat. Sn. III I\$96, p. 20.

Rostral more broad than deep; internasal single or double; frontal as long as its distance from the rostral or the tip of the snout, shorter than the parietals; one or two prae- and

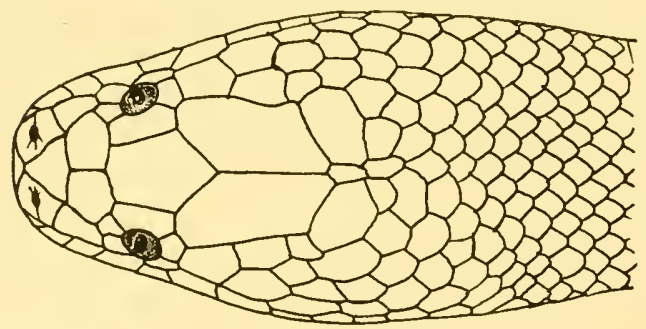

Fig. 74. Myron richardsoni Gray.

Upper view of head. two postoculars; loreal more long than deep; temporals $I+2$; eight or nine upper labials, fourth or fifth entering the eye; three or four lower labials in contact with the anterior chinshields, which are followed by two other pairs, in contact on the median line. Scales fecbly keeled, in 2 r rows; ventrals $132-140$; anal divided; subcaudals $30-40$.

Olive or grey above, with black transverse bands; two outer rows of scales yellowish; head dark; a dark streak through the eye to the nape. Lower surface yellowish or brownish, the ventrals edged with black anteriorly and with a dark median streak. Length of head and body $365 \mathrm{~mm}$.; tail $60 \mathrm{~mm}$. 
Type-specimen examined in the British Museum.

Habitat: Aru Islands (Kobroor); New Guinea (Lorentz river!'). - N. W. Australia!.

\section{Hip istes Gray. \\ (Gray, Cat, Sn. p. 77, I 849 ).}

Head small, not distinct from neck; eye very small; pupil vertically elliptic; shields of head small, parietals broken up; nasals divided, separated by a single internasal; nostril transverse; loreal present. Maxillary teeth $\delta$ or 9 , followed by two enlarged grooved teeth after an interspace. Body long, a little compressed, covered with smooth scales without pits, juxtaposed or imbricate, in 35-43 rows; ventrals narrow, with two keels. Tail short, a little compressed; subcaudals narrow, in two rows.

Distribution. Mouth of rivers and coasts of Burma, Pegu, Siam, Malay Peninsula; Sumatra.

A single species.

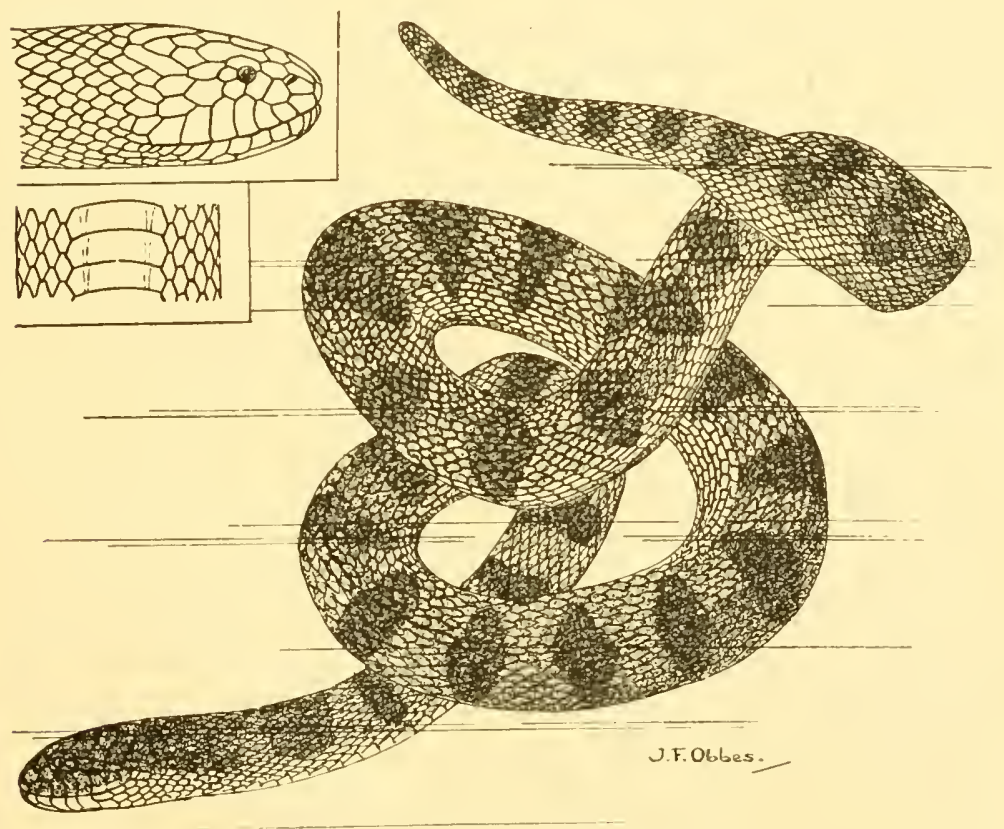

Fig. 75. Hipistes hydrinus (Cant.). $\times 3 / 4$. Side view of head; ventral shields with two keels.

I) Two specimens have a narrow shield between the two praefrontals. INDO-AUSTRALIAN REPTILES II. 


\section{Hipistes hydrinus (Cantor).}

Homalopsis hydrina, Cantor, Cat. Mal. Rept. 1847, p. 104, pl. XL, fig. 4. Hipistes hydrinus, Boulenger, Cat. Sn. III 1896, p. 24; Rept. Malay Penin. 1912 , p. 166, fig. 52 .

Frontal narrow, twice as long as broad, as long as or longer than its distance from the tip of the snout; a praeocular; a small postocular and a subocular; seven upper labials, separated from the eye; five lower labials in contact with the anterior chin-shields; posterior chin-shields very small. Scales in $35-43$ rows; ventrals I 53-I 72 ; anal divided; subcaudals $2 \mathrm{I}-35$.

Greyish or brownish above, with black transverse bands as broad as the interspaces or narrower. Lower surface whitish. Length of head and body $435 \mathrm{~mm}$; t tail $50 \mathrm{~mm}$.

Habitat: Sumatra (Ramunia in Deli!). - Pegu; Siam; Malay Peninsula; Penang; Singapore.

Feeds on fish; often captured in fishing-stakes. The head shows much resemblance with a Hydrophine snake.

Subfamily Dipsadomorphinae.

Key to the Indo-Australian genera.

A. Pupil vertical, or vertically elliptic.

1. Body compressed; maxillary teeth sub-equal; scales in $17-31$ rows, vertebral scales enlarged 45. Dipsadomorphus p. I94.

2. Body round; third and fourth maxillary teetl enlarged; scales in 17 or 19 rows, vertebral scales not enlarged........... 46. Psammodynastes p. 202.

F. Pupil horizontal.

I. One or two middle maxillary teeth enlarged; scales in 15 rows; vertebral scales slightly enlarged .............. 47. Dryophis p. 204.

2. Maxillary teeth subequal; scales in 15 rows;

vertebral scales not enlarged ....... 48. Dryophiops p. 208.

C. Pupil round.

I. Scales in 21 rows, the vertebral row enlarged. 49. Dipsadoides p. 210.

2. Scales in 17 rows, vertebrals not enlarged. 50. Chrysopelea p. 211.

Terrestrial or arboreal snakes.

\section{Dipsadomorphus Fitz.}

(Frtzinger, in Tschudi, Fauna Per. Herp. p. 55, 1845).

Head very distinct from neck; eye moderate or large; pupil 
vertically elliptic; posterior nasal concave. Maxillary teeth IO-I4, about equal, followed by two or three enlarged, grooved teeth; anterior mandibular teeth longest. Body compressed, covered with smooth scales, more or less oblique, with pits, in I7-3I rows, the vertebral row enlarged; ventrals angulate laterally. Tail long; subcaudals in two rows.

Distribution. Tropical Africa; S. Asia; Papuasia; Australia. Arboreal and nocturnal.

Key to the Indo-Australian species.

A. Anterior palatine teeth not or a little enlarged.

I. Scales in 19 (I7) rows.

a. Snout longer than eye; praeocular not

extending to upper surface of head ... I. D. multimaculatus p. I95.

b. Snout as long as the eye; praeocular ex-

tending to upper surface of the head ..2. D. drapiesii p. 196.

II. Scales in 21 (23) rows.

a. Snout longer than the eye.

I. Subcaudals S9-IIo; posterior chin-

shields as long as anterior or shorter. 3. D. dendrophilus p. 197.

2. Subcaudals I40-154; posterior chin-

shields longer than anterior... . 4. D. nigriceps p. I 99.

b. Snout as long as the cyc........ 5. D. jaspideus p. I99.

$B$. Anterior palatine teeth strongly enlarged.

I. Praeocular extending to upper surface of head.

aa. Scales in 23 (25) rows; ventrals $248-290$;

subcaudals II 4 -I59 . . . . . 6. D. cynodon p. 200.

b6. Scales in $19-23$ rows: ventrals $217-272$;

subcaudals I00--125 ........ 7. D. irregularis p. 201.

II. Praeocular not extending to upper surface

of head. . . . . . . . . . . 8. D. flavescens p. 202 .

\section{Dipsadomorphus multimaculatus (Boie).}

Dipsas multimaculata, Boie, Isis, IS27, p. 549.

Dipsadomorphus multimaculatus, Boulenger, Cat. Sn. III rS96, p. 63.

Roiga multimaculata, Barbour, Mem. Mus. Comp. Zool. Harv. Coll. XLIV I 9 I2, p. I 24 .

Snout longer than eye; rostral more broad than deep, visible from above; internasals shorter than praefrontals; frontal as long as or a little longer than its distance from the tip of the snout, shorter than the parietals; loreal as long as deep or a little more deep; a praeocular not extending to the upper 
surface of the head; two postoculars; temporals $2+2$ or $2+3$ $(\mathrm{I}+2)$; eight upper labials, third to fifth entering the eye; four or five lower labials in contact with the anterior chinshields; latter as long as or shorter than the posterior; anterior palatine teeth not much larger than the posterior. Scales in I9 (I7) rows, vertebral row much enlarged; ventrals 202-245; anal entire; subcaudals 8o-III.

Brown or greyish above, with two alternating series of round dark brown spots; on each side a series of smaller spots; two black bands on the head, diverging behind, a black streak from the eye to the corner of the mouth. Lower surface white, spotted with brown or marbled; along each side a row of brown spots. Length of head and body $585 \mathrm{~mm}$.; tail $\mathrm{I} 65 \mathrm{~mm}$.

N o m. in d i g. Ular puspo kadjang (mal.); oraj bedudak (sund.).

Habitat: Sumatra; Java (Buitenzorg, Depok, Semarang!, Salatiga!, Ambarawa, Mount Wilis 5000 feet, Kediri!, Tengger Mts. I 200 M., Pasuruan); Borneo (Bandjermassin); Celebes (Minahassa). - Penang; Malay Peninsula; Siam; Burma; Indo China; S. China.

\section{Dipsadomorphus drapiezii (Boie).}

Dipsas drapiezii, Boie, Isis, I827, p. 559.

Dipsadomorplius drapiezii, Boulenger, Cat. Sn. III 1896, p. 74.

Eye as long as snout; rostral more broad than deep, just visible from above; internasals shorter than the praefrontals; frontal as long as its distance from the tip of the snout, shorter than the parietals; loreal small or absent; a praeocular, in contact with the frontal or narrowly separated from it; two postoculars; temporals $2+2,2+3$ or $3+3$; eight upper labials, third to fifth or fourth and fifth entering the eye; five or six lower labials in contact with the anterior chin-shields; latter as long as or longer than the posterior; anterior palatine teeth not much enlarged. Scales in I9 rows, vertebrals enlarged; ventrals 250-276; anal entire; subcaudals I I4-I63.

Light brown above with dark brown transverse spots or brown with yellow or red, dark-edged transverse bands, each band ending in a white spot. Lower surface brownish-white, uniform or speckled with brown and with two brown longitudinal lines, sometimes indistinct. Total length $1524 \mathrm{~mm}$.

Habitat: Sumatra (Labuan, Deli!, Indragiri, Djambi!, 
Benakat in Palembang, Kaju tanam!); Borneo (Sandakan, Kuching, Baram, Pangkalan ampat, Sarawak); IV. Java! (Mt. Parang); Ambon. - Singapore; Malacca.

\section{Dipsadomorphus dendrophilus (Boie).}

Dipsas dendrophila, Boie, Isis, I 827, p. 549.

Dipsadomorphus dendrophilus, Boulenger, Cat. Sn. III I\$96, p. 70.

Boiga dendrophila, Barbour, Mem. Mus. Comp. Zool. Harv. Coll. XLIV 1912 p. 125.

Snout longer than eye; rostral more broad than deep, visible from above; internasals as long as or shorter than the praefrontals; frontal as long as or slightly shorter than its distance from the tip of the snout; loreal as long as deep or more long; a praeocular extending to the upper surface of the head, not reaching the frontal; two postoculars; temporals $2+2$ or $2+3$; eight (nine) upper labials, third to fifth entering the eye; four or five lower labials in contact with the anterior chin-shields; latter as long as or longer than the posterior; anterior palatine teeth not much larger than the posterior. Scales in 2 I (23) rows, vertebral row enlarged; ventrals 209-239; anal entire; subcaudals 89 - I IO.

Black above, with yellow transverse bands, continuous or not extending across the back; labials yellow, with black edges. Lower surface black or bluish, uniform or speckled with yellow; throat yellow. Total length $2310 \mathrm{~mm}$.

Nom. indig. Ular katam tebu (mal.); Oraj taliwangsa or Oraj santja manuk (sund.).; Ular chin chin mas (Borneo); Ulentipojo (Toradja-name).

H a b it a t: Nias!; Batu Islands (Pulu Tello!); Sumatra (Labuan, Stabat, Deli!, Serdang!, Langkat, Assahan, Indragiri, Djambi!, Tandjong Laut! and Benakat in Palembang, Ringgat!, Batang Singalang!, Silago, Ajerbangis!, Padang!); Siak!; Riou; Banka!; Borneo (Labuan, Bulangan river, Sandakan Bay, Kudat, Sebruang Valley, Santubong, Kuching, Sarawak, Sintang, Singkawang, Pontianak river, Bandjermassin!, Balikpapan, Muara Djawa!, Samarinda!); Java (Buitenzorg, Depok, Anjer, Pekalongan!); Celebes (Manado!, Kema, Kandari, Macassar). Philippines; Singapore; Penang; Malay Peninsula; Lower Siam.

Feeds on small mammals, lizards, frogs, snakes, fish.

Nocturnal. 

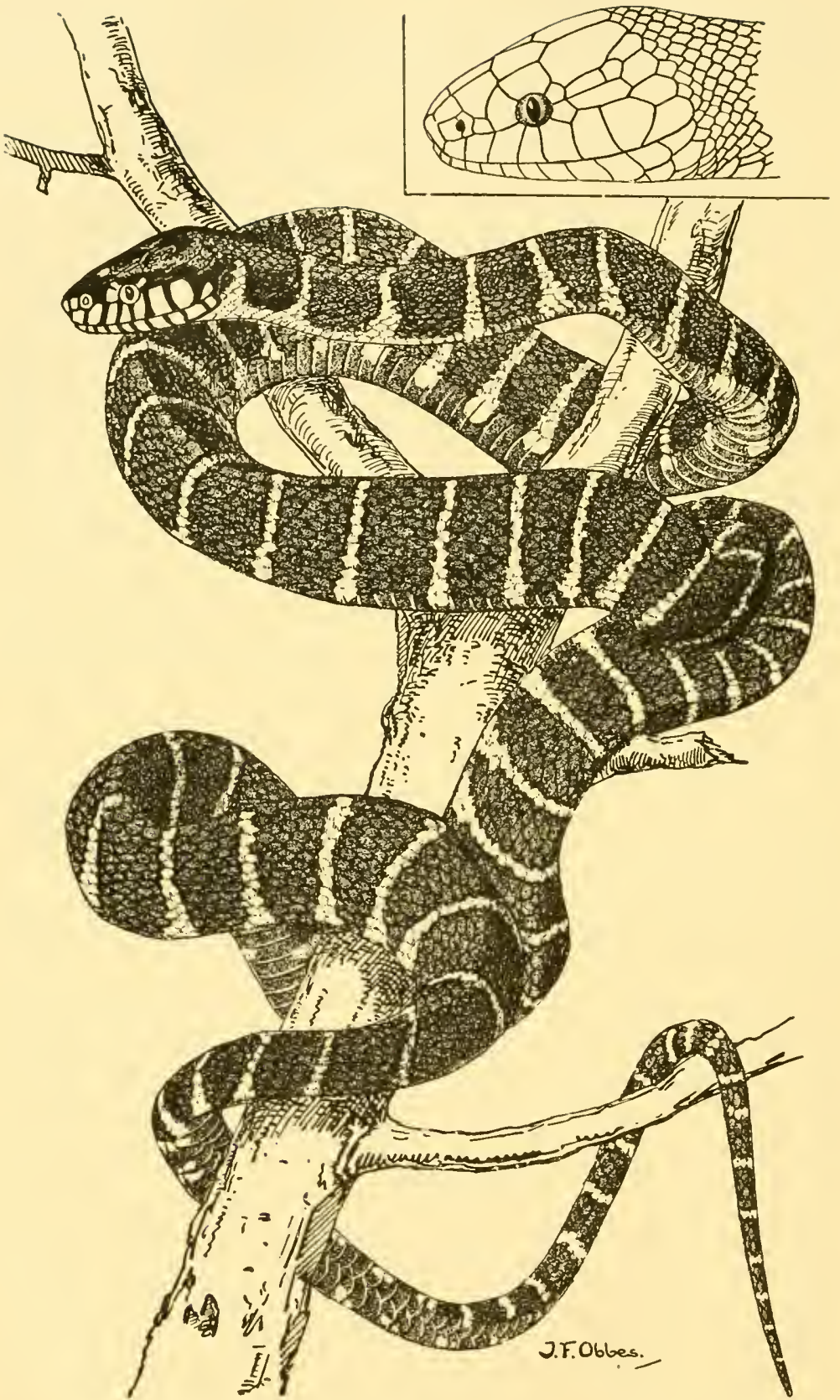

Fig. 76. Dipsadomorphus dendrophilus (Boie) $\times 1 / 2$. Side view of head. 


\section{Dipsadomorphus nigriceps (Gthr.).}

Dipsas nigriceps, Günther, Ann. Nat. Hist. (3) XII 1863, p. 359.

Dipsadomorphus nigriceps, Boulenger, Cat. Sn. III IS96, p. 72.

Snout longer than eye; rostral more broad than deep, visible from above; internasals shorter than the praefrontals; frontal as long as its distance from the tip of the snout, shorter than the parietals; loreal as long as deep or more long; a praeocular, in contact with the frontal or narrowly separated from it; two postoculars; temporals $\mathbf{I}+2$ or $2+3$ or $3+3$; eight upper labials, third to fifth entering the eye; four or five lower labials in contact with the anterior chin-shields; latter often much shorter than the posterior; anterior palatine teeth not much enlarged. Scales in 2 I rows, vertebrals much enlarged; ventrals 240-263; anal entire; subcaudals 140-1 54 .

Brownish or reddish-grey, uniform or speckled with dark brown, sometimes a series of black spots on the back; head dark or reddish; upper lip light. Lower surface grey, with dark dots. Length of head and body $1240 \mathrm{~mm}$.; tail $410 \mathrm{~mm}$.

Habitat: Simalur!; Nias!; Mentawei Islands (Siberut!); Sumatra (Upper Langkat, Tandjung Laut in Palembang); Borneo (Bongon); Java (Gadok). - Malay Peninsula; Siam.

\section{Dipsadomorphus jaspideus (Dum. \& Bibr.).}

Triglyphodon jaspidentm, Duméril \& Bibron, Erp. Gén. VII I 854, p. 1093. Dipsadomorphus jaspideus, Boulenger, Cat. Sn. III IS96, p. 73.

Eye as long as snout; rostral more broad than deep, just visible from above; internasals as long as praefrontals; frontal longer than its distance from the tip of the snout, as long as or shorter than the parietals; loreal as long as deep or more deep; a praeocular narrowly scparated from the frontal; two postoculars; temporals $2+2$; eight upper labials, third to fifth entering the eye; four or five lower labials in contact with the anterior chin-shields; posterior chin-shields as long as the anterior or longer, separated from one another by scales; anterior palatine teeth a little enlarged. Scales in 21 rows, vertebrals much enlarged; ventrals 243-266; anal entire; subcaudals 140-i66.

Brown or reddish above, speckled with black or dark brown and with black transverse bars, interrupted on the vertebral line, sometimes indistinct; a series of large, white spots on 
each side, partly on the ventrals; shields of head with black spots, the larger light-edged; on the occiput a black, lightedged longitudinal streak. Lower surface yellowish, speckled with brown. Length of head and body $1030 \mathrm{~mm}$; tail $370 \mathrm{~mm}$.

Habitat: Nias!; Sumatra (Gambir in Deli!, Pagarkaja, Muara Lakitan in Palembang); Java!; Borneo (Sandakan Bay!, Labuan, Kuching, Saribas, Baram, Pankalan ampat, Balikpapan). - Singapore; Penang; Malay Peninsula.

\section{Dipsadomorphus cynodon (Boie).}

Dipsas cynadon, Boie, Isis, I 827, p. 559 .

Dipsadomorphus cynodon, Boulenger, Cat. Sn. 111 I 896, p. 78.

Snout longer than eye; rostral more broad than deep, just visible from above; internasals shorter than the praefrontals; frontal as long as or longer than its distance from the tip of the snout, shorter than the parietals; loreal as long as deep or more long; a praeocular, extending to the upper surface of the head, narrowly separated from the frontal; two postoculars; temporals $2+2,2+3$ or $3+3$; eight to ten upper labials, third to fifth, fourth and fifth, fourth to sixth or fifth to seventh entering the eye; four or five lower labials in contact with the anterior chin-shields; latter smaller than the posterior; anterior palatine teeth strongly enlarged. Scales in 23 (25) rows, vertebrals strongly enlarged; ventrals 248-290; anal entire; subcaudals I I4-I 59.

Yellow or reddish-brown above, with dark brown or black transverse spots or bars, sometimes absent, or blackish above with lighter transverse bars and a series of white spots on the sides; a dark streak on each side of the head behind the eye; labials sometimes with dark vertical lines. Lower surface yellow, uniform or speckled with brown, or entirely black. Total length $2450 \mathrm{~mm}$.

Habitat: Nias!; Mentawei Islands (Sipora); Sumatra! (Langkat, Deli, Indragiri); Banka!; Borneo (Sandakan, Baram, Kapuas river, Sebruang Valley, Sarawak, Kuching, Busau, Santubong, Rejang river, Balikpapan, Samarinda!); Java (Batavia, Salatiga!); Bali; Flores!. - Philippines; Malay Peninsula; Singapore; Burma; Assam; Siam. 


\section{Dipsadomorphus irregularis (Merr.).}

Coluber irregularis, Merrem, Bechst. Uebers. Lacép. IV I8o2, p. 239, pl. XXXVII, fig. I.

Dipsadomorphus irregularis, Boulenger, Cat. Sn. III 1896, p. 75 (s. syn.). Boiga irregnlaris, Barbour, Mem. Mus. Comp. Zool. Harv. Coll. XLIV I9I2, p. I26.

Snout longer than eye; rostral more broad than deep, visible from above; internasals shorter than the praefrontals; frontal as long as its distance from the rostral, shorter than the parietals; loreal as long as deep or more long; a praeocular, extending to the upper surface of the head, in contact with the frontal or narrowly separated from it; two postoculars; temporals $2-3+3-4$; nine (eight or ten) upper labials, fourth to sixth or third to fifth or fifth to seventh entering the eye; four or five lower labials in contact with the anterior chinshields; latter shorter than the posterior; anterior palatine teeth strongly enlarged. Scales in $19-23$ rows, vertebrals enlarged; ventrals 2I $7-272$; anal entire; subcaudals $100-125$ ( 69 or 75 ), of which some may be single.

Yellowish, grey, brown or olive above, uniform or with dark transverse bands or spots; usually a dark streak on each side of the head behind the eye; upper labials yellow, usually dark-edged. Lower surface yellowish, sometimes speckled with dark; subcaudals sometimes black. Length of head and body I700 $\mathrm{mm}$. ; tail $450 \mathrm{~mm}$.

II a b it at: Celebes (Gorontalo, Minahassa, Manado!, Kema, Kandari, Barabatuwa, Macassar); Sangir Islands; Ternate!; Halmahera!; Batjan!; Salawatti; Misol; Ceram!; Buru!; Ambon!; Goram; Kei Islands; Aru Islands; New Guinea (Sorong, Fak Fak, Passim, Dorei, Mt. Arfak, Mansinam, Manokwari, Sermowai river!, Humboldt Bay!, Lake Sentani, Mimika, Stekwa and Lorentz! rivers, Fly river, Hula, Kapa Kapa, Bara Bara, Dinawa in Owen Stanley Range 4000 feet, Fife Bay, S. of Huon Gulf, Tami, Bogadjim, Bongu, Stephansort, Astrolabe Bay, Lialun, Berlinhafen, Simpsonhafen, Simbang, Seleo Island, Yule Island, Jobi); Schouten Islands (Mysore). - Ferguson, Trobriand and Woodlark Islands; Louisiade Archipelago; Islands of Torres Straits; Solomon Islands; Bismarck Archipelago.

Note. A form from German New Guinea: Stephansort and Seleo Island has been called by MÉHELY ${ }^{1}$ ) Dipsadomorphus irre-

1) Termesz. Füzetek XXI I\$g\$, p. I 72. 
gularis var. papuanus. Its colour is somewhat different from the usual one. Pinkish-grey above, each scale speckled with fine brown dots; ventrals and subcaudals speckled with brown. In the stomach of one of those specimens were 7 shells of fowl's eggs.

\section{Dipsadomorphus flavescens (Dum. \& Bibr.).}

Triglyphodon flavescens, Duméril \& Bibron, Erp. Gén. VII I 854, p. Io80. Dipsadormorphus Havescens, Boulenger, Cat. Sn. III 1896, p. 77.

Rostral triangular, visible from above; loreal small; praeocular not extending to the upper surface of the head; three postoculars; temporals $2+4$; eight upper labials. Scales in I 9 rows, vertebrals enlarged; ventrals 260; anal entire; subcaudals i 6.

Brown or yellowish-brown above, with indistinct angular spots or transverse bands. Lower surface lighter. Length of head and body $887 \mathrm{~mm}$; tail $234 \mathrm{~mm}$. (After DUMÉril \& BiBRON; not seen by me).

$\mathrm{Hab}$ it at: Celebes (Macassar).

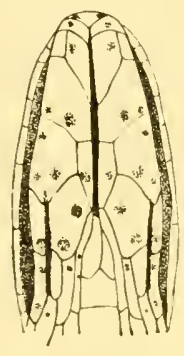

Fig. 77. Psammodynastespictus Gthr.

\section{Ps a m modynastes Günther.}

(Günther, Cat. Col. Sn. p. 140, 1858 ).

Head distinct from neck; canthus rostralis angular; eye large; pupil vertically elliptic; nasal single; frontal very narrow. Maxillary teeth 9-I I, third or third and fourth enlarged, separated from the following by a short interspace, last enlarged and grooved; anterior mandibular teeth strongly enlarged. Body round, covered with smooth scales, without pits, in 17 or 19 rows; ventrals rounded. Tail short; subcaudals in two rows. Chin-shields $\times 2$. Distribution. S. E. Asia.

Key to the Indo-Australian species.

A. Lower labials separated by the chin-shields... 1. P. pulverulentus p. 202. $B$. Third lower labial large, bordering the mental groove behind the anterior chin-shields (fig. 77). 2. P. pictus p. 203.

\section{Psammodynastes pulverulentus (Boie).}

I'sammophis pulverulenta, Boie, Isis, 1827 , p. 547.

Psammodynastes pulverulentus, Boulenger, Cat. Sn. III I $\$ 96$, p. I'72 (s. syn.). Anisodon Lilljchorgi, Rosèn, Ann. Nat. Hist. (7) XV 1905, p. 176. 
Snout short, pointed or slightly turned up in the adult. Rostral more broad than deep; internasals shorter than the praefrontals; frontal two times or two times and a lialf as long as broad, narrower than the supraocular, longer than its distance from the tip of the snout, shorter than the parictals; loreal as long as deep, sometimes vertically divided; one or two prae- and two to four postoculars; temporals $2+3$ or $2+2$; eight upper labials, third to fifth entering the eye; three or four lower labials in contact with the anterior chin-shields; two smaller pairs of chin-shields posteriorly. Scales in 17 (19) rows; ventrals I46-I75; anal entire; subcaudals 44-70.

Dark brown or reddish-brown above, with small dark and light spots; a dark band along each side; head with symmetrical longitudinal markings, a dark band on each side of the head, passing through the eye. Lower surface speckled with brown and with dark lines and spots. Length of head and body $497 \mathrm{~mm}$; tail $\mathrm{I} 2 \mathrm{~S} \mathrm{~mm}$.

Nom. in dig. Duwata (Toradja-name).

Habitat: Engano; Sumatra (Peudawa in Atjeh, Labuan, Bindjey, Medan!, Upper Langkat, Laut Tador, Djambi!, Palembang, Gunung Sugei in Lampong district); Banka; Riou!; Natuna Islands; Borneo (Baram river, Kina Balu, Sebruang Valley, Pangkalan Ampat, Singkawang, Sintang, Kapuas river, Putus Genting!, Barabei, Bandjermassin); Java (Gadok, Sindanglaia, Tjibodas 1425 M.!, Mt. Gedeh 4500 feet, Mount Wilis 5000 feet, Volcano Pengalengan 4000 feet, Tengger Mits. I 200 M.); Lombok; Flores!; Sumba; Celebes (Sudara 4450 feet, Upper Bone Valley, Buol, Matinang Mts. I70o feet, Posso! 2000 feet); Togian Islands; Sangir Islands (Siao). - Malay Peninsula; Siam; Burma; Assam; E. Himalayas; Philippines; Indo China; Formosa.

Ovoviviparous; feeds on lizards and frogs. Still common at elevations over 5000 feet.

\section{Psammodynastes pictus Gthr.}

Psammodynastes pictus, Gïnther, Cat. Col. Sn. IS58, p. 25 I.

Psammodynastes pictus, Boulenger, Cat. Sn. III I 896 , p. I 74 (s. syn.).

Internasals as long as or a little shorter than the praefrontals; frontal two and a half or three times as long as broad, narrower than the supraocular, as long as the parietals; loreal 
as long as deep; two or three prae- and three or four postoculars; eight upper labials, third to fifth entering the eye; third lower labial very large, bordering the mental groove behind the anterior chin-shields. Scales in 17 rows; ventrals I52-I7I; anal entire; subcaudals 60-80.

Yellowish, reddish or pale brown above, with dark transverse bands between two light stripes or a dark vertebral band; a dark streak on each side of the head, passing through the eye and across the rostral, edged above with white in

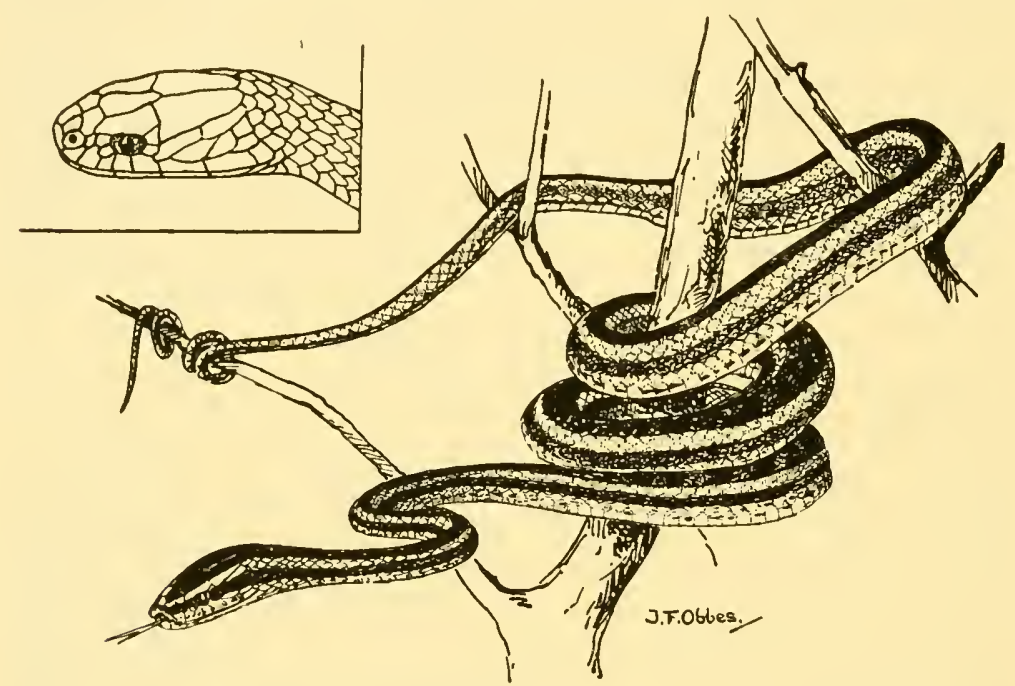

Fig. 78. Psammodynastes pictus Gthr. Nat. size. Side view of head.

young specimens. Lower surface whitish, speckled with brown and with brown dots. Length of head and body $400 \mathrm{~mm}$.; tail is $8 \mathrm{~mm}$.

Nom. indig. Ular percha or U. bêrang (Borneo).

Habitat: Simalur!; Sumatra (Perlak in Atjeh, Tandjong Morawa, Labuan, Medan!, Deli, Langkat, Gunung Sahilan!, Ajer bangis!); Banka; Biliton; Riou!; Borneo! (Sandakan Bay, Labuan, Mt. Dulit, Rejang river, Kuching, Kidi district, Kapuas river, Telang, Balikpapan). - Malay Peninsula.

\section{Dryophis Dalman.}

(Dalman, Oefvers, of Zool. Arb. Stockholm, 1822).

Head long, distinct from neck; canthus rostralis strong; lores 
concave; eye large; pupil horizontal; nasal single, frontal narrow. Maxillary teeth I2-I5, one or two middle ones enlarged, separated from the posterior by an interspace; one or two last grooved, large and situated below the posterior border of the eye; three or four anterior mandibular teeth increasing in length, posterior small. Body long, compressed, covered with smooth scales, in 15 rows, without pits, oblique; the vertebral row enlarged; ventrals rounded. Tail long; subcaudals in two rows.

Distribution. S. E. Asia.

Arboreal; ovoviviparous.

Key to the Indo-Australian species.

$A$. Snout without appendage.

I. Less than 200 ventral shields; subcaudals

115-156................... . . . xanthozona p. 205.

II. Usually more than 200 ventral shields; sub-

caudals $15 \mathrm{I}-207$.

I. Frontal longer than the parietals; anal divided

(rarely entire)...............2. D. prasinus p. 206.

2. Frontal as long as the parietals; anal usu-

ally entire............... 3. D. fasciolatus p. 207.

B. Snout with a rostral appendage..........4. D. mycterizans p. 208.

\section{Dryophis xanthozona Boie.}

Dryophis xanthozona, Boie, Isis, 1827, p. 545.

Dryophis xanthozona, Boulenger, Cat. Sn. III r896, p. 180.

Snout pointed, projecting, nearly twice as long as the eye; internasals in contact with the rostral; frontal longer than its distance from the tip of the snout, as long as the parietals; three or four small loreals in a row; a praeocular in contact with the frontal; two postoculars; temporals $2+2$; eight or nine upper labials, fourth and fifth or fourth to sixth entering the eye; four lower labials in contact with the anterior chinshields; latter shorter than posterior. Scales in 15 rows; ventrals I 86-I95; anal entire (rarely divided); subcaudals I I5-I56.

Green or purple above; greenish or purplish below, with a yellow streak on each side and two indistinct stripes in the middle, separated by a purple streak. Length of head and body $752 \mathrm{~mm}$; tail $410 \mathrm{~mm}$.

Ha bitat: Java (Depok, Salak, Kediri!). - Penang; W. Siamese Malay States.

Much rarer than the following species. 


\section{Dryophis prasinus Boie.}

Dryophis prasinus, Boie, Isis, 1827, p. 545 .

Dryophis prasinus, Boulenger, Cat. Sn. III I 896 , p. ISo (s. syn.).

Snout sharply pointed, projecting, more than twice as long as the eye; internasals usually in contact with the labials; one to four small loreals in a row between the praefrontal and the labials; frontal as long as or a little longer than its distance from the tip of the snout, longer than the parietals; a praeocular, in contact with the frontal; two postoculars; temporals $2+2$ or $3+3(I+2)$; nine upper labials, fourth to sixth

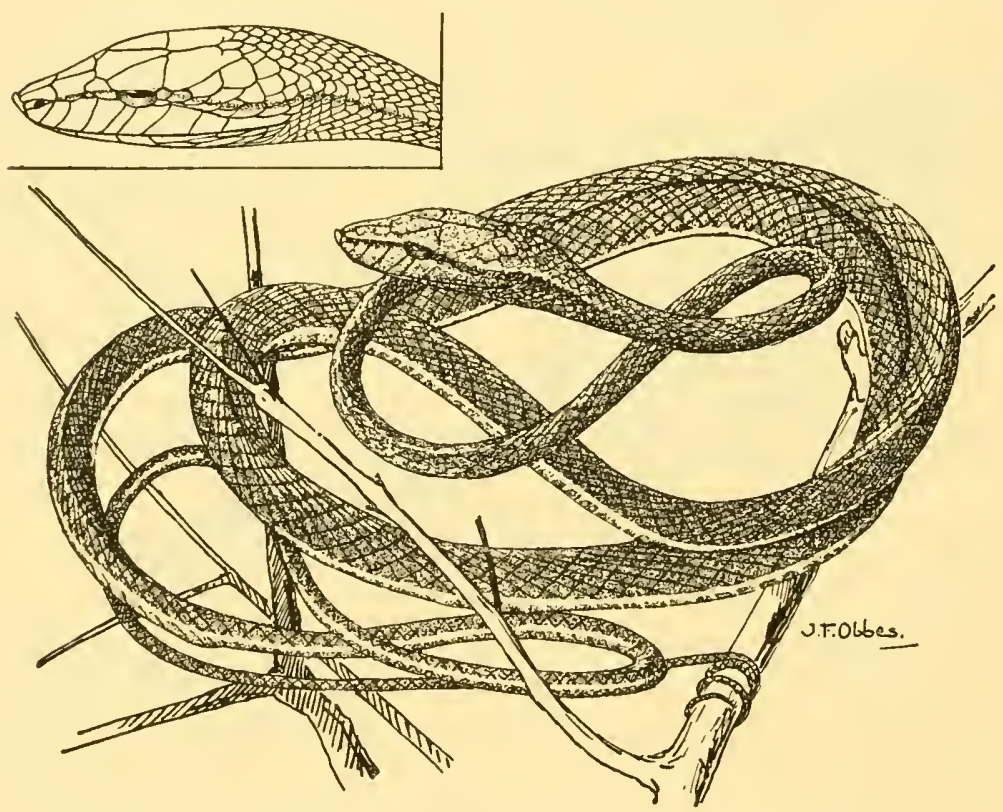

Fig. 79. Dryophis prasinns Boie. $\times 3 / 5$. Side view of head.

entering the eye; four lower labials in contact with the anterior chin-shields; latter shorter than the posterior. Scales in I 5 rows, those of the sacral region usually keeled; ventrals $194-235$; anal divided (rarely entire); subcaudals I 5 I-207.

Green, olive or greyish-brown; skin of the neck black and white. Lower parts greenish or greyish; a yellow line on each side. Length of head and body I $190 \mathrm{~mm}$; tail $600 \mathrm{~mm}$.

Nom. indig. Sawa lèul (Simalur); Oraj gadung (Sund., Buitenzorg); Puchok pisang, Ular daun (Kuching); Ulendui, baluntete and lewora (Toradja-names). 
Habitat: Simalur!; Nias!; Mentawei Islands (Sipora); Sumatra (Sabang on Pulu Weh!, Atjeh, Bindjey, Labuan, Medan!, Brastagei!, Serdang!, Pangkalan Brandan!, Assahan, Langkat, Laut Tador; Bedagei; Battak Highlands! 800-I00o M., Indragiri, Djambi!, Kertadjaja and Tandjung Laut in Palembang, Gunung Sugei in Lampong district, Gunung Sahilan!, Sidjundjung!, Taluk!, Ringgat!, Kaju tanam!, Surian, Silago, Rau, Kalung!, Ajerbangis!, Padang, Agam, Padang Highlands!, Indrapura, Tandjong); Banka!; Riou!; Natuna Islands; Borneo (Bulangan river, Sandakan Bay, Baram river, Mt. Dulit, Sebruang Valley, Buntok, Brooketon, Sadong, Banting, Kuching, Tegora, Busam, Landak!, Sintang, Singkawang, Pontianak, Bandjermassin!, Samarinda!, Kapuas river); Sibutu Island; Java (Tangerang!, Batavia, Buitenzorg!, Anjer, Mt. Salak, Depok, Preanger!, Sukabumi!, Pekalongan!, Gunung Ungaran!, Temangung!, Ambarawa!, Salatiga!, Wonosobo, Malang!, Mount Wilis, Kraksaän!, Ngawi, Kediri!, Tengger Mts. I 200 M.); Lombok; Sumbawa; Buton; Celebes (Gorontalo, Minahassa, Manado!, Kema, Marapo river near Batulappa, Kandari, Muna Raha, Dongala Kabonga, Macassar!); Sangir Islands (Siao, Tabukan); Ternate. - Philippines; Indo China; Burma; Assam; Siam; Malay Peninsula; Penang; Singapore; E. Himalayas.

Feeds chiefly on lizards and frogs.

\section{Dryophis fasciolatus (Fischer).}

Tragops fasciolatus, Fischer, Arch. f. Nat. I $\$ \delta_{5}$, p. 66, pl. V, fig. 4 . Dryophis fasciolatus, Boulenger, Cat. Sn. III i 896, p. I 82 .

Snout pointed, projecting, about twice as long as the eye; internasals in contact with the first or second labial; frontal as long as or shorter than its distance from the tip of the snout, as long as the parietals; two or three loreals in a row; a pracocular in contact with the frontal; two postoculars; temporals $2+2$ or 3 ; nine upper labials, fourth to sixth entering the eye; four lower labials in contact with the anterior chinshields; latter shorter than the posterior. Scales in I5 rows; ventrals $2 \mathrm{II}-23 \mathrm{I}$; anal usually entire; subcaudals I78-I94.

Grey above, with black spots, arranged in transverse bands anteriorly; shields of the head and labials with dark brown spots; a dark band from the rostral to the sides of the neck, passing through the eye. Lower surface with a grey, black- 
edged band in the middle, a white streak on each side. Length of head and body $900 \mathrm{~mm}$; tail $500 \mathrm{~mm}$.

Type-specimen examined in the British Museum.

Habitat: Sumatra (S. Atjeh, Labuan, Deli!, Padang I $500-3000$ feet); Natuna Islands!; Borneo (Baram river, Kuching, S. E. Borneo!).

\section{Dryophis mycterizans (L.).}

Coluber mycterizans, Linné, Mus. Ad. Frid. 1754, p. 28, pl. V, fig. I ; pl. XIX, fig. 2. Dryophis mycterizans, Boulenger, Cat. Sn. III I896, p. 182.

Snout pointed, projecting, ending in a dermal appendage formed by the rostral and shorter than the eye; snout without the appendage twice or more the diameter of the eye; internasals and praefrontals in contact with the labials; no loreal; frontal as long as the parietals or a little longer, in contact with the praeocular; two praeoculars; a subocular, or one praeocular and two suboculars; two postoculars; temporals I +2 or $2+2$; eight upper labials, fifth entering the eye; four lower labials in contact with the anterior chin-shields; latter shorter than the posterior. Scales in 15 rows; ventrals 172-203; anal divided; subcaudals I40-I74.

Green or pale brown above, the skin of the neck between the scales black and white; a yellow line on each side. Length of head and body $940 \mathrm{~mm}$.; tail $560 \mathrm{~mm}$.

Habitat: Java!. - Siam; Burma; Ceylon; India.

\section{Dryophiops Boulenger.}

(Boulenger, Cat. Sn. III p. I93, 1896).

Head distinct from neck, with distinct canthus rostralis; eye large; pupil horizontal; nasal entire; frontal narrow. Maxillary teeth 20, subequal, the last two or three slightly enlarged and grooved; anterior mandibular teeth enlarged. Body slender, compressed, covered with smooth scales, in I 5 rows, oblique, with pits; ventrals with a keel and a notch on each side. Tail long; subcaudals in two rows, keeled and notched like the ventrals.

Distribution. S. E. Asia.

A single species. 


\section{Dryophiops rubescens (Gray).}

Dipsas rubescens, Gray, 11l. Ind. Zool. II I834, pl. LXXXIV, fig. 2. Dryophiops rubescens, Boulenger, Cat. Sn. III I 896 , p. I 94 (s. syn.).

Rostral two times as broad as deep, just visible from above; internasals shorter than the praefrontals; frontal as long as its distance from the tip of the snout, shorter than the parietals; loreal long; one praeocular, in contact with the frontal; two or three postoculars; temporals $2+2$; nine upper labials, fourth to sixth entering the eye; four or five lower labials in contact with the anterior chin-shields, posterior larger. Scales

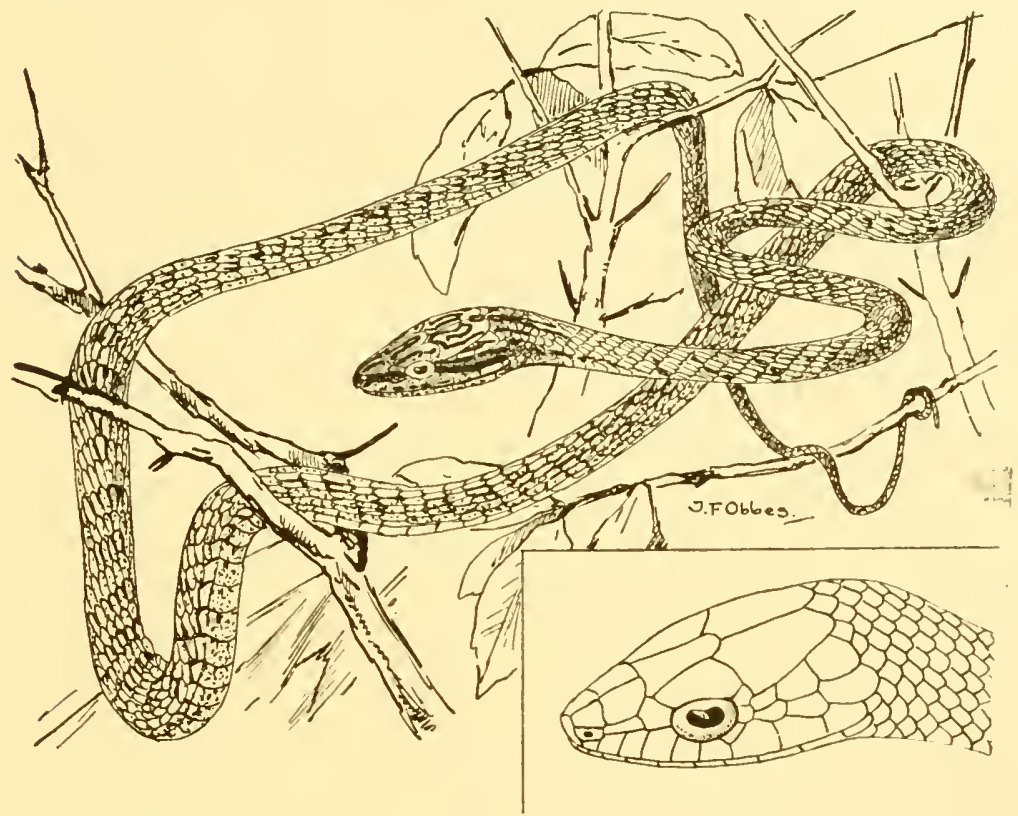

Fig. 8o. Dryophiops rubescens (Gray). Nat. size. Side view of head.

in 15 rows; ventrals IS6-I99; anal divided; subcaudals II I - I 36 .

Reddish-brown above, with small black spots; on the head wavy longitudinal markings and a median streak on the occiput and neck; a dark streak on each side passing through the eye; labials with black spots. Lower surface yellow or greenish, reddish or brownish posteriorly, dotted with dark and with or without small dark spots. Length of head and body $540 \mathrm{~mm}$.; tail $210 \mathrm{~mm}$. 
Habitat: Mentawei Islands (Sipora); Sumatra (Lower Langkat); Natuna Islands; Borneo (Sarawak, Sandakan, Samarinda!); E. Java (Sumber Arum!). - Penang; Malay Peninsula; Siam.

Arboreal.

49. Dipsadoides Annandale.

(Annandale, Journ. $\Lambda$ siat. Soc. Bengal I p. 212, I905).

Head distinct from neck; eye large; pupil round; nasal undivided. Maxillary teeth 6 , followed by a pair of moderate, almost vertical grooved teeth after an interspace; mandibular teeth subequal. Body strongly compressed, covered with 2 I rows $\left.{ }^{1}\right)$ of scales with pits, the vertebral row enlarged; ventrals keeled on each side. Tail slender; subcaudals in two rows.

Distribution. Indo-Australian Archipelago.

A single species.

\section{Dipsadoides decipiens Annandale.}

Dipsadoides decipiens, Annandale, Journ. Asiat. Soc. Bengal I 1905, p. 213 , fig. 3.

Head small, flattened; snout short; eye prominent, almost as long as the snout; nostril large, directed backwards. Rostral more broad than deep, just visible from above; internasals larger than praefrontals; frontal more long than broad, as long as its distance from the tip of the snout, shorter than the parietals; praeocular large; postocular small; supraocular very large; loreal more deep than long; temporals $2+2$; eight upper labials, third to fifth entering the eye; five lower labials in contact with the anterior chin-shields; latter followed by a second large pair, which are separated from one another ${ }^{2}$ ). Scales narrow, oblique, in 2 I rows, dorsal row enlarged; ventrals 258; anal entire; subcaudals 152 .

Pale brown above, spotted and marbled with dark brown and dull yellow, and with irregular dark bars; head marbled with dark brown and with dark brown spots. Lower surface dull yellow, marbled posteriorly with dark brown; chin and throat spotted with dark brown. Length of head and body $603 \mathrm{~mm}$.; tail $265 \mathrm{~mm}$.

I) In the original description: I9 rows.

2) In the description: both in contact with their neighbours. 
Type-specimen received from the Indian Museum, Calcutta, examined.

Habitat: "Malay Archipelago"! (Java ?).

Only one single specimen known.

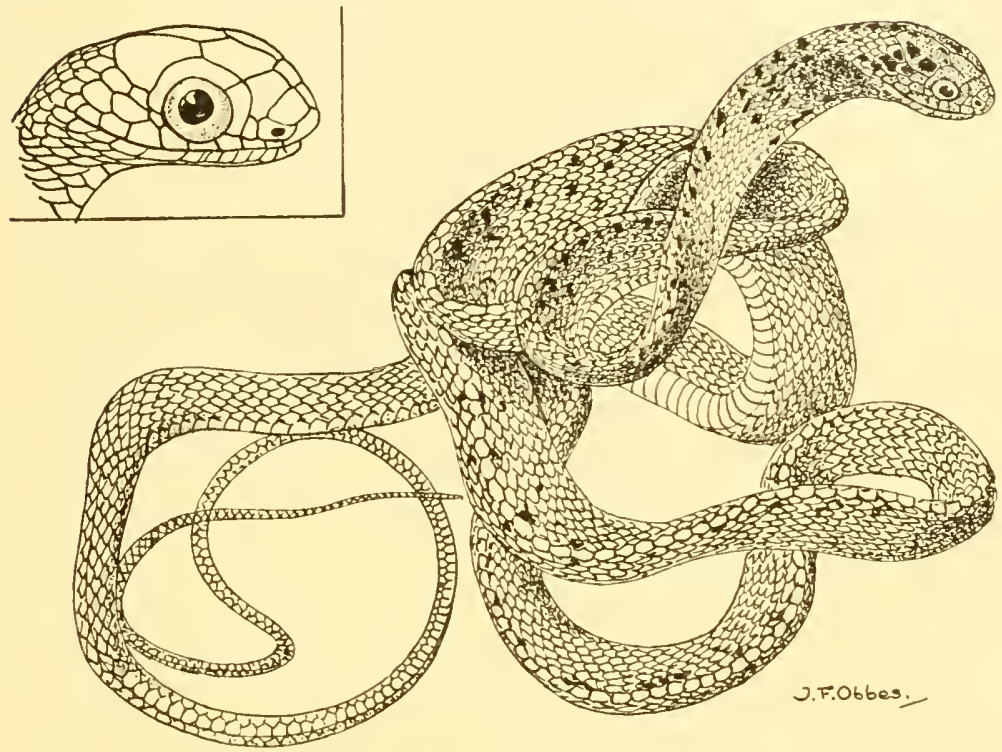

Fig. 81. Dipsadoides decipiens Annandale. $\times 3 / 4$. Side view of head.

50. Chrysopelea Boie.

(BoIk, Isis, p. 520, I 827 ).

Head distinct from neck; eye large; pupil round. Maxillary teeth 20-22, last three longest and grooved; anterior mandibular teeth longest. Body long, compressed, covered with smooth or feebly keeled scales, oblique, with pits, in 17 rows; ventrals with a keel and a notch on each side. Tail long; subcaudals in two rows, keeled and notched.

Distribution. S. E. Asia.

The tree-snakes belonging to the genus Chrysopelea are known as Flying-Snakes, because they can suddenly descend from trees, keeping their bodies very rigid. The part of the ventral scales between the lateral keels can be made concave.

Key to the Indo-Australian species.

$A$. Three or more dorsal rows of scales feebly keeled;

subcaudals 146-186; ventrals 192-221.... I. C. rhodopleuron p. 2 I2. 
h. Scales smooth or feebly keeled; subcaudals 106-r 39 ; ventrals $198-238 \ldots . . .2$. C. ornata p. 2 I2.

C. Scales smooth; subcaudals 98 -r 20 ; ventrals

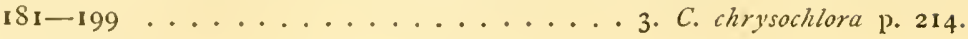

\section{Chrysopelea rhodopleuron Boie.}

Chrysopelea rhodopleuton, Boie, Isis, 1827, p. 547.

Chrysopelea rhodopleuron, Boulenger, Cat. Sn. III I896, p. I95 (s. syn.).

Snout depressed; rostral more broad than deep, just visible from above; internasals shorter than praefrontals; frontal as long as its distance from the tip of the snout, shorter than the parietals; loreal long; a praeocular, sometimes in contact with the frontal; two postoculars; temporals $2+2$; nine upper labials, fifth and sixth entering the eye; four or five lower labials in contact with the anterior chin-shields; latter shorter than the posterior. Scales in 17 rows, three or more median rows feebly keeled; ventrals I92-22I; anal divided; subcaudals I46-i 86.

Olive-brown, greenish or black above, without or with light centres in the scales; outer row of scales and sides of ventrals sometimes red, black-edged; a dark streak on each side of the head; upper lip white. Lower surface pale green or yellow, often with a black streak along the tail. Length of head and body $780 \mathrm{~mm}$.; tail $380 \mathrm{~mm}$.

Ha bitat: Sangir Islands; Batjan!; Misol; Ceram!; Buru; Ambon!; Banda; Timor Laut.

\section{Chrysopelea ornata (Shaw).}

Coluber ornatus, Shaw, Zool. III I 802, p. 477.

Chrysopelea ornata, Boulenger, Cat. Sn. III I 896 , p. I96 (s. syn.).

Snout depressed; rostral more broad than deep, visible from above; internasals about as long as praefrontals; frontal almost as long as its distance from the tip of the snout, as long as or a little shorter than the parietals; loreal long, sometimes fused with the praefrontal; a praeocular, often in contact with the frontal; two postoculars; temporals $2+2$; nine or ten upper labials, fifth and sixth or fourth to sixth entering the eye; five lower labials in contact with the anterior chin-shields; latter shorter than the posterior. Scales in 17 (rarely I 5) rows, smooth or feebly keeled; ventrals $198-238$, last often divided; anal divided; subcaudals I06-I 39. 


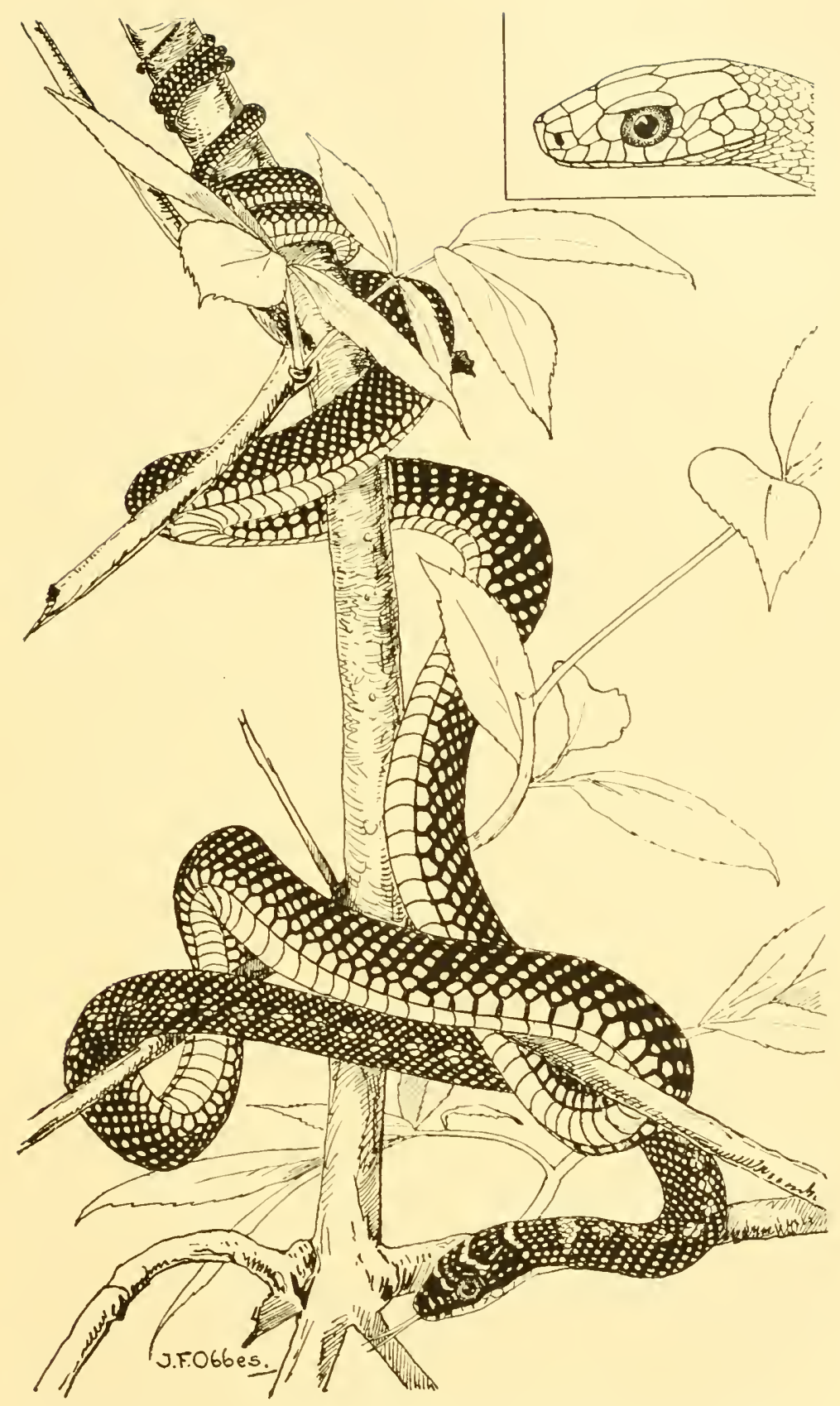

Fig. 82. Chrysopelea ornata (Shaw). Nat. size. Side view of head. 
Coloration variable. Black above, each scale with a round greenish or yellowish spot, the vertebral spots sometimes forming a stripe anteriorly, or green above, the scales black-edged; often coral-red spots on the back, in groups of four; head black, with yellow transverse bands and spots. Lower surface greenish or yellowish, ventrals often edged with black. Young specimens green, with black transverse bands, or pale brownish with black and yellow bars on head and nape; a series of small black spots on the middle of the back; a series of transverse vermilion spots on the posterior part of the body. Beneath pale olive with black lateral keels. Length of head and body 8 IO $\mathrm{mm}$.; tail 3 IO $\mathrm{mm}$.

Nom. indig. Ular jĕlotong (mal.); ule alo (Toradja-name).

Habitat: Nias; Mentawei Islands (Sipora); Sumatra (Atjeh, Medan!, Stabat, Assahan, Labuan, Langkat, Laut Tador, Indragiri, Djambi!, Kertadjaja and Tandjung Laut in Palembang; Gunung Sahilan!, Indrapura, Padang I 500-3000 feet); Banka!; Riou; Natuna Islands; Borneo (Bulangan river, Baram river, Labuan, Mt. Dulit, Braang, Kuching, Sarawak, Oya, Rejang river, Batang Lupar, Buntok, Sungei Duri, Singkawang, Pontianak, Bandjermassin!, Samarinda!, Muara Djawa!); Java! (Batavia, Tengger Mts. I 200 M.); Celebes (Gorontalo, Manado!, Kema, Marissa, Posso!, Kandari, Macassar). -- Sulu Islands; Philippines; Malay Peninsula; Singapore; Penang; Andamans; S. China; Siam; Burma; India; Ceylon.

Feeds on lizards (Geckos) and frogs, sometimes on bats. Diurnal. The female lays $6-S$ white, long-cylindrical eggs.

\section{Chrysopelea chrysochlora (Schleg.).}

Dendrophis chry'sochloros, Schlegel, Phys. Serp. Il I 837, p. 234. Chry'sopelea chrysochlora, Boulenger, Cat. Sn. III I 896, p. I9S (s. syn.).

Snout not much depressed; rostral more broad than deep, visible from above; internasals as long as or slightly shorter than praefrontals; frontal a little longer than its distance from the tip of the snout, shorter than the parietals; loreal about twice as long as deep; a praeocular, in contact with or separated from the frontal; two postoculars; temporals $2+2$; nine upper labials, fifth and sixth or fourth to sixth entering the eye; five lower labials in contact with the anterior chin-shields; latter shorter than the posterior. Scales in 17 rows, smooth; 
ventrals I 8 I-I99, last often divided; anal divided; subcaudals $98-\mathrm{I} 20$.

Red or orange above, with pairs of black transverse bands, bordering a narrow white band; head olive-brown with one to three red transverse bands; on each side of the head a black line; lips yellow. Lower surface olive-green, sides of ventrals yellow, lateral keels dark. Length of head and body 5 IO mm.; tail $190 \mathrm{~mm}$; reaches a total length of $739 \mathrm{~mm}$.

Habitat: Nias; Pulu Nako!; Sumatra (Labuan, Medan!, Serdang!, Langkat, Laut Tador, Bedagei, Indragiri, Muara Rupit in Palembang, Taluk!, Kaju tanam); Banka!; Natuna Islands; Borneo (Kuching, Sarawak, Samarinda!); Java!. Malay Peninsula; Singapore; Penang; Burma; Bengal.

Subfamily Hydrophiinae.

Key to the Indo-Australian genera.

A. Ventral shields large.

I. Nostrils lateral; nasals separated ...... 51. Platurus p. 216.

II. Nostrils superior; nasals in contact. ..... 52. Aip;surus p. 2 18.

$B$. Ventral shields, if distinct, very small.

I. A deep groove in the chin, partly concealing the narrow mental shield. .......... 53. Enhydtrina p. 220.

II. No mental groove; mental shield triangular.

$a$. Internasals separating the nasals; scales juxtaposed.............. 54. Thalassophis p. 222.

6. Nasals in contact.

1. Ventral shields absent: scales juxtaposed. 55. Hydrus p. 224.

2. Ventral shields distinct, or in the anterior part of the body only; scales imbricate in the anterior part of the body......5 56. Hydrophis p. 225.

3. Ventral shields distinct, at least in the anterior part of the body; scales all juxtaposed, the lower three or four rows enlarged. 57. Enhydris p. 240.

Poisonous marine snakes (except a Hydrophis species, which occurs in a freshwater lake in Luzon), never leaving the water, with the exception of Platurus and perhaps Aipysurus; viviparous. Feeding on fish and crustaceans.

Tail strongly compressed; rostral with two notches, only the two ends of the tongue protrusible; maxillary teeth grooved ${ }^{\prime}$ ). Nom. indig. Ular laut.

I) Wall, Mem. Asiat. Soc. Bengal II No. 8, 1909. 


\section{I. Platurus Daudin.}

(DAUdin, Rept. VII p. 223, I803).

Nostrils lateral; eye small; pupil round; nasals separated by internasals; head-shields large; praeocular present; loreal absent. Maxillary teeth two large fangs separated from one or two small teeth. Body long, covered with smooth, imbricate scales in 19-25 rows; ventrals large. Tail strongly compressed.

Distribution. Indian Ocean and West Pacific Ocean.

$$
\text { Key to the species. }
$$

A. Rostral in contact with five shields; scales in $2 \mathrm{I}-23$ rows. ............... I. P. schistorhynchus p. $2 \mathrm{I} 6$. B. Rostral in contact with six shields.

I. Frontal in contact with six shields; scales in 19 rows...................... laticaudatus p. 217 .

II. Frontal in contact with seven shields; scales in $2 \mathrm{I}-25$ rows ............... P. colubrinus p. $2 \mathrm{I} 7$.

\section{Platurus schistorhynchus Günther.}

Platurus schistorhynchus, Günther, Proc. Zool. Soc. I 874, p. 297, pl. XLV, fig. A. Platurus schistorhynchus, Boulenger, Cat. Sn. III I896, p. 309.

Rostral more broad than deep, in contact with five shields; praefrontals with a third shield in a transverse row, not reaching the labials; frontal longer than the parietals, in contact with seven shields; supraoculars entire; parietals entire; nasals lateral, in contact with the three anterior labials; one prae- and two postoculars; temporals small, $2+3$; seven upper labials, third and fourth entering the eye; anterior chin-shields distinct, posterior indistinct and separated. Scales smooth, in $2 \mathrm{I}-23$ rows; ventrals $178-200$, three or more times as broad as the last row of scales, the last one or two often divided, the posterior with a median keel; anal divided.

Yellowish or greyish above, with blackish bands, $25-45$ annuli. Lower surface yellowish. Length of head and body I $95 \mathrm{~mm}$; tail II $4 \mathrm{~mm}$.

Habitat: Java; E. Flores!; Pulu Kambing in Lobetobi strait!; Ambon!; New Guinea (Bertrand Island on the north coast). - Loo Choo Islands; Savage Island; Society Islands; Samoa. 


\section{Platurus laticaudatus (L.).}

Coluber laticaudatus, Linné, Mus. Ad. Frid. I754, p. 31, pl. XVI, fig. I.

Platurus laticaudatus, Boulenger, Cat. Sn. III I\&96, p. 307.

Laticauda laticaudata, Barbour, Mem. Mus. Comp. Zool. Harv. Coll. XLIV 1912, p. 131 .

Rostral more deep than broad, in contact with six shields; two internasals and two praefrontals, separated from the labials; frontal not longer than the parietals, in contact with six shields; supraoculars entire; parietals entire; nasals lateral, in contact with the two anterior labials; one prae- and two postoculars; temporals $1+2$; seven or eight upper labials, third and fourth entering the eye; two pair of chin-shields, both in contact. Scales smooth, in 19 rows, vertebrals enlarged in the posterior part of the body; ventrals $210-246$, the last ventral sometimes divided; anal divided.

Olive or greyish above, with $29-48$ black annuli. Lower surface yellowish. Length of head and body $880 \mathrm{~mm}$.; tail $90 \mathrm{~mm}$.

Habitat: Pulu Babi!; Nias; Sumatra (Sabang on Pulu Weh!, Atjeh!, Serdang, Gunung Sugei in Lampong district); Java; Flores!; Timor!; Borneo; Ternate; Halmahera; Aru Islands; New Guinea; Schouten Islands (Mysore). - Australia; New Hebrides; Fiji Islands; Loo Choo Islands; China; Philippines; Siam; Bengal.

\section{Platurus colubrinus (Schneider).}

Hydrus colubrinus, Schneider, Hist. Amph. I 1799 , p. 238.

Platurus colubrinus, Boulenger, Cat. Sn. III i 896, p. 308.

Rostral more deep than broad, in contact with six shields; two internasals; praefrontals with a third shield in a row, separated from the labials; frontal as long as or shorter than the parietals, in contact with seven shields; supraoculars and parietals entire; nasals lateral, in contact with the two or three anterior labials; one prae- and two postoculars; temporals $1+2$ or $2+2$; six or seven upper labials, third and fourth entering the eye; two pair of chin-shields, both in contact. Scales smooth, in $2 \mathrm{I}-25$ rows; ventrals $195-245$, the last or two often divided; anal divided.

Olive-brown above, with $2 S-54$ black annuli, sometimes interrupted below. Lower surface yellowish. Length of head and body II $45 \mathrm{~mm}$.; tail I $25 \mathrm{~mm}$.; reaches a length of $1.60 \mathrm{M}$. 
Habitat: Pulu Babi!; Engano; Sumatra (Atjeh!, Siboga!); Borneo (North coast); Java; Lamakera on Solor!; Flores!; Rotti!; Timor; N. Celebes!; Ternate; Halmahera; Ambon!; Buru; Kur!; Kei Islands!; Aru Islands; Salawatti; New Guinea (Jobi, Sorong, Dorei, Mansinam, Kaiser Wilhelmsland!, Bore-

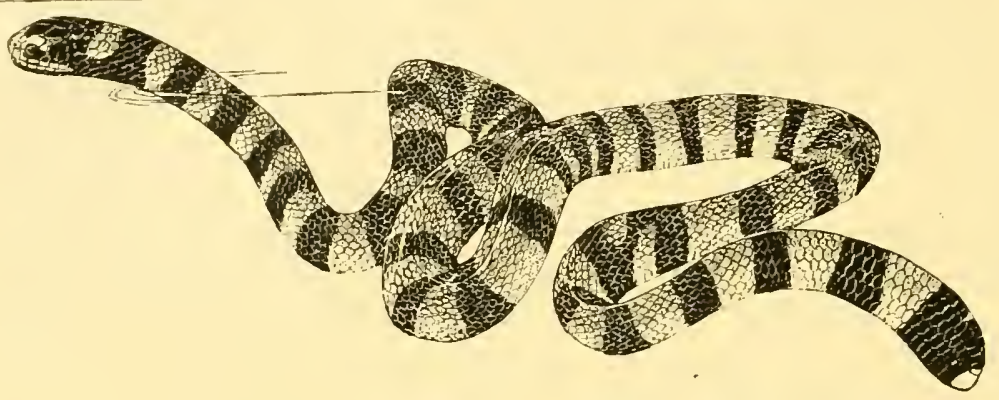

Fig. 83. Platurus colubrinus (Schn.). $\times \frac{2 / 3}{3}$

pata); Schouten Islands (Mysore). - Australia; New Zealand; Fiji Islands; New Caledonia; New Hebrides; Solomon, Admiralty and Pelew Islands; Sulu Islands; Philippines; China; Penang; Singapore; Andamans; Nicobars.

This snake is sometimes found out of the water.

\section{A i pysurus Lacépède.}

(LACÉPÈde, Ann. Mus. IV p. I97, ISO4).

Snout short; nostrils superior; eye small; pupil round; headshields large or broken up into scales; nasals in contact. Maxillary teeth two fangs, separated by a short interspace from S-IO grooved teeth; anterior mandibular teeth feebly grooved. Body moderate, covered with smooth or keeled, imbricate scales in $17-25$ rows; ventrals large, keeled in the middle. Tail strongly compressed.

Distribution. Western Tropical Pacific Ocean; Indo-Australian Archipelago.

Key to the species.

A. Scales in 17 rows; head covered with shields ..... I. A. eydouxi p. 2 Ig.

$B$. Scales in 19 rows; head covered with small scales. 2. A. australis p. 219.

$C$. Scales in $2 \mathbf{I}-25$ rows; head-shields more or less

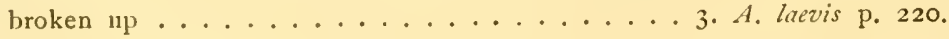




\section{Aipysurus eydouxi (Gray).}

Tomogaster eydouxii, Gray, Cat. IS49, p. 59.

Aipysurus eydouxii, Bonlenger, Cat. Sn. Ill is96, p. 304.

Rostral more broad than deep, in contact with four shields; praefrontals usually undivided, separated from the labials; frontal longer than its distance from the tip of the snout, as long as or longer than the parietals, in contact with six shields; nasal in contact with the first and second upper labials and with the praeocular or narrowly separated from the latter; one prae- and two postoculars; temporals $\mathrm{I}+2$ or $2+2$; six upper labials, fourth entering the eye; anterior chin-shields

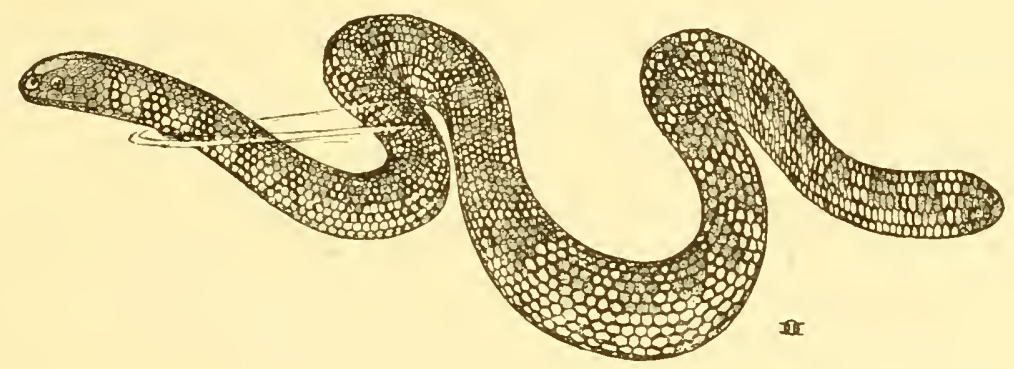

Fig. S4. Lipysurus eydouxi (Gray). X1/2.

shorter than the posterior, which are separated by a shield. Scales smooth, in 17 rows; ventrals $134-142$, with a median tubercle on eacli shield.

Dark brown above, with transverse bands of yellow, blackedged scales, often interrupted on the vertebral line; the bands widening towards the flanks. Lower surface yellow, sometimes with dark brown spots. Length of head and body $479 \mathrm{~mm}$.; tail so $\mathrm{mm}$.

Habitat: Java (Cheribon, Probolingo!); Borneo!; New Guinea (Lorentz river!). - Singapore; Philippines.

\section{Aipysurus australis Sauvage.}

Aipysurus australis, Sauvage, Bull. Soc. Philom. (7) I 1877 , p. I14. Aipysurus australis, Boulenger, Cat. Sn. 111 I 896, p. 305.

Shields of the head broken up into small and irregular scales with small granular tubercles. Rostral more broad than 
deep, in contact with four shields; nasal in contact with the first and second upper labials; eight or nine upper labials, fifth sometimes entering the eye, which is bordered by 8 or 9 small shields; the anterior five or six labials well developed, the others divided; chin-shields small, indistinct. Scales smooth or obtusely keeled, in 19 rows; ventrals $156-166$.

Brown or yellowish with brown spots, forming irregular transverse bars. Length of head and body $820 \mathrm{~mm}$.; tail IIO mm.

Habitat: New Guinea (Yule Island). - Australia!.

\section{Aipysurus laevis Lacépède.}

Aipysurus lacvis, Lacépède, Ann. Mus. IV 1804, p. 197, 210, pl. LVI, fig. 3. Aipysurus laevis, Boulenger, Cat. Sn. III 1896, p. 305 (s. syn.).

Rostral more broad than deep; praefrontals in a single row of four or a double row of three or four, not in contact with the labials; frontal more long than broad or broken up; supraocular divided into two; parietals broken up; nasals separated from the labials; one to three prae- and two or three postoculars; seven to ten upper labials, fourth to sixth entering the eye, if not broken up; two small pair of chin-shields, both or the posterior only separated by scales. Scales smooth, in 2 I -25 rows, vertebrals sometimes enlarged; ventrals I $37-$ I 62 , sometimes with an obtuse keel posteriorly; anal divided.

Brown, uniform or with small dark spots. Length of head and body $1550 \mathrm{~mm}$; t tail $170 \mathrm{~mm}$.

Habitat: Arafura Sea; Kei Islands!; Aru Islands; New Guinea. - Torres Straits; Cape York; Queensland; Loyalty Islands.

\section{Enhydrina Gray. \\ (Gray, Cat. Sn. p. 47, I849).}

Nostrils superior; eye small; pupil round; head-shields large; nasals in contact; a praeocular; no loreal; mental shield narrow, partly concealed in a deep groove (fig. 85 ). Maxillary teeth 2 large fangs, followed by four teeth. Body moderate, covered with imbricate scales; ventrals small. Tail strongly compressed.

Distribution. From the Persian Gulf to New Guinea.

A single species. 
I. Enhydrina valakadyn (Boie).

Hydrus valakady'n, Boie, Isis, I $\$ 27$, p. 554 .

Enhydrina valakadien, Boulenger, Cat. Sn. III I896, p. 302.

Rostral more deep than broad, in contact with four shields; frontal more long than broad, shorter than the parietals; nasals in contact with the two anterior labials; sometimes partially divided; one prae- and one or two postoculars; temporals I-3; seven or eight upper labials, fourth or third and fourth
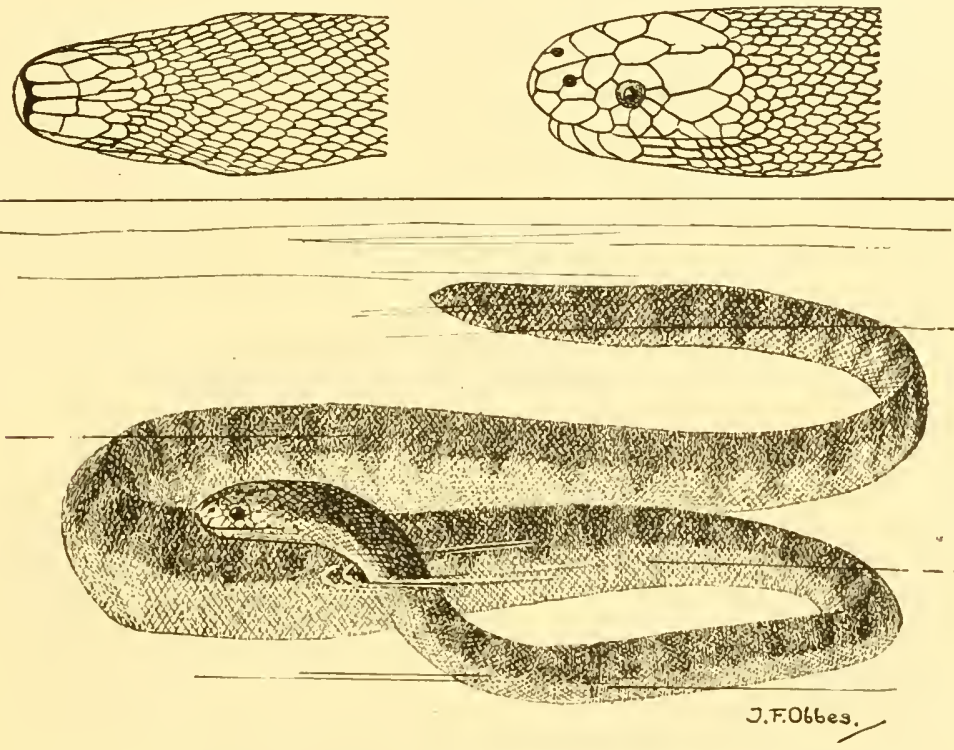

Fig. 85. Enhydrina valakadyn (Boie). Chin-shields; head from above.

entering the eye, the last sometimes divided; anterior chinshields rather indistinct, separated. Scales with a tubercle or keel, in 50-70 rows; ventrals 230-314, slightly enlarged.

Uniformly dark grey above; sides and lower parts whitish. Young specimens olive or grey with black transverse bands, broadest in the middle. Length of head and body II IO mm.; tail $190 \mathrm{~mm}$.

Habitat: Sumatra! (Bagan Api Api!, Banju asin in Palembang); Java (Cheribon Sea!, Semarang!, E. Java); Borneo! (Baram, Santubong, Sarawak river, Trusan river, Kuching, Buntal); Moluccas!; New Guinea (South coast). - Persian Gulf; India; Burma; W. Ceylon; Penang; Singapore; Malay Peninsula; Siam. 
54. Thalas s ophis Schmidt.

(SchmidT, Abh. Naturw. Hamburg II p. 75, I852).

Snout short; nostrils superior; nasals separated by the inter-
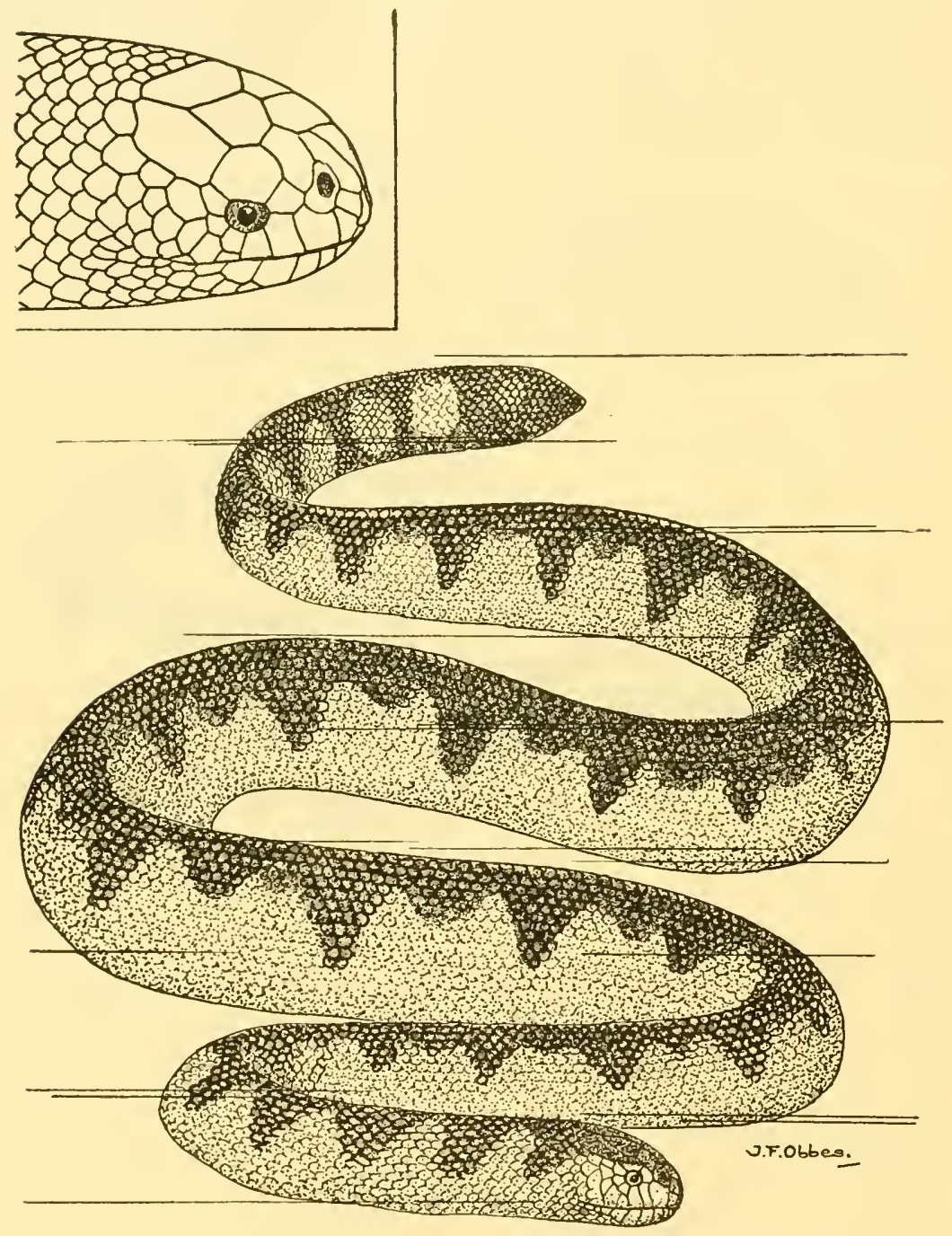

Fig. 86. Thalassophis anomalus Schmidt. $X \frac{4}{5}$. Side view of head,

nasals; eye small; pupil round; praeocular present; no loreal. Maxillary teeth two fangs followed by 5 small teeth. Body 
long, covered with hexagonal, juxtaposed scales. Ventrals small, equal or smaller than the last row of scales. Tail strongly compressed.

Distribution. Siak; Java; Borneo; Moluccas.

Key to the Indo-Australian species.

$A$. Rostral broken up into scales; parietals large;

scales in $31-33$ rows .............. T. anomalus p. 223 .

B. Rostral more broad than deep; parietals small,

separated by scales; scales in 89-100 rows ... 2. T. annandalei p. 223.

\section{Thalassophis anomalus Schmidt.}

Thalassophis anomalus, Schmidt, Abh. Naturw. Hamb. II I852, P. SI, pl. IV. Thalassophis anomalus, Boulenger, Cat. Sn. III 1896, p. 269.

Rostral broken up into small shields; internasals narrow, longer than the praefrontals; latter usually in contact with the second labial; frontal small, entire or divided; supraoculars entire; parietals large; nasals in contact with the two anterior labials; one prae- and two postoculars; temporals small; seven to nine upper labials, third and fourth entering the eye, which is sometimes separated by suboculars from the fourth and fifth labials; two pair of chin-shields, the posterior usually entirely separated. Scales with a strong tubercular keel, in $3 \mathrm{I}-33$ rows, juxtaposed; ventrals small, with two keels.

Yellowish, with dark annuli, widest on the back, or with black bands on the back, not reaching the belly. Length of head and body $726 \mathrm{~mm}$; tail $\$_{4} \mathrm{~mm}$.

Habitat: Siak E. off Sumatra!; coast of Java (Cheribon!); Borneo (Sarawak); Moluccas!.

\section{Thalassophis annandalei (Laidlaw).}

Distira annandalei, Laidlaw, Proc. Zool. Soc. I 90 I II p. 579, pl. XXXV, fig. I and 2. Thalassophis annandalii, Boulenger, Fasc. Malay. Zool. I I903, p. I6; Rept. Malay Penin. 1912, p. I95.

Rostral more broad than deep; nasals small, separated by the internasals, which are large and widen in front behind the rostral; praefrontals small; frontal and supraocular large; one or two prae- and one or two postoculars; parietals small, separated from one another and sometimes from the frontal by small scales; temporals small, numerous; nine to twelve 
upper labials; chin-shields usually broken up into scales. Body short and stout, compressed behind the neck; scales

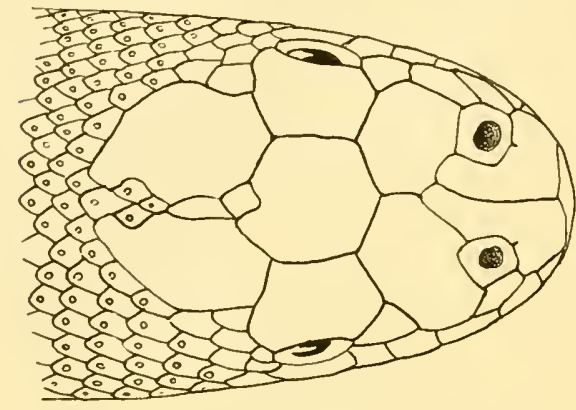

Fig. 87. Thalassophis annandalei (Laidlaw). Head from above. very small, juxtaposed, in 89- 100 rows, dorsals with a central tubercle or keel; ventrals small, $310-370$.

Pale olive-grey above, with dark transverse bars narrower than the interspaces and tapering to a point on the sides. Lower surface white. Length of head and body $520 \mathrm{~mm}$; tail so $\mathrm{mm}$.

Habitat: Java (mouth of the Mengala river!). - Malay Peninsula.

\section{Hydrus Schneider.}

(Schneider, Hist. Amph. I p. 233, 1799).

Snout long; nostrils superior; eye small; pupil round; headshields large; nasals in contact; praeocular present; no loreal. Maxillary teeth two fangs, separated by a short interspace from $7-8$ smaller teeth. Body short, covered with juxtaposed scales; ventrals indistinct.

Distribution. Indian and Pacific Oceans.

A single species.

\section{Hydrus platurus (L.).}

Anguis platura, Linné, Syst. Nat. I I 766, p. 39 I.

Hydrus platurus, Boulenger, Cat. Sn. III I 896, p. 267 (s. syn.).

Rostral as deep as broad or a little more broad; nasals large, superior; praefrontals in contact with the second labial; frontal large, at least as long as the parietals; one or two prae- and two or three postoculars; sometimes one or two suboculars; temporals small; seven or eight irregular upper labials, fourth and fifth usually entering the eye; chin-shields small or indistinct. Scales smooth in the female and young, laterals and ventrals with one to three tubercles in the male, in $45-47$ rows, juxtaposed.

Yellow above, with brown, black-edged bands across the 
body, sometimes with a black median stripe anteriorly and transverse rhombs posteriorly or entirely black above; tail with or without dorsal and lateral spots. Lower surface and sides yellow with a lateral series of black spots or a black

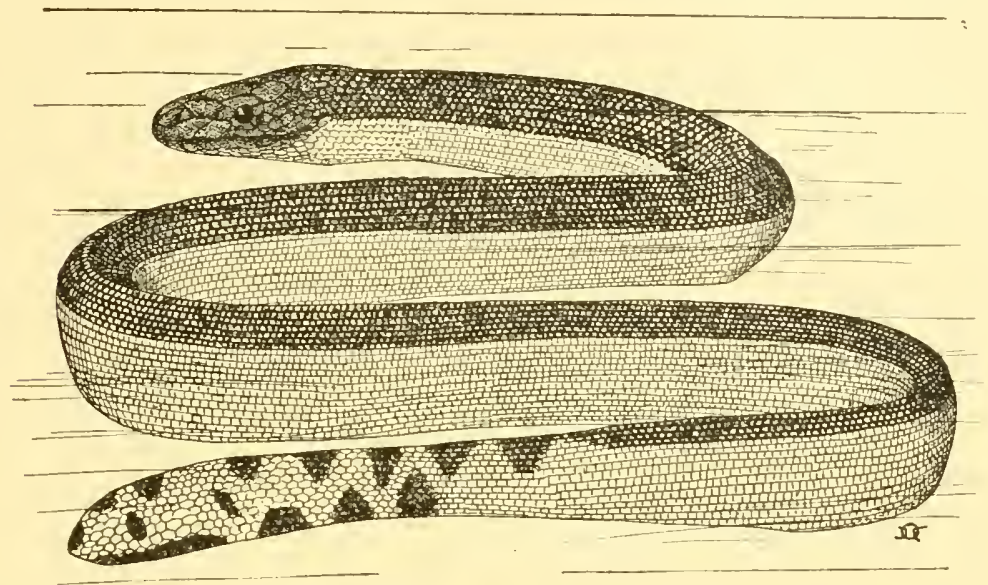

Fig. S8. Hytrus platurus (L.) $\times 1 / 2$.

stripe, or belly brown with a yellow lateral stripe. Length of head and body $620 \mathrm{~mm}$; tail $80 \mathrm{~mm}$.

Habitat: Sumatra; Banka!; Borneo! (Oya in Sarawak); Java coast (Batavia, Semanang!); Strait of Madura; Sailus Ketjil!; S. Flores!; S. W. Sumba!; Celebes (Manado!, Macassar!); Ambon!; Ternate; New Guinea (Jobi, Nafoor, Mios nom, Mansinam, Tami); Schouten Islands (Mysore). - Solomon Islands; Australia; New Zealand; Samoa; Formosa; China; Sianı; Nicobars; Singapore; Malay Peninsula; Ceylon; India; Madagascar; Panama; Mexico; Ecuador.

The most widely spread sea-snake.

\section{Hydroph is Daudin.}

(DAUDIN, Hist. Rept. YII p. 372, I 803 ).

Nostrils superior; eye small; pupil round; head-shields large; nasal single or divided, in contact with its fellow; praeocular present; loreal usually absent. Maxillary teeth two large fangs followed by $4-$ is small teeth. Body long, often very slender anteriorly, covered with imbricate or juxtaposed scales; ventrals small. Tail strongly compressed.

Distribution. Indian and Pacific Oceans. 


\section{Key to the Indo-Australian species.}

A. Head very small; neck very slender.

I. Two superposed anterior temporals.

a. Praefrontals separated by the frontal .... I. H. frontalis p. 227.

6. Praefrontals in contact ......... 2. H. nigrocinctus p. 227.

II. A single anterior temporal.

a. Frontal as long as its distance from the rostral.

I. Scales in $29-37$ rows round the body.

$\times 29-33$ scales round body; ventrals

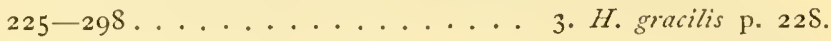

$X \times 37$ scales round body; ventrals $298-32$ I. 4. H. floweri p. 229.

2. Scales in $40-50$ rows round body.

aa. $3 \mathrm{I}-40$ scales round the neck; $40-50$ round the body; ventrals $310-438$. 5. H. diadema p. 229.

bb. 25-3I scales round the neck; $40-48$ round the body; ventrals $345-500$. . . cc. 30 scales round the neck; 42 round the body; ventrals $4 \mathrm{i} 6 \ldots \ldots \ldots$

b. Frontal shorter than its distance from the rostral. 6. H. fasciatus p. 230.

7. H. brookei p. 230.

8. H. torquatus p. $23 \mathrm{I}$. $B$. Ilead moderately small; neck not very slender.

I. Anterior ventrals three or four times as broad as the last row of scales .......... 9. H. viperinus p. $23 \mathrm{I}$.

II. Anterior ventrals not more than twice as broad as the last row of scales.

$a$. One anterior temporal.

I. I9--2 I scales round the body. ........ I0. H. jerdoni p. 232.

2. Scales round the body in more than 21 rows. † Ventrals 159............. I I. H. mertoni p. 233. †† Ventrals $270-354$

$a a$. Scales round body in 45 rows .... 12. H. polyodontus p. 233.

b6. Scales round body in $32-40$ rows.

× Head yellow.......... 13. H. brugmansi p. 233.

$X \times$ Head black with a curved yellow marking. . . . . . . 14. H. spiralis F. 234.

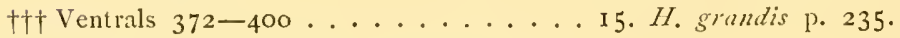

b. Two or three superposed anterior temporals.

I. Scales round body in $34-50$ rows; ventrals squarish.

$X$ Second pair of chin-shields, if distinct, separated by several scales.

aa. One postocular........... I6. H. hybridus p. 235 .

66. Two or three postoculars...... 17. H. ornatus p. 236 . 
$X X$ Second pair of chin-shields in contact or separated by one scale.

$\odot$ Scales all imbricate.

aa. Ventrals 220-256; two postoculars. Is. H. macfarlani p. 237.

66. Ventrals $28 \mathbf{I}-385$; two postoculars. 19. $H$. cyanocinctus p. 237.

cc. Ventrals 306; one postocular ...20. H. saravacensis p. 238 .

$\odot \odot$ Scales on posterior part of body jux-

taposed.

a. 34 scales round body; ventrals 317. 21. H. belcheri p. 238 .

b. $3^{S}$ or 39 scales round body;

ventrals $258-260 \ldots . .22 .4$. pachycercus p. 239.

2. Scales round body in $48-59$ rows; ventrals

usually in pairs, except anteriorly, not larger

than the scales and pointed....... 23. H. stokesi p. 239.

\section{Hydrophis frontalis Jan.}

Hydrophis frontalis, Jan, Elenco $1 \$ 6_{3}$, p. п1o.

Hydrophis frontatis, Bonlenger, Cat. Sn. III is96, p. 276.

Head very small; rostral more broad than deep; praefrontals separated by the point of the frontal; latter more long than broad, as long as its distance from the tip of the snout, shorter than the parietals; one prae- and one postocular; two superposed anterior temporals; seven upper labials, third and fourth entering the eye; chin-shields small, the posterior separated. Body very slender anteriorly, scales rhomboidal, imbricate, with a strong keel, in $42-45$ rows (34 or 35 anteriorly); ventrals $285-29 \mathrm{I}$.

Yellowish-white, with greyish transverse bars, broadest on the back; head blackish, a yellow band above and behind the eye. Length of head and body $630 \mathrm{~mm}$.; tail $65 \mathrm{~mm}$.

Type-specimen cxamined in the Leiden Museum.

Habitat: Indian Ocean!; Java (Batavia, Pasuruan!).

\section{Hydrophis nigrocinctus Daudin.}

Hydrophis nigrocinctus, Daudin, Rept. VII ISo3, p. 3 So.

IIy'drophis nigrocinctus, Boulenger, Cat. Sn. III IS96, p. 277; Rept. Malay l'enin. I9⿺2, p. I $\$ 7$.

Head small; eye as long as its distance from the mouth. Rostral more broad than deep; nasals shorter than the frontal, about twice as long as the suture between the praefrontals, which are separated from the labials; frontal more long than 
broad, as long as its distance from the tip of the snout; one prae- and one or two postoculars; two superposed anterior temporals; seven upper labials, third and fourth, third to fifth or fourth and fifth entering the eye or some of them divided; posterior chin-shields separated. Body long, slender anteriorly; scales imbricate, keeled, in 39 rows (27-29 anteriorly); ventrals 3IO-33I, entire.

Olive above, yellow beneath, with $42-62$ black annuli, broader on the back; upper lip with a curved black streak; head dark on the crown, with a yellow marking from the rostral above the eyes to the temporal region; a short lateral black band on the neck. Length of head and body $900 \mathrm{~mm}$.; tail $100 \mathrm{~mm}$.

Habitat: Ternate ${ }^{1}$ ). - Bay of Bengal; Strait of Malacca; Malay Peninsula; Siam.

\section{Hydrophis gracilis (Shaw).}

Hydrus gracilis, Shaw, Zool. III I So2, p. 560 .

Hydrophis gracilis, Boulenger, Cat. Sn. III I \$96, F. 2So; Rept. Malay Peninsula 1912 , p. I91.

Head very small; snout projecting; eye at least as long as its distance from the mouth. Rostral as deep as broad; praefrontals usually touch the second upper labial; frontal very small, more long than broad, about as long as its distance from the rostral; one prae- and one or two postoculars; a large anterior temporal, in contact with the fifth and sixth labials, followed by another large shield; six upper labials, third and fourth entering the eye; both pairs of small chin-shields in contact. Body long, extremely slender anteriorly; scales with two or more tubercles, which are strong in males, imbricate anteriorly, juxtaposed posteriorly, in 29-33 rows (I9-2 I anteriorly); ventrals 225-298, entire anteriorly, grooved or divided posteriorly.

Black or olive above, with indistinct lighter transverse bands anteriorly. Young specimens with the head and neck black, neck with light bands; body with 42-6I rhombic bands continued to the belly or nearly interrupted on the sides, or black with elliptical vertical white spots on the sides. Length of head and body $930 \mathrm{~mm}$; tail $90 \mathrm{~mm}$.

Habitat: Java; Madura; Borneo; Indian Ocean!. - Gulf of

I) Peters \& Doria, Ann. Mus. Genova XIII is78, p. 416. 
Persia; India!; Burma; Tenasserinı; Siam; Malay Peninsula; Singapore.

\section{Hydrophis floweri Boulenger.}

Hydrophis Floweri, Bonlenger, Proc. Zool. Soc. I 898 , p. Io6, pI. IX.

Head very small; rostral more broad than deep; frontal one time and a half as long as broad, as long as its distance from the rostral, much shorter than the parietals; one prae- and one postocular; a single anterior temporal; six or seven upper labials, third and fourth entering the eye; two pairs of chinshields, the posterior separated. Body very slender anteriorly; scales imbricate, almost smooth on the neck, keeled on the body, in 37 rows (27 anteriorly); ventrals distinct, 298-32 I.

Dark olive or black above, with 69 yellow transverse bars on body and tail, narrower than the interspaces; head with a yellow band from eye to eye across the snout and a yellow band behind the eye; small yellow markings on the crown. Length of head and body $\$ 20 \mathrm{~mm}$; tail $\$ 0 \mathrm{~mm}$.

Type-specimen examined in the British Museum.

Habitat: Borneo (Brunei Bay!).

\section{Hydrophis diadema Gthr.}

Hydrophis diadema, Günther, Repl. Br. Ind. IS64, p. 373, pI. XXV, fig. S. Hydrophis obscurtus, Boulenger, Cat. Sn. III I $\$ 96$, p. 284.

Hy'drophis diadema, Boulenger, Rept. Malay Penin. I9I2, P. ISS.

Head very small; eye as long as its distance from the mouth. Rostral more broad than deep; frontal more long than broad, as long as its distance from the rostral or the tip of the snout; one prae- and one or two postoculars; a single anterior temporal; seven or eight upper labials, third and fourth entering the eye; posterior chin-shields small and usually separated. Body long, extremely slender anteriorly; scales imbricate, rhomboidal, feebly keeled in the female, strongly in the male, the keels often broken up in tubercles, in $40-50$ rows $(3 \mathrm{I}-40$ anteriorly); ventrals $310-438$, feebly enlarged, with two keels in the male.

Olive or dark green above, with yellowish transverse bars, forming complete rings in the anterior part, interrupted on the back more behind; or pale olive with dark bands, forming rings in front; a yellow spot on the snout and a yellow streak 
on each side of the head. Length of head and body $865 \mathrm{~mm}$; tail $105 \mathrm{~mm}$.

Habitat: Borneo!. - Bay of Bengal; Pegu; Gulf of Siam.

\section{Hydrophis fasciatus (Schneider).}

Hydrus fasciatus, Schneider, Hist. Amph. I I799, p. 240.

Hydrophis fasciatus, Bonlenger, Cat. Sn. III I\$96, p. 281; Rept. Malay Penins. 1912, p. 189.

Head very small; eye a little longer than its distance from the mouth. Rostral almost as deep as broad; praefrontals usually in contact with the second upper labial; frontal more long than broad, as long as its distance from the rostral; one prae- and one or two postoculars; a single anterior temporal; sis or seven upper labials, third and fourth entering the eye; both pairs of chin-shields in contact. Body long, very slender anteriorly; scales imbricate, sometimes juxtaposed posteriorly, smooth on the neck, with a tubercle or keel on the body, in $40-48$ rows (25-3I anteriorly); ventrals $345-500$, entire.

Pale above, with $48-7$ I black bands or annuli, sometimes expanded vertebrally and lost ventrally in old specimens; head and neck black; neck with yellow transverse bands. Length of head and body $915 \mathrm{~mm}$.; tail $85 \mathrm{~mm}$.

Habitat: Sumatra! (Bantung river near Tandjung Laut in Palembang); Borneo (coast of N. Borneo); Java (Cheribon Sea!, Pasuruan!); Aru Islands; New Guinea (Kaiser Wilhelmsland). - Coasts of India, Siam, China; Penang.

\section{Hydrophis brookei Gthr.}

Hydrophis brookii, Günther, Proc. Zool. Soc. 1872 , p. 597, fig. 5.

IHydrophis brookii, Boulenger, Cat. Sn. III I 896, p. $2 \mathrm{~S}_{2}$.

Head very small; rostral more broad than deep; praefrontal in contact with the second labial; frontal more long than broad, as long as its distance from the tip of the snout, much shorter than the parictals; one prae- and one postocular; a single anterior temporal, followed by another large one; six upper labials, third and fourth entering the eye, second largest; both pairs of chin-shields in contact. Body long, extremely slender in the fore part, covered with rhomboidal, imbricate scales, smooth on the neck, with a tubercle or keel on the body, in 42 rows (30 anteriorly); ventrals 416 , feebly enlarged. 
Black above, with yellow rings on the anterior part of the body, the anterior rings interrupted beneath; posterior part with narrow olive interspaces above between black broad rings, and broader yellow interspaces below; head black, with a horse-shoe-shaped yellow marking. Length of head and body $875 \mathrm{~mm}$; tail $95 \mathrm{~mm}$.

Type-specimen examined in the British Museum.

Habitat: Borneo! (Sarawak river).

Note. The female specimen in the British Museum contained young ones with the praefrontals in contact.

\section{S. Hydrophis torquatus Günther.}

Hydrophis torquata, Gunther, Rept. Brit. Ind. 1864, p. 369, pl. XXV, fig. H. Hydrophis torquatus, Boulenger, Cat. Sn. III I 896, p. $2 \delta_{3}$; Rept. Malay Penin. I 912 , p. 190.

Head small; eye as long as its distance from the mouth. Rostral more broad than deep; nasals longer than the frontal, at least $t$ wice as long as the suture between the praefrontals; frontal small, shorter than its distance from the rostral; one prae- and one postocular; a single anterior temporal; six or seven upper labials, third and fourth entering the eye, sume of the posterior may be divided; posterior chin-shields separated or in contact. Body long, very slender anteriorly; scales imbricate, keeled, in 43-45 rows (33-35 anteriorly); ventrals 240-290, mostly entire.

Greyish-olive above, yellow below, with black annuli, narrower on the sides; head dark, with a curved yellow marking from the temporal region passing above the eye, to the nasals. Length of head and body $510 \mathrm{~mm}$.; tail $50 \mathrm{~mm}$.

Type-specimens examined in the British Museum.

Habitat: "East Indies"!; Sumatra (Bagan Api Api!) Bay of Bengal; Strait of Malacca.

\section{Hydrophis viperinus (Schmidt).}

Thalassophis viperina, Schmidt, Abh. Naturw. Hamb. II I $\$_{52}$, p. 79, pl. III. Distira viperina, Boulenger, Cat. Sn. III 1896, p. 298.

Head small; rostral as deep as broad; nasals as long as or shorter than the frontal; suture between the praefrontals very short; they are separated from the labials; frontal as broad as long, as long as its distance from the rostral or the tip of 
the snout, shorter than the parietals, two or three times as broad as a supraocular; one or two prae- and one or two postoculars; one or two anterior temporals; seven or eight upper labials, often the posterior divided, fourth, third and fourth or third to fifth entering the eye, second largest; both pairs of chin-shields in contact, posterior largest. Body moderate, slender anteriorly; scales juxtaposed, obtusely keeled, in $37-43$ rows $(27-29$ anteriorly); ventrals $235-267$, entire, with two keels in the male.

Grey above, uniform or with 26-37 black dorsal bars, sometimes confluent vertebrally, or with rhomboidal black spots. Lower surface white or pink. Young specimens completely banded; end of tail black. Length of head and body $\$ 20 \mathrm{~mm}$.; tail $\mathrm{I} 00 \mathrm{~mm}$.

Habitat: Indian Ocean!; Java '); Borneo (Oya) $\left.{ }^{2}\right)$. - Gulf of Persia; Burma; Siam; Hongkong; Hainan.

\section{IO. Hydrophis jerdoni (Gray).}

Kerilia jerdonii, Gray, Cat. Sn. I $\$ 49$, p. 57 .

Distira jerdouii, Boulenger, Cat. Sn. IlI IS96, p. 299.

Hydrophis jerdonii, Boulenger, Rept. Malay Penin. I9I2, p. I\$6.

Head short; snout rather pointed; eye as long as its distance from the mouth. Rostral as deep as broad; nasals shorter than the frontal, more than twice as long as the suture between the praefrontals; frontal more long than broad, almost as long as its distance from the tip of the snout; one prae- and one postocular; anterior temporal large, bordering the lip; five upper labials anterior to the temporal, third and fourth entering the eye; one or two pair of chin-shields. Body moderate; scales strongly keeled, imbricate, in $19-2 \mathrm{I}$ rows (15-I7 anteriorly); ventrals $224-238$, entire, with two keels.

Olive above, with 3I-4I black transverse bands, forming rings in young specimens; a black spot between each pair of rings may be present. Lower surface yellowish. Length of head and body SIO $\mathrm{mm}$.; tail $\mathrm{rOO} \mathrm{mm}$.

Habitat: Borneo (Pontianak river); Indian Ocean!. Coasts of the Malay Peninsula!; Sian, Penang; Bay of Bengal.

I) Boulenger, Cat. p. 299.

2) Shelford, J. Straits Br. Asiat. Soc. XXXV 190i, p. 66. 


\section{Hydrophis mertoni (Roux).}

Distira mertoni, Roux, Abh. Senckenb. Ges. XXXIII IgIo, p. 222, Taf. XIII, fig. 4.

Head moderate; rostral more broad than deep; nasals much shorter than the frontal, more than twice as long as the suture between the praefrontals; frontal about one time and two thirds as long as broad, much longer than its distance from the rostral, almost as long as the parietals; one prae- and one postocular; a single anterior temporal, not reaching the border of the lip; six upper labials, third and fourth under the eye, second deepest, in contact with the praefrontal; both pairs of chin-shields in contact, posterior longest. Body not very long; scales imbricate, with two or three small tubercles, in 39 rows (37 anteriorly); shields of the head with small granules; ventrals I59, the posterior obtusely keeled.

Blackish-olive above, with 46 yellow rings on the body, io on the tail; the yellow scales of the back speckled with olivegrey; some of the rings are oblique and alternate on the belly; all the rings narrowed on the back and the belly; shields of the head with yellow spots, rostral and labials black. Total length $380 \mathrm{~mm}$. (After Roux; not seen by me).

Habitat: Aru Islands (Sungi Waskai on Wokam).

\section{I2. Hydrophis polyodontus Jan.}

Hydrophis polyodoutus, Jan, Icon. gén. 4 I I 872 , pl. I, fig. I. Hydrophis polyodontus, Boulenger, Cat. Sn. III IS96, p. 274.

Head small; rostral more broad than deep; frontal slightly more long than broad, as long as its distance from the rostral, much shorter than the parietals; one prae- and two postoculars; one anterior temporal; seven upper labials, second large, third and fourth entering the eye; both pairs of chinshields in contact. Body long, scales juxtaposed, with a small tubercle, in 45 rows; ventrals 3 I 2.

Yellowish above with black transverse rhomboidal spots; head black. Lower surface black. Length of head and body $345 \mathrm{~mm}$; tail $33 \mathrm{~mm}$.

Habitat: Java (Probolingo!).

\section{I3. Hydrophis brugmansi Boie.}

Hydrophis brugmansii, Boie, Isis, IS27, p. 554.

Distira brugmansii, Boulenger, Cat. Sn. III I 896, p. 292.

Hydrophis bragmansii, Boulenger, Rept. Malay Penin. I9I2, p. IS4. 
Head moderate; eye shorter than its distance from the mouth. Rostral more broad than deep; nasals shorter than

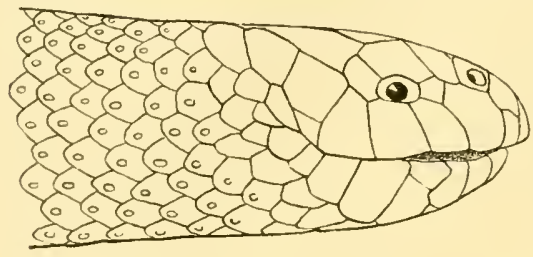
the frontal, about twice as long as the suture between the praefrontals; frontal much more long than broad, as long as its distance from the rostral or the tip of the snout; one prae- and one or two postoculars; a single large anterior temporal,

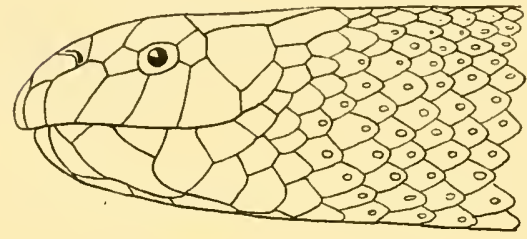
sometimes reaching the border of the mouth; seven upper labials, third and fourth or third to fifth entering the eye; both pairs of chin-shields in contact. Body long; scales imbricate, smooth or with a tubercle

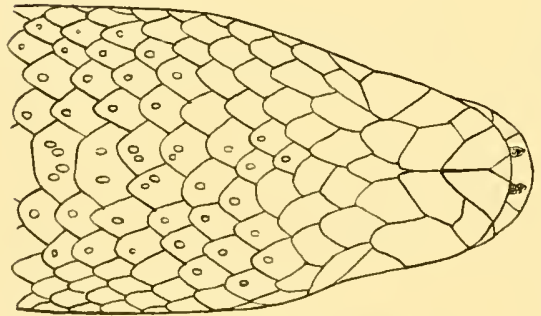

Fig. 89. Hydrophis brugmansi Boie. or keel, in $32-40$ rows (27-3 I anteriorly); ventrals distinct, smooth or with two tubercles, 300-354.

Greenish-yellow above, the scales with black margins, with narrow black bands or annuli; sides and lower parts yellow; head yellow; end of tail black. Length of head and body I680 mm.; tail $\mathrm{I} 20 \mathrm{~mm}$.

Type-specimen examined in the Leiden Museum.

Habitat: Borneo! (Muka); Sumba (Taraba Bay!); Celebes (Macassar!); Waigeu!; New Guinea; Indian Ocean!. - Persian Gulf; Penang!; Philippines.

\section{I4. Hydrophis spiralis (Shaw).}

Hydrus spiralis, Shaw, Zool. III ISo2, p. 564, pl. CXXV. Hydrophis spiralis, Boulenger, Cat. Sn. III IS96, p. 273.

Head moderate; eye shorter than its distance from the mouth. Rostral more broad than deep; praefrontals usually in 
contact with the second upper labial; frontal more long than broad, as long as its distance from the rostral; one prae- and one postocular; a single anterior temporal, sometimes descending to the border of the mouth; six or seven upper labials, second largest, third and fourth entering the cye; posterior pair of chin-shields usually in contact. Body long; scales imbricate, smooth in the young, with a tubercle in the adult, in $33-35$ rows (28-29 anteriorly); ventrals feebly enlarged $270-334$.

Olive or yellowish above, with black annuli, sometimes connected by a black ventral band; often round black spots between the bands dorsally; head black, with a curved yellow marking, extending to the praefrontals; end of tai! black. Length of head and body I $680 \mathrm{~mm}$; tail $120 \mathrm{~mm}$.

Type-specimen examined in the British Museum.

Habitat: "Malay Archipelago"; Sumatra!; Indian Ocean!Coast of India; Ceylon.

\section{I5. Hydrophis grandis (Boulenger).}

Distira grandis, Boulenger, Cat. Sn. III I 896 , p. 293, pl. XVI.

Head small; rostral as deep as broad; nasals shorter than the frontal, two or three times the length of the suture between the praefrontals; latter in contact with the second labial; frontal more long than broad, as long as or longer than its distance from the rostral, shorter than the parietals; one praeand two postoculars; a. single anterior temporal; seven upper labials, second largest, third and fourth entering the eye; both pairs of chin-shields in contact. Body long, scales imbricate, keeled, in $4 \mathrm{I}-45$ rows $(27-29$ anteriorly); ventrals small, smooth in the female, with two tubercles in the male, $372-400$.

Olive-grey above, yellowish on the sides and below; neck with dark transverse bars, disappearing on the body. Length of head and body $2140 \mathrm{~mm}$; tail $160 \mathrm{~mm}$.

Habitat: "Malay Archipelago"! - Queensland.

\section{I6. Hydrophis hybridus Schlegel.}

Hydrophis hybrida, Schlegel, Abbild. IS44, p. II 5, pl. XXXVII.

Hydrophis hybridus, Boulenger, Cat. Sn. III I\$96, p. 274.

Head moderate; rostral more broad than deep; nasals more than twice the length of the suture between the praefrontals; frontal much more long than broad, as long as its distance 
from the tip of the snout, shorter than the parietals; one prae- and one postocular; two superposed anterior temporals; seven upper labials, third and fourth entering the eye; posterior pair of small chin-shields separated by scales. Body long; scales imbricate anteriorly, juxtaposed posteriorly, with a tubercle or keel, in 43 rows (32 anteriorly); ventrals $33 \mathrm{I}$, enlarged, with two keels.

Yellowish, with a series of transverse, rhomboidal black spots on the back; head black above. Lower surface yellow. Length of head and body $580 \mathrm{~mm}$.; tail $85 \mathrm{~mm}$.

Type-specimen examined in the Leiden Museum.

Habitat: Molucca Sea!.

\section{I7. Hydrophis ornatus (Gray).}

Aturia ornata, Gray, Zool. Misc. I\$ 42, p. $6 \mathbf{1}$.

Distira ornata, Boulenger, Cat. Sn. III I896, p. 290.

Hydrophis ornatus, Boulenger, Rept. Malay Penin. I912, p. IS4.

Head moderate; eye as long as or longer than its distance from the mouth; rostral more broad than deep; nasals shorter than the frontal, two or three times as long as the suture between the praefrontals; praefrontals usually in contact with the second labial; frontal more long than broad, as long as or longer than its distance from the rostral or the tip of the snout; one prae- and two or three postoculars; two or three superposed anterior temporals; seven or eight upper labials, third and fourth entering the eye, the posterior often divided, second largest; posterior chin-shields absent or separated by two or three scales. Body moderate; scales imbricate anteriorly, juxtaposed posteriorly, smooth in the young, with a keel or tubercle in the adult, in $40-50$ rows ( $35-42$ anteriorly); ventrals $2 \mathrm{IO}-300$, entire or a few divided posteriorly.

Young specimens banded with black, the bands interrupted ventrally, and with one or more series of round dark spots on the sides. Sometimes the bands confluent, forming a blackish upper part; white below. Length of head and body $1070 \mathrm{~mm}$.; tail I $30 \mathrm{~mm}$.

Habitat: Aru Islands!; New Guinea (S. W. New Guinea!, Kapaor '). - Persian Gulf; Coasts of India and Ceylon; Siam!; Malay Peninsula; Philippines; N. Australia.

1) Peters \& DoriA, Ann. Ius. Genova XIII i $\$_{7} S$, p. 416 as Hydrophis ocellata Gray. 


\section{I8. Hydrophis macfarlani (Boulenger).}

Distira macfarlani, Boulenger, Cat. Sn. III I896, p. 294, pl. XVII, fig. I.

Head moderate; rostral more broad than deep; nasals shorter than the frontal, about three times the length of the suture between the praefrontals; latter in contact with the second labial; frontal more long than broad, as long as or longer than its distance from the tip of the snout, shorter than the parietals; one prae- and two postoculars; two superposed anterior temporals; seven or eight upper labials, second largest, third and fourth entering the eye, fifth entering the eye or divided and forming a subocular; both pairs of chin-shields in contact. Body long; scales imbricate, smooth or dorsals keeled, in $43-45$ rows ( $31-35$ anteriorly); ventrals small, $220-256$.

Whitish, with a dorsal and ventral series of black rhomboidal spots or bars; on the neck and just before the tail the dorsal and ventral spots unite on each side; head black, with a yellow spot on the forehead and a yellow streak from the eye along the temple. Length of head and body $420 \mathrm{~mm}$.; tail $40 \mathrm{~mm}$.

Type-specimen examined in the British Museum.

Habitat: New Guinea. - Murray Island!.

\section{Hydrophis cyanocinctus Daudin.}

Hydrophis cyanocinctus, Daudin, Rept. VII 1803, p. $3 S_{3}$. Distira cyanocincta, Boulenger, Cat. Sn. III I 896 , p. 294. Hydrophis cyunocinctus, Boulenger, Rept. Malay Penin. 1912, p. I 85 .

Head moderate; eye shorter than its distance from the mouth in the adult. Rostral slightly more broad than deep; nasals shorter than the frontal, more than twice as long as the suture between the praefrontals; pracfrontals usually in contact with the second upper labial; frontal more long than broad, as long as its distance from the rostral or the tip of the snout; one prae- and two postoculars; two superposed anterior temporals; seven or eight upper labials, third, fourth and usually fifth entering the eye or divided; both pairs of chin-shields in contact or posterior separated by one scale. Body long; scales sub-imbricate, keeled or with two or three tubercles, in $39-45$ rows $(27-33$ anteriorly); ventrals $28 \mathrm{I}-385$, smooth or with two or more tubercles. 
Greenish-olive above, with blackish or olive transverse bars or annuli, broadest on the back, sometimes connected by a black band along the belly; or yellowish, with a black vertebral band and a few black bars on the neck. Length of head and body I $360 \mathrm{~mm}$; t tail $140 \mathrm{~mm}$.

Habitat: Java! (Batavia); Aru Islands!; New Guinea (Matterer Bay, near Astrolabe Bay); Indian Ocean!. - Persian Gulf; Coast of India; Singapore!; China; Japan; Philippines.

\section{Hydrophis saravacensis (Boulenger).}

Distira saraz'acensis, Boulenger, Proc. Zool. Soc. I900, p. IS4, pl. XIV, fig. 2.

Head moderate; rostral more broad than deep; nasals shorter than the frontal, two times and a half as long as the suture between the praefrontals, frontal almost twice as long as broad, as long as its distance from the rostral, shorter than the parietals; one or two prae- and one postocular; seven upper labials, fourth or third and fourth entering the eye, second largest; two superposed anterior temporals; both pairs of chinshields in contact. Body moderately long; scales imbricate, keeled, in 43 rows (27 anteriorly); ventrals with two keels, 306.

Blackish, with $\$ 5$ yellowish rings, interrupted on the ventrals; a chevron-shaped marking on the head, the apex on the nasals, the branches on the praefrontals, the supra- and postoculars and on the temple. Length of head and body $6_{30} \mathrm{~mm}$.; tail $80 \mathrm{~mm}$. (After Boulenger; not seen by $\mathrm{me}$ ).

Habitat: Borneo (Sarawak coast).

\section{Hydrophis belcheri (Gray).}

Aturia belcheri, Gray, Cat. I 849, p. 46 .

Distira belcheri, Boulenger, Cat. Sn. III I 896, p. 296 , pl. XVIl, fig. 2.

Head small; rostral as deep as broad; nasals shorter than the frontal, twice the length of the suture between the praefrontals; frontal about twice as long as broad, as long as its distance from the rostral, shorter than the parietals; one praeand two postoculars; two superposed anterior temporals; five or six upper labials, fourth entering the eye; both pairs of chin-shields in contact. Body long; scales imbricate anteriorly, juxtaposed posteriorly, feebly keeled, in 34 rows ( 25 anteriorly); ventrals distinct, smooth, $3 \mathrm{I}_{j}$.

Olive above, neck with dark transverse bands; head dark, 
lighter on the crown. Lower surface yellowish. Length of head and body $735 \mathrm{~mm}$; tail $75 \mathrm{~mm}$.

Type-specimen examined in the British Museum.

Habitat: New Guinea!.

\section{Hydrophis pachycercus Fischer.}

Hydrophis pachycercos, Fischer, Abh. Naturw. Hamb. III I 856 , p. 44, pl. II. Distira pachycercus, Boulenger, Cat. Sn. III i 896, p. 297.

Head small; rostral as deep as broad; nasals shorter than the frontal, more than twice as long as the suture between the praefrontals; frontal more long than broad, as long as its distance from the rostral, shorter than the parietals; one praeand two pestoculars; two superposed anterior temporals; eight upper labials, fourth or third and fourth entering the eye, fifth divided; two pair of chin-shields in contact. Body stout; scales imbricate anteriorly, juxtaposed posteriorly, keeled, each keel formed of two tubercles, in 38 or 39 rows $(27-29$ anteriorly); ventrals distinct. $258-260$.

Yellowish above, with dark transverse bands; head and nape brown; cnd of tail black. Lower parts white. Length of head and body $820 \mathrm{~mm}$.; tail $110 \mathrm{~mm}$.

Habitat: Malay Archipelago!.

\section{Hydrophis stokesi (Gray).}

Ifydrus stokesii, Gray, in Stokes, Discov. Austr. I I 466, p. 502, pl. III.

Distira stokcsii, Boulenger, Cat. Sn. III I 896, p. $28 S$.

Astrotia stokesi, Wall, Mem. Asiat. Soc. Bengal II No.S I909, p. 250, fig. 65-67. Hydrophis stokcsii, Boulenger, Rept. Malay Penin. I9I2, p. IS 3 .

Rostral as deep as broad; nasals more than twice as long as the suture between the praefrontals; latter usually in contact with the second or second and third labials; frontal more long than broad; one prae- and two (three) postoculars; temporals two or three superposed scales; nine or ten upper labials, fourth to sixth entering the eye, if not divided and forming suboculars; chin-shields absent. Body stout; scales imbricate, pointed, keeled or the keels broken up into two tubercles, in $48-59$ rows (39-4S anteriorly), the last rows irregularly dentate; ventrals $230-267$, anteriorly a few entire, rest divided into two, pointed and very much like the adjacent scales.

Yellowish or pale brown, with broad black transverse bands 
on the back or with black annuli, sometimes dorsal bars and ventral bars, alternating on the flanks, and a dorsal line between the bars. Length of head and body I3IO mm.; tail $200 \mathrm{~mm}$.

Habitat: Java; Aru Islands (near Karang); New Guinea. Chinese sea; Kurrachee Harbour; Singapore!; N. coast of Australia.

The I 2 or I4 young specimens, produced by the female, have a length of $30-42 \mathrm{~mm}$.

\section{Enhydris Merrem.}

(Merrem, Tent. Syst. Amph. p. I40, IS20).

Nostrils superior; eye small; pupil round; head-shields large; nasals in contact; praeocular present; loreal present or absent. Maxillary teeth 2 large fangs and $2-4$ small teeth. Body short and stout, covered with juxtaposed scales, in $27-37$ rows; ventrals small if distinct. Tail strongly compressed.

Distribution. From India to China and New Guinea.

A single species.

\section{Enhydris hardwickei (Gray).}

Lapemis hardaickii, Gray, Ill. Ind. Zool. II IS34, pl. LXXXVII, fig. 2. Enhydris hardwickii, Boulenger, Cat. Sn. III IS96, p. 30I (s. syn.).

Rostral as deep as broad or slightly more broad; praefrontals in contact with the second labial; frontal large; parietals large; nasals in contact with the two anterior labials, sometimes a loreal present; one prae- and one to three postoculars; temporals two to four superposed shields; seven or eight upper labials, third and fourth usually entering the eye; chin-shields small or absent. Scales with a tubercle, in $34-37$ rows, the last three or four rows enlarged; ventrals I30-200, small.

Olive or yellowish, with blackish transverse bands or annuli, sometimes confluent on the back. Length of head and body $670 \mathrm{~mm}$; tail $80 \mathrm{~mm}$.

Nom. in $\mathrm{ig}$. Ular lempe.

Habitat: Java (Batavia, Cheribon Sea!, Pekalongan!, Semarang!, Kembang, Pasuruan!, Panarukan!); Borneo (Santubong); Flores!; Sumba (Taraba Bay!); Celebes (Manado!, Macassar); Moluccas!; New Guinea. - Malay Peninsula; Siam; Singapore; Bay of Bengal; Chinese Sea; Philippines. 


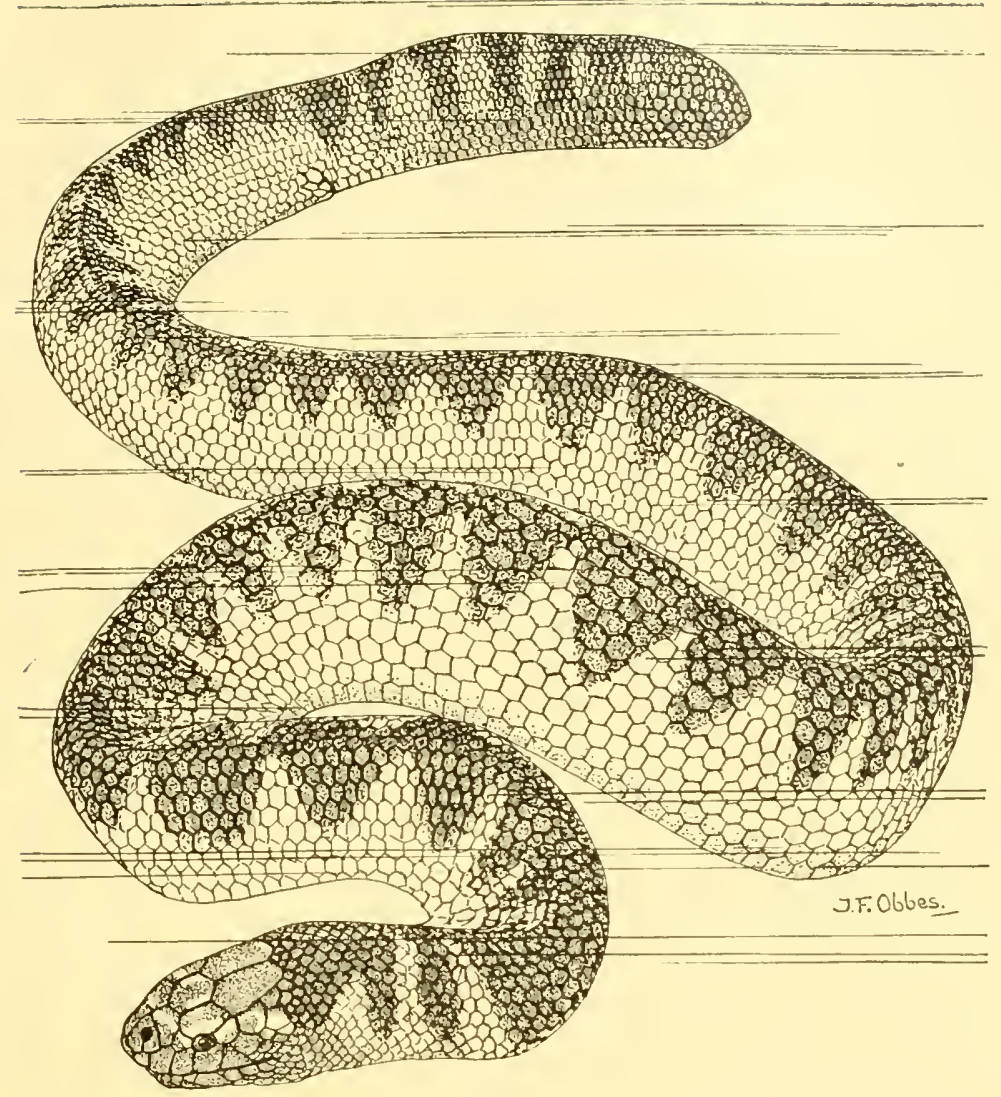

Fig. 90. Enhydris hardwickei (Gray). Nat. size.

Subfamily Elapinae.

Key to the Indo-Australian genera.

A. Vertebral scales enlarged; scales in 13-17 rows. . 58. Bungarns p. 243. $B$. Vertebral scales not enlarged.

I. Maxillary extcnding forwards beyond the palatine.

a. Internasal bordering the nostril; scales in $15-25$

rows.................. 59. Naja p. 245.

6. Internasals not bordering the nostril.

I. Anal divided; poison-gland not extending beyond

the head; scales in $\mathrm{I}_{3}$ rows........6. Callophis p. 250.

INDO-AUSTRALIAN REPTILES II. 
2. Anal entire; poison-gland extending along each side of the anterior third of the body; heart far posteriorly; scales in 13 rows .......... 6. Doliophis p. 251 .

II. Maxillary not extending forwards beyond the palatine.

a. Poison-fangs followed by 4-6 grooved teeth; head not distinct from neck; subcaudals in two rows.

I. Anterior maxillary and mandibular teeth abruptly enlarged; nostril between two nasals; scales in 17 rows. . . . . . . 62. Glyphodon p. 254.

2. Maxillary and mandibular teeth gradually decreasing in size.

$\dagger$ No praeocular.

$a a$. Pupil round; nostril between two nasals; internasals present; scales in I5 or I 7 rows ......... 6.3. Toxicocalamus p. 255 . bb. Pupil round; nostril in a single nasal; no internasals; scales in 13 rows. . 64. Ctltrocalamus p. 258 . †† Praeocular present.

I. Pupil vertically elliptic; nostril between two nasals; scales in 15 rows. 65. Apistocalamus p. 260.

2. Pupil round; nostril in a single nasal; scales in 15 rows ........66. Pseadapistocalamus p. 262.

b. Poison-fangs followed by $7-15$ small grooved teeth; head slightly distinct from neck; subcaudals in two rows.

I. Pupil vertical; no canthus rostralis; scales in 15 rows ...........67. Psendelaps p. 264 .

2. Pupil round; canthus rostralis distinct: scales in 15 rows........... 68. Dicmenia p. 266.

c. Poison-fangs followed by $1-5$ small teeth, sometimes indistinctly grooved.

$\dagger$ IIabit colubriform or elapiform.

I. Scales in 17 - 23 rows; subcaudals in two rows or partly single........ 69. Pscudechis p. 268. 2. Scales in $\mathbf{I} 5$ rows; subcaudals in two rows. 70. Micropechis p. 270.

+Habit viperiform; posterior subcaudals paired; end of tail compressed, ending in a long spine; scales in 21 or 23 rows.. 71 . Acanthophis p. $27 \mathrm{I}$.

Terrestrial snakes; mostly viviparous. 


\section{Bungarus Daudin.}

(Daudin, Hist. Rept. V p. 263, I803).

Head not or slightly distinct from neck; eye small; pupil round or vertically elliptic; nostril between two nasals; loreal absent. Maxillary teeth 2 large, grooved fangs, followed by I-4 small, feebly grooved teeth; anterior mandibular teeth longest and feebly grooved. Body round or compressed, covered with smooth scales without pits, in $\mathrm{r} 3-\mathrm{r} 7$ rows, disposed obliquely, vertebral row enlarged, hexagonal; ventrals rounded. Tail moderate or short; subcaudals single or in two rows.

Distribution. S. E. Asia.

$$
\text { Key to the Indo-Australian species. }
$$

A. Subcaudals single; scales in 15 or 17 rows.

1. A dorsal ridge; tail ending obtusely; anterior temporal scarcely more long than deep ...... I. R. fasciatus p. 243.

II. No dorsal ridge; tail ending in a point; anterior temporal much mere long than deep ...... 2. B. candidus p. 244. $B$. Subcaudals partly single, partly in two rows; scales in 13 rows.......................... F. flaviceps p. 245 .

\section{Bungarus fasciatus (Schneider).}

Pseudoboa fasciata, Schneider, Hist. Amph. II I Sor, p. $28_{3}$.

Bungarus fasciatus, Boulenger, Cat. Sn. III 1896, p. 366.

Rostral much more broad than deep, visible from above; internasals shorter than the praefrontals; frontal as long as or longer than its distance from the tip of the snout, as long as or shorter than the parietals; one prae-and two postoculars; temporals $I+2$, anterior scarcely more long than deep; seven upper labials, third and fourth entering the eye; three lower labials in contact with the anterior chin-shields; latter about as long as the posterior, both pairs short. An obtuse keel or ridge along the back and tail, latter ending obtusely. Scales in 15 rows, vertebrals much enlarged; ventrals 200-234; anal entire; subcaudals 23-29, single.

Yellow above, with broad black annuli; a black band on the head and nape, beginning between the eyes and widening behind; snout brown. Lower surface yellow with black bars. Length of head and body $1320 \mathrm{~mm}$; tail $130 \mathrm{~mm}$.

Nom. indig. Ular welang (mal.); oraj welang (sund.). 
Habitat: Sumatra (Stabat, Medan!, Bulo Telang in Langkat); Siak!; Java (Gadok, Buitenzorg!, Depok, Cheribon!, Ambarawa, Wonosobo, Kedu!, Salatiga!, Tengger Mts. I 200 M.); Borneo (Baram river, Kuching, Singkawang). - Penang; Malay Peninsula; Siam; Burma; Assam; Bengal; S. India; S. China; Indo China.

Lives in dry places, in hollows of the ground; in Java often found in Sawahdikes. Feeds on small mammals, lizards and snakes. The eggs, $S$ in number, are incubated by the female.

\section{Bungarus candidus (L.).}

Coluber candidus, Linné, Mus. Ad. Frid. I754, p. 33, pl. VII, fig. I. Bungarus candidus, Boulenger, Cat. Sn. III I 896, p. 368 (s. syn.).

Rostral more broad than deep, visible from above; internasals shorter than the praefrontals; frontal as long as its distance from the tip of the snout, shorter than the parietals; one prae- and two postoculars; temporals $\mathrm{I}+\mathrm{I}$ or $\mathrm{I}+2$, anterior much more long than deep; seven upper labials, third

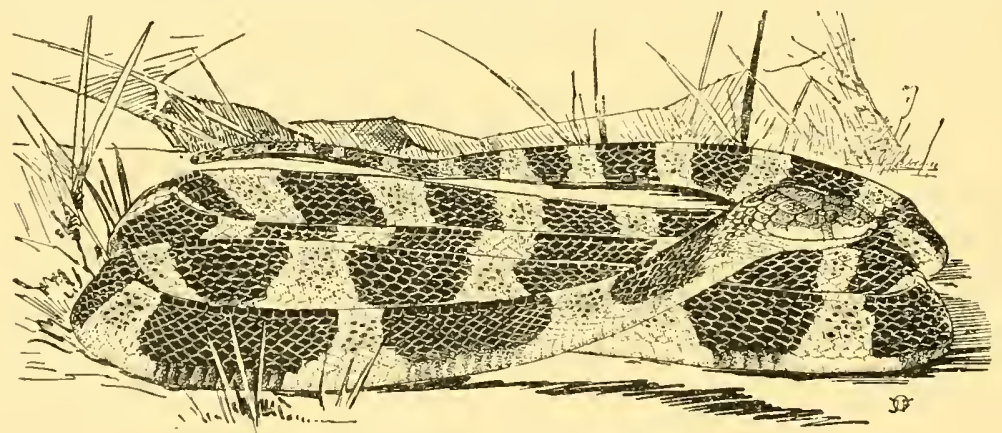

Fig. 91. Bungarus candidus (L.) $\times 3 / 5$.

and fourth entering the eye; three (four) lower labials in contact with the anterior chin-shields; latter as long as the posterior. Scales in I5 (I 7 ) rows, vertebrals much enlarged; ventrals 194-237; anal entire; subcaudals $37-56$, single.

Barred with dark brown and yellow, 27-34 (42-60) dark bars on body and tail, the first continuous with the dark colour of the head, narrowed and rounded on the sides; the broad yellow interspaces may be spotted with black; or dark brown or bluish black above, with narrow, transverse, white streaks or with small white spots. Lower surface white. Length of head and body $920 \mathrm{~mm}$; tail $160 \mathrm{~mm}$. 
Nom. indig. Ular weling (mal.); oraj weling (sund.). Habitat: Sumatra (Lower Langkat) '); Java (Batavia!, Buitenzorg!, Anjer, Krawang!, Depok, Sukabumi!, Kudus near Semarang!, Kediri!, Ambarawa, Prigan I $800-2300$ feet, Tengger Mts. I 200 M.); Celebes (Manado, Minahassa). - Penang; Malay Peninsula; Siam; Indo China; S. China; Burma; India.

Feeds on snakes, toads, lizards and small mammals. The female of the Krait as it is called in British India, deposits 6 - Io eggs in holes in the ground.

\section{Bungarus flaviceps Reinh.}

Fungarus flaviceps, Reinhardt, Vidensk. Selsk. Skrift. X I $\$_{43}$, p. 267, pl. IlI, fig. 4. Bungarus flaviceps, Boulenger, Cat. Sn. III i 896, p. 37 I.

Rostral more broad than deep, visible from above; internasals much shorter than the praefrontals; frontal as long as its distance from the tip of the snout, shorter than the parietals; one prae- and two postoculars; temporals $\mathrm{I}+2$, seven upper labials, third and fourth entering the eye; three or four lower labials in contact with the anterior chin-shields; latter as long as the posterior. Scales in I 3 rows, vertebrals much cnlarged; ventrals 193-230; anal entire; subcaudals 42-54, partly single, partly in two rows.

Black above, with or without a yellow vertebral line, a yellow lateral line along the two outer rows of scales; sometimes a series of yellow dots along the vertebral line; head red or yellow, sometimes with a black marking; tail and sometimes the posterior part of the body orange-red, with or without pairs of black annuli, enclosing a yellowish-white, blackspotted region. Lower surface brown or yellow with brownedged shields. Length of head and body I $630 \mathrm{~mm}$.; tail $220 \mathrm{~mm}$.

Ha bitat: Sumatra (Deli, Asahan, Indragiri, Padang!); Java; Borneo (Kina Balu, Baram, Kuching, Sibu, Simanggang, Pangkalan ampat, Balikpapan). - Penang; Malay Peninsula; Cochin China; Tenasserim.

\section{9. $\mathrm{N}$ a j a Laurenti.}

(Laurentr, Syn. Rept. p. 90, I 768 ).

Head not or slightly distinct from neck; eye rather large;

I) See Werner, Zool Jahrb. Syst. Xill I900, p. 49 I. 
pupil round; nostril between two nasals and the internasal; loreal absent. Maxillary teeth 2 large, grooved fangs, separated by an interspace from one to three small, feebly grooved teeth; anterior mandibular teeth longest. Body round, covered with smooth scales without pits, in $15-25$ rows, more on the neck, disposed obliquely; ventrals rounded. Tail moderate; subcaudals all or greater part in two rows.

Distribution. Africa; S. Asia.

Key to the Indo-Australian species.

A. Internasals in contact with the praeocular ..... I. N. tripudians p. 246. $B$. Internasals separated from the praeocular; a pair of

large shields behind the parietals ........ 2. N. bungarus p. 249.

\section{Naja tripudians Merrem.}

Naja tripudians, Merrem, Tent. IS20, p, 147.

Naja tripudians, Boulenger, Cat. Sn. III ISg6, p. 3 So (s. syn.).

Rostral more broad than deep, visible from above; internasals as long as or shorter than the praefrontals, in contact with the praeocular; frontal as long as or longer than its distance from the rostral, as broad as or broader than the supraocular; one prae- and three (two) postoculars; temporals $2+3$ or $3+3$; seven upper labials, third deepest, third and fourth entering the eye, seventh largest; three or four lower labials in contact with the anterior chin-shiclds; latter as long as or longer than the posterior. Neck dilatable. Scales in $15-25$ rows, $19-35$ round the neck; ventrals $163-207$; anal entire; subcaudals $42-75$.

Pale brown or grey to blackish; no marking on the hood or a pale $\mathrm{U}$ - or $\mathrm{O}$-shaped marking. Lower surface brown or yellowish with one or more dark transverse bands anteriorly. Length of head and body $1320 \mathrm{~mm}$; tail $230 \mathrm{~mm}$; reaches a length of $1900 \mathrm{~mm}$.

Nom. in dig. Ular sendoq (mal.) or ular bedul; oraj sinduk or oraj babi (sund.); ular biludah (Padang Highlands); hantipeh pura (Dajak-name); tedong naga (Kuching).

Habitat: Sumatra (Atjeh!, Medan!, Labuan, Serdang!, Bedagei, Asahan, Langkat, Laut Tador, Battak Mts. 800-1000 M., Indragiri, Djambi!, Tanah Lemba, Palembang, Singkarah!, Silago, Ringat!, Indrapura, Padang!); Riou; Banka!; Borneo 
(Kudat, Bongon, Kina Balu, Limbawan on Padas river, Rejang river, Kuching, Oya, Paku, Busau, Pangkalan ampat, Montrado, Singkawang!, Sungi duri, Labuan, Samarinda!, Balik-

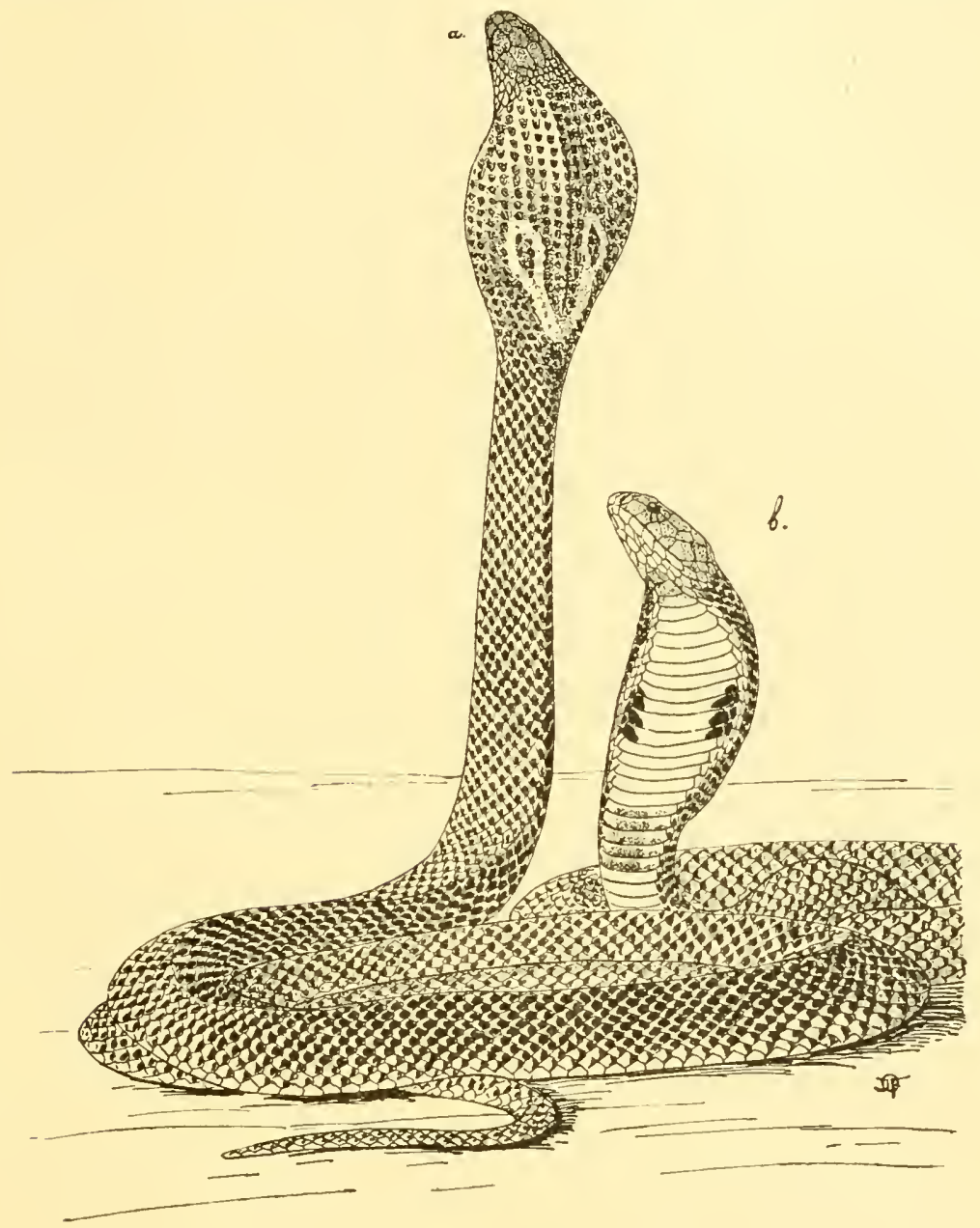

Fig. 92. Naja tripudians Merr. X $1 / 2$.

a. Specimen from British India with the typical marking on the hood, not occurring in Iutch East India.

b. Tar. lencodira Blgr.

papan); Java (Batavia!, Buitenzorg, Depok, Anjer, Sukabumi, Djampang, Bandung!, Pekalongan!); Lombok; Sumbawa; Flores!; Alor (Ombaai). - From the Malay Peninsula to Transcaspia and China. 
Feeds on small mammals, birds, frogs and lizards. Lives in sawahs, near rivers under stones or in hollows in the ground.

Of the many different forms of this species the following are found in the Dutch East Indies:

I. Var. caeca Gmel. 25-3I scales across the neck, 2I-25 across the middle of the body. Uniform pale brown or grey to black; no marking on the hood; one or more dark transverse bands on the anterior part of the belly.

Habitat: Java.

2. Var. sputatrix Boie. 25 scales across the neck, I9-2 I across the middle of the body. Black or dark brown above and below; sides of head and neck yellow or orange. Young specimens with a pale $U$ - or $\mathrm{O}$-shaped marking on the hood; chin and throat whitish.

Habitat: Sumatra; Java.

3. Var. leucodira Blgr. $2 \mathrm{I}-25$ scales across the neck, I 7 or I 9 across the middle of the body. Brown or black; no marking on the hood; neck whitish below, with a black transverse band and a black spot anteriorly and one or two on each side. Habitat: Sumatra.

4. Var. miolepis Blgr. $2 \mathrm{I}-23$ scales across the neck, I7-I9 across the middle of the body. Dark brown or black; no marking on the hood; sides of head and throat yellowish. Young ones with a white throat, the white extending backwards towards its fellow, forming an angular band behind the hood; body and tail with complete white rings.

Habitat: Borneo.

5. Var. paucisquamis Peracca. I9 scales across the neck, I 5 across the middle of the body. Black above and below; throat yellowish-white; head brown, paler towards the sides.

Habitat: Borneo.

6. Var. sumatrana F. Müller. 2 I scales across the neck, I 7 across the middle of the body. Black above; throat yellow with a transverse black band; two confluent black spots anteriorly. Young specimens with about $\&$ narrow whitish rings on the posterior part of the body.

Habitat: Sumatra. 
7. Another var. with 2 I scales on the neck, 19 across the middle of the body is distinguished by BOULENGER. Uniformly olive-brown above, white beneath.

Habitat: Flores; Alor.

\section{Naja bungarus Schlegel.}

Naja bungarus, Schlegel, Phys. Serp. 1837, p. 476, pl. XVII, fig. S \& 9. Naja bungarus, Boulenger, Cat. Sn. III 1896, p. 386 (s. syn.).

Rostral more broad than deep, just visible from above; internasals as long as or shorter than the praefrontals, separated from the praeocular; frontal as long as its distance from the tip of the snout, much shorter than the parietals, as broad as the supraocular; a pair of large occipitals (fig. 93); onc (two) praeocular and three postoculars; temporals $2+2$; seven upper labials, third deepest, third and fourth entering the eye, seventh longest; four lower labials in contact with the anterior chin-shields; latter as long as or longer than the posterior. Scales in 15 rows, $19-2$ I round the neck; ventrals 2I $5-262$; anal entire; subcaudals So-r 20 , the anterior usually single.

Yellowish, brown, olive or black above, with or without dark or white transverse bars; sometimes black edges to the scales. Lower surface whitish, the shields black-

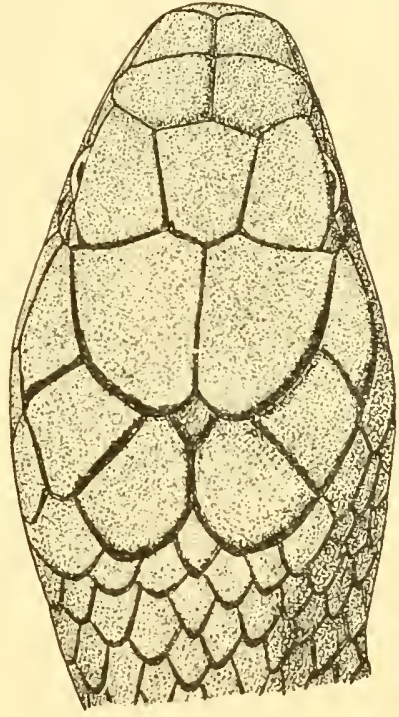

Fig. 93. Naja bungarus Schleg. Head $\times 5 / 6$. edged, or dark brown, chin and throat yellow. Young specimens black, with yellow round spots in transverse series (fig. 94) or with a yellow spot on each scale. Length of head and body $3165 \mathrm{~mm}$; tail $870 \mathrm{~mm}$.

Nom. indig. Ular tedong sélar (Borneo); ular anang (jav.); oraj totok (sund.).

Ha bitat: Simalur!; Nias!; Sumatra (Tamiau in Atjeh!, Deli!, Langkat, Bedagei, Indragiri, Gunung Sahilan!, Ajerbangis!, Tebing Tinggi in Palembang!); Borneo! (Bulangan river, Paku, 
Claudetown, Baram, Pangkalan ampat, Kuching, Sibu, Kapit on Rejang river, Lundu, Balikpapan); Java (Krawang!, Tjikao!); Celebes (Soputan Volcano in Minahassa). - Singapore; Malay

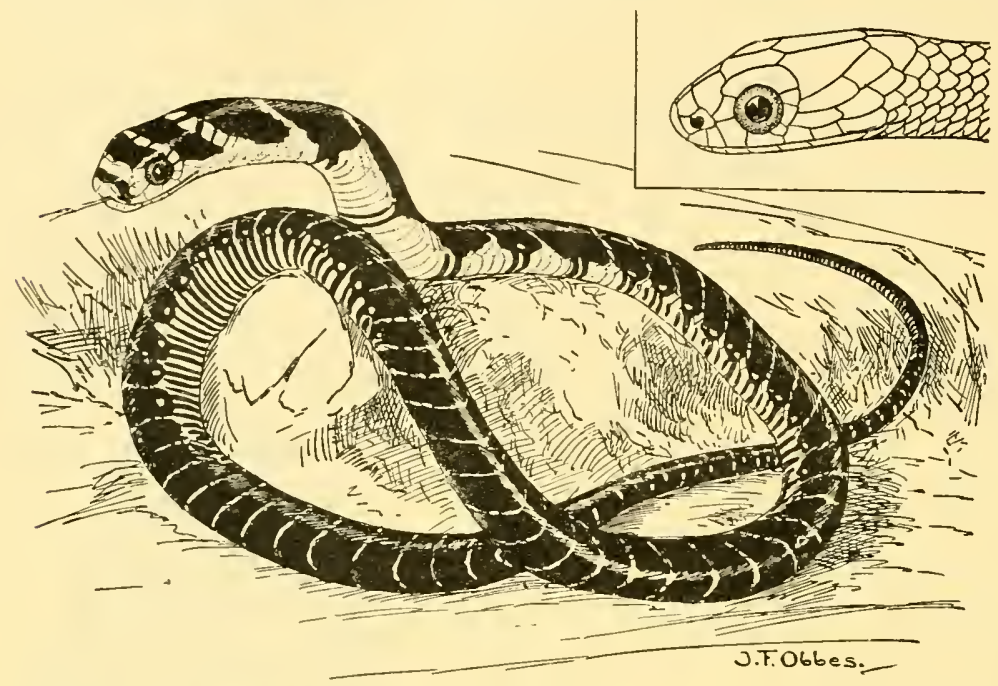

Fig. 94. Naja bungarus Schleg. Young specimen. $\times 3 / 4$. Side view of head. Peninsula; Siam; Andamans; Burma; India; Indo China; S. China; Philippines.

Usually feeds on snakes.

\section{6o. Callophis Günther.}

(Günther, Proc. Zool. Soc. p. Si, I 859).

Head small, not distinct from neck; eye small; pupil round; nostril between two nasals; loreal absent. Maxillary teeth 2 large, grooved fangs, no more teeth; mandibular teeth about equal. Praefrontal bones in contact in the median line. Body long, round, covered with smooth scales without pits, in I3 rows; ventrals rounded. Tail short; subcaudals in two rows.

Distribution. S. E. Asia.

A single species.

\section{Callophis gracilis Gray.}

Calliophis gracilis, Gray, Ill. Ind. Zool. II 1834 , pl. LXXXVI, fig. I. Callophis gracilis, Boulenger, Cat. Sn. III I 896, p. 396.

Eye very small, about half its distance from the mouth. Rostral more broad than deep; internasal not bordering the 
nostril; frontal as long as its distance from the rostral or the tip of the snout, much shorter than the parietals; one praeand two postoculars; a single temporal; six upper labials, third and fourth entering the eye; four lower labials in contact with the anterior chin-shields; latter as long as the posterior. Scales in I 3 rows; ventrals 303-320; anal divided; subcaudals $2 \mathrm{I}-3 \mathrm{O}$.

Pale brown or reddish above, with three dark longitudinal lines passing through round, dark brown or black spots, the lateral spots alternating with the median; two large black blotches across the tail, the first at the base of the tail; two outer rows of scales dark with a yellow longitudinal streak. Lower surface barred black and yellow. Length of head and body $705 \mathrm{~mm}$.; tail $35 \mathrm{~mm}$.

Habitat: Sumatra (Labuan in Deli). - Singapore; Penang; Malay Peninsula!; Bangkok.

Rare.

\section{I. Doliophis Girard.}

(Girar1), Proc. Ac. Philad. p. I\$2, I 857 ).

Head small, not distinct from neck; cye small; pupil round; nostril between two nasals; loreal absent. Maxillary teeth 2 grooved fangs; mandibular teeth subequa,l. Poison glands extending along each side of the body for about one third of its length, thickening and ending in front of the heart, which is shifted far back. Body round, long, covered with smooth scales without pits, in 13 rows; ventrals rounded. Tail short; subcaudals in two rows.

Distribution. Burma; Cochin China; Malay Peninsula and Archipelago.

Key to the Indo-Australian species.

A. Subcaudals $34-53 \ldots \ldots$. . . . . D. bivirgatus p. 25 I.

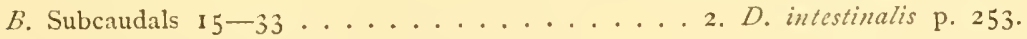

\section{Doliophis bivirgatus (Boie).}

Elaps bivirgatus, Boie, Isis, I $\$ 27$, p. 556 .

Doliophis bivirgatus, Boulenger, Cat. Sn. III I 896, p. 400 (s. syn.).

Rostral slightly more broad than deep; frontal large, as long as or longer than its distance from the tip of the snout, 
as long as or shorter than the parietals; one prae- and two postoculars; temporals I + I or I +2 ; six upper labials, third and fourth entering the eye; three or four lower labials in contact with the anterior chin-shields; latter a little longer than the posterior. Scales in I 3 rows; ventrals $244-295$; anal entire; subcaudals $34-53$.

Black or dark purple above, with a fine white lateral line between the two outer rows of scales, or with four white lines, the outer broader and running along the two outer rows of

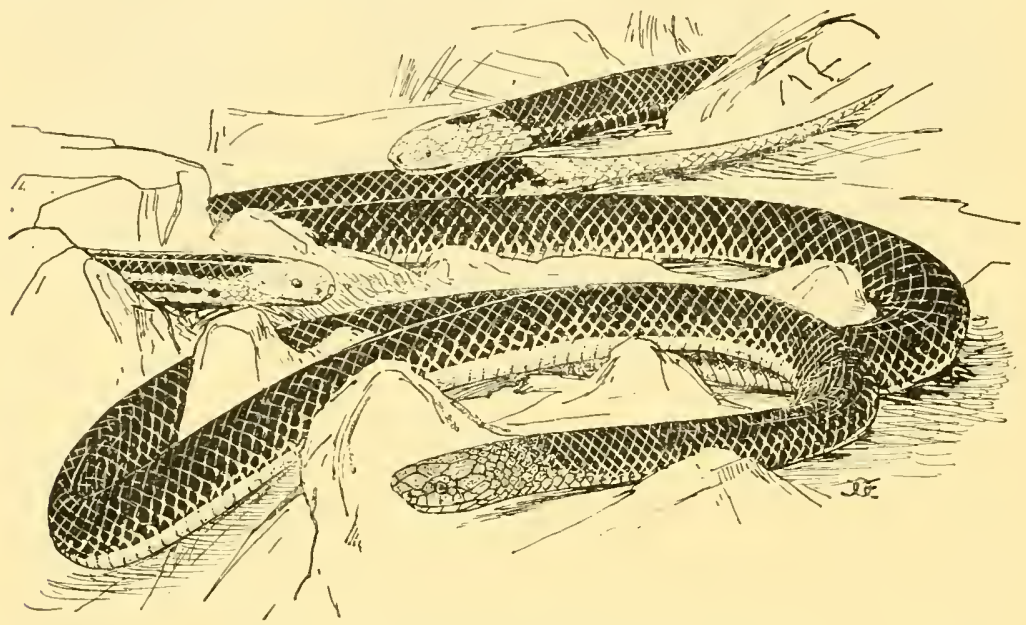

Fig. 95. Doliophis birirgatus (Boie) $\times 1 / 2$.

Three differently marked specimens.

scales, or with a pale blue lateral band along the two outer rows; head and tail red. Lower surface red. Length of head and body I420 $\mathrm{mm}$.; tail $190 \mathrm{~mm}$.

Nom. indig. Kendawang or Kranawang (Dajak-name); ular tjabeh (mal.).

Habitat: Nias!; Sumatra (Labuan, Medan!, Serdang!, Bindjey, Langkat, Battak Highlands Soo- IOOO M., Indragiri, near Supat, Palembang!, Indrapura, Taluk!, Agam); Banka!; Riou; Borneo (Sandakan, Bongon, Sintang, Matang, Sibu, Busau, Kuching, Tegora, Limbang, Banting, Pangkalan ampat, Buntok, Landak!; Pontianak, Muara Djawa!, Muara Tebe!, Balikpapan, Bandjermassin!) ; Java! (Tengger Mts. I 200 M.). Singapore; Penang; Malay Peninsula; Siam; Cochin China; Burma. 
2. Doliophis intestinalis (Laur.).

Aspis intestinalis, Laurenti, Syn. Rept. I768, p. 106.

Doliophis intestinalis, Boulenger, Cat. Sn. III I $\$ 96$, p. 40 I (s. syn.).

Rostral slightly more broad than deep; frontal as long as or longer than its distance from the tip of the snout, shorter

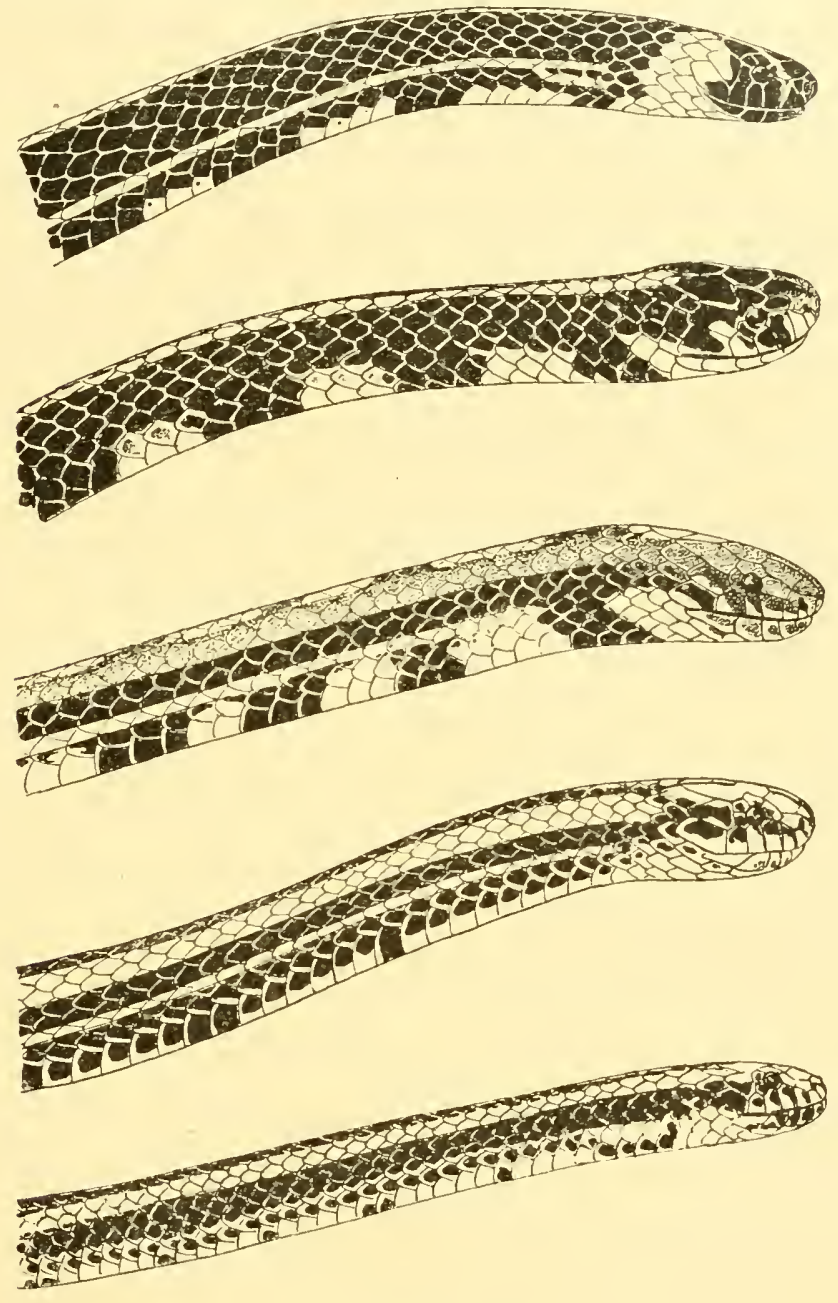

Fig. 96. Doliophis intestinalis (Laur.). Five different forms of this species.

than the parietals; one prae- and two postoculars; temporals I +2 ; six upper labials, third and fourth entering the eye; 
three or four lower labials in contact with the anterior chinshields; latter as long as or longer than the posterior. Scales in 13 rows; ventrals 197-273; anal entire; subcaudals I5-33.

Dark brown, pale greyish, reddish-brown or black above, with a narrow orange or yellow vertebral line, sometimes forked on the head and extending to behind the nostril; usually a large triangular yellow blotch on the temporal region; a black stripe along each side, divided by a narrow yellow line. The yellow vertebral line sometimes bordered by dark brown, pale grey or blackish lines or broken up by dark brown spots; sometimes a dark vertebral band, three scales wide, bordered by a pale reddish-brown streak, two scales wide; a pale brown line between the two outer rows of scales. Lower surface yellow witi black transverse bars, which are sometimes confluent with the black of the sides; tail pink or red below. Length of head and body $535 \mathrm{~mm}$.; tail $45 \mathrm{~mm}$.

Nom. indig. Ular tjabeh (mal.); tadung munggu(Landak).

Habitat: Nias!; Sumatra (Atjeh, Labuan, Stabat, Deli!, Langkat, Raja Mts., Siboga, Indragiri, Kertadjaja in Palembang, Kaju tanam!, Indrapura, Agam, Padang!); Riou!; Banka!; Borneo (Sandakan Bay, Kina Balu, Matang, Sintang, Pangkalan ampat, Brooketon, Rejang, Paku, Kuching, Kidi district, Tegora, Busau, Simanggang, Mt. Dulit, Landak!, Labuan, Tandjong); Java (Gadok, Mt. Salak, Buitenzorg!, Tjibodas!, Krawang, Sukabumi!, Semarang, Salatiga!, Wonosobo, Malang!, Mt. Wilis 5000 feet, Nongkodjadjar in Tengger Mts. I 300 M.!, Prigan ISOO-2300 feet); Celebes (Manado). - Singapore; Penang; Malay Peninsula; Siam; Burma.

\section{Glyphod on Günther.}

(Günther, Cat. Col. Snakes p. 210, 1858).

Head small, not distinct from neck; eye very small; pupil round or vertically clliptic; nostril between two nasals; loreal absent. Maxillary teeth 2 large, grooved fangs, followed by 6 small, grooved teeth after an interspace; mandibular teeth feebly grooved, anterior strongly enlarged. Body round, covered with smooth scales without pits, in 17 rows; ventrals rounded. Tail short; subcaudals in two rows.

Distribution. Aru Islands; New Guinea; N. Australia.

A single species. 


\section{Glyphodon tristis Günther.}

Glyphodon tristis, Günther, Cat. I 85 S, p. 211.

Glyphodon tristis, Boulenger, Cat. Sn. III I 896 , p. 3I4, pl. XVIII, fig. I.

Snout rounded; eye about half as long as its distance from the mouth. Rostral more broad than deep, visible from above; posterior nasal separated from the praeocular; no loreal; internasals shorter than the praefrontals; frontal twice as broad as the supraocular, as long as its distance from the rostral or the tip of the snout, shorter than the parietals; one prae- and two postoculars; temporals $2+2$, lower anterior wedged in between the fifth and sixth upper labials; six upper labials, second or second and third in contact with the praefrontal, third and fourth entering the eyc; four lower labials in contact with the anterior chinshields; latter as long as or shorter than the posterior. Scales in 17 rows; ventrals I65-I79; anal divided; subcaudals $33-52$, in two rows or somc of
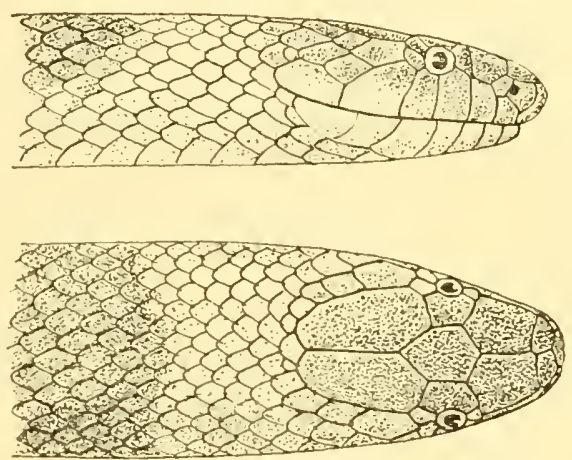

Fig. 97. Glyphodon tristis Githr. After Boulenger.

the anterior single.

Dark brown or blackish above, the scales light-edged; occiput and nape sometimes yellowish or pale reddish. Lower surface yellow, the outer ends of the ventrals dark brown; subcaudals dark brown anteriorly, yellow posteriorly. Length of head and body $775 \mathrm{~mm}$.; tail $125 \mathrm{~mm}$.

Habitat: Aru Islands; New Guinea (St. Joseph's river, Fly river!). - Islands of Torres Straits; N. E. Australia.

\section{Toxicocalamus Boulenger.}

\section{(Boulenger, Ann. Nat. Hist. (6) XVIII p. I52, I896).}

Head small, not distinct from neck; eye very small; pupil round; nostril between two nasals; no loreal; no praeocular. Postfrontal bone absent. Maxillary teeth 6 , gradually decreasing in size, the first perforated; mandibular teeth gradually decreasing in length. Body very long, round, covered with smooth 
scales without pits, in 15 or 17 rows; ventrals rounded. Tail short; subcaudals in two rows.

Distribution. New Guinea; Woodlark Island.

$$
\text { Key to the species. }
$$

A. Scales in 17 rows; ventrals $274-305 \ldots$. . I. T. longissimus p. 256.

D. Scales in 15 rows; ventrals $230-261$. . . . 2. T. stanleyanus p. 256 .

\section{Toxicocalamus longissimus Boulenger.}

Toxicocalamus longissimus, Boulenger, op. cit.; Proc. Zool. Soc. I903 II pl. XIII, fig. 2.

Rostral slightly more broad than deep, visible from above; internasals half as long as the praefrontals, which are in contact with the second and third labials and with the eye; frontal small, as long as its distance from the tip of the snout, much shorter than the parietals, a little broader than the supraocular; no praeocular, one postocular; temporals $\mathrm{I}+2$; six upper labials, third and fourth entering the eye; three lower labials in contact with the anterior chin-shields; latter a little longer than the posterior. Scales in 17 rows; ventrals $274-305$; anal divided; subcaudals $30-46$. Tail ending in a compressed horny scale, which is keeled above.

Grey-brown above, with dark streaks on the scales; sides whitish, each scale with a grey-brown streak; a reddish bar across the snout; a reddish spot behind the eye and another, sometimes indistinct, on the occiput; the dark colour of the head forming two vertical bars across the yellow upper lip, one passing through the eye, the other behind the corner of the mouth. Lower surface white, with two grey-brown longitudinal streaks. Length of head and body $612 \mathrm{~mm}$; tail $38 \mathrm{~mm}$.

Type-specimens examined in the British Museum.

Habitat: Woodlark Island! and Ferguson Island, Brit. New Guinea.

\section{Toxicocalamus stanleyanus Boulenger.}

Toxicocalamus stanleyanus, Boulenger, Proc. Zool. Soc. 1903 II p. I2S, pl. XIII, fig. 3 .

Rostral much more broad than deep, visible from above, internasals almost as long as the praefrontals, which are in contact with the second upper labial and with the eye; frontal 
small, as long as its distance from the tip of the snout, a little shorter than the parietals, slightly broader than the supraocular; no praeocular, one postocular; temporals $I+2$; five upper labials, second and third entering the eye; three lower labials in contact with the anterior chin-shields; latter larger than the posterior. Scales in I 5 rows; ventrals $230-26 \mathrm{I}$, the

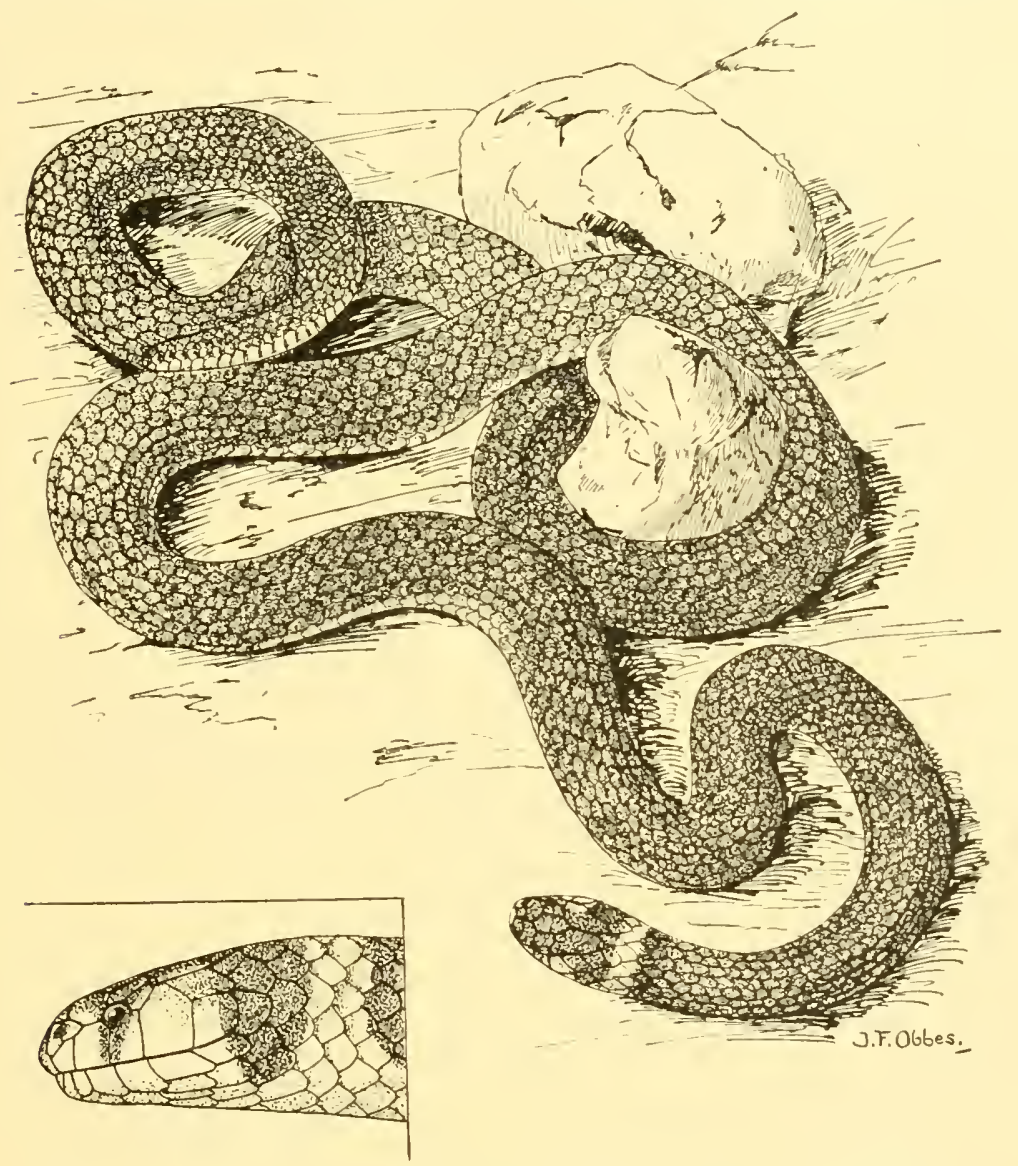

Fig. 9S. Toxicocalamus stanlyynus Blgr. Nat, size. Side view of head.

last sometimes divided; anal entire; subcaudals 25-5I. Tail ending in a compressed, obtuse scale, which is keeled above.

Blackish-brown above; two outer rows of scales white, each scale with a blackish centre; a yellow nuchal collar, bordered posteriorly with blackish; head dark brown or blackish, the dark colour forming two vertical bands across the yellow upper INDO-AUSTRALIAN REPTILES II. 
lip, the anterior passing through the eye, the other just behind the corner of the mouth. Lower surface white, with a black spot on each side of the shields; some of the ventrals with an interrupted blackish border. Length of head and body $570 \mathrm{~mm}$; tail $40 \mathrm{~mm}$.

Type-specimen examined in the British Museum.

Habitat: New Guinea (Dinawa in Owen Stanley Range 4000 feet!, Madew on St. Joseph river 2-3000 feet, Beaufort river near Lorentz river!).

\section{U1trocalamus Sternfeld.}

(Sternfelr, Sitz. ber. Gesellsch. Naturf. Fr. p. 388 , 1913).

Head small, not distinct from neck; eye very small; pupil round; nostril in a single nasal; no loreal; no praeocular; no

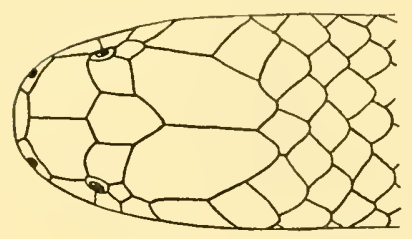
internasals; praefrontals entering the eye; no anterior temporal, parietals in contact with labials. Maxillary teeth 6 , gradually decreasing in size, first grooved;

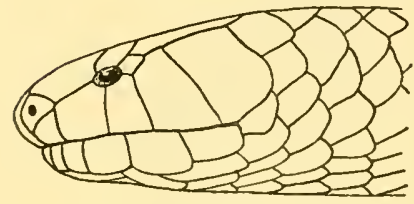

Fig. 99. Ultrocalamus preussi Sternf. Head $\times 2 \frac{1}{2}$.

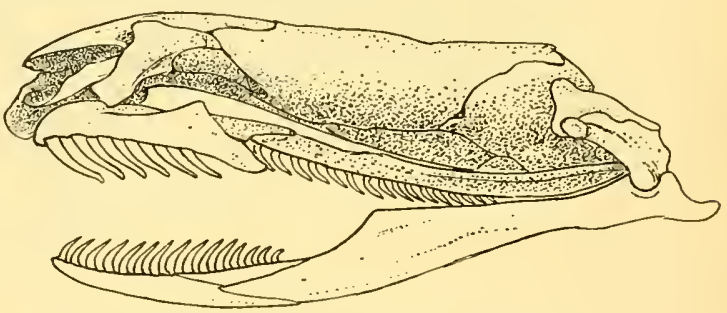

Fig. 100. Lltrocalamus preussi Sternf. Skull $\times 5$.

mandibular teeth gradually decreasing in length. Body very long, round, covered with smooth scales without pits in I3 rows; ventrals rounded. Tail short; subcaudals in two rows.

Distribution. New Guinea.

A single species.

\section{Uitrocalamus preussi Sternfeld.}

C'ltrocalamus proussi, Sternfeld, Sitz. ber. Gesellsch. Naturf. Fr. I9I3, p. 388 , fig. I $\$ 2$.

Rostral nearly twice as broad as deep, visible from above; no internasals; praefrontals large, in contact with the rostral, the nasal, the second upper labial and the eye; frontal small, 
a little broader than the supraocular, one time and a half as long as broad, shorter than its distance from the tip of the

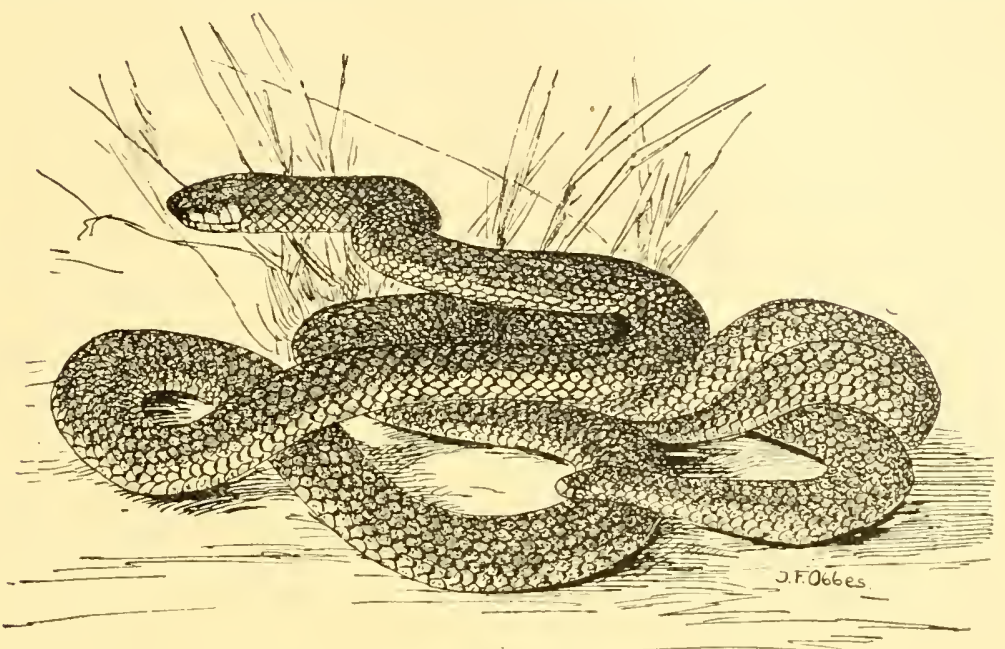

Fig. 101. Cltrecalumus prenssi Sternf, $X^{3} / 4$.

snout, half the length of the parietals; one postocular; no anterior temporal, the parietals forming a suture with the last

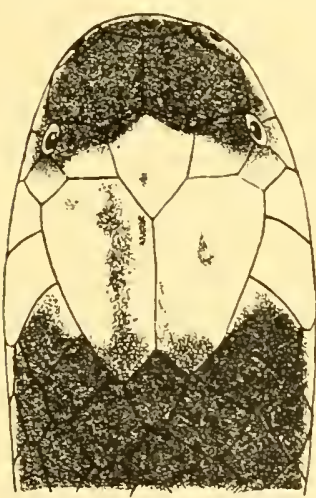

Fig. 102. Litrocalamus proussi Sternf. Head of young specimen. $\times 7$. labial; five upper labials, second and third entering the eye; three lower labials in contact with the anterior chin-shields, which are larger than the posterior. Scales in 13 rows; ventrals $300-328$; anal entire; subcaudals I6-48; tail ending in a compressed obtuse scute, obtusely keeled above.

Dark brown above, the scales edged with dark; two outer rows of scales yellowish, each scale with a brown centre; a broad yellowish band across the head on the parietals, disappearing with age; upper lip yellow. Lower surface yellowish, each ventral and subcaudal with a brown bar; throat yellow. Length of head and body $730 \mathrm{~mm}$.; tail $35 \mathrm{~mm}$.

Habitat: N. New Guinea (Sermowai river!, Humboldt Bay!, Njao on Tjano river!, Seleo Island near Berlinhafen). 
Note. Another Elapine snake is mentioned by STERNFELD: Ultrocalamus biirgersi n. sp. from New Guinea. As the head had been dried, the head-shields could not be seen very distinctly. The specimen had 15 rows of scales; internasals absent. Ventrals 293; subcaudals 40. Brown above; scales of outer row margined with light; upper lip and end of tail yellow. Length $330+35 \mathrm{~mm}$.

\section{A p istocalamus Boulenger.}

(Boulenger, Ann. Mus. Civ. Genova (2) XVili p. 705, 1897).

Head small, not distinct from neck; eye very small; pupil vertically elliptic; nostril between two nasals; praeocular in contact with or narrowly separated from the posterior nasal. Maxillary teeth 5 long, grooved teeth, gradually decreasing in length; mandibular teeth decreasing in length. Body round, covered with smooth scales without pits, in I 5 rows; ventrals rounded. Tail moderate; subcaudals in two rows or partly single.

Distribution. New Guinea.

Key to the species.

A. Ventrals 190; subcaudals 4 I ........... I. A. pratti p. 260.

B. Ventrals I96; subcaudals 50 or more ........ . A. loriae p. 26 I.

C. Ventrals 207 ; subcaudals $27 \ldots \ldots . . . .3$. A. grandis p. $26 \mathbf{1}$.

D. Ventrals 199-218; subcaudals 22-32 ..... 4. A. lonnbergi p. 262.

\section{Apistocalamus pratti Boulenger.}

Apistocalamus Pratti, Boulenger, Ann. Nat. Hist. (7) XIII I904, p. 45 I.

Snout short, rounded. Rostral slightly more broad than deep, visible from above; posterior nasal in contact with the praeocular; internasals half as long as the praefrontals; frontal as long as its distance from the tip of the snout, much shorter than the parietals; one prae- and one postocular; temporals I + I ; six upper labials, third and fourth entering the eye; three lower labials in contact with the anterior chin-shields; latter larger than the posterior, which are separated by a large scale. Scales in I 5 rows; ventrals 190 ; anal divided; subcaudals $4 \mathrm{I}$, partly single, partly in two rows. Tail ending in a pointed scale, which is keeled above.

Olive-brown above; an oblique yellowish streak on each side of the nape; upper lip yellow. Lower surface yellowish with a median series of olive-brown spots, becoming confluent 
into a band after the anterior fourth of the body. Length of head and body $305 \mathrm{~mm}$.; tail $50 \mathrm{~mm}$.

Type-specimen examined in the British Museum.

Habitat: New Guinea (Dinawa in Owen Stanley Range 4000 feet!).

\section{Apistocalamus loriae Boulenger.}

Apistocalamus loriaz, Boulenger, Ann. Mus. Civ. Genova (2) XVIII I 897, p. 705, pl. VIII, fig. I.

Snout short, broadly rounded. Rostral slightly more broad than deep, visible from above; posterior nasal in contact with the praeocular; internasals about one third the length of the praefrontals; frontal as long as its distance from the tip of the snout, much shorter than the parietals; one pracocular and two postoculars, upper much larger than lower; temporals $\mathrm{I}+2$; six upper labials, third and fourth entering the eye, sixth largest; three lower labials in contact with the anterior chin-shields; latter larger than the posterior, which are separated by a large scale. Scales in I 5 rows; ventrals 196; anal divided; subcaudals $48+$ ?

Dark greyish-olive above; upper lip yellowish. Lower surface yellowish, with three series of small dark spots along the ventrals; subcaudals dark with light edges. Length of head and body $490 \mathrm{~mm}$; t tail (injured) $90 \mathrm{~mm}$. (After BOULENGER; not seen by me).

Habitat: New Guinea (Haveri).

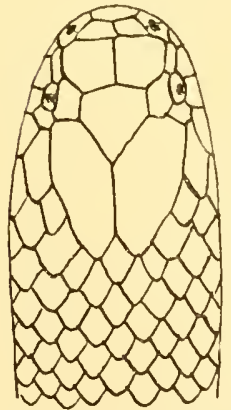

Fig. 103. Apistocalamus grandis $\mathrm{Blg}$.

After Boulenger.

3. Apistocalamus grandis Boulenger.

Apistocalamus grandis, Boulenger, Transact. Zool. Soc. XX 1914, p. 265, pl. XXX, fig. 3.

Snout short, broadly rounded. Rostral more broad than deep, just visible from above; posterior nasal in contact with the praeocular; internasals not quite half so long as the praefrontals; frontal as long as its distance from the tip of the snout, much shorter than the parietals; one prae- and one postocular; temporals I +2 ; six upper labials, third and fourth entering the eye, last largest; three lower labials in contact with the anterior chin-shields; latter slightly 
larger than the posterior, which are separated by a scale. Scales in 15 rows; ventrals 207; anal divided; subcaudals 27. Tail ending in a pointed scale, which is keeled above.

Dark brown above, with irregular whitish blotches; upper lip white. Lower surface white. Length of head and body s6o $\mathrm{mm}$. ; tail so $\mathrm{mm}$.

Type-specimen examined in the British Museum.

Habitat: S. New Guinea (Setekwa river!).

\section{Apistocalamus lönnbergi Boulenger.}

Apistocalamus loennbergii, Boulenger, Ann. Nat. Hist. (8) I I 908, p. 248 ; Transact. Zool. Soc. XX 1914 pl. XXX, fig. 4 .

Snout short, broadly rounded. Rostral slightly more broad than deep, visible from above; posterior nasal in contact with or narrowly separated from the praeocular; internasals about half as long as the praefrontals; frontal as long as or shorter than its distance from the tip of the snout, much shorter than the parietals; one prae- and one postocular (rarely two); temporals I + I or 2 ; six upper labials (seven), third and fourth (third to fifth) entering the eye, last largest; three or four lower labials in contact with the anterior chin-shields; latter as large as the posterior, which are sometimes separated by a scale. Scales in 15 rows; ventrals $199-2 \mathrm{I} 8$; anal divided; subcaudals 22-32. Tail ending in a pointed scale, which is keeled above.

Dark olive-brown above; scales of the sides with yellowish centre; upper lip yellowish;

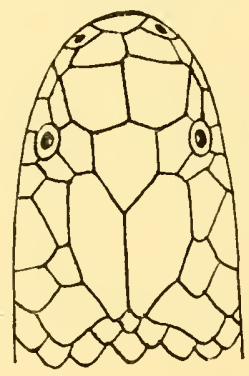

Fig. 104. Apistocalamus lömbergi Blgr. After Boulenger. a yellow collar and a yellowish spot on each parietal may be present. Lower surface uniformly yellowish. Length of head and body $550 \mathrm{~mm}$.; tail $40 \mathrm{~mm}$.

Type-specimens examined in the British Museum.

Habitat: New Guinea (North of Fak Fak I700 feet!, German New Guinea).

\section{Pseudapist ocalamus Lönnberg.}

(Lönnberg, Ann. Hist. (7) VI p. 578, 1900).

Head small, depressed, hardly distinct from neck; eye very small; pupil round; nostril in a single nasal, the margin of 
the latter bordering the first labial and the internasal comparatively narrow; praeocular large, in contact with the nasal. Maxillary teeth 2 grooved ones, followed by four grooved teeth, gradually decreasing in length. Body round, covered with smooth scales, in 15 rows; ventrals rounded. Tail short; subcaudals in two rows.

Distribution. New Guinea.

A single species.

\section{Pseudapistocalamus nymani Lönnberg.}

Psendapistocalamus Nymani, Lönnberg, op. cit.

Snout short, bluntly rounded. Rostral more broad than deep, visible from above; internasals small, about half as long as the praefrontals; frontal almost as long as its distance from the rostral, much shorter than the parietals; a prae- and two

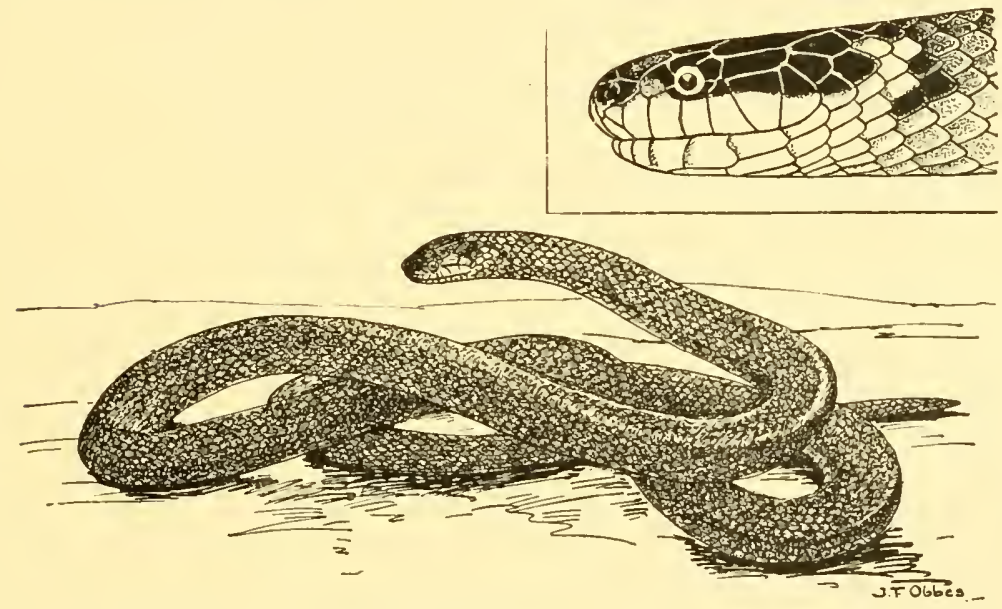

Fig. 105. I'seudapistocalamus nymani Lönnberg. Nat. size. Side view of head. postoculars, the upper largest; temporals I +2 ; six (seven) upper labials, third and fourth entering the eye, sixth largest, sometimes divided; three lower labials in contact with the anterior chin-shields; latter longer than the posterior, which are sometimes separated by a scale. Scales in 15 rows; ventrals I 88-205; anal divided; subcaudals 26-43. Tail ending in a pointed scale, which is keeled above.

Dark bronze-brown or blackish, iridescent above; flanks lighter; upper lip and a spot on each side of the nape yel- 
lowish; a yellow transverse band across the praefrontals. Lower surface blackish-brown, the shields edged with light grey. Young specimen with the outer rows of scales blackish, edged with grcy. Length of head and body $398 \mathrm{~mm}$.; tail $47 \mathrm{~mm}$.

Type-specimen received from the Upsala Museum, examined.

Habitat: New Guinea! (Sattelberg Soo M.!, Lialun).

A female specimen contained eggs of about $13 \mathrm{~mm}$.

\section{Ps eudelaps Dum. \& Bibr.}

(Duméril, \& Brbron, Mém. Ac. Sc. XXili p. 5i7, i 853 ).

Head slightly distinct from neck; eye small; pupil vertically elliptic; nasal single or divided; loreal absent. Maxillary teeth 2 large, grooved fangs, separated by an interspace from 8-I2 small, grooved teeth; anterior mandibular teeth strongly enlarged. Body round, covered with smooth scales without pits, in 15 or 17 rows; ventrals rounded. Tail short; subcaudals in two rows.

Distribution. Moluccas; New Guinea; Australia.

A single species.

\section{Pseudelaps mülleri (Schlegel).}

Elaps miillwit, Schlegel, Ihys. Serp. I\$37, p. 452, pl. XVI fig. I6 \& I7. Pseudelaps muelleri, Boulenger, Cat. Sn. III IS96, p. 316 (s. syn.).

Rostral twice as broad as deep, scarcely visible from above; nasal divided, in contact with the praeocular; internasals shorter than the praefrontals; frontal longer than its distance from the tip of the snout, shorter than the parietals; one prae- and two postoculars; temporals $2+2$, lower anterior wedged in between the fifth and sixth upper labials; six upper labials, third and fourth entering the eye; three or four lower labials in contact with the anterior chin-shields: latter as long as or shorter than the posterior. Scales in 15 rows; ventrals ${ }_{3} 8-177$; anal divided; subcaudals i6-39.

Brown above; sometimes a light vertebral line anteriorly; head sometimes spotted with dark brown; a dark, light-edged streak on each side of the head, passing through the eye and sometimes continued along the neck. Lower surface yellowish or coral-red, uniform or spotted with brown or black; throat brown or black. Ioung specimens sometimes with a dark brown nuchal collar. Length of head and body $556 \mathrm{~mm}$.; tail $72 \mathrm{~mm}$. 
Habitat: Ceram; Misol; Salawatti; New Guinea (Jobi, Mafoor, Djamna, Sorong, Fak Fak, Dorei, Rubi, Mansinam, Andai, Mt. Arfak, Krudu, lake Sentani, Wendèsi, Humboldt Bay!, near Kasawari!, Tana, Etna Bay, Utakwa river 2500 feet, Lorentz river!, Sattelberg, Simpsonhafen, Stephansort, Bongu, Astrolabe Bay, Haveri, Moroka 2300 feet, Bara Bara, Madew on St. Joseph river, Albert Edward Range 6000 feet, Mt.

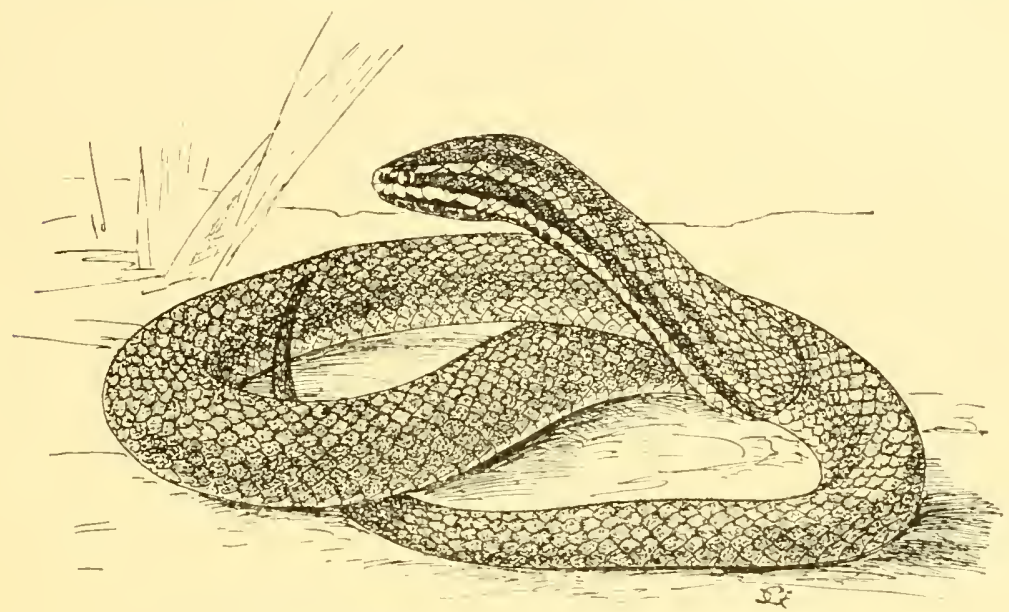

Fig. 106. Psendelips mülleri (Schleg.). Nat. size.

Victoria in Owen Stanley Range, Valise Island, Seleo Island); Schouten Islands (Mysore). Ferguson, Trobiand and Woodlark Islands; St. Aignan; Bismarck Archipelago.

Note. Werner described a specimen from New Guinea (Zool. Anz. XXVI 1903, p. 25I) with IS I ventrals and 40 subcaudals as $P$. miulleri var. lineaticollis. Sides of neck with two longitudinal lines; throat not black; tail with a median dark line below.

BARBOUR made for a very dark specimen from Djamna Island a new subspecies: $P$. miulleri insulae. In the Leiden Museum there are in the collection of snakes some specimens of this dark race, showing a connection with the typical specimens by one animal with an indication of a light vertebral line. (See Barbour, Bull. Mus. Zool. Cambr. LI ig07/08 p. 320 and Mem. Mus. Comp. Zool. XLIV igi 2, p. I32; V. LidTh de Jeude, Nova Guinea Zool. V I9I I, p. 529). 


\section{Diem enia Günther.}

(Günther, Ann. Nat. Hist. (3) XlI p. 350, 1863).

Head slightly distinct from neck; eye moderate or large; pupil round; canthus rostralis distinct; nasal entire or divided; loreal absent. Maxillary teeth 2 large, grooved fangs, separated by an interspace from 7-I5 small, grooved teeth; anterior mandibular teeth strongly enlarged. Body round, covered with smooth scales without pits, in 15 -19 rows, more on the neck; ventrals rounded. Tail moderate or long; subcaudals all or the greater part in two rows.

Distribution. New Guinea; Australia.

Key to the Indo-Australian species.

$A$. Rostral almost as deep as broad; internasals at

least half as long as praefrontals .......... I. D. psammophis p. 266.

b. Rostral much more broad than deep; internasals

not more than half so long as praefrontals ... 2. D. olizacea p. 267.

\section{Diemenia psammophis (Schlegel).}

Elaps psammophis, Schlegel, Phys. Serp. 1837, p. 455.

Diemenia psammophis, Boulenger, Cat. Sn. III I\$96, p. 322 (s. syn.).

Rostral about as deep as broad, visible from above; nasal

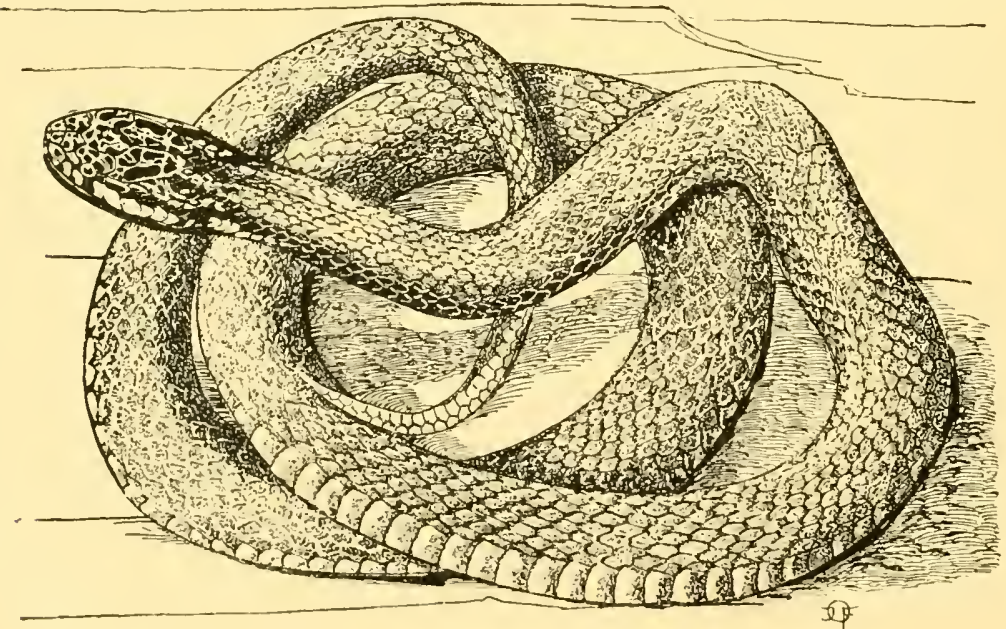

Fig. 107. Diemenia psammophis (Schleg.). $\times \% / 3$.

divided, in contact with the praeocular; internasals one half 
to two thirds the length of the praefrontals; frontal as long as or longer than its distance from the tip of the snout, shorter than the parietals; one praeocular, two (three) postoculars; temporals $2+2$, lower anterior wedged in between the fifth and sixth labials; six upper labials, third and fourth entering the eye; three lower labials in contact with the anterior chinshields; latter shorter than the posterior. Scales in 15 rows; $17-20$ on the neck; ventrals $170-225$; anal divided; subcaudals 69-105.

Olive or reddish-brown or blackish above, the scales with black narrow edges or tipped with black, sometimes the black colour forms a reticulation. Lower surface olive, greyish or yellowish, darker at the outer ends of the ventrals, sometimes darker along the median line; tail yellow or orange at the end. Young specimens with a dark line across the rostral and two oblique, dark-edged yellow streaks, one in front, the other behind the eye. Length of head and body roso mm.; tail $340 \mathrm{~mm}$.

Habitat: New Guinea (Sermowai river!, lake Sentani!, Humboldt Bay!, Lorentz river!, Merauke, Fly river, Port Moresby, Madew on St. Joseph river 2-3000 feet). - Australia.

\section{Diemenia olivacea (Gray).}

Lj codon olivaceus, Gray, Zool. Miscell. IS42, p. 54.

Dicmenia olivacea, Boulenger, Cat. Sn. III I $\$ 96$, p. 323, pl. XVIII, fig. 2 (s. syn.).

Rostral more broad than deep, visible from above; nasal divided, in contact with the pracocular; internasals about half the length of the praefrontals; frontal much longer than its distance from the tip of the snout, shorter than the parietals; one prae- and two postoculars; temporals $2+2$, lower anterior wedged in between the fifth and sixth upper labials, sometimes reaching the lip; six upper labials, third and fourth entering the eye; three or four lower labials in contact with the anterior chin-shields; latter shorter than the posterior. Scales in 15 rows, 17 on the neck; ventrals $162-215$; anal divided; subcaudals 79-99.

Olive, reddish or dark brown above, the greater part of the scales black at the base, some with light edges; snout and sides of head speckled or vermiculated with dark brown; an oblique dark streak below the eye to beyond the angle of the mouth, disappearing in adult specimens. Lower surface yel- 
lowish, uniform or speckled with olive; throat and anterior ventrals spotted with black in the young; tail yellow or red. Length of head and body $770 \mathrm{~mm}$.; tail $240 \mathrm{~mm}$.

Typc-specimen examined in the British Museum.

Habitat: New Guinea (Yule Island). - Australia!.

\section{Pseudechis Wagler.}

(IVAgler, Syst. Amph. p. I 7 I, I830).

Head distinct from neck; eye moderate or small; pupil round; canthus rostralis distinct; nostril between two nasals; loreal absent. Maxillary teeth 2 large, grooved fangs followed by 2-5 small solid teeth; anterior mandibular teeth longest. Body round, covered with smooth scales without pits, in $17-23$ rows, more on the neck; ventrals rounded. Tail moderate; subcaudals in two rows or partly single, partly in two rows.

Distribution. New Guinea; Australia.

Key to the Indo-Australian species.

A. Anal divided; anterior subcaudals single.

I. Scales in 17 rows...................... australis p. 268.

II. Scales in I9 or 2 I rows ............. 2. P. papuanus p. 269. B. Anal entire; subcaudals in two rows; scales in 23 rows. 3. P. scutellatus p. 269.

\section{Pseudechis australis (Gray).}

Naja australis, Gray, Zool. Misc. I $8_{42}$, p. 55.

Pseudechis australis, Boulenger, Cat. Sn. III 1896, p. 330.

Eye small, almost as large as its distance from the mouth. Rostral more broad than deep, visible from above; posterior nasal in contact with the praeocular; internasals half as long as the praefrontals; frontal small, as long as its distance from the rostral, much smaller than the parietals; one prae- and two postoculars; temporals $2+2$, lower anterior wedged in between the fifth and

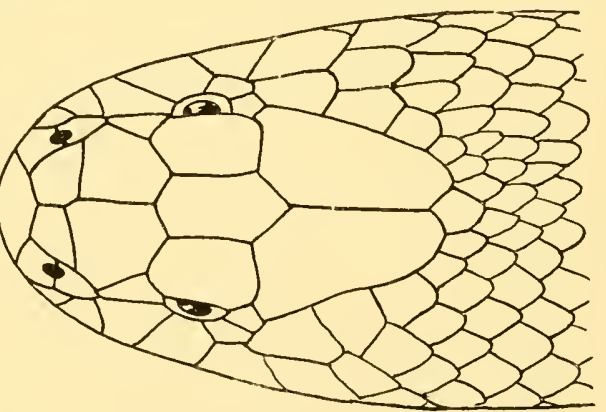

Fig. Io8. Pseudechis australis (Gray). Upper view of head. sixth labials; six upper labials, third and fourth entering the 
eye, third larger than fourth; three lower labials in contact with the anterior chin-shields; latter shorter than the posterior,

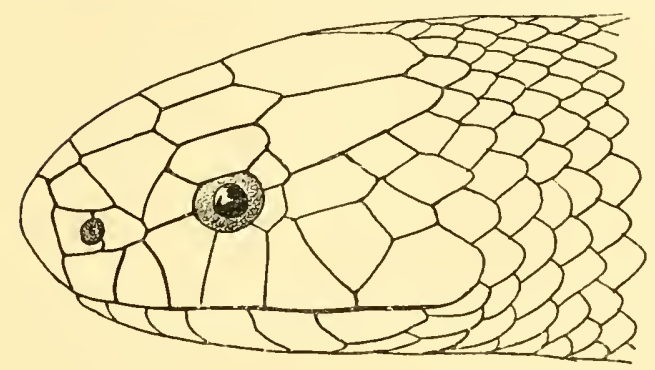

Fig. 109. Pseudechis australis (Gray). Side view of head. which are separated by a scale. Scales in 17 rows, 19 or 20 on the neck; ventrals 199-220; anal divided; subcaudals $57-70$, the 26-4 I anterior single.

Pale brown above; yellowish below. Length of head and body 9 ro $\mathrm{mm}$.; tail $170 \mathrm{~mm}$.

Type-specimen examined in the British Museum.

Habitat: S. New Guinea (Etna Bay!). - N. and N. E. Australia.

\section{Pseudechis papuanus Ptrs. \& Doria.}

Psudechis papuanus, Peters \& Doria, Ann. Mus. Genova XIII IS78, p. 409. Psewlechis papuanus, Boulenger, Cat. Sn. III I 896, p. $33 \mathbf{I}$.

Eye smaller than its distance from the mouth. Rostral more broad than deep, visible from above; posterior nasal in contact with the praeocular; internasals smaller than the praefrontals; frontal small, as long as the praefrontals, half as long as the parietals; one prae- and two postoculars; temporals $2+2$, lower anterior large, wedged in between the fifth and sixth labials; six upper labials, third and fourth entering the eye, third larger than fourth; three lower labials in contact with the anterior chin-shields; latter shorter than the posterior, which are separated by two scales. Scales in 19 or 2 I rows, 26 or 27 on the neck; ventrals $221-224$; anal divided; subcaudals $49-6 \mathrm{I}$; the 26 or 27 anterior single.

Blackish above and below, chin whitish. Length of head and body $1690 \mathrm{~mm}$; t tail $210 \mathrm{~mm}$.

Habitat: S. E. New Guinea (Yule Island, Port Moresby, Rigo !).

\section{Pseudechis scutellatus Peters.}

Pseutechis scutellatus, Peters, Mon. Berl. Ac. I867, p. 710.

Pseudichis scutellatus, Boulenger, Cat. Sn. III IS96, p. 33 I. 
Eye moderate, larger than its distance from the mouth. Rostral as deep as broad or more broad, visible from above; posterior nasal in contact with or narrowly separated from the praeocular; internasals shorter than the praefrontals; frontal as long as its distance from the rostral or the tip of the snout, as long as or shorter than the parietals; praeocular single or divided; two postoculars; temporals $2+3$, anterior lower wedged in between the fifth and sixth labials; six upper labials, third and fourth entering the eye; three lower labials in contact with the anterior chin-shields; latter as long as the posterior. Scales in 23 rows, $25-30$ on the neck; ventrals 230-233; anal entire; subcaudals $6 \mathrm{I}-78$ in two rows.

Pale brown or blackish-brown above; snout and sides of head lighter or yellowish. Lower surface yellowish, in the young spotted with dark. Length of head and body $830 \mathrm{~mm}$.; tail $240 \mathrm{~mm}$.

Habitat: New Guinea (Fly river!). - Queensland; N. Australia.

\section{Micropechis Bolilenger.}

(Boulenger, Cat. Sn. III p. 346, i $\$ 96$ ).

Head distinct from neck; eye small, pupil round; nostril between two nasals; loreal absent. Maxillary teeth 2 large, grooved fangs, followed by three small solid teeth; anterior mandibular teeth longest. Body round, covered with smooth scales without pits, in 15 or 17 rows; ventrals rounded. Tail short; subcaudals in two rows.

Distribution. New Guinea; Solomon Islands.

A single species.

\section{Micropechis ikaheka (Lesson).}

Coluber ikaheka, Lesson, Voy. Coquille, Zool. II Rept. I830, p. 54, pl. V. Micropechis ikaheka, Boulenger, Cat. Sn. III I896, p. 347 (s. syn.).

Eye not quite half so long as its distance from the mouth. Rostral more broad than deep, visible from above; posterior nasal in contact with the praeocular; internasals shorter than the praefrontals; frontal broader than the supraocular, as long as its distance from the rostral or the tip of the snout, shorter than the parietals; one prae- and two postoculars; temporals $2+2$, anterior large, the lower wedged in between the fifth and sixth upper labials; six upper labials, third and fourth 
entering the eye; three or four lower labials in contact with the anterior chin-shields; latter as long as or shorter than the posterior. Scales in I 5 rows; ventrals $178-223$; anal divided; subcaudals $37-55$.

Yellow and black above, sometimes in irregular transverse bands; the black scales edged with yellow; head and tail black.

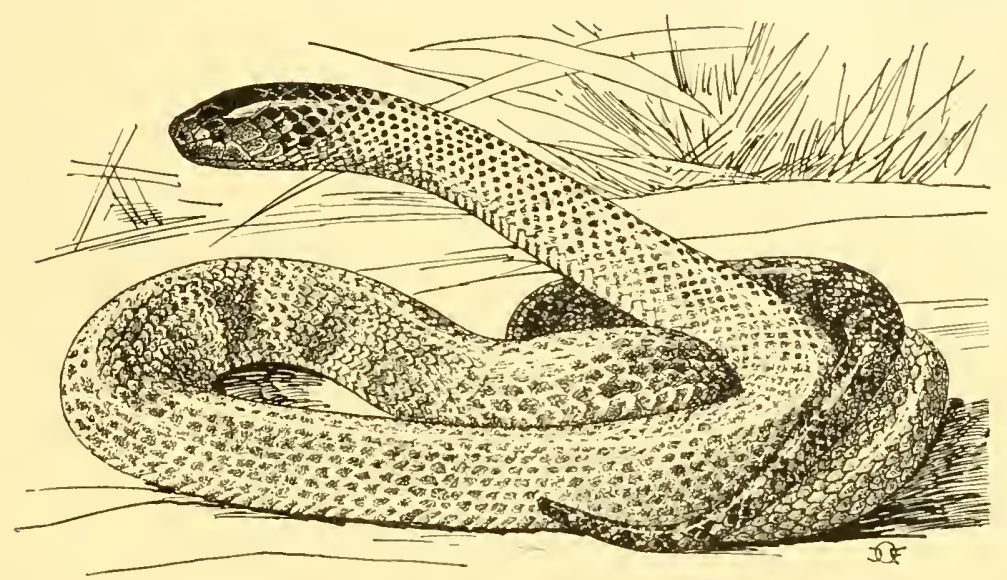

Fig. I 10. Mirropechis ikaheka (Less.). $\times 4 / 5$.

Lower surface yellow, sometimes some of the shields blackedged. Length of head and body $1370 \mathrm{~mm}$; tail 1 SO $\mathrm{mm}$.

Habitat: Batanta; New Guinea (Mafoor, Mios nom, Jobi, Sorong, Fak Fak, Andai, Mt. Arfak, Mansinam, Mt. Karon, Rubi, Koimé river!, Humboldt Bay, Mimika and Lorentz rivers, Germaniabucht, Stephansort on Astrolabe Bay, Sattelberg, Haveri, Dinawa 4000 feet, Valise Island).

\section{Acanthophis Iaud.}

(Jaudin, Ilist. Rept. V, p. 287, I803).

Head distinct from neck; eye small; pupil vertically elliptic; nostril in the upper part of the nasal; loreal absent. Maxillary teeth 2 large grooved fangs, followed by two or three small teeth; anterior mandibular teeth strongly enlarged. Body stout, round, covered with keeled scales without pits, in 2 I or 23 rows; ventrals rounded. Tail short, compressed posteriorly and ending in a long spine, directed upwards; anterior subcaudals single, posterior in two rows.

Distribution. Borneo; Moluccas; New Guinea; Australia. A single species. 
1. Acanthophis antarcticus (Shaw).

Boa antarctica, Shaw, Nat. Misc., 1794, pl. 535.

Acanthophis antarcticus, Boulenger, Cat. Sn. III 1S96, p. 355 (s. syn.).

Head with elevated sides; lores oblique; eye much shorter than its distance from the mouth. Rostral more broad than deep, with horizontal edge; nasal large, in contact with the praeocular; internasals as long as or shorter than the praefrontals; frontal narrower than the supraocular, as long as or shorter

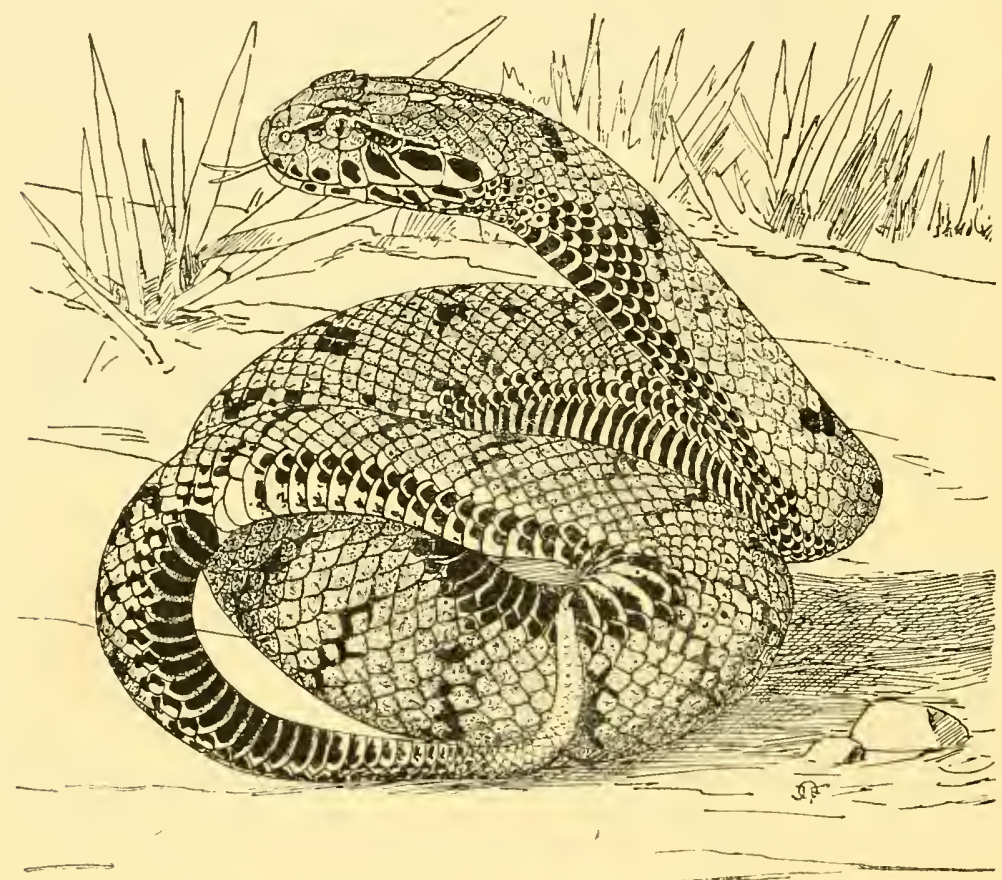

Fig. 1II. Acanthophis anturcticus (Shaw). Nat. size.

than its distance from the tip of the snout, as long as or longer than the parietals; supraocular sometimes angular and hornlike; the head-shields rugose or striated; one prae- and two postoculars; two or three suboculars; temporals $2-3+2-4$; six or seven upper labials, separated from the eye; four lower labials in contact with the anterior chin-shields; latter as long as or shorter than the posterior. Scales in 2 I or 23 rows, dorsals keeled; ventrals I I3-I36; anal entire; subcaudals $4 \mathrm{I}-57$, the $5-27$ last divided.

Yellowish, reddish or greyish-brown above, with dark trans- 
verse bands, sometimes indistinct, with or without small black spots; sides black-spotted; lips with black spots or bars. Lower surface yellowish-white, sometimes spotted with brown or black; end of tail yellow or black. Length of head and body $700 \mathrm{~mm}$.; tail $150 \mathrm{~mm}$.

Habitat: Borneo '); Obi; Ceram!; Haruku; Timor Laut; Kei Islands; Aru Islands; New Guinea (Jobi, Mafoor, Yule Island, Dorei, Rubi, Andai, Mt. Arfak, Mansinam, Nanokwari, Pokembo, lake Sentani, Koimé river!, Tami river!, Humboldt Bay, Tana, Etna Bay, Mimika river, Lorentz river!, Paup, Bogadjim, Stephansort and Bongu on Astrolabe Bay, Berlinhafen, Friedrich-Wilhelmshafen, St. Josephs river, Inawi, S. of Huon Gulf); Schouten Islands (Mysore). - N. W. Australia; Queensland; New South Wales.

Feeds on small birds and frogs.

\section{Fam. Amblycephalidae.}

Body usually compressed, covered with imbricate scales; ventrals transversely enlarged. Bones of the head slightly movable; ectopterygoid present; pterygoid short, not extending to the quadrate or the mandible; supratemporal rudimentary; praefrontal not in contact with the nasal. Mlaxillary horizontal, parallel with or converging towards the palatine; mandible without coronoid; solid teeth in both jaws; no mental groove (fig. I I 3 ).

Nocturnal; feeding on worms and slugs.

Key to the Indo-Australian genera. A. Subcaudals single; scales in 13 rows ....... I. Haplopeltura p. 273. B. Sulcaudals in two rows; scales in 15 rows. ...2. Amblycephalus p. 275.

\section{Haplope1tura Dum. \& Bibr.}

(Duméril \& Bibron, Mlém. Ac. Sc. XXIII p. 463, I\$53).

Head distinct from neck; eye large, with vertical pupil; nasal single; maxillary short, deep, with 5 equal teeth; maxillary and mandibular teeth decreasing in size posteriorly. Body strongly compressed, covered with smooth scales, oblique, in

I) See Werner, Verh. Ges. Wien XliII 1894, p. $35^{8}$.

INDO-AUSTRALIAN REPTILES II. 
13 rows, the vertebral row strongly enlarged; ventrals rounded. Tail moderate; subcaudals single.

Distribution. Malay Peninsula; Sumatra; Java; Borneo.

A single species.

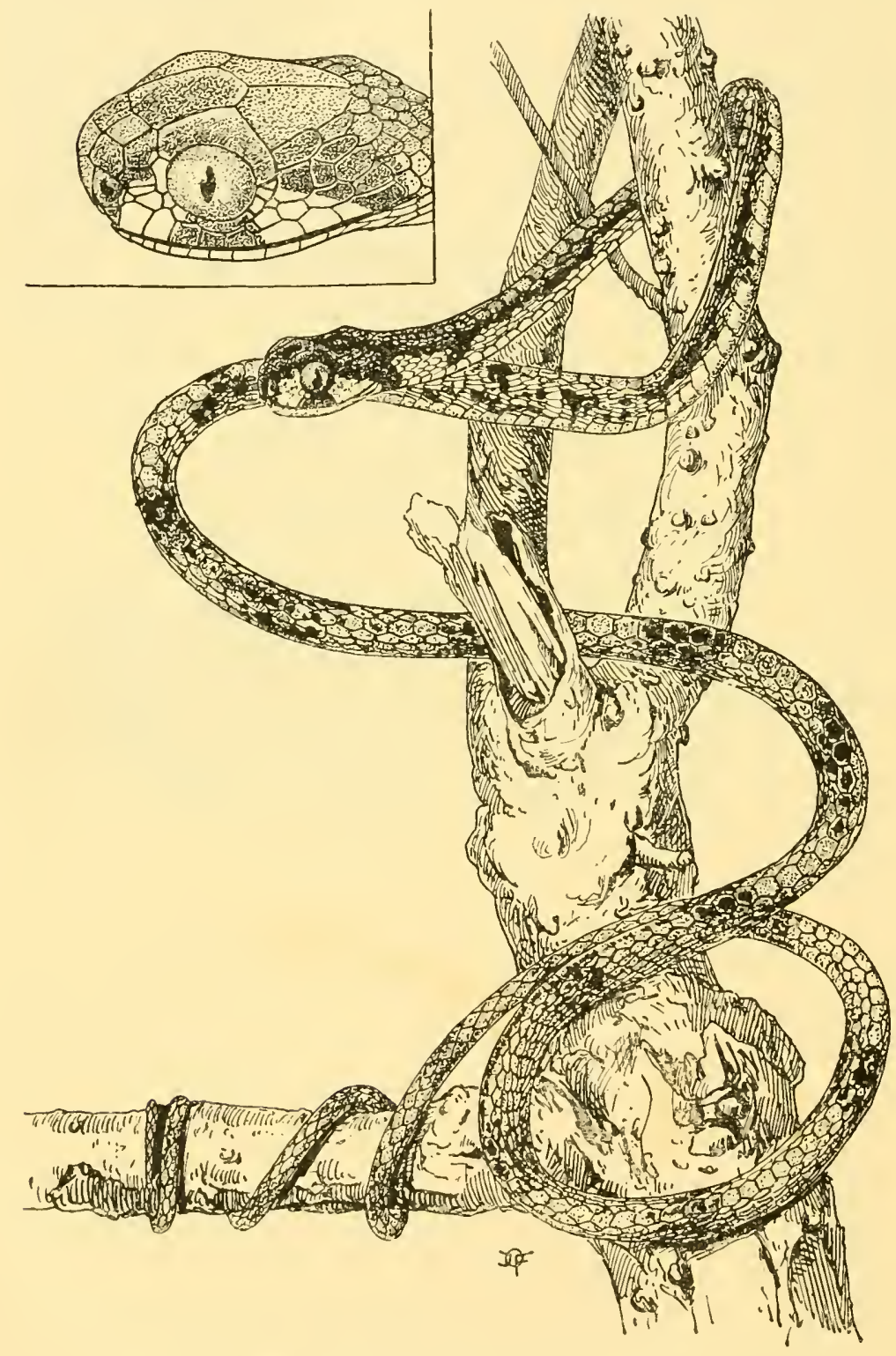

Fig. 112. Haplopeltura hoa (Boie). Nat. size. Side view of head. $\times 21 / 2$. 


\section{Haplopeltura boa (Boie).}

Amblycephalus boa, Boie, Isis I\$2S, p. 1034.

Haplopeltura boa, Boulenger, Cat. Sn. III I896, p. 439 (s. syn.).

Snout very short, deep; rostral narrow, much more deep than broad; frontal not broader than the supraocular, almost twice as long as broad, longer than its distance from the tip of the snout, as long as or a little longer than the parietals; two or three enlarged occipitals; two or three superposed loreals, the lower sometimes entering the eye; $6-8$ shields in addition to the supraocular round the eye; temporals $3+3$ or 4 ; eight to ten upper labials; two pair of lower labials in contact behind the mental; three or four pair of large chin-shields, the anterior sometimes fused or preceded by an azygous shield. Scales in 13 rows; ventrals 148 - I9I; anal entire; subcaudals 88-I 27.

Pale brown or yellowish above, usually with large, dark brown blotches, sometimes extending to the belly; a large, dark brown spot on the head; sides of head whitish, with dark streaks radiating from the eye. Lower surface yellowish, mottled with dark brown. Length of head and body $530 \mathrm{~mm}$.; tail $220 \mathrm{~mm}$.

Habitat: Nias!; Sumatra ') (Peudawa in Atjeh); Banka!, Borneo (Kuching, Saribas, Pankalan ampat, Baram, Sandakan Bay); Java (Buitenzorg, Barang!, Nongkodjadjar in Tengger Mts. I 300 M.!); Moluccas? '2). - Malay Peninsula up to 2000 feet; Siam; Penang; Philippines.

\section{Amblycephalus Kuhl.}

\section{(KUHL, Isis p. 474, IS22).}

Head distinct from neck; eye moderate, with vertical pupil; nasal single; maxillary short, deep, with 5 or 6 equal teeth; mandibular teeth decreasing in size. Body compressed, covered with smooth or feebly keeled scales, oblique, in 15 rows, the vertebral row sometimes enlarged; ventrals rounded. Tail short or moderate; subcaudals in two rows.

Distribution. S. E. Asia; Malay Peninsula and Archipelago.

I) Nelly DE Rooy, Reptiles of Nias, in Kleiweg de Zwaan, Craniol. Unters. Niass. Schädel 1915, p. 307 .

2) See Boulenger's Catalogue. 
Key to the Indo-Australian species.

$A$. One or two labials entering the eye; one shield between the nasal and the eye; praefrontal entering the eye.

I. Six upper labials. . . . . . . . . . . . . A. laczis p. 276.

2. Seven upper labials............... . A. malaccanus p. 276 .

B. A series of suboculars; loreal and praeocular distinct.

a. Praefrontal entering the eye ......... 3. Auchalis p. 277 .

b. Praefrontal separated from the eye ..... 4. A. carinatus p. 277.

\section{Amblycephalus laevis Boie.}

Amblycephalus laevis, Boie, Isis, IS27, p. 520.

Amblycephalus laevis, Boulenger, Cat. Sn. III I896, p. 44I (s. syn.).

Rostral a little more broad than deep; praefrontal entering the eye; frontal as long as broad or slightly more broad than long, as long as its distance from the tip of the snout or a little longer, two thirds the length of the parietals; supraocular very small; loreal entering the eye; no praeocular; one or two postoculars; temporals $2+2$; six upper labials, third and fourth or third to fifth entering the eye, last very long; mental in contact with a small azygous chin-shield; third lower labial in contact with its fellow; two pair of large chin-shields, more broad than long. Scales in 15 rows, smooth, the vertebral row enlarged; ventrals $148-$ i 76 ; anal entire; subcaudals $34-69$.

Brown above, with irregular transverse dark bands; sides dull orange. Lower surface brown or yellowish, with brown spots or transverse brown spots on the sides. Length of head and body $480 \mathrm{~mm}$; tail $65 \mathrm{~mm}$.

Habitat: Sumatra (Peudawa in Atjeh, Labuan, Deli!, Raja Mts., Gunung Sahilan!, Indragiri); Banka!; Natuna Islands; Borneo (Kina Balu, Bongon, Baram river, Kuching, Pangkalan ampat, Limbang, Kidi district, Sarawak, Bandjermassin !); Java! (Buitenzorg). - Malay Peninsula.

\section{Amblycephalus malaccanus (Ptrs.).}

Asthenodipsas malaccana, Peters, MIon. Berl. Ac. 1864, p. 273. Amblycephalus malaccanus, Boulenger, Cat. Sn. III IS96, P. 442.

Rostral a little more broad than deep; praefrontal entering the eye; frontal as long as broad or a little more broad, as long as or longer than its distance from the tip of the snout, much shorter than the parietals; supraocular small; loreal entering 
the eye; no praeocular; two postoculars; temporals $2+2$, sometimes the two upper fused; seven upper labials; third and fourth entering the eye, last large; mental in contact with a small azygous shield; second or third lower labial usually in contact with its fellow; two pair of large chin-shields, more broad than long. Scales in 15 rows, smooth, three median rows enlarged; ventrals 154-170; anal entire; subcaudals 26-55.

Pale brown or yellowish above, with irregular dark transverse bars, sometimes interrupted on the vertebral line; median dorsal scales yellowish; head sometimes light; sides of neck black. Lower surface whitish, sometimes speckled with brown; neck black below. Length of head and body $390 \mathrm{~mm}$.; tail $50 \mathrm{~mm}$.

$\mathrm{H}$ a bit at: Mentawei Islands (Siberut!); Sumatra (Deli!, Kaju tanam!, Indragiri, Benakat in Palembang); Borneo (Bongon, Mt. Dulit, Sarawak, Samarinda!). - Malay Peninsula.

\section{Amblycephalus nuchalis Boulenger.}

Amblycephalus nuchalis, Boulenger, Proc. Zool. Soc. Igoo, p. IS 5 , pl. XVII, fig. I.

Rostral as broad as deep; praefrontal entering the eye; frontal one time and two thirds as long as broad, twice as long as its distance from the tip of the snout, one time and a half as long as the parietals; two praeoculars; two postoculars; three narrow suboculars; three superposed anterior temporals; a pair of nuchals; eight upper labials, last very long; first lower labial in contact behind the mental; three pair of large chinshields, first more broad than long. Body strongly compressed; scales in 15 rows, dorsals feebly keeled; the enlarged vertebrals bicarinate; ventrals 195-2I3; anal entire; subcaudals I05-II 3 .

Pale buff, with narrow brown transverse lines and dark dots; a large black blotch on the nape with a black line on each side of the eye; a black vertical line below the eye and on the temple. Length of head and body $365 \mathrm{~mm}$.; tail $\mathrm{r} 25 \mathrm{~mm}$.

$\mathrm{Hab}$ it at: Borneo (Matang, Saribas!).

\section{Amblycephalus carinatus Boie.}

Amblycephalus carinatus, Boie, Isis, $182 \mathrm{~S}, \mathrm{p} .1035$.

Amblycephalus carinatus, Boulenger, Cat. Sn. III ISg6, p. 445 (s. syn.).

Rostral more deep than broad; praefrontal separated from the eye; frontal as long as broad or a little more long, longer than its distance from the tip of the snout, as long as or a little 
shorter than the parietals; loreal more deep than long; one or two praeoculars; one or two postoculars; two or three suboculars; temporals $2+3$ or $3+4$; seven or eight upper labials, last very long; first lower labial in contact with its fellow behind the mental; three pair of large chin-shields, more broad than long. Scales in 15 rows, three median rows enlarged and feebly keeled; ventrals I6I-189; anal entire; subcaudals 53-80.

Yellow or reddish-brown above, with black transverse spots or medially interrupted transverse bars; a black line on each side behind the eye, confluent with an X-shaped spot on the

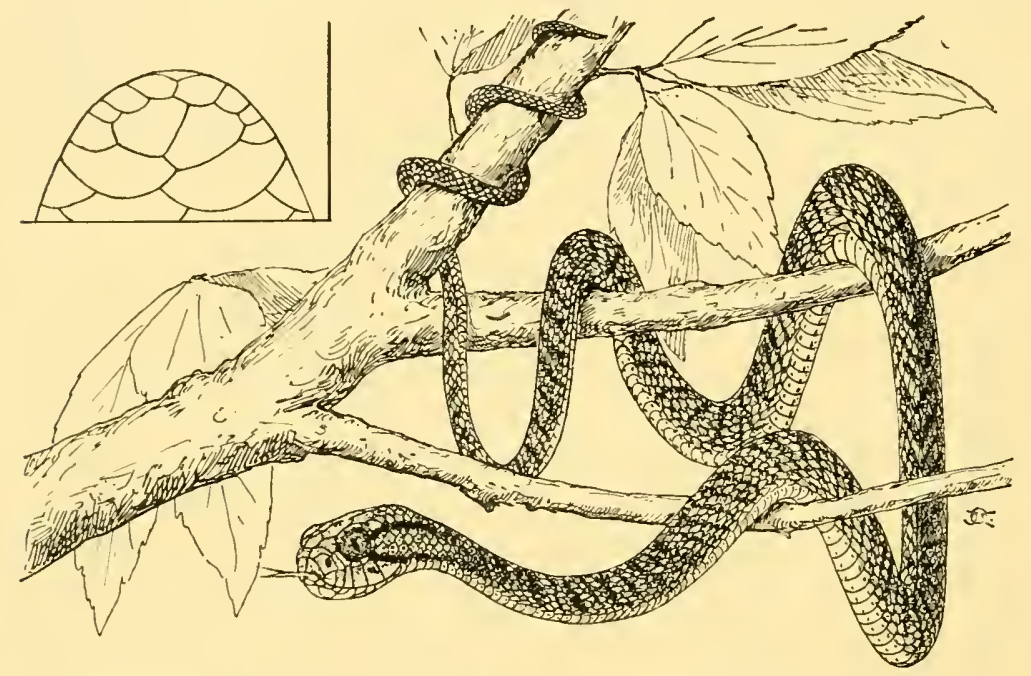

Fig. II3. Amblycephalus carinatus Boie. Nat. size. Chin-shields. $\times 3$.

nape; an oblique black line from below the eye to the anterior border of the last upper labial. Lower surface yellow, dotted with black or with black lines or a median black line. Length of head and body $385 \mathrm{~mm}$; tail I $5 \mathrm{~mm}$.

Habitat: Sumatra (Langkat, Medan!); Borneo (Labuan, Singkawang, Samarinda!, Bandjermassin); Java (Batavia!, Buitenzorg!, Depok, Tjibodas, Mt. Pangerango 4500 feet, Sukabumi, Salatiga!, Malang!, Mt. Willis, Tengger Mts. I 200 M., Prigan I800-2300 feet). - Burma; Cochin China; Siam. 


\section{Fam. Viperidae.}

Body round or compressed, covered with imbricate scales with or without apical pits, smooth or keeled; ventrals transversely enlarged. Bones of head movable; ectopterygoid present, extending to the mandible; supratemporal suspending quadrate; praefrontal not in contact with the nasal. Maxillary short, vertical, supporting a pair of large perforated poison-fangs; mandible without coronoid; a mental groove.

Semi-nocturnal; mostly ovoviviparous. All Viperidae are poisonous; they include burrowing, terrestrial, semiaquatic and arboreal forms. Of the two sub-families: Viperinae (without a pit on the snout) and Crotalinae (with a deep pit on each side of the snout) only the latter occurs in the Indo-Australian region. About the occurrence of Vipera russelli (Shaw) belonging to the Viperinae, in Sumatra and Java, no certainty exists. In Boulenger's Catalogue III p. 490 this species is mentioned from those islands, Java with a ? ; in DUMÉrIL \& BIBRON VII I854, p. I435, a specimen from Java is mentioned. Other records could not be found and as it is missing in Borneo and the Malay Peninsula this Viper probably does not belong to the fauna of the above-named islands. Its habitat is: Ceylon, India, Burma and Siam.

\section{Key to the genera.}

A. Head covered above with large symmetrical shields. I. Aykistrodon p. 279. B. Head covered above with scales or small shields...2. Lachesis p. $28 \mathrm{I}$.

I. Agkistrodon Palisot de Beauvois.

(Palisot de Beaurois, Tr. Am. Philos. Soc. IV p. 3 S r, I799).

Head distinct from neck; eye with vertical pupil. Nine shields on the head or internasals and praefrontals broken up into scales. Body round, covered with smooth or keeled scales, with apical pits. Tail short or moderate; subcaudals single or in two rows.

Distribution. Round the Caspian Sea; Asia; N. and C. America. A single species.

\section{Agkistrodon rhodostoma (Boie).}

Trigonocephalus rhodostoma, Boie, Isis, I\$27. p. 56I.

Anistrodon rhodostoma, Boulenger, Cat. Sn. III I896, p. 527 (s, syn.). 
Agkistrodon rhodostoma, Barbour, Mem. Mus. Comp. Zool. Harv. Coll. XLIV 1912 , p. 139.

Snout somewhat turned up at the end; rostral as deep as broad or a little more deep; internasals and praefrontals present; frontal as long as its distance from the tip of the snout or a little longer, about as long as the parietals; loreal separating

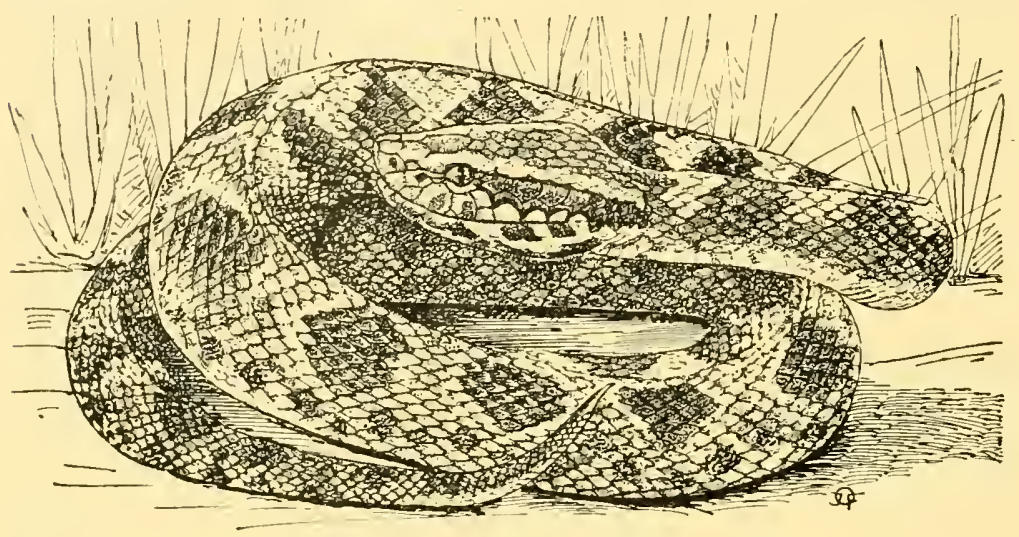

Fig. 114. Agkistrodon rhodostoma". (Boie). $\times 9 / 10$.

the posterior nasal from the upper praeocular; one or two postoculars; one subocular; loreal pit separated from the labials; 7-9 upper labials. Scales in 2 I rows, smooth; ventrals I $38-$ I6r; anal entire; subcaudals $33-54$, in two rows.

Grey, reddish or light brown above, with large angular,

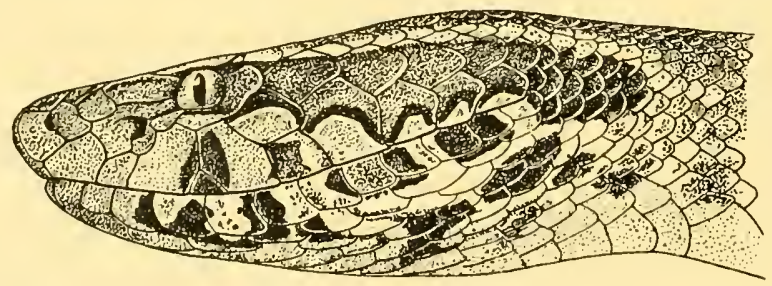

Fig. I I5. Agkistrodon rhodostoma (Boie). Side view of head. $X 2$.

dark brown spots in pairs or alternating, the spots black-edged; a dark median line on the back; lips yellow or pink, browndotted; a broad brown, black-edged band, wavy below, from the eye to the corner of the mouth, with a light band above. Lower surface yellowish, uniform or with greyish-brown spots or dots. Length of head and body $720 \mathrm{~mm}$; tail $90 \mathrm{~mm}$. Largest specimen known $900 \mathrm{~mm}$. 
Nom. indig. Ular biludak; ular tanah, ular gebuk, ular bandotan bedor; oraj lemah (C. Java).

Habitat: Sumatra! (Siboga); Java (Batavia, Buitenzorg!, Anjer, Gunung Bunder, Depok, Bantam, Mt. Willis 5000 feet). Malay Peninsula; Siam.

A dangerous, poisonous snake, feeding on mammals, small birds and frogs. The female deposits $15-20$ eggs and watches over them.

2. Lachesis Daudin.

(Daudin, Hist. Rept. V p. 349, I803).

Head distinct from neck; eye with vertical pupil. Head covered above with scales or small shields. Body round or
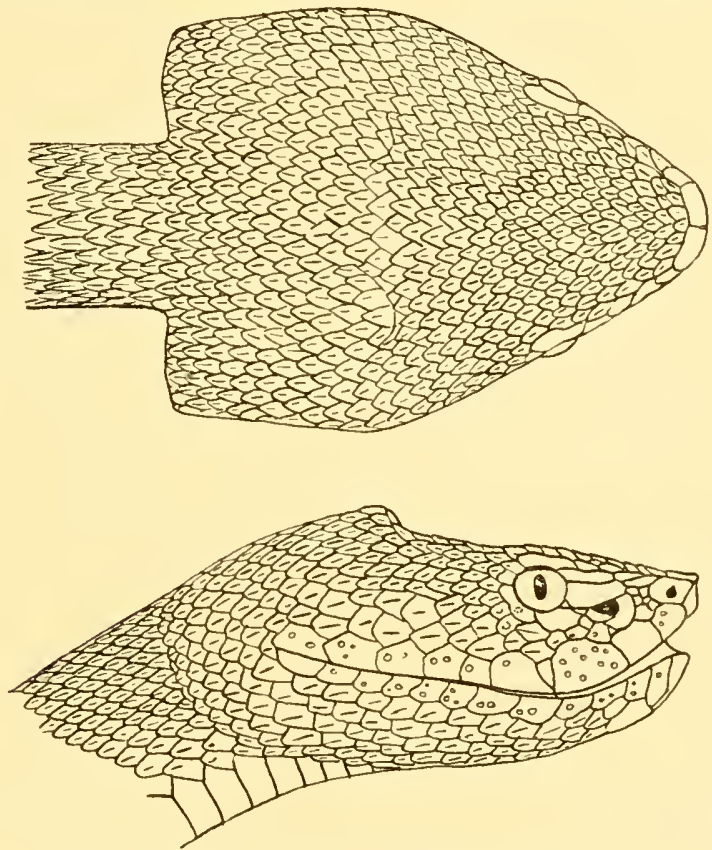

Fig. I16. Lachesis wagleri (Boie). Head $\times 11 \frac{1}{2}$.

compressed, covered with smooth or keeled scales, with or without apical pits. Tail short or moderate; subcaudals single or in two rows.

Distribution. South-Eastern Asia; Central and South America. 
Key to the Indo-Australian species.

$A$. Scales between the eyes smooth or obtusely keeled; gular scales smooth.

I. Snout not prominent, not raised above the nostrils.

a. Supraoculars large.

1. Supraoculars separated by $5-8$ scales; scales smooth or feebly keeled, in $2 \mathrm{I}-25$ (27) rows; ventrals $\mathrm{I} 32-$ I5S; tail not prehensile........ I. L. monticola p. 282.

2. Supraoculars separated by $4-9$ scales; scales feebly keeled, in $2 \mathrm{I}$ row's; ventrals I80-I9I; tail prehensile ............. 2. L. sumatranus p. $28_{3}$.

3. Supraoculars separated by 6 scales; scales feebly keeled, in 21 rows; ventrals 162; tail feebly prehensile. 3. L. fasciatus p. 284.

b. Supraoculars narrow if distinct.

aa. Supraoculars separated by $12-15$ scales; scales strongly keeled, in 25 or 27 rows; ventrals $160-182$; tail slightly prehensile......... 4. L. purpurcomaculatus p. $28_{4}$.

66. Supraoculars separated by $8-13$ scales; scales almost smooth or distinctly keeled, in 19-23 rows; ventrals $145-175$; tail prehensile. . 5. L. gramincus p. $2 S_{5}$.

II. Snout prominent, the upper edge raised above the nostrils ..........6. . . puniceus p. 286 .

$B$. Scales between the eyes strongly keeled; gular scales keeled ........... 7. L. wagleri p. 286 .

\section{Lachesis monticola (Gthr.).}

Trimeresurus monticola, Günther, Rept. Brit. Ind: IS64, p. 3 SS, pl. XXIV, fig. B. Lachesis monticola, Boulenger, Cat. Sn. III I 896 , p. $54 \mathrm{~S}$ (s. syn.).

Snout very short; eye small. Rostral as broad as deep or a little more broad; nasal divided or partly divided; scales on the head small, smooth; supraocular large; $1-3$ scales between the internasals, which are sometimes in contact; $5-8$ scales between the supraoculars; eight or nine upper labials, separated from the eye by 3 or 4 rows of scales; second labial usually bordering the loreal pit anteriorly; temporal scales 
smooth. Scales feebly keeled or almost smooth, in $2 \mathrm{I}-25$ rows (27); ventrals I32-I58; anal entire; subcaudals $2 \mathrm{I}-57$, in two rows; tail not prehensile.

Brown or yellowish above, with one or two series of large dark brown squares on the back and a lateral series of small spots; head dark brown above, lighter on the sides; a dark brown temporal streak; lips with two broad, oblique, dark brown bands between three light ones. Lower surface whitish, powdered with brown or with brown spots, which fuse sometimes in two stripes. Length of head and body $625 \mathrm{~mm}$.; tail II $5 \mathrm{~mm}$.

Habitat: Sumatra. - Singapore!; Penang; Malay Peninsula; Burma; Assam; Himalayas; Tibet.

Oviparous; about Io eggs are laid.

The occurrence of this species in the Indo-Australian Archipelago is indicated by BOULENGER in his Catalogue and in Fauna of Malay Peninsula igi2, p. 216.

\section{Lachesis sumatranus (Raffles).}

Coluber sumatranus, Rafles, Trans. Linn. Soc. XIII I822, p. 334. Lachesis sumatranus, Boulenger, Cat. Sn. III I\$96, p. 557 (s. syn.).

Head long; snout short; eye moderate. Rostral as broad as deep or a little more broad; nasal entire or divided; scales on the head large, smooth, largest on the snout; supraocular large; no scales or only one between the internasals; $4-9$ scales between the supraoculars; two or three postoculars; a subocular, in contact with the third or third and fourth labials; nine to eleven upper labials, second bordering the loreal pit, third largest; temporal scales smooth. Scales feebly keeled, in 2 I rows; ventrals I80-I9I; anal entire; subcaudals $58-82$, in two rows; tail prehensile.

Bright green above, the scales usually black-edged, with or without black transverse bands; sometimes two series of small light spots on the back; a yellowish streak on each side along the outer row of scales usually present. Lower surface yellowish or green, sometimes the ventrals black-edged; end of tail red. Length of head and body $1093 \mathrm{~mm}$; tail $167 \mathrm{~mm}$.

Nom. in dig. Bŭrĭt tiu (Simalur); ular bisa (W. Sumatra).

Habitat: Simalur!; Nias!; Mentawei Islands (Sipora); Sumatra (Deli!, Langkat, Battak Highlands 800-Iooo M., Indra- 
giri, Tandjung Morawa, Kertadjaja, Tandjung Laut in Palembang); Banka!; Biliton; Borneo (Mt. Dulit, Baram, Bandjermassin). - Singapore; Malay Peninsula, abundant at elevations of 2000-3000 fect; Palawan.

\section{Lachesis fasciatus Boulenger.}

Lachesis fasciatues, Boulenger, Ann. Nat. Hist. (6) XVIII I896, p. 63.

Snout a little turned up, with strong edge. Rostral more broad than deep; nasal entire; scales on the head small, smooth on the snout and between the eyes, obtusely keeled on the occiput; supraocular large; one scale between the internasals, which are large; 6 scales between the supraoculars; two postoculars; a subocular, separated from the labials by one series of scales anteriorly, two posteriorly; nine or ten upper labials, first fused with the nasal, second bordering the loreal pit, third largest; temporal scales obtusely keeled. Scales feebly keeled, in 2 I rows; ventrals I62; anal entire; subcaudals 60, in two rows; tail feebly prehensile.

Grey-brown above, with numerous dark olive transverse bands, some of them broken up on the vertebral line and alternating; head uniformly dark olive. Lower surface whitish, speckled with dark brown. Length of head and body $375 \mathrm{~mm}$; tail $80 \mathrm{~mm}$.

Type-specimen examined in the British Museum.

Habit at: Djampea Island!.

\section{Lachesis purpureomaculatus (Gray).}

Trigonocephalus purpureomaculatus, Gray, Ill. Ind. Zool. II I 832 , pl. LXXXI. Lachesis purpureomaculatus, Boulenger, Cat. Sn. III 1896, p. 553 (s. syn.).

Snout short; eye small. Rostral as broad as deep; nasal entire; scales on the head very small, convex or obtusely keeled; supraocular very narrow, sometimes broken up; one or two scales between the internasals, which are small; I $2-15$ scales between the supraoculars; two or three small postoculars; a subocular, separated from the labials by two or three series of scales; eleven to thirteen upper labials, first usually fused with the nasal, second usually bordering the loreal pit anteriorly, fourth and rest small; temporal scales keeled. Scales strongly keeled, in 25 or 27 rows; ventrals $160-182$; anal entire; subcaudals $55-76$, in two rows; tail slightly prehensile.

Purplish-brown or blackish above, uniform or variegated 
with pale green; flanks pale green or spotted with pale green, or with pale spots on the outer row of scales; some specimens uniformly green. Lower surface olive or greenish-white, uniform or spotted with black. Length of head and body $S_{30} \mathrm{~mm}$.; tail $150 \mathrm{~mm}$.

Habitat: Sumatra (Deli). - Malay Peninsula!; Penang!; Singapore; Andamans; Nicobars; Burma; Assam; Bengal; E. Himalayas.

\section{Lachesis gramineus (Shaw).}

Coluber gramineus, Shaw, Zool. III ISo2, p. 420.

Lachesis gramineus, Boulenger, Cat. Sn. III IS96, p. 554 (s. syn.).

Trimeresurus gramineus, Barbour, Mem. Mus. Comp. Zool. IIarv. Coll. XLIV I 9 I 2, p. I 4 I.

Snout with distinct edge; eye small. Rostral as broad as deep or a little more broad; nasal usually entire; scales on the head small, smooth; supraocular narrow, sometimes divided; one or two scales between the internasals or latter shields in contact; 8 - I 3 scales between the supraoculars; two or three postoculars; a subocular, sometimes in contact with the third labial, usually separated from the labials by one to three series of scales; eight to twelve upper labials, second bordering the loreal pit anteriorly, third largest; temporal scales smooth. Scales almost smooth or keeled, in 2 I ( 19 or 23 ) rows; ventrals 145-I75; anal entire; subcaudals 52-78, in two rows; tail prehensile.

Bright green above, or olive or yellowish, with or without indistinct black transverse bands; a light, yellowish streak usually present along the outer row of scales; end of tail yellow or red. Lower surface green, yellow or whitish. Length of head and body $720 \mathrm{~mm}$.; tail $150 \mathrm{~mm}$.

Nom. in di g. Ular bisa (IV. Sumatra); oraj bungka (sund.); esau (Timor); semelo (Kupang); keisau (Rotti).

Ha bitat: Nias; Sumatra (Deli!, Labuan, Langkat, Battak Highlands Soo-1000 M., Indrapura, Padang Highlands!); Borneo (Kina Balu, Saiap on Kina Balu, Mt. Dulit, Pangkalan ampat); Java! (Batavia, Buitenzorg, Krawang, Semarang); Lombok; Sumbawa; Flores!; Adonara!; Alor (Ombaai); Roma!; Sumba!; Rotti; Timor!; Samao!. - Penang; Malay Peninsula; Andamans; Nicobars; S. China; Siam; Bengal; Himalayas; Philippines. 
Found on trees; feeds on small mammals, birds, lizards and amphibians. The female brings forth 7-12 young ones.

\section{Lachesis puniceus (Boie).}

Cophias punicea, Boie, Isis, 1827 , p. 561 .

Atropophis borneensis, Peters, Ann. Mus. Civ. Genova III I87I, p. 4I.

Bothrops sandakanensis, v. Lidth de Jeude, Notes Leyden Mus. I893, p. 256.

Lachesis borneensis, Boulenger, Cat. Sn. III I 896, p. $56 \mathbf{I}$.

Lachesis puniceus, Boulenger, Cat. Sn. III I896, p. 560.

Trimeresurus puniceus, Barbour, Mem. Mus. Comp. Zool. Harv. Coll. XLIV

I 912 , p. I 40.

Snout short, truncate, with sharp, raised angle, especially above the nostrils; eye small. Rostral as broad as deep or a little more deep; scales on the head small, smooth; supraocular narrow or broken up into pointed, erect scales; two pair of internasals; 9-I4 scales between the supraoculars; two to four postoculars; one or two suboculars, separated from the labials by two or three series of scales; ten to twelve upper labials, sometimes second bordering the labial pit, third largest; first lower labial divided, forming a pair of chin-shields; temporal scales smooth or obtusely keeled. Scales feebly keeled, in I $9-23$ rows; ventrals I 44-176; anal entire; subcaudals $38-65$, in two rows; tail prehensile.

Grey, brown or reddish above, with dark spots, the spots sometimes black-edged and forming a wavy band on the back; a light dark-edged streak on each side of the head behind the eye. Lower surface brown with a series of yellowish spots on each side or speckled with brown; end of tail reddish. Length of head and body $690 \mathrm{~mm}$.; tail IO2 $\mathrm{mm}$.

Nom. ind ig. Ular gibuk; oraj lemah (sund.); sawah tadung or sawah tadung bisa (Simalur).

Habitat: Simalur!; Sumatra (Battak Highlands $800-$ I 000 M., Padang!); Natuna Islands; Borneo (Pangkalan ampat, Kuching, Baram river, Kidi district, Matang, Paitan, Mt. Dulit, Sandakan Bay!, Samarinda!); Java (Buitenzorg!, Mt. Salak, Sukabumi, Mt. Willis 5000 feet, Tengger Mts. I 200 M.). - Malay Peninsula 3000 feet.

\section{Lachesis wagleri (Boic).}

Cophias wagleri, Boie, Isis, I827, p. 56 I.

Lachesis wagleri, Boulenger, Cat. Sn. III I $\$ 96$, p. 562 (s. syn.). 
Head very broad; snout short and broad, with rather distinct canthus; eye very small. Rostral as broad as deep or a little more broad; nasal entire; scales on the head small, keeled; supraocular narrow or broken up; internasals sometimes indistinct; 7-i 3 scales between the supraoculars; one to three postoculars; a subocular, separated from the labials by one or two series of scales, sometimes in contact with the third labial; eight to ten upper labials, second not bordering the loreal pit, third very large; temporal scales keeled; gular scales keeled.

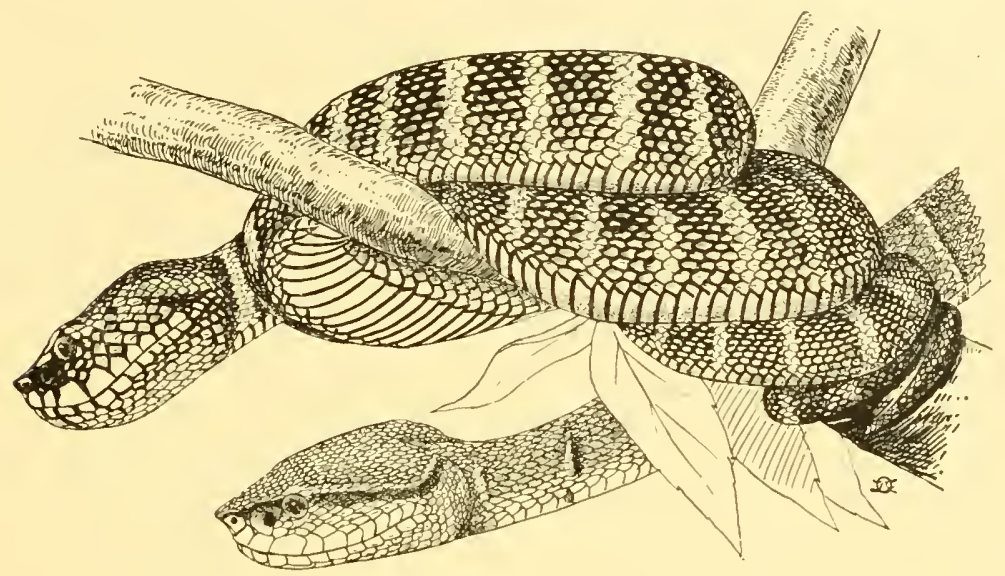

Fig. I17. Lachesis wagleri (Boie).

Scales keeled, in $21-25$ ( 19 or 27 ) rows; ventrals $127-154$; anal entire; subcaudals $45-56$, in two rows; tail prehensile.

Green above, the scales black-edged, with bright yellow, black-edged transverse bands (fig. I I7, upper snake), or black with yellow transverse bands, or green above with large red, black-edged spots; head black, yellow-spotted. Lower surface yellow or greenish, the ventrals black-edged, or white with black spots and powdered with red; end of tail black or red. Young specimens green, with yellow or white transverse lines, edged with blue or purple posteriorly (fig. I I7, lower snake), or with two series of small spots on the back; a light line on each side of the head, passing through the eye and edged below with blue or purple. Lower parts white or green, uniform or with black borders to the scales; end of tail red or reddishbrown. Length of head and body $S_{30} \mathrm{~mm}$.; tail $150 \mathrm{~mm}$.

Nom. indig. Ular nanti bulau (mal.); djalimóo (Toradja-name). 
Habitat: Nias; Mentawei Islands (Siberut!); Sumatra (Medan!, Labuan, Bindjey, Bedagei, Langkat, Raja Mts., Battak Highlands 800- I000 M., Kaju tanam!, Gunung sahilan!, Pakanten!, Ajerbangis!, Padang!, Indragiri, Djambi!, Indrapura, Kertadjaja in Palembang); Banka!; Biliton; Natuna Islands; Borneo! (Kuching, Mt. Dulit, Kapuas river, Baram river, Rejang river, Pangkalan ampat, Busau, Oya, Sebruang Valley, Labuan, Sandakan, Muara Djawa!, Pontianak, Singkawang, Sintang, Sungei Duri); Celebes! (Minahassa, Posso!, between Posso and Tomini Gulf, Bone Valley 650-1000 feet, Sonder, Kandari); Sangir Islands. - Singapore; Penang; Malay Peninsula; Philippines.

Lives on the ground and on trees; feeds on mammals, birds and lizards. It is said to be very slow and is kept in trees near the house, in order to bring good luck to its people. From time to time a small bird (Cymborhynchus macrorhynchus $\mathrm{Gm}$.) comes to feed it. (See: Oulvens, De Indische Giftslangen I916, p. 22). 


\title{
DISTRIBUTION
}

\section{OF SPECIES ON THE ISLANDS OF THE INDO-AUSTRALIAN ARCHIPELAGO.}

\author{
Simalur. \\ Python reticulatus (Schneider) \\ Xenopeltis unicolor Reinw. \\ Tropidonotus chrysargus Schlegel \\ Coluber melanurus Schlegel \\ Lycodon subcinctus Boie \\ Calamaria elegans de Rooy \\ Calamaria simalurensis de Rooy \\ Calamaria lautensis de Rooy \\ Hypsirhina albomaculata (D. B.) \\ Cerberus rhynchops (Schneider) \\ Dipsadomorphus nigriceps (Gthr.) \\ Psammodynastes pictus Gthr. \\ Dryophis prasinus Boie \\ Naja bungarus Schlegel \\ Lachesis sumatranus (Raffles) \\ Lachesis puniceus (Boie)

\section{Pulu Babi.} \\ Dendrelaphis caudolineatus (Gray) \\ Platurus laticaudatus (L.) \\ Platurus colubrinus (Schneider)
}

Cocos Islands, N.W. off Simalur.

Calamaria lautensis de Rooy

\section{Nias.}

Typhlops lineatus Boie

Typhlops braminus (Daud.)

Typhlops nigroalbus D. B. 
Python reticulatus (Schneider)

Xenopeltis unicolor Reinw.

Polyodontophis geminatus (Boie)

Dendrophis pictus (Gmel.)

Dendrelaphis caudolineatus (Gray)

Zaocys fuscus (Gthr.)

Tropidonotus trianguligerus Boie

Tropidonotus chrysargus Schlegel

Macropisthodon flaviceps (D. B.)

Coluber melanurus Schlegel

Coluber oxycephalus Boie

Iycodon subcinctus Boie

Lycodon albofuscus (D. B.)

Simotes octolineatus (Schneider)

Simotes purpurascens (Schlegel)

Oligodon trilineatus (D. B.)

Ablabes tricolor (Schlegel)

Ablabes baliodirus (Boie)

Pseudorhabdium longiceps (Cantor)

Calamaria lumbricoidea (Boie)

Calamaria stahlknechti Stol.

Hypsirhina albomaculata D. B.

Cerberus rhynchops (Schneider)

Dipsadomorphus dendrophilus (Boie)

Dipsadomorphus nigriceps (Gthr.)

Dipsadomorphus jaspideus (D. B.)

Dipsadomorphus cynodon (Boie)

Dryophis prasinus Boie

Chrysopelea ornata (Shaw)

Chrysopelea chrysochlora (Schlegel)

Platurus laticaudatus (I..)

Naja bungarus Schlegel

Doliophis bivirgatus (Boie)

Doliophis intestinalis (Laur.)

Haplopeltura boa (Boie)

I achesis sumatranus (Raffles)

I achesis gramineus (Shaw)

Lachesis wagleri (Boie)

\section{Pulu Nako.}

Cerberus rhynchops (Schneider)

Chrysopelea chrysochlora (Schlegel)

\section{Batu Islands.}

l)ipsarlomorphus dendrophilus (Boie) 


\section{Mentawei Islands.}

Python reticulatus (Schneider)

Dendrophis pictus (Gmel.)

Dendrelaphis caudolineatus (Gray)

Tropidonotus trianguligerus Boie

Tropidonotus chrysargus Schlegel

Coluber melanurus Schlegel

Lycodon subcinctus Boie

Simotes purpurascens (Schlegel)

Calamaria everetti Boulenger.

Cerberus rhynchops (Schneider)

Dipsadomorphus nigriceps (Gthr.)

Dipsadomorphus cynodon (Boie)

Dryophis prasinus Boie

Dryophiops rubescens (Gray)

Chrysopelea ornata (Shaw)

Amblycephalus malaccanus (Ptrs.)

Lachesis sumatranus (Raffles)

Lachesis wagleri (Boie)

\section{Engano.}

Coluber enganensis Vincig.

Cerberus rhynchops (Schneider)

Psammodynastes pulverulentus (Boie)

Platurus colubrinus (Schneider)

\section{Sumatra.}

Typhlops lineatus Boie

Typhlops braminus (Daud.)

Typhlops nigroalbus 1). B.

Typhlops mülleri Schlegel

Python reticulatus (Schneider)

Python curtus Schlegel

Anomalochilus weberi Lidth

Cylindrophis rufus (Laur.)

Xenopeltis unicolor Reinw.

Acrochordus javanicus Hornst.

Chersydrus granulatus (Schneider)

Xenodermus javanicus Reinh.

Anoplohydrus aemulans Werner

Iguanognathus werneri Boulenger

Opisthotropis rugosa (Lidth)

Xenochrophis viperinus Schenkel

Polyodontophis geminatus (Boie) 
Dendrophis pictus (Gmel.)

Dendrophis formosus Boie

Dendrelaphis caudolineatus (Gray)

Zaocys tornieri Werner

Zaocys fuscus (Gthr.)

Zaocys carinatus (Gthr.)

Tropidonotus piscator (Schneider)

Tropidonotus conspicillatus Gthr.

Tropidonotus trianguligerus Boie

Tropidonotus petersi Blgr.

Tropidonotns vittatus (L.)

Tropidonotus chrysargus Schlegel

Tropidonotus maculatus Edeling

Macropisthodon flaviceps (D. B.)

Macropisthodon rhodomelas (Boie)

Senelaphis hexagonotus (Cantor)

Zamenis korros (Schlegel)

Zamenis mucosus (L.)

Coluber porphyraceus Cantor

Coluber melanurus Schlegel

Coluber radiatus Schlegel

Coluber taeniurus (Cope)

Coluber oxycephalus Boie

Lycodon subcinctus Boie

Lycodon albofuscus (D. B.)

Lycodon aulicus (L.)

Lycodon effrenis Cantor

I)ryocalamus subannulatus (I). B.)

Simotes octolineatus (Schneider)

Simotes signatus Gthr.

Simotes subcarinatus Gthr.

Simotes purpurascens (Schlegel)

Oligodon trilineatus (D. B.)

Oligodon durheimi Baumann

Oligodon petronellae Roux

Oligodon pulcherrimus Werner

Oligodon praefrontalis Werner

Elapoides fuscus Boie

Ablabes tricolor (Schlegel)

Ablabes baliodirus (Boie)

Ablabes longicauda Peters

Pseudorhabdium longiceps (C'antor)

Calamaria lumbricoidea Boie

Calamaria vermiformis D. B.

Calamaria stahlknechti Stol. 
Calamaria indragirica Schenkel

Calamaria margaritophora Bleeker

Calamaria sumatrana Edeling

Calamaria virgulata Boie

Calamaria leucogaster Bleeker

Calamaria mecheli Schenkel

Calamaria ornata IVerner

Calamaria leucocephala I). B.

Calamaria agamensis Bleeker

Calamaria döderleini Gough

Calamaria schlegeli D. B.

Calamaria linnaei Boie

Calamaria javanica Blgr.

Calamaria pavimentata D. B.

Hypsirhina alternans (Reuss)

Hypsirhina plumbea (Boie)

Hypsirhina enhydris (Schneider)

Hypsirhina albomaculata (D. B.)

Hypsirhina punctata (Gray)

Homalopsis buccata (L.)

Cerberus rhynchops (Schneider)

Fordonia leucobalia (Schlegel)

Cantoria violacea Girard

Hipistes hydrinus (Cantor)

Dipsadomorphus multimaculatus (Boie)

Dipsadomorphus drapiezii (Boie)

Dipsadomorphus dendrophilus (Boie)

Dipsadomorphus nigriceps (Gthr.)

Dipsadomorphus jaspideus (D. B.)

Dipsadomorphus cynodon (Boie)

Psammodynastes pulverulentus (Boie)

Psammodynastes pictus Gthr.

Dryophis prasinus Boie

Dryophis fasciolatus (Fischer)

Dryophiops rubescens (Gray)

Chrysopelea ornata (Shaw)

Chrysopelea chrysochlora (Schlegel)

Platurus laticaudatus (L.)

Platurus colubrinus (Schneider)

Enhydrina valakadyn (Boie)

Hydrus platurus (I.)

Hydrophis fasciatus (Schneider)

Hydrophis spiralis (Shaw)

Bungarus fasciatus (Schneider)

Bungarus candidus (L.) 
Bungarus flaviceps Reinh.

Naja tripudians Merr.

Naja bungarus Schlegel

Callophis gracilis Gray

Doliophis bivirgatus (Boie)

Doliophis intestinalis (Laur.)

Haplopeltura boa (Boie)

Amblycephalus laevis Boie

Amblycephalus malaccanus (Ptrs.)

Amblycephalus carinatus Boie

Agkistrodon rhodostoma (Boie)

Lachesis monticola (Gthr.)

Lachesis sumatranus (Raffles)

Lachesis purpureomaculatus (Gray)

Lachesis gramineus (Shaw)

Lachesis puniceus (Boie)

Lachesis wagleri (Boie)

\section{Siak.}

Xenopeltis unicolor Reinw.

Acrochordus javanicus Hornst.

Simotes octolineatus (Schneider)

Cerberus rhynchops (Schneider)

Dipsadomorphus dendrophilus (Boie)

Thalassophis anomalus Schmidt

Bungarus fasciatus (Schneider)

\section{Riou.}

Typhlops braminus (Daud.)

Python reticulatus (Schneider)

Cylindrophis rufus (Laur.)

Nenopeltis unicolor Reinw.

Dendrophis pictus (Gmel.)

Dendrelaphis caudolineatus (Gray)

Coluber melanurus Schlegel

Coluber oxycephalus Boie

Dryocalamus subannulatus (D. B.)

Simotes octolineatus (Schneider)

Homalopsis buccata (L.)

Cerberus rhynchops (Schneider)

I)ipsadomorphus dendrophilus (Boie)

Psammodynastes pulverulentus (Boie)

Psammodynastes pictus Gthr. 
Dryophis prasinus Boie

Chrysopelea ornata (Shaw)

Naja tripudians Merr.

Doliophis bivirgatus (Boie)

Doliophis intestinalis (Laur.)

\section{Singkep Island.}

Tropidonotus conspicillatus Gthr.

\section{Banka.}

'Typhlops braminus (Daud.)

Python reticulatus (Schneider)

Cylindrophis rufus (Laur.)

Xenopeltis unicolor Reinw.

Dendrophis pictus (Gmel.)

Zaocys fuscus (Gthr.)

Tropidonotus trianguligerus Boie

'Tropidonotus vittatus (I.)

Macropisthodon rhodomelas (Boic)

Xenelaphis hexagonotus (Cantor)

Coluber melanurus Schlegel

Coluber oxycephalus Boie

Simotes octolineatus (Schneider)

Ablabes tricolor (Schlegel)

Iypsirhina alternans (Reuss)

Hypsirhina enhydris (Scheider)

Hypsirhina punctata (Gray)

Homalopsis buccata (L.)

Cerberus rhynchops (Schneider)

Dipsadomorphus dendrophilus (Boie)

Dipsadomorphus cynodon (Boie)

Psammodynastes pulverulentus (Boie)

Psammodynastes pictus Gthr.

Dryophis prasinus Boie

Chrysopelea ornata (Shaw)

Chrysopelea chrysochlora (Schlegel)

Hydrus platurus (I.)

Naja tripudians Merr.

Doliophis bivirgatus (Boie)

Doliophis intestinalis (Laur.)

Haplopeltura boa (Boie)

Amblycephalus laevis Boie

Lachesis sumatranus (Raffles)

Lachesis wagleri (Boie) 


\section{Biliton.}

Psammodynastes pictus Gthr. Lachesis sumatranus (Raffles)

Lachesis wagleri (Boie)

\section{Natuna Islands.}

Python reticulatus (Schneider)

Dendrophis pictus (Gmel.)

Dendrelaphis caudolineatus (Gray)

Zaocys fuscus (Gthr.)

Tropidonotus conspicillatus Gthr.

Tropidonotus maculatus Edeling

Coluber oxycephalus Boie

Dryocalamus tristrigatus Gthr.

Ablabes baliodirus (Boie)

Calamaria vermiformis D. B.

Psammodynastes pulverulentus (Boie)

Dryophis prasinus Boie

Dryophis fasciolatus (Fischer)

Dryophiops rubescens (Gray)

Chrysopelea ornata (Shaw)

Chrysopelea chrysochlora (Schlegel)

Amblycephalus laevis Boie

Lachesis puniceus (Boie)

Lachesis wagleri (Boie)

\section{Borneo.}

Typhlops lineatus Boie

Typhlops braminus (Daud.)

Typhlops olivaceus (Gray)

Typhlops nigroalbus D. B.

Python reticulatus (Schneider)

Python curtus Schlegel

Cylindrophis rufus (Laur.)

Cylindrophis lineatus Blanford

Xenopeltis unicolor Reinw.

Acrochordus javanicus Hornst.

Chersydrus granulatus (Schneider)

Xenodermus javanicus Reinh.

Stoliczkaia borneensis Boulenger

Opisthotropis typica (Mocq.)

Polyodontophis geminatus (Boie)

Dendrophis pictus (Gmel.)

Dendrophis formosus Boie 
Dendrelaphis caudolineatus (Gray)

Zaocys fuscus (Gthr.)

Zaocys carinatus (Gthr.)

'Tropidonotus piscator (Schneider)

Tropiclonotus conspicillatus Githr.

Tropidonotus trianguligerus Boie

'Tropidonotus petersi Blgr.

Tropidonotus sarawacensis Gthr.

'Tropidonotus flavifrons $\mathrm{Blgr}$.

? Tropidonotus stolatus (L.)

Tropidonotus subminiatus Schlegel

Tropidonotus chrysargus Schlegel

Tropidonotus maculatus Edeling

Macropisthodon flaviceps (D. B.)

Macropisthodon rhodomelas (Boie)

Xenelaphis hexagonotus (Cantor)

Xenelaphis ellipsifer Blgr.

Zamenis korros (Schlegel)

Coluber melanurus Schlegel

Coluber radiatus Schlegel

Coluber oxycephalus Boie

Gonyophis margaritatus (Peters)

Lycodon subcinctus Boie

Lycodon albofuscus (D. B.)

Lycodon effrenis Cantor

Lepturophis borneensis Blgr.

Dryocalamus tristrigatus Gthr.

Simotes annulifer Blgr.

Simotes octolineatus (Schneider)

Simotes violacens (Cantor)

Simotes subcarinatus (ithr.

Simotes purpurascens (Schlegel)

Oligodon everetti Blgr.

Oligodon vertebralis (Gthr.)

Hydrablabes periops (Gthr.)

Hydrablabes praefrontalis (Mocq.)

Ablabes tricolor (Schlegel)

Ablabes baliodirus (Boie)

Ablabes longicauda Peters

Oreocalanus hanitschi Blgr.

Idiopholis collaris Mocq.

Idiopholis everetti Shelford

Agrophis saravacensis Shelford

Agrophis albonuchalis (Gthr.)

Pseudorhabdium longiceps (Cantor) 
Brachyorrhus albus (L.)

Calamaria vermiformis D. B.

Calamaria baluensis Bigr.

Calamaria grabowskyi Fischer

Calamaria prakkei Lidth

Calamaria sumatrana Edeling

Calamaria everetti Blgr.

Calamaria leucogaster Bleeker

Calamaria bicolor D. B.

Calamaria brookei BIgr.

Calamaria brachyura Blgr.

Calamaria lateralis Mocq.

Calamaria beccarii Peters

Calamaria rebentischi Bleeker

Calamaria picteti Peracca

Calamaria lencocephala D. B.

Calamaria agamensis Bleeker

Calamaria semiannulata Böttger

Calamaria schlegeli 1). B.

Calamaria limnaei Boie

Calamaria borneensis Bleeker

Calamaria benjaminsi Edeling

Calamaria melanota Jan

Calamaria lowi Blgr.

Calamaria gracillima Githr.

Calamaria hosei Gthr.

Hypsirhina alternans (Reuss)

Hypsirhina plumbea (Boie)

Hypsirhina enhydris (Schneider)

Hypsirhina punctata (Gray)

Hypsirhina doriae (Peters)

Homalopsis buccata (L.)

Cerberus rhynchops (Schneider)

Fordonia lencobalia (Schlegel)

Cantoria violacea Girard

Dipsadomorphus multimaculatus (Boie)

Dipsadomorphus drapiezii (Boie)

Dipsadomorphus dendrophilus (Boie)

Dipsadomorphus nigriceps (Gthr.)

Dipsadomorphus jaspideus (D. B.)

Dipsadomorphus cynodon (Boie)

P'sammodynastes pulverulentus (Boic)

P'sammodynastes pictus Gthr.

Dryophis prasinus Boie

Dryophis fasciolatus (Fischer) 
Dryophiops rubescens (Gray)

Chrysopelea ornata (Shaw)

Chrysopelea chrysochlora (Schlegel)

Platurus laticaudatus (L.)

Platurus colubrinus (Schneider)

Aipysurus eydouxi (Gray)

Enhydrina valakadyn (Boie)

Thalassophis anomalus Schmidt

Hydrus platurus (L.)

Hydrophis gracilis (Shaw)

Hydrophis floweri Blgr.

Hydrophis diadema Gthr.

Hydrophis fasciatus (Schneider)

Hydrophis brookei (ithr.

Hyclrophis viperinus (Schmidt)

Hydrophis jerdoni (Gray)

Hydrophis brugmansi Boie

Hydrophis saravacensis (Blgr.)

Enhydris hardwickei (Gray)

Bungarus fasciatus (Schneider)

Bungarus flaviceps Reinh.

Naja tripudians Merr.

Naja bungarus Schlegel

Doliophis bivirgatus (Boic)

Doliophis intestinalis (Laur.)

? Acanthophis antarcticus (Shaw)

IIaplopeltura boa (Boie)

Amblycephalus laevis Boie

Aniblycephalus malaccanus (Ptrs.)

Amblycephalus nuchalis Blgr.

Amblycephalus carinatus Boie

Lachesis sumatranus (Raffles)

I achesis gramineus (Shaw)

Lachesis puniceus (Boie)

Lachesis wagleri (Boie)

Sibutu Island.

Dryophis prasinus Boie

\section{Pulu Miang besar.}

Typhlops lorenzi Werner

Java.

Typhlops lineatus Boie

Typhlops braminus (Daud.) 
Typhlops polygrammicus Schlegel ?'Typhlops kapaladua Annandale Typhlops ater Schlegel

'Typhlops bisubocularis Böttger Python reticulatus (Schneicler)

Python molurus (I..)

Cylindrophis rufus (Laur.)

Xenopeltis unicolor Reinw.

Acrochordus javanicus Hormst.

Chersydrus granulatus (Schneider)

Xenodermus javanicus Reinh.

Polyodontophis geminatus (Boie)

Pseudoxenodon inornatus (Boie)

Dendrophis pictus (Gmel.)

Dendrophis formosus Boie

Dendrelaphis caudolineatus (Gray)

Zaocys carinatus (Gthr.)

Tropidonotus piscator (Schneider)

Tropidonotus trianguligerus Boie

'Tropidonotus chrysargoides Gthr.

Tropidonotus vittatus (I.)

Tropidonotus subminiatus Schlegel

Tropidonotus chrysargus Schlegel

Macropisthodon rhodomelas (Boie)

Xenelaphis hexagonotus (Cantor)

Zamenis korros (Schlegel)

Zamenis mucosus (I.)

Coluber melanurus Schlegel

Coluber radiatus Schlegel

Coluber oxycephalus Boie

Iycodon subcinctus Boie

Lycodon aulicus (I.)

Tetralepis fruhstorferi Böttger

Simotes octolineatus (Schneider)

Simotes signatus Githr.

simotes purpurascens (Schlegel)

Oligodon bitorquatus Boie

Oligodon propinquus Jan

Elapoides fuscus Boie

Ablabes tricolor (Schlegel)

Ablabes libertatis (Barbour)

Ablabes baliodirus (Boie)

Ablabes longicauda Peters

Brachyorrhus albus (L.)

Calamaria lumbricoidea Boie 
Calamaria vermiformis D. B.

Calamaria margaritophora Bleeker

Calamaria sumatrana Edeling

Calamaria occipitalis Jan

Calamaria virgulata Boie

Calamaria sondaica Barbour

Calamaria leucocephala D. B.

Calamaria agamensis Bleeker

? Calamaria bungaroides Werner

Calamaria linnaei Boie

Calamaria javanica Blgr.

Calamaria pavimentata D. B.

Calamaria melanota Jan

Hypsirhina altermans (Reuss)

Hypsirhina plumbea (Boie)

Hypsirhina enhydris (Schneider)

Homalopsis buccata (L.)

Cerberus rhynchops (Schneider)

Fordonia leucobalia (Schlegel)

Dipsadomorphus multimaculatus (Boic)

Dipsadomorphus drapiezii (Boie)

Dipsadomorphus dendrophilus (Boie)

Dipsadomorphus nigriceps (Gthr.)

I)ipsadomorphus jaspicleus (D. B.)

Dipsadomorphus cynodon (Boie)

Psammodynastes pulverulentus (Boie)

Dryophis xanthozona Boie

Dryophis prasinus Boie

Dryophis mycterizans (L.)

Dryophiops rubescens (Gray)

? Dipsadoides decipiens Annand.

Chrysopelea ornata (Shaw)

Chrysopelea chrysochlora (Schlegel)

Platurus schistorhynchus Gthr.

Platurus laticaudatus (L)

Platurus colubrinus (Schnei(ler)

Aipysurus eydouxi (Gray)

Enhydrina valakadyn (Boie)

Thalassophis anomalus Schmidt

Thalassophis annandalei (Laidlaw)

Hydrus platurus (L.)

Hydrophis frontalis Jan

Hydrophis gracilis (Shaw)

Hydrophis fasciatus (Schneider)

Hydrophis viperinus (Schmidt) 
Hydrophis polyodontus Jan

Hydrophis cyanocinctus Daudin

Hydrophis stokesi (Gray)

Enhydris hardwickei (Gray)

Bungarus fasciatus (Schneider)

Bungarus candidus (L.)

Bungarus flaviceps Reinh.

Naja tripudians Merr.

Naja bungarus Schlegel

Doliophis bivirgatus (Boie)

Doliophis intestinalis (Laur.)

Haplopeltura boa (Boie)

Amblycephalus laevis Boie

Amblycephalus carinatus Boie

Agkistrodon rhodostoma (Boie)

Lachesis gramineus (Shaw)

Lachesis puniceus (Boie)

Madura.

Typhlops braminus (Daud.).

Hydrus platurus (I.)

Hydrophis gracilis (Shaw)

\section{Paternoster Islands.}

Hydrus platurus (L.)

\section{Bali.}

Dendrophis pictus (Gmel.)

I.ycodon aulicus (L.)

Cerberus rhynchops (Schneider)

Dipsadomorphus cynodon (Boic)

\section{Lombok.}

Typhlops elberti Roux

Cylindrophis opisthorhodus Boulenger

Polyodontophis geminatus (Boie)

Dendrophis pictus (Gmel.)

Coluber oxycephalus Boie

Coluber subradiatus Schlegel

1ycolon subcinctus Boie

Cerberus rhynchops (Schneider)

Psammodynastes pulverulentus (Boie)

Dryophis prasinus Boie

Naja tripudians Merr.

Lachesis gramineus (Shaw) 


\section{Sumbawa.}

Python reticulatus (Schneider)

Dendrophis pictus (Gmel.)

Lycorlon subcinctus Boie

Lycodon aulicus (L.)

Dryophis prasinus Boie

Naja tripudians Merr.

lachesis gramineus (Shaw)

\section{Sumba.}

Typhlops braminus (Daud.) Dendrelaphis inornatus Blgr.

Coluber subradiatus Schlegel

Lycodon aulicus (L.)

Cerberus rhynchops (Schneider)

Psammodynastes pulverulentus (Boie)

Hydrus platurus (L.)

Enhydris hardwickei (Gray)

Hydrophis brugmansi Boie

Lachesis gramineus (Shaw)

\section{Savu}

Liasis mackloti D. B.

Dendrelaphis inornatus Blgr.

Lycodon aulicus (L.)

\section{Rotti.}

Dendrophis pictus (Gmel.)

Coluber subradiatus Schlegel

Lycodon aulicus (L.)

Cerberus rhynchops (Schneider)

Platurus colubrinus (Schneider)

Iachesis gramineus (Shaw)

\section{Samao.}

Liasis mackloti D. B.

Dendrelaphis inornatus Blgr.

Coluber subradiatus Schlegel

Stegonotus modestus (Schle_el)

Lachesis gramineus (Shaw)

\section{Timor.}

Typhlops braminus (Daud.)

Typhlops polygrammicus Schlegel 
Liasis fuscus Peters

Liasis mackloti D. B.

Python reticulatus (Schneider)

Python amethystinus (Schneider)

Python timoriensis (Ptrs.)

Chersydrus granulatus (Schneider)

I)endrophis pictus (Gmel.)

?Coluber melanurus Schlegel

Coluber subradiatus Schlegel

Jycodon aulicus (L.)

Brachyorrhus albus (L.)

Cerberus rhynchops (Schneider)

Fordonia leucobalia (Schlegel)

Cantoria violacea Girard

Platurus laticaudatus (L.)

Platurus colubrinus (Schneider)

lachesis gramineus (Shaw)

\section{Flores.}

Typhlops braminus (Daud.)

Typhlops florensis Boulenger

Python reticulatus (Schneider)

Python timoriensis (Ptrs.)

Chersydrus granulatus (Schneider)

Dendrophis pictus (Gmel.)

Tropidonotus chrysargus Schlegel

Coluber subradiatus Schlegel

Lycodon florensis de Rooy

Lycodon aulicus (L.)

Cerberus rhynchops (Schneider)

Dipsadomorphus cynodon (Boie)

Psammodynastes pulverulentus (Boie)

Platurus schistorhynchus Gthr.

Platurus laticaudatus (I.)

Platurus colubrinus (Schneider)

Hydrus platurus (1..).

Enhydris hardwickei (Gray)

Naja tripudians Merr.

Lachesis gramineus (Shaw)

\section{Solor.}

I'laturus colubrinus (Schneider)

\section{Lomblem.}

Typhlops braminus (Dand.)

Lycodon aulicus (L.) 
Adonara.

Lachesis gramineus (Shaw)

Alor.

Dendrophis pictus (Gmel.)

Coluber subradiatus Schlegel

I.ycodon aulicus (L.)

Naja tripudians Merr.

Lachesis gramineus (Shaw)

Pulu Kambing in Lobetobi Strait.

Platurus schistorhynchus Gthr.

\section{Wetar.}

Cylindrophis boulengeri Roux

Lycodon aulicus (L.)

Cerberus rhynchops (Schneider)

Roma.

Lachesis gramineus (Shaw)

\section{Damma Island.}

Simotes forbesi Blgr.

\section{Timor Laut.}

Python reticulatus (Schneider)

Python amethystinus (Schneider)

Enygrus carinatus (Schneider)

Dendrophis calligaster Gthr.

Simotes forbesi Blgr.

Chrysopelea rhodopleuron Boie

Acanthophis antarcticus (Shaw)

\section{Djampea Island.}

Cylindrophis isolepis Boulenger

Lachesis fasciatus Blgr.

\section{Kalao Island.}

Lycodon aulicus (L.)

\section{Saleyer.}

Typhlops braminus (Daud.)

Lycodon aulicus (L.) 


\section{Buton.}

Typhlops braminus (Daud.) Python reticulatus (Schneider) Dendrophis pictus (Gmel.) Coluber erythrurus (D. B.) Dryophis prasinus Boie

\section{Celebes.}

Typhlops braminus (Daud.)

Typhlops conradi Peters

Typhlops ater Schlegel

Python reticulatus (Schneider)

Python molurus (L.)

Enygrus carinatus (Schneider)

Cylindrophis rufus (Laur.)

Xenopeltis unicolor Reinw.

Chersydrus granulatus (Schneider)

Dendrophis pictus (Gmel.)

Dendrelaphis terrificus (Peters)

Tropidonotus piscator (Schneider)

Tropidonotus celebicus (P. D.)

Tropidonotus sarasinorum Blgr.

Tropidonotus trianguligerus Boie

Tropidonotus chrysargoides Gthr.

Tropidonotus vittatus (L.)

Tropidonotus subminiatus Schlegel

Tropiclonotus chrysargus Schlegel

? Macropisthodon rhodomelas (Boie)

Zamenis dipsas (Schlegel)

Coluber melanurus Schlegel

Coluber erythrurus (D. B.)

Coluber janseni (Bleeker)

Coluber oxycephalus Boie

I.ycodon stormi Böttger

Lycodon aulicus (L.)

Simotes octolineatus (Schneider)

Oligodon waandersi (Bleeker)

Agrophis sarasinorum F. Müller

Rhabdophidium forsteni (D. B.)

Pseudorhabdium longiceps (Cantor)

Calamaria lumbricoidea Boie

Calamaria nuchalis Blgr.

Calamaria gracilis Blgr.

Calamaria acutirostris Blgr. 
Calamaria curta Blgr.

Calamaria mülleri Blgr.

Calamaria virgulata Boie

Calamaria collaris Blgr.

Calamaria linnaei Boie

Hypsirhina plumbea (Boie)

Hypsirhina enhydris (Schneider)

Hypsirhina matannensis Blgr.

Homalopsis buccata (L.)

Cerberus rhynchops (Schneider)

Dipsadomorphus multimaculatus (Boie)

Dipsadomorphus dendrophilus (Boie)

Dipsadomorphus irregularis (Merr.)

Dipsadomorphus flavescens (D. B.)

Psammodynastes pulverulentus (Boie)

Dryophis prasinus Boie

Chrysopelea ornata (Shaw)

Platurus colubrinus (Schneider)

Hydrus platurus (L.)

Hydrophis brugmansi Boie

Enhydris hardwickei (Gray)

Bungarus candidus (I.)

Naja bungarus Schlegel

Doliophis intestinalis (Laur.)

Lachesis wagleri (Boie)

\section{Togian Islands.}

Psammodynastes pulverulentus (Boie)

\section{Sangir Islands.}

Typhlops olivaceus (Gray)

Enygrus carinatus (Schneider)

Cylindrophis rufus (Laur.)

Dendrophis pictus (Gmel.)

Tropidonotus trianguligerus Boie

Tropidonotus chrysargoides Gthr.

Cerberus rhynchops (Schneider)

Dipsadomorphus irregularis (Merr.)

Psammorlynastes pulverulentus (Boie)

Dryophis prasinus Boie

Chrysopelea rhodopleuron Boie

Lachesis wagleri (Boie)

Salibabu Islands.

Enygrus carinatus (Schneider) 


\section{Buru.}

Stegonotus modestus (Schlegel)

Brachyorrhus albus (L.)

Cerberus rhynchops (Schneider)

Dipsadomorphus irregularis (Merr.)

Chrysopelea rhodopleuron Boie

Platurus colubrinus (Schneider)

\section{Ambon.}

Typhlops braminus (Daud.)

Python reticulatus (Schneider)

Python amethystinus (Schneider)

Enygrus carinatus (Schneider)

Chersydrus granulatus (Schneider)

Dendrophis pictus (Gmel.)

Stegonotus modestus (Schlegel)

Stegonotus batjanensis (Gthr.)

? Oligodon bitorquatus Boie

Brachyorrhus albus (L.)

Cerberus rhynchops (Schneider)

Fordonia leucobalia (Schlegel)

- Dipsadomorphus drapiezii (Boie)

Dipsadomorphus irregularis (Merr.)

Chrysopelea rhodopleuron Boie

Platurus schistorhynchus Gthr.

Platurus colubrinus (Schneider)

Hydrus platurus (L.)

\section{Haruku.}

Python amethystinus (Schneider)

Enygrus carinatus (Schneider)

Brachyorrhus albus (L.)

Acanthophis antarcticus (Shaw)

\section{Saparua.}

Python amethystinus (Schneider)

Enygrus carinatus (Schneider)

Cerberus rhynchops (Schneider)

\section{Ceram.}

Typhlops braminus (I)aud.)

Typhlops multilineatus Schlegel

Python reticulatus (Schneider)

Python amethystinus (Schneider) 
Enygrus carinatus (Schneider)

Dendrophis pictus (Gmel.)

Tropidonotus elongatus Jan

Stegonotus modestus (Schlegel)

Brachyorrhus albus (I.)

Calamaria ceramensis de Rooy

Cerberus rhynchops (Schneider)

Fordonia lencobalia (Schlegel)

Dipsadomorphus irregularis (Merr.)

Chrysopelea rhodopleuron Boie

Pseudelaps mülleri (Schlegel)

Acanthophis antarcticus (Shaw)

\section{Banda.}

Python reticulatus (Schneider)

Python amethystinus (Schneider)

Enygrus carinatus (Schneider)

Brachyorrhus albus (L.)

Chrysopelea rhodopleuron Boie

\section{Goram .}

Enygrus carinatus (Schneider)

Enygrus asper (Gthr.)

Cerberus rhynchops (Schneider)

Dipsadomorphus irregularis (Merr.)

Obi.

Python reticulatus (Schneider)

Acanthophis antarcticus (Shaw)

\section{Batjan.}

Typhlops flaviventer Peters

Python reticulatus (Schneider)

Python amethystinus (Schneider)

Enygrus carinatus (Schneider)

Cylindrophis rufus (Laur.)

Dendrelaphis modestus Blgr.

Tropilonotus truncatus (Peters)

Tropidonotus halmahericus Böttger

Stegonotus batjanensis (Gthr.)

Brachyorrhus albus (L.)

Calamorhabdium kükenthali Böttger

Cerberus rhynchops (Schneider)

Dipsadomorphus irregularis (Merr.)

Chrysopelea rhodopleuron Boie 


\section{Ternate.}

Typhlops braminus (Daud.)

Typhlops flaviventer Peters

Typhlops ater Schlegel

Python reticulatus (Schneider)

Enygrus carinatus (Schneider)

Chersydrus granulatus (Schneider)

Dendrophis pictus (Gmel.)

Dendrophis calligaster Gthr.

Dendrelaphis modestus Blgr.

Tropidonotus truncatus (Peters)

Tropidonotus trianguligerus Boie

Tropidonotus subminiatus Schlegel

Tropiclonotus chrysargus Schlegel

Stegonotus modestus (Schlegel)

Brachyorrhus albus (L.)

Calamaria vermiformis D. B.

Cerberus rhynchops (Schneider)

Dipsadomorphus irregularis (Merr.)

Dryophis prasinus Boie

Platurus laticaudatus (L.)

Platurus colubrinus (Schneider)

Hydrus platurus (L.)

Hydrophis nigrocinctus Daudin

\section{Halmahera.}

Typhlops braminus (Daud.)

Typhlops flaviventer Peters

Typhlops ater Schlegel

Python reticulatus (Schneider)

Python amethystinus (Schneider)

Enygrus carinatus (Schneider)

Dendrophis calligaster Gthr.

Dendrelaphis modestus Blgr.

Tropidonotus truncatus (Peters)

Tropidonotus punctive utris Böttger

Tropidonotus halmahericus Böttger

Zamenis dipsas (Schlegel)

Stegonotus modestus (Schlegel)

Stegonotus batjanensis (Gthr.)

Brachyorrhus albus (L.)

Cerberus rhynchops (Schneider)

Dipsadomorphus irregularis (Merr.)

Platurus laticaudatus (L.)

Platurus colubrinus (Schneider) 
Morotai.

Stegonotus batjanensis (Gthr.)

\section{Waigeu.}

Enygrus asper (Gthr.)

Dendrophis calligaster Gthr.

Dendrophis lineolatus H. J.

Tropidonotus picturatus Schlegel

Hydrophis brugmansi Boie

\section{Batanta.}

Enygrus carinatus (Schneider)

Enygrus asper (Gthr.)

Dendrophis calligaster Gthr.

Micropechis ikaheka (Lesson)

\section{Salawatti.}

Liasis albertisi Ptrs. \& Doria Python amethystinus (Schneider)

Enygrus carinatus (Schneider)

Enygrus asper (Gthr.)

Dendrophis calligaster Gthr.

Stegonotus modestus (Schlegel)

Dipsadomorphus irregularis (Merr.)

Platurus colubrinus (Schneider)

Pseurlclaps mülleri (Schlegel)

\section{Misol.}

Typhlops olivaceus (Gray)

Python amethystinus (Schneider)

Enygrus carinatus (Schneider)

Enygrus asper (Gthr.)

Dendrophis pictus (Gmel.)

Dendrophis lineolatus H. J.

Stegonotus modestus (Schlegel)

Dipsadomorphus irregularis (Merr.)

Chrysopelea rhodopleuron Boie

Pseudelaps mülleri (Schlegel)

Kur.

l'laturus colubrinus (Schneider)

\section{Kei Islands.}

Typhlops kraali Doria 
'Typhlops braminus (Daud.)

Typhlops multilineatus Schlegel

Python amethystinus (Schneider)

Dendrophis calligaster Gthr.

Stegonotus modestus (Schlegel)

Dipsadomorphus irregularis (Merr.)

Platurus colubrinus (Schneider)

Aipysurus laevis I acépède

Acanthophis antarcticus (Shaw)

\section{Aru Islands.}

'Typhlops braminus (Daud.)

Python amethystinus (Schneider)

Chondropython viridis (Schlegel)

Dendrophis calligaster Gthr.

Dendrophis lineolatus $\mathrm{H}$. J.

Tropidonotus picturatus Schlegel

Tropidonotus doriae Blgr.

Stegonotus modestus (Schlegel)

Brachyorrhus albus (L.)

Myron richardsoni Gray

Dipsadomorphus irregularis (Merr.)

Platurus laticaudatus (L.)

Platurus colubrinus (Schneider)

Aipysurus laevis I acépède

Hydrophis fasciatus (Schneider)

Hydrophis mertoni (Roux)

Hydrophis ornatus (Gray)

Hydrophis cyanocinctus Daudin

Hydrophis stokesi (Gray)

Glyphodon tristis Gthr.

Acanthophis antarcticus (Shaw)

\section{New Guinea.}

Typhlops erycinus Werner

Typhlops polygrammicus Schlegel

Typhlops multilineatus Schlegel

Typhlops depressiceps Sternfeld

Typhlops bipartitus Sauvage

Typhlops leucoproctus Boulenger

Typhlops flaviventer Peters

Typhlops inornatus Boulenger

Nardoa boa (Schlegel)

Liasis fuscus Peters

Liasis tornieri Werner 
Liasis albertisi Ptrs. \& Doria

Liasis papuanus Ptrs. \& Doria

Python amethystinus (Schneider)

Python spilotes (Lacépède)

Chondropython viridis (Schlegel)

Enygrus carinatus (Schneider)

Enygrus asper (Gthr.)

Acrochordus javanicus Hornst.

Chersydrus granulatus (Scheider)

l)endrophis calligaster Githr.

Dendrophis lorentzi Lidth

Déndrophis punctulatus (Gray)

Dendrophis gastrostictus Bigr.

Dendrophis lineolatus H. ].

Dendrophis meeki Blgr.

Dendrophis nouhuysi Lilth

Tropidonotus picturatus Schlegel

Tropidonotus novae-guineae Lidth

Tropidonotus mairi Gray

Tropidonotus montanus Lidth

Tropidonotus doriae BIgr.

Tropidonotus hypomelas Gthr.

Stegonotus magnus (Meyer)

Stegonotus modestus (Schlegel)

Stegonotus plumbeus (Macleay)

Stegonotus güntheri Blgr.

Stegonotus diehli Lindholm

Brachyorrhis albus (L.)

Hypsirhina enhydris (Schneider)

Hypsirhina polylepis Fischer

Cerberus rhynchops (Schneicler)

Fordonia leucobalia (Schlegel)

Myron richardsoni Gray

Dipsadomorphus irregularis (Merr.)

Platurus schistorhynchus Gthr.

Platurus laticaudatus (L.)

Platurus colubrinus (Schneider)

Aipysurus eydouxi (Gray)

Aipysurus australis Sauvage

Aipysurus laevis Lacépède

Enbydrina valakadyn (Boie)

Hydrus platurus (L.)

Hydrophis fasciatus (Schneider)

Hydrophis brugmansi Boie

Hydrophis ornatus (Gray) 
Hydrophis macfarlani (Blgr.)

Hydrophis cyanocinctus Daudin

Hydrophis belcheri (Gray)

Hydrophis stokesi (Gray)

Enhydris hardwickei (Gray)

Glyphorlon tristis Gthr.

Toxicocalamus stanleyanus Blgr.

Ultrocalamus preussi Sternfeld

A pistocalamus pratti Blgr.

Apistocalamus loriae Blgr.

A pistocalamus grandis Blgr.

Apistocalamus lonnbergi Blgr.

Pseudapistocalamus nymani Lönnberg

Pseurlelaps mülleri (Schlegel)

Diemenia psammophis (Schlegel)

Diemenia olivacea (Gray)

Pseudechis australis (Gray)

Pseudechis papuanus P. 1).

Pseudechis scutellatus Peters

Microjechis ikaheka (I.esson)

Acanthophis antarcticus (Shaw) 




\section{ALPHABE'TICAL INDEX}

$\mathrm{OF}$

\section{GENERA AND SPECIES.}

Ablabes 48, I36, I 37 .

Ablabes baliodirus 137, 139.

Ablabes libertatis 137,138 .

Ablabes longicauda I37, I 40.

Ablabes periops i 36 , I 37 .

Ablabes periops praefrontalis $\mathbf{I} 37$.

Ablabes tricolor $\mathbf{1 3 7}, \mathrm{I}_{3} 8$.

Acanthophis $242,27 \mathrm{I}$.

Acanthophis antarcticus 272 .

Acrochordinae $4 \mathrm{I}$.

Acrochordus $4 \mathrm{r}, 42$.

Acrochorclus jaranicus 43 .

acutirostris, Calamaria I5 I, I60.

aemulans, Anoplohydrus 49.

agamensis, Calamaria I 52, I 7 I.

Agkistrodon 279.

Agkistrodon rhodostoma 279.

Aglypha 4 .

Agrophis 48,143 .

Agrophis albonuchalis I $43, \mathrm{I} 44$.

Agrophis sarasinorum I 43

Agrophis saravacensis 143,144 .

Ahaetulla 68 .

Ahaetulla caudolineata 68,69 .

Aipysurus 2 I 5,2 I 8.

Aipysurus australis 2 I $S, 2$ I 9.

Aipysurus eydouxi 2 I 8,2 I 9.

Aipysurus laevis $2 \mathrm{I} 8,220$.

albertisi, Liasis I 6, I 8 .

albofuscus, Lycodon ros, I 09.

albofuscus, Sphecodes 109.

albomaculata, Hypsirhina $\mathbf{s} 0, \mathbf{1} \delta_{j}$. albomaculatus, Homalopsis $1 \delta_{3}$. albonuchalis, Agrophis I $43, \mathrm{I}+4$. albonuchalis, Geophis $\mathrm{I}+4$.

albopunctata, Calamaria I 52, 165 .

albus, Brachyorrhus i $4 \delta$.

albus, Coluber 148 .

alternans, Brachyorrhos ISo.

alternans, Hypsirhina ISo.

Amblycephalidae $\mathbf{~ , ~} 273$.

Amblycephalus 273, 275 .

Amblycephalus boa 275 .

Amblycephalus carinatus 276,277 .

Amblycephalus laevis 276 .

Amblycephalus malaccanus 276 .

Amblycephalus nuchalis 276,277 .

amethystina, Boa 24 .

amethystinus, Python 20, 24 .

Amphiesma 9r.

Amphiesma tlaviceps 9 $\mathbf{I}$. anceps, Calamaria 167 .

Ancistrodon 279 .

Ancistrodon rhodostoma 279 .

Anguis 36, 224.

Anguis platura 224 .

Anguis rufa 36 .

Anisodon 202.

Anisodon lilljeborgi 202. annandalei, Distira 223.

annandalei, Thalassophis 223 .

annandalii, Thalassophis 223 .

annulifer, Simotes 122.

Anomalochilus 34 
Anomalochilus weberi 34 .

anomalus, Thalassophis 223.

Anoplohydrus 46, 49.

Anoplohydrus aemulans 49 .

antarctica, Boa 272.

antarcticus, Acanthophis 272.

A pistocalamus 242, 260 .

A pistocalamus grandis $260,26 \mathrm{I}$.

A pistocalamus lönnbergi 260,262 .

Apistocalamus loriae 260, 26I.

A pistocalamus pratti 260 .

asper, Enygrus 3i, 32.

asper, Erebophis 32.

Aspis 253.

Aspis intestinalis 253 .

Asthenodipsas 276 .

Asthenodipsas malaccana 276 .

Astrotia 239.

Astrotia stokesi 239 .

ater, Typhlops 4, 10, I3.

Atropophis 286.

Atropophis borneensis 286 .

Aturia $236,238$.

Aturia belcheri 238 .

Aturia ornata 236.

aulicus, Coluber i i.

aulicus, Lycodon roS, irr.

austıalis, Aipysurus 218,2 I 9.

australis, Boa 33 .

australis, Enygrus 3 I, 33.

australis, Naja 268.

australis, Pseudechis 268 .

baliodeira, Coronella I 39 .

baliodirus, Ablabes I37, I 39 .

baliodirus, Liopeltis I 39 .

baluensis, Calamaria I 50, 155 .

batjanensis, Coluber i 6 .

batjanensis, Lielaphis i 6 .

batjanensis, Stegonotus II4, ir 6 .

beccarii, Calamaria 152, 168.

belcheri, Aturia 238 .

belcheri, Distira 238 .

belcheri, Hychophis 227,238 .

henjaminsi, Calamaria I53, I 75 . bicolor, Calamaria 152,165 .

bipartita, Simotes 123 .

bipartitus, Typhlops 3, 10.

bipunctatus, Diadophis 140.

bisubocularis, Typhlops 4, 13 .

bitorquatus, Oligodon 127, I 28 .

bivirgatus, Doliophis $25 \mathrm{x}$.

bivirgatus, Elaps 251 .

bivittatus, Python 22, 23.

Boa 20, 24, 31, 33, 272.

boa, Amblycephalus 275 .

Boa amethystina 24 .

Boa antarctica 272 .

Boa australis 33 .

Boa carinata 31.

boa, Haplopeltura 275 .

boa, Nardoa 15.

Boa reticulata 20.

boa, Tortrix i 5 .

bogorensis, Calamaria 162 .

Boidae I, 14.

Boiga 195, I97, 20 I.

Boiga dendrophila 197.

Boiga irregularis 201 .

Boiga multimaculata r 95 .

Boinae i 5, 31 .

borneensis, Atropophis 286.

borneensis, Calamaria 153,175 .

borneensis, Iachesis 286 .

borneensis, Lepturophis in 3 .

borneensis, Stoliczkaia 45 .

Bothrops 286.

Bothrops sandakanensis 286 .

boulengeri, Cylindrophis $36,3^{8}$.

Brachyorrhos i 80 .

Brachyorrhos alternans i 80 .

Brachyorrhus 48, 147 .

brachyorrhus albus 148 .

brachyura, Calamaria 152,167 .

braminus, Eryx 5 .

braminus, Typhlops 2, 5 .

brookei, Calamaria r 52, 166.

brookei, Hydrophis 226, 230.

brookii, Calamaria 166 .

brookii, Hydrophis 230. 
brugmansi, Hydrophis 226, 233. brugmansii, Distira 233 . buccata, Homalopsis i $\$ 6$. buccatus, Coluber I 86. bungaroides, Calamaria 152,173 . Bungarus 24I, 243.

Bungarus candidus 243, 244.

Bungarus fasciatus $2+3$.

Bungarus flaviceps $2+5$. bungarus, Naja 246,249 . bürgersi, Ultrocalamus 260.

caeca, Naja 24 S.

Calamaria 49, I46, I 49 .

Calamaria acutirostris I5I, I60.

Calamaria agamensis I 52, I 71 .

Calamaria albopunctata 152,165 .

Calamaria anceps 167 .

Calmaria baluensis I 50, I 55 .

Calamaria beccarii 152, I68.

Calamaria benjaminsi I 53, I 75 .

Calamaria bicolor 152, I65.

Calamaria bogorensis 162 .

Calamaria borneensis I 53, I 75 .

Calamaria brachyura I52, 167 .

Calamaria brookei I 52, I 66.

Calamaria brookii I 66 .

Calamaria bungaroides 152, I 73 .

Calamaria ceramensis I 52, I 69 .

Calamaria collaris 152, I 67 .

Calamaria curta I5I, I60.

Calamaria döderleini 152, I 72 .

Calamaria elegans i 5 r, I5S.

Calamaria everetti I5I, I6 I.

Calamaria gervaisii $\mathbf{I} 6 \mathbf{I}$.

Calamaria grabowskyi I 50, I 55 .

Calamaria gracilis I 5 I, I 59 .

Calamaria gracillima 153,178 .

Calamaria hoeveni 179 .

Calamaria hosei $\mathbf{z} 7$.

Calamaria indragirica i 50, I 54.

Calamaria javanica 153,176 .

Calamaria lateralis 152 , 168 .

Calamaria lautensis I $_{5} \mathrm{I}, \mathbf{1}_{3}$.

Calamaria leucocephala I52, I 7 I.
Calamaria lencogaster 152,164 .

Calamaria linnaei I 53, I 7 t.

Calamaria limnaei gastrogramma I 77 .

Calamaria linnaei melanota 177 .

Calamaria longiceps I 46 .

Calamaria lovii 177 .

Calamaria lowi I 53, 177 .

Calamaria lumbricoidea I 50, I $_{53}$.

Calamaria margaritifera I 56 .

Calamaria margaritophora I5o, I 56, I 79 .

Calanuaria mecheli I52, I69.

Calamaria melanota I53, I 77 .

Calamaria mülleri $\mathbf{5} 5 \mathbf{I}, \mathbf{1} 6 \mathbf{I}$.

Calamaria nuchalis $15 \mathrm{I}, \mathrm{I}_{57}$.

Calamaria occipitalis I5 I, I62.

Calamaria ornata $17 \mathrm{~S}$.

Calamaria pavimentata 153,176 .

Calamaria picteti I52, I 70, I 72.

Calamaria prakkei i 50, I 56.

Calamaria prakkii ${ }_{5} 6$.

Calamaria quinquetaeniata I $_{52}$, I64.

Calamaria rebentischi I52, I 69 .

Calamaria schlegeli I52, I 73.

Calamaria semiannulata 152, I 72 .

Calamaria simalurensis I5 I, 159 .

Calamaria sondaica I 52, I66.

Calamaria stahlknechti i 50, I 54 .

Calamaria sumatrana 15 I, 157 .

Calamaria variabilis I $\mathbf{5 3}$.

Calamaria vermiformis $\mathrm{I} 50, \mathrm{I} 53$.

Calamaria virgulata I 51, I62.

Calamorhabdium 49, I4S.

Calamorhabdium kükenthali $\mathbf{1} 49$.

calligaster, Dendrophis 57, 60 .

Calliophis 250 .

Calliophis gracilis 250 .

callistus, Tropidonotus S6.

Callophis $24 \mathrm{I}, 25^{\circ}$.

Callophis gracilis 250 .

candidus, Bungarus $2+3,24+$.

candidus, Coluber $24 \%$.

Cantoria 179, 190. 
Cantoria violacea 191.

carinata, Boa $3 \mathrm{r}$.

carinatus, Amblycephalus 276, 277 .

carinatus, Coryphodon 73 .

carinatus, Enygrus 3 r.

carinatus, Zaocys 71, 73 .

caudolineata, Ahaetulla 68.

caudolineatus, Dendrelaphis 67,68 .

celebicus, Styporhynchus 78 .

celebicus, Tropidonotus 74,78 .

ceramensis, Calamaria $\mathbf{1 5 2}, \mathbf{1} 69$.

Cerberus I 79, 187 .

Cerberus rhynchops 187 .

Chersydrus $42,+3$.

Chersydrus granulatus 43 .

Chondropython $15,28$.

Chondropython viridis 29 .

chrysarga, Natrix 89.

chrysargoides, Tropidonotus 75, 86 .

chrysargus, Tropidonotus 75,89 .

chrysochlora, Chrysopelea 2 I 2,2 I 4.

chrysochloros, Dendrophis 214.

Chrysopelea I 94, 2 I I.

Chrysopelea chrysochlora 2 I 2, 2 I 4 .

Chrysopelea ornata 2 I 2.

Chrysopelea rhodopleuron 2 I I, 2 I 2.

collaris, Calamaria 152, 167 .

collaris, Idiopholis 142.

Coluber $22,26,47,54,58,87,88$, $93,96,98$, I I I, 1 1 6, 1 48, г 86, 201, 208,2 I 2,2 I $7,244,270,28_{3}, 28_{5}$.

Coluber albus 148 .

Coluber aulicus I I .

Coluber batjanensis I 16 .

Coluber buccata 186.

Coluber candidus 244.

Coluber enganensis 99, 105 .

Coluber erythrurus 99, 102.

Coluber geminatus 54 .

Coluber gramineus 285 .

Coluber hexahonotus 93 .

Coluber ikaheka 270.

Coluber irregularis 201.

Coluber janseni 99, 102.

Coluber korros $9^{6}$.
Coluber laticaudatus 2 r 7 .

Coluber melanurus 99.

Coluber melanurus timoriensis ror.

Coluber molurus 22.

Coluber mucosus 98 .

Coluber mycterizans 208.

Coluber ornatus $2 \mathbf{2} 2$.

Coluber oxycephalus 99, I04.

Coluber pictus $5^{8}$.

Coluber porphyraceus 99.

Coluber radiatus 99, 101 .

Coluber spilotes 26 .

Coluber stolatus 87 .

Coluber subradiatus 99, 106.

Coluber sumatranus $28_{3}$.

Coluber taeniurus 99, 103.

Coluber vittatus 88 .

Colubridae I, 4 I.

Colubrinae $4 \mathrm{r}, 4^{6}$.

colubrinus, Hydrus 217.

colubrinus, Platurus 216, 217.

conradi, Typhlops 3 , $\mathbf{~ o . ~}$

conspicillatus, Tropidonotus 75,83 .

Cophias 286.

Cophias punicea 286.

Cophias wagleri 286 .

Coronella I 24, I 39 .

Coronella baliodeira I 39 .

Coronella violacea I 24 .

Coryphodon 72, 73 .

Coryphodon carinatus 73 .

Coryphodon fuscus $\mathbf{7 2 .}$

Crotalinae 279.

cucullatum, Lycodon I I 5 .

cucullatus, Stegonotus I I 5 .

curta, Calamaria I 5 I, 160.

curtus, Python 20, 28.

cyanocincta, Distira 237.

cyanocinctus, Hydrophis 227,237 .

Cylindrophis 34,35 .

Cylindrophis boulengeri $36,3^{8}$.

Cylindrophis isolepis $36,3^{8}$.

Cylindrophis lineatus 36,37 .

Cylindrophis opisthorhodus $3^{6}, 37$.

Cylindrophis rufus 36 . 
cynodon, Dipsadomorphus 200.

cynotlon, Dipsas 200.

decipiens, Dipsadoirles 2 io.

Dendorophis 60.

Dendorophis pictus striata 60.

Dendrelaphis $47,60,67$.

Dendrelaphis caudolineatus 67,68 .

Dendrelaphis inornatus 67 .

Dendrelaphis modestus 67,70 .

Denclrelaphis papuensis 67,70 .

Dendrelaphis schlenckeri 60 .

Dendrelaphis terrificus 67,69 .

dendrophila, Buiga i 97.

dendrophila, Dipsas 197.

(lendrophilus, Dipsadomorphus

I $95,197$.

Dendrophis $47,57,69,214$.

Dendrophis calligaster 57,60 .

Dendrophis chrysochloros 2 I 4.

Dendrophis elegans 65 .

Dendrophis formosus $5^{8}, 64$.

Dendrophis gastrostictus 58,64 .

Dendrophis lineolatus 58,65 .

Dendrophis lineolatus elegans $6_{5}$.

Dendrophis lorentzi 57, 62 .

Dendrophis meeki 58,66 .

Dendrophis nouhuysi 58,66 .

Dendrophis pictus 57,58 .

1)endrophis pictus striata 60 .

Dendrophis punctulatus 57,63 .

Dendrophis terrificus 60 .

depressiceps, Typhlops 3, 9.

diadema, Hydrophis 226, 229.

I)iadophis r 40 .

Diadophis bipunctatus 140 .

diehli, Stegonotus I14, I I 8 .

Diemenia $242,266$.

Diemenia olivacea 266,267 .

Diemenia psammophis 266.

Dipsadoides 194, 2 1 0.

Dipsadoides decipiens 210.

Dipsadomorphinae 4r, 194.

Dipsadomorphus i 94 .

INDO-AUSTRALIAN REPTILES 11 .
195. Dipsadomorphus cynodon I 95, 200.

Dipsadomorphus dendrophilus i 95 , 197.

Dipsadomorphus drapiezii i 95, 196.

1)ipsarlomorphus flavescens I95, 202.

Dipsadomorphus irregularis I95, 201 .

Dipsadomorphus irregularis prapuanus 201.

Dipsadomorphus jaspicleus 195 , I 99.

Dipsadomorphus multimaculatus I 95 .

Dipsarlomorphus nigriceps 195, I 99.

Dipsas 1 95, 196, 197, 199, 200, 209.

Dipsas cynodon 200.

Dipsas dendrophila 197.

Dịssas drapiezii r 96.

dipsas, Herpetodryas 96.

1)ipsas multimaculata $\mathbf{1 9 5 .}$

l)ipsas nigriceps 199.

1)ipsas rubescens 209.

dipsas, Zamenis 95, 96.

Distira 223, 231, 232, 233, 235, $236,237,238,239$.

Distira amnandalei 223.

)istira belcheri 238 .

1)istira brugmansi 233 .

Distira cyanocincta 237.

1)istira grandis 235 .

Distira jerdonii 232.

1)istira macfarlani 237 .

Distira mertoni 233.

Distira ornata $23^{6}$.

Distira pachycercus 239.

Distira saravacensis 238 .

Distira stokesii 239.

Distira viperina $23 \mathbf{r}$.

dötlerleini, Calamaria I 52, 172.

Doliophis 242, $25 \mathrm{I}$.

Doliophis bivirgatus $25 \mathrm{r}$.

Doliophis intestinalis $251,253$.

doriae, Homalophis 185 .

doriae, Hypsirhina I So, I 85 . 
doriae, Tropidonotus 74, 82 . drapiezii, Dipsadomorphus I 95, $19^{6 .}$ (lrapiezii, I)ipsas 196.

1)ryocalamus 48, i is.

1) ryocalamus subannulatus i 9 .

1) ryocalamus trilineatus I 20.

T)ryocalamus tristrigatus I 9 , I 20.

1)ryophiops 194, 208 .

Dryophiops rubescens 209.

Dryophis $194,204$.

I) ryophis fasciolatus 205,207 .

Dryophis mycterizans $205,208$.

1)ryophis prasinus $205,206$.

I) ryophis xanthozona 205 .

clurheimi, Oligodon :27, 129.

effienis, I,ycorlon IoS, I I 2.

Elaphe roo.

Elaphe melanura roo.

Elaphis 103 .

Elaphis taeniurus ro3.

Elapinae 4I, $24 \mathrm{I}$.

Elapoides 48 , 134 .

Elapoides fuscus I 34 .

Elaps I 23, 25 I, 264, 266.

Elaps bivirgatus $25 \mathrm{I}$.

Elaps müllerii 264 .

Elaps octolineatus 123.

liaps psammophis 266.

clberti, Typhloys 3, 7 .

elegans, Calamaria I 5 I, 158 .

elegans, Dendrophis 65 .

ellipsifer, Xenelaphis 93, 95.

elongatus, Tropidonotus 7.4 , So.

enganensis, Coluber 99, 105 .

Enhydrina 2 I 5, 220.

Enhydrina valakadien 221 .

Enhydrina valakadyn 221.

Enhydris $215,240$.

Enhydris hardwickei 240.

Enhydris hardwickii 240.

enhydris, Hyclrus $\mathrm{I} S \mathrm{r}$.

enhydris, Hypsithima $1 S 0$, I 8 I.

Enygrus ז 5,3 r.

Enygrus asper 3r, 32.
Enygrus australis 3 I, 33 .

Enygrus carinatus $3 \mathrm{I}$.

Erebophis 32 .

Erebophis asper 32 .

erycinus, Typhlops 2, 6.

erythrurus, Coluber 99, I02.

erythrurus, Plagiodon I02.

Eryx 5.

Eryx braminus 5 .

everetti, Calamaria I5 I, I6 I.

everetti, Idiopholis $\mathbf{I} \mathbf{2} 2$.

everetti, Oligodon I 28 , 130 .

eydouxi, Aipysurus 2 I $S, 2$ I 9.

eyclouxii, Tomogaster 2 I 9 .

fasciata, Pseudoboa 243.

fasciatus, Bungarus 243 .

fasciatus, Hydrophis 226,230 .

fasciatus, Hydrus 230.

fasciatus, Iachesis $2 \mathrm{~S}_{2}, 2 \mathrm{~S}_{4}$.

fasciatus, Lycodon I I 3 .

fasciolatus, Dryophis 205, 207.

fasciolatus, Tragops 207.

flavescens, Dipsadomorphus I95, 202.

flavescens, Triglyphodon 202.

flaviceps, Amphiesma 9r.

flaviceps, Bungarus 243, 245.

flaviceps, Macropisthodon 9

flavifrons, Tropidonotus $75,8_{7}$.

flaviventer, Typhlops 3, I I.

florensis, Iycodon IoS, I I o.

florensis, Typhlops 3, го.

floweri, Hydrophis 226, 229 .

forbesi, Simotes I 22, 124.

Fordonia I 79, I 89 .

Fordonia leucobalia $\mathbf{s} 9$, I 90 .

Fordonia papuensis rgo.

formosus, Dendrophis $5^{8}, 64$.

forsteni, Rhabdion $\mathbf{I} 45$.

forsteni, Rhabdophidium 145 .

frontalis, Hydrophis 226,227 .

fruhstorferi, Tetralepis 12 I.

fuscus, Coryphodon 72 .

fuscus, Elapoides I 34. 
fuscus, Liasis 16 .

fuscus, Zaocys 7 I, 72.

gastrogramma, Calamaria 177 .

gastrostictus, Dendrophis 58,64 . geminatus, Coluber 54 .

geminatus, Polyodontophis 54.

geminatus, Sibynophis 55 .

Geophis I 44 .

Geophis albonuchalis 144 . gervaisii, Calamaria $\mathbf{6} 6 \mathbf{r}$.

Glyphodon 242, 254.

Glyphorlon tristis 255 .

Gonyophis 47, 106.

Gonyophis margaritatus 106.

Gonyosoma 102, 104, 106.

Gonyosoma jansenii ro2.

Gonyosoma margaritatum 106.

Gonyosoma oxycephala 104.

grabowskyi, Calamaria I 50, 155.

gracilis, Calamaria 15 I, I 59.

gracilis, Calliophis 250 .

gracilis, Callophis 250.

gracilis, Hydrophis 226,228 .

gracilis, Hydrus 228.

gracilis, Leiopython I $S$, I 9 . gracillima, Calamaria I 53, I 7 S.

gramineus, Coluber $28_{5}$.

gramineus, Lachesis $28_{2}, 2 S_{5}$.

gramineus, Trimeresurus $2 S_{5}$.

grandis, Apistocalamus $260,26 \mathrm{I}$.

grandis, 1)istira 235 .

grandis, Hydrophis $226,235$.

granulatus, Chersydrus 43 .

granulatus, Hydrus 43 .

güntheri, Stegonotiss I I 4, I I 7 .

halmahericus, Tropidonotus 74, $S_{2}$. hanitschi, Oreocalamus ifr.

Haplopeltura 273 .

Haplopeltura boa 275 .

hardwickei, Enhydris 2.0.

hardwickii, Enhydris 240.

hardwickii, Lapemis 2.40 .

Helicopsoides 52 .
Helicopsoides typicus 52 .

Herbertophis I 7 .

Herbertophis plumbeus i I 7 .

Herpetodryas 96, ${ }_{3}$ S.

Herpetodryas dipsas 96 .

Herpetodryas tricolor i 38 .

hexagonotus, Nenelaphis 93.

hexahonotus, Coluber 93.

Hipistes 1 79, 193.

Hipistes hydrinus I 94.

hoeveni, Calamiria 179.

Holarchus I 23.

Holarchus octolineatus 123.

Homalophis $18_{5}$.

Homalophis doriae $\mathrm{I}_{5}$.

Homalopsinae 4r, I 79.

Homalopsis I 79, I $S_{1}, \quad$ I $S_{3}, \quad$ I $S_{5}$, I $89,194$.

Homalopsis albomaculatus i $S_{3}$.

Homalopsis buccata I 86 .

Homalopsis hydrina i 94.

Homalopsis leucobalia $\mathbf{I} \mathbf{S g}$.

Homalopsis plumbea I $S \mathbf{I}$.

hosei, Calamaria $\mathbf{7} \delta$.

Hurria 187 .

Hurria rhynchops 187 .

hybrida, Hydrophis 235.

hybridus, Hychophis $226,235$.

Hydrablabes 48 , 135 .

Hydrababes periops I $_{3} 6$.

Hydrablabes praefrontalis 136,137

hydrina, Homalopsis ind.

hydrinus, Hipistes I 94 .

Hydrophiinae 4I, 2 I 5.

Hydrophis $215,225$.

Hydrophis belcheri $227,23 \mathrm{~S}$.

Hydrophis brookei $226,230$.

Hydrophis brookii 230 .

Hydrophis brugmansi 226, 233.

Hydrophis cyanocinctus 227,237 .

Hydrophis diadema $226,229$.

Hydrophis fasciatus 226, 230.

Hydrophis floweri 226, 229.

Hydrophis frontalis 226,227 .

Hydroplis hybrida 235 . 
Hydrophis hybridus 226, 235 . Hydrophis jerdoni 226, 232 . Hydrophis gracilis 226,228 . Hydrophis grandis 226,235 . Hydrophis macfarlani 227,237 . Hydrophis mertoni 226,233 . Hydrophis nigrocinctus $226,227$. Hydrophis obscurus 229 .

Hydrophis ocellata 236 . Hydrophis ornatus 226,236 . Hydrophis pachycercos 239 . Hydrophis pachycercus 227, 239. Hydrophis polyodontus 226, 233 . Hydrophis saravacensis 227,238 . Hydrophis spiralis 226,234 . Hydrophis stokesi 227, 239 . Hydrophis torquatus 226, $23 \mathrm{I}$. Hydrophis viperinus 226, $23 \mathrm{I}$. Hydrus 43,75, I $\delta$ I, I 87,2 I 5,2 I 7 , $221,224,228,230,234,239$.

Hvdrus colubrinus 2 I 7 .

Hydrus enhydris $\mathrm{I} S \mathrm{I}$. Hydrus fasciatus 230 .

Hydrus gracilis 228 .

Hydrus granulatus 43 .

Hydrus piscator 75 .

Hydrus platurus 224.

Hydrus rhynchops 187 .

Hydrus spiralis 234 .

Hydrus stokesii 239.

Hydrus valakadyn 221.

hypomelas, Tropidonotus 75,83 . Hypsirhina 179 , $\mathrm{x} 80$.

Hypsirhina albomaculata i 80, I 83 Hypsirhina alternans i 80.

Hypsirhina doriae 180,185 .

Hypsirhina enhydris i 80 , I8r. Hypsirhina matannensis i So, I 82 . Hypsirhina plumbea $\mathrm{I} \delta \mathrm{o}, \mathrm{I} S \mathrm{I}$. Hypsirhina polylepis $\mathrm{I} 80, \mathbf{1} 83$. Hypsirhina punctata $180, \mathrm{I} 84$.

Idiopholis 48 , I 4 I.

Idiopholis collaris $\mathbf{1} 4 \mathbf{2}$. Idiopholis everetti $\mathbf{I}_{42}$.
Iguanognathus 46,50 .

Iguanognathus werneri 50.

ikaheka, Coluber 270.

ikaheka, Micropechis 270 .

Ilysiidae 1,34 .

indragirica, Calamaria 150, I54.

inornatus, Dendrelaphis 67 .

inornatus, Pseudoxenodon $5^{6 .}$

inornatus, Typhlops + I 4 .

inornatus, Jenodon $5^{6 .}$

insulae, Pseudelaps 265.

intermedius, Pseudoxenorlon 89.

intestinalis, Aspis 253.

intestinalis, Doliophis 25r, 253 .

irregularis, Boiga $20 \mathrm{r}$.

irregularis, Coluber $20 \mathrm{r}$.

irregularis, Dipsadomorphus i 95,

$20 \mathrm{I}$.

isolepis, Cylindrophis $36,3^{8}$.

janseni, Coluber 99, 102.

jansenii, Gonyosoma roz.

jaspideum, Triglyphodon 199.

jaspideus, Dipsadomorphus I95,

I 99.

javanica, Calamaria I53, I76.

javanicus, Acrochordus 43 .

javanicus, Xenodermus 44.

jerdoni, Hydrophis 226, 232 .

jerdonii, Distira 232.

jerdonii, Kerilia 232.

kapaladua, Typhlops 3, 9 .

Kerilia 232.

Kerilia jerdonii 232.

korros, Coluber $9^{6 .}$

korros, Ptyas 96.

korros, Zamenis 95, 96.

kraali, Typhlops 2, 4 .

kükenthali, Calamorhabdium 149 .

Lachesis $279,28 \mathrm{I}$.

Lachesis borneensis 286 .

Lachesis fasciatus $28_{2}, 28_{4}$.

Lachesis gramineus 282,285 . 
I achesis monticola 282 .

Jachesis puniceus 282,286 .

Lachesis purpureomaculatus 282 , 28. .

Lachesis sumatranus $2 S_{2}, 2 S_{3}$.

Lachesis wagleri 282,286 .

laevis, Aipysurus 2i $8,220$.

laevis, Amblycephalus 276 .

Lapemis 240.

Lapemis hardwickii 240.

lateralis, Calamaria 152, 168.

Laticanda 217.

Laticauda laticaudata 217.

laticandata, Laticauda 217.

laticaudatus, Coluber 217 .

laticaudatus, Platurus $216,217$.

lautensis, Calamaria $\mathbf{1}_{5} \mathbf{1}, \mathbf{1}_{3}$.

Leiopython is.

Leiopython gracilis is, 19 .

Lepidognathus 5 I.

Lepidognathus rugosus 51 .

Leptophis 63 .

Leptophis punctulatus $6_{3}$.

Lepturophis $47, \mathrm{I}_{3} 3$.

Lepturophis borneensis II 3 .

leucobalia, Fordonia 189 , 190 .

lencobalia, Homalopsis 189 .

leucocephala, Calamaria 152, i 7 I.

lencodira, Naja 248 .

leucogaster, Calamaria i52, 164.

leucoproctus, Typhlops 3 , I.

Liasis $15, \mathrm{r} 6$.

Liasis albertisi 16, i 8 .

Liasis amethystinus 25 .

Liasis amethystinus timoriensis 25 .

Liasis fuscus i6.

Liasis mackloti 16,17 .

Liasis papuanus $16, \mathrm{~g}$.

Liasis petersi 26 .

Liasis tornieri 16 , I8

libertatis, Ablabes ${ }_{3} 37$, I39.

libertatis, Liopeltis 138 .

Lielaphis in 6 .

Lielaphis batjanensis I 6 .

lilljeborgi, Anisodon 202. lineaticollis, Pseudelays 265.

lineatus, Cylindrophis 36,37 .

lineatus, Typhlops 2, 4 .

lineolatus, Dendrophis 58,65 .

limnaei, Calamaria 553, I 74 .

Liopeltis I 38 , I 39 .

Liopeltis baliodirus 139 .

liopeltis libertatis 138 .

longicauda, Ablabes I37, I 40.

longiceps, Calamaria 146 .

longiceps, Pseudorhabdium 146 .

longissimus, Toxicocalamus 256 .

lönnbergi, Apistocalamus 260, 262.

lorentzi, Dendrophis 57, 62 .

lorenzi, Typhlops 3,8 .

loriae, Apistocalamus 260, $26 \mathrm{r}$.

lovii, Calamaria 177.

lowi, Calamaria 153,177 .

lumbricoidea, Calamaria $150,153$.

'Lycodon 47, 107, 114, II 5, 267.

lycodon albofuscus io8, III.

Lycodon aulicus roS, III.

Lycodon cucullatum is 5 .

l.ycodon effrenis 108, I1 2 .

lycodon florensis 108, г 10.

Lycodon fasciatus 113 .

Lycodon magnus I I 4 .

Iycodon modestus i 5 .

Lycodon olivacens 267 .

Lycodon stormi ros, i 10.

Lycodon subcinctus ro8.

macfarlani, Distira 237.

macfarlani, Hydrophis $227,237$.

mackloti, Liasis 16,17 .

Macropisthodon 47,91 .

Macropisthodon flaviceps $9 \mathrm{r}$.

Macropisthodon plumbicolor 93.

Macropisthodon thodomelas 91,92 .

macrospila, Python 27.

maculata, Natrix 90.

maculatus, Tropidonotus $75,8_{5}, 9 \circ$.

magnus, Lycodon 114.

magnus, Stegonotus 114.

mairi, Tropidonotus 74,79 . 
mairii, Natrix 79.

malaccana, Asthenodipsas 276 .

malaccanus, Amblycephalus 276 .

margaritatum, Gonyosoma 106.

margaritatus, Gonyophis 106.

margaritifera, Calamaria ${ }_{5} 6$.

margaritophora, Calamaria i 50, I $56, \quad$ I 79.

matannensis, Hypsirhina 580, I 82. mecheli, Calamaria 152, 169.

meeki, Dendrophis 58,66 . melanota, Calamaria i 53, I 77 .

melanura, Elaphe roo.

melanurus, Coluber 99.

mertoni, Distira 233.

mertoni, Hydrophis 226, 233.

Micropechis $242,270$.

Micropechis ikaheka 270.

miolepis, Naja 24 S.

modestus, Dendrelaphis 67,70 .

modestus, Lycodon 1 I 5 .

modestus, Stegonotus I14, 115 .

molurus, Coluber 22.

molurus, Python 20, 22, 23, 2. . montanus, Tropidonotus 74 , So. monticola, Lachesis 282 .

monticola, Trimeresurus 282.

mucosus, Coluber 98 .

mucosus, Zamenis 95, $9^{8 .}$

mülleri, Calamaria I5 I, 16 I.

mülleri, Pseudelaps 264 .

mülleri, Typhlops $3,12$.

mülle rii, Elaps 264.

multilineatus, Typhlops 3,7 .

multimaculata, Boiga 195.

multimaculata, Dipsas 195.

multimaculatus, Dipsadomorphus

I95.

mycterizans, Coluber 208.

mycterizans, Dryophis 205, 208.

Myron i 79, төг.

Myron richardsoni 192.

Najil 2fI, 245, 268.

Najal australis 268 .
Naja buingarus 246,249 .

Naja tripudians 246 .

Naja tripudians caeca 248 .

Naja tripudians leucodira 248 .

Naja tripudians miolepis 248 .

Naja tripudians paucisquamis 248 .

Naja tripudians sputatrix 2.48 .

Naja tripudians sumatrana 248 .

Nardoa 15.

Nardoa boa i 5 .

Natrix 75, 79, $84,88,89,90$.

Natrix chrysarga $S_{9}$.

Natrix maculata 90.

Natrix mairii 79 .

Natrix piscator 75 .

Natrix subminiata 89 .

Natrix trianguligera $\delta_{4}$.

Natrix vittata $\delta 8$.

nigriceps, Dipsadomorphus I 95, I 99.

nigriceps, Dipsas 199.

nigroalbus, Typhlops 3, I 2.

nigrocinctus, Hydrophis 226,227 .

nouhuysi, lendroph is 58,66 .

novae-guineae, Tropidonotus $7+78$.

nuchalis, Amblycephalus 276, 277 .

nuchalis, Calamaria I5 I, 157.

nymani, Pseudapistocalamus 263 .

obscurus, Hydrophis 229.

ocellata, Hydrojhis 236.

occipitalis, Calamaria I5 I, 162.

octolineatus, Elaps 123.

octolineatus, Holarchus 123.

octolineatus, Simotes I 22, I 23 .

Odontomus i $\mathbf{9}$.

Udontomus subannulatus i 19 .

Oligodon 48 , I 27 .

Oligodon bitorquatus I 27, I 28.

Oligodon durheimi I27, 129.

Oligodon everetti i $2 S$, I 30 .

Oligodon ornatus $\mathrm{I} 3 \mathrm{I}$.

Oligodon petronellae 128 , I 3 I.

Oligodon praefrontalis $128, \mathrm{I}^{2}$.

Oligodon propinquus r 28 , $13 \mathrm{I}$. 
Oligodon pulcherrimus I 28, I 3 I.

Oligodon taeniurus I 33 .

Oligodon trilineatus 127, I 29.

Oligodon vertebralis I 28 , 133 .

Oligodon waandersi 128, I 33 .

olivacea, Diemenia 266, 267 .

olivaceus, Lycodon 267.

olivaceus, Onychophis 8 .

olivacens, Typhlops 3,8 .

Onychophis 8.

Onychophis olivaceus 8 .

Opisthoglypha +1, 179.

opisthorhodus, Cylindrophis 36,38 .

Opisthotropis 46, $5 \mathrm{I}$.

Opisthotropis rugosa $5 \mathrm{I}$.

Opisthotropis typica 51, 52 .

Oreocalamus 48, iғo.

Oreocalamus hanitschi if I.

ornata, Aturia 236.

ornata, Calamaria i 78 .

ornata, Chrysopelea 2 I 2.

ornata, Listira 236.

ornatus, Coluber 2 I 2.

ornatus, Hydrophis 226, 236 .

ornatus, Oligodon I 3 I.

oxycephala, Gonyosoma rot.

oxycephalus, Coluber 99, ro.

pachycercos, Hydrophis 239.

pachycercus, Distira 239.

pachycercus, Hydrophis 227, 239. papuanus, Dipsadomorphus $20 \mathrm{r}$.

papuanus, Liasis เ 6 , I 9 .

papuanus, Psendechis 268, 269.

papuensis, Dendrelaphis 67,70.

papuensis, Fordonia 190.

paucisquamis, Naja 248 .

parimentata, Calamaria I53, 176. periops, Ablabes i 36,137 .

periops, Hydrablabes 136 .

petersi, Liasis 26.

petersi, Tropidonotus 75,85 .

petronellae, Oligodon I2S, I 3 I.

phaenochalinus, Simotes 127.

Phytolopsis is $8_{4}$.
Phytolopsis punctata i $S_{4}$. picteti, Calamaria I52 $_{2}$ 170, 172. picturatus, Tropidonotus $7+76$. pictus, Coluber 58 .

pictus, Dendrophis $57,5^{8}$.

pictus, Psammodynastes 202, 203.

piscator, Hydrus 75 .

piscator, Natrix 75.

piscator, Tropidonotus $7+, 75$.

Plagiodon 102.

Plagiodon erythrurus io2.

platura, Anguis 22.

Platurus 2 I5, 216.

Platurus colubrinus 216, 2 I 7 .

platurus, Hydrus $22+$.

Platurus laticaudatus $216,217$.

Platurus schistorhynchus 216,217 .

plumbea, Homalopsis is $\mathrm{I}$.

plumbea, Hypsirhina $\mathbf{8} 80$, I 8 r.

plumbeus, Herbertophis I 7 .

plumbeus, Stegonotus ilt, II 7 .

plumbicolor, Macropisthodon 93.

polygrammicus, Typhlops 2, 6 .

polylepis, Hypsirhina iso, I 83 .

Polyodontophis 57,54 .

Polyodontophis geminatus 54 .

polyodontus, Hydrophis 226,233 .

porphyraceus, Coluber 99.

praefrontalis, Ablabes 137 .

praefrontalis, 1 fydrablabes i 36, I 37 .

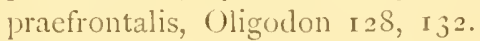

prakkei, Calamaria I50, 156.

prakkii, Calamaria 156.

prasinus, Dryophis 205, 206.

pratti, Apistocalamus 260.

preussi, Ultrocalamus 258 .

propinquus, Oligodon 128, г 3 I.

Proteroglypha 4I, 215.

Psammodynastes I94, 202.

Psammodynastes pictus 202, 203.

P'sammodynastes pulverulentus 202.

Psammophis 202.

psammophis, Diemenia 266.

psammophis, Elaps 266.

Psammophis pulverulenta 202. 
Pseudapistocalamus 242, 262 .

Pseudapistocalamus nymani 263 .

Pseudechis 242, 268.

Psendechis australis 268.

I'seudechis papuanus 268, 269 .

Pseudechis scutellatus 268,269 .

Pseudelaps 242, 264.

Pseudelaps mülleri 264 .

Pseudelaps mülleri insulae 265 .

Pseudelaps mülieri lineaticollis $\mathbf{2 6} 5$.

Pseudoboa 243.

Pseudoboa fasciata 243 .

Pseudorhabdium 48, 146.

Pseudorhabdium longiceps I 46.

Pseudoxenodon 47, 56, 89.

Pseudoxenodon inornatus 56 .

Pseudoxenodon intermedius 89 .

1'tyas $9^{6 .}$

Ptyas korros 96.

pulcherrimus, Oligodon $\mathbf{I}_{2} 8, \mathrm{I}_{3} 2$. pulverulenta, Psammophis 202. pulverulentus, Psammodynastes 202.

punctata, Hypsirhina $\mathbf{1} 80, \mathbf{1} 84$. punctata, Phytolopsis I 84 .

punctiventris, Tropidonotus 74, 8I. punctulatus, Dendrophis 57,63.

punctulatus, Leptophis 63 .

punicea, Cophias 286.

puniceus, Lachesis $282,286$.

puniceus, Trimeresurus 286.

purpurascens, Simotes I22, I 26.

purpurascens, Xenodon i 26 .

purpureomaculatus, Lachesis 282 , 284 .

purpureomaculatus, Trigonocephalus 284 .

Python I 5, 19, 29.

Python amethystinus 20, 24.

Python bivittatus 22, 23.

Python curtus 20, 28 .

Python molurus 20, 22, 23, 24.

Python molurus sondaica 24 .

Python reticulatus 20.

Python spilotes 20, 26 .
Python spilotes macrospila 27 .

Python timorensis 26.

Python timoriensis 20, 25.

Python viridis 29.

Pythoninae I 4, 15.

quinquetaeniata, Calamaria I $_{52}$, I64.

radiatus, Coluber 99, гог.

rebentischi, Calamaria I52, I69.

reticulata, Boa 20.

reticulatus, Python 20.

reticulatus, Stegonotus II 5 .

Rhabdion I33, I 45.

Rhabdion forsteni 145 .

Rhabdion waandersi 133 .

Rhabdophidium 48, 145 .

Rhabdophidium forsteni $\mathbf{1} 45$.

rhodomelas, Macropisthodon 91,92.

rhodomelas, Tropidonotus 92 .

rhodopleuron, Chrysopelea 2 II, 2 I 2.

rhodostoma, Agkistrodon 279 .

rhodostoma, Ancistrodon 279.

rhodostoma, Trigonocephalus 279 .

rhynchops, Cerberus i 87 .

rhynchops, Hurria i 87 .

rhynchops, Hydrus i 87.

richardsoni, Myron I92.

rubescens, Dipsas 209.

rubescens, Dryophiops 209.

rufa, Anguis 36.

rufus, Cylindrophis 36 .

rugosa, Opisthotropis 51 .

rugosus, Lepidognathus $5 \mathrm{r}$.

russelli, Vipera 279.

sandakanensis, Bothrops 286 .

sarasinorum, Agrophis I 43 .

sarasinorum, Tropidonotus 74,79 .

saravacensis, Agrophis 143, 144.

saravacensis, I) istira 238 .

saravacensis, Hydrophis $227,238$.

saravacensis, Tropidlonotus $\delta_{5}$. 
sarawacensis, Tropidonotus $75, \Omega_{5}$. schistorhynchus, Platurus 2 I 6. schlegeli, Calamaria 152, 173. schlenckeri, Dendrelaphis 60. scutellatus, Pseudechis $268,269$. semiannulata, Calamaria 152, I 72. Sibynophis 55 .

Sibynophis geminatus 55 . signatus, Simotes I 22 , I 25. simalurensis, Calamaria I 5 I, I 59. Simotes 48, I 2 I, I 29, I33. Simotes annulifer 122. Simotes annulifer bipartita $\mathbf{2} 3$. Simotes forbesi 122 , I 24. Simotes octolineatus I 22 , I 23. Simotes phaenochalinus 127 . Simotes purpurascens 122, I 26 . Simotes signatus $122,125$. Simotes subcarinatus I22, 125 . Simotes trilineatus $\mathbf{1} 29$.

Simotes vertebralis $\mathbf{1} 33$.

Simotes violaceus I 22 , I 24 . sondaica, Calamaria I52, 166. sondaica, Python 24.

Sphecodes rog.

Sphecodes albofuscus Iog.

spilotes, Coluber 26.

spilotes, Python 20,26 .

spiralis, Hydrophis 226, 234.

spiralis, Hydrus 234.

sputatrix, Naja 248 .

stahlknechti, Calamaria I50, 154. stanleyanus, Toxicocalamus 256 . Stegonotus 4S, I I 4 .

Stegonotus batjanensis I 4 , I 16 . Stegonotus cucullatus I I 5 . Stegonotus diehli I I 4, I 8 . Stegonotus güntheri I I 4, I I 7 . Stegonotus magnus I I 4 . Stegonotus modestus II 4, I1 5 . Stegonotus plumbeus i i 4 , I I 7 . Stegonotus reticulatus I I 5 . stokesi, Astrotia 239. stokesi, Hydrophis $227,239$. stokesii, Distira 239. stolatus, Coluber $S_{7}$.

stolatus, Tropidonotus 75,87 .

Stoliczkaia $\$ 2,45$.

Stoliczkaia borneensis 45 . stormi, Lycodon roS, i ro. striata, Dendorophis 60 . striata, Dendrophis 60 . Styporhynchus 77,78 . Styporhynchus celebicus 78 Styporhynchus truncatus 77 . subannulatus, Dryocalamus I 19. subannulatus, Odontomus I 19. subcarinatus, Simotes 122, I 25. subcinctus, Lycodon IoS. subminiata, Natrix $S_{9}$. subminiatus, Tropidonotus 75: S9. subradiatus, Coluber 99, 106. sumatrana, Calamaria I5 I, I 57. sumatrana, Naja $24 S$. sumatrana, Typhlops 4. sumatranus, Coluber $2 S_{3}$. sumatranus, Lachesis $282,28_{3}$.

taeniurus, Coluber 99, ro3. taeniurus, Elaphis 103.

taeniurus, Oligodon 133 . terrificus, Dendrelaphis 67,69 . terrificus, Dendrophis 69 .

Tetralepis $48,120$.

Tetralepis fruhstorferi 121. Thalassophis $215,222,231$. Thalassophis annandalei 223 . Thalassophis annandalii 223. Thalassophis anomalus 223 . Thalassophis viperina $23 \mathrm{I}$. timorensis, Python 26 . timoriensis, Coluber ror. timoriensis, Liasis 25. timoriensis, Python 20, 25. Tomogaster 2 I 9. Tomogaster eydouxii 2 r 9 . tornieri, Liasis ı 6, I 8 . tornieri, Zaocys $7 \mathbf{1}$. torquatus, Hydrophis $226,23 \mathrm{I}$. Tortrix I 5 . 
Tortrix boa 15 .

Toxicocalamus 242, 255 .

Toxicocalamus longissimus 256 .

Toxicocalamus stanleyanus 256 .

'Tragops 207 .

Tragops fasciolatus 207 .

trianguligera, Natrix 8.4.

trianguligerus, Tropidonotus 75 ,

84 .

tricolor, Ablabes $137,13 S$.

tricolor, Herpetodryas i $3 S$

Triglyphodon 199, 202.

Triglyphodon flavescens 202.

Triglyphodon jaspideum 199.

Trigonocephalus 279,284 .

Trigonocephalus purpureomaculatus 28 .

Trigonocephalus rhodostoma 279.

trilineatus, Dryocalamus 120.

trilineatus, Oligodon 127 , I29.

trilineatus, Simotes I 29.

Trimeresurus $282,285,286$.

'Trimeresurus gramineus 285 .

Trimeresurus monticola 282 .

Trimeresurus puniceus 286 .

tripudians, Naja $2+6$.

tristis, Giyphodon 255 .

tristrigatus, Dryocalamus I 19, I 20 .

Tropidonotus 47, 73, 92.

Tropidonotus callistus 86 .

Tropidonotus celebicus 74,78 .

Tropidonotus chrysargoides 75,86 .

Tropiclonotus chrysargus 75,89 .

Tropidonotus conspicillatus $75,8_{3}$.

Tropidonotus doriae $74, S_{2}$.

Tropidonotus elongatus 75 , So.

Tropiclonotus flavifrons 75,87 .

Tropidonotus halmahericus 74,82 .

Tropidonotus hypomelas $75,8_{3}$.

'Tropiclonotus maculatus $75,85,90$.

Tropidonotus mairi 74,79 .

Tropidonotus montanus 74 , 80 .

Tropiclonotus novae-guineae 74,78 .

Tropiclonotus petersi $75, S_{5}$.

'Tropidonotus picturatus 74,76 .
Tropidonotus picturatus elongatus So.

Tropidonotıs piscator 74,75 .

Tropidonotus punctiventris $74,8 \mathrm{I}$.

Tropidonotus rhodomelas 92 .

Tropidonotus sarasinorum 74,79 .

Tropidonotus saravacensis 85 .

Tropidonotus sarawacensis 75,85 .

Tropidonotus stolatus 75,87 .

Tropidonotus subminiatus 75,89 .

Tropidonotus trianguligerus 75,84 .

Tropidonotus truncatus 74,77 .

Tropidonotus vittatus 75,88 .

truncatus, Styporhynchus 77 .

truncatus, Tropidonotus 74,77 .

Typhlopidae $\mathbf{i}, 2$.

Typhlops 2.

Typhlops ater 4, Iо, 13.

Typhlops bipartitus 3,10 .

Typhlops bisubocularis 4, 13 .

Typhlops braminus 2, 5 .

Typhlops conradi $3,10$.

Typhlops depressiceps 3,9 .

Typhlops elberti 3,7 .

Typhlops erycinus 2,6 .

Typhlops flaviventer 3, I I.

Typhlops florensis 3 , ro.

Typhlops inornatus 4, r4.

Typhlojs kapaladua 3, 9.

Typhlops kraali 2,4 .

Typhlops leucoproctus 3,1 I.

Typhlops lineatus 2, 4 .

Typhlops lineatus sumatrana 4 .

Typhlops lorenzi 3,8 .

Typhlops mülleri 3 , I 2.

Typhlops multilineatus 3,7 .

Typhlops nigroalbus 3 , 12 .

Typhlops olivaceus 3,8 .

Typhiops polygrammicus 2, 6 . typica, Opisthotropis 5 I, 52 . typicus, Helicopsoides 52 .

UItrocalamus $2+2,25 \mathrm{~S}$. Uitrocalamus bürgersi 260 .

Ultrocalamus preussi 258 . 
unicolor, Xenopeltis 39.

valakadien, Enhydrina $22 \mathrm{I}$. valakadyn, Enhydrina 22I. valakadyn, Hydrus $22 \mathrm{x}$. variabilis, Calamaria 153 . remiformis, Calamaria I50, 153. vertebralis, Oligodon I 28,133 . vertebralis, Simotes 133 . violacea, Cantoria I9I. violacea, Coronella I 24. violaceus, Simotes $122,124$. Vipera 279.

Vipera russelli 279 .

Viperidae 1, 279. viperina, Distira $23 \mathrm{I}$.

viperina, Thalassophis 231 .

Viperinae 279 .

viperinus, Hydrophis 226, $23 \mathrm{I}$.

viperinus, Xenochrophis 53 . virgulata, Calamaria 151, 162. viridis, Chondropython 29.

riridis, l'ython 29. vittata, Natrix 88 . vittatus, Coluber $8 S$. vittatus, Tropidonotus 75,88 . waandersi, Oligodon г 28 ; 133 . waandersi, Rhabdion I33. wagleri, Cophias 286 . weberi, Anomalochilas 34 . werneri, Iguanognathus 50.

xanthozona, Dryophis 205 .

Xenelaphis 47, 93 .

Xenelaphis ellipsifer 93, 95.

Xenelaphis hexagonotus 93.

Xenochrophis $+6,53$.

Xenochrophis viperinus 53 .

Senodermus 42, 44.

Xenodermus javanicus 4 .

Jenodon 56, 126.

Yenodon inornatus 56 .

Nenodon purpurascens i 26.

Senopeltidae 1, 39.

Jenopeltis 39.

Tenopeltis unicolor 39.

Zamenis 47,95 .

Zamenis dipsas 95, 96.

Zamenis korros 95, 96.

Zamenis mucosus 95,98 .

Zaucys $47,7 \mathrm{I}$.

Zaocys carinatus 71,73 .

Zaocys fuscus $71,72$.

Zaocys tornieri $7 \mathrm{I}$. 



\title{
ADDENDA AND CORRIGENDA.
}

\author{
VOI. I.
}

p. 22. Gymiodactylus consobrinus Ptrs., add to the habitat Borneo: Baram river.

p. 57. Gecko verticillatus Laur., add to the habitat Java: Salatiga!.

p. 64. Sub E. read vertebral instead of ventral.

p. 72. Draco iolans L., add to the habitat Java: Salatiga!.

p. 73. Draco cormutus Gthr. add to the liabitat Borneo: Lio Matu on Baram river.

p. I 4. Gonyocephalus modestus Meyer, add to the habitat New Guinea: Uwumbi in German New Guinea!.

p. I22. Calotes cristatellus (Kuhl), add to the habitat Java: Salatiga!, and N. W. New Guinea.

P. I 47. Varamus salvator (I aur.), add to the habitat: KrakatauIV. off Java.

P. I 55. Tachydromus sexlineatus Daud., add to the habitat Java: Semarang.

p. I64. Mabuia multifasciata (Kuhl), add to the habitat Java: Semarang!

p. 2S4. Dibams notae-guineae D.B., add to the habitat Sumatra: Deli!.

p. 309. Chelonia mydas (L.), add to the habitat: Simalur; Pulu Babi.

p. 310. Chelonia imbricata (L.), add to the habitat: Simalur; Pulu Babi.

p. 338. Crocodilus porosus Schn., add to the habitat Pulu Babi; Banka; Sulu Islands.

p. 339. Crocodilns siamensis Schn., add to the habitat Java:

Tjilatjap and Panarukan. Length about 2.50 M.

p. 340. Add to the list of Simalur: Chelonia mydas (L.); Chelonia imbricata (L.). 
p. 340. Add to the list of Pulu Babi: Chelonia mydas (L.);

Chelonia imbricata (L.); Crocodilus porosus Schn.

p. 344. Add to the list of Banka: Crocodilus porosus Schn.

p. 363. Add to the list of New Guinea: Calotes cristatellus (Kuhl).

VOL. II.

p. 20. Sub 4. read timoriensis instead of timorensis.

p. 75. Sub 17. read sarawacensis instead of saravacensis. 


\title{
THE REPTILES
}

\author{
OF THE
}

\section{INDO-AUSTRALIAN ARCHIPELAGO}

\author{
II \\ OPHIDIA
}

with 117 illustrations

BY

\section{Dr. NELLY DE ROOIJ}

Curator of the Zoological Museum, Amsterlam.

LEIDEN - I9I7.

E. J. B R I L L Ltd. 


\section{THE FISHES}

OF THE

\section{INDO-AUSTRALIAN ARCHIPELAGO}

I

INDEX OF THE ICHTHYOLOGICAL PAPERS

$\mathrm{OF}$

P. BLEEKER

BY

Dr. MAX WEBER

Professor of the University of Amsterdam

AND

Dr. L. F. DE BEAUFORT

igit. (XI. 4Io. With portr. of P. Bleeker) gr. in-8vo.

$$
\begin{aligned}
& f 4 .- \\
& \text { Cloth }, 4.75
\end{aligned}
$$

\section{II}

MALACOPTERYGII, MYCTOPHOIDEA, OSTARIOPHYSI: I SILUROIDEA

BY

Dr. MAX WEBER

Professor of the University of Amsterlam

AND

\section{Dr. L. F. DE BEAUFORT}

igi4. (XX. 404. With I portr. of Medchior Treup and I 5 I illustr.) gr. in-Svo. 


\section{III}

OSTARIOPHYSI: II CYPRINOIDEA, APODES, SYNBRANCHI

PY

\section{Dr. MAX WEBER}

Professor at the University of Amsterdam

ANI)

\section{Dr. L. F. DE BEAUFORT}

I9 6. (XV. 455 and $21+$ illustrations) gr. in-Svo.

$$
\begin{aligned}
& f 9 .- \\
\text { Cloth } & =9.75
\end{aligned}
$$

\section{THE REPTILES}

OF THE

\section{INDO-AUSTRALIAN ARCHIPELAGO}

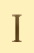

135

\section{Dr. NELLY DE ROOIJ}

Curator of the Zoological Museum, Amsterlam

1915. (XIV. ${ }_{3} S_{4}$ and I $_{3} 2$ illustrations) gr. in- 8 ro.

$$
\begin{array}{ll}
f 6 .- \\
\text { Cloth } \quad \text { "6.75 }
\end{array}
$$




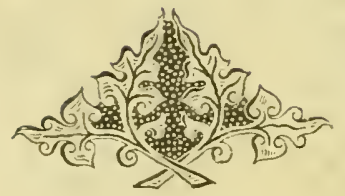

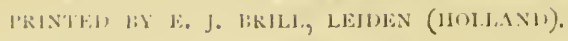










\section{Date Due}

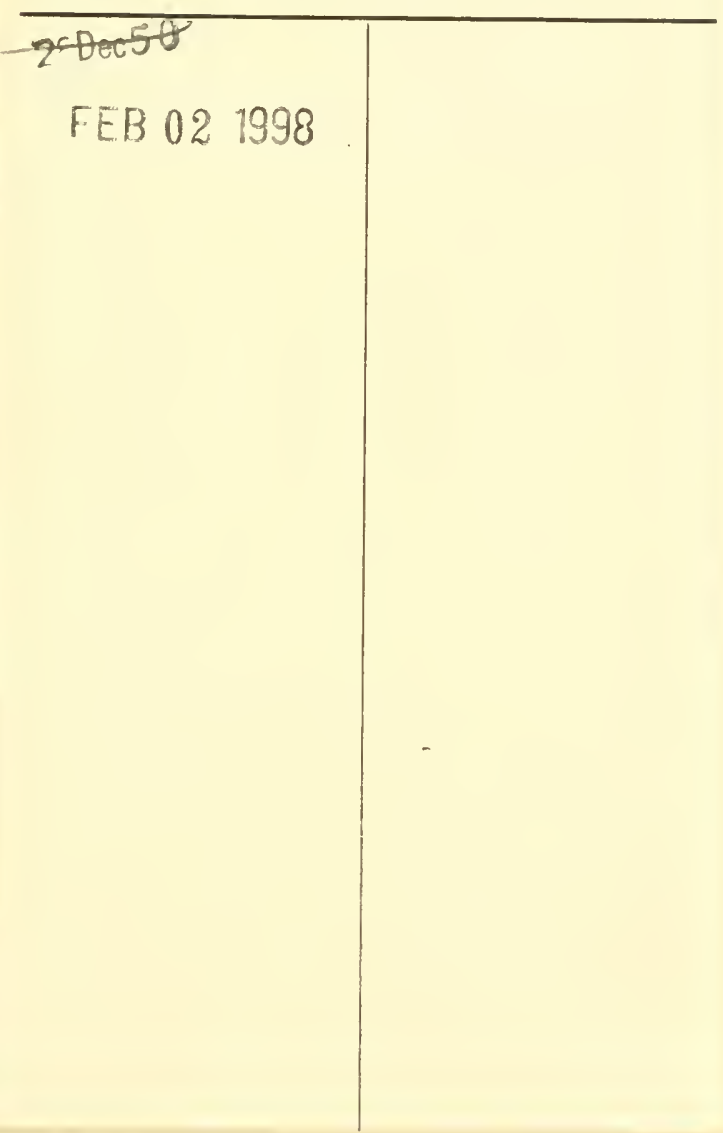


(2) 81 